





\section{New Jersey. State Geologist \\ COFPTIRS \& AMFPTRIAMS

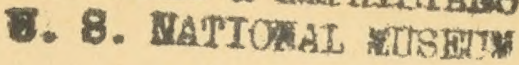

GEOLOGICAL SURVEY OF NEW JERSEY.

\section{FINAL REPORT}

OF THF

\section{STATE GEOLOGIST,}

VOL. II.

MINERALOGY.

BOTANY.

ZOÖLOGY.

TRENTON, N. J.:

Printed by The John L. Murphy Publishing Company.

$1 \overline{890}$. 



\section{PART 2.}

ZOÖLOGY. 



\section{BOARD OF MANAGERS.}

His Excellency Robert S. Green, Governor and ex-officio President of the Board.

..Trenton.

I. CONGRESSIONAL DISTRICT.

Hon. John Clement Haddonfield.

Hon. Clement H. Sinnickson Salem.

II. CONGRESSIONAL DISTRICT.

EMmor Roberts, Esq Moorestown.

Hon. H. S. Little.. Trenton.

III. CONGRESSIONAL DISTRICT.

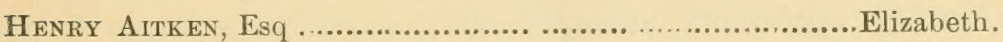

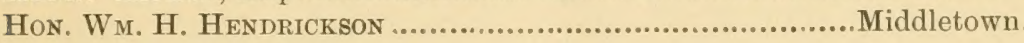

IV. CONGRESSIONAL DISTRICT.

Selden T. Scranton, Esq Oxford.

Hon. Thomas Lawrence Hamburg.

V. CONGRESSIONAL DISTRICT.

Hon. Augustus W. Cutler. Morristown.

GeORGE Richards, Esq. Dover.

\section{CONGRESSIONAL DISTRICT.}

William M. Force, Esq Newark.

Thomas T. Kinney, Esq. Newark.

VII. CONGRESSIONAL DISTRICT.

Lebbeus B. Ward, C.E Jersey City.

Rev. Samuel B. Dod Hoboken.

\section{GEO. H. COOK,}

State Geologist. 

Netw Brunswick, N. J., July 29th, 1889.

To His Excellency Robert S. Green, Governor of the State of New Jersey, and ex-officio President of the Board of Managers of the State Geological Survey:

SIR-I bave the honor herewith to submit the second rolume of my final report as State Geologist. Its subject is Natural History, and it contains catalogues of the Minerals, Plants and Animals of the State of Nerv Jersey.

With high respect,

Your obedient servant,

GEO. H. COOK,

State Geologist. 



\section{CONTENTS.}

PAGE.

I. Catalogue of Insects Found in New Jersey................... 1-486

Introduction ............................................... $3-7$

Catalogue of Insects....................................... $\quad 7-46 t$

Order Hymenoptera..................................... $\quad$ 7-68

Order Coleoptera......................................... 69-271

Order Lepidoptera.................................... 271-359

Order Diptera............................................. 360-405

Order Orthoptera ........................................ 405-415

Dermaptera ................................... 405-406

Ortboptera................................... 406-415

Order Hemiptera..................................... 416-452

Sul).Order Heteroptera............................. 416-436

Sub-Order Homoptera.............................. 436-452

Order Neuroptera .................................... 453-464

Conclusion................................................. 465

Errata ..................................................... $\quad 466$

Principal Abbreviations of Authors' Names................. 467-471

Index of Genera........................................... 473-486

I1. Catalogue of Vertebrates..................................... 487

Class Mammalia.. ............................................ 494

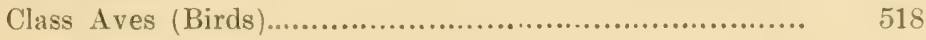

\& Scansores (Climbing Birds)...................... 518

?. Insessores (Perching Birds)........................ 525

\& Cursores (Running Birds)......................... 583

\& Natatores (Swimming Birds)....................... 609

Class Reptilia................................................ 637

Class Amphibia [Batrachia] ................................. 649

Class Pisøes (Fishes)... ....................................... 657

Sub-Class Marsipobranchii [Cyclostomi]................ 657

Sub-Class Elasmobranchii (Selachians).................. 659

?. Plagiostomi ........................................ $\quad 659$ 


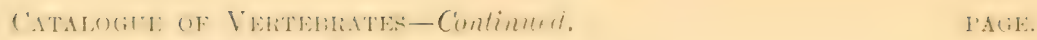

sul-Class Gitnuidei...................................... fific

? Chondrostei........................................ titin

\& Holostei.............................................. liti!

Sub-Class Teleostei (Bony Fishes)........................ 任

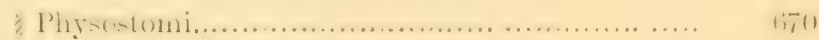

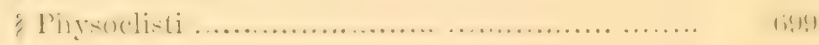

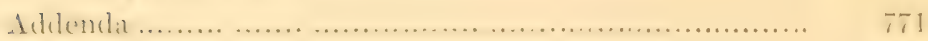

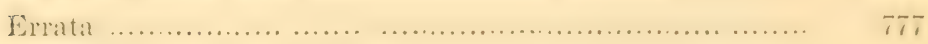

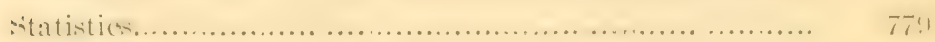

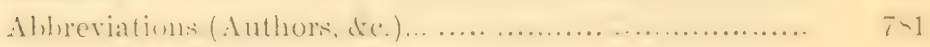

General Ahlireviations....................................

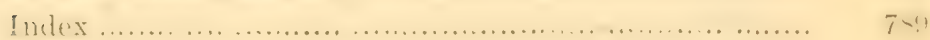




\section{CATALOGUE OF INSECTS FOUND IN NEW JERSEY.}

BY JOHN B. SMITH. 



\section{CATALOGUE OF INSECTS FOUND IN NEW JERSEY.}

BY JOHN B. SMITH.

INTRODUCTION.

Any faunal list making pretense to completeness, must be based upon years of careful collecting and observation, not by one, but by many individuals. In my work of compiling the present list I have been hampered in every possible direction, and incompleteness of the work will, I hope, be not entirely charged as incompetence in the compiler. The labor on material for the list has been confined to the few spare hours I could gather from a summer's active field-work, and to about three weeks' work in compiling the results obtained from my correspondents. New Jersey offers quite distinct contrasts in her geological features, and, as this influences the botany to a very large extent, it necessarily also affects the character of the insect fauna. There are no large general collections of insects in the State, and records of this kind were shut off. Collectors of insects are few, and are massed in two or three localities, hence many parts of the State are entirely unexplored, and the contrasts between the fauna of the sandy pine-barren region and of the rocky Orange mountain district are not well brought out. Collectors lacking, little material has come into the hands of the systematists, and hence there are few references in the literature to New Jersey as the home of species. Pennsylvania and New York are constantly referred to. New Jersey seldom. The material for a list of insects was therefore not to be sought in literature. In Philadelphia there are a number of active collectors who do a large part of their collecting in this State. From some of these I have obtained most valuable lists of captures. The excursions made by these gentlemen were generally confined to the Camden and Gloucester county region, or extended to the sea-shore-a part of the pine 
barrens was therefore covered, but not nearly as thoroughly as desirable. Unfortunately these gentlemen were all collectors of Coleopter $a$ or of Lepidoptera, and in Lepidoptera of only small portions of the order. So far as the fauna of the pine barrens is concerned, we know absolutely nothing of it save in Coleoptera and Lepidoptera. In Newark and its immediate vicinity are a number of collectors who have formed an Entomological Society, which holds semi-monthly meetings. This society and its members have furnished me valuable lists giving the collective experiences of its members. These lists are cited in the following pages as the "Newark List," and the species are generally taken not many miles from the city of Newark. As this includes territory from salt marshes to mountain, further specialization in future lists will be desirable. As in Philadelphia, all the collectors confine themselves to Coleopterc or Lepidoptera, and in Lepidoptera none collect the micros, so called. The ouly collector who has a general collection of any size is Mr. M. S. Crane, of Caldwell, and from him I had lists in Hymenoptera, Hemiptera, Diptera, Orthoptera, Neuroptera, Coleoptera and Lepidoptera, which proved of the greatest assistance to me. In the cities of New York and Brooklyn there are a considerable number of entomologists and collectors who do a great deal of their collecting in New Jersey, and some of these have added materially to the completeness of the present list. As usual, these gentlemen confine themselves to Colcoptera and Lepidoptera. Had the time been less pressing I could probably have gotten further aid from these gentlemen, but the collecting season and immediately after are bad times to expect aid from entomologists. It will be noticed that, except in Coleoptera and Lepidoptera, New Jersey is practically unexplored, and even in the collected orders, northern and northwestern New Jersey are entirely unrepresented. These facts must be my excuse for any incompleteness in the list. So far as my own collections are concerned, I must say that I lived in the city of Brooklyn during the period of my most enthusiastic collecting days and that many a pleasant day was passed in the hills back of Montelair, in the woods near Fort Lee, or in early spring along the foot of the Palisades from Hoboken to Weehawken and further north. I have also spent many pleasant days on Dr. Brakeley's plantations in Ocean county and have taken many good species there. As I collected in all orders, I have been able to add considerable to all lists, from my own experience.

To specialize: In the Hymenopterc I have used Mr. E. T. Cres- 
son's classification and list as a guide, and have included all the species marked by him as occurring in New Jersey, as well as those so distributed that their occurrence in the State is certain. Mr. M. S. Crane furnished me with a very good list of his captures, and, supplemented by my own experience, this added to the accuracy of the list. Finally, by the courtesy of the American Entomological Society, I was enabled to examine the E. T. Cresson collection of Hymenoptera, from which I gleaned many New Jersey species, and Mr. Geo. B. Cresson, the curator of the Society, kindly gave me a list of specimens recently taken near Westville, all of which aided in completing the list.

In Coleoptera, the Henshaw check list has been my guide. Messrs. Charles Liebeck and Henry W. Wenzel, of Philadelphia, have furnished me most excellent annotated lists of the species taken by them. The Newark list was very full in some families and forms an important part of the record. In the Carabida, a list of the species taken near New York by Mr. F. G. Schaupp, which I aided in compiling some years ago, furnished many species. In the families of rove and water beetles (Staphylinida, Dytiscido, Hydrophilidce, \&c.), all the general lists were poor, and as my own collection, now in the United States National Museum, contained many species from this State, I obtained, through the courtesy of Mr. Howard, acting for Professor Riley, a list of these species in the National Museum.

Mr. M. L. Linell, Professor Riley's aide in the museum, also kindly furnished me with a partial list of his collections in New Jersey, and these were very valuable.

Dr. John Hamilton, of Allegheny, Pennsylvania, had passed a short season in September at Brigantine Beach for some years past, and his list of captures was of extreme interest. Mr. C. H. Roberts, who inakes rather a specialty of aquatic Coleoptera, furnished me with a list of the New Jersey specimens in his collection, which largely supplemented the other lists. Mr. W. Julich, of New York, gave a most excellent list of Rhynchophora taken by himself. Mr. Fred. C. Paulmier, of Madison, N. J., furnished me a list of captures, which, though small in extent, was still valuable as adding facts in the distribution of some species. A few days spent in collecting at Anglesea, near Cape May, in company with Messrs. E. A. Schwarz, of Washington, and H. W. Wenzel, of Philadelphia, produced a large number of species which were kindly determined and listed by Mr. Sehwarz. Finally, to the courtesy of Dr. Horn I owe an opportunity of examining his 
extensive collection, and from this I obtained many records not on other lists. The list in Coleoptera is very fairly complete in most families. Mr. Samuel Henshaw, of Cambridge, also sent me a short list containing several species not elsewhere noted.

In Lepidopterc, the list furnished by the Newark society was the base. In the Rhopalocera, Mr. E. M. Aaron, of Philadelphia, gave me a most valuable list, and the records in the lists and works of Messrs. Strecker, Edwards and Scudder, supplemented by my own experience, have made this part of the list almost complete. Mr. Scudder's order of genera has been followed.

In the Sphingid and Zygenid families, my own works have been followed, and I believe the list to be nearly complete. In the balance of the Macro-Lepidoptera, Mr. Grote's list has been, in the main, followed; the Newark list being supplemented chiffiy by my own experience. In the Geometrida and Pyralide, Rev. Geo. D. Hulst, of Brooklyn, has furnished the material for the list almost as it stands. In the Tortricidce, Professor Fernald's catalogue has given me most of the information. In the Tineida, Mr. Wm. Bentenmuiller, of the American Museum of Natural History, has furnished the entire list, which is based almost exclusively upon his own collections and observation. Mr. Simon Seib, of Newark, gave me a list containing many dates, and this has been utilized as far as possible.

In the Diptera, Baron Osten-Sacken's catalogue has been my guide, supplemented in the Syrphidce by Dr. S. W. Williston's excellent monograph. Mr. Crane furnished me with a record of his captures in this order, and this, in addition to my own observations, gives a basis of fact to this part of the list.

In the Orthoptera, Mr. Lawrence Bruner, of Lincoln, Nebraska, has kindly furnished the list, which I have used exactly as he sent it, simply adding the records obtained from Mr. Crane and my own collecting. All the matter in brackets [ ] represents additions by myself.

In the Hemiptera-Heteroptera, Uhler's check list has been my guide, supplemented by Mr. Crane's records and my own collections.

In the Hemiptera-Homoptera, Mr. W. H. Ashmead, of Jacksonville, Fla., has kindly furnished the list, and very little, indeed, has been added to it by Mr. Crane's records and my own collecting.

In the Neuroptera, Dr. Hagen's synopsis has been my guide. Mr. Crane's list contained many species. I took many myself during the 
season. In running over the collection of the American Entomological Society I obtained a few records not otherwise obtainable.

The Thysanura have been entirely omitted, since there have been absolutely no collections made and no lists exist.

For much the same reasons all reference to the sub-class Arachnida. and Myriapoda has been omitted, though the Arachnida at least are well represented in the State.

Finally, I desire to thank, most sincerely, the gentlemen who by their courtesy and assistauce have enabled me to give to the present catalogue its measure of completeness.

CATALOGUE OF INSECTS.

\section{Family TENTHIREDINIDE.}

Sub-Family CIMBICIN

C. americana, Leach.

CIMBEX, Oliv.

Common at Caldwell-Crane.

TRICHIOSOMA, Leach.

T. triangulum, Kirby.

Z. americana, Cress.

ZARAIA, Leach.

Z. inflata, Norton.

A. cerasi, Fitch.

ABIA, Leach.

A. dorsalis, Say.

ACORDULECERA, Say.

S. ebenus, Norton.

Sub-Family HYLOTOMINA.

S. plumiger, Klug.

S. sericeus, Norton.

SCHIZOCERUS, Latr. 
ATOMACERA, Say.

A. ruficollis, Norton.

THEMOS, Norton.

T. hyaline, Norton.

HYLOTOMA, Latr.

H. abdominalis, Leach.

H. cœrulea, Norton.

H. humeralis, Beauv.

New Jersey specimens are in Mr. Cresson's collection.

H. moleayi, Leach.

H. pectoralis, Leach.

H. rubiginosa, Beaur.

H. rubra, Klug.

H. scapularis, Klug.

Rare at Caldwell_Crane.

\section{Sub-Family TENTHREDININIE.}

C. isomera, Harris.

CLADIUS, Illig.

PRIOPHORUS, Dablb.

P. æqualis, Norton.

PRISTIPHORA, Latr.

P. grossulariæ, Walsh.

P. identidem, Norton.

P. tibialis, Norton.

正. orbitalis, Norton.

EUURA, Newn.

F. salicis-nodus, Walsh.

झ. salicis-ovum, Walsh. 
C. latitarsus, Norton.

\author{
CR里SUS, Leach.
}

N. aureopectus, Norton.

NEMATUS, Jur.

N. bivittatus, Norton.

N. chloreus, Norton.

N. concolor, Norton.

N. corniger, Norton.

New Jersey specimens are in Mr. Cresson's collection.

N. erythrogaster, Norton.

N. fulvipes, Norton.

N. integer, Say.

New Jersey specimens are in Mr. Cresson's collection.

N. lateralis, Norton.

N. longulicornis, Norton.

N. luteolus, Norton.

N. luteotergum, Norton.

N. pallicornis, Norton.

N. proximatus, Norton.

N. ribesii, Scop.

I have taken this in the State, myself. It is the common currant slug. Common at Caldwell-Crane.

N. similaris, Norton.

N. subalbatus, Norton.

N. trilineatus, Norton.

N. trivittatus, Norton.

N. ventralis, Say.

New Jersey specimens are in Mr. Cresson's collection.

N. vertebratus, Say.

M. hyalina, Norton.

MESSA, Leach.

F. ambigua, Norton.

FENUSA, Leach. 
EMPHYTUS, Klug.

E. apertus, Norton.

E. cinctipes, Norton.

E. inornatus, Say.

E. mellipes, Norton.

HARPIPHORUS, Hartig.

H. maculatus, Norton.

H. semicornis, Say。

H, tarsatus, Say.

H. testaceus, Norton.

H. varianus, Norton.

B. versicolor, Norton.

DOLERUS, Jur.

D. abdominalis, Norton.

Taken at Caldwell by Mr. Crane.

D. albifrons, Norton.

Taken at Caldwell by Mr. Crane.

D. apricus, Norton.

I have taken this myself in New Jersey.

D. arvensis, Say.

I have taken this at New Brunswick, in early spring; not common.

D. bicolor, Beauv.

New Jersey specimens are in Mr. Cresson's collection.

D. collaris, Say.

D. maculicollis, Norton.

D. sericeus, Say.

D. similis, Norton.

D. unicolor, Beauv.

Taken at Caldwell by Mr. Crane. 


\section{BLENNOCAMPA, Hartig.}

B. capitalis, Norton.

B. pygmæa, Say.

I have taken this in New Jersey.

MONOPHADNUS, Hartig.

M. caryæ, Norton.

M. tiliæ, Norton.

New Jersey specimens are in Mr. Cresson's collection.

M. marginicollis, Norton.

M. medius, Norton.

Recorded from New Jersey.

M. rubi, Harris.

M. tiliæ, Norton.

PHYMATOCERA, Dahlb.

P. fumipennis, Norton.

New Jersey specimens are in Mr. Cresson's collection.

P. nubilipennis, Norton.

P. rudis, Norton.

HOPLOCAMPA, Hartig.

H. halcyon, Norton.

C. obsoleta, Norton.

CALIROA, Costa.

MONOSTEGIA, Costa.

M. ignota, Norton.

M. quercus-alba, Norton.

M. rosæ, Harris.

I have taken this in New Jersey.

E. cerasi, Peck.

ERIOCAMPA, Hartig.

I have seen this in the State.

๒. fasciata, Norton. 
S. Hlavipes, Norton.

\section{SELANDRIA, Leach.}

New Jersey specimens are in Mr. Cresson's collection.

S. media, Norton.

New Jersey specimens are in Mr. Cresson's collection.

A. basilaris, Say.

ALLANTUS, Jur.

I have taken this myself, not rarely.

L. originalis, Norton.

LABIDIA, Prov.

S. excavata, Norton.

SIOBLA, Cam.

\section{MACROPHYA, Dahlb.}

M. albomaculata, Norton.

M. epinota, Say.

M. externa, Say.

Taken by Mr. Crane, at Caldwell.

M. Alavicoxæ, Norton.

New Jersey specimens are in Mr. Cresson's collection.

M. formosa, Klug.

New Jersey specimens are in Mr. Cresson's collection.

M. fuliginea, Norton.

M. goniphora, Say.

M. incerta, Norton.

Mr. Cresson has specimeus from all surrounding States, and the species is almost certain to occur here.

M. intermedia, Norton.

M. nigra, Norton.

M. pannosa, Say.

M. pulchella, Klug.

Mr. Cresson has specimens from all surrounding States. 
M. tibiator, Norton.

New Jersey specimens are in Mr. Cresson's collection.

M. trisyllaba, Norton.

New Jersey specimens are in Mr. Cresson's collection.

M. trosula, Norton.

M. varia, Norton.

P. omega, Norton.

PACHYPROTASIS, Hartig.

TAXONUS, Hartig.

T. albidopictus, Norton.

T. dubitatus, Norton.

T. multicolor, Norton.

T. nigrisoma, Norton.

T. unicinctus, Norton.

S. apicalis, Say.

STRONGYLOGASTER, Dahlb.

S. epicera, Say.

S. mellosus, Norton.

S. pallidicornis, Norton.

S. pallipes, Say:

S. pinguis, Norton.

S. rufocinctus, Norton.

S. tacitus, Say.

S. terminalis, Say.

TENTEREDO, Linn.

T. angulata, Norton.

T. angulifera, Norton.

T. eximia, Norton.

T. flavomarginis, Norton.

T. grandis, Norton.

T. lineata, Prov.

T. lobata, Norton. 


\section{GEOLOGICAL SURVEY OF NEW JERSEY.}

T. mellina, Norton.

T. ruficolor, Norton.

T. ruflpes, Say.

T. rufopectus, Norton.

Taken at Caldwell by Mr. Crane; also in Mr. Cresson's collection from the State.

T. rufopediba, Norton.

T. signata, Norton.

T. tricolor, Norton.

T. verticalis, Say.

TENTHREDOPSIS, Costa.

T. atroviolacea, Norton.

Mr. Cresson has specimens from New Jersey.

T. confusa, Norton.

T. semilutea, Norton.

New Jersey specimens are in Mr. Cresson's collection.

\section{Sub-Family LYDINE.}

L. abbotii, Leach.

LOPHYRUS, Latr.

L. akhurstii, Norton.

Recorded from New Jersey only.

L. lecontei, Fitch.

L. apicalis, Westw.

LYDA, Fabr.

L. discolor, Cress.

L. excavata, Norton.

L. fasciata, Norton.

L. inconspicua, Norton.

L. luteicornis, Norton.

L. maculiventris, Norton. 
L. ocreata, Say.

L. pallimacula, Norton.

L. plagiata, Klug.

L. tesselata, Klug.

Sub-Family XYELIN死.

X. minor, Norton.

\author{
XYELA, Dalm.
}

\title{
Family UROCERIDE.
}

C. abbreviatus, Say.

CEPHUS, Latr.

C. integer, Norton.

C. trimaculatus, Say.

O. sayi, Westw.

ORYSSUS, Latr.

O. terminalis, Newn.

$\mathrm{X}$. abdominalis, Say.

XIPHYDRIA, Latr.

$\mathrm{X}$. albicornis, Harris.

X. attenuata, Norton.

New Jersey specimens are in Mr. Cresson's collection.

X. tibialis, Say.

U. abdominalis, Harr.

UROOERUS, Gөoff.

U. albicornis, Fabr.

U. cressoni, Norton.

New Jersey specimens are in Mr. Cresson's collection.

U. cyaneus, Fabr.

U. edwardsii, Brullé.

U. Hlavicornis, Fabr.

U. nigricornis, Fabr.

New Jersey specimens are in Mr. Cresson's collection. 
T. columba, Linn.

\author{
TREMEX, Jur.
}

Reported as injuring pear trees during the summer of 1889. I have taken it at Greenville and at New Brunswick. It occurs all over the State. Common at Caldwell-Crane.

\title{
Family CYNIPID瓜。
}

Sab-Family IBALIINAE.

I. ensiger, Norton.

IBALIA, Latr.

I. maculipennis, Hald.

\section{Sub-Family CYNIPIN E.}

R. bicolor, Harr.

REODITES, Hartig.

R. dichlocerus, Harr.

Taken at Caldwell by Mr. Crane.

R. ignota, O. S.

R. radicum, O.S.

R. rosæ, Linn.

R. verna, O.S.

D. nebulosus, O.S.

DIASTROPHUS, Hartig.

D. radicum, Bass.

D. similis, Bass.
A. ilicifoliæ, Bass.
AMPHIBOLIPS, Reinh.

A. inanis, O.S.

A. spongifica, O.S.

Taken at Caldwell by Mr. Crane. 

A. clavula, Bass.
ANDRICUS, Hartig.

A. cornigera, O. S.

A. seminator, Harris.

A. chinquapin, Fitch.

A. fusiformis, O. S.

A. tubicola, O. S.

C. batatus, Fitch.

$$
\text { CYNIPS, Linn. }
$$

B. nigra, Fitch.

BIORHIZA, Westw.

L. mammula, Bass.

LOXAULUS, Mayr.

H. globulus, Fitch.

HOLCASPIS, Mayr.

H. rugosa, Bass.

D. polita, Bass.

DRYOPHANTA, Först.

Recorded from New Jersey.

D. papula, Bass.

D. ignota, Bass.

N. majalis, Bass.

NEUROTERUS, Hartig.

N. saltatorius, H. Edw.

\section{Sub-Family INQUILIN IE.}

P. sylvestris, O.S.

\section{PERICLISTUS, Forst.}

C. petiolicola, O.S.

CEROPTRES, Hartig.

C. tuber, Fitch. 
S. campanula, O.S.

\author{
SYNERGUS, Hartig.
}

S. dimorphus, O.S.

S. læviventris, O.S.

S. lana, Fitch.

S. lignicola, O. S.

S. oneratus, Harris.

\title{
Sub-Family ALLOTRIINA.
}

A. avenæ, Fitch. ALLOTRIA, Westw.

A. tritici, Fitch.

\section{Sub-Family FIGITINA.}

E. pedata, Say.

EUCOILA, Westw.

F. impatiens, Say.

FIGITES, Latr.

\section{Family EVANIID E.}

A. fasciatus, Say.

AULACUS, Jur.

A. stigmaterus, Cress.

Recorded from New Jersey.

F. tarsatorius, Say.

FENUS, Fabr.

E. appendigaster, Linn.

EVANIA, Fabr.

H. reticulatum, Say.

HYPTIA, Illig.

Caldwell-Crane. 


\section{Family ICHNEUMONID 㕕.}

\section{Sub-Family ICHNEUMONIN A.}

I. acerbus, Cress.

ICHNEUMON, Linn.

I. agnitus, Cress.

I. annulatus, Prov.

I. annulipes, Cress.

I. apertus, Cress.

I. ater, Cress.

I. azotus, Cress.

I. brevicinctor, Say.

I. brevipennis, Cress.

I. bronteus, Cress.

I. cœruleus, Cress.

New Jersey specimens are in Mr. Cresson's collection.

I. centrator, Say.

I have taken this myself within New Jersey.

I. cincticornis, Cress.

I. citrifrons, Cress.

I. comes, Cress.

I. comptus, Say.

Taken at Caldwell by Mr. Crane.

I. confirmatus, Cress.

I. consignatus; Cress.

I. creperus, Cress.

I. devinctor, Say.

I. duplicatus, Say.

I have taken this myself in the State.

I. extrematatis, Cress.

I. feralis, Cress.

I. finitimus, Cress.

I. Havicornis, Cress.

I have taken this myself in the State.

I. Hlavizonatus, Cress. 
I. funestus, Cress.

I. fuscifrons, Cress.

I. galenus, Cress.

New Jersey specimens are in Mr. Cresson's collection.

I. germanus, Cress.

I. grandis, Brullé.

I. helvipes, Cress.

I. insolens, Cress.

I. instabilis, Cress.

Specimens from New Jersey are in Mr. Cresson's collection.

I. jejunus, Cress.

I. jucundus, Brullé.

I. lætus, Brullé.

New Jersey specimens are in Mr. Cresson's collection.

I. leucaniæ, Fitch.

I. leviculus, Cress.

I. lewisii, Cress.

I. libens, Cress.

New Jersey specimens are in Mr. Cresson's collection.

I. longulus, Cress.

I. maius, Cress.

I. malacus, Say.

Mr. Cresson has this from New Jersey.

I. merus, Cress.

I. milvus, Cress.

I. mimicus, Cress.

I. mucronatus, Prov.

I. munificus, Cress.

I. nanus, Cress.

New Jersey specimens are in Mr. Cresson's collection.

I. navus, Say.

I. nigratorius, Fabr.

I. orpheus, Cress.

I. otiosus, Say.

New Jersey specimens are in Mr. Cresson's collection. 
I. paratus, Say.

I. parvus, Cress.

I. pepticus, Cress.

Recorded from New Jersey and specimens are in Mr. Cresson's collection.

I. pomilius, Prov.

I. pulcher, Brullé.

I. residuus, Say.

I. rubicundus, Cress.

I. rufiventris, Brullé.

Specimens from New Jersey are in Mr. Cresson's collection.

I. saucius, Cress.

I. scitulus, Cress.

I. seminiger, Cress.

New Jersey specimens are in Mr. Cresson's collection.

I. signatipes, Cress.

I. sorror, Cress.

I. subcyaneus, Cress.

Taken at Caldwell by Mr. Crane.

I. subdolus, Cress.

I. sublatus, Cress.

I. succinctus, Brullé.

Common at Caldwell. I have taken or seen it everywhere in the State.

I. trogiformis, Cress.

New Jersey specimens are in Mr. Cresson's collection.

I. unifasciatorius, Say.

Taken at Caldwell by Mr. Crane.

I. utilis, Cress.

I. variegatus, Cress.

I. velox, Cress.

Mr. Cresson has it from New Jersey.

I. versabilis, Cress. 

I. vescus, Prov.
I. viola, Cress.
I. volens, Cress.
I. w-album, Cress.
I. wilsoni, Cress.
I. zebratus, Cress.

\section{HOPLISMENUS, Grav.}

H. morulus, Say.

New Jersey specimens are in Mr. Cresson's collection.

\section{AMBLYTELES, Wesm.}

A. anceps, Cress.

A. detritus, Brullé.

Specimens from New Jersey are in Mr. Cresson's collection.

A. excultus, Cress.

New Jersey specimens are in Mr. Cresson's collection.

A. fraternus, Cress.

A. improvisus, Cress.

Recorded from New Jersey, and specimens in Mr. Cresson's collection.

A. indistinctus, Prov.

A. luctus, Cress.

A. nubivagus, Cress.

A. ormenus, Cress.

A. rufizonatus, Cress.

Recorded from New Jersey, and specimen in Mr. Cresson's collection.

A. semicæruleus, Cress.

A. subrufus, Cress.

A. suturalis, Say.

Taken at Caldwell by:Mr. Crane. New Jersey specimens are also in Mr. Cresson's collection.

A. ultus, Cress. 
T. brullei, Cress.

TROGUS, Grav.

T. copei, Cress.

T. exesorius, Brullé.

Taken by me in New Jersey. Common near CaldwellCrane.

T. nubilipennis, Hald.

T. obsidianator, Brullé.

I have taken this in New Jersey near Montclair.

PLATYLABUS, Wesm.

P. thoracicus, Cress.

巴. agilis, Cress.

EURYLABUS, Wesm.

PHAOGENES, Wesm.

P. fungor, Norton.

P. hebe, Cress.

P. hebrus, Cress.

P. helvolus, Cress.

CENTETERUS, Wesm.

C. tuberculifrons, Prov.

COLPOGNATHUS, Wesm.

C. helvus, Cress.

Sub-Family CRYFTINA.

STILPNUS, Grav.

S. americanus, Cress.

P. vulgaris, Cress.

PHYGADEUON, Grav. 
C. alacris, Cress.

CRYPTUS, Fabr.

C. americanus, Cress.

C. contiguus, Cress.

C. extrematis, Cress.

C. limatus, Cress.

C. nuncius, Say.

C. persimilis, Cress.

C. semirufus, Brullé.

C. subclavatus, Say.

MESOSTENUS, Grav.

M. albomaculatus, Cress.

M. americanus, Cress.

M. thoracicus, Cress.

HEMITELES, Grav.

H. nemativorus, Walsh.

H. tenellus, Say.

H. utilis, Norton.

APTESIS, Först.

A. micropterus, Say.

P. dimidiatu's, Cress.

PEZOMACHUS, Grav.

P. gentilis, Cress.

P. gracilis, Cress.

P. macer, Cress,

P. obscurus, Cress.

Recorded from New Jersey only.

P. unicolor, Cress. 


\section{Sub-Family OPHIONINRE.}

O. bifoveolatum, Brullé.

OPHION, Fabr.

O. bilineatum, Say.

Not common at Caldwell-Crane. Specimens are in Cresson's collection from New Jersey.

O. glabratum, Say.

O. macrurum, Linn.

I have taken this in New Jersey myself. Common at Caldwell-Crane.

O. purgatum, Say.

I have taken this in New Jersey.

T. morio, Fabr.

THYREODON, Brullé.

NOTOTRACHYS, Marsh.

N. ejuncidus, Say.

EXOCHILUM, Wesm.

E. fuscipenne, Norton.

I have taken this not uncommonly in the State.

E. mundum, Say.

Common at .Caldwell_Crane.

HETEROPELMA, Wesm.

H. flavicornis, Brullé.

I have taken this in the State.

E. datanæ, Riley.

A. anale, Say.

ANOMALON, Grav.

A. curtum, Norton.

A. laterale, Brullé.

A. metallicum, Norton. 
26 GEOLOGICAL SURVEY OF NEW JERSEY.

A. nigritum, Norton.

A. nigrorufum, Norton.

A. prismaticum, Norton.

A. relictum, Fabr.

A. semirufum, Norton.

OPHELTES, Holmgr.

O. glaucopterus, Linn.

P. geminatus, Say.

PANISCUS, Grav.

Common at Caldwell-Crane.

C. alius, Norton.

CAMPOPLEX, Grav.

C. argenteus, Norton.

C. diversus, Norton.

LIMNERIA, Holm.

L. compressa, Cresson.

L. distincta, Cress.

Recorded from New Jersey only.

L. dubitata, Cress.

L. flaviricta, Cress.

L. fugitiva, Say.

L. major, Cress.

L. obscura, Cress.

L. oxylus, Cress.

L. subrubida, Cress.

Recorded from New Jersey.

L. tibiator, Cress.

Recorded from New Jersey.

L. valida, Cress.

L. vicina, Cress.

Recorded from New Jersey. 
MESOCHORUS, Grav.

M. americanus, Cress.

M. luteipes, Cress.

Recorded in the United States from New Jersey only.

M. melleus, Cress.

M. obliquus, Cress.

M. scitulus, Cress.

THERSILOCHUS, Holmgr.

T. conotracheli, Riley.

EXETASTES, Grav.

E. scutellaris, Cress.

CERATOSOMA, Cress.

C. fasciata, Cress.

\section{Sab-Family TRYPHONINA.}

M. bicolor, Cress.

$$
\text { MESOLEPTUS, Grav. }
$$

M. concolor, Cress.

Recorded in the United States from New Jersey only.

M. cultus, Cress.

Recorded from New Jersey only.

M. decens, Cress.

M. discolor, Cress.

M. flavifrons, Cress.

Recorded from New Jersey only.

M. fucatus, Cress.

M. honestus, Cress.

Recorded from New Jersey. 
M. peregrinus, Cress.

Recorded from New Jersey.

M. propinquus, Cress.

M. sedulus, Cress.

Recorded from New Jersey.

M. unicolor, Cress.

MESOLEIUS, Holmgr.

M. submarginatus, Cress.

T. affinis, Cress.

TRYPHON, Grav.

Recorded from New Jersey.

T. americanus, Cress.

T. analis, Cress.

T. capitatus, Cress.

T. communis, Cress.

T. pleuralis, Cress.

Recorded from New Jersey only.

GRYPOCENTRUS, Ruthe.

G. nasutus, Cress.

EUCEROS, Grav.

E. flavescens, Cress.

POLYBLASTUS, Hartig.

P. subcrassus, Cress.

ERROMENUS, Holmgr.

E. crassus, Cress.

Recorded from New Jersey.

E, dimidiatus, Cress.

Recorded from New Jersey. 
C. flavicoxæ, Cress.

CTENISCUS, Hal.

C. orbitalis, Cress.

EXYSTON, Schiödte.

上. clavatus, Cress.

FXOCHOIDES, Cress.

E. trifasciata, Cress.

\section{EXOCHUS, Grav.}

E. dorsalis, Cress.

Recorded from New Jersey only.

E. fulvipes, Cress.

E. propinquus, Cress.

E. semirufus, Cress.

B. agilis, Cress.

BASSUS, Grav.

B. frontalis, Cress.

B. sycophanta, Walsh.

METOPIUS, Grav.

M. pollinctorius, Say.

Sub-Family PIMPLIN 2 .

A. amœnus, Cress.

AROTES, Grav.

A. decorus, Say.

A. venustus, Cress.

R. albomaculata, Cr.

RHYSSA, Grav.

Mr. Cresson's collection contains New Jersey specimens.

R. persuasoria, Linn. 
T. atrata, Fabr.

\section{THALESSA, Holmgr.}

Common throughout the State. Caldwell-Crane.

T. lunator, Fabr.

Less common, but equally wide-spread.

T. nitida, Cress.

Has been taken on the Palisades near Fort Lee.

T. nortonii, Cress.

Rare at Caldwell-Crane.

E. albipes, Cress.

EPHIALTES, Grav.

Recorded from New Jersey.

E. irritator, Fabr:

E. rex, Kriech.

E. tuberculatus, Fourc.

\section{THERONIA, Holmgr.}

T. melanocephala, Brullé.

P. alboricta, Cress.

PIMPLA, Fabr.

P. annulicornis, Cress.

P. annulipes, Brullé.

I have taken this in New Jersey. Caldwell-Crane.

P. conquisitor, Say.

I have taken this in New Jersey.

P. indagatrix, Walsh.

P. inquisitor, Say.

I have seen this from the State. Not common at CaldwellCrane.

P. notanda, Cress.

Recorded from the State. Specimens with Mr. Cresson. 
P. pedalis, Cress.

Rare at Caldwell-Crane.

P. picticornis, Cress.

Recorded from the State. Specimens in Collection Cresson.

P. rufopectus, Cress.

P. rufovariata, Cress.

Recorded from the State. Specimens with Mr. Cresson.

P. scriptifrons, Cress.

P. tenuicornis, Cress.

Specimens from New Jersey are in Mr. Cresson's collection.

P. pterelas, Say.

Specimens from New Jersey are in Mr. Cresson's collection.

P. limata, Cress.

\section{POLYSPHINCTA, Grav.}

Recorded from New Jersey.

G. animosa, Cress.

GLYPTA, Grav.

G. erratica, Cress.

G. rufiscutellaris, Cress.

New Jersey specimens are in Mr. Cresson's collection.

G. scitula, Cress.

Recorded from New Jersey only. Specimen in Mr. Cresson's collection.

G. simplicipes, Cress.

G. vulgaris, Cress.

Specimens from New Jersey are in the Cresson collection.

A. nigrita, Walsh.

ARENETRA, Holmgr.

A. ventralis, Cress.

CYLLOCERIA, Schiötte.

C. occidentalis, Cress. 
L. agilis, Cress.

LAMPRONOTA, Curtis.

L. americana, Cress.

L. insita, Cress.

Recorded from New Jersey. Specimens with Mr. Cresson.

L. occidentalis, Cress.

L. parva, Cress.

L. pleuralis, Cress.

L. pulchella, Cress.

Recorded from New Jersey only. Specimens with Mr. Cresson.

L. punctulata, Cress.

L. rubrica, Cress.

New Jersey specimens are in the Cresson collection.

L. tegularis, Cress.

L. varia, Cress.

MENISCUS, Schiödte.

M. elegans, Cress.

M. mirabilis, Cress.

M. scutellaris, Cress.

PHYTODIETUS, Grav.

P. distinctus, Cress.

P. vulgaris, Cress.

EUXORIDES, Cress.

E. americanus, Cress.

XYLONOMUS, Grav.

X. albopictus, Cress.

$\mathrm{X}$. stigmapterus, Say.

ODONTOMERUS, Grav.

O. bicolor, Cress.

O. mellipes, Say.

New Jersey specimens are in Collection Cresson. 

L. grallator, Say.
LABENA, Cress.
G. anguina, Cress.
GROTEA, Cress.

\title{
Family STEPHANID FE.
}

M. rufipes, Say.

\author{
MECISCHUS, Brulló.
}

\section{Family BRACONIDFE.}

\section{Sub-Family BRACONINIE.}

B. dichrous, Brullé.

BRACON, Fabr.

B. erythrogaster, Brullé.

B. eurygaster, Brullé.

B. ligator, Say.

B. pectinator, Say.

B. simplex, Cress.

\section{Sub-Family HECABOLIN丑.}

H. 1ycti, Cress.

HECABOLUS, Curtis.

H. minimus, Cress.

H. utilis, Cress.

\section{Sub-Family RHOGADINAE.}

R. abdominalis, Cress.

RHOGAS, Nees.

New Jersey specimens are in the Cresson collection. 
R. aciculatus, Cress.

New Jersey specimens are in the Cresson collection.

R. burrus, Cress.

R. intermedius, Cress.

New Jersey specimens are in the Cresson collection.

R. lectus, Cress.

New Jersey specimens are in the Cresson collection.

R. terminalis, Cress.

Taken at Caldwell-Crane.

\section{Sab-Family SIGALPHIN死。}

S. curculionis, Fitch.

$$
\text { SIGALPHUS, Latr. }
$$

\section{Sub-Family CHELONINEE.}

PHANEROTOMA, Wesm.

P. tibialis, Hald.

C. basilaris, Say.

CHELONUS, Jur.

C. lunatus, Hald.

C. sericeus, Say.

C. sobrinus, Hald.

S. bicolor, Cress.

$$
\text { SPHAROPYX, Hal. }
$$

\section{Sub-Family MICROGASTERINÆ.}

A. acronyctæ, Riley.

$$
\text { APANTELES, Först. }
$$

I have bred this species during the present (1889) season. 


\section{CATALOGUE OF INSECTS.}

A. carpatus, Say.

A. congregatus, Say.

Occurs in New Jersey quite commonly.

A. limenitidis, Riley.

M. gortynæ, Riley.

MICROPLITIS, Först.

M. oleracea, Taylor.

MICROGASTER, Latr.

\section{Sub-Family AGATHIDIN 死.}

A. hæmatodes, Brullé.

AGATHIS, Latr.

New Jersey specimens are in the Cresson collection.

A. liberator, Brullé.

A. semirubra, Brullé.

New Jersey specimens are in the Cresson collection.

A. vulgaris, Cress.

Caldwell-Crane.

E. limitaris, Say.

EARINUS, Wesm.

M. annulipes, Cress.

MICRODUS, Nees.

M. earinoides, Cress.

M. imitatus, Cress.

Specimens from New Jersey are with Mr. Cresson.

M. simillimus, Cress.

New Jersey specimens are in the Cresson collection.

\section{Sab-Family EUPHORIN}

E. mellipøs, Cress.

FUPHORUS, Nees.

Recorded from New Jersey. Specimens in the Cresson collection. 


\section{Sub-Family METEORIN X.}

M. communis, Cress.

$$
\text { METEORUS, Hal. }
$$

Recorded from New Jersey. Specimens with Mr. Cresson.

M. dimidiatus, Cress.

New Jersey specimens are in Mr. Cresson's collection.

M. pallitarsis, Cress.

Recorded from New Jersey only. Specimens with Mr. Cresson.

M. vulgaris, Cress.

Specimens from New Jersey are in the Cresson collection.

\section{Sub-Family CALYPTINA.}

EUBADIZON, Nees.

F. americanus, Cress.

Recorded from New Jersey.

C. major, Cress.

$$
\text { CALYPTUS, Hal. }
$$

C. tibiator, Cress.

Recorded from New Jersey only. Specimens with Mr. Cresson.

T. populator, Say.

\section{Sub-Family TOXONEURINAE.}

TOXONEURA, Say.

T. tibiator, Say.

\section{Sab-Family HELCONINAE.}

H. dentipes, Brullé.

HELCON, Nees.

GYMNOSCELUS, Först.

G. americanus, Cress. 


\title{
Sub-Family MACROCENTRIN王.
}

MACROCENTRUS, Curtis.

M. delicatus, Cress.

\section{Sub-Family APHIDIIN压。}

P. avenaphis, Fitch.

PRAON, Hal.

P. polygonaphis, Fitch.

P. viburnaphis, Fitch.

T. triticaphis, Fitch.

TOXARES, Westw.

T. cerasaphis, Fitch.

TRIOXYS, Hal.

T. populaphis, Fitch.

T. salicaphis, Fitch.

A. lactucaphis, Fitch.

\section{APHIDIUS, Nees.}

\section{Family CHALCIDID}

\section{Sub-Family LEUCOSPIDIN Æ.}

L. affinis, Say.

\author{
LEUCOSPIS, Fabr.
}

Caldwell-Crane. Specimens in the Cresson collection, from New Jersey.

L. integra, Hald.

L. shuckardi, Westw.

\section{Sab-Family CHALCIDIN}

S. bracata, Sanb.

SMICRA, Spin.

Caldwell, rare-Crane. 
S. igneoides, Kirby.

S. maculata, Fabr.

S. mariæ, Riley.

S. microgaster, Say.

S. nigrifex, Wlk.

S. tourina, Cress.

C. flavipes, Fabr.

\section{CHALCIS, Fabr.}

New Jersey specimens are in Collection Cresson.

\section{PHASGONOPHORA, Westw.}

P. sulcata, Westw.

P. hyalinus, Say.

\section{Sub-Family PERILAMPINAE.}

PERILAMPUS, Latr.

$$
\text { Caldwell, common-Crane. }
$$

P. triangularis, Say.

P. violaceous, Dalm.

\section{Snb-Family EURYTOMINA.}

EURYTOMA, Illig.

E. diastrophi, Walsh.

F. lanulæ, Fitch.

E. studiosa, Say.

DECATOMA, Spin.

D. hyalipennis, Walsh.

D. varians, Walsh.

I. hordei, Harr.

ISOSOMA, Walk.

I. tritici, Riley.

I. vitis, Saund. 


\section{Sub-Family TORYMIN E.}

D. zabriskii, Cress

DIOMORUS, WIk.

T. æa, Wlk.

TORYMUS, Dalm.

T. chrysochlora, O.S.

T. harrisii, Fitch.

T. tubicola, O. S.

Sub-Family EUPELMINE.

Æ. allynii, French.

EUPELMUS, Dalm.

Sub-Family ENCYRTINA.

R. coccois, Smith.

RHOPUS, Först.

A. brunneus, Howard.

APHYCUS, Mayr.

Recorded from New Jersey only.

ENCYRTUS, Dalm.

E. bucculatricis, Howard.

E. turni, Pack.

COPIDOSOMA, Ratz.

C. gelechiæ, Howard.

C. intermedium, Howard.

Recorded from New Jersey.

C. truncatellum, Dalm.

CHILONEURUS, Westw.

C. albicornis, Howard. 
40. GEOLOGICAL SURVEY OF NEW JERSEY.

Sub-Family APHELININ正.

C. ater, Howard.

COCCOPHAGUS, Westw.

C. lecanii, Fitch.

A. mali, Hald.

APHELINUS, Dalm.

A. mytilaspidis, Le B.

Snb-Family PIRENIN正.

MACROGLENES, Westw.

M. querci-globuli, Fitch.

M. querci-pisi, Fitch.

\section{Sub-Family TRIDYMINE.}

SEMIOTELLUS, Westw.

S. chalcidephagus, Walsh.

S. clisiocampæ, Fitch.

Sab-Family SPALANGINAE.

SPALANGIA, Latr.

S. querci-lanæ, Fitch.

Sub-Family PTEROMALINA.

M. destructor, Say.

MERISUS, Wlk.

P. gelechiæ, Webst.

PTEROMALUS, Swed.

P. onerati, Fitch. 
P. puparum, Linn.

P. querci-pilulæ, Fitch.

P. tabacum, Fitch.

\section{Sub-Family ELACHISTINAE.}

EUPLECTRUS, Westw.

E. catocalæ, Howard.

E. comstockii, Howard.

E. plathypenæ, Howard.

\section{Sab-Family EULOPHINE.}

EULOPHUS, Geoff.

E. theclæ, Pack.

Snb-Family TRICHOGRAMMIN AE.

TRICEOGRAMMA, Westw.

T. fraterna, Fitch.

T. odontotæ, Howard.

T. orgyiæ, Fitch.

T. pretiosa, Riley.

\section{Family PROCTOTRUPID互.}

Sub-Family BETHYLINA.

SCLEROCHROA, Först.

S. thoracica, Westw.

\section{Sub-Family CERAPHRONIN死.}

C. triticum, Taylor.

CERAPHRON, Jur. 


\section{Sub-Family SCELIONIN XE.}

TELENOMUS, Bal.

T. bifldus, Riley.

T. orgyiæ, Fitch.

Sub-Family PLATYGASTRINA.

P. error, Fitch.

PLATYGASTER, Latr.

Sub-Family MYMARINA.
A. aleurodinus, Hald.
AMITUS, Hald.
E. corni, Hald.
ERETMOCERUS, Hald.

Sab-Family DIAPRIN臣.

COPTERA, Say.

C. polita, Say.

DIAPRIA, Latr.

D. apicalis, Say.

\section{Family PELECINIDA.}

P. polyturator, Dru.

PELECINUS, Latr.

Caldwell, common-Crane. Occurs throughout New Jersey quite commonly. 


\section{Family CHRYSIDID王.}

\section{Sub-Family ELAMPIN}

O. coruscans, Norton.

OMALUS, Panz.

O. iridescens, Norton.

O. læviventris, Cress.

O. sinuosus, Say.

N. marginatus, Patton.

NOTOZUS, Först.

N. viridicyaneus, Norton.

HEDYCHRIDIUM, Perrin.

H. dimidiatum, Say.

H. viride, Cress.

HEDYCHRUM, Latr.

H. obsoletum, Say.

ㅍ. violaceum, Brullé.

\section{Snb-Family CHRYSIDINA.}

C. cœruleans, Fabr. CHRYSIS, Linn.

New Jersey specimens are with Mr. Cresson.

C. frey-gessneri, Grib.

C. hilaris, Dahlb.

C. inæquidens, Dahlb.

C. intricata, Brullé.

C. nitidula, Fabr.

C. nortoni, Aaron.

C. parvula, Fabr.

Not common at Caldwell-Crane.

C. smaragdula, Fabr.

C. tota, Aaron.

C. verticalis, Patton. 


\section{Family FORIMICID瓜.}

C. atriceps, Smith.

\section{CAMPONOTUS, Mayr.}

C. castaneus, Latr.

Caldwell-Crane.

C. esuriens, Smith.

Caldwell-Crane.

C. herculaneus, Smith.

Caldwell-Crane.

C. lateralis, Latr.

C. marginatus, Latr.

Caldwell-Crane.

C. pubescens, Fabr.

C. sylvaticus, Oliv.

P. lucidus, Mayr.

POLYERGUS, Latr.

F. exsectoides, Forel.

FORMICA, Linn.

F. fusca, Linn.

Caldwell-Crane.

F. gnava, Buck.

F. gracilis, Buck.

F. integra, Nyl.

Caldwell-Crane. Also in Cresson collection.

F. occidentalis, Buck.

F. pallidefulva, Latr.

Recorded from New Jersey.

F. pratensis, De G.

F. rufa, Linn.

Caldwell, common-Crane. I have seen this not uncommon throughout the State.

F. sanguinea, Latr.

New Jersey specimens are in the Cresson collection. 


\section{CATALOGUE OF INSECTS.}

F. schaufussi, Mayr.

Caldwell, common-Crane.

F. truncicola, Nyl.

\section{LASIUS, Fabr.}

L. brunneus, Latr.

L. claviger, Roger.

Caldwell-Crane.

L. flavus, De G.

Caldwell-Crane.

L. interjectus, Mayr.

Caldwell-Crane.

L. niger, Linn.

Caldwell, common-Crane.

L. umbratus, Nyl.

Caldwell, common-Crane.

B. heeri, Forel.

$$
\text { BRACHYMYRMEX, Mayr. }
$$

PRENOLEPIS, Mayr.

P. nitens, Mayr.

Caldwell-Crane.

P. vividula, Nyl.

DORYMYRMEX, Mayr.

D. pyramicus, Roger.

TAPINOMA, Först.

T. sessile, Say.

Caldwell, common-Crane.

DOLICHODERUS, Lund.

D. mariæ, Forel.

Recorded from New Jersey.

D. postulatus, Mayr.

Recorded from New Jersey. 


\section{Family PONERIDE.}

P. contracta, Latr.

PONERA, Latr.

P. gilva, Roger.

P. pennsylvanica, Buck.

D. testacea, Roger.

DISCOTHYREA, Roger.

AMBLYOPONE, Erich.

A. pallipes, Hald.

\section{Family MYRMICID王。}

A. tardigrada, Buck.

ATTA, Fabr.

Recorded from New Jersey.

A. fulva, Roger.

APHANOGASTER, Mayr.

Caldwell-Crane.

A. pennsylvanica, Buck.

A. treatæ, Forel.

Recorded from New Jersey. Specimen with Mr. Cresson.

POGONOMYRMEX, Mayr.

P. transversus, Mayr.

Caldwell-Crane. Heretofore only recorded from Florida and Georgia.

M. dimidiata, Say.

MYRMICA, Latr.

M. lævinodis, Nyl.

M. opposita, Say. 
M. punctiventris, Roger.

Recorded from New Jersey.

M. scabrinodis, Nyl.

Caldwell-Crane.

M. sulcinodis, Nyl.

Recorded from New Jersey.

TETRAMORIUM, Mayr.

T. cæspitum, Linn.

STENAMMA, Westw.

S. neoarcticum, Mayr.

M. latreillii, Curtis.

MYRMECINA, Curtis.

M. minutum, Mayr.

MONOMORIUM, Mayr.

M. molesta, Say.

M. pharaonis, Linn.

P. morrisi, Forel.

PHEIDOLE, Westw.

P. pennsylvanica, Roger.

P. vinelandica, Forel.

Recorded from New Jersey.

S. debilis, Mayr.

SOLENOPSIS, WestW.

Recorded from New Jersey.

S. fugax, Latr.

Caldwell-Crane.

S. madara, Roger.

S. sulfurea, Roger.

CREMASTOGASTER, Lund.

C. læviuscula, Mayr.

C. lineolata, Say.

Caldwell-Crane.

C. scutellaris, Oliv. 


\section{Family MUTILIDA.}

M. bifasciata, Swed.

\section{MUTILLA, Linn.}

M. dubitata, Smith.

Westville-Cresson.

M. hexagona, Say.

M. ornativentris, Cress.

Westville-Cresson.

M. rufa, St. Farg.

M. scrupea, Say.

M. thoracica, Blake.

SPH开ROPHTHALMA, Blake.

S. balteola, Blake.

S. canadensis, Blake.

Westville-Cresson.

S. cypris, Blake.

Westville-Cresson.

S. fenestrata, St. Farg.

S. ferrugata, Fabr.

Caldwell, rare-Crane. Westville-Cresson.

S. macra, Cress.

New Jersey specimens are in the Cresson collection. It l as heretofore been recorded from Texas only.

S. mutata, Blake.

Westville-Cresson.

S. occidentalis, Linn.

Westville-Cresson.

S. pennsylvanica, St. Farg.

S. scærola, Blake.

Caldwell, common-Crane. Westville-Cresson.

S. simillima, Smith.

Caldwell, common-Crane.

M. unicolor, Say.

MYRMOSA, Latr. 


\section{Family SCOLIID王.}

T. inornata, Say.

TIPHIA, Fabr.

Caldwell, common-Crane. New Brunswick; not common.

M. ephippium, Fabr.

MYZINE, Latr.

M. hæmorrhoidalis, Fabr.

M. interrupta, Say.

Westville-Cresson.

M. marginata, Say.

M. obscura, Fabr.

Westville-Cresson.

M. sexcincta, Fabr.

I have taken this commonly in New Jersey.

S. bicincta, Fabr.

SCOLIA, Fabr.

Westville-Cresson.

S. dubia, Say.

Westville-Cresson.

S. nobilitata, Fabr.

E. plumipes, Dru.

ELIS, Fabr.

Caldwell-Crane.

E. quadrinotata, Fabr.

New Jersey specimens are in Mr. Cresson's collection.

E. trifasciata, Fabr.

\section{Family POMPILID E.}

P. æthiops, Cress.

\section{POMPILUS, Fabr.}

Caldwell, not common-Crane. 
P. americanus, Beauv.

Caldwell, rare-Crane.

P. atramentarius, Dahlb.

P. atrox, Dahlb.

Caldwell, not common-Crane.

P. biguttatus, Fabr.

New Jersey specimens are in the Cresson collection.

P. bipartitus, St. Farg.

P. brevicornis, Cress.

P. cylindricus, Cress.

P. ephippiger, Smith.

P. ferrugineus, Say.

P. funereus, St. Farg.

P. humilis, Cress.

P. ingenuus, Cress.

P. interruptus, Cress.

P. marginatus, Say.

New Jersey specimens are in the Cresson collection.

P. maurus, Cress.

P. philadelphicus, St. Farg.

P. scelestus, Cress.

P. subviolaceus, Cress.

P. tenebrosus, Cress.

P. tropicus, Linn.

New Jersey specimens are in the Cresson collection.

P. virginiensis, Cress.

\section{PRIOCNEMIS, Schiödte.}

P. alienatus, Smith.

New Jersey specimens are in the Cresson collection.

P. conicus, Say.

P. fortis, Cress.

P. fulvicornis, Cress.

P. germanus, Cress. 
P. maculipennis, Smith.

P. nebulosus, Dahlb.

P. pompilius, Cress.

Recorded from New Jersey. Specimens in Collection Cresson.

P. subopacus, Cress.

P. unifasciatus, Say.

AGENIA, Schiödte.

A. architecta, Say.

A. bombycina, Cress.

Caldwell-Crane.

A. calcarata, Cress.

A. iridipennis, Cress.

Recorded from New Jersey.

A. mellipes, Say.

A. pulchripennis, Cress.

P. niger, Cress.

PLANICEPS, Latr.

C. bipunctata, Say.

CEROPALES, Latr.

Caldwell, rare-Crane.

C. fraterna, Smith.

C. longipes, Smith.

PEPSIS, Fabr.

P. elegans, St. Farg.

Family SPHECID ZE.

A. arvensis, St. Farg.

AMMOPHILA, Kirby.

A. conditor, Smith.

A. gracilis, St. Farg.

Caldwell, rare-Crane. 
A. gryphus, Snith.

Caldwell, common-Crane.

A. intercepta, St. Farg.

Westville-Cresson.

A. procera, Klug.

A. urnaria, Klug.

Caldwell, not common-Crane.

A. violaceipennis, St. Farg.

P. cementarius, Dru.

PELOPGUS, Latr.

Caldwell, common-Crane. Westville-Cresson.

C. cæruleum, Linn.

CEALYBION, Dahlb.

C. cæruleum, Dru.

CHLORION, Latr.

Caldwell, common-Crane.

ISODONTIA, Patton.

I. philadelphica, St. Farg.

Caldwell-Crane. Westville-Cresson.

I. tibalis, St. Farg.

Caldwell, not common-Crane. Westville-Cresson.

S. crœesus, St. Farg.

\section{SPEEX, Linn.}

S. dimidiata, St. Farg.

S. ichneumonea, Linn.

Common everywhere in New Jersey. Caldwell-Crane.

S. instabilis, Smith.

S. pennsylvanica, Linn.

Common everywhere in New Jersey.

S. violaceipennis, St. Farg. 
P. atrata, St. Farg.

PRIONONYX, Dahlb.

Caldwell, not common-Crane.

P. thomæ, Fabr.

Westville-Cresson.

\section{Family AMPULICID瓜.}

RHINOPSIS, Westw.

R. canaliculata, Say.

\section{Family LARRIDE.}
A. bicolor, Say.
ASTATA, Latr.

New Jersey specimens are in the Cresson collection.

A. unicolor, Say.

Westville-Cresson.

L. subita, Say.

\section{LYRODA, Say.}

Westville-Cresson.

L. analis, Fabr.

\section{LARRA, Latr.}

L. argentata, Beauv.

Westville-Cresson.

L. distincta, Smith.

Westville-Cresson.

L. pennsylvanica, Beauv.

Westville-Cresson.

L. terminata, Smith. 
T. aurulentus, Fabr.

TACHYTES, Panz.

T. distinctus, Smith.

T. mandibularis, Patton.

Westville-Cresson.

\section{Family BEMBECID E.}

S. speciosus, Dru.

SPHECIUS, Dahlb.

Not uncommon throughout New Jersey. Caldwell, common -Crane.

S. servillii, St. Farg.

STIZUS, Latr.

B. americana, Fabr.

BEMBEX, Fabr.

B. fasciata, Fabr.

MICROBEMBEX, Patton.

M. monodonta, Say.

Caldwell, common-Crane.

M. carolina, Fabr.

MONEDULA, Latr.

M. quadrifasciata, Say.

M. ventralis, Say.

\section{Family NYSSONID王.}

G. nebulosus, Pack.

GORYTES, Latr.

Recorded from New Jersey.

HOPLISUS, St, Farg.

H. fulvipennis, Smith. 
EUSPONGUS, St. Farg.

E. bipunctatus, Say.

ALYSON, Jur.

A. melleus, Say.

Recorded from New Jersey. Specimens in Cresson collection

A. oppositus, Say.

Westville-Cresson.

N. lateralis, Pack.

NYSSON, Latr.

N. opulentus, Gerts.

\section{Family PHILANTHIDE.}

PHILANTHUS, Fabr.

P. barbatus, Smith.

P. bilunatus, Cress.

P. dubius, Cress.

P. politus, Say.

Westville-Cresson.

P. punctatus, Say.

Caldwell, common-Crane. Westville-Cresson.

P. solivagus, Say.

P. ventilabris, Cress.

EUCERCERIS, Cress.

E. laticeps, Cress.

E. zonatus, Say.

C. bicornuta, Giner.

CERCERIS, Latr.

C. clypeata, Dahlb.

C. compacta, Cress.

Cald well-Crane.

C. dentrifrons, Cress. 
C. deserta, Say.

Caldwell, common-Crane. Common everywhere in the State.

C. fumipennis, Say.

Westrille-Cresson.

C. venator, Cress.

Westville-Cresson. Other specimens in Cresson collection, from other parts of New Jersey.

\section{Family MIMESID}

M. cressonii, Pack.

MIMESA, Shuck.

Recorded from New Jersey. Specimens in the Cresson collection.

M. denticulata, Pack.

M. pauper, Pack.

Westville-Cresson.

P. leucopus, Say.

PSEN, Latr.

P. niger, Pack.

\section{Family PEMPHREDONID EE.}

S. pusilla, Say.

$$
\text { SPILOMENA, Shuck. }
$$

STIGMUS, Jur.

S. americanus, Pack.

S. fraternus, Say.

C. inornatus, Pack.

CEMONUS, Jur.

New Jersey specimens are in the Cresson collection. 
P. concolor, Say.

PEMPHREDON, Latr.

P. marginatus, Say.

P. annulatus, Say.

PASSALGCUS, Shuck.

P. mandibularis, Cress.

\section{Family CRABRONIDEE.}

T. clavatum, Say.

TRYPOXYLON, Latr.

T. frigidum, Smith.

New Jersey specimens are in the Cresson collection.

T. pennsylvanicum, Sauss.

T. politum, Say.

Caldwell-Crane. Westville-Cresson.

T. rubrocinctum, Pack.

Westville-Cresson.

T. tridentatum, Pack.

Recorded from New Jersey.

\section{REOPALUM, Kirby}

R. pedicellatum, Pack.

C. ater, Cress.

CRABRO, Fabr.

C. brunneipes, Pack.

C. chrysarginus, St. Farg.

C. decim-maculatus, Say.

Caldwell, common-Crane.

C. denticulatus, Pack.

C. effossus, Pack.

C. frigidus, Smith. 
O. interruptus, St. Farg.

New Jersey specimens are in the Cresson collection.

C. maculatus, Fabr.

C. obscurus, Smith.

New Jersey specimens are in the Cresson collection.

C. pauper, Pack.

C. producticollis, Pack.

Recorded from New Jersey only: Specimens in the Cresson collection.

O. quadrangularis, Pack.

C. sex-maculatus, Say.

Caldwell, common-Crane.

C. singularis, Smith.

Westville-Cresson.

C. stirpicola, Pack.

Recorded from New Jersey by Packard. Specimens in the Crfsson collection.

C. trapezoideus, Pack.

Westville-Cresson.

C. villosifrons, Pack.

Recorded from New Jersey by Packard. Specimens in the Cresson collection.

T. advenus, Smith.

THYREOPUS, St. Farg.

T. cribrellifer, Pack.

T. latipes, Smith.

T. tumidus, Pack.

Westville-Cresson.

A. ocellatus, Pack.

ANACRABRO, Pack.

Westville-Cresson.

O. emarginatus, Say.

OXYBELUS, Latr.

Specimens from New Jersey are in the Cresson collection. 
O. mucronatus, Pack.

Caldwell-Crane.

O. quadri-notatus, Say.

Sperimens from New Jersey are in the Cresson collection.

\section{Family EUMENID王.}

Z. spinipes, Say.

ZETHUS, Fabr.

Caldwell-Crane.

Đ. agilis, Sauss.

EUMENES, Latr.

E. fraternus, Say.

Caldwell, common-Crane.

E. globulosus, Sauss.

New Jersey specimens are in the Cresson collection.

M. quadridens, Linn.

MONOBIA, Sauss.

Caldwell, common-Crane.

NORTONIA, Sauss.

N. symmorpha, Sauss.

Caldwell, not common-Crane.

ODYNERUS, Latr.

O. albomarginatus, Sauss.

O. albophaleratus, Sauss.

Westville-Cresson.

O. annulatus, Say.

O. anormis, Say.

O. arvensis, Sauss.

O. birenimaculatus, Sauss.

O. boscii, St. Farg. 
O. campestris, Sauss.

O. capra, Sauss.

Caldwell, not common-Crane.

O. conformis, Sauss.

O. debilis, Sauss.

O. dorsalis, Sauss,

O. foraminatus, Sauss.

Caldwell, not common-Crane. Westville-Cresson.

O. fulvipes, Sauss.

O. huro, Sauss.

O. leucomelas, Sauss.

O. megæra, St. Farg.

Caldwell-Crane.

O. pedestris, Sauss.

Caldwell, not common-Crane.

O. pennsylvanicus, Sauss.

Westville-Cresson.

O. perennis, Sauss.

New Jersey specimens are in the Cresson collection.

O. philadelphiæ, Sauss.

Caldwell-Crane.

O. quadrisectus, Say.

O. spinolæ, Stuuss.

O. tigris, Sauss.

Caldwell, not common-Crane. Westville-Cresson.

O. turpis, Sauss.

O. unifasciatus, Sauss.

Caldwell, common-Crane.

O. vagus, Sauss.

\section{Family VESPID E.}

P. annularis, Linn.

POLISTES, Latr.

P. instabilis, Sauss. 
P. metricus, Say.

Caldwell, common-Crane. Common everywhere in the State.

P. nestor, Fabr.

P. pallipes, St. Farg.

Common everywhere in the State.

P. rubiginosus, St. Farg.

P. variatus, Cress.

New Jersey specimens are in the Cresson collection.

VESPA, Linn.

V. arenaria, Fabr.

$\nabla$. borealis, Kirby.

Caldwell, common-Crane.

V. crabro, Linn.

Caldwell, not common-Crane.

$\nabla$. carolina, Dru.

V. communis, Sauss.

V. cuneata, Fabr.

$\nabla$. diabolica, Sauss.

Westville-Cresson.

V. germanica, Fabr.

I have taken this everywhere in New Jersey. Caldwell, common-Crane.

$\nabla$. infernalis, Sauss.

V. maculata, Linn.

Common everywhere in the State. Caldwell, common-Crane.

V. pennsylvanica, Sauss.

$\nabla$. serripes, Fabr.

V. vidua, Sauss.

Westville-Cresson.

V. vulgaris, Linn.

Caldwell, not common-Crane. 


\section{Family ANDRENIDE.}

C. americana, Cress.

COLLETES, Latr.

C. compacta, Cress.

C. inæqualis, Say.

C. propinqua, Cress.

o. valida, Cress.

PROSOPIS, Fabr.

P. affinis, Smith.

Caldwell-Crane.

P. antennata, Cress.

Recorded from New Jersey only.

P. modestus, Say.

P. sparsa, Cress.

P. verticalis, Cress.

SPEECODES, Latr.

S. arvensis, Patton.

S. dichroa, Smith.

Caldwell-Crane.

S. falcifer, Patton.

HALICTUS, Latr.

H. albitarsis, Cress.

H. imitatus, Smith.

H. ligatus, Say.

Caldwell, common-Crane.

H. pilosus, Smith.

AUGOCHLORA, Smith.

A. fervida, Smith.

A. purus, Say.

Caldwell, common-Crane.

A. vividula, Smith. 


\section{AGAPOSTEMON, Smith.}

A. nigricornis, Fabr.

Caldwell, not common-Crane.

A. pulchra, Smith.

A. radiatus, Say.

A. sericea, Först.

ANDRENA, Fabr.

A. fimbriata, Smith.

A. fragilis. Smith.

A. hilaris, Smith.

A. integra, Smith.

A. perplexa, Smith.

A. placida, Smith.

A. simplex, Smith.

A. valida, Say.

O. americana, Smith.

CILISSA, Leach.

\section{Family APIDA.}

CALLIOPSIS, Smith.

C. andreniformis, Smith.

C. pauper, Cress.

\section{PERDITA, Smith.}

P. octomaculata, Say.

Westville-Cresson. New Jersey specimens also in Cresson collection.

N. affabilis, Cress.

NOMADA, Fabr.

N. articulata, Smith.

N. bisignata, Say.

Caldwell, not common-Crane. 
N. electa, Cress.

N. festiva, Cress.

Recorded from New Jersey only. Specimens in Collection Cresson.

N. imbricata, Smith.

N. incerta, Cress.

New Jersey specimens are in the Cresson collection.

N. luteola, St. Farg.

New Jersey specimens are in the Cresson collection.

N. modesta, Cress.

N. placida, Cress.

N. ruficornis, Linn.

N. texana, Cress.

Westville-Cresson.

N. torrida, Smith.

N. vespiformis, Först.

N. vincta, Say.

New Jersey specimens are in the Cresson collection.

EPEOLUS, Latr.

E. concavus, Cress.

E. donatus, Smith.

Westville-Cresson.

E. fumipennis, Say.

E. lunatus, Say.

Westville-Cresson. Also in Cresson collection, from New Jersey.

E. mercatus, Fabr.

E. remigatus, Fabr.

Westville-Cresson.

C. alternata, Say.

CGLIOXYS, Latr.

C. altilis, Cress.

New Jersey specimens are in the Cresson collection. 
C. dubitata, Smith.

C. lateralis, Cress.

C. lucrosa, Cress.

C. modesta, Smith.

C. mosta, Cress.

C. 8-dentata, Say.

Caldwell, rare-Crane.

C. rufitarsis, Smith.

C. sodalis, Cress.

O. albiventris, Cress.

OSMIA, Panz.

Caldwell-Crane. New Jersey specimens are in Collection Cresson.

O. atriventris, Cress.

New Jersey specimens are in Collection Cresson.

O. cognata, Cress.

O. faceta, Cress.

O. frigida, Smith.

O. latitarsis, Cress.

O. lignaria, Say.

Caldwell, rare-Crane. New Jersey specimens are in Collection Cresson.

O. purpurea, Cress.

O. rustica, Cress.

O. vicina, Cress.

O. simillima, Smith.

Caldwell, common-Crane.

B. carinatum, Cress.

HERIADES, Spin.

New Jersey specimens are in Collection Cresson.

H. variolosum, Cress. 
A. producta, Cress.

\section{ALCIDAMEA, Cress.}

Caldwell-Crane. New Jersey specimens are in Collection Cresson.

A. notatum, Latr.

\section{ANTHIDIUM, Fabr.}

New Jersey specimens are in Collection Cresson.

M. addenda, Cress.

\section{MEGACHILE, Latr.}

New Jersey specimens are in the Cresson collection.

M. brevis, Say.

Caldwell, common-Crane.

M. exilie, Cress.

New Jersey specimens are in the Cresson collection.

M. frigida, Smith.

Westville-Cresson.

M. latimanus, Say.

Caldwell, common-Crane. Westville-Cresson.

M. melanophæa, Smith.

Westville-Cresson.

M. mendica, Cress.

Caldwell, not common-Crane. Westville-Cresson.

M. montivaga, Cress.

M. morio, Smith.

M. optiva, Cress.

M. perbrevis, Cress.

New Jersey specimens of this species, heretofore recorded only from Texas, are in the Cresson collection.

M. pruina, Smith.

M. pugnata, Say.

New Jersey spccimens are in the Cresson collection.

M. relativa, Cress.

M. sayi, Cress. 
C. dupla, Say.

\author{
CERATINA, Latr.
}

Caldwell, not common-Crane. Westville-Cresson.

\title{
MELISSODES, Latr.
}

M. aurigenia, Cress.

M. bimaculata, St. Farg.

Westville, common-Cresson.

M. compta, Cress.

Westville-Cresson.

M. dentiventris, Smith.

M. desponsa, Smith.

New Jersey specimens are in the Cresson collection.

M. obliqua, Say.

M. pennsylvanica, St. Farg.

M. rustica, Say.

Westville-Cresson.

\section{XENOGLOSSA, Smith,}

X. pruinosa, Say.

EMPHOR, Patton.

E. bombiformis, Cress.

ENTECHNIA, Patton.

E. taurea, Say.

ANTHOPHORA, Latr.

A. abrupta, Say.

Caldwell, common-Crane.

A. bomboides, Kirby.

A. pyralitarsis, Dours.

XYLOCOPA, Latr.

X. virginica, Dru.

Common all over the State. 
A. ashtoni, Cress.

\section{APATHUS, Newn.}

Caldwell-Crane.

A. citrinus, Smith.

A. elatus, Fabr.

Caldwell-Crane.

A. laboriosus, Fabr.

Caldwell-Crane.

B. affinis, Cress.

BOMBUS, Latr.

Greenwood Lake, rare-Crane.

B. borealis, Kirby.

B. carolinus, Linn.

B. consimilis, Cress.

Caldwell, not common-Crane.

B. fervidus, Fabr.

B. pennsylvanicus, De G.

Caldwell, common-Crane.

B. ridingsii, Cress.

B. separatus, Cress.

Caldwell, common-Crane.

B. ternarius, Say.

B. terricola, Kirby.

B. vagans, Smith.

Caldwell, rare-Crane.

B. virginicus, Oliv.

Caldwell, common-Crane.

A. mellifica, Linn.

APIS, Linn.

Common everywhere in New Jersey. 


\section{Order coleoptera.}

\section{Family CICINDELID五.}

C. unipunctata, Fabr.

\section{CICINDELA, Linn.}

Atco, Woodstown, rare-Liebeck. Gloucester county, rareWenzel.

C. modesta, Dej.

Gloucester, Camden and Atlantic counties, Jocally commonWenzel. Gloucester, Egg Harbor, moderately abundant-Liebeck. Brigantine Beach, mainland-Hamilton. Newark. I have taken it at Greenville, and in Ocean county. The species is very local, but usually not rare where it occurs. It appears in May, and again in September.

C. sexguttata, Fabr.

Gloucester, Camden and Atlantic counties, common-Wenzel. Generally distributed-Liebeck. Newark. Madison. This species occurs rather commonly all over the State, and frequents woods rather than open sand.

Var. consentanea, Dej.

Atco, rare-Liebeck. Brigantine Beach, mainland, abundant - Hamilton. This is usually extremely rare and quite different from the typical form.

Var. patruela, Dej.

Specimens from New Jersey are in Dr. Horn's collection.

C. purpurea, Oliv.

Generally distributed, moderately abundant-Liebeck. Gloucester, Camden and Atlantic counties, not common-Wenzel. Caldwell-Crane. Newark. Madison. I have found this in Ocean county and near Jersey City, along roads in sandy meadows.

C. ancocisconensis, Harris.

Caldwell, rare, one specimen only taken-Crane. 
C. generosa, Dej.

Gloucester, Camden and Atlantic counties, common locallyWenzel. Gloucester, moderately abundant-Liebeck. Newark, Ocean county, Greenville-Smith. Brigantine Beach, in September, abundant-Hamilton. Also rather local, but quite generally distributed.

C. vulgaris, Say.

Gloucester, Camden and Atlantic counties, common-Wenzel. Generally distributed, moderately abundant-Liebeck. Brigantine Beach, in September, abundant-Hamilton. Caldwell, common-Crane. Not on the Newark list, and I have not myself taken it.

C. repanda, Dej.

Common everywhere. Reported on all lists and everywhere as abundant. I have seen it in all parts of the State visited.

Var. 12-guttata, Dej.

Gloucester, moderately abundant-Liebeck. Gloucester and Camden counties, common-Wenzel. Newark. Caldwell, rare -Crane.

C. hirticollis, Say.

Gloncester, Camden and Atlantic counties, common-Wenzel. Gloucester, sea-shore, common-Liebeck. Brigantine Beach, in September, common-Hamilton. Madison. I have taken it at Sandy Hook, Loung Branch and Five-Mile Beach. It will be found common everywhere along the coast. It is not on the Newark list.

C. punctulata, Fabr.

Common everywhere, and reported on all lists. It is found even in cities, along side streets, and is perhaps the most abundant and widely distributed of all the species of the genus.

C. tortuosa, Dej.

Atlantic City, rare-Liebeck.

C. dorsalis, Say.

Occurs all along the sea-shore from Sandy Hook to Cape May; common.

C. marginata, Fabr.

Atlantic county, not common-Wenzel. Delaware Bay, rare -Liebeck. I have not taken it in this State, but have found 
it on Long Island, along the muddy margins of ponds near the shore; always scarce.

C. lepida, Dej.

Atlantic City, not common-Liebeck, Wenzel. Brigantine Beach, in September, not abundant-Hamilton. It has also been taken at Sandy Hook. Mr. Wenzel informs me that the species lives in holes made beneath little tufts of long grass.

C. marginipennis, Dej.

Essex, and along the Delaware-Wenzel.

C. abdominalis, Fabr.

Dacosta, rare-Liebeck. Atlantic, rare-Wenzel.

\section{Family CARABID $2 E$.}

\section{OMOPHRON, Latr.}

O. labiatum, Fabr.

Camden, rare-Liebeck. Atlantic county, not commonWenzel. Brigantine Beach, in September-Hamilton.

O. americanum, Dej.

Atlantic county, not common-Wenzel. Gloucester, rareLiebeck. Greenville, June and September-Schaupp. Caldwell, rare-Crane.

O. tessellatum, Say.

Atlantic county, not common-Wenzel.

\section{CYCHRUS, Fabr.}

C. stenostomus, Web.

Gloucester, rare-Wenzel. Rare; no exact locality-Liebeck. Caldwell, rare-Crane. Palisades, May and June, under stones -Schaupp. Newark.

Var. lecontei, Dej.

Gloucester, rare-Wenzel. Westville, rare-Liebeck. Madison. Newark. Palisades, under stones, May and JuneSchaupp. 
C. elevatus, Fabr.

Cape May county, rare-Wenzel. Egg Harbor, Anglesea, rare-Liebeck. Newark.

C. viduus, Dej.

Newark; on the list without comment. Fort Lee, rareLinell.

\section{CARABUS, Linn.}

C. sylvosus, Say.

Gloucester, rare-Liebeck, Wenzel. Camden county, rareWenzel. Greenville, in June, rare-Schaupp. Newark.

C. serratus, Say.

Gloucester, rare-Liebeck. Gloucester and Camden counties, not common-Wenzel. Caldwell, rare-Crane. Hoboken, Palisades, June to September-Schaupp. Newark. Madison. This species is more usually at the base of trees, hiding among the grass. It is quite frequently taken at night, while "sugaring" for moths, being attracted by the bait.

C. limbatus, Say.

Rare at Gloucester-Liebeck, Wenzel ; and Camden-IVenzel. Newark. Greenville, May aud September-Schaupp. Caldwell, common-Crane. This was the common species at Lahaway, Ocean county, on the cranberry bogs.

C. vinctus, Weber.

Generally distributed, common-Liebeck. Camden, Gloucester and Atlantic counties, common-Wenzel. Caldwell, common-Crane. Newark. Palisades. Jersey City. New Brunswick. The most common of the genus, and the most general under stones and logs.

\section{CALOSOMA, Weber.}

C. externum, Say.

Gloucester, rare-Liebeck. Gloucester, Camden, Atlantic and Cape May counties, not common-Wenzel. Newark, Greenville, June and September, rare, under stones-Schaupp.

C. scrutator, Fabr.

Generally distributed, abundant-Liebeck. Same localities as externum, common-Wenzel. Cast up on Brigantive Beach 
in September-Hamilton. Caldwell, common-Crane. Madison. Newark. Often on trees-Schaupp. This species is not often found in fields under stones, and is rather a tree slimber and caterpillar hunter. It is quite commonly cast up by the tide along the sea-shore.

C. willcoxi, Léc.

Cape May county, not common-Wenzel. Atlantic City, rare-Liebeck. Newark.

C. sayi, Dej.

Camden, Gloucester, Atlantic and Cape May counties, rareWenzel. Atlantic City, rare-Liebeck.

c. calidum, Fabr.

Same localities as above, common-Wenzel. Generally distributed, abundant-Liebeck. Caldwell, common-Crane. Madison. Newark. Occurs throughout the State under stones. It is much less commonly cast ashore than is scrutator.

E. fuliginosus, Say.

ELAPHRUS, Fabr.

Snake Hill-Linell.

E. ruscarius, Say.

Camden and Gloucester counties, common-Wenzel. Westville, moderately abundant-Liebeck. June and July, Greenville. Mud flats behind Hoboken-Schaupp. Newark.

B. quadricollis, Hald.

BLETHISA, Bon.

Caldwell, rare-Crane.

\section{NOTIOPHILUS, Dum.}

N. æneus, Hbst.

Camden and Gloucester counties, common-Wenzel. Caldwell, rare-Crane.

N. sibiricus, Mots.

Newark. This species is not rare on Long Island among leaves in open woods. Madison. 
N. pallipes, Say.

NEBRIA, Latr.

Camden and Gloucester counties, common-Wenzel. Generally distributed, abundant-Liebeck. Fort Lee. Orange Mountains, June and September, along running water-Schaupp. This species is common along the margin of rocky streams under stones just at the edge of the water.

P. sublævis, Beauv.

PASIMACHUS, Bon.

Anglesea, rare-Wenzel, Liebeck. Brigantine Beach, island, September, frequent-Hamilton. I found a dead specimen in July, at Anglesea.

P. elongatus, Lec.

Atlantic county, rare-Wenzel.

P. punctulatus, Hald.

Egg Harbor, rare-Liebeck.

S. subterraneus, Fabr.

SCARITES, Fabr.

Generally distributed, abundant-Liebeck. Brigantine Beach, island, in September, frequent-Hamilton. Caldwell, common-Crane. Newark. Madison. I have found it all over the State, though never in any large number.

Var. substriatus, Hald.

Camden and Gloucester counties, common-Wenzel.

D. globulosus, Say.

DYSCHIRIUS, Bon.

Generally distributed, rare-Liebeck. Camden and Gloucester counties, not common-Wenzel. Newark.

D. terminatus, Lec.

Atlantic City, rare-Liebeck, Wenzel.

D. sphæricollis, Say.

Gloucester, rare-Liebeck. Brigantine Beach, salt marshes, in September-Hamilton. Marshy meadows near Hoboken, April and September-Schaupp. 
D. sellatus, Lec.

Atlantic City, not common-Liebeck, Wenzel.

D. pallipennis, Say.

Atlantic City, rare-Liebeck. Salt marshes, Brigantine Beach, in September-Hamilton.

D. fliformis, Lec.

Salt marshes, Brigantine Beach, September-Hamilton.

D. pumilus, Dej.

Salt marshes, Brigantine Beach, September-Hamilton.

C. impressifrons, Lec.

CLIVINA, Latr.

Generally distributed, rare-Liebeck.

C. rubicunda, Lec.

Atlantic City, rare-Liebeck.

C. americana, Dej.

Generally distributed, not rare-Liebeck. Marshy meadows near Hoboken, May and September-Schaupp.

C. striatopunctata, Dej.

Salt marshes, Brigantine Beach, September-Hamilton.

C. ferrea, Lec.

Gloucester, not common-Wenzel.

C. convexa, Lec.

Atlantic City, rare-Liebeck.

C. bipustulata, Fabr.

Generally distributed, moderately abundant-Liebeck. Camden and Gloucester counties, not common-Wenzel. Caldwell, rare-Crane.

S. lineolatus, Say.

\section{SCHIZOGENIUS, Putz.}

Generally distributed, moderately abundant-Liebeck. Camlen and Gloucester counties, not common-Wenzel. Under stones on banks of Passaic, June and September-Schaupp.

S. ferrugineus, Putz.

Salt marshes, Brigantine Beach, September-Hamilton. 
ARDISTOMIS, Putz.

A. obliquata, Putz.

Atlantic City, moderately abundant-Liebeck.

A. viridis, Say.

Generally distributed, moderately abundant-Liebeck. Camden and Gloucester counties, not common-Wenzel. Newark. Clifton, in June-Schaupp.

P. crucigerus, Say.

PANAGÆUS, Latr.

Northern New Jersey, rare-Liebeck. Brigantine Beach, in September, frequent-Hamilton. Snake Hill, under stones, May and June-Schaupp.

P. fasciatus, Say.

Atlantic county, rare-Wenzel. Snake Hill, under stones, May and June-Schaupp. Caldwell, rare-Crane.

N. pygmæus, Dej.

\section{NOMIUS, Lap.}

Near Newark, one specimen-Bischoff.

\section{BEMBIDIUM, Latr.}

B. punctatostriatum, Say.

Banks of Passaic, May and September-Schaupp.

B. inæquale, Say.

Westville, moderately abundant-Liebeck. Camden and Gloucester counties, not common-Wenzel. Banks of Passaic, May and September-Sehaupp.

B. nitidulum, Dej.

Banks of Passaic, May and September-Schaupp.

B. americanum, Dej.

Camden and Gloucester counties, common-Wenzel. Gloucester, moderately abundant-Liebeck. Banks oí Passaic, May and September-Schaupp. Raritan, at New Brunswick-Smith. 
B. antiquum, Dej.

Camden and Gloucester counties, not common-Wenzel. Banks of Passaic, May and September-Schaupp.

B. chalceum, Dej.

Banks of Passaic, May and September-Schaupp.

B. nigrum, Say.

Camden and Gloucester counties, not common-Wenzel. Banks of Passaic, May and September-Schaupp.

B. planatum, Lec.

Banks of Passaic, May and September-Schaupp.

B. rupestre, Dej.

Gloucester, moderately abundant-Liebeck. Camden and Gloucester counties, common-Wenzel. Newark.

B. lacunarium, Zimm.

Fort Lee, in running brooks-Linell.

B. dorsale, Say.

Gloucester county, rare-Wenzel.

B. patruele, Say.

Banks of Passaic, May and September-Schaupp.

B. variegatum, Say.

Camden and Gloucester counties, common-Wenzel. Gloucester, moderately abundant-Liebeck. Banks of Passaic, May and September-Schaupp. Newark-Bischoff.

B. intermedium, Kirby.

Gloucester, moderately abundant-Liebeck.

B. versicolor, Lec.

Camden and Gloucester counties, common-Wenzel. Banks of Passaic, May and September-Schaupp.

B. pictum, Lec.

Camden and Gloucester counties, common-Wenzel. Camden, moderately abundant-Liebeck.

B. constrictum, Lec.

Atlantic county, common-Wenzel. Brigantine Beach, September, abundant-Hamilton. 
B. contractum, Say.

Atlantic City, not common-Wenzel, Liebeck. Brigantine Beach, September, not common-Familton. Anglesea, JulySchwarz.

B. affine, Say.

Camden, moderately abundant-Liebeck. Ocean countySmith.

B. quadrimaculatum, Linn.

Camden and Gloucester counties, not common-Wenzel, Liebeck. The most abundant species in fields and gardens everywhere-Smith.

B. semistriatum, Hald.

Banks of Passaic, May and September-Schaupp.

T. proximus, Say.

TACHYS, Schaum.

Sandy banks of Passaic, May and September-Schaupp. Generally distributed, moderately abundant-Liebeck.

T. scitulus, Lec.

Sandy banks of Passaic, May and September-Schaupp. Camden, Gloucester, common-Wenzel.

T. occultator, Casey.

Brigantine Beach, in September-Hamilton.

T. lævus, Say.

New Brunswick, rare-Smith.

T. nanus, Gyll.

Generally distributed, common-Wenzel, Liebeck. Newark. Brigantine Beach, mainland and island, September-Hamilton. Sandy banks of Passaic, May and September-Schaupp.

T. flavicauda, Say.

Generally distributed, common-Wenzel, Liebeck. I have taken this everywhere in the State, under bark of trees.

T. tripunctatus, Say.

Sandy banks of Passaic, May and September-Schaupp.

T. capax, Lec.

Ocean county, cranberry bogs, not common-Smith. 
T. xanthopus, Say.

Generally distributed, moderately abundant-Liebeck.

T. incurvus, Say.

Generally distributed, common-Liebeck, Wenzel. Sandy banks of Passaic, May and September-Schaupp. Brigantine Beach, September-Hamilton.

T. fuscicornis, Chd.

Brigantine Beach, September-Hamilton.

P. longicornis, Say.

PATROBUS, Dej.

Generally distributed, moderately abundant-Liebeck. Camden and Gloucester counties, not common-Wenzel. Newark.

P. texanus, Chd.

\section{POGONUS, Dej.}

Atlantic City-Collections Drs. Horn and Castle. According to Dr. Horn, this Texan species has been twice taken at Atlantic City.

M. coracinus, Say.

$$
\text { MYAS, Dej. }
$$

Gloucester, rare-Wenzel. Newark.

M. cyanescens, Dej.

Clifton, Fort Lee, June and July-Schaupp.

P. adoxus, Say.

\section{PTEROSTICHUS, Bon.}

Camden, Gloucester, not common-Wenzel, Liebeck. Palisades-Schaupp. Brigantine Beach, mainland, SeptemberHamilton.

P. rostratus, Newn.

Palisades--Schaupp. New Jersey-Wenzel.

P. diligendus, Chd.

Palisades-Schaupp. Newark.

P. honestus, Say.

Foot of Palisades above Hoboken-Schaupp, Smith. 
P. lachrymosus, Newn.

Palisades-Schaupp, Smith. Newark.

P. coracinus, Newn.

Newark.

P. stygicus, Say.

Generally distributed, moderately abundant-Liebeck. Camden and Gloucester counties, not common-Wenzel. Brigantine Beach, mainland and island, September-Hamilton.

P. moestus, Say.

Newark. Caldwell, common-Crane. New Brunswick; rare.

P. sculptus, Lec.

Atlantic City-Dr. Castle.

P. sayi, Brullé.

Generally distributed, common-Wenzel, Liebeck. Newark. P. lucublandus, Say.

Generally distributed, common-Wenzel, Liebeck. Caldwell, common-Crane. Newark. Madison. Brigantine Beach, in September-Hamilton. Common along the shore, under wreckage, and abundant in tilled fields, under all shelter-Smith.

P. ebeninus, Dej.

Atlantic City, rare-Liebeck.

P. caudicalis, Say.

Generally distributed, moderately common-Liebeck.

P. luctuosus, Dej.

Rare, exact locality unknown-Liebeck.

P. corvinus, Dej.

Moderately common, generally distributed-Liebeck. Palisades-Schaupp.

P. tartaricus, Say.

Hoboken, rare-Linell.

P. mutus, Say.

Generally distributed, common-Liebeck. PalisadesSchaupp. Caldwell, common-Crane.

P. erythropus, Dej.

Generally distributed, rare-Liebeck. Atlantic county, common-Wenzel. Brigantine Beach, in September, common- 
Hamilton. Palisades-Schaupp. Newark. Common on cranberry bogs in Ocean county, May-Smith. •

P. patruelis, Dej.

Generally distributed, rare-Liebeck. Canden and Gloucester counties, not common-Wenzel. Palisades-Schaupp. Newark. Common on cranberry bogs, Ocean county, May-Smith.

EVARTHRUS, Lec.

E. sigillatus, Say.

Atlantic City, rare-Liebeck. Madison, not uncommonPaulmier. Caldwell, rare-Crane.

A. avida, Say.

AMARA, Bon.

Camden county, rare-Wenzel. Westville, Gloucester, rare -Liebeck. Palisades-Schaupp.

A. exarata, Dej.

Generally distributed, not uncommon-Liebeck. Caldwell, rare-Crane.

A. latior, Kirby.

On the Newark list.

A. angustata, Say.

Generally distributed, not uncommon-Liebeck. PalisadesSchaupp.

A. pallipes, Kirby.

Camden, Gloucester and Atlantic counties, common-Wenzel.

A. impuncticollis, Say.

Generally distributed, rather common-Wenzel, Liebeck. Caldwell, common-Crane. Newark. Palisades-Schaupp.

A. basillaris, Say.

New Jersey-Henshaw.

A. cupreolata, Putz.

New Jersey-Henshaw. 
A. interstitialis, Dej.

Generally distributed, moderately abundant--Liebeck. Camden and Gloucester counties, not common-Wenzel. PalisadesSchaupp. Newark-Bischoff.

A. obesa, Say.

Sea-shore, not uncommon-Liebeck. Atlantic county, not common-Wenzel. Cape May, in July-Schwarz. Newark. Palisades-Schaupp.

A. chalcea, Dej.

Palisades-Schaupp.

A. gibba, Lec.

New Jersey-Henshaw.

A. rubrica, Hald.

On the Newark list.

A. subænøa, Lec.

Brigantine Beach, in September-Hamilton.

A. musculus, Say.

Gloucester, sea-shore, not uncommon-Liebeck. Atlantic and Cape May counties, not common-Wenzel. Brigantine Beach, in September, frequent on herbage-Hamilton. PalisadesSchaupp.

A. acutangula, Putz.

Westville, rare-Liebeck.

D. laticollis, Lec.

\section{DIPLOCHILA, Brullé.}

Atlantic City, rare-Liebeck. Palisades, May and June, not common-Schaupp, Smith.

Var. major, Lec.

Palisades, May and June, more rare than the typical formSmith.

D. dilatatus, Say.

\section{DICAึLUS, Bon.}

Fort Lee, Clifton, June and September, not rare-Schaupp. Generally distributed, not common-Wenzel. Caldwell, rareCrane. Newark. 
D. purpuratus, Bon.

Camden county, rare-Wenzel. Clifton, June and. July, rare-Schaupp. Newark. Madison.

D. ovalis, Lec.

Gloucester, Camden and Atlantic counties, not commonWenzel. Westville, rare-Liebeck.

D. elongatus, Bon.

Generally distributed, not uncommon-Wenzel, Liebeck. Caldwell, common-Crane. Palisade woods-Schaupp. Newark.

D. teter, Bon.

Palisade woods-Schaupp.

D. politus, Dej.

Gloucester, Camden and Atlantic counties, not common-Wenzel. Atlantic City, rare-Liebeck. Palisade woods-Schaupp.

B. notatus, Hald.

BADISTER, Clairv.

Gloucester, rare-Liebeck.

B. micans, Lec.

Westville, rare-Liebeck.

C. gregarius, Say.

CALATHUS, Bon.

Generally distributed, common-Wenzel, Liebeck. Brigantine Beach, mainland and island, September-Hamilton. Palisades, everywhere common-Schaupp.

C. opaculus, Lec.

New Jersey-Henshaw.

C. impunctatus, Say.

Atco, sea-shore, not common-Wenzel. Atlantic City, rareLiebeck. Fort Lee, rare-Schaupp.

P. angustatus, Dej.

\section{PLATYNUS, Bon.}

Fort Lee, not common-Schaupp. Ocean county, cranberry bogs, rare-Smith. 
P. decens, Say.

Palisades, Fort Lee, common-Schaupp. Caldwell, common,

Crane. Anglesea, July-Schwarz. Newark.

P. sinuatus, Dej.

Generally distributed, moderately common-Liebeck. Camden and Gloucester counties, not rare-Wenzel. Palisades, Fort Lee-Schaupp. Ocean county, cranberry bogs, rare-Smith.

P. opaculus, Lec.

Fort Lee, rare-Schaupp.

P. tenuicollis, Lec.

Atlantic City-Castle.

P. cincticollis, Say.

Generally distributed, moderately abundant-Liebeck. Camden and Gloucester counties, not uncommon-Wenzel. Fort Lee-Schaupp. Newark.

P. reflexus, Lec.

Generally distributed, moderately abundant-Liebeck. Fort Lee-Schaupp.

P. extensicollis, Say.

Generally distributed, common-Liebeck, Wenzel. Fort Lee, Clifton, Weehawken, common-Schaupp. Newark. Madison.

P. decorus, Say.

Generally distributed, moderately abundant-Liebeck. Camden and Gloucester counties, not uncommon-Wenzel. Palisades, common-Schaupp. Caldwell, common-Crane. Newark.

P. atratus, Lec.

Caldwell, very rare, one specimen only-Crane.

P. melanarius, Dej.

Camden and iloucester counties, not uncommon-Wenzel. Fort Lee, Palisade woods-Schaupp. Newark.

P. propinquus, G. \& H.

Camden and Gloucester counties, not uncommon-Wenzel.

P. affinis, Kirby.

Palisade woods-Schaupp. Caldwell, rare-Crane. 
P. metallescens, Lec.

Palisade woods-Schaupp. Newark.

P. cupripennis, Say.

Generally distributed, common-Wenzel. Sea-shore, moderately abundant-Liebeck. Common in fields-Schaupp. Newark. Caldwell, common-Crane.

P. excavatus, Dej.

Generally distributed, rare-Liebeck. Palisades, rareSchaupp.

P. ferreus, Hald.

Gloucester, rare-Liebeck. Palisades, rare-Schaupp.

P. basalis, Lec.

Hoboken, very rare-Linell.

P. nutans, Say:

Palisades, rare-Schaupp.

P. octopunctatus, Fabr.

Sea-shore, rare-Liebeck. Generally distributed, rare-Wenzel. Caldwell, rare-Crane. Palisades, rare-Schaupp. Newark.

P. placidus, Say.

Westville, Gloncester, moderately common-Liebrck. Palisades, not rare-Schaupp, Smith. Madison.

P. obsoletus, Say.

Sea-shore, quite common-Liebeck. Palisades-Schaupp. Newark.

P. æruginosus, Dej.

Generally distributed, not common-Wenzel. Under bark, Hoboken-Schaupp.

P. crenistriatus, Lec.

Palisades-Schaupp. Brigantine Beach, in September-Hamilton.

P. rubripes, Zimm.

Sea-shore, not uncommon-Liebeck, Wenzel. Brigantine Beach, in September-Hamilton. Palisades-Schaupp.

P. punctiformis, Say.

Generally distributed, moderately abundant-Liebeck, Wenzel. Brigantine Beach, in September, common-Hamilton. 
Fort Lee, Palisades-Schaupp. Ocean county, cranberry bogs, rare-Smith. Anglesea-Wenzel.

P. sordens, Kirby.

Palisades-Schaupp.

P. ruficornis, Lec.

Generally distributed, not common-Wenzel, Liebeck. Palisades, Fort Lee-Schaupp.

P. picipennis, Kirby.

Hoboken, rare-Linell.

P. lutulentus, Lec.

Camden, rare-Liebeck. Hoboken, rare-Linell. Palisades -Schaupp. Newark. Cranberry bogs, rare-Smith.

O. parmatus, Say.

OLISTHOPUS, Dej.

Generally distributed, rare-Wenzel. Atlantic City, rareLiebeck.

O. micans, Lec.

Atlantic City, rare-Liebeck.

A. pubescens, Dej.

\section{ATRANUS, Lec.}

Camden and Gloucester, rare-Wenzel. Westville, rareLiebeck. Palisades, in June, rare-Schaupp. Fort Lee, in running brooks-Linell. Newark.

L. dorsalis, Fabr.

\section{LEPTOTRACHELUS, Latr.}

New Jersey-Schaupp. I have seen isolated specimens of this species from different parts of the State.

\section{CASNONIA, Latr.}

C. pennsylvanica, Linn.

Generally distributed, rather common-Wenzel, Liebeck. Brigantine Beach, in September-Hamilton. Caldwell, common-Crane. Newark. 
G. janus, Fabr.

\section{GALERITA, Fabr.}

Generally distributed, moderately abundant-Wenzel, Liebeck. Brigantine Beach, in September-Hamilton. Caldwell, comamon -Crane. Newark. Madison.

G. bicolor, Dru.

Generally distributed, more rare-Liebeck, Wenzel.

T. fasciatus, Hald.

\section{TETRAGONODERUS, Dej.}

Generally distributed, rare-Wenzel. Camden, rare-Liebeck.

L. grandis, Hentz.

\section{LEBIA, Latr.}

Generally distributed, common-Wenzel, Liebeck. New Jersey, July and September-Schaupp. Brigantine Beach, in September-Hamilton. Caldwell, common-Crane. Newark. Madison.

L. atriventris, Say.

Generally distributed, rather common-Liebeck, Wenzel. New Jersey, July and September-Schaupp. Caldwell, common -Crane. Newark. Madison.

L. tricolor, Say.

Atlantic City, rare-Liebeck.

L. pulchella, Dej.

Sea-shore, rare-Liebeck. Gloucester and Atlantic counties, rare-Wenzel.

L. cyanipennis, Dej.

Generally distributed, rare-Liebeck. Gloucester county, rare-Wenzel.

L. marginicollis, Dej.

Dacosta, rare-Liebeck.

L. viridis, Say.

Generally distributed, common-Wenzel, Lieberk. Greenville, Ridgewood, Passaic, June and July-Schaupp. Caldwell, rare-Crane. Newark. Madison. 
Var. mœsta, Lec.

Atco, rare-Liebeck.

L. pumila, Dej.

Generally distributed, rare-Liebeck. Greenville, Ridgewood, Passaic, June and July-Schaupp. Newark.

L. pleuritica, Lec.

Fort Lee, rare-Schaupp.

L. viridipennis, Dej.

Brigantine Beach, in September, frequent-Hamilton. Fort Lee-Schaupp. Newark.

L. ornata, Say.

Generally distributed, rare-Liebeck. Common-Wenzel.

Greenville, Ridgewood, Passaic, June and July-Schaupp.

Caldwell, rare-Crane. Anglesea, in July-Schaupp. Newark.

L. analis, Dej.

Generally distributed, not rare-Wenzel. Westville, rareLiebeck. Fort Lee-Schaupp.

L. fuscata, Dej.

Generally distributed, rare-Liebeck. Greenville, Ridgewood, Passaic, June and July-Schaupp.

L. scapularis, Dej.

Generally distributed, not common-Wenzel, Liebeck. Fort Lee-Schaupp. Newark.

L. vittata, Fabr.

Generally distributed, rare-Liebeck. Madison.

Var. spraguei, Horn.

Collected in New Jersey-Castle.

L. bivittata, Fabr.

Sea-shore, rare-Liebeck.

C. ærata, Dej.

COPTODERA, Dej.

Sea-shore, rare-Liebeck. 
D. piceus, Dej.

\section{DROMIUS, Bon.}

Generally distributed, rare-Liebeck. Camden, Gloucester, not common-Wenzel. Hoboken, under bark-Schaupp. Newark.

A. cordicollis, Lec.

\section{APRISTUS, Chd.}

Gloucester, rare-Liebeck.

BLECHRUS, Mots.

B. nigrinus, Mann.

Hoboken, under bark-Schaupp.

METABLETUS, Schm.-Goeb.

M. americanus, Dej.

Gloucester and Camden, rare-Wenzel.

\section{AXINOPALPUS, Lec.}

A. biplagiatus, Dej.

Hoboken, under bark-Schaupp.

C. purpurea, Say.

\section{CALLIDA, Dej.}

Dacosta, rare-Liebeck. Atlantic county, rare-Wenzel. Greenwood Lake, sometimes not uncommon.

C. punctata, Lec.

Caldwell, rare-Crane.

P. timidus, Hald.

\section{PLOCHIONUS, Dej.}

Generally distributed except along shore-Wenzel. Westville, not rare-Liebeck. Hoboken, under bark-Schaupp.

P. amandus, Newn.

Very rare, one specimen only, Caldwell-Crane. I have not seen this. 
P. limbata, Dej.

\section{PINACODERA, Schaum}

Camden and Gloucester counties, sea-shore-Wenzel. Seashore, not rare-Liebeck. Anglesea, in July-Schwarz. Newark.

P. platicollis, Say.

Gloucester and Camden counties, sea-shore-Wenzel. Westville, rare-Liebeck. Madison.

C. americana, Dej.

\section{CYMINDIS, Latr.}

Generally distributed, not rare-Wenzel. Sea-shore, rareLiebeck.

C. pilosa, Say.

Generally distributed, moderately abundant-Liebeck. Camden and Gloucester counties, not common-Wenzel. Caldwell, common-Crane.

C. neglecta, Hald.

Camden and Gloucester, rare-Wenzel. Newark.

A. Iucidula, Dej.

APENES, Lec.

Sea-shore, rare-Liebeck. Atlantic county, not commonWenzel.

A. sinuata, Say.

Atlantic county, rare-Wenzel. Anglesea, rare-Liebeck. Newark-Bischoff. Both species will be found from Sandy Hook to Cape May.

\section{HELLUOMORPHA, Lap.}

H. bicolor, Harris.

Camden county, rare-Wenzel. Newark.

H. ferruginea, Lec.

Greenville, under logs, rare-Schaupp.

B. viridipennis, Dej.

BRACHYNUS, Web.

New Jersey-Schaupp. Newark. 
B. minutus, Harr.

Along the Palisades-Schaupp.

B. perplexus, Dej.

Along the Palisades-Schaupp.

B. medius, Harr.

Along the Palisades-Schaupp.

B. quadripennis, Dej.

Along the Palisades-Schaupp.

B. conformis, Dej.

Along the Palisades-Schaupp.

B. cyanipennis, Say.

Along the Palisades-Schaupp.

B. alternans, Dej.

Along the Palisades-Schaupp.

B. fumans, Fabr.

Generally distributed, common-Wenzel, Liebeck. Caldwell, common-Crane. Along the Palisades-Schaupp. Madison.

B. similis, Lec.

Brigantine Beach, in September-Hamilton.

B. cordicollis, Dej.

Generally distributed, moderately abundant-Liebeck. Along the Palisades-Schaupp. Caldwell, common-Crane.

The species of Brachynus are ill defined, and not generally named in collections. It is therefore almost impossible to get an accurate list. The species collected by Mr. Schaupp may, however, be considered fairly reliable.

C. erythropus, Germ.

\section{CHL ÆENIUS, Bon.}

Atlantic county, rare-Wenzel.

C. sericeus, Först.

Generally distributed, moderately abundant-Wenzel, Liebeck. Caldwell, common-Crane. Palisades, Fort Lee, Snake Hill, Ridgewood-Schaupp. Newark. Madison. 
C. laticollis, Say.

Generally distributed, rare-Wenzel. Anglesea, rare-Liebeck. Brigantine Beach, in September-Hamilton. Caldwell, rare-Crane. Palisades, Fort Lee, Snake Hill, RidgewoodSchaupp. The most abundant Carabid at Snake Hill-Linell.

C. diffinis, Chd.

Palisades, in spring-Schaupp.

C. æstivus, Say.

Geuerally distributed, rather common-Wenzel, Liebeck. Palisades, Fort Lee, Snake Hill, Ridgewood-Schaupp. Caldwell, common-Crane. Newark. Madison.

C. prasinus, Dej.

Caldwell, common-Crane.

C. nemoralis, Say.

Generally distributed, common-Wenzel, Sea-shore, moderately abundant-Liebeck. Caldwell, common-Crane. Palisades, in spring-Schaupp. Newark.

C. tricolor, Dej.

Generally distributed, moderately abundant-Liebeck. Palisades, in spring-Schaupp. Madison.

C. pennsylvanicus, Say.

Generally distributed, not common-Wenzel. Westville, rare -Liebeck. Palisades, in spring-Schaupp.

C. impunctifrons, Say.

Generally distributed, moderately abundant-Liebeck, Wenzel. Caldwell, very rare-Crane. Palisades, in spring.

C. niger, Rand.

Palisades, in spring, rare-Schaupp.

C. purpuricollis, Rand.

A New Jersey specimen is in Dr. Horn's collection.

C. tomentosus, Say.

Generally distributed, not common-Wenzel. Sea-shore, rare -Liebeck. Newark. Madison. 


\section{ANOMOGLOSSUS, Chd.}

A. emarginatus, Say.

Generally distributed, not common-Wenzel. Sea-shore, moderately abundant-Liebeck. Fort Lee, Ridgewood, not rare -Schaupp. Caldwell, common-Crane.

A. pusillus, Say.

Generally distributed, rather common-Wenzel. Rare-Liebeck. New Jersey, rare-Schaupp. Newark. Madison.

\section{BRACHYLOBUS, Chd.}

B. lithophilus, Say.

Palisades, in March, rare-Schaupp. Gloucester, rare-Liebeck.

\section{LACHNOCREPIS, Lec.}

L. parallelus, Say.

Gloucester, Westville, rare-Liebeck. Snake Hill, common -Linell.

O. amaroides, Dej.

OODES, Bon.

Palisades, rare-Schaupp.

O. americanus, Dej.

Palisades, common—Schaupp. Westville, rare-Liebeck.

O. fluvialis, Lee.

Westville, Gloucester, rare-Liebeck. Camden, Gloucester, not rare-Wenzel.

o. lecontei, Chd.

Camden and Gloucester counties, rare-Wenzel.

G. incrassatus, Dej.

\section{GEOPINUS, Lec.}

Generally distributed in sandy districts along water-Wenzel. Westville, moderately abundant-Liebeck. Brigantine Beach, in September, frequent-Hamilton. Greenville, six inches deep, in sandy soil-Schaupp. Newark. 
C. dubius, Beauv.

\section{CRATACANTHUS, Dej.}

Generally distributed, moderately abundant-Liebeck. In sandy districts along water-courses, common-Wenzel. Newark. New Brunswick.

\section{AGONODERUS, Dej.}

A. lineola, Fabr.

Generally distributed, rather common-Wenzel, Liebeck. Brigantine Beach, in September-Hamilton. Along PalisadesSchaupp. Caldwell, common-Crane. Newark.

A. infuscatus, Dej.

Generally distributed, not uncommon-Wenzel. Anglesea, rare-Liebeck. Brigantine Beach, in September-Hamilton.

A. pallipes, Fabr.

Generally distributed, common-Wenzel, Liebeck. Brigantine Beach, in September, frequent-Hamilton. Along the Palisades, common-Schaupp. Newark. Madison. In my experience, one of the most abundant Carabids in the State, flying to light, in spring.

A. partiarius, Say.

Generally distributed, rare-Liebeck. Along Palisades, in spring, common-Schaupp. Newark.

A. pauperculus, Lec.

Ocean county, common on cranberry bogs-Smith.

A. indistinctus, Say.

Anglesea, rare-Wenzel. Along the Palisades, rare-Schaupp.

A. testaceus, Dej.

Atlantic City-Castle.

\section{DISCODERUS, Lec.}

D. parallelus, Hald.

Atlantic City, not uncommon-Liebeck. Sea-shore, not common-Wenzel. 
G. hylacis, Say.

GYNANDROPUS, Dej.

Generally distributed, not common-Wenzel. Atlantic City, not rare-Liebeck. Under bark of trees, Hoboken-Schaupp. Caldwell, common-Crane.

H. dichrous, Dej.

\section{HARPALUS, Latr.}

Generally distributed, rather rare-Wenzel. Westville, rare -Liebeck. Caldwell, rare-Crane.

H. vulpeculus, Say.

Generally distributed, more common-Wenzel, Liebeck.

H. autumnalis, Say.

Sea-shore, rare-Liebeck.

H. erraticus, Say.

Generally distributed, moderately abundant-Liebeck, Wenzel.

Brigantine Beach, in September, abundant-Hamilton. Passaic, Greenville-Schaupp.

H. viridiæneus, Beauv.

Generally distributed, not rare-Wenzel. Sea-shore, rareLiebeck. Newark. Madison.

H. caliginosus, Fabr.

Generally distributed, common-Wenzel, Liebeck, Schaupp. Brigantine Beach, in September, abundant-Hamilton. Caldwell, common-Crane. Newark.

H. faunue, Say.

Generally distributed, moderately abundant-Schaupp, Wenzel, Liebeck.

H. convivus, Lec.

New Brunswick, rare-Smith.

H. vagans, Lec.

Generally distributed, rather common-Schaupp, Wenzel, Liebeck.

H. pennsylvanicus, De G.

Generally distributed, common-Wenzel, Liebeck, Schaupp. Brigantine Beach, in September, abundant-Hamilton. Caldwell, common-Crane. Newark. Madison. 
Var. compar, Lec.

Generally distributed, not so common as the type-Wenzel, Liebeck, Schaupp. Brigantine Beach-Hamilton. Caldwell, common-Crane.

Var. erythropus, Dej.

Along the Palisades, common-Schaupp.

H. spadiceus, Dej.

Along the Palisades, rather rare-Schaupp. Madison.

H. fallax, Lec.

New Jersey-Henshaw.

H. pleuriticus, Kirby.

Along the Palisades, common-Schaupp.

H. herbivagus, Say.

Generally distributed, rather common-Wenzel. Gloucester, Westville, rare-Liebeck. Brigantine Beach, in SeptemberHamilton. Madison. Ocean county, common on cranberry bogs-Smith.

H. nitidulus, Chd.

Sea-shore, rare-Liebeck.

\section{SELENOPHORUS, Dej.}

S. pedicularius, Dej.

Sea-shore, moderately abundant-Liebeck. Brigantine Beach, in September, frequent-Hamilton. Atlantic City-Castle. Ocean Beach-Paulmier.

S. opalinus, Lec.

Sea-shore, moderately abundant-Liebeck. Under leaves, in spring-Wenzel. Atlantic City-Castle. Ocean Beach-Paulmier.

S. ovalis, Dej.

Brigantine Beach, in September-Hamilton.

S. ellipticus, Dej.

Sea-shore, moderately common-Liebeck. Under leaves, in spring-Wenzel. Brigantine Beach, in September-Hamilton. Atlantic City-Castle. 


\section{STENOLOPEUS, Dej.}

S. carbonarius, Brullé.

Anglesea, Atlantic City, rare-Liebeck. Brigantine Beach, in September-Hamilton. Ocean Beach-Paulmier.

S. fuliginosus, Dej.

Generally distributed, common-Wenzel. Rare-Liebeck.

S. plebeius, Dej.

Brigantine Beach, in September-Hamilton. Ocean BeachPaulmier.

S. conjunctus, Say.

Generally distributed, common-Wenzel, Liebeck. Brigantine Beach, in September-Hamilton. Newark. Cranberry bogs, Ocean county, common-Smith.

S. nova species, Horn dixit.

Madison. Several specimens were taken by Mr. Paulmier. It is in Dr. Horn's collection from Allegheny, Pa.

S. ochropezus, Say.

Generally distributed, common-Wenzel, Liebeck. Brigantine Beach, in September-Hamilton. Newark. Ocean county, on cranberry bogs, common-Smith.

S. dissimilis, Dej.

Sea-shore, rare-Liebeck.

\section{ACUPALPUS, Latr.}

A. hydropicus, Lec.

Ocean county, common on cranberry bogs, in May-Smith.

A. carus, Lec.

Generally distributed, common-Wenzel, Liebeck.

B. rupestris, Say.

\section{BRADYCELLUS, Er.}

Generally distributed, moderately abundant-Wenzel, Liebeck. Brigantine Beach, in September-Hamilton. Newark. Ocean county, cranberry bogs, not common-Smith. 
A. dulcicollis, Laf.

\section{ANISODACTYLUS, Dej.}

Brigantine Beach, in September-Hamilton.

A. rusticus, Dej.

Generally distributed, common-Wenzel, Liebeck. Brigantine Beach, in September-Hamilton. Newark.

A. carbonarius, Say.

Generally distributed, not rare-Wenzel. Atlantic City, moderately abundant-Liebeck.

A. interpunctatus, Kirby.

Generally distributed, not common-Wenzel.

A. harrisii, Lec.

Sea-shore, rare-Liebeck.

A. agricola, Say.

Generally distributed, not common-Wenzel. New Brunswick, rare-Smith.

A. melanopus, Hald.

Generally distributed, moderately abundant-Liebeck.

A. nigerrimus, Dej.

Brigantine Beach, in September-Hamilton.

A. discoideus, Dej.

Sea-shore, rare-Liebeck, Wenzel. Gloucester, rare-Wenzel.

A. baltimorensis, Say.

Generally distributed, common-Wenzel, Liebeck. Newark.

Caldwell, common-Crane. Occurs everywhere in the StateSmith.

A. verticalis, Lec.

Anglesea, in August-Smith.

A. piceus, Men.

Brigantine Beach, in September-Hamilton.

A. terminatus, Say.

Generally distributed, rather common-Wenzel. Sea shore, m sderately abundant-Liebeck. Brigantine Beach, in September-Hamilton.

A. nitidipennis, Lec.

Newark-Bischoff. 
A. lætus, Dej.

Brigantine Beach, in September, very rare-Hamilton. Atlantic county, rare-Wenzel.

A. cœnus, Say.

Atlantic City, rare-Liebeck. Newark-rare.

A. lugubris, Dej.

Generally distributed, common-Wenzel. Gloucester, rareLiebeck.

A. sericeus, Harris.

Gloucester, rare-Liebeck. Newark, rare-Smith.

A. interstitialis, Say.

Generally distributed, moderately common-Wenzel, Liebeck. Newark. Madison.

\section{Family HALIPLID正.}

H. fasciatus, Aubé.

HALIPLUS, Latr.

Camden and Gloucester counties-Wenzel. Camden, rare-

Liebeck. New Jersey-Collection Roberts and United States National Museum.

H. punctatus, Aubé.

New Jersey-Collection United States National Museum.

H. triopsis, Say.

New Jersey-Collection Roberts.

H. ruficollis, De G.

Generally distributed, common-Liebeck, Wenzel. New Jersey - Collection United States National Museum and Roberts.

C. 12-punctatus, Say.

CNEMIDOTUS, Er.

Generally distributed, common-Wenzel. Camden, moderately abundant-Liebeck. New Jersey-Collection Roberts and United States National Museum. Madison.

C. edentulus, Lec.

New Jersey-Collection Roberts. 


\section{Family DYTISCID E.}

C. bicolor, Say.

CANTHYDRUS, Sharp.

Anglesea-Wenzel.

HYDROCANTHUS, Say.

H. iricolor, Say.

Generally distributed, rather common-Liebeck. Newark. New Jersey-Collection United States National Museum.

\section{LACCOPHILUS, Leach.}

L. maculosus, Germ.

Generally distributed, moderately abundant-Liebeck. Caldwell, common-Crane. Newark: Madison. New JerseyCollection Roberts and United States National Museum.

L. proximus, Say.

New Jersey-Collection United States National Míuseum.

L. fasciatus, Aubé.

Generally distributed, moderately abundant-Liebeck. New Jersey-Collection Roberts and United States National Museum.

L. undatus, Aubé.

New Jersey-Collection Roberts and United States National Museum.

HYDROVATUS, Mots.

H. cuspidatus, Germ.

Camden, rare-Liebeck.

H. pustulatus, Melsh.

New Jersey-Collection Roberts and United Stater National Museum.

DESMOPACHRIA, Bab.

D. convexa, Aubé.

Camden, rare-Liebeek. New Jersey-Collection Roberts. 
B. affinis, Say.

\section{BIDESSUS, Sharp.}

Generally distributed, moderately abundant-Liebeck. New Jersey-Collection Roberts and United States National Museum.

B. granarius, Aubé.

New Jersey-Collection United States National Museum.

C. inæqualis, Fabr.

CGLAMBUS, Thom.

New Jersey - Collection United States National Museum.

C. punctatus, Say.

Generally distributed, common-Liebeck. New Jersey-Collection Roberts.

C. nubilus, Lec.

Generally distributed, moderately abundant-Liebeck. New Jersey-Collection Roberts.

C. impressopunctatus, Sch.

Sea-shore, rare-Liebeck. New Jersey-Collection Roberts. Generally distributed, not uncommon-Wenzel.

DERONECTES, Sharp.

D. griseostriatus, De G.

New Jersey-Collection United States National Museum.

HYDROPORUS, Clairv.

H. concinnus, Lec.

New Jersey-Roberts.

H. pulcher, Lec.

New Jersey-Collection United States National Museum.

H. integer, Sharp.

New Jersey-Roberts.

F. undulatus, Say.

Newark. New Jersey-Collection Roberts and United States National Museum. Madison. 
H. consimilis, Lec.

New Jersey-Collection United States National Museum.

H. obscurus, Sturm.

Generally distributed, moderately abundant-Liebeck.

H. tenebrosus, Lec.

New Jersey-Collection United States National Museum.

H. americanus, Aubé.

New Jersey-Collection United States National Museum.

H. dichrous, Melsh.

New Jersey-Collection United States National Museum.

H. modestus, Aubé.

New Jersey-Coilection Roberts and United States National Museum.

H. stagnalis, G. \& H.

New Jersey-Collection United States National Museum.

I. biguttulus, Gem.

\section{ILYBIUS, Er.}

Generally distributed, moderately abundant-Liebeck. New Jersey-Collection Roberts and United States National Museum. Madison.

C. interrogatus, Fabr.

\section{COPTOTOMUS, Say.}

Caldwell, common-Crane. Sea-shore, moderately abundant -Liebeck. Madison. New Jersey-Collection Roberts and United States National Museum.

C. glyphicus, Say.

\section{COPELATUS, Er.}

Generally distributed, moderately abundant-Liebeck. Brigantine Beach, in September-Hamilton. New Jersey-Collection Roberts and United States National Museum.

M. bicarinatus, Say.

\section{MATUS, Aubé.}

New Jersey-Collection Roberts and United States National Museum. 
A. seriatus, Say.

AGABUS, Leach.

New Jersey-Collection Roberts and United States National Museum.

A. obtusatus, Say.

New Jersey-Collection Roberts.

A. punctatus, Melsh.

New Jersey-Collection United States National Museum.

A. tæniolatus, Harr.

New Jersey, exact locality unknown, rare-Liebeck.

A. disintegratus, $\mathrm{Cr}$.

Generally distributed, moderately abundant-Liebeck. Newark. New Jersey-Collection Roberts and United States National Museum.

A. erythropterus, Say.

New Jersey-Collection Roberts and United States National Museum.

A. gagates, Aubé.

Fort Lee, common-Linell. New Jersey-Collection Roberts.

A. clavatus, Lec.

Camden and Gloucester counties-Wenzel.

R. binotatus, Harr.

RHANTUS, Esch.

Newark.

R. calidus, Fabr.

Camden and Gloucester counties, not common-Wenzel.

R. bistriatus, Bergst.

Camden, Gloucester and Atlantic counties, not commonWenzel.

C. sculptilis, Harr.

COLYMBETES, Clairv.

Caldwell, rare-Crane. Newark. New Jersey-Collection Roberts and United States National Museum. 
H. piceus, Lec.

\section{HYDATICUS, Leach.}

Very rare, one spocimen only; Caldwell-Crane.

H. bimarginatus, Say.

Anglesea, rare-Liebeck.

D. harrisii, Kirby.

\section{DYTISCUS, Linn.}

Caldwell, common-Crane.

D. fasciventris, Say.

Camden, Gloucester and Atlantic counties-Wenzel. Caldwell, rare-Crane. New Jersey-Collection Roberts and United States National Museum. Madison.

D. hybridus, Aubé.

New Jersey-Collection Roberts and United States National Museum.

D. verticalis, Say.

New Jersey-Collection United States National Museum. Madison.

\section{ACILIUS, Leach.}

A. semisulcatus, Aubé.

Caldwell, common-Crane. Newark. New Jersey-Collection United States National Museum.

A. fraternus, Harr.

Anglesea, rare-Liebeck. New Jersey-Collection Roberts and United States National Museum. Madison.

A. mediatus, Say.

Sea-shore, rare-Liebeck. Camden, Gloucester and Atlantic counties-Wenzel. New Jersey-Collection Roberts aud United States National Museum. Fort Lee, abundant-Linell.

THERMONECTES, Esch.

T. basilaris, Harr.

Generally distributed, moderately abundant-Liebeck. New .Jersey-Collection Roberts and United States National Museum. 
G. liberus, Say.

GRAPHODERUS, Esch.

Madison. New Jersey-Collection Roberts and United States National Museum.

G. fasciaticollis, Harr.

New Jersey-Collection United States National Museum.

C. fimbriolatus, Say.

CYBISTER, Curt.

Caldwell, rare-Crane. New Jersey-Collection Roberts and United States National Museum.

\section{Family GYRINID圧.}

GYRINUS, Linn.

G. rockinghamensis, Lec.

Atlantic county, common-Wenzel. Atco, common-Liebeck.

G. limbatus, Say.

Atco, Egg Harbor, moderately abundant-Liebeck.

G. dichrous, Lec.

New Jersey-Collection Roberts and United States National Museum.

G. ventralis, Kirby.

Generally distributed, moderately abundant-Liebeck. New Jersey-Collection United States National Museum.

G. affinis, Aubé.

New Jersey-Collection United States National Museum.

G. analis, Say.

Atlantic county, common-Wenzel.

G. borealis, Aubé.

Atlantic county, common-Wenzel. New Jersey-Collection Roberts and United States National Museum. Madison.

G. lugens, Lec.

Atco, rare-Liebeck. 
D. vittatus, Germ.

\author{
DINEUTES, MacL.
}

Generally distributed, moderately abundant-Liebeck. Atlantic county, common-Wenzel. Newark. Clifton, Ccean county, in ditches and small streams, never in ponds-Smith.

D. discolor, Aubé.

Ocean county, common-Smith. New Jersey-Collection Roberts and United States National Museum.

D. assimilis, Aubé.

Generally distributed, moderately abundant-Liebeck. Atlantic county, common-Wenzel. Clifton, Ocean county, common-Smith. New Jersey-Collection Roberts and United States National Museum.

D. emarginatus, Say.

Generally distributed, moderately abundant-Liebeck.

\title{
Family HYDROPHILID
}

H. lacustris, Lec.

HELOPHORUS, Fabr.

Hoboken, common-Linell. Palisades, common-Smith.

E. lineatus, Say.

Generally distributed, common-Liebeck. Newark. New Jersey-Collection United States National Museum.

H. tuberculatus, Gyll.

Westville, rare-Liebeck.

\section{HYDROCHUS, Leach.}

H. scabratus, Muls.

Generally distributed, common-Liebeck. Newark. New Jersey-Collection United States National Museum.

H. inæqualis, Lec.

New Jersey-Collection United States National Museum. 
H. subcupreus, Rand.

New Jersey-Collection Roberts and United States National Museum.

H. variolatus, Lec.

Camden, moderately abundant-Liebeck.

O. benefossus, Lec.

OCHTHEBIUS, Leach,

New Jersey-Collection Horn.

표. pennsylvanica, Kies.

\section{HYDR坐NA, Kug.}

New Jersey-Collection Roberts and United States National Museum.

H. ovatus, G. \& H.

\section{HYDROPHILUS, Geoffr.}

Newark; rare.

H. triangularis, Say.

Generally distributed, common-Liebeck. Camden and Gloucester counties, common-Wenzel. Newark; common. Caldwell, common-Crane.

H. nimbatu's, Say.

Generally distributed, common-Liebeck. Newark. New Jersey-Collection Roberts and United States National Museum.

H. mixtus, Lec.

Generally distributed, moderately abundant-Liebeck. Madison.

H. glaber, Hbst.

Brigantine Beach, in September-Hamilton. Along Palisades, common-Smith. Caldwell, rare-Crane. New JerseyCollection Roberts and United States National Museum.

H. obtusatus, Say.

HYDROCHARIS, Latr.

Generally distributed, rare-Liebeck. Camden and Gloucester counties, common-Wenzel. Newark. Madison. New Jersey_Collection Roberts and United States National Museum. 
B. pantherinus, Lec.

\section{BEROSUS, Leach.}

New Jersey-Collection Roberts.

B. peregrinus, Hbst.

Generally distributed, moderately abundant-Liebeck. New Jersey-Collection Horn and United States National Museum.

B. striatus, Say.

Generally distributed, moderately abundant-Liebeck. Camden and Gloucester counties, common-Wenzel. Caldwell, common-Crane. New Jersey-Collection Roberts and United States National Museum. Madison.

L. agilis, Rand.

\section{LACCOBIUS, Er. ,}

Westville, rare-Liebeck. New Jersey-Collection Roberts and United States National Museum.

\section{PHILHYDRUS, Sol.}

P. nebulosus, Say.

New Jersey-Collection United States National Museum.

P. bifidus, Lec.

New Jersey-Collection Horn and United States National Museum.

P. ochraceus. Mels.

Camden and Gloucester counties, common-Wenzel. Brigantine Beach, in September, common in fresh-water poolsHamilton. New Jersey-Collection United States National Museum.

P. reflexipennis, Zimm.

Brigantine Beach, in September, common in fresh-water pools -Hamilton. New Jersey-Collection Roberts.

P. cinctus, Say.

Generally distributed, moderately abundant-Liebeck. Newark. New Jersey-Collection Roberts and United States National Museum. 
P. diffusus, Say.

New Jersey-Collection United States National Museum.

P. perplexus, Lec.

Brigantine Beach, in September, in fresh-water pools-Hamilton. New Jersey-Collection Roberts and United States National Museum.

P. hamiltoni, Horn.

Brigantine Beach, in September-Hamilton.

\section{HYDROCOMBUS, Sharp.}

H. fimbriatus, Melsh.

Camden and Gloucester counties, common-Wenzel. New Jersey-Collection Roberts and United States National Museun.

H. lacustris, Lec.

Sea-shore, common-Liebeck. Hoboken, common-Linell. H. rotundatus, Say.

Caldwell, rare-Crane.

H. globosus, Say,

\section{HYDROBIUS, Leach.}

Westville, rare-Liebeck. Caldwell, rare-Crane. Newark. New Jersey-Collection Roberts and United States National Museum.

ㅍ. fuscipes, Linn.

Camden and Gloucester counties-Wenzel. New JerseyCollection Roberts and United States National Museum.

H. subcupreus, Say.

Generally distributed, common-Liebeck. Brigantine Beach, in September-Hamilton. New Jersey-Collection Roberts and United States National Museum.

E. suturalis, Lec。

Brigantine Beach, in September-Hamilton.

\section{CERCYON, Leach.}

C. centromaculatum, Sturm.

Oravge Mountains, rare-Smith. 
C. prætextatum, Say.

Generally distributed, moderately abundant-Liebeck. Brigantine Beach, in September-Hamilton. New Jersey-Collection Roberts and United States National Museum.

C. ocellatum, Say.

Geuerally distributed, moderately abundant-Liebeck. New Jersey-Collection United States National Museum.

C. pygmæum, Ill.

New Jersey-Collection United States National Museum.

C. unipunctatum, Linn.

Generally distributed, moderately common-Liebeck.

C. anale, Payk.

Camden, rare-Liebeck. New Jersey-Collection United States National Museum. Ocean county, cranberry bogs, common-Smith.

There are a number of unnamed species in collections, which will probably add a few to the above list.

\section{PHENONOTUM, Sharp.}

P. extriatum, Say.

Brigantine Beach, in September-Hamilton.

\section{Family SILPHID \#.}

\section{NECROPHORUS, Fabr.}

N. americana, Oliv.

Generally distributed, not ragre-Wenzel. Westville, rareLiebeck. Caldrvell, common-Crane. Newark. Hudson county-Linell.* Madison.

N. sayi, Lap.

Hudson county-Linell.

* Mr. Linell's collecting was done very largely along the Palisades to Fort Lee, in the marshes back of Hoboken, and at Snake Hill and its immediate vicinity. 'This is particularly so in the Staphylinide families. 
N. orbicollis, Say.

Generally distributed, not rare-Wenzel. Westville, rareLiebeck. Caldwell, common-Crane. Newark. Hudson county-Linell. Madison.

N. marginatus, Fabr.

Generally distributed, common-Wenzel, Liebeck. Hudson county-Linell. Caldwell, common-Crane. Madison.

N. guttula, Mots.

Hudson county-Linell.

N. tomentosus, Weber.

Generally distributed, common-Wenzel, Liebeck. Hudson county-Linell. Caldwell, common-Crane. Newark.

N. vespilloides, Hbst.

Caldwell, common-Crane.

\section{SILPHA, Linn.}

S. surinamensis, Fabr.

Generally distributed, common-Wenzel, Liebeck. Caldwell, common-Crane. Hudson county-Linell. Newark.

S. lapponica, Hbst.

Newark; not common.

S. inæqualis, Fabr.

Generally distributed, not rare-Wenzel. Westville, rareLiebeck. Caldwell, common-Crane. Hudson county-Linell. Newark. Madison.

S. noveboracensis, Först.

Generally distributed, common-Wenzel. Westville, rareLiebeck. Caldwell, common-Crane. Hudson county-Linell. Newark. Madison.

S. americana, Linn.

Generally distributed, not rare-Wenzel. Camden, rareLiebeck. Caldwell, common-Crane. Hudson county-Linell. Newark. Madison.

C. simplex, Say.

CHOLEVA, Latr.

In ants' nests, near Newark, rare-Bischoff. 
C. basillaris, Say.

Hudson county-Linell.

C. clavicornis, Lec.

In ants' nests, near Newark-Bischoff.

C. terminans, Lec.

Anglesea, in July-Schwarz.

P. opaca, Say.

\section{PRIONOCH ÆFTA, Horn.}

Anglesea, in July-Schwarz. Hudson county-Linell.

PTOMOPHAGUS, Ill.

P. parasitus, Lec.

Hudson county-Linell.

L. discolor, Melsh.

\section{LIODES, Latr.}

Hudson county-Linell.

\section{AGATHIDIUM, Ill.}

A. oniscoides, Beauv.

Snake Hill, abundant on fallen trees-Linell.

A. exiguum, Melsh.

Hudson county-Linell. Generally distributed, rare-Liebeck.

\section{Family SCYDMENID EE.}

SCYDM A世NUS, Latr.

S. perforatus, Schaum.

Camden county, not common-Wenzel.

S. fossiger, Lec.

Canden, moderately abundant-Liebeck. Hudson countyLinell. 
S. capillosulus, Lec.

Ocean county, cranberry bogs, rare-Smith.

S. brevicornis, Say.

Ocean county, cranberry bogs, in May, rare-Smith.

S. obscurellus, Lec.

Ocean county, cranberry bogs, in May, rare-Smith.

S. clavipes, Say.

Camden, rare-Liebeck. Hudson county-Linell. Newark.

S. salinator, Lec.

Hudson county-Linell. Under stones and sticks in salt marshes, not rare-Smitb.

S. bicolor, Lec.

Camden county, not common-Wenzel.

B. nitidus, Lec.

BRATHINUS, Lec.

Fort Lee, near running brooks, rare-Linell.

\title{
Family PSELAPHIDA.
}

C. ziegleri, Lec.

\author{
CEDIUS, Lec.
}

Hudson county-Linell. Newark; rare.

C. piceus, Lec.

\section{CTENISTES, Reichenb.}

Camden, not rare-Liebeck. Hudson county-Linell.

T. humeralis, Aubé.

$$
\text { TYRUS, Aubé. }
$$

Westville, rare-Liebeck.

P. erichsonii, Lec.

$$
\text { PSELAPHUS, Hbst. }
$$

Recorded on the Newark list. 
D. abnorme, Lec.

\section{DECARTHRON, Brend.}

Canden, not rare-Liebeck.

BATRISUS, Aubé.

B. monstrosus, Lec.

Hudson county-Iinell. Ocean county, on cranberry bogs, in May-Smith.

B. ferox, Lec.

Camden, not rare-Liebeck.

B. riparius, Say.

Anglesea, in July, not common-Schwarz.

B. globosus, Lec.

Westville, rare-Liebeck.

B. brendelii, Horn.

BRYAXIS, Leach.

Ocean county, common on cranberry bogs, in May-Smith.

B. rubicunda, Aubé.

Camden, not rare-Liebeck. Hudson county-Linell.

B. puncticollis, Lec.

Ocean county, common on cranberry bogs, in May-Smith.

T. dubium, Lec.

$$
\text { TRIMIUM, Aubé }
$$

Ocean county, not uncommon on cranberry bogs, in MaySmith.

\section{Family STAPHYIINIDEE.}

F. cingulata, Lec.

FALAGRIA, Mann.

New Jersey-Collection United States National Museum.

F. dissecta, Er.

New Jersey-Collection United States National Museum. 
F. venustula, Er.

New Jersey-Collection United States National Museum.

ㅍ. plana, Gyll.

HOMALOTA, Mann.

New Jersey-Collection United States National Museum.

H. trimaculata, Er.

New Jersey-Collection United States National Museum.

H. lividipennis, Mann.

New Jersey-Collection United States National Museum.

Three species at Anglesea, in July-Schwarz; and there are many unnamed and unnamable species in collections generally.

L. cava, Lec.

\section{LOMECHUSA, Grav.}

Snake Hill, occurs in the nest of a large red ant-Linell.

T. cavicollis, Lec.

TACHYUSA, Er.

New Jersey-Collection United States National Museum.

T. nigrella, Lec.

New Jersey-Collection United States National Museum.

P. maritima, Casey.

\section{POLYSTOMA, Steph.}

Brigantine Beach, in September-Hamilton. Cape May, in July-Schwarz.

A. lata, Grav.

ALEOCHARA, Grä.

Generally distributed, common-Wenzel. New JerseyCollection United States National Museum.

A. brachypterus, Fourc.

New Jersey-Collection United States National Museum.

A. bimaculata, Grav.

Brigantine Beach, in September-Hamilton. New JerseyCollection United States National Museum. 
A. nitida, Grav.

New Jersey-Collection United States National Museum.

O. sagulata, Er.

OXYPODA, Mann.

New Jersey-Collection United States National Museum.

G. vinula, Er.

GYROPH正NA, Mann.

New Jersey-Collection United States National Museum.

M. rufipennis.

$$
\text { MYLL正NA，Er。 }
$$

Anglesea, in July-Schwarz.

A. pronus, Er.

ACYLOPHORUS, Nordm.

Snake Hill, Palisades, excessively common-Linell. Madison.

H. fumigatus, Lec.

\section{HETEROTHOPS, Steph.}

New Jersey-Collection United States National Museum.

Q. fulgidus, Fabr.

\section{QUEDIUS, Steph.}

Hudson county-Linell. Caldwell, common-Crane. New Jersey-Collection United States National Museum.

Q. peregrinus, Grav.

New Jersey-Collection Horn and United States National Museum. Newark.

Q. capucinus, Grav.

Hudson county-Linell. New Jersey-Collection Horn and United States National Museum.

Q. lævigatus, Gyll.

Brigantine Beach, mainland, in September-Hamilton. Hudson county, rare-Linell. 
Q. molochinus, Grav.

Hudson county-Linell. New Jersey-Collection United States National Museum.

Q. brunneipennis, Mann.

Brigantine Beach, in September, not uncommon-Hamilton.

Q. ferox, Lec.

Hudson county, rare-Linell.

Q. vernix, Lec.

Hudson county, rare-Linell. New Jersey-Collection United States National Museum. Newark.

L. cingulatus, Grav.

\section{LISTOTROPHUS, Perty.}

Generally distributed, common-Wenzel. Hudson countyLinell. Caldwell, common-Crane.' Newark. Madison.

L. capitatus, Bland.

New Jersey-Collection United States National Museum.

C. villosus, Grav.

\section{CREOPHILUS, Kirby.}

Generally distributed, common-Wenzel. Brigantine Beach, in September-Hamilton. Caldwell, common-Crane. Hudson county-Linell. Newark. Madison.

\section{STAPHYLINUS, Linn.}

S. vulpinus, Nordm.

Brigantine Beach, in September, not common-Hamilton. Caldwell, rare-Crane. Hudson county-Linell. New Jersey -Collection United States National Museum.

S. maculosus, Grav.

Generally distributed, common-Wenzel. Caldwell, common -Crane. Hudson county-Linell. Newark. Madison. I have taken it throughout the State, quite commonly.

S. mysticus, Er.

Generally distributed, not rare-Wenzel. Hudson countyLinell. Madison. New Jersey-Collection United States National Museum. 
S. tomentosus, Grav.

Brigantine Beach, in September, rare-Hamilton. Hudson county-Linell. Newark. New Jersey-Collection United States National Museum.

S. fossator, Grav.

Generally distributed, not rare-Wenzel. Brigantine Beach, mainland, in September-Hamilton. New Jersey-Collection United States National Museum.

S. cinnamopterus, Grav.

Generally distributed, common-Wenzel. Hudson county, abundant-Linell. Caldwell, common-Crane. Newark. Madison.

S. violaceus, Grav.

Generally distributed, not common-Wenzel. Madison. New Jersey-Collection United States National Museum.

S. prælongus, Mann.

Brigantine Beach, in September, common-Hamilton. Anglesea, in July-Schwarz. Hudson county-Linell.

O. ater, Grav.

\section{OCYPUS, Kirby.}

Generally distributed, common-Wenzel. Brigantine Beach, in September, occasional-Hamilton. Caldwell, commonCrane. Hudson county-Linell.

\section{BELONUCHUS, Nordm.}

B. formosus, Grav.

Generally distributed, not common-Wenzel. Hudson county -Linell. Newark. New Jersey-Collection United States National Museum.

P. æneus, Rossi.

\section{PHILONTHUS, Curt.}

Brigantine Beach, in September, frequent-Hamilton. Hudson county-Linell. Caldwell, common-Crane. Newark. New Jersey-Collection United States National Museum. 
P. sericinus, Horn.

Hudson county, rare-Linell. New Jersey-Collection United States National Museum. Newark.

P. umbratilis, Grav.

New Jersey-Collection Horn, one specimen.

P. lætulus, Say.

New Jersey-Collection United States National Museum.

P. hepaticus, Er:

Brigantine Beach, in September, frequent-Hamiltov. Hudson county-Linell. New Jersey-Collection United States National Museum.

P. umbrinus, Grav.

Brigantine Beach, in September, very rare-Hamilton. Hudson county, rare-Linell. New Jersey-Collection Horn.

P. quadricollis, Horn.

Newark.

P. debilis, Grav.

New Jersey-Collection United States National Museum.

P. varians, Payk.

New Jersey-Collection United States National Museum.

P. longicornis, Steph.

Hudson county-Linell. New Jersey-Collection United States National Museum.

P. discoideus, Grav.

Hudson county-Linell. New Jersey-Collection United States National Museum.

P. alumnus, Er.

Palisades and Snake Hill, very common, in spring-Linell. Brigantine Beach, in September, rare-Hamilton. Anglesea, in July -Schwarz. New Jersey - Collection United States National Museum.

P. fusiformis, Melsh.

Brigantine Beach, in September, common-Hamilton.

P. schwarzi, Horn.

Snake Hill, one specimen-Linell. Newark. 
P. micans, Grav.

Brigantine Beach, in September, frequent-Hamilton.

P. lomatus, Er.

Generally distributed, common-Wenzel. Brigantine Beach, in September, common-Hamilton. Palisades and Snake Hill, early in spring, common-Linell.

P. brunneus, Grav.

Hudson county-Linell. Anglesea, in July-Schwarz. New Jersey-Collection United States National Museum.

P. cyanipennis, Fabr.

Generally distributed, common-Wenzel. Brigantine Beach, mainland, in September-Hamilton. Hudson county-Linell. Newark.

P. blandus, Grav.

Brigantine Beach, mainland, in September-Hamilton. Hudson county-Linell. New Jersey-Collection United States National Museum. Newark.

P. sordidus, Grav.

Hudson county-Linell.

P. cephalotes, Grav.

Hudson county-Linell.

P. nigritulus, Grav.

Hudson county-Linell. New Jersey-Collection United States National Museum.

P. microphthalmus, Horn.

Brigantine Beach, in September-Hamilton. Anglesea, in July-Schwarz.

P. baltimorensis, Grav.

Generally distributed, not rare-Wenzel. Hudson county, in rotten wood-Linell. Madison. New Jersey-Collection United States National Museum.

P. apicalis, Say.

Camden and Gloucester counties, not common-Wev\%el. Caldwell, rare-Crane. 
A. cinerascens, Grav.

\section{ACTOBIUS, Steph.}

Hudson county-Linell. New Jersey-Collection United States National Museum.

A. nanus, Horn.

Hudson county-Linell. New Jersey-Collection Horn.

A. sobrinus, Er.

Generally distributed, not rare-Wenzel. Hudson county-

Linell. New Jersey - Collection United States National Museum.

A. parcus, Horn.

Hudson county-Linell.

A. pæderoides, Lec.

Brigantine Beach, in September, frequent-Hamilton. Hudson county-Linell. New Jersey-Collection United States National Museum.

C. bistriatus, Er.

CAFIUS, Steph.

Brigantine Beach, in September, abundant-Hamilton. Anglesea, Cape May, in July-Schwarz.

\section{XANTHOLINUS, Serv.}

X. cephalus, Say.

Generally distributed, common-Wenzel. Fort Lee, abundant under leaves in the woods-Linell. Brigantine Beach, in September, frequent-Hamilton.

X. obsidianus, Melsh.

Generally distributed-Wenzel. New Jersey-Collection United States National Museum.

X. emmesus, Grav.

Hudson county-Linell. New Jersey-Collection United States National Museum.

X. obscurus, Er.

Brigantine Beach, in September, frequent-Hamilton. Anglesea, in July-Schwarz. Hudson county-Linell. 
X. sanguinipennis, Lec.

Anglesea and Cape May, in July-Schwarz. Hudson county, rare-Linell.

X. pusillus, Sachse.

Hudson county-Linell.

X. hamatus, Say.

Hudson county-Linell.

L. batychrus, Gyll.

LEPTACINUS, Er.

New Jersey-Collection United States National Museum.

D. schaumii, Kraatz.

DIOCHUS, Er.

Camden and Gloucester counties, not rare-Wenzel. Hudson county-Linell. New Jersey-Collection United States National Museum.

S. bipunctatus, Er.

STENUS, Latr.

New Jersey-Collection United States National Museum.

S. juno, Fabr.

Palisades, Snake Hill, common in spring-Linell. New Jersey-Collection United States National Museum.

S. femoratus, Say.

Hudson county-Linell. New Jersey-Collection United States National Museum.

S. colonus, Er.

New Jersey-Collection United States National Museum.

S. stygicus, Say.

New Jersey-Collection United States National Museum.

S. sectilifer, Casey.

Anglesea, in July-Schwarz.

S. flavicornis, Er.

Palisades and Snake Hill, in spriog, abundant-Linell. New Jersey-Collection United States National Museum. 
S. annularis, Er.

With the preceding and equally abundant; same authorities.

S. reconditus, Casey.

New Jersey-Collection United States National Museum.

S. arculus, Er.

Anglesea, in July-Schwarz.

S. punctatus, Er.

Hudson county-Linell. New Jersey-Collection United States National Museum.

There will undoubtedly be many additions to this list, when the species now in collections are properly identified.

E. americanus, Er.

\section{EUAPSHETUS, Grav.}

Generally distributed, common-Wenzel. New JerseyCollection United States National Museum.

C. badium, Grav.

\section{CRYPTOBIUM, Mann.}

Snake Hill, abundant-Linell. New Jersey-Collection United States National Museum.

C. lugubre, Lec.

Brigantine Beach, in September, occasional-Hamilton.

C. bicolor, Grav.

Hudson county-Linell. Madison. Ocean county, on cranberry bogs, in May, not common-Smith.

C. pallipes, Grav.

Generally distributed, common-Wenzel. Hudson countyLinell. New Jersey-Collection United States National Museum. Ocean county, common on cranberry bogs, in May -Smith.

C. latebricola, Nordm.

Brigantine Beach, in September, occasional-Hamilton. Ocean county, common on cranberry bogs, in May-Smith.

C. cribratum, Lec.

Hudson county, rare-Linell. Madison. 
L. grande, Lec.

\section{LATHROBIUM, Grav.}

New Jersey-Collection United States National Museum.

L. punctulatum, Lec.

Anglesea, in July-Schwarz. Hudson county-Linell. New Jersey-Collection United States National Museum.

L. armatum, Say.

Recorded on the Newark list.

L. simile, Lec.

Hudson county-Linell.

L. seriatum, Lec.

Brigantine Beach, in September, rare-Hamilton.

L. longiusculum, Grav.

Brigantine Beach, in September, common-Hamilton. Hudson county-Linell. Newark.

L. collare, Er.

New Jersey-Collection United States National Museum.

L. dimidiatum, Say.

Brigantine Beach, in September, rare-Hamilton.

S. opaculus, Lec.

\section{STILICUS, Latr.}

New Jersey-Collection United States National Museum.

S. angularis, Lec.

Anglesea, in July—Schwarz. Generally distributed-Wenzel. Hudson county-Linell.

S. biarmatus, Lec.

Newark.

MEGASTILICUS, Casey.

M. formicarius, Casey.

Near Newark, in ant hills; not rare.

L. corticina, Grav.

\section{LITHOCHARIS, Er.}

Generally distributed, not rare-Wenzel. New Jersey-Collection United States National Museum. 
L. confluens, Say.

Camden and Gloucester counties-Wenzel. Hudson county -Linell. New Jersey-Collection United States National Museum. Madison.

P. littorarius, Grav.

\section{P 开DERUS, Grav.}

Brigantine Beach, in September, abundant-Hamilton. Hudson county-Linell. Newark. Camden and Gloucester counties -Wenzel. Madison.

P. obliteratus, Lec.

Brigantine Beach, in September, less common-Hamilton.

S. prolixus, Er.

\section{SUNIUS, Steph.}

Brigantine Beach, in September, common-Hamilton. Newark.

S. longiusculus, Mann.

Gloucester and Camden counties, common-Wenzel. Hudson county-Linell. New Jersey-Collection United States National Museum.

P. normalis, Lec.

PALAMINUS, Er.

Anglesea, in July—Schwarz.

T. memnonius, Grav.

\section{TACHINUS, Grav.}

New Jersey_Collection United States National Museum.

T. repandus, Horn.

New Jersey-Collection United States National Museum.

T. Alavipennis, Dej.

New Jersey-Collection United States National Museum.

T. fimbriatus, Grav.

Brigantine Beach, mainland, in September-Hamilton. Camden and Gloucester counties, rather common-Wenzel. New Jersey-Collection United States National Museum. 
T. limbatus, Melsh.

New Jersey-Collection United States National Museum.

T. pallipes, Grav.

Camden and Gloucester counties, common-Wenzel. New Jersey-Collection United States National Museum.

T. jocosus, Say.

\section{TACBYPORUS, Grav.}

Camden and Gloucester counties, common-Wenzel. New Jersey-Collection United States National Museum.

T. chrysomelinus, Linn.

Brigantine Beach, in September-Hamilton. New JerseyCollection United States National Museum.

T. brunneus, Er.

Camden and Gloucester counties, common-Wenzel. New Jersey-Collection United States National Museum.

E. ventriculus, Say.

\section{ERCHOMUS, Mots.}

Brigantine Beach, mainland, in September-Hamilton. Camden and Gloucester counties, common-Wenzel. Newark. New Jersey-Collection United States National Museum.

\section{CONOSOMA, Kraatz.}

C. crassum, Grav.

Generally distributed, common-Wenzel. New Jersey-Collection United States National Museum.

C. pubescens, Payk.

Camden and Gloucester counties, common-Wenzel. New Jersey-Collection United States National Museum. Madison.

C. basale, Er.

New Jersey-Collection United States National Museum.

C. opicum, Say.

Ocean county, under bark-Smith. 
BOLETOBIUS, Leach.

B. cingulatus, Mann.

Newark.

B. intrusus, Horn.

Brigantine Beach, mainland, in September-Hamilton. New Jersey-Collection United States National Museum.

B. cincticollis, Say.

New Jersey-Collection United States National Museum.

B. anticus, Horn.

New Jersey-Collection United States National Museum.

B. pygmæus, Fabr.

Brigantine Beach, mainland, in September-Hamilton.

B. trinotatus, Er.

Anglesea, in July-Schwarz. Brigantine Beach, mainland, in September-Hamilton. New Jersey-Collection United States National Museum.

B. cinctus, Grav.

Generally distributed, common-Wenzel. New JerseyCollection United States National Museum.

Var. gentilis, Lec.

Brigantine Beach, mainland, in September-Hamilton.

B. rufescens, Lec.

BRYOPORUS, Kraatz.

New Jersey-Collection United States National Museum.

MYCETOPORUS, Mann.

M. americanus, Er.

Anglesea, in July-Schwarz. New Jersey-Collection United States National Museum.

O. femoralis, Grav.

\section{OXYPORUS, Fabr.}

Camden and Gloucester counties, common-Wenzel. New Jersey-Collection United States National Museum. 
O. major, Grav.

Camden and Gloucester counties, not rare-Wenzel. New Jersey-Collection United States National Museum.

O. vittatus, Grav.

New Jersey-Collection United States National Museum.

O. lateralis, Grav.

Camden and Gloucester counties, not rare-Wenzel. New Jersey-Collection United States National Museum.

B. pallipennis, Er.

\section{BLEDIUS, Leach.}

Recorded on the Newark list.

B. mandibularis, Er.

Brigantine Beach, salt marshes, September, common-Hamilton.

B. brevidens, Lec.

Atlantic county- Wenzel.

B. politus, Er.

Brigantine Beach, salt marshes, September, frequent-Hamilton.

B. basalis, Lec.

Brigantine Beach, in September, salt marshes, commonHamilton. Anglesea, in July-Schwarz. New Jersey-Collection United States National Museum.

B. cordatus, Say.

Brigantine Beach, common in salt marshes, SeptemberHamilton.

PLATYSTETHUS, Mann.

P. americanus, Er.

Brigantine Beach, common, September-Hamilton. New Jersey-Collection United States National Museum.

O. rugosus, Grav.

OXYTELUS, Grav.

New Jersey-Collection United States National Museum. 
O. pennsylvanicus, Er.

New Jersey-Collection United States National Museum.

O. insignitus, Grav.

Brigantine Beach, September-Hamilton. New Jersey-CoIlection United States National Museum.

O. nitidulus, Grav.

New Jersey-Collection United States National Museum.

O. exiguus, Er.

Anglesea, in July-Schwarz.

T. simplarius, Lec.

TROGOPHLGUS, Mann.

Anglesea, in July-Schwarz.

T. arcifer, Lec.

New Jersey-Collection United States National Museum.

T. 4-punctatus, Say.

Camden and Gloucester counties-Wenzel. New JerseyCollection United States National Museum.

A. sphæricollis, Say.

APOCELLUS, Er.

Brigantine Beach, in September-Hamilton. New JerseyCollection United States National Museum.

G. cæsus, Er.

GEODROMICUS, Redt.

Gloucester and Camden counties-Wenzel.

O. obtectum, Er.

OLOPERUM, Er.

New Jersey-Collection United States National Museum. Madison. Newark.

H. rufipes, Grav.

HOMALIUM, Grav.

New Jersey-Collection United States National Museum. 
G. costale, Er.

GLYPTOMA, Er.

New Jersey-Collection United States National Museum.

\section{Family TRICHOPTERYGID FE.}

P. hornianum, Math.

PTILIUM, Er.

Anglesea, in July—Schwarz.

P. ulkei, Math.

$$
\text { PTENIDIUM, Er. }
$$

Cape May, in July-Schwarz.

P. atomaroides, Mots.

Cape May, in July-Schwarz.

TRICHOPTERYX, Kirby.

T. haldemanni, Lec.

Anglesea, in July—Schwarz.

\section{Family SCAPHIDIIDAE.}

SCAPHIDIUM, Oliv.

S. quadriguttatum, Say.

Generally distributed, moderately abundant-Liebeck.

S. piceum, Mots.

Generally distributed, moderately abundant-Wenzel, Liebeck.

S. convexum, Say.

SCAPHISOMA, Leach.

Generally distributed, not rare-Liebeck, Wenzel. Newark. 


\section{Family PHALACRID 里.}

P. politus, Melsh.

PHALACRUS, Payk.

Taken in Ocean county-Smith.

O. lecontei, Casey.

OLIBRUS, Er.

"Atlantic States; not rare."

O. consimilis, Marsh.

Newark. Generally distributed, not rare-Wenzel.

O. nitidus, Melsh.

Generally distributed, common-Wenzel, Liebeck. Hudson county-Linell.

\section{STILBUS, Seidl.}

S. subalutaceus, Casey.

Cape May ; only recorded locality.

LITOCHRUS, Er.

L. immaculatus, Casey.

"New Jersey"-Casey.

\section{Family CORYLOPHID}

S. amabile, Lec.

\section{SACIUM, Lec.}

Anglesea, in July-Schwarz.

S. fasciatum, say.

Anglesea, in July-Schwarz. Newark.

S. lunatum, Lec.

Anglesea, in July-Schwarz.

S. nova species, Schwarz dixit.

Anglesea, in July-Schwarz. 


\section{ARTHROLIPS, Woll.}

A. marginicollis, Lec.

I have taken this in the State, exact locality unknown-Smith.

CORYLOPHUS, Steph.

C. truncatus, Lec.

Camden and Gloucester counties, not rare-Wenzel.

\section{RHYPOBIUS, Lec.}

R. marinus, Lec.

Brigantice Beach, in September, common-Hamilton. Anglesea, in July, common-Schwarz.

O. glaber, Lec.

\section{ORTHOPERUS, Steph.}

Camden and Gloucester counties, not common-Wenzel. Anglesea, in July-Schwarz.

o. scutellaris, Lec.

Anglesea, in July-Schwarz.

\section{Family COCCINELLIDEE.}

A. seriata, Melsh.

ANISOSTICTA, Dup.

Sea-shore, not rare-Wenzel. Atlantic City, moderately abundant-Liebeck. Brigantine Beach, in September, frequent -Hamilton. Cape May, in July-Schwarz. New JerseyLinell.

A. strigata, Thunb.

Hudson county-Linell.

MEGILLA, Muls.

M. maculata, De G.

Generally distributed, common-Wenzel, Liebeck. Brigantine Beach, in September, common-Hamilton. Hudson county, 
common-Linell. Caldwell, common-Crane. Newark. Madison. New Brunswick.

ㅍ. glacialis, Fabr.

$$
\text { HIPPODAMIA, Muls. }
$$

Generally distributed, common-Wenzel, Liebeck. Hudson county, abundant-Linell. New Brunswick. Ocean county, common-Smith. Caldwell, common-Crane. Newark. Madison.

H. convergens, Guer.

Common throughout the State. Reported as abundant by all observers.

H. 13-punctata, Linn.

Hudson county, not common-Linell. 'Caldwell, commonCrane.

H. parenthesis, Say.

Occurs throughout the State; moderately abundant. Reported by all collectors.

C. affinis, Rand.

COCCINELLA, Linn.

Atlantic county, rare-Wenzel.

C. trifasciata, Linn.

Newark, Madison; not common.

C. novemnotata, Hbst.

Common throughout the State.

C. sanguinea, Linn.

Common throughout the State.

A. bipuncta, Linn.

ADALIA, Muls.

Common throughout the State.

ㅍ. picta, Rand.

HARMONIA, Muls.

Gloucester, Dacosta, common-Liebeck. Camden, Gloucester and Atlantic counties, common-Wenzel. Hudson countyLinell. New Brunswick, not common-Smith. 
M. pullata, Say.

MYSIA, Muls.

Westville, moderately abundant-Liebeck. Common in spring-Wenzel.

ANATIS, Muls.

A. 15-punctata, Oliv.

Reported from all parts of the State; not rare.

PSYLLOBORA, Muls.

P. 20-maculata, Say.

Common throughout the State.

C. bivulnerus, Mels.

CHILOCORUS, Leach.

Moderately common throughout the State.

EXOCHOMUS, Redt.

E. marginipennis, Lec.

Generally distributed, rare-Wenzel. Dacosta, rare-Liebeck.

E. tripustulata, De G.

Generally distributed, more common on the shore-Wenzel. Atlantic City, rare-Liebeck.

P. misella, Lec.

\section{PENTILIA, Muls.}

Anglesea-Wenzel.

BRACHYACANTHA, Chevr.

B. dentipes, Fabr.

Anglesea, rare-Wenzel. Woodbury, rare-Liebeck.

B. ursina, Fabr.

Common throughout the State.

Var. 10-pustulata, Melsh.

With the type; generally less common. 


\section{HYPERASPIS, Chevr.}

H. fimbriolata, Melsh.

Hudson county-Linell.

H. undulata, Say.

Generally distributed, not rare-Wenzel. Hudson countyLinell.

H. lewisii, Cr.

Generally distributed, rare-Wenzel.

H. signata, Oliv.

Generally distributed, not rare-Wenzel, Liebeck. Hudson county-Linell.

स. proba, Say.

Generally distributed, not rare-Wenzel. Hudson countyLinell.

H. bigeminata, Rand.

Atco, rare-Liebeck.

S. bioculatus, Muls.

SCYMNUS, Kug.

Atco, rare-Liebeck.

S. terminatus, Say.

Generally distributed, not rare-Wenzel.

S. americanus, Muls.

Atco, rare-Liebeck.

S. fraternus, Lec.

Generally distributed, rare-Liebeck.

S. hæmorrhous, Lec.

Generally distributed, not rare-Wenzel.

S. punctatus, Melsh.

Anglesea, in July-Schwarz.

C. lepida, Lec.

COCCIDULA, Kug.

Gloucester ; rare. 
E. borealis, Fabr.

\section{BPILACHNA, Chevr.}

Generally distributed, moderately abundant - Wenzel, Liebeck. New Brunswick. Newark. Caldwell, common-Crane.

Unlike all others of this family, this species is a leaf-feeder and injurious; all the others are highly beneficial. When more careful collections are made, the number of our species in some genera will be largely increased.

\section{Family ENDOMYCHID FE.}

R. unicolor, Ziegl.

RHANIS, Lec.

Generally distributed, rare-Liebeck. Camden and Gloucester counties, not common-Wenzel.

L. ferruginea, Lec.

\section{LYCOPERDINA, Latr.}

Camden and Gloucester counties, not common-Wenzel. Gloucester, rare-Liebeck. Hudson county-Linell. Newark.

A. vittata, Fabr.

\section{APHORISTA, Gorh.}

Generally distributed, not rare-Wenzel. Gloucester, rareLiebeck. Caldwell, common-Crane:

MYCETINA, Muls.

M. perpulchra, Newn.

Newark-Bischoff.

M. testacea, Ziegl.

Generally distributed, not common-Wenzel. Sea-shore, rare -Liebeck.

P. pulchella, Newn.

$$
\text { PHYMAPHORA, Newn. }
$$

Caldwell, common-Crane. Madison. Nervark. 
S. hispidus, Hbst.

\section{STENOTARSUS, Perty.}

Atlantic and Cape May counties, not common-Wenzel. Atlantic City, Landisville, rare-Liebeck. Newark.

E. cinctus, Lec.

EPIPOCUS, Germ.

Generally distributed, rare-Wenzel.

E. biguttatus, Say.

\section{ENDOMYCHUS, Panz.}

Generally distributed, not common-Wenzel, Liebeck. Hudson county-Iinell.

\section{Family EROTYLID五.}

L. bicolor, Fabr.

\section{LANGURIA, Latr.}

Camden, rare-Wenzel. Westville, sea-shore, rare-Liebeck. Brigantine Beach, in September, two specimens-Hamilton. Newark.

L. mozardi, Lec.

Generally distributed, rather common-Wenzel, Liebeck. Caldwell, common-Crane. Hudson county-Linell. Newark.

L. tædata, Lec.

Sea-shore, not common-Wenzel, Liebeck. Hudson countyLinell.

L. angustata, Beauv.

Generally distributed, not rare-Wenzel. Hudson countyLinell. Newark.

Var. trifasciata, Say.

Generally distributed, rare-Liebeck. Newark.

L. gracilis, Newn.

Generally distributed, not common-Wenzel. Gloucester, rare-Liebeck. Hudson county-Linell. 
D. 4-maculata, Say.

DACNE, Latr.

New Jersey, exact locality unknown, rare-Liebeck.

M. fasciata, Fabr.

MEGALODACNE, Cr.

Generally distributed, rather common-Liebeck. Same, except sea-shore-Wenzel.' Caldwell, common-Crane. Newark.

I. 4-punctatus, Oliv.

ISCHYRUS, Lac.

Caldwell, common-Crane.

M. pulchra, Say.

MYCOTRETUS, Lac.

Hudson county-Linell.

TRITOMA, Fabr.

T. humeralis, Fabr.

Generally distributed, not common-Liebeck, Wenzel. Brigantine Beach, mainland, in September-Hamilton. Hudson county-Linell.

T. biguttata, Say.

Anglesea, in July-Schwarz. Brigantine Beach, mainland, in September-Hamilton. Hudson county-Linell. Newark.

T. angulata, Say.

Hudson county-Linell. New Jersey-Collection Horn.

T. unicolor, Say.

Generally distributed, not common-Wenzel, Liebeck.

T. thoracica, Say.

Generally distributed, not rare-Wenzel. Sea-shore, rareLiebeck. Hudson county-Linell.

T. flavicollis, Lec.

Generally distributed, moderately abundant-Liebeck, Wenzel. Brigantine Beach, mainland, in September-Hamilton. Hudson county-Linell. 


\section{Family COLYDIIDE.}

S. obscura, Horn.

SYNCHITA, Hellw.

Anglesea, in July-Schwarz.

S. fuliginosa, Melsh.

Hudson county-Linell.

D. quadriguttata, Say.

DITOMA, Illig.

Dacosta, rare-Liebeck. Hudson county-Linell.

C. guttulatus, Lec.

COXELUS, Latr.

Westville, rare-Liebeck.

PENTHELISPA, Pasc.

P. hæmatodes, Fabr.

Anglesea-Wenzel.

AULONIUM, Er.

A. parallelopipedum, Say.

Hudson county, not common-Linell.

C. lineola, Say.

COLYDIUM, Fabr.

Camden and Gloucester counties, rare-Wenzel. Hudson county-Linell.

B. geminatus, Say.

BOTHRIDERES, Er.

Generally distributed, rare-Liebeck.

C. castaneum, Say.

CERYLON, Latr.

Generally distributed, rare-Wenzel. Hudson countyLinell. 
PHILOTHERMUS, Aubé.

P. glabriculus, Lec.

Generally distributed, moderately abundant-Liebeck. RareWenzel. Hudson oounty-Linell.

\title{
Family RHYSSODID卮.
}

C. sculptile, Newn.

CLINIDIUM, Kirby.

Gənerally distributed, rare-Liebeck. Camden and Gloucester counties, rare-Wenzel.

\section{Family CUCUJID}

\author{
SILVANUS, Latr.
}

S. surinamensis, Linn.

Generally distributed; often injurious to stored grain. Common in the mangers, in stables.

S. bidentatus, Fabr.

Generally distributed, not rare-Wenzel. Hudson countyLinell.

S. planatus, Germ.

Brigantine Beach, mainland, in September-Hamilton. Hudson county-Linell. Newark.

S. imbellis, Lec.

Generally distributed, not uncommon-Liebeck.

S. advena, Waltl.

I have taken this rarely, under bark.

N. dentatus, Marsh.

NAUSIBIUS, Redt.

Generally distributed, not uncommon-Liebeck. 
C. rufus, Fabr.

\section{CATOGENUS, Westw.}

Generally distributed, rare-Liebeck. Locally commonWenzel. Caldwell, rare-Crane. Hudson county-Linell. Newark.

C. clavipes, Fabr.

\section{CUCUJUS, Fabr.}

Generally distributed, not uncommon-Wenzel, Liebeck. Fort Lee, abundant in fall-Linell. Caldwell, common-Crane. Newark.

L. biguttatus, Say.

\section{LAPMOPHLCFUS, Lap.}

Westville, not uncommon-Liebeck. Anglesea, in JulySchwarz. Hudson county-Linell.

L. fasciatus, Melsh.

Anglesea, in July-Schwarz. Newark.

L. convexulus, Lec.

Hudson county-Linell.

L. adustus, Lec.

Hudson county-Linell.

I. testaceus, Lec.

Hudson county-Linell.

L. vernalis, Lec.

LATHROPUS, Er.

Anglesea, in July-Schwarz. Hudson county-Linell.

B. dubius, Fabr.

\section{BRONTES, Fabr.}

Generally distributed, rare-Wenzel. Camden, not uncommon -Liebeck. Caldwell, common-Crane. Newark.

B. debilis, Lec.

Hudson county-Linell. Mr. Linell adds, "according to Captain Casey, the northern form is not dubius." 
T. velox, Hald.

TELEPHANUS, Er.

Generally distributed, not uncommon-Liebeck. Brigantiue Beach, in September-Hamilton. Hudson county-Linell. Newark.

\section{Family CRYPTOPHAGID E.*}

TELMATOPHILUS, Heөr.

T. americanus, Lec.

Hudson county-Linell.

L. impressus, Lec.

\section{LOBERUS, Lec.}

I have taken this either in Hudson or Essex county, rarely. Hudson county-Linell.

T. pulchellus, Lec.

TOMARUS, Lec.

Anglesea, in July-Schwarz. Hudson county-Linell.

\section{ANTHEROPHAGUS, Latr.}

A. ochraceus, Melsh.

Westville, rare-Liebeck. Hudson county-Linell.

A. ephippiata, Zimm.

$$
\text { ATOMARIA, Steph. }
$$

Camden, moderately common-Liebeck. Hudson countyLinell. Newark-Loeffler.

\section{Family MYCETOPHAGID五.}

M. punctatus, Say.

\section{MYOETOPHAGUS, Hellw.}

Generally distributed, rather common-Liebeck. Hudson county--Linell.

\footnotetext{
*A number of species in this family are in collections, awaiting identification.
} 
M. flexuosus, Say.

Generally distributed, rather common-Liebeck. Hudson county-Linell.

M. melsheimeri, Lec.

Camden, rare-Liebeck.

M. pluripunctatus, Lec.

Westville, rare-Liebeck.

M. pini, Ziegl.

Westville, rare-Liebeck.

L. sez-punctatus, Say.

\section{LITARGUS, Er.}

Anglesea, in July-Schwarz. Hudson county-Linell.

L. didesmus, Say.

Anglesea, in July-Schwarz. Hudson county-Linell.

T. fumata, Linn.

TҮPHФA, Steph.

Westville, rare-Liebeck. Newark-Loeffler.

\section{Family DERMESTID}

B. unicolor, Say.

BYTURUS, Latr.

Generally distributed, not rare-Liebeck. Hudson countyLinell.

D. caninus, Germ.

DERMESTES, Linn.

Generally distributed, not uncommon-Liebeck, Wenzel. Brigantine Beach, in September-Hamilton. Newark.

D. lardarius, Linn.

Generally distributed, common-Wenzel, Liebeck. Brigantine Beach, in September-Hamilton. Caldwell, commonCrane. Newark. Madison. 
D. vulpinus, Fabr.

Westville, rare-Liebeck. Tenerally distributed-Wenzel. Caldwell, common-Crane.

D. frischii, Kug.

Sea-shore, moderately abundant-Liebeck. Brigantine Beach, in September, abundant-Hamilton.

A. piceus, Oliv.

\section{ATTAGENUS, Latr.}

Common throughout the State.

\section{TROGODERMA, Latr.}

T. ornatum, Say.

I have taken specimens on flowers. Caldwell, rare-Crane.

T. tarsale, Melsh.

Generally distributed, rather common-Liebeck. Sometiues quite annoying as a museum pest.

\section{ANTHRENUS, Geoffr.}

A. scrophulariæ, Linn.

New Brunswick; excessively abundant in April. This is the carpet beetle, the parent of the so-called "Buffalo Moth." Caldwell, common-Crane. Newark.

A. varius, Fabr.

Generally distributed; common. This is the ordinary museum pest, so often injurious to all dried specimens of animals or plants.

A. musæorum, Linn.

Also a museum pest, but more rare than the preceding.

C. ruficorne, Lec.

CRYPTORHOPALUM, Guer.

Not uncommon on flowers in Ocean county.

C. triste, Lec.

Brigantine Beach, mainland, in September, on SolidagoHamilton. 
O. glabratus, Fabr.

ORPHILUS, Er.

Not uncommon on flowers.

\section{Family HISTERID臣.}

HOLOLEPTA, Payk.

H. quadridentata, Fabr.

Hudson county-Linell.

H. lucida, Lec.

Hudson county_Linell.

H. fossularis, Say.

Camden and Gloucester counties, not common-Wenzel. Gloucester, Dacosta, rare-Liebeck. Caldwell, rare-Crane. Hudson county-Linell. Newark.

H. arcuatus, Say.

\section{HISTER, Linn.}

Sea-shore, not rare-Wenzel. Brigantine Beach, in September, frequent-Hamilton. Nervark. Madison.

H. biplagiatus, Lec.

Generally distributed, not common-Wenzel. Westville, not uncommon-Liebeck. Brigantine Beach, in September, rareHamilton.

H. interruptus, Beauv.

Generally distributed, common-Wenzel, Liebeck. Hudson county, common-Linell. Newark.

H. marginicollis, Lec.

Madison-Paulmier.

H. abbreviatus, Fabr.

Generally distributed, common-Wenzel. Brigantine Beach, in September, frequent-Hamilton. Newark. Hudson countyLinell. 
H. civilis, Lec.

Sea-shore, rare-Liebeck. Camden and Gloucester counties, not common-Wenzel. Brigantine Beach, in September, less frequent-Hamilton.

H. furtivus, Lec.

Madison-Paulmier.

H. depurator, Say.

Hudson county-Linell. A common species near Jersey City.

H. bimaculatus, Linn.

Sea-shore, rare-Liebeck. Atlantic county, rare-Wenzel.

Caldwell, common-Crane. Madison.

H. sedecimstriatus, Say.

Hudson county-Linell. Caldwell, common-Crane.

H. americanus, Payk.

Generally distributed, common-Wenzel, Liebeck. Hudson county-Linell.

H. perplexus, Lec.

I have found this not uncommon in the State.

H. exaratus, Lec.

Brigantine Beach, in September, rare-Hamilton.

H. subrotundatus, Say.

Generally distributed, common-Liebeck, Wenzel. Hudson county-Linell. Newark.

H. vernus, Say.

Generally distributed, not common-Wenzel.

E. carolinus, Payk.

Generally distributed, common-Liebeck. Under barkWenzel. Hudson county-Linell.

E. lecontei, Mars.

Generally distributed, under bark-Wenzel. Westville, not uncommon-Liebeck. Caldwell, rare-Crane. Newark. Hudson county-Linell.

E. parallelus, Say.

Not uncommon under bark-Wenzel. Madison. 
H. attenuatus, Lec.

Under bark, rather rare-Wenzel.

E. pulicarius, Er.

EPIERUS, Er.

Camden and Gloucester counties, under bark, not commonWenzel.

\section{HET ÆॄRIUS, Er.}

H. brunnipennis, Rand.

Orange Mountains, in ants' nests, not rare-Linell and Newark list.

P. æqualis, Say.

PAROMALUS, Er.

Snake Hill, under bark-Linell. Generally distributed, under bark-Wenzel.

P. estriatus, Lec.

Snake Hill, under bark-Linell.

P. geminatus, Lec.

Brigantine Beach, in September, rare-Hamilton.

P. 14-striatus, Steph.

Brigantine Beach, in September-Hamilton. Snake Hill, under bark-Linell.

P. bistriatus, Er.

Snake Hill, under bark-Linell.

P. seminulum, Er.

Snake Hill, under bark-Linell.

Mr. Linell adds that these species are found under bark of freshly-cut, not decayed stumps, but where the sap is still flowing.

\section{SAPRINUS, Er.}

వ. pennsylvanicus, Payk.

Generally distributed, common-Wenzel, Liebeck. Brigantine Beach, in September, common-Hamilton. Sandy Hook, common-Smith. This species is abundant all along the seashore, under carrion. 
S. assimilis, Payk.

Sea-shore, not uncommon-Wenzel. Brigantine Beach, in September-Hamilton. Atlantic City-Castle.

S. sphæroides, Lec.

Brigantine Beach, in September, rare-Hamilton.

S. fraternus, Say.

Generally distributed, not rare-Wenzel. Anglesea, in July -Schwarz. Brigantine Beach, in September, common-Hamilton. Sandy Hook, common-Smith. Caldwell, commonCrane.

S. patruelis, Lec.

Brigantine Beach, in September, frequent-Hamilton. Cape May, in July-Schwarz.

S. dimidiatipennis, Lec.

Sea-shore, rare-Wenzel, Liebeck.

P. transversus, Say.

\section{PLEGADERUS, Er.}

Generally distributed, not common-Wenzel. Atlantic City -Castle.

A. politus, Lec.

\section{平LETES, Horn.}

Ocean county, common on cranberry bogs, in May-Smith.

\section{Family NITIDULID王.}

Under this family Mr. Linell remarks: "Sap beetles are, in my experience, most abundant in September and October, on tree stumps cut in the spring of the same year." Mr. Wenzel also says that decaying fruit in the fall is prolific in species of this family.

B. urticæ, Fabr.

\section{BRACHYPTERUS, Er.}

Generally distributed, not rare-Wenzel. I have taken it near Hoboken. 
C. abdominalis, Er.

\section{CERCUS, Latr.}

Westville, not uncommon-Liebeck. Hudson county-Linell. Newark.

\section{CARPOPHILUS, Steph.}

C. hemipterus, Linn.

Hudson county, not rare locally-Linell.

C. niger, Say.

Generally distributed, common-Wenzel. Hudson countyLinell.

C. corticinus, Er.

Camden, rare-Liebeck.

C. brachypterus, Say.

Hudson county-Linell.

C. antiquus, Melsh.

Hudson county-Linell.

I have taken all these myself on the wooded slopes of the Palisades.

C. maculatus, Er.

COLASTUS, Er.

Hudson county-Linell.

C. semitectus, Say.

Generally distributed, common-Wenzel. Hudson countyLinell.

C. unicolor, Say.

Same as before.

C. truncatus, Rand.

Same as before.

All these are about equally common.

c. obscurus, Er.

CONOTELUS, Er.

Generally distributed, rare-Liebeck. Brigantine Beach, in September-Hamilton. Hudson county-Linell. 
E. helvola, Er.

\section{EPUR平A, Er。}

Generally distributed, not rare-Wenzel. Anglesea, in July -Schwarz. Brigantine Beach, mainland, in SeptemberHamilton. Hudson county-Linell.

E. rufa, Say.

Hudson county-Linell. Madison.

E. avara, Rand.

Hudson county-Linell.

E. peltoides, Horn.

Hudson county-Linell.

Ð. labilis, Er.

Generally distributed, common-Wenzel. Hudson countyLinell.

N. rufipes, Linn.

\section{NITIDULA, Fabr.}

Camden, rare-Liebeck. Brigantine Beach, in SeptemberHamilton. Hudson county-Linell. Madison.

N. ziczac, Say.

Common all over the State.

S. geminata, Say.

\section{STELIDOTA, Er.}

Generally distributed-Wenzel. Westville, rare-Liebeck. Hudson county-Linell.

S. 8-maculata, Say.

Anglesea, in July-Schwarz. Hudson county-Linell.

S. strigosa, Gyll.

Brigantine Beach, mainland, in September-Hamilton.

P. 6-maculata, Say.

\section{PROMETOPIA, Er.}

Generally distributed, common-Wenzel, Liebeck. Hudson county-Linell. Caldwell, common-Crane. Newark. 
P. grossa, Fabr.

\author{
PHENOLIA, Er.
}

Generally distributed, not uncommon-Wenzel, Liebeck. Hudson county-Linell. Newark.

O. colon, Linn.

OMOSITA, Er.

Generally distributed, common-Wenzel, Liebeck. Brigantine Beach, in September-Hamilton. Hudson countyLinell. Newark.

S. guttulata, Lec.

SORRONIA, Er.

Hudson county, rare-Linell.

S. undulata, Say.

Generally distributed, moderately abundant-Liebeck, Wenzel. Hudson county-Linell.

S. ulkei, Lec.

Sea-shore, rare-Liebeck.

P. helvolus, Er.

\title{
POCADIUS, Er.
}

Fort Lee, abundant-Linell. Generally distributed, not common-Wenzel.

P. infuscatus, Reitter.

New Jersey-One specimen in Dr. Horn's collection.

O. histrina, Lec.

\section{OXYCNEMUS, Er.}

Generally distributed, not common-Wenzel. Sea-shore, rare -Liebeck. Hudson county-Linell.

\section{A. ciliatus, Oliv. \\ AMPHICROSSUS, Er.}

Generally distributed, not rare-Wenzel. Hudson countyLinell. 
P. silaceus, Er.

\section{PALLODES, Er.}

Generally distributed, not rare-Wenzel. Anglesea, in JulySchwarz. Hudson county-Linell. Newark. Madison.

C. adustus, Er.

\section{CYCHRAMUS, Kug.}

Near Hoboken, rare-Smith.

C. ampla, Er.

\section{CRYPTARCHA, Shuck.}

Generally distributed, rather common-Wenzel, Liebeck. Hudson county-Linell.

C. strigata, Fabr.

Hudson county-Linell. Newark-Loeffler.

C. concinna, Melsh.

Hudson county-Linell.

I. obtusus, Say.

\section{IPS, Fabr.}

Westville, rare-Liebeck. Snake Hill, rare-Linell. Newark.

I. fasciatus, Oliv.

Generally distributed, common-Wenzel, Liebeck. Brigantine Beach, in September-Hamilton. Hudson county-Linell. Caldwell, common-Crane. Newark.

I. sanguinolentus, Oliv.

Camden. Gloucester county, not uncommon-Wenzel. Westville, not uncommon-Liebeck. Hudson county-Linell. Newark.

I. cylindricus, Lec.

Caldwell, rare-Crane.

R. cylindricus, Lec.

\section{RHIZOPHAGUS, Hbst.}

Generally distributed, not uncommon-Liebeck.

$R$. bipunctatus, Say.

Hudson county-Linell. 


\section{Family LATRIDIID王.}

\$. liratus, Lec.

\section{STEPHOSTETHUS, Lөc.}

Generally distributed and locally not rare-Smith.

C. deleta, Mann.

\section{CORTICARIA, Marsh.}

Generally distributed, not common-Smith. NewarkLoeffler.

C. americana, Mann.

Hudson county-Linell.

C. longipennis, Lec.

Newark-Loeffler.

C. cavicollis, Mann.

Hudson county-Linell.

C. simplex, Lec.

Anglesea, in July-Schwarz.

\section{Family TROGOSITIDEE.}

N. parallelum, Melsh.

NEMOSOMA, Latr.

Hudson county-Linell. Newark; rare.

T. virescens, Fabr.'

\section{TROGOSITA, Oliv.}

Generally distributed, rather common-Wenzel, Liebeck. Newark.

T. corticalis, Melsh.

TENEBRIOIDES, Pall.

Generally distributed, rather common-Wenzel, Liebeck. Hudson county-Linell. Caldwell, rare-Crane. 


\section{5t GEOLOGICAL SURVEY OF NEW JERSEY.}

T. castanea, Melsh.

Generally distributed-Wenzel. Camden, rare-Liebeck. Hudson county-Linell.

T. bimaculata, Melsh.

Hudson county-Linell.

T. fulgidus, Er.

THYMALUS, Duft.

Hudson county-Linell. Newark.

M. producta, Lec.

MONOTOMA, Hbst.

Brigantine Beach, in September, abundant-Hamilton. Anglesea, in July, common-Schwarz.

M. picipes, Hbst.

Hudson county-Linell.

BACTRIDIUM, Lec.

B. ephippigerum, Guer.

Hudson county-Linell.

B. striolatum, Reit.

Hudson county-Linell.

B. cavicolle, Horn.

Hudson county-Linell.

\section{Family BYRRHIDE.}

N. unicolor, Say.

NOSODENDRON, Latr.

Camden and Gloucester counties, rare-Wenzel.

C. sericeus, Först.

CYTILUS, Er.

Hudson county-Linell. Newark. 
B. americanus, Lec.

BYRRHUS, Linn.

Sea-shore, not common-Wenzel, Liebeck.

\section{Family PARNID}

P. lecontei, Lec.

\section{PSEPHENUS, Hald.}

Newark; not common.

D. lithophilus, Germ.

DRYOPS, Oliv.

Clifton, abundant-Linell. Newark.

D. fastigiatus, Say.

Clifton, abundant-Linell. New Jersey-Collection Roberts. Newark-Bischoff.

D. striatus, Lec.

New Jersey-Collection Roberts.

F. 4-notatus, Say.

\section{ELMIS, Latr.}

Clifton-Linell. New Jersey-Collection Roberts.

E. pusillus, Lec.

Clifton, not rare-Linell.

S. crenatus, Say.

STENELMIS, Dup.

Clifton, abundant-Linell. New Jersey-Collection Roberts.

S. vittipennis, Zimm.

Clifton, not common-Linell.

S. quadrimaculatus, Horn.

Nervark-Bischoff.

M. glabratus, Say.

MACRONYCEUS, Müll.

Clifton, common-Linell. New Jersey-Collection Roberts. 
A. variegatus, Germ.

ANCYRONYX, Er.

Clifton, not common-Linell. New Jersey-Collection Roberts.

\section{Family HETEROCERID止.}

H. tristis, Mann.

HETEROCERUS, Fabr.

Sea-shore, rare-Liebeck.

H. fatuus, Kies.

Brigantine Beach, in September-Hamilton. Newark.

H. substriatus, Kies.

Sea-shore, not rare-Wenzel.

H. mollinus, Kies.

Sea-shore, not rare-Wenzel.

H. collaris, Kies.

Sea-shore, not rare-Wenzel.

H. brunneus, Melsh.

Newark; a single specimen.

\section{Family DASCYLLID王。}

E. niger, Melsh.

EURYPOGON, Mots.

Hudson county-Linell. Newark-Bischoff.

O. trivittis, Germ.

ODONTONYX, Guer.

Newark-Bischoff.

PTILODACTYLA, Lat.

P. serricollis, Say.

Hudson county-Linell. 
E. terminalis, Lec.

EUCINETUS, Germ.

Hudson county-Linell.

E. nervosa, Melsh.

$$
\text { ECTOPRIA, Lec. }
$$

Hudson county-Linell.

H. thoracica, Guer.

\section{HELODES, Latr.}

Newark. Not uncommon in Ocean and Monmouth counties.

S. orbiculatus, Fabr.

SCIRTES, Ill.

Hudson county-Linell.

S. tibialis, Guer.

I have several times taken this in the State.

C. collaris, Guer.

CYPHON, Payk.

Hudson county-Linell.

O. variabilis, Thunb.

Common on flowers, Ocean and Monmouth counties. Anglesea, in July-Schwarz.

\section{Family RHIPICERID王.}

\section{SANDALUS, Knoch.}

S. petrophya, Knoch.

Northern Jersey, rare-Liebeck. Newark.

\section{Family ELATERIDA.}

MELASIS, Oliv.

M. pectinicornis, Melsh.

Newark. Atlantic City-Castle. 
T. ruflcornis, Say.

\section{TEAROPS, Lap.}

Sea-shore, rare-Liebeck. Hudson county-Linell.

\section{DELTOMETOPUS, Bonv.}

D. amcenicornis, Say.

Generally distributed, rare-Liebeck. Hudson countyLinell.

\section{MICRORRHAGUS, Esch.}

M. triangularis, Say.

Newark, compared with Dr. Horn's specimens. Madison.

\section{ADELOCERA, Latr.}

A. marmorata, Fabr.

Gloucester and Camden counties, not common-Wenzel. Westville, rare-Liebeck.

A. discoidea, Web.

Generally distributed, not rare-Wenzel, Liebeck.

A. maculata, Lec.

Exact locality unknown; rare; not taken recently-Liebeck.

\section{CHALCOLEPIDIUS, Esch.}

C. viridipilis, Say.

Gloucester and Camden counties, not rare-Wenzel. Westville, rare-Liebeck.

A. oculatus, Linu.

\section{ALAUS, Esch.}

Occurs everywhere in the State, not uncommonly.

A. myops, Fabr.

Generally distributed, moderately abundant-Wenzel, Liebeck. ()ecurs throughout the pine districts; more common southward.

C. cardisce, Say.

CARDIOPHORUS, Esch.

Generally distributed, not uncommon-Wenzel. 
C. gagates, Er.

Madison-Paulmier.

C. robustus, Lec.

New Jersey-Collection Dr. Horn.

HORISTONOTUS, Cand.

H. curiatus, Say.

Gloucester and Camden counties, not common-Wenzel. Westville, rare-Liebeck. Hudson county-Linell.

CRYPTOHYPNUS, Esch.

C. guttulatus, Melsh.

Camden, rare-Liebeck.

C. pulchellus, Linn.

Westville, rare-Liebeck. New Jersey-Collection Dr. Horn.

C. obliquatulus, Melsh.

Camden, rare-Liebeck. Ocean county, not rare-Smith.

M. lividus, De G.

\section{MONOCREPIDIUS, Esch.}

Generally distributed, common-Liebeck, Wenzel. Hudson county-Linell.

M. vespertinus, Fabr.

Generally distributed, common-Liebeck, Wenzel. Hudson county-Linell. Caldwell, common-Crane.

M. auritus, Hbst.

Camden and Gloucester counties, not uncommon-Wenzel. Westville, rather common-Liebeck. Brigantine Beach, mainland, in September, common-Hamilton. Hudson countyLinell. Madison. Ocean county-Smith.

M. bellus, Say.

Camden and Gloucester counties, not uncommon-Wenzel. Westville, Gloucester, not uncommon-Liebeck. Hudson county-Linell.

E. hepaticus, Melsh.

$$
\text { ELATER, Linn. }
$$

Camden and Gloucester counties, not rare-Wenzel. 
E. pedalis, Germ.

Generally distributed, not rare-Wenzel. Atco, rare-Liebeck.

E. mixtus, Hbst.

New Jersey-Collection Dr. Horn.

E. nigricollis, Hbst.

Generally distributed, not rare-Wenzel. Rare-Liebeck. Hudson county_Linell. Newark.

E. linteus, Say.

Generally distributed, not rare-Wrenzel. Rare-Liebeck. Hudson county-Linell.

E. sayi, Lec.

Gloucester and Camden counties, very rare-Wenzel. New Jersey-Collection Dr. Horn.

E. rubricollis, Hbst.

Gloucester and Camden counties, rare-Wenzel. Westville, rare-Liebeck. Newark.

E. nigricans, Germ.

Hudson county-Linell.

E. rubricus, Say.

Hudson county-Linell. New Jersey-Collection Dr. Horn. Ocean county, rare-Smith.

E. collaris, Say.

Camden, rare-Liebeck.

E. sanguinipennis, Say.

Brigantine Beach, mainland, in September, very rareHamilton.

E. xanthomus, Germ.

Camden and Gloucester counties, rare-Wenzel. Dacosta, rare-Liebeck.

E. obliquus, Say.

Generally distributed, not rare-Wenzel, Liebeck. Hudson county-Linell. Newark. Ocean county, rare-Smith.

E. pusio, Germ.

Hudson county-Linell. 
D. elegans, Fabr.

\section{DRASTERIUS, Esch.}

Generally distributed, common-Wenzel, Liebeck. Hudson county-Linell. Newark.

D. amabilis, Lec.

Camden and Gloucester counties, rare-Wenzel. Camden, rare-Liebeck. Hudson county-Linell.

M. limbalis, Hbst.

\section{MEGAPENTHES, Kies.}

Generally distributed, rare-Liebeck. Hudson countyLinell. Newark.

M. rufilabris, Germ.

Atco, rare-Liebeck. Hudson county-Linell.

L. attenuatus, Say.

\section{LUDIUS, Latr.}

Camden, rare-Liebeck. Hudson county-Linell. Caldwell, rare-Crane.

L. abruptus, Say.

Westville, rare-Liebeck. Hudson county-Linell. Caldwell, rare-Crane.
A. mancus, Say.
AGRIOTUS, Esch.

Hudson county-Linell. Newark. Caldwell, rare-Crane.

A. insanus, Cand.

Hudson county-Linell.

A. pubescens, Melsh.

Generally distributed, rare-Liebeck. Camden and Gloucester counties, not common-Wenzel.

A. oblongicollis, Melsh.

As before: also Hudson county-Linell.

D. Jateralis, Esch.

\section{DOLOPIUS, Esch.}

Landisville, Atco, rare-Liebeck. Hudson county-Linell. Caldivell, rare-Crane. 
B. bigeminatus, Rand.

\section{BETARMON, Kies.}

$$
\text { Hudson county-Cinell. }
$$

G. recticollis, Say.

\section{GLYPHONYX, Cand.}

Generally distributed, not rare-Liebeck. Hudson countyLinell. Ocean county, in May, common-Smith.

G. testaceus, Melsh.

Camden and Gloucester counties, not rare-Wenzel. Anglesea, in July-Schwarz. Hudson county-Linell. Ocean county, ip May, common-Smith.

\section{MELANOTUS, Esch.}

M. decumanus, Er.

Generally distributed, not rare-Wenzel. Hudson countyLinell.

M. secretus, Lec.

Atco, rare-Liebeck.

M. ignobilis, Melsh.

New Jersey-Collection Dr. Horn.

M. depressus, Melsh.

Generally distributed, not rare-Wenzel.

M. tænicollis, Lec.

New Jersey. All of Dr. Horn's specimens are so marked.

M. glandicolor, Melsh.

Hudson county-Linell.

M. fissilis, Say.

Occurs commonly throughout the State.

M. communis, Gyll.

Occurs commonly throughout the State.

M. exuberans, Lec.

New Jersey-Collection Dr. Horu.

M. parumpunctatus, Melsh.

Hudson county-Linell. 
M. cribulosus, Lec.

Generally distributed, not common-Wenzel.

M. tenax, Say.

New Jersey-Collection Dr. Horn.

M. americanus, Hbst.

Generally distributed, not common-Wenzel, Liebeck. Hudson county-Linell.

M. insipiens, Say.

Generally distributed, rare-Liebeck.

M. variolatus, Lec.

Recorded on the Newark list.

L. auripilis, Say.

\section{LIMONIUS, Esch.}

Camden and Gloucester counties, rare-Wenzel. Atco, rareLiebeck.

I. stigma, Hbst.

New Jersey-Collection Dr. Horn.

I. griseus, Beauv.

Generally distributed, common-Wenzel, Liebeck. Hudson county-Linell.

L. confusus, Lec.

Generally distributed, not uncommon-Liebeck.

L. plebeius, Say.

Hudson county-Linell.

L. æger, Lec.

Not rare in Ocean county.

L. quercinus, Say.

Generally distributed, common-Liebeck. Hudson countyLinell. Madison. I have taken this abundantly in Ocean county.

L. basillaris, Say.

Generally distributed, common-Liebeck, Wenzel.

L. agonus, Say.

Atlantic City-Castle. 


\section{GEOLOGICAL SURVEY OF NEW JERSEY.}

L. nimbatus, Say.

Generally distributed, not rare-Wenzel. Westville, rareLiebeck. Hudson county-Linell.

P. anguinus, Lec.

\section{PITYOBIUS, Lec.}

Atlantic City, rare, not taken recently-Liebeck. Atlantic City, Dacosta-Castle.

A. brightwelli, Kirby.

\section{ATHOUS, Esch.}

Hudson county-Linell.

A. acanthus, Say.

Hudson county-Linell.

A. cucullatus, Say.

Generally distributed, not rare-Liebeck. Anglesea, in July -Schwarz. Hudson county-Linell.

A. equestris, Lec.

New Jersey-Collection Dr. Horn.

A. limbatus, Lec.

Atlantic City_Castle.

O. tenuicollis, Rand.

\section{ФSTODES, Lec.}

Ocean county; not common.

S. viridanus, Say.

\section{SERICOSOMUS, Steph.}

Sea-shore, rare-Liebeck.

S. debilis, Say.

Landisville, rare-Liebeck.

C. tesselatus, Linn.

\section{CORYMBITES, Latr.}

Camden and Gloucester counties, rare-Wenzel.

C. cylindriformis, Hbst.

Generally distributed, common-Wenzel, Liebeck. Caldwell, common-Crane. Hudson county-Linell. Newark. 
C. pyrrhos, Hbst.

Generally distributed, rather common-Wenzel, Liebeck. Hudson county-Linell. Newark. Caldwell, common-Crane.

C. bivittatus, Melsh.

Sea-shore, rare-Liebeck.

C. tarsališ̉, Melsh.

Generally distributed, not uncommon-Liebeck, Wenzel.

C. sulcicollis, Say.

Generally distributed, rare-Wenzel.

C. æthiops, Hbst.

Generally distributed, rare-Wenzel. Hudson county—Linell. Newark.

O. hieroglyphicus, Say.

Generally distributed, not uncommon-Liebeck. Hudson county-Linell. Newark. Caldwell, rare-Crane.

C. møtallicus, Payk.

Camden and Gloucester counties, rare-Wenzel.

C. inflatus, Lec.

Gloucester, rare-Liebeck. Hudson county-Linell.

A. decoloratus, Say.

\section{ASAPEES, Kirby.}

Hudson county-Linell. Not an uncommon species in the Orange Mountains. Madison.

A. memnonius, Hbst.

Generally distributed, not uncommon-Liebeck. Hudson county-Linell. Newark. Caldwell, common-Crane. Madison.

A. bilobatus, Say.

Hudson county-Linell. Caldwell, common-Crane.

M. piceus, Deg.

\section{MELANACTES, Lec.}

Generally distributed, rare-Liebeck. Camden and Gloucester counties, not rare-Wenzel. Hudson county-Linell. Newark. 
M. morio, Fabr.

Camden and Gloucester counties, not rare-Wenzel. Hudson county-Linell. Newark. Caldwell, rare-Crane.

O. bicolor, Fabr.

\author{
CEBRIO, Oliv.
}

Camden and Gloucester counties, rare-Wenzel.

P. mucida, Gyll.

PEROTHOPS, Er.

Camden, rare-Liebeck.

\title{
Family THROSCID王.
}

D. geminatus, Say.

DRAPETES, Redt.

Westville, rare-Liebeck. Hudson county-Linell.

T. constrictor, Say.

THROSCUS, Latr.

Ocean county, rare-Smith. Newark-Loeffler.

T. chevrolati, Bonv.

Hudson county, not common-Linell. Newark-Loeffler.

\section{Family BUPRESTID 瓜.}

C. virginiensis, Dru.

\section{OHALCOPHORA, Sol.}

Generally distributed, common-Wenzel. Westville, rather common-Liebeck. Newark.

C. liberta, Germ.

Atlantic county, not common-Wenzel. Westville, Egg Harbor, rare-Liebeck. 
D. prolongata, Lec. DICERCA, Esch.

Recorded on the Newark list.

D. divaricata, Say.

Generally distributed, common-Wenzel. Camden, rareLiebeck. Hudson county-Linell. Madison. Caldwell, common-Crane.

D. pugionata, Germ.

Gloucester county, on Black Alder, rare-Wenzel. Westville, rare-Liebeck. Hudson county-Linell. Newark.

D. obscura, Fabr.

Generally distributed, common-Wenzel, Liebeck. Hudson county-Linell. Newark. Caldwell, rare-Crane.

Var. lurida, Fabr.

Same distribution as type, and equally common.

D. spreta, Gory.

Camden and Gloucester counties, rare-Wenzel. Newark.

D. asperata, Lap. \& Gory.

Exact locality unknown, rare-Liebeck.

D. punctulata, Sch.

Camden and Gloucester counties, rare-Wenzel. Sea-shore, rare-Liebeck.

P. cyanipes, Say.

PGCILONOTA, Esch.

Sea-shore, rare-Liebeck. Newark.

P. thureura, Say.

Atlantic county, rare-Wenzel. Gloucester, rare-Liebeck.

B. rufipes, Oliv.

\section{BUPRESTIS, Linn.}

Sea-shore, rare-Liebeck.

B. lineata, Say.

Generally distributed, common-Wenzel, Liebeck. Brigantine Beach, in September, in drifted wood-Hamilton. Newark. 


\section{GEOLOGICAL SURVEY OF NEW JERSEY.}

B. consularis, Gory.

Sea-shore, rare-Liebeck.

B. nuttalli, Kirby.

Generally distributed, not rare-Wenzel.

B. fasciata, Fabr.

Gloucester county, rare-Wenzel.

B. striata, Fabr.

Atlantic county, rare-Wenzel. Dacosta, Westville, rareLiebeck. Newark.

B. decora, Fabr.

Gloucester county, very rare-Wenzel.

B. ultramarina, Say.

Generally distributed, rare-Liebeck. Gloucester and Atlantic counties, rare-Wenzel.

C. gracilipes, Melsh.

CINYRA, Lap. \& Gory.

Gloucester county, rare-Wenzel. Westville, rare-Liebeck. Hudson county-Linell.

MELANOPHILA, Esch.

M. notata, Lap. \& Gory.

Sea-shore, rare-Liebeck.

M. longipes, Say.

Generally distributed, rather common-Wenzel, Liebeck. Newark.

M. fulvoguttata, Harr.

Recorded on the Newark list.

M. ænөola, Melsh.

Landisville, rare-Liebeck. New Jersey-Collection Dr. Horn. Atlantic City-Castle.

ANTHAXIA, Esch.

A. æeneogaster, Lap.

Recorded on the Newark list.

A. viridifrons, Lap.

Generally distributed, not common-Wenzel. 
A. cyanella, Gory.

Generally distributed, not common-Wenzel.

A. quercata, Fabr.

Generally distributed, not common-Wenzel. Dacosta, not rare-Liebeck.

A. flavimana, Gory.

Generally distributed, not uncommon-Wenzel, Liebeck.

C. femorata, Fabr.

\section{CHRYSOBOTHRIS, Esch.}

Common all over the State.

Var. 4-impressa, Lap. \& Gory.

New Jersey-Collection Dr. Horn.

C. Aloricola, Gory.

Generally distributed, rare-Wenzel. Landisville, Dacosta, rare-Liebeck. Hudson county-Linell.

C. dentipes, Germ.

Generally distributed, rare-Wenzel. Gloucester, Dacosta, rare-Liebeck. Hudson county-Linell.

C. pusilla, Lap. \& Gory.

Atlantic county, rare-Wenzel. Landisville, Dacosta, rareLiebeck.

C. sexsignata, Say.

Generally distributed, rare-Liebeck. Camden and Gloucester counties, rare-Wenzel. Hudson county-Linell. Newark.

C. chrysoela, Ill.

Orange Mountains, rare-Smith.

C. chlorocephala, Gory.

Landisville, Dacosta, rare-Liebeck. New Jersey-Collection Dr. Horn.

A. acornis, Say.

\section{ACTENODES, LaC.}

Atlantic county, rare-Wenzel. Sea-shore, not rare-Liebeck. Brigantine Beach, in September, washed up by tide, rareHamilton. Newark. 
A. ornata, Fabr.

ACM开ODERA, Esch.

Generally distributed, not common-Wenzel.

A. pulchella, Hbst.

Atco, not common-Liebeck. Atlantic county, rare-Wenzel.

A. culta, Web.

Quite generally distributed throughout the State; not rare.

P. gibbicollis, Say.

PTOSIMA, Sol.

Sea-shore, ,rare-Liebeck.

MASTOGENIUS, Sol.

M. subcyaneus, Lec.

Camden and Gloucester counties, rare-Wenzel. Landisville, rare-Liebeck. Hudson county-Linell. Newark.

E. cogitans, Web.

\section{EUPRISTOCERUS, Deyr.}

Camden and Gloucester counties, not common-Wenzel. Westville, rare-Liebeck. Hudson county-Linell. Newark.

A. ruficollis, Fabr.

AGRILUS, Steph.

Common throughout the State.

A. fulgens, Lec.

Westville, rare-Liebeck.

A. otiosus, Say.

Generally distributed, not rare-Liebeck. Newark. Hudson county-Linell.

Var. pusillus, Say.

With the type, and equally common-Liebeck.

Var. defectus, Lec.

Newark, according to list. 
A. bilineatus, Web.

Not rare throughout the State-Wenzel, Liebeck, Linell,

Smith. Newark.

A. lecontei, Saund.

Hudson county-Linell.

A. fallax, Say.

Camden and Gloucester counties, rare-Wenzel.

A. interruptus, Lec.

Hudson county-Linell. Newark.

A. subcinctus, Gory.

Westville, rare-Liebeck.

A. plumbeus, Lec.

Hudson county-Linell.

A. politus, Say.

Recorded on the Newark list. Taken by myself near Jersey City.

A. egenus, Gory.

Generally distributed, common-Wenzel, Liebeck. Hudson county-Linell. Newark. Madison. Ocean county.

A. lacustris, Lec.

Generally distributed, not rare-Liebeck.

T. gracilis, Say.

\section{TAPHROCERUS, Sol.}

Generally distributed, not uncommon-Liebeck. Gloucester county, locally not uncommon-Wenzel. Hudson countyLinell. Newark.

B. ovata, Web.

BRACEYS, Sol.

Common throughout the State-Wenzel, Liebeck, Linell, Smith. Anglesea, in July-Schwarz.

Var. tessellata, Fabr.

I have seen specimens from Newark.

B. ærosa, Melsh.

Not rare throughout the State-Liebeck, Wenzel, Linell, Smith. 
P. purpureus, Say.

\section{PACHYSCELUS, Sol.}

Recorded on the Newark list.

P. lævigatus, Say.

Generally distributed, not rare-Liebeck, Wenzel. Hudson county-Linell. Newark.

\section{Family LAMPYRID王.}

C. terminale, Say.

\section{CALOPTERON, Guer.}

Hudson county-Linell.

C. reticulatum, Fabr.

Found not uncommonly throughout the State.

C. basalis, Lec.

\section{CELETES, Nown.}

Sea-shore, not common-Liebeck. Hudson county-Linell.

C. dimidiata, Fabr.

\section{CGNIA, Newn.}

Sea-shore, rare-Liebeck. Caldwell, common-Crane.

L. fraternus, Rand.

\section{LOPHEROS, Lec.}

Rare, near Paterson-Smith.

E. thoracicus, Rand.

\section{EROS, Newn.}

Westville, rare-Liebeck.

E. aurora, Hbst.

Generally distributed, not uncommon-Liebeck. Gloucester county, rare-Wenzel.

E. trilineatus, Melsh.

Westville, rare-Liebeck. Hudson county-Linell. 


\section{PLATEROS, Bourg.}

P. timidus, Lec.

Hudson county-Linell.

P. modestus, Say.

Generally distributed, not rare-Wenzel. Atco, rare-Liebeck. Hudson county-Linell.

P. canaliculatus, Say.

Generally distributed, not rare-Liebeck. Hudson countyLinell.

P. sollicitus, Lec.

Generally distributed, not rare-Wenzel.

P. floralis, Melsh.

Atco, rare-Liebeck.

C. perfaceta, Say.

CALOCHROMUS, Guer.

Generally distributed, rare-Liebeck. Orange Mountains, rare-Smith.

L. atra, Say.

\section{LUCIDOTA, Lap.}

Gloucester, rare-Liebeck. Hudson county-Linell. Newark.

L. punctata, Lec.

Dacosta, rare-Liebeck.

E. corrusca, Linn.

\section{FLLYCHNIA, Lec.}

Generally distributed, common-Wenzel, Liebeck. Newark.

$$
\text { PYROPYGA, Mots. }
$$

P. nigricans, Say.

Hudson county-Linell.

P. decipiens, Harr.

Generally distributed, common-Liebeck, Wenzel. 
P. angulata, Say.

\section{PYRACTOMENA, LEC.}

Generally distributed, not common-Wenzel. Newark. Caldwell, rare-Crane.

P. Jucifera, Melsh.

Generally distributed, common-Wenzel. Rare-Liebeck.

P. consanguineus, Lec.

\section{PEOTINUS, Lap.}

Generally distributed, not rare-Liebeck. Hudson countyLinel].

P. lineellus, Lec.

Atco, rare-Liebeck.

P. pyralis, Linn.

Hudson county, common-Linell, Smith. Newark.

P. marginellus, Lec.

Generally distributed, common-Wenzel, Liebeck. Caldwell, common-Crane.

P. scintillans, Say.

Generally distributed, common-Liebeck. Caldwell, common -Crane.

This genus contains the common "fire-flies," which form so attractive a feature of the early summer evenings. The species are somewhat local, and the common "fire-fly" in different parts of the State is apt to belong to different species.

\section{PHOTURIS, Lec.}

P. pennsylvanica, De G.

Generally distributed throughout the State, and the largest and most brilliant of our "fire-flies."

\section{'TYTTHONYX, Lec.}

T. erythrocephalus, Fabr.

Atco, rare-Liebeck. 
O. marginatus, Lec.

\section{OMETHUS, Lec.}

Atco, rare-Liebeck.

\section{CHAULIOGNATHUS, Hentz.}

C. scutellaris, Lec.

Pine districts, common in spring-Wenzel.

C. pennsylvanicus, De G.

Generally distributed, common-Wenzel. Hudson countyLinell. Newark. Madison. I have taken this abundantly, in fall, on Solidago. Caldwell, common-Crane.

C. marginatus, Fabr.

Generally distributed, rather common-Liebeck. Brigantine Beach, mainland, in September-Hamilton. I have taken this commonly enough, in spring, in Ocean county. Caldwell, common-Crane.

\section{PODABRUS, Westw.}

P. tricostatus, Say.

Hudson county-Linell. Orange Mountains, rare-Smith.

P. rugulosus, Lec.

Generally distributed, common-Wenzel, Liebeck. Hudson county-Linell.

P. frater, Lec.

Generally distributed, rather common-Wenzel. Westville, rare-Liebeck.

P. basilaris, Say.

Generally distributed, rare-Liebeck. Hudson countyLinell. Caldwell, common-Crane. Madison.

P. diadema, Fabr.

Gloucester, rare-Liebeck.

P. modestus, Say.

Atco, rare-Liebeck. Caldwell, common-Crane.

P. comes, Lec.

Orange Mountains, rare-Smith. 
P. tomentosus, Say.

Generally distributed, not rare-Linell.

P. protensus, Lec.

Hudson county-Linell.

P. brunnicollis, Lec.

Atco, rare-Liebeck.

T. dentiger, Lec.

TELEPHORUS, Schäff.

Hudson county-Linell.

T. excavatus, Lec.

Generally distributed, common-Wenzel. Dacosta, rareLiebeck. Hudson county-Linell.

T. fraxini, Say.

Generally distributed, not rare-Wenzel. Atco, rareLiebeck.

T. carolinus, Fabr.

Common throughout the State.

T. lineola, Fabr.

Less common, but as generally distributed.

T. rectus, Melsh.

Generally distributed, not common-Wenzel.

T. flavipes, Lec.

Recorded on the Newark list.

T. scitulus, Say.

Cummon throughout the State; often excessively abundant on flowers.

T. pusillus, Lec.

Atco, rare-Liebeck.

T. rotundicollis, Say.

Westville, rare-Liebeck. Hudson county-Linell. Newark.

T. tuberculatus, Lec.

Generally distributed, not rare-Wenzel. Ocean county, common-Smith.

'T. bilineatus, Say.

Found throughout the State, though scarcely common. 
D. bidentatus, Say.

\author{
DITEMNUS, Lec.
}

Generally distributed, not rare-Liebeck. Hudson countyLinell.

T. latipennis, Germ.

TRYPHERUS, Lec.

Atco, rare-Liebeck. Hudson county-Linell.

M. occipitalis, Lec.

\title{
MALTHINUS, Latr.
}

Atco, rare-Liebeck.

M. concavus, Lec.

MALTHODES, Kies.

Hudson county-Linell.

\section{Family MALACHID王。}

C. eximius, Er.

\section{COLLOPS, Er.}

Generally distributed, not uncommon-Wenzel, Liebeck. Hudson county-Linell. Newark.

C. nigriceps, Say.

Generally distributed, not rare-Wenzel. Hudson countyLinell.

C. 4-maculatus, Fabr.

Common throughout the State. Caldwell, rare-Crane.

A. flavilabris, Say.

ANTHOCOMUS, Er.

Hudson county-Linell.

P. oblitus, Lec.

PSEUDOB AIUS; Horn.

IIudson county-Linell. Orange Mountains-Smith. 
A. terminalis, Er.

\section{ATTALUS, Er.}

Hudson county - Linell. Ocean county-Smith.

A. morulus, Lec.

Hudson county-Linell. Orange Mountains-Smith.

A. granularis, Er.

Anglesea, in July-Schwarz.

A. circumscriptus, Say.

Atco, rare-Liebeck.

A. scincetus, Say.

Generally distributed, not uncommon-Liebeck. Hudson county-Linell. Orange Mountains, not rare-Smith.

\section{Family CLERIDF.}

C. brunnea, Melsh.

CYMATODERA, Gray.

Generally distributed, rare-Wenzel.

C. bicolor, Say.

Westville, rare-Liebeck.

C. inornata, Say.

Hudson county-Linell.

C. undulata, Say.

Generally distributed, rare-Wenzel. Camden, rare-Liebeck.

T. apivorus, Germ.

TRIOHODES, Hbst.

Atlantic county, rare-Wenzel.

C. quadrisignatus, Say.

\section{CLERUS, Geoff.}

Generally distributed, not rare-Wenzel. 
C. quadriguttatus, Oliv.

Generally distributed, not uncommon-Wenzel, Liebeck. Hudson county-Linell.

C. rosmarus, Say.

Generally distributed, not rare-Wenzel. Rare-Liebeck. Hudson county-Linell. Newark.

C. Iunatus, Spin.

Generally distributed, not rare-Wenzel. Dacosta, rareLiebeck.

C. thoracicus, Oliv.

Generally distributed, not common-Wenzel, Liebeck. Hudson county-Linell. Newark.

T. dubius, Fabr.

THANASIMUS, Latr.

Generally distributed, but local-Wenzel. Hudson countyLinell.

T. aanguineus, Say.

\section{THANEROCLERUS, Spin.}

Sea-shore, rare-Liebeck. Madison.

\section{HYDNOCERA, Newn.}

H. unifasciata, Say.

Generally distributed, rare-Wenzel. Atco, rare-Liebeck. Hudson county-Linell.

H. humeralis, Say.

Common throughout the State.

Var. cyanescens, Lec.

Var. difficilis, Lec.

With the type and hardly less common.

H. pallipennis, Say.

Generally distributed, not uncommon-Wenzel, Liebeck. Hudson county-Linell. Newark.

H. verticalis, Say.

Same as with pallipennis. 
H. tabida, Lec.

Dacosta, rare-Liebeck.

ㅍ. longicollis, Say.

Atco, rare-Liebeck.

P. dislocatus, Say.

\section{PHYLLOBÆANUS, Spin.}

Camden, rare-Liebeck. Hudson county-Linell.

C. vestita, Spin.

CHARIESSA, Perty.

Hudson county-Linell.

C. dichroa, Lec.

Generally distributed, rare-Wenzel.

C. pilosa, Först.

Generally distributed, not uncommon-Wenzel, Liebeck. Hudson county-Linell. Caldwell, one specimen-Crane.

Var. onusta, Say.

Same as type form-Liebeck.

C. vetusta, Spin.

\section{CREGYA, Lec.}

Generally distributed, rare-Wenzel. Westville, rare-Liebeck.

C. oculata, Say.

Generally distributed, not rare-Wenzel, Liebeck. Hudson county-Linell.

O. damicornis, Fabr.

ORTHOPLEURA, Spin.

Generally distributed, rare-Liebeck.

N. rufipes, Fabr.

NECROBIA, Latr.

Generally distributed, not uncommon-Wenzel, Liebeck. Newark. 
N. ruficollis, Fabr:

Same distribution as before.

N. violaceus, Linn.

Generally distributed; not rare-Wenzel.

\section{Family PTINID E.}

P. fur, Linn.

PTINUS, Linn.

Generally distributed, not rare-Wenzel. Camden, rare-Liebeck. Caldwell, rare-Crane.

P. brunneus, Duft.

Camden, rare-Liebeck.

E. humeralis, Melsh.

EUCRADA, Lec.

New Brunswick, rare-Smith.

E. mollis, Linn.

ERNOBIUS, Thom.

Generally distributed, not common-Wenzel, Liebeck.

E. granulatus, Lec.

Brigantine Beach, in September, once only, six specimensHamilton.

E. luteipennis, Lec.

Westville, rare-Liebeck.

O. floridanus, Lec.

OZOGNATHUS, Lec.

Anglesea-Wenzel. Heretofore not found north of Florida.

O. sericans, Melsh.

OLIGOMERUS, Redt.

Anglesea, in July-Schwarz. 
S. panicea, Linn.

\author{
SITODREPA, Thom.
}

Newark; not uncommon.

HADROBREGMUS, Thom.

H. errans, Mrelsh.

Westville, rare-Liebeck. Anglesea, in July_Schwarz.

H. carinatus, Say.

Westville, not uncommon-Liebeck.

T. gibbosa, Say.

TRICHODESMA, Lec.

Gloucester, rare-Wenzel. Westville, rare-Liebeck. Newark.

T. sericeus, Say.

TRYPOPITYS, Redt.

I have taken this along the Palisades, rarely.

P. bistriatum, Say.

PETALIUM, Lec.

Anglesea, in July—Schwarz.

Đ. nitidus, Lec.

EUPACTUS, Lec.

Hudson county-Linell. Anglesea-Wenzel.

X. peltatus, Harr.

XYLETINUS, Latr.

Generally distributed, rare-Liebeck.

X. fucatus, Lec.

Caldwell, common-Crane.

P. serricorne, Fabr.

LASIODERMA, Steph.

The so-called "tobacco beetle ;" not uncommon in old cigarettes. Anglesea-Wenzel. Ocean county-Smith. 
L. nova species, Horn dixit.

Anglesea, in July—Schwarz.

H. gravis, Lec.

$$
\text { HEMIPTYCHUS, Lec. }
$$

Anglesea-Wenzel.

D. setulosum, Lec.

DORCATOMA, Hbst.

Anglesea-Wenzel.

PROTHECA, Lec.

P. puberula, Lec.

Generally distributed, not common-Wenzel.

C. oculata, Say.

CAFNOCARA, Thom.

Generally distributed, not rare-Liebeck. Newark-Loeffler.

PTILINUS, Geoff.

P. ruficornis, Say.

Landisville, rare-Liebeck.

ENDECATOMUS, Mell.

E. reticulatus, Hbst.

Generally distributed, not rare-Liebeck.

S. basilare, Say.

SINOXYLON, Duft.

Generally distributed, not common-Wenzel, Liebeck.

B. bicornis, Web.

BOSTRICHUS, Geoff.

Generally distributed, not common-Wenzel, Liebeck.

A. bicaudatus, Say.

AMPHICERUS, Lec.

Atlantic county, rare-Wenzel. 
D. porcatus, Lec.

\section{DINODERUS, Steph.}

Sea-shore, rare-Liebeck.

D. cribratus, Lec.

Generally distributed, not rare-Liebeck.

D. pusillus, Fabr.

Atlantic county, common-Wenzel.

L. striatus, Melsh.

LYCTUS, Fabr.

Hudson county-Linell. Specimens are in Newark collections.

L. opaculus, Lec.

Hudson county-Linell.

\section{Family CUPESID $\mathbb{E}$.}

C. concolor, Westw.

CUPES, Fabr.

New Jersey-Linell. Gloucester, rare-Wenzel.

C. capitata, Fabr.

New Jersey-Linell. Caldwell, one specimen-Crane.

\section{Family LYMEXYLIDAE.}

L. sericeum, Harr.

LYMEXYLON, Fabr.

Gloucester, rare-Wenzel. Newark; one specimen in Mr. Bischoff's collection.

\section{Family CIOID死.}

C. fuscipes, Mell.

$$
\text { CIS, Lat. }
$$

Hudson county-Linell. 
C. punctatus, Mell.

Generally distributed, common-Wenzel. Anglesea, in July -Schwarz.

C. sp. sp.

Anglesea, in July, two undetermined species-Schwarz.

ENNEARTHRON, Mell.

E. thoracicornis, Ziegl.

Anglesea, in July—Schwarz. Generally distributed, not rare -Wenzel.

\section{Family SPHINDID平.}

S. americanus, Lec.

SPHINDUS, Chev.

I have taken this not infrequently in New Jersey.

\section{Family LUCANID $\boldsymbol{A}$.}

L. dama, Thunb.

\section{LUCANUS, Linn.}

Generally distributed, not rare-Liebeck, Wenzel. Newark. Decidedly more rare on and north of the red sandstone region. Caldwell-Crane.

D. parallelus, Say.

\section{DOROUS, MacL.}

Generally distributed, not uncommon-Liebeck, Wenzel. Newark. Madison. Caldwell, rare-Crane.

D. brevis, Say.

Dacosta ; rare. The only known specimens were taken here by Mr. Bland.

\section{P. quercus, Web.}

PLATYCERUS, Geoff.

Generally distributed, not rare-Wenzel, Liebeck. Caldwell, rare-Crane. Newark. 
C. piceus, Web.

\section{CERUCHUS, MacL.}

Generally distributed, rare-Liebeck. Gloucester and Camden counties, rare-Wenzel. Newark.

N. obscurus, Lec.

$$
\text { NICAGUS, Lec. }
$$

Gloucester, not uncommon-Wenzel, Liebeck.

P. cornutus, Fabr.

$$
\text { PASSALUS, Fabr. }
$$

Common everywhere throughout the State.

\section{Family SCARABAID王.}

C. ebenus, Say.

CANTHON, Hoffm.

Sea-shore, rare-Liebeck.

C. lecontei, Harold.

Sea-shore, rare-Liebeck, Wenzel. Gloucester, rare-Wenzel.

C. vigilans, Lec.

Atlantic county, rare-Wenzel. Sea-shore, rare-Liebeck.

C. læovis, Dru.

Common all over the State.

C. viridis, Beauv.

Atlantic City, rare, not taken recently-Liebeck.

C. histeroides, Web.

$$
\text { CHERIDIUM, Lap. }
$$

Generally distributed, not rare-Wenzel. Atco, rare-Liebeck.

C. minutus, Dru.

COPRIS, Geoffr.

Generally distributed, not uncommon-Wenzel. Sea-shore, not rare-Liebeck. Newark, Caldwell, rare-Crane. 


\section{CATALOGUE OF INSECTS.}

C. anaglypticus, Say.

Common all over the State.

C. carolina, Linn.

Common all over the State.

P. carnifex, Linn.

\section{PHANÆUS, MacL.}

More or less common throughout the State.

ONTHOPHAGUS, Latr.

O. nuchicornis, Linn.

Camden, rare-Werzel, Liebeck.

O. hecate, Panz.

Generally distributed, common-Wenzel, Liebeck. Brigantine Beach, in September-Hamilton. Newark. Madison. Caldwell, common-Crane.

O. janus, Panz.

Generally distributed throughout the State; common.

Var. striatulus, Beauv.

Brigantine Beach, in September-Hamilton.

O. tuberculifrons, Harold.

Brigantine Beach, in September-Hamilton.

O. pennsylvanicus, Harold.

Common throughout the State.

R. scaber, Hald.

\section{REYSSEMUS, Muls.}

Atlantic and Cape May counties, common-Wenzel. Atlantic City, not uncommon-Liebeck. Brigantine Beach, salt marshes, in September-Hamilton.

A. cognatus, Lee.

\section{AT \& \&NIUS, Harold.}

Brigantine Beach, in September, common-Hamilton.

A. wenzeli, Horn.

Atlantic county, rare-Wenzel. Brigantine Beach, in September, not rare-Hamilton. 
A. strigatus, Horn.

Brigantine Beach, in September-Hamilton.

A. gracilis, Melsh.

Brigantine Beach, in September-Hamilton.

A. imbricatus, Melsh.

New Jersey-Collection Dr. Horn.

A. stercorator, Fabr.

Newark. New Brunswick.

A. socialis, Horn.

Atlantic county, rare-Wenzel.

\section{APHODIUS, Ill.}

A. fossor, Linn.

Hudson county-Linell.

A. fimetarius, Linn.

Common all over the State.

A. ruricola, Melsh.

Generally distributed, rare-Liebeck.

A. granarius, Linn.

Common all over the State.

A. vittatus, Say.

Generally distributed, common-Liebeck. Atlantic county, rare-Wenzel. Newark.

A. inquinatus, Hbst.

Common all over the State.

A. rubeolus, Beauv.

Landisville, Camden, common-Liebeck.

A. stercorosus, Melsh.

Generally distributed, common-Liebeck. Not commonWenzel.

A. bicolor, Say.

Westville, not uncommon-liebeck. 
A. phalerioides, Horn.

Atlantic and Cape May counties, not common-Wenzel. Atlantic City, not rare-Liebeck. Brigantine Beach, in September, not frequent-Hamilton. Anglesea, in July-Schwarz.

A. femoralis, Say.

Generally distributed, not uncommon-Wenzel, Liebeck.

A. parcus, Horn.

Anglesea-Wenzel.

B. farctus, Fabr.

BOLBOCERAS, Kirby.

Generally distributed, rare-Wenzel. Atlantic City, rareLiebeck. Newark. Caldwell, rare-Crane. Madison.

B. lazarus, Fabr.

Generally distributed, rare-Wenzel. Sea-shore, not uncommon--Liebeck.

O. filicornis, Say.

ODONT AॄUS, Kl.

Atlantic City, rare-Liebeck. Ocean Beach-Paulmier.

O. cornigerus, Melsh.

New Jersey-Linell.

G. splendidus, Fabr.

GEOTRUPES, Latr.

Generally distributed, rather common-Wenzel, Liebeck.

Madison. Caldwell, rare since 1887-Crane.

G. semiopacus, Jek.

Atlantic City, rare-Liebeck. Newark. Madison.

G. egeriei, Germ.

Generally distributed, not uncommon-Wenzel. Camden, rare-Liebeck.

G. blackburnii, Fabr.

Rather common throughout the State.

G. balyi, Jek.

Gloucester county, rare-Wenzel. Westville, rare-Liebeck. 
T. scabrosus, Beauv.

\section{TROX, Fabr.}

Generally distributed, not common-Wenzel. Atlantic City, not rare-Liebeck. Brigantine Beach, in September, frequentHamilton.

T. asper, Lec.

Brigantine Beach, in September, in carcasses-Hamilton.

T. suberosus, Fabr.

Generally distributed, not uncommon-Wenzel, Liebeck.

T. tuberculatus, De G.

Recorded on the Newark list. Caldwell, rare-Crane.

T. erinaceus, Lec.

Generally distributed, not rare-Wenzel, Liebeck. Hudson county-Linell.

T. unistriatus, Beauv.

Generally distributed, not uncommon-Liebeck.

T. sordidus, Lec.

Westville, rare-Liebeck. Madison-Paulmier.

T. foveicollis, Harr.

Generally distributed, rare-Liebeck.

T. terrestris, Say.

Hudson county-Linell.

T. scaber, Linn.

Generally distributed, not uncommon-Wenzel.

T. atrox, Lec.

New Jersey-Henshaw.

A. lupina, Lec.

АMPHIOOMA, Latr.

Sea-shore, rare-Liebeck.

A. vulpina, Hentz.

Recorded on the Newark list. 
H. trifasciata, Say.

\author{
HOPLIA, III.
}

Sea-shore, rare-Liebeck. In my experience, occurs very early in spring.

H. trivialis, Harold.

Sea-shore, rare-Liebeck.

H. modesta, Hald.

Generally distributed, common-Wenzel. Sea-shore, not uncommon-Liebeck. Newark.

\title{
DICHELONYCHA, Kirby.
}

D. elongata, Fabr.

Generally distributed, rare-Wenzel. Westville, not uncommon-Liebeck. Newark.

D. fuscula, Lec.

Gloucester, rare-Liebeck.

D. albicollis, Burm.

Generally distributed, common-Wenzel. Westville, not rare-Liebeck.

S. vespertina, Gyll.

SERIOA, MacL.

Common throughout the State.

S. iricolor, Say.

Dacosta, rare-Liebeck. Atlantic county, common-Wenzel. Ocean county, on Scrub Oak, not rare-Smith.

S. sericea, Illiger.

Common throughout the State.

S. trociformis, Burm.

Atlantic county, common-Wenzel. Landisville, not uncommon-Liebeck. Ocean county, not rare on Scrub Oak, in May.

MACRODACTYLUS, Latr.

M. subspinosus, Fabr.

The well-known "rose bug;" common all over the State. 
D. sordida, Say.

DIPLOTAXIS, Kirby.

Generally distributed, not common-Wenzel. Sea-shore, not uncommon-Liebeck.

D. liberta, Germ.

Sea-shore, common-Wenzel, Liebeck. Nervark. Madison.

D. frondicola.

New Jersey-Linell.

\section{LACENOSTERNA, Hope.}

L. glaberrima, Blanch.

Brigantine Beach, September 10th-Hamilton. Anglesea, in July-Schwarz. New Jersey specimens are in the Collection United States National Museum, without exact locality.

L. ephilida, Say.

I have taken it during the present season (1889) in small numbers. Generally distributed-Liebeck, Wenzel.

L. clemens, Horn.

There is a single specimen marked "New Jersey" in the Collection United States National Museum, but the locality may be erroneous.

L. dispar, Burm.

Camden and Gloucester counties, not common-Wenzel.

L. gracilis, Burm.

Rather uncommon near New Brunswick. Sea-shore, rareLiebeck. Camden and Gloucester counties, not rare-IVenzel.

L. gibbosa, Burm.

Common at New Brunswick, in June. Camden and Gloucester counties, not rare-IVenzel.

L. subpruinosa, Casey.

Not actually recorded from New Jersey, but it has been taken near Philadelphia and on Long Island.

L. inverea, Horn.

I took one specimen in Ocean county. It does not occur near Tewark, apparently, and it is not in the Philadelphia collections from New Jersey. It is probably confined to the southern counties. 
L. micans, Knoch.

Common locally, and generally distributed. Newark. Westville-Liebeck. Camden and Gloucester counties, commonWenzel.

L. arcuata, Smith.

I have taken two specimens in Ocean county. It appears to belong to the southern counties.

L. insperata, Smith.

Snake Hill, New Jersey; apparently rare.

L. dubia, Smith.

The common form in Ocean county. The only fusca form taken at New Brunswick, and I have seen it from the vicinity of Jersey City.

L. fusca, Frohl.

The common form near Jersey City and Newark, and probably throughout the northern part of the State. Camden and Gloucester counties-Wenzel.

L. grandis, Smith.

Rare near Jersey City, and probably found in small numbers throughout the State. Camden and Gloucester countiesWenzel.

L. fraterna, Harris.

Var. cognata, Burm.

Var. forsteri, Burm.

I have taken all forms of this species in the State, probably all near Jersey City. Camden and Gloucester counties-Wenzel.

L. nova, Smith.

I have not seen it from the State, but have taken it on Long Island, and have no doubt it occurs with us.

L. knochii, Gyll.

Camden and Gloucester counties, very rare-Wenzel. Riverton-Castle.

L. rugosa, Mels.

Sea-shore, rare-Liebeck. Camden and Gloucester countiesWenzel. 
L. hirsuta, Knoch.

Not common; generally distributed. Rare, Westville-Liebeck. Camden and Gloucester counties-Wenzel.

L. balia, Say.

I have taken this in the State. Exact locality unknown.

L. hirticula, Knoch.

Common everywhere. I took it at New Brunswick this season.

L. crenulata, Frohl.

Not common. I have taken it near Jersey City. Camden and Gloucester counties-Wenzel.

L. ilicis, Knoch.

Not rare. A few specimens near Jersey City. Newark. Generally distributed, moderately abundant-Liebeck, Wenzel.

L. quercus, Knoch.

Rare. Isolated specimens from different localities seen.

L. tristis, Fabr.

Common everywhere in the State.

In this list I have added two species not actually taken in the State, but which are so distributed faunally that their occurrence is almost a certainty. Two other species-

L. marginalis, Lec.

L. villifrons, Lec.-

Are also almost certain to occur. My collection, now in the United States National Museum, contained many specimens collected by me in this State, and from my paper in the Proceedings United States National Museum for 1888, these localities are taken.

P. georgianus, Horn.

PHYTALUS, Er.

Hammonton, a single specimen only-Schwarz.

P. variolosa, Hentz.

POLYPHYLLA, Harr.

Atlantic county, rare-Wenzel. Atlantic City, rare-Liebeck. Sandy Hook, rather commonly washed up on the shore-Smith. 
A. binotata, Gyll. ANOMALA, Kœppe.

Generally distributed, common-Wenzel, Liebeck.

A. minuta, Burm.

Anglesea, not uncommon-Liebeck.

A. undulata, Melsh.

New Jersey-Linell. Rare near Fort Lee-Smith.

A very distinctly varietal form occurs at Anglesea; taken by Mr. Wenzel.

A. Iurida, Fabr.

Atlantic City-Castle.

A. lucicola, Fabr.

More or less common all over the State.

A. oblivia, Horn.

Generally distributed; common. Dacosta, Landisville, common-Liebeck.

A. marginata, Fabr.

Generally distributed, rare-Wenzel. Sea-shore, rare-Liebeck.

\section{STRIGODERMA, Burm.}

S. pygmæa, Fabr.

Generally distributed, not uncommon-Liebeck. Common in May and June-Wenzel. Madison.

S. arboricola, Fabr.

Generally distributed, common-Wenzel, Liebeck. Newark. Monmouth county, in July, not common-Smith. Caldwell, common-Crane.

P. punctata, Linn.

PELIDNOTA, MacL.

Common on grape vines all over the State.

C. lanigera, Linn.

COTALPA, Burm.

Occurs throughout the State; usually not common. Feeds on a Swamp Willow. 
CYCLOCEPHALA, Latr.

C. immaculata, Oliv.

Generally distributed, common-Wenzel. Sea-shore, not rare -Liebeck

C. villosa, Burm.

A specimen in a Newark collection is referable here.

C. puberula, Lec.

Atlantic City-Castle.

CHALEPUS, MacL.

C. trachypygus, Burm.

Generally distributed, common-Liebeck, Wenzel. Brigantine Beach, in September, come to light abundantly-Hamilton. Newark. Madison.

L. gibbosus, De G.

\section{LIGYRUS, Burm.}

Sea-shore, common-Wenzel, Liebeck. Brigantine Beach, in September, come to light abundantly-Hamilton. Newark. Caldwell, common-Crane.

I. relictus, Say. .

Atlantic City, rare-Liebeck. Sea-shore, not rare-Wenzel. Newark. Caldwell, common-Crane. Madison.

L. rugiceps, Lec.

Caldwell, common-Crane.

\section{APHONUS, Lec.}

A. castaneus, Melsh.

Atlantic City, rare-Liebeck. Sea-shore, not rare-Wenzel. Anglesea, in July-Smith. Newark. Madison.

X. satyrus, Fabr.

\section{XYLORYCTES, Hope.}

Generally distributed, locally common-Liebeck, Wenzel. Newark. Feeds in roots of Ash. 
S. antæus, Fabr. STRATEGUS, Hope.

Atlantic and Cape May counties, not rare-Wenzel. Westville, not rare-Liebeck. On the Newark list.

P. truncatus, Beauv.

\section{PHILEURUS, Latr.}

On the Newark list.

A. nitida, Linn.

ALLORHINA, Burm.

Generally distributed, common-Wenzel, Liebeck. Newark. Cape May, in July-Schwarz. Long Branch, rare-Crane.

E. areata, Fabr.

\section{EUPHORIA, Burm.}

Westville, not uncommon-Liebeck. Gloucester, Atlantic and Cape May counties, very local-Wenzel. Brigantine Beacb, in September, abundant once, but none have occurred the past five years-Hamilton.

E. sepulchralis, Fabr.

Generally distributed, not common-Wenzel.

E. fulgida, Fabr.

Generally distributed-Liebeck. Locally common-Wenzel. Newark. Caldwell, rare until three years ago-Crane.

叉. herbacea, Oliv.

Generally distributed, not common-Wenzel. Westville, rare -Liebeck.

E. inda, Linn.

Occurs throughout the State, in fall and early in spring.

C. pilosicollis, Horn.

\section{CREMASTOCHILUS, Knoch.}

On the Newark list.

C. variolosus, Kirby.

Westville, rare-Liebeck. Gloucester county, rare-Wenzel. Madison-Paulmier. 
C. harrisii, Kirby.

Woodbury, rare-Liebeck. Gloucester county, rare-Wenzel.

OSMODERMA, Knoch.

O. eremicola, Knoch.

Generally distributed, not rare-Wenzel. Westville, not uncommon-Liebeck. Newark. Madison. Caldwell, commonCrane.

O. scabra, Beauv.

Generally distributed, not rare-Wenzel. Sea-shore, rareLiebeck. Newark. Madison. Caldwell, rare-Crane.

G. maculosus, Knoch.

GNORIMUS, Lap.

Generally distributed, rare-Wenzel. Sea-shore, rare-Liebeck.

T. piger, Fabr.

TRICEIUS, Fabr.

Occurs rather commonly all over the State.

T. affinis, Gory.

Occurs with the preceding.

T. delta, Först.

Williamstown, Dacosta, rare-Wenzel.

VALGUS, Scriba.

V. squamiger, Beauv.

Occurs rather commonly throughout the State.

\section{Family SPONDYLIDAE.}

P. brunnea, Fabr.

PARANDRA, Latr.

Occurs rather commonly throughout the State. 


\title{
Family CERAMBYCIDF.
}

O. brunneum, Först.

\author{
ORTHOSOMA, Serv.
}

Not uncommon throughout the State.

P. laticollis, Dru.

\section{PRIONUS, Geoff}

Not uncommon throughout the State. Rare at CaldwellCrane.

P. pocularis, Dalm.

Landisville, not uncommon-Liebeck. Atlantic and Cape May counties, not rare-Wenzel. Cape May, in July-Schwarz.

T. harrisii, Lee.

\section{TRAGOSOMA, Serv.}

On the Newark list. I have found it along shore, cast up by the tide.

S. taslei, Buq.

\section{SPHENOSTETHUS, Hald.}

New Jersey, rare, not taken recently-Liebeck. One specimen in Collection Dr. Horn, marked "New Jersey."

A. moestum, Hald.

\section{ASEMUM, Esch.}

Not rare throughout the State. Rare at Caldwell-Crane.

C. agrestis, Kirby.

$$
\text { CRIOCEPHALUS, Muls. }
$$

Brigantine Beach, in September, rare-Hamilton.

C. obsoletus, Rand.

Generally distributed, rather common-Wenzel, Liebeck. Brigantine Beach, in September, not common-Hamilton. Newark.

S. cucujiforme, Say.

\section{SMODIOUM, Hald.}

Generally distributed, not rare-Liebeck. Camden and Gloucester counties, rare-Wenzel. Newark. 


\section{PHYSOCNEMUM, Hald.}

P. brevilineum, Say.

Atlantic and Cape May counties, common-Wenzel. Seashore, moderately abundant-Liebeck. Newark.

E. bajulus, Limn.

\section{HYLOTRUPES, Serv.}

Quite generally distributed throughout the State; not uncommon.

E. ligneus, Fabr.

Generally distributed, common, feeds on Cedar-Wenzel. Dacosta, not uncommon-Liebeck. Newark.

P. variabilis, Fabr.

PHYMATODES, Muls.

Common throughout the State.

P. amœnus, Say.

Westville, rare-Liebeck. In Grape, not common-Wenzel. I bred quite a number from grape stems this spring. Caldwell, common-Crane. Madison.

P. varius, Fabr.

Not uncommon throughout the State.

\section{CALLIDIUM, Fabr.}

C. antennatum, Newn.

Common throughout the State.

O. rigida, Say.

\section{CFME, Newn.}

Generally distributed, rare-Wenzel. Sea-shore, rare-Liebeck, Anglesea, in July-Schwarz. Newark.

C. cinctụs, Dru.

\section{CHION, Newn.}

Not rare, generally distributed-Wenzel. 
E. 4-geminata, Say.

\author{
EBURIA, Serv.
}

Generally distributed, rare-Liebeck.

\title{
ROMALEUM, White.
}

R. simplicicolle, Hald.

Atlantic county, common-Wenzel. Sea-shore, rather com mon-Liebeck. Newark.

R. atomarium, Dru.

Generally distributed, not common-Wenzel. Dacosta, not uncommon-Liebeck.

R. rufulum, Hald.

Westville, rare-Liebeck. Camden and Gloucester counties, rare-Wenzel. Hudson county-Linell. Newark.

\section{ELAPHIDION, Serv.}

E. mucronatum, Fabr.

Common throughout the State. Rare at Caldwell-Crane.

E. incertum, Newn.

On the Newark list.

E. villosum, Fabr.

Not uncommon throughout the State. Larvæ in Oak.

E. parallelum, Newn.

Same as the preceding and equally common.

E. aculeatum, Lec.

Generally distributed, rare-Liebeck.

E. unicolor, Rand.

Camden and Gloucester counties, rare-Wenzel. Westville, common-Liebeck.

\section{TYLONOTUS, Hald.}

T. bimaculatus, Hald.

Camden and Gloucester counties, rare-Wenzel. Westville, rare-Liebeck. 


\section{HETERACHTHES, Newn.}

H. quadrimaculatus, Newn.

Generally distributed, rare-Liebeck. Gloncester and Camden counties, rare, in Hickory-Wenzel. Hudson county-Linell. Newark.

H. ebenus, Newn.

Atlantic county, rare-Wenzel. Westville, rare-Liebeck. Newark.

P. pallidum, Say.

$$
\text { PHYTON, Newn. }
$$

On the Newark list.

O. rubrum, Newn.

\section{OBRIUM, Serv.}

New Jersey, rare, not taken recently-Liebeck.

O. rubidum, Lec.

New Jersey, rare, not taken recently-Liebeck.

\section{MOLORCHUS, Fabr.}

M. bimaculatus, Say.

Not rare throughout the State.

R. longipes, Say.

\section{RHOPALOPHORA, Serv.}

Sea-shore, not uncommon-Liebeck.

T. coquus, Lec.

\section{TRAGIDION, Serv.}

Generally distributed, more common in Atlantic and Cape May counties-Wenzel. Sea-shore, not uncommon-Liebeck. Brigantine Beach, in September, a ferv specimens washed upHamilton. Caldwell, rare-Crane.

P. humeralis, Say.

\section{PURPURICENUS, Serv.}

Generally distributed, common-Wenzel. Sea-shore, common -Liebeck. Newark. New Jersey-Linell. 
B. suturalis, Say.

BATYLE, Thom.

Generally distributed and not uncommon throughout the State.

S. notatus, Oliv.

\section{STENOSPHENUS, Hald.}

Generally distributed, common-Wenzel. Westville, rareLiebeck.

C. pictus, Dru.

CYLLENE, Newn.

Generally distributed, rare-Wenzel, Liebeck. Caldwell, rare -Crane. Bores in Hickory, and emerges in spring.

C. robiniæ, Först.

Found throughout the State commonly. Lives in Locust, and emerges in fall.

P. speciosus, Say.

\section{PLAGIONOTUS, Muls.}

"Snake Hill, on Oak trees in every instance. There are very few Maples left there, so it possibly really lives in Oak too"Linell. Newark. Madison.

C. nobilis, Say.

CALLOIDES, Lec.

Generally distributed, locally common, abundant on the shore -Wenzel. Sea-shore, rather common-Liebeck. Newark.

A. fulminans, Fabr. ARHOPALUS, Serv.

Found throughout the State, but rarely common.

$\mathrm{X}$. colonus, Fabr.

XYLOTRECHUS, CheVr.

Common throughout the State.

X. sagittatus, Germ.

Generally distributed, rare-Wenzel.

$\mathrm{X}$. quadrimaculatus, Hald.

Brigantine Beach, in September, one specimen-Hamilton。 
X. undulatus, Say.

Newark. Not rare in the Orange Mountains.

$V a r$ lunulatus, Kirby.

On the Newark list.

NEOCLYTUS, Thom.

N. scutellaris, Oliv.

Generally distributed, rare-Wenzel.

N. luscus, Fabr.

Generally distributed, rare-Wenzel.

N. capræa, Say.

Generally distributed, rare-Wenzel. Newark.

N. erythrocephalus, Fabr.

Rather common throughout the State.

C. ruricola, Oliv.

CLYTANTHUS, Thom.

New Jersey, not taken recently-Liebeck.

C. verrucosus, Oliv.

\section{CYRTOPHORUS, Lec.}

Camden and Gloucester counties, rare-Wenzel. Caldwell. rare-Crane.

E. picipes, Fabr.

\section{EUDERCES, Lec.}

Generally distributed, common-Wenzel, Liebeck. Newark. Orange Mountains, not rare-Smith.

E. pini, Oliv.

Landisville, not uncommon-Liebeck. Newark. Caldwell, rare-Crane.

A. confusa, Say.

$$
\text { ATIMIA, Eald. }
$$

Gloucester and Camden counties, rare, in Cedar-Wenzel. Atco, rare-Liebeck.

D. undata, Oliv.

$$
\text { DISTENIA, Serv. }
$$

Westville, rare-Liebeck. Hudson county-Linell. Nerrark. 
D. palliatus, Först.

\section{DESMOCERUS, Serv.}

Found throughout the State, on Elder; not rare.

E. cœruleus, Say.

\section{ENCYCLOPS, Newn.}

Gloucester, not uncommon-Liebeck.

R. lineatum, Oliv.

\section{RHAGIUM, Fabr.}

Generally distributed, common-Wenzel, Liebeck. Newark.

C. decolorata, Harr.

\section{CENTRODERA, Lec.}

I found one specimen in this State, years ago; exact locality I do not now remember.

C. picta, Hald.

Recorded on the Newark list.

\section{TOXOTUS, Serv.}

T. cylindricollis, Say.

New Jersey-Collection Dr. Horn.

A. bivittata, Say.

\section{ACM平OPS, Lec.}

Generally distributed, not uncommon-Liebeck. Newark.

A. directa, Nerwn.

Westville, rare-Liebeck.

A. discoidea, Hald.

Sea-shore, rare-Liebeck. New Jersey-Collection Dr. Horn. Atlantic City-Castle.

G. cyanipennis, Say.

\section{GAUROTES, Lec.}

Geuerally distributed, not common-Wenzel, Liebeck. Hudson county-Linell. Newark. Caldwell, rare-Crane. 
S. famelica, Newn.

\section{STRANGALIA, Serv.}

Found throughout the State, not rarely.

S. acuminata, Oliv.

Westville, rare-Liebeck. New Jersey-Linell. Newark.

s. luteicornis, Fabr.

Found throughout the State, not rarely.

S. bicolor, Swed.

Generally distributed, rare-Wenzel. Anglesea, rare-Liebeck. Newark.

T. zebratus, Fabr.

\section{TYPOCERUS, Lec.}

Landisville, rare-Liebeck.

T. velutinus, Oliv.

Common throughout the State.

T. lugubris, Say.

New Jersey-Henshaw.

L. emarginata, Fabr.

LEPTURA, Serv.

Newark. Trenton; one specimen some years ago. Fort Lee.

L. deleta, Lec.

New Jersey, rare, not taken recently-Liebeck.

L. plebeja, Rand.

New Jersey-Collection Dr. Horn. Caldwell, rare-Crane.

L. abdominalis, Hald.

Sea-shore, rare-Liebeck. Atlantic City-Castle.

L. lineola, Say.

Rather common throughout the State.

L. hæmatites, Newn.

Westville, not rare-Liebeck. Newark.

L. zebra, Oliv.

Not rare throughout the State.

L. cordifera, Oliv.

Newark. New Jersey-Collection Dr. Horn. 
L. rubrica, Say.

Rather common throughout the State.

L. circumdata, Oliv.

Atco, rare-Liebeck. Newark.

L. vagans, Oliv.

Specimens are in the Newark collections.

L. proxima, say.

Westville, rare-Liebeck.

L. octonotata, Say.

On the Newark list.

L. vittata, Germ.

Generally distributed, not rare-Liebeck. Newark. Rather common near Montclair-Smith. Caldwell, very rare-Crane.

L. pubera, Say.

On the Newark list.

C. pygmæus, Hald.

\section{CYRTINUS, Lec.}

Camden and Gloucester counties, rare-Wenzel. Atco, rareLiebeck. Hudson county-Linell. Newark.

P. supernotatus, Say.

\section{PSENOCORUS, Lec.}

Occurs throughout the State, though not common.

M. titillator, Fabr.

\section{MONOHAMMUS, Serv.}

Rather common throughout the State.

M. confusa, Kirby.

Atlantic and Cape May counties, rare-Wenzel. Camden, rare-Liebeck. Newark.

D. alternatum, Say.

\section{DORCASCHEMA, Lec.}

Generally distributed, not rare-Liebeck.

D. nigrum, Say.

Westville, rare-Liebeck. Caldwell, rare-Crane. Madison. 
H. cinera, Oliv.

HETEMIS, Hald.

Generally distributed, not uncommon-Liebeck. Newark.

C. pullata, Hald.

CACOPLIA, Lec.

Gloucester and Atlantic counties, rare-Wenzel.

G. tigrina, De G.

GOES, Lec.

Newark, rare. Caldwell, one specimen-Crane.

G. pulchra, Hald.

Gloucester and Camden counties, rare-Wenzel. Westville, rare-Liebeck. Hudson county-Linell. Newark.

G. debilis, Lec.

Camden and Gloucester, rare-Wenzel. Dacosta, not uncommon-Liebeck.

G. tesselata, Hald.

Gloucester, rare-Wenzel. Newark.

G. pulverulentus, Hald.

Gloucester and Atlantic counties, rare-Wenzel. Camden, rare-Liebeck. Newark.

\section{ACANTHODERES, Serv.}

A. quadrigibbus, Say.

Northern Jersey, rare-Liebeck. Newark. Caldwell, rareCrane.

A. decipiens, Hald.

Gloucester and Camden counties, rare-Wenzel. Sea-shore, not rare-Liebeck. Newark. Hudson county.

L. aculiferus, Say.

\section{LEPTOSTYLUS, Lec.}

Generally distributed, not rare-Wenzel. Sea-shore, rareLiebeck.

L. commixtus, Hald.

Generally distributed, not rare-Wenzel. 
L. biustus, Lec.

Anglesea, in July—Schwarz.

L. collaris, Hald.

Hudson county-Linell.

L. macula, Say.

Generally distributed, rather common-Wenzel, Liebeck. Madison. Caldwell, rare-Crane.

L. crassulus, Lec.

\section{LIOPUS, Serv.}

Madison-Paulmier.

L. variegatus, Hald.

Generally distributed, not rare-Wenzel. Atco, rare-Liebeck.

L. fascicularis, Harris.

On the Newark list.

L. alpha, Say.

Occurs quite commonly throughout the State.

L. cinereus, Lec.

Generally distributed, rather common-Liebeck. Hudson county-Linell.

L. punctatus, Lec.

A single specimen in Mr. Bischoff's collection, Newark.

D. spinosus, Say.

DECTES, Lec.

Atco, rare-Liebeck. Newark. Madison.

\section{LEPTURGES, Bates.}

L. symmetricus, Hald.

Hudson county-Linell.

Var. angulatus, Lec.

Generally distributed, not common-Wenzel, Liebeck.

L. signatus, Lec.

Hudson county-Linell. Newark. Caldwell, rare-Crane. 
L. querci, Fitch.

Not rare throughout the State.

L. facetus, Say.

Hudson county-Linell. Orange Mountains-Smith. Caldwell, rare-Crane.

\section{HYPERPLATYS, Bates.}

H. aspersus, Say.

Not rare throughout the State.

H. maculatus, Hald.

Occurs, not rarely, throughout the State.

U. Pasciatus, De G.

\section{UROGRAPEIS, Horn.}

Atlantic and Cape May counties, common-Wenzel. Hudson county-Linell. Caldwell, common-Crane.

G. pusillus, Kirby.

\section{GRAPHISURUS, Kirby.}

Atlantic and Cape May counties, common-Wenzel. Newark.

\section{ACANTHOCINUS, Steph.}

A. obsoletus, Oliv.

Generally distributed, rare-Wenzel.

A. nodosus, Fabr.

Egg Harbor, September, rare-Wenzel. Atco, rare-Liebeck.

D. spinosus, Say.

DECTES, Lec.

Caldwell, common-Crane.

P. mixtus, Hald.

POGONOCHERUS, Latr.

Generally distributed, not rare-Wenzel. Sea-shore, not uncommon-Liebeck. Newark. 
E. dasycerus, Lec.

ECYRUS, Lec.

Generally distributed, common-Liebeck. Anglesea, in July -Schwarz. Newark.

\section{EUPOGONIUS, Lec.}

E. tomentosus, Hald.

Generally distributed, common-Wenzel, Liebeck. Cape May Court House, in July-Schwarz. Newark.

E. vestitus, Say.

Generally distributed, not uncommon-Liebeck.

O. cingulata, Say.

\section{ONCIDERES, Serv.}

Camden, rare, not taken recently-Liebeck. New JerseyCollection Dr. Horn.

H. lemniscata, Fabr.

HIPPOPSIS, Serv.

Westville, rare-Liebeck.

S. obliqua, Say.

SAPERDA, Fabr.

Gloucester and Camden counties, rare, on Black AlderWenzel. Westville, rare-Liebeck. Newark. Orange Mountains, rare-Linell.

S. calcarata, Say.

Newark. Not rare near the Hudson-Smith.

S. mutica, Say.

Gloucester, on Willow, rare-Wenzel. Caldwell, rare-Crane.

S. candida, Fabr.

Atco, rare-Liebeck. Hudson county-Linell. Newrark. Madison, larvæ in Apple trees. I have taken it in Warren county, on Pear, have received it from Newark on Quince, and have taken the imago abundantly on Thorn, back of Jersey City Heights-Smith. Caldwell, common-Crane. 


\section{2}

GEOLOGICAL SURVEY OF NEW JERSEY.

S. fayi, Bland.

New Jersey-Linell.

S. vestita, Say.

Rather common, bores in Linden-Wenzel. Camden, rare-

Wenzel. Hudson county, rather common-Linell. Newark. Caldwell, common-Crane.

s. discoidea, Fabr.

Generally distributed, not rare, larve in Hickory-Wenzel. Camden, not uncommon-Liebeck. Newark.

S. tridentata, Oliv.

Hudson county-Linell. Newark, Caldwell, common-Crane.

S. lateralis, Fabr.

On Hickory, common-Wenzel. Westville, not uncommonLiebeck. Hudson county-Linell. Newark. Madison.

S. puncticollis, Say.

Camden and Gloucester counties, rare, on Rhus radicansWenzel. Camden, rare-Liebeck. Hudson county-Linell. Newark.

S. concolor, Lec.

Hudson county-Linell. Newark.

O. bimaculata, Oliv. OBERA, Muls.

Hudson county-Linell.

Var. tripunctata, Fabr.

Atco, Dacosta, not uncommon-Liebeck. Newark. Greenwood Lake, rare-Crane. Madison.

o. schaumii, Lec.

On the Newark list.

O. ocellata, Hald.

Atlantic county, rare-Wenzel. Hudson county-Linell. Newark.

O. tripunctata, Swed.

Rather common throughout the State.

O. gracilis, Fabr.

Dacosta, rare-Liebeck. 
O. ruficollis, Fabr.

Atlantic and Gloucester counties, rare-Wenzel. Dacosta, Landisville, rare-Liebeck. Madison.

T. canescens, Lec.

\section{TETROPS, Steph.}

Gloucester county, on Black Alder, rare-Wenzel.

T. discoideus, Lec.

TETRAOPES, Serv.

Gloucester, common-Liebeck.

T. canteriator, Drap.

Common throughout the State, but rather local.

T. tetraophthalmus, Först.

Common throughout the State, on Asclepias (Milk Weed).

D. tenuipes, Hald.

DYSPHAGA, Lec.

Gloucester, very rare-Wenzel.

\section{Family CHRYSOMELID五.}

D. palmata, Oliv.

DONACIA, Fabr.

Camden and Gloucester counties, not rare-Wenzel.

D. proxima, Kirby.

Hudson county-Linell. Madison.

D. distincta, Lee.

Hudson county-Linell.

D. subtilis, Kunze.

Hudson county-Linell.

D. æqualis, Say.

Camden and Gloucester' counties-Wenzel. 
D. torosa, Lec.

Camden and Gloucester counties, not rare-Wenzel.

D. emarginata, Kirby.

Camden and Gloucester counties, not rare-Wenzel.

D. cuprea, Kirby.

New Jersey-Collection Dr. Horn.

D. kirbyi, Lec.

Atlantic City-Castle.

O. atra, Ahr.

ORSODACHNA, Latr.

Newark. I have found it quite commonly very early in spring, on blossoms.

ZEUGOPHORA, Kunze.

Z. consanguinea, $\mathrm{Cr}$.

Newark. A specimen named by myself.

Z. varians, $\mathrm{Cr}$.

Newark-Bischoff.

S. ferruginea, Germ.

SYNETA, Esch.

Hudson county-Linell. Newark.

L. brunnicollis, Lac.

LEMA, Fabr.

Hudson county-Linell:

L. collaris, Say.

On the Newark list.

L. trilineata, Oliv.

Occurs throughout the State, but scarcely common.

C. asparagi, Linn.

CRIOCERIS, Geoff.

Common wherever Asparagus is raised; often very injurious. 
A. laticlavia, Först.

ANOMGE, Lac.

Occurs throughout the State; usually not common.

C. dominicana, Fabr.

COSCINOPTERA, Lac.

Dacosta, not common-Liebeck, Wenzel. Hudson countyLinell. Newark.

B. quadriguttata, Oliv.

BABIA, Chevr.

Atco, not rare-Liebeck. Orange Mountains, rare-Smith.

S. omogera, Lec.

SAXINIS, Lac.

Newark. Determined by myself.

C. polycocca, Lac.

\section{CHLAMYS, Knoch.}

Generally distributed, rare-Wenzel.

C. plicata, Fabr.

Hudson county-Linell.

C. foveolata, Knoch.

On the Newark list.

E. gibber, Oliv.

EXEMA, Lac.

Generally distributed, not common-Liebeck, Wenzel. Newark.

\section{BASSAREUS, Hald.}

B. formosus, Melsh.

Generally distributed, not rare-Wenzel. Hudson county-

Linell. Newark. Ocean county-Smith.

B. mammifer, Newn.

Generally distributed, not rare-Wenzel.

Var. Iuteipennis, Melsh.

Hudson county-Linell. 
B. lituratus, Fabr.

Not rare throughout the State.

Var. recurvus, Say.

Generally distributed-Wenzel.

Var. lativittis, Germ.

Newark. Determined by myself.

\section{CRYPTOCEPEALUS, Geoff.}

C. mucoreus, Lec.

Orange Mountains, taken rarely-Smith.

C. 4-maculatus, Say.

Hudson county-Linell. Newark. Ocean county-Smith.

Var. notatus, Fabr.

Generally distributed-Wenzel.

C. quadruplex, Newn.

Hudson county-Linell. Ocean county-Smith.

c. guttulatus, Oliv.

Generally distributed-Wenzel. Newark.

C. leucomelas, Suffr.

Camden county, rare, on Poplar-Wenzel.

C. venustus, Fabr.

Common throughout the State.

Var. ornatus, Fabr.

Anglesea, in July-Schwarz. Caldwell, rare-Crane.

C. nsertus, Hald.

Generally distributed, not rare-Wenzel. Newark.

C. calidus, Suffr.

Hudson county-Linell.

C. gibbicollis, Hald.

Generally distributed-Wenzel.

C. incertus, Oliv.

Generally distributed-Wenzel.

C. mutabilis, Melsh.

Newark. Determined by myself. 
C. badius, Suffr.

Caldwell, common-Crane.

C. schreibersii, Suffr.

Hudson county-Linell. Ocean county-Smith.

C. striatulus, Lec.

Hudson county-Linell. Newark-Bischoff.

\section{PACHYBRACHYS, CheVr.}

P. morosus, Hald.

Generally distributed, not rare-Wenzel.

P. abdominalis, Say.

Generally distributed, not rare-Wenzel.

P. othonus, Say.

Hudson county-Linell. Newark. Orange Mountains, quite common-Smith.

P. trinotatus, Melsh.

Generally distributed, not rare-Wenzel. Hudson countyLinell.

P. intricatus, Suffr.

Not rare throughout the State. I have seen it from all quarters.

P. tridens, Melsh.

Hudson county-Linell. On Poison Ivy when in bloom, not rare-Wenzel.

P. luridus, Fabr.

Hudson county-Linell.

P. atomarius, Melsh.

Generally distributed, not rare-Wenzel. Newark-Bischoff.

P. femoratus, Oliv.

Recorded on the Newark list.

P. subfasciatus, Hald.

New Jersey-Collection Dr. Horn.

P. dilatatus, Suffr.

New Jersey-Collection Dr. Horn. 
M. ater, Hald.

\section{MONACEUS, Ohevr.}

New Jersey-Henshaw.

D. auratus, Fabr.

DIACHUS, Lec.

Anglesea, in July-Schwarz. Orange Mountains, commonSmith.

T. atomus, Suffr.

TRIACHUS, Lec.

Anglesea, in July-Schwarz.

X. $1^{2} 0$-notata, Say.

XANTHONIA, Baly.

Common throughout the State.

X. villosula, Melsh.

New Jersey-Collection Dr. Horn.

$\mathrm{X}$. stevensii, Baly.

Swampy meadows, not rarely-Smith.

F. murina, Cr.

FIDIA, Baly.

Generally distributed, not common-Wenzel. Newark.

F. longipes, Mels.

Common at Caldwell-Crane.

A. vitis, Linn.

ADOXUS, Kirby.

Madison-Paulmier. I have received this also from Southern Jersey.

G. hirtus, Lec.

\section{GLYPTOSCELIS, Lec.}

Generally distributed, rare-Wenzel. New Jersey-Collection Dr. Horn.

G. barbatus, Say.

Generally distributed, common-Wenzel. 
C. auratus, Fabr.

\title{
CHRYSOCHUS, Chevr.
}

Locally common throughout the State.

T. tricolor, Fabr.

\author{
TYMNES, Chap.
}

Not rare throughout the State.

P. 6-notata, Say.

\author{
PARIA, Lec.
}

Common throughout the State; its varieties more rare. Brigantine Beach, in September, small variety-Hamilton.

P. aterrima, Oliv.

Also common throughout the State.

M. quercata, Fabr.

\section{METACHROMA, Lec.}

Camden and Atlantic counties, rare-Wenzel. Orange Mountains, rare-Smith.

M. pallida, Say.

Anglesea, in July-Schwarz. New Jersey-Collection Dr. Horn. Ocean county, rare-Smith.

G. pubescens, Melsh.

GRAPHOPS, Lec.

Hudson county-Linell. Newark. Caldwell, commonCrane.

G. curtipennis, Mels.

Ocean county, on cranberry bogs, in May-Smith.

G. nebulosus, Lec.

Generally distributed, common-Wenzel. Ocean county, in May, on cranberry bogs-Smith.

C. globosa, Say.

\section{CHRYSODINA, Baly.}

Hudson county - Linell. Newark. Orange Mountains, quite common-Smith. 
C. brunnea, Fabr.

\section{COLASPIS, Fabr.}

Not rare in Ocean county.

Var. flavida, Say.

Generally distributed, common-Wenzel. Newark.

Var. costipennis, Dej.

Rare near Jamesburg.

C. prætexta, Say.

Atlantic and Cape May counties, not common-Wenzel. Newark-Bischoff.

C. tristis, Oliv.

On the Newark list.

Var. puncticollis, Say.

Generally distributed, common-Wenzel.

P. varipes, Lec.

\section{PRASOCURIS, Lat.}

Not uncommon throughout the State.

D. clivicollis, Kirby.

DORYPHORA, Ill.

Nore or less common throughout the State, on Asclepias.

D. 10-lineata, Say.

The well-known potato beetle; common everywhere.

C. suturalis, Fabr.

CHRYSOMELA, Linn.

Quite common throughout the State.

C. similis, Rog.

Generally distributed, common-Wenzel.

C. elegans, Oliv.

Quite common throughout the State.

C. lunata, Fabr.

Newark; rare. Caldwell, rare-Crane. 
C. scalaris, Lec.

I have taken this in New Jersey, but do not recollect where. Caldwell, rare-Crane.

C. philadelphica, Linn.

Generally distributed, common-Wenzel. Newark. Quite abundant in Ocean county. Caldwell, rare-Crane.

C. multipunctata, Say.

Newark. Orange Mountains, not rare-Smith. Caldwell, common-Crane.

P. viridis, Melsh.

PLAGIODERA, Redt.

Orange Mountains, rare-Smith.

G. polygoni, Linn.

\section{GASTROIDEA, Hope.}

Common throughout the State.

G. cyanea, Melsh.

Quite common throughout the State.

L. lapponica, Linn.

\section{LINA, Megerle.}

Generally distributed, common-Wenzel. Newark.

L. scripta, Fabr.

Generally distributed, common-Wenzel. Newark. I have bred this on Willow-Smith. Caldwell, common-Crane.

\section{PHYLLODECTA, Kirby.}

P. vulgatissima, Linn.

Orange Mountains, not common-Smith. Madison.

C. caminea, Fabr.

OEROTOMA, Chevr.

Quite abundant throughout the State.

L. meraca, Say.

LUPERUS, Geoff. .

New Jersey-Henshaw. 
P. discoidea, Fabr.

\section{PHYLLOBROTICA, Redt.}

Gloucester, rare-Liebeck. Hudson county-Linell. Newark -Bischoff.

D. 12-punctata, Oliv.

\section{DIABROTICA, Chevr.}

D. vittata, Fabr.

Both species are extremely common throughout the State.

D. atripennis, Say.

Hudson county-Linell. Caldwell, rare-Crane.

T. tomentosa, Linn.

\section{TRIRHABDA, Lec.}

Newark. Orange Mountains, not rare-Smith. Madison. Var. virgata, Lec.

Var. canadensis, Kirby.

With the type form, and sometimes replacing it.

A. americana, Fabr.

\section{ADIMONIA, Leach.}

Atlantic and Cape May counties, rare-Wenzel.

Var. cribrata, Lec.

Newark. Quite generally distributed, not rare-Smith.

A. rufosanguinea, Say.

Generally distributed, common-Wenzel. Newark.

A. conferta, Lec.

Nerw Jersey-Henshaw.

A. cavicollis, Lec.

New Jersey-Henshaw.

G. sagittariæ, Gyll.

GALERUCA, Geoff.

Generally distributed, common-Wenzel. Caldwell, common -Crane. Madison.

G. decora, Say.

Anglesea, in July—Schwarz. 
G. notata, Fabr.

Generally distributed, common-Wenzel. Newark. Caldwell, common-Crane.

G. xanthomelæna, Schr.

The elm-leaf beetle; quite generally distributed throughout the State.

G. integra, Lec.

Caldwell, rare-Crane.

G. maritima, Lec.

Common everywhere along shore.

B. rhois, Först.

\section{BLEPHARIDA, Rog.}

Generally distributed throughout the State, on Sumac, but not common.

H. pilosa, Ill.

HYPOLAMPSIS, Clark.

Atlantic county, not rare-Wenzel. Sea-shore, not uncommon-Liebeck.

P. paradoxus, Mels.

PH开DROMUS, Clark.

Atlantic City-Castle.

EDIONYCHIS, Latr.

F. gibbitarsa, Say.

Generally distributed, not rare-Wenzel, Liebeck. Newark. Brigantine Beach, in September, abundant-Hamilton. New Brunswick.

CE. thoracica, Fabr.

Generally distributed, not rare-Wenzel. Westville, rather common-Liebeck. Caldwell, rare-Crane. Newark.

Ф. vians, Illig.

Generally distributed, not rare-Wenzel. Rare-Liebeck. Caldwell, rare-Crane. Madison.

⿷. petaurista, Fabr.

Sea-shore, rare-Liebeck. 
E. miniata, Fabr.

Generally distributed-Wenzel. Anglesea, not uncommonLiebeck.

⿷. sexmaculata, Illig.

Generally distributed, not common-Wenzel, Liebeck. Newark. Orange Mountains, not rare-Smith.

(E) limbalis, Mels.

Ocean county, on cranberry bogs, in May, common-Smith. Var. subvittata, Horn.

At same time and place, and equally common with the typical form-Smith.

E. suturalis, Fabr.

Atlantic county, not common-Wenzel. Newark.

Ф. quercata, Fabr.

Generally distributed, moderately abundant-Liebeck, Wenzel. Caldwell, rare-Crane.

⿷匚. scalaris, Mels.

Egg Harbor, rare-Liebeck.

\section{DISONYCHA, CheVr.}

D. pennsylvanica, Ill.

Generally distributed throughout the State; not rare.

Vur. pallipes, Cr.

On the Newark list. New Jersey-Collection Dr. Horn.

D. crenicollis, Say.

Hudson county-Linell.

D. caroliniana, Fabr.

Hudson county-Linell. Newark. Westville, rare-Liebeck. Caldwell, rare-Crane.

D. glabrata, Fabr.

Hudson county-Linell. Newark.

D triangularis, Say.

Generally distributed, rather common-Liebeck. Hudson county-Linell. Madison. 
D. xanthomelæna, Dalm.

Generally distributed, rather common-Wenzel, Liebeck. Hudson county-Linell. Newark.

D. mellicollis, Say.

Generally distributed, not rare-Wenzel. Hudson countyLinell.

D. collata, Fabr.

Generally distributed, not rare-Liebeck. Hudson countyLinell.

H. bimarginata, Say.

HALTICA, Geoffr.

Newark. Determined by myself. New Jersey-Collection Dr. Horn.

H. chalybea, Ill.

Common all over the State. The grape-vine flea beetle.

H. carinata, Germ.

Dacosta, rare-Liebeck.

H. ignita, Ill.

Not uncommon throughout the State.

H. marevagans, Horn.

Gloucester, Atlantic and Cape May counties, not uncommonWenzel. . Sea-shore, not uncommon-Liebeck. Anglesea, in July-Smith. Newark. New Jersey-Linell.

H. fuscoænөa, Melsh.

Anglesea, in July-Schwarz. Atco, rare-Liebeck.

H. rufa, Illig.

Newark; not rare. Determined by myself.

O. copalina, Fabr.

ORTHALTICA, Cr.

Rather common throughout the State.

C. rufipes, Linn.

CREPIDODERA, Chevr.

Generally distributed, rare-Liebeck. Hudson countyLinell. 
C. helexinus, Linn.

Common throughout the State.

C. atriventris, Melsh.

Atco, rare-Liebeck. Hudson county-Linell. NewarkLoeffler. Ocean county, not rare, in May-Smith.

E. fuscula, Cr.

\section{EPITRIX, Foudr.}

Generally distributed, rare-Liebeck.

E. cucumeris, Harr.

Common throughout the State. The cucumber flea beetle.

M. flloridana, Cr.

\section{MANTURA, Steph.}

Anglesea, in July-Schwarz.

\section{CH开TOCNEMA, Steph。}

C. subcylindrica, Lec.

Westville, rare-Liebeck.

C. denticulata, Illig.

Hudson county-Linell. Generally distributed, not uncommon-Liebeck. Ocean county, not rare-Smith.

C. pulicaria, Mels.

Hudson county-Linell. Anglesea-Wenzel.

C. minuta, Mels.

Newark-Bischoff.

C. pinguis, Lec.

Newark-Bischoff.

S. hudsonias, Först.

SYSTENA, Clark.

Rather common throughout the State.

S. rontalis, Fabr:

Generally distributed, not rare-Wenzel. Westville, rareLiebeck. Hudson county-Linell. Orange Mountains, in July, not rare-Smith. 
S. tæniata, Say.

Not uncommon throughout the State.

S. marginalis, Illiger.

Generally distributed throughout the State; not common.

G. spuria, Lec.

GLYPTINA, Lec.

Generally distributed, rare-Liebeck. Hudson countyLinell.

P. sinuata, Steph.

\section{PHYLLOTRETA, Foudr.}

Generally distributed, common-Wenzel. Hudson countyLinell.

P. vittata, Fabr.

Quite common thronghout the State.

P. bipustulata, Fabr.

Generally distributed, not common-Wenzel, Liebeck. Hudson county-Linell.

P. chalybeipennis, $\mathrm{Cr}$.

Cape May, in July—Schwarz.

P. picta, Say.

Generally distributed throughout the State; not common.

L. insolens, Horn.

\section{LONGITARSUS, Latr.}

New Jersey-Collection Dr. Horn.

L. melanurus, Mels.

Newark-Loeffler.

D. borealis, Chevr.

DIBOLIA, Latr.

Atco, rare-Liebeck. Hudson county-Linell.

P. punctulata, Melsh.

PSYLLIODES, Latr.

Generally distributed, rare-Liebeck. Anglesea, in JulySchwarz. Hudson county-Linell. 
P. convexior, Lec.

Generally distributed, rare-Liebeck. Hudson countyLinell.

M. vittata, Fabr.

$$
\text { MICRORHOPALA, Baly. }
$$

Not rare along the coast-Wenzel. Anglesea, in JulySchwarz. Hudson county-Linell. Newark.

M. zerene, Newn.

Generally distributed, not common-Wenzel. Westville, rare -Liebeck.

M. porcata, Melsh.

Hudson county-Linell.

O. scapularis, Oliv.

ODONTOTA, Chevr.

Generally distributed, common-Wenzel. Hudson countyLinell. Newark.

O. bicolor, Oliv.

Newark; apparently not rare. Determined by myself.

O. dorsalis, Thunb.

Generally distributed wherever the Locust (Robinia pseudaccacia) is found.

O. rubra, Web.

Quite common throughout the State. Ocean county, in May, common on Locust-Smith.

O. nervosa, Panz.

Common throughout the State. Found in Ocean county with the preceding.

O. nigrita, Oliv.

CHARISTENA, Baly.

Newark; rare. Determined by myself.

8. metallica, Fabr.

STENISPA, Baly.

New Jersey, rare-Liebeck. Collection_Dr. Horn. Newark. Ocean county, rare-Smith. 
C. nigripes, Oliv.

\author{
CASSIDA, Linn.
}

Generally distributed, common-Wenzel.

C. bivittata, Say.

Generally distributed, common-Wenzel.

COPTOCYCLA, Chevr.

C. aurichalcea, Fabr.

Generally distributed throughout the State; locally quite common.

C. guttata, Oliv.

Madison. Newark.

C. clavata, Eabr.

More rare than aurichalcea, but as generally distributed and sometimes locally abundant. Caldwell, common-Crane.

C. argus, Licht.

\title{
CHELYMORPHA, Chevr.
}

Common throughout the State.

C. phytophagica, Cr.

On the Newark list.

\section{Family BRUCHID庄.}

B. pisi, Linn.

\section{BRUCHUS, Linn.}

Common; generally distributed. The well-known "pea weevil."

B. bivulneratus, Horn.

Hudson county-Linell.

B. nigrinus, Horn.

New Jersey-Collection Dr. Horn.

B. alboscutellatus, Horn.

Hudson county-Linell. 
B. calvus, Horn.

Anglesea, in July-Schwarz.

B. obsoletus, Say.

Common throughout the State; infesting beans.

B. musculus, Say.

Brigantine Beach, in September, mainland, on SolidagoHamilton. Madison.

The list in this family is very incomplete. We have at least as many more specimens as are above recorded.

\section{Family TENEBRIONID FE.}

E. arundinis, Lec.

EPITRAGUS, Lec.

Common along the coast, from Sandy Hook to Cape May. July (Sandy Hook) to September (Brigantine Beach)-Hamiltou.

P. obcordata, Kirby.

\section{PHELLOPSIS, Lec.}

On dry fungoid growths on trees. Hudson county-Linell. Fort Lee-Smith.

\section{NYCTOBATES, Guér.}

N. pennsylvanica, De G.

Common all over the State, under bark.

Var, barbata, Knoch.

With the type-Wenzel.

M. 1ævis, Oliv.

\section{MERINUS, Lec.}

Generally distributed, rare-Wenzel. Hudson county-Linell.

U. ceramboides, Linn.

\section{UPIS, Fabr.}

On the Newark list. 
H. femoratus, Fabr.

\section{HAPLANDRUS, Lec.}

Generally distributed throughout the State; not uncommon. H. ater, Lec.

Generally distributed, rare-Wenzel. I have taken it at New Brunswick.

C. parallelus, Lec.

\section{CENTRONOPUS, Sol.}

Generally distributed, common-Wenzel.

S. calcaratus, Fabr.

\section{SCOTOBATES, Horn.}

Generally distributed, common-Wenzel. Newark. Caldwell, very rare-Crane. Madison.

$\mathrm{X}$. saperdioides, Oliv.

\section{XYLOPINUS, Lec.}

Generally distributed, not common-Wenzel, Liebeck. Newark. Caldwell, common-Crane.

$X$. rufipes, Say.

Generally distributed, not common-Wenzel, Liebeck. Caldwell, rare-Crane.

$\mathrm{X}$. ænescens, Lec.

New Jersey-Collection Dr. Horn. Caldwell, common-Crane.

T. obscurus, Fabr.

$$
\text { TENEBRIO, Linn. }
$$

Common throughout the State.

T. molitor, Linn.

Equally common with the preceding.

T. castaneus, Knoch.

Dacosta, rare-Liebeck.

T. tenebrioides, Beauv.

Generally distributed, common-Wenzel, Liebeck. Caldwell, common-Crane. 
O. notus, Say.

\section{OPATRINUS, Latr.}

Quite common throughout the State.

O. aciculatus, Lec.

Rare. I have taken a few specimens near Jersey City.

B. mœstus, Melsh.

\section{BLAPSTINUS, Lat.}

Brigantine Beach, in September-Hamilton.

B. pulverulentus, Mann.

Gloucester county, not common-Wenzel.

B. interruptus, Say.

Anglesa, in July-Schwarz. Brigantine Beach, in September-Hamilton.

B. metallicus, Fabr.

Gloucester county and sea-shore, not common-Wenzel. Hudson county-Linell. Brigantiue Beach, in September-Hamilton. Madison.

E. latimanus, Lec.

EPHALUS, Lec.

Ocean Beach-Paulmier. A single specimen only, now in the College collection. A very rare species, which I have taken sparingly on Long Island.

TRIBOLIUM, MacL.

T. ferrugineum, Fabr.

Newark. Determined by myself. I have taken this commonly.

G. cornutus, Fabr.

GNATHOCERUS, Thunb.

On the Newark list. New Jersey-Collection Dr. Horn. Atlantic City-Castle.

A. diaperinus, Panz.

\section{ALPHITOBIUS, Steph.}

On the Newark list. 
U. impressa, Melsh.

\author{
ULOMA, Lap.
}

Generally distributed, common-Wenzel. Brigantine Beach, in September, mainland-Hamilton. Newark.

$\mathrm{U}$. imberbis, Lec.

Generally distributed, common-Wenzel. Brigantine Beach, in September, mainland-Hamilton.

U. punctulata, Lec.

Generally distributed, less common than the precedingWenzel.

E. picea, Melsh.

EUTOCHIA, Lec.

Generally distributed, rare-Wenzel, Liebeck. Atlantic City -Castle.

A. brunneus, Ziegl.

\title{
ANAFDUS, Blanch.
}

Generally distributed, rare-Wenzel. I have taken this not infrequently under leaves, almost anywhere in the State.

P. fuscus, Lec.

PARATENETUS, Spin.

Anglesea, in July-Schwarz.

P. testacea, Say.

PHALERIA, Latr.

Common all along the sea-coast, from Sandy Hook to Cape May.

D. hydni, Fabr.

DIAPERIS, Geoff.

Generally distributed throughout the State, and locally common.

HOPLOCEPHALA, Lap.

H. Viridipennis, Fabr.

Generally distributed, common-Wenzel. Hudson countyLinell. 
H. bicornis, Oliv.

On the Newarkflist. Caldwell, common-Crane.

P. excavatum, Say.

$$
\text { PLATYDEMA, Lap. }
$$

Generally distributed, common-Wenzel. Anglesea, in July -Schwarz. Newark. Caldwell, common-Crane.

P. ruflcorne, Sturm.

Generally distributed, common-Wenzel. Newark. Brigantine Beach, in September-Hamilton.

P. ellipticum, Fabr.

Locally common, generally distributed-Wenzel.

P. americanum, Lap.

Common, generally distributed-Wenzel.

P. bifasciatus, Say.

PHYLETUS, Meg.

Hudson county-Linell. Newark.

H. cavus, Lec.

HYPOPHLFUS, Fabr.

Generally distributed, rare-Wenzel.

H. parallelus, Melsh.

Newark. Brigantine Beach, in September, mainland-Hamilton. Generally distributed, common-Weuzel. WestvilleCastle.

H. thoracicus, Melsh.

Generally distributed, rare-Wenzel.

B. bifurcus, Fabr.

BOLETOTHERUS, Cand.

Common all over the State.

B. corticola, Say.

BOLETOPHAGUS, III.

Hudson county-Linell. 
B. depressus, Rand.

Hudson county-Linell. Generally distributed, commonWenzel.

H. micans, Fabr.

HELOPS, Fabr.

Locally common throughout the State.

H. americanus, Beauv.

Generally distributed, rare-Wenzel.

H. venustus, Say.

Generally distributed, rare-Wenzel. Atlantic City-Castle.

H. gracilis, Bland.

Atlantic and Cape May counties, rare-Wenzel. Atlantic City and Central New Jersey-Castle.

H. æreus, Germ.

Common throughout the State; more rare than micans.

MERACANTHA, Kirby.

M. contracta, Beauv.

Generally distributed, rare-Wenzel, Liebeck.

S. tenuicolle, Say.

$$
\text { STRONGYLIUM, Kirby. }
$$

Hudson county-Linell. Madison.

\section{Family CHSTELID E.}

A. punctulata, Melsh.

ALLECULA, Fabr.

Generally distributed, rare-Wenzel. Anglesea, in JulySchwarz.

H. obscurus, Say.

HYMENORUS, Muls.

Generally distributed, common-Wenzel.

H. rufipes, Lec.

Caldwell, rare-Crane. 
C. brevis, Say.

\author{
CISTELA, Fabr.
}

Generally distributed, rare-Wenzel.

C. sericea, Say.

Newark; common.

I. quadristriata, Coup.

ISOMIRA, Muls.

Generally distributed, common-Wenzel.

M. fraterna, Say.

MYCETOCHARES, Lec.

New Jersey-Collection Dr. Horn.

ANDROCHIRUS, Lec.

A. erythropus, Kirby.

Generally distributed, not common-Wenzel.

C. fuliginosa, Melsh.

CAPNOCHROA, Lec.

On the Newark list. Caldwell, rare-Crane.

\title{
Family LAGRIID IE.
}

A. æøea, Say.

ARTHROMACRA, Kirby.

Atlantic and Cape May counties, rare-Wenzel. Newark.

S. resplendens, Melsh.

STATIRA, Latr.

Generally distributed, not common-Wenzel.

S. gagatina, Melsh.

Generally distributed, common-Wenzel. Newark; rare. 


\title{
Family MELANDRYID
}

T. truncorum, Lec.

\author{
TETRATOMA, Fabr.
}

Westville, rare-Liebeck.

P. obliquata, Fabr.

\section{PENTHE, Newn.}

Generally distributed, common-Liebeck, Wenzel. Newark. Madison. Caldwell, rare-Crane.

P. pimelia, Fabr.

I have taken this not rarely, with the preceding, along the Palisades.

S. punctata, Newn.

SYNCHROA, Newn.

Generally distributed, common-Wenzel.

M. striata, Say.

MELANDRYA, Fabr.

On the Newark list.

E. labiata, Say.

EMMESA, Newn.

I have taken this rarely near Fort Lee.

E. sericea, Hald.

\section{ENCHODES, Lec.}

Recorded on the Newark list.

H. simulator, Newn.

\author{
HYPULUS, Payk.
}

Newark. Determined by myself.

D. liturata, Lec.

DIRC笛A, Fabr.

Newark. Determined by myself. Anglesea, in JulySchwarz. Caldwell, rare-Crane. 


\section{GEOLOGICAL SURVEY OF NEW JERSEY.}

S. rugosa, Hald.

SYMPHORA, Lөc.

Anglesea, in July-Schwarz. Newark-Loeffler.

A. glaucula, Lec

ANISOXYA, Muls.

Anglesea, in July-Schwarz. Newark-Loeffler.

E. confinis, Lec.

HUSTROPHUS, Ill.

Generally distributed, rare-Wenzel.

E. bicolor, Say.

Taken by me near Hoboken.

ㅂ. bifasciatus, Say.

Generally distributed, rare-Wenzel.

E. tomentosus, Say.

I have taken this near Hoboken.

В. Scapularis, Mels,

HALLOMENUS, Panz.

Newark-Loeffler.

O. castanea, Melsh.

ORCHESIA, Latr.

Anglesea, in July-Schwarz. Newark.

S. sericea, Melsh.

SCRAPTIA, Latr.

Newark-Loeffler.

C. pallipes, Mels.

CANIFA, Lec.

Newark-Loefller.

M. scaber, Hald.

MYOTERUS, Clairv.

Not rare in the vicinity of Jersey City and Hoboken.

There will be considerable additions in this family when the State is more thoroughly collected over. 


\section{Family PYTHIDIE.}

P. americanus, Kirby.

PYTEO, Latr.

I have taken this rarely along the Palisades.

\section{Family CEDEMERIDE.}

M. sericans, Lec.

\section{MICROTONUS, Lec.}

Anglesea, in July_Schwarz. Newark-Loeffler.

N. melanura, Linn.

NACERDES, Schm.

Common near Newark and Jersey City. Madison.

\section{XANTHOCHROA, Schm.}

X. lateralis, Melsh.

Recorded on the Newark list.

O. notozoides, Fabr.

$$
\text { OXACIS, Lec. }
$$

Newark. Determined by myself.

O. dorsalis, Melsh.

Common along the shore, from Sandy Hook to Cape May.

A. ruficollis, Say.

$$
\text { ASCLERA, Schm. }
$$

Newark. Determined by myself.

\section{Family CEPHALOID 2 .}

C. lepturoides, Newn.

CEPHALOON, Newn.

Newark. Determined by myself. 


\title{
Family MORDELLID正.
}

P. trifasciata, Melsh.

\author{
PENTARIA, Muls.
}

Generally distributed, not common-Wenzel.

A. rufa, Say.

ANASPIS, Geoffr.

Common in the Orange Mountains.

TOMOXIA, Costa.

T. bidentata, Say.

Newark. On dead trees; not common. Caldwell, rareCrane.

M. melæna, Germ.

\section{MORDELLA, Linn.}

Orange Mountains, not rare-Smith. Caldwell, commonCrane.

M. scutellaris, Fabr.

Camden and Gloucester counties, not common-Wenzel.

Orange Mountains, common-Smith. Caldwell, commonCrane.

M. octopunctata, Fabr.

Camden and Gloucester counties, rare-Wenzel.

M. marginata, Melsh.

Generally distributed, not common-Wenzel. Orange Mountains, common-Smith.

M. triloba, Say.

Newark. Determined by myself.

M. discoidea, Melsh.

Rare in the Orange Mountains. Caldwell, rare-Crane.

MORDELLISTENA, Costa.

M. trifasciata, Say.

Newark. Determined by myself.

M. lepidula, Lec.

Orange Mountains, rare-Smith. 
M. limbalis, Melsh.

Orange Mountains, rare-Smith.

M. vapida, Lec.

Orange Mountains, rare-Smith.

M. fulvicollis, Melsh.

Orange Mountains, only a single specimen-Smith.

M. scapularis, Say.

Orange Mountains, rare-Smith.

M. comata, Lec.

Generally distributed, not common-Wenzel. Orange Mountains, common-Smith.

M. aspersa, Melsh.

Orange Mountains, the most common species-Smith.

M. ancilla, Lec.

Generally distributed, not common-Wenzel.

M. varians, Lec.

Orange Mountains, common-Smith. Brigantine Beach, in September-Hamilton.

M. nigricans, Melsh.

Generally distributed, not common-Wenzel. Orange Mountains, not uncommon-Smith.

M. ruficeps, Lec.

New Jersey, exact locality unknown-Smith.

M. splendens, Smith.

Mr. Wenzel has taken a specimen in New Jersey.

M. pustulata, Mels.

Orange Mountains, not rare-Smith.

M. fuscipennis, Mels.

New Jersey, near Hoboken-Smith.

M. ambusta, Lec.

New Jersey, rare-Smith.

M. unicolor, Lec.

Generally distributed, rare-Wenzel. Orange MountainsSmith. 
M. marginalis, Say.

Orange Mountains, not rare-Smith.

M. pubescens, Fabr.

Orange Mountains, rather common-Smith.

M. bihamata, Melsh.

Newark. Determined by myself.

M. liturata, Melsh.

Anglesea, in July-Schwarz.

M. fuscata, Mels.

Orange Mountains, rare-Smith.

Most of my collections in this family were made in the hills back of Montelair, and on the first ridge, and almost always in July.

\title{
Family ANTHICID无.
}

C. funebris, Horn.

\author{
CORPHYRA, Say.
}

Along the coast, not rare-Wenzel.

C. collaris, Say.

Along the coast, not rare-Wenzel. Caldwell, rare-Crane.

C. elegans, Hentz.

Caldwell, rare-Crane.

M. murina, Newn.

\section{MACRATRIA, Newn.}

I have taken this commonly in Ocean county. NewarkLoeftler.

N. bicolor, Say.

\section{NOTOXUS, Geoffr.}

Generally distributed, rather common-Wenzel, Liebeck.

N. bifasciatus, Lec.

Atco, rather common-Wenzel, Liebeck. Clifton, locally common-Smith. Newark. 
N. planicornis, Laf.

Anglesea, in July-Schwarz.

N. monodon, Fabr.

Common throughout the State.

Var. delicatus, Casey.

Brigantine Beach, in September-Hamilton.

N. anchora, Hentz.

Ocean county, not common-Smith.

MECYNOTARSUS, Laf.

M. candidus, Lec.

Westville, not rare-Liebeck.

A. formicarius, Laf.

\section{ANTHICUS, Payk.}

Sea-shore, common-Wenzel. Anglesea, in July-Schwarz. Brigantine Beach, in September, abundant-Hamilton.

A. cinctus, Say.

Anglesea, in July-Schwarz.

A. rejectus, Lec.

Brigantine Beach, in September, frequent-Hamilton.

A. floralis, Linn.

Sea-shore, common-Wenzel. Newark-Loeffler.

A. cribratus, Lec.

Recorded on the Newark list.

A. difficilis, Lec.

Anglesea, in July-Schwarz.

A. confusus, Lec.

Anglesea-Wenzel.

A. cervinus, Laf.

Sea-shore, not rare-Wenzel. New Jersey-Collection Dr. Horn.

A. spretus, Lec.

Anglesea, in July-Schwarz. 


\section{GEOLOGICAL SURVEY OF NEW JERSEY.}

A. fulvipes, Laf.

Newark-Loeffler.

A. pallens, Lec.

Sea-shore, not rare-Wenzel. Anglesea, in July-Schwarz. Brigantine Beach, in September, rare-Hamilton.

\section{Family PYROCHROIDAE.}

P. flabellata, Fabr.

PYROCHROA, Geoff.

New Jersey-Collection Dr. Horn. Caldwell, commonCrane.

P. femoralis, Lec.

Generally distributed, rare-Wenzel.

DENDROIDES, Latr.

D. canadensis, Latr.

Recorded on the Newark list. Caldwell, rare-Crane.

\section{Family MELOID王.}

\section{MELOE, Linn.}

M. angusticollis, Say.

On the Newark list. Caldwell, rare-Crane. Madison.

M. americanus, Leach.

Recorded on the Newark list.

M. unicolor, Kirby.

$$
\text { MACROBASIS, Lec. }
$$

Generally distributed; sometimes conmon. Madison. Caldwell. 
E. trichrus, Pall.

\author{
EPICAUTA, Redt.
}

Westville, rare-Liebeck.

E. vittata, Fabr.

On the Newark list. Madison. Caldwell, common-Crane.

E. cinerea, Först.

Not uncommon throughout the State.

E. pennsylvanica, De G.

Common in fall, on Solidago, almost everywhere. Brigantine Beach, in September-Hamilton.

P. ænea, Say.

\title{
POMPHOPGA, Lec,
}

Westville, rare-Liebeck.

\section{Family RHIPIPHORID王.}

R. flavipennis, Lec.

\section{RHIPIPHORUS, Fabr.}

Generally distributed, rare-Wenzel.

R. dimidiatus, Fabr.

Hudson county-Linell.

R. pectinatus, Fabr.

Generally distributed, rare-Wenzel. Newark. Caldwell, rare-Crane.

R. limbatus, Fabr.

Generally distributed, rare-Wenzel. Newark.

\section{Family STYLOPIDÆE.}

X. peckii, Kirby.

XENOS, Rossi.

I have frequently caught the infested Polistes, but have not taken or bred the imago. 


\section{Family RHINOMACERID王.}

R. pilosus, Lec.

RAINOMACER, Fabr.

Gloucester, rare-Wenzel.

R. elongatus, Lec.

Gloucester, rare-Wenzel. Westville, rather common-Liebeck. Morristown, on dry pine branches-Julich.

\section{Family RHYNCHITIDEE.}

A. ater, Lec.

AULETES, Sch.

Landisville, Dacosta, rare-Liebeck. Fort Lee, on Sweet Fern-Julich. Anglesea-Wenzel.

EUGNAMPTUS, Sch.

E. angustatus, Hbst.

Generally distributed, rather common-Liebeck. On Hickory-Wenzel. Newark. Madison.

E. collaris, Fabr.

On the Newark list. New Jersey-Julich.

R. bicolor, Fabr.

R日YNCHITES, Hbst.

Common throughout the State, on Rose.

R. hirtus, Fabr.

Atlantic and Cape May counties, rare-Wenzel. Dacosta, rare -Liebeck. Newark. Bergen-Julich.

R. fossifrons, Lec.

Atco, very rare-Wenzel.

R. æratus, Say.

Landisville, not uncommon-Liebeck. Bloomfield-Julich. Anglesea-Wenzel. 
P. ovatus, Fabr.

PTEROCOLUS, Sch.

Generally distributed, rather common-Liebeck. Camden, Atco, on Scrub Oak, rather common-Wenzel. Newark. Orange, Fort Lee, on Oak-Julich.

\section{Family ATTELABID正.}

A. analis, Ill.

ATTELABUS, Linn.

Generally distributed, rather common-Liebeck. Newark. On Sumac-Julich. Caldwell, common-Crane.

A. nigripes, Lec.

Atlantic and Cape May counties, on Scrub Oak, not rareWenzel.

A. bipustulatus, Fabr.

Same as before-Wenzel. Generally distributed, not rareLiebeck. Ocean county, common-Smith.

A. rhois, Boh.

Newark. Ocean county, on Rhus, not rare-Smith. Orange, on Hazel-Julich.

\section{Family OTIORHYNCHID压.}

E. imbricatus, Say.

EPICARUS, Sch.

Camden, rare-Liebeck. Generally distributed-Wenzel.

H. undulatus, Uhler.

HORMORUS, Horn.

On the Newark list. West Hoboken-Julich.

A. grisea, Horn.

ANAMETIS, Horn.

On the Newark list. 
P. erinaceus, Say.

\section{PANSCOPUS, Sch.}

On the Newark list. Under stones-Julich.

P. rigidus, Say.

\section{PHYXELIS, Sch.}

Generally distributed, rare-Wenzel. Camden, rare-Liebeck. Newark, under stones-Julich. Madison.

A. bellicus, Say.

AGRAPHUS, Say.

On the Newark list. Shrewsbury, on Solidago-Julich.

O. sulcatus, Fabr.

OTIORHYNCHUS, Germ.

On the Newark list. New Jersey-Julich.

O. ovatus, Linn.

Generally distributed, rare-Liebeck. Newark. New Jersey -Julich.

C. chrysorhœus, Say.

CERCOPEUS, Sch.

Orange-Julich.

T. confertus, Gyll.

TANYMECUS, Sch.

Generally distributed, rather common-Wenzel, Liebeck. Newark. Hudson county-Linell.

P. hilaris, Hbst.

\section{PANDELETEJUS, Sch.}

Generally distributed, common-Liebeck, Julich. Newark.

B. acutus, Say.

BRACHYSTYLUS, Sch.

On the Newark list. 


\section{CATALOGUE OF INSECTS.}
A. fulleri, Horn.
ARAMIGUS, Horn.

New Jersey-Collection Dr. Horn. West Hoboken-Julich. Madison.
A. tæniatus, Gyll.
APERASTUS, Gyll.

Rather common throughout the State.

C. dorsalis, Horn.

CYPHOMIMUS, Horn.

Hudson county-Linell. Fort Lee, on Prunus virginicaJulich.

\section{Family CURCULIONIDEF.}

S. hispidulus, Germ.

SITONES, Sch.

Anglesea, in July-Schwarz. Generally distributed, rareWenzel. Hudson county-Linell. New Brunswick, rather common-Smith. This is a clover-root pest.

S. Havescens, Marsh.

Generally distributed, rare-Wenzel. Hudson county-Linell. New Jersey-Julich.

\$. crinitus, Oliv.

New Jerșey-Julich.

I. noveboracensis, Först.

\section{ITHYCERUS, Sch.}

Generally distributed, rare-Wenzel, Liebeck. Hudson county -Linell. Newark. New Jersey-Julich.
A. decoloratum, Smith.
APION, Ebst.

Camden and Gloucester counties-Wenzel.

A. herculaneum, Smith.

On the Newark list. On Cratogus-Julich. 
A. segnipes, Say.

Gloucester county, common-Wenzel.

A. griseum, Smith.

Gloucester county-Wenzel.

A. rostrum, Say.

Sweet Fern-Julich.

A. nigrum, Hbst.

August 26th-Chittenden.

Many more species of this genus will be added to the list when full collections are made.

P. punctatus, Fabr.

\section{PHYTONOMUS, Sch.}

Camden, common-Wenzel, Liebeck. Brigantine Beach, in September, one dead specimen-Hamilton. Anglesea, in JulySchwarz. Newark. This species has invaded New Jersey the present year (1889), and has become extremely abundant in the vicinity of Philadelphia and Camden. I received it early in the season from the northwestern part of the State. Beaten from trees at Fort Lee-Julich. Newark, common-Bischoff.

P. comptus, Say.

Westville, rare-Liebeck. Gloucester, rare-Wenzel. Hudson county-Linell. New Jersey-Julich.

P. nigrirostris, Fabr.

Hudson county-Linell. Newark. This is a common species on the Long Island coast in early summer. 'CommunipawJulich.

L. tuberosus, Lec.

LISTRONOTUS, Jek.

Gloucester county, rare-Wenzel.

L. squamiger, Say.

Gloucester, rare-iVenzel.

L. callosus, Lec.

Hudson county-Linell.

L. inæqualipennis, Boh.

Hudson county-Linell. Newark-Bischoff. 
L. appendiculatus, Boh.

Camden county. Atco, common on Pickerel Weed-Wenzel. In reeds, New Jersey_Julich. Newark, in reeds-Bischoff.

L. latiusculus, Boh.

Gloucester and Camden counties, rare-Wenzel. Hudson county-Linell.

L. teretrirostris, Lec.

New Jersey, in reeds-Julich.

S. coryli, Fabr.

\section{STROPHISOMA, Billb.}

Orange Mountains, on Betula lenta-Julich.

M. sparsus, Say.

MACROPS, Kirby.

New Jersey-Julich. Newark-Bischoff.

M. humilis, Gyll.

Brigantine Beach, in September, three specimens-Hamilton. New Jersey-Julich. Ocean county, not common-Smith.

M. solutus, Boh.

Generally distributed, rare-Liebeck. Camden and Gloucester counties, not rare-Wenzel. New Jersey-Julich. Newark -Bischoff.

P. strobi, Peck.

PISSODES, Germ.

Generally distributed throughout the State; injurious to Pine and Spruce.

P. picivorus, Germ.

\section{PACHYLOBIUS, Lec.}

Generally distributed, common-Wenzel. Rare-Liebeck. Brigantine Beach, in September, four specimens washed upHamilton.

H. pales, Hhst.

HYLOBIUS, Germ.

Generally distributed throughout the State and common. 
EUDOCIMUS, Sch.

E. mannerheimii, Boh.

In cedar swamps-Julich.

L. sylvius, Boh.

LIXUS, Fabr.

Fort Lee-Linell, Julich.

L. terminalis, Lec.

Generally distributed, rather common-Wenzel. Westville, rather common-Liebeck. Hudson county-Linell.

L. rectus, Lec.

Arlington-Julich.

L. concavus, Say.

More or less common throughout the State.

I. musculus, Say.

Westville, rare-Liebeck. Camden and Gloucester counties, rare-Wenzel. Hudson county-Linell. Newark. New Jersey-Julich.

D. mucidus, Say.

DORYTOMUS, Steph.

New Jersey-Julich.

D. laticollis, Lec.

Guttenburg, on Poplar-Julich.

D. brevicollis, Lec.

Hudson county-Linell.

E. puncticollis, Lec.

ERYCUS, Tourn.

Hudson county-Linell. West Hoboken-Julich. Newark -Bischoff.

B. amœnus, Say.

BARYTYCHIUS, Jek.

On the Newark list.

S. griseus, Lec.

SMICRONYX, Sch.

Hudson county-Linell. Newark-Bischoff. 
S. squammulatus, Lec.

Anglesea-Wenzel.

P. ferrugineus, Lec.

\section{PHYLLOTROX, Sch.}

Anglesea, in July-Schwarz.

E. limatulus, Gyll.

ENDALUS, Lap.

Hoboken, salt meadows-Julich.

T. lemnæ, Fabr.

TANYSPHYRUS, Sch.

Westville, rather eommon-Liebeck. Hudson county-Linell. Hoboken, salt meadows-Julich.

A. angustus, Lec.

ANCHODEMUS, Lec.

Hoboken, salt meadows-Julich.

L. apiculatus, Gyll.

\section{LISSORHOPTRUS, Lec.}

Generally distributed, rare-Liebeck. Camden and Gloncester counties, common-Wenzel.

L. simplex, Say.

Hudson county_Linell. Hoboken, salt meadows-Julich.

B. obliquus, Lec.

\section{BAGOUS, Germ.}

Hudson county-Linell. New Jersey-Julich.

B. magister, Lec.

Hudson county-Linell.

O. myrmex, Hbst.

\section{OTIDOCEPHALUS, Chevr.}

Generally distributed, rather common-Wenzel, Liebeck. Hudson county-Linell. New Jersey-Julich. 
O. scrobicollis, Boh.

Generally distributed, rare-Wenzel. Hudson county-Linell.

O. chevrolatii, Horn.

Generally distributed, rare-Wenzel. Hudson county-Linell, Julich.

O. lævicollis, Horn.

Hudson county-Linell, Julich.

M. perforata, Horn.

MAGDALIS, Germ.

Generally distributed, rare-Wenzel.

M. lecontei, Horn.

Generally distributed, rare-Wenzel. Rather common-Liebeck.

M. barbita, Say.

Generally distributed, rare-Wenzel. Newark. New Jersey -Julich. Caldwell, rare-Crane.

M. ænescens, Lec.

Anglesea-Wenzel.

M. olyra, Hbst.

Generally distributed, rare-Wenzel. Hudson county-Linell. Atlantic City. Anglesea.

IM. pandura, Say.

Sea-shore counties, rare-Wenzel. Westville, rare-Liebeck. New Jersey-Julich.

M. armicollis, Say.

Generally distributed, rare-Wenzel. Newark. New Jersey -Julich. Atlantic City-Castle.

M. pallida, Say.

As before-Wenzel. Newark. New Jersey-Julich. Atlantic City-Castle.

\section{ANTHONOMUS, Germ.}

A. quadrigibbus, Say.

Camden and Gloucester counties, on Wild Cherry-Wenzel. Dacosta, rather common-Liebeck. Newark. New JerseyJulich. 


\section{CATALOGUE OF INSECTS.}

A. profundus, Lec.

Westville, rare-Liebeck.

A. scutellatus, Gyll.

Dacosta, rare-Liebeck. New Jersey-Julich.

A. signatus, Say.

Generally distributed, rare-Wenzel. Westville, rather common-Liebeck. Hudson county-Linell, Julich. Anglesea.

A. helvolus, Boh.

Hudson county-Linell. New Jersey-Julich.

A. sycophanta, Walsh.

On the Newark list. New Jersey-Julich.

A. suturalis, Lec.

Generally distributed, rare-Wenzel. Newark. New Jersey -Julich.

A. musculus, Say.

Generally distributed, rare-Wenzel. Newark.

A. corvulus, Lec.

New Jersey-Julich.

A. disjuncta, Lec.

Gloucester county, rare-Wenzel. New Jersey-Collection Dr. Horn. Atlantic City-Castle.

A. ungularis, Lec.

New Jersey-Julich.

A. mixtus, Lec.

Generally distributed, rare-Wenzel.

O. pallicornis, Say.

OROHESTES, III.

Newark. Determined by myself.

O. niger, Horn.

New Jersey-Julich.

O. ephippiatus, Say.

New Jersey_Julich. 
E. bipunctatus, Linn.

\section{ELLESCHUS, Steph.}

New Jersey-Julich.

E. ephippiatus, Say.

New Jersey-Julich. Newark-Bischoff.

P. calceatus, Say.

PRIONOMERUS, Sch.

Sea-shore, rare-Liebeck. Newark.

P. scutellaris, Say.

PIAZORHINUS, Sch.

Generally distributed, rare-Liebeck. Hudson countyLinell, Julich.

P. pictus, Lec.

Shrewsbury, collected by Soltau-Julich.

T. fraxini, Lec.

THYSANOCNEMIS, Lec.

Westville, rare-Liebeck. Gloucester, in a hard fungus, rare - Wenzel. Atlantic City-Castle.

P. ulmi, Lec.

\section{PLOCETES, Lec.}

Westville, rare-Liebeck. Gloucester, a single specimen only -Wenzel. Hudson county-Linell. Atlantic City-Castle.

T. sordidus, Lec.

\section{TYCHIUS, Sch.}

Anglesea-Wenzel.

G teter, Fabr.

\section{GYMNETRON, Sch.}

Rather common throughout the State, on Mullen.

MI. hispidulus, Lec.

MIARUS, Steph.

On the Newark list. New Jersey-Julich. 
L. plagiatus, Sch.

\section{L再MOSACCUS, Sch.}

Generally distributed, rather common-Liebeck. Not common, on Oak-Wenzel. Hudson county-Linell. Newark. On Oak-Julich.

\section{CONOTRACHELUS, Sch.}

C. juglandis, Lec.

Generally distributed, rare-Wenzel. Hudson county-Linell. Newark. New Jersey-Julich.

C. nenuphar, Hbst.

The plum curculio; common throughout the State.

C. elegans, Say.

Generally distributed, common-Wenzel. Hudson countyLinell. Newark. New Jersey-Julich.

C. aratus, Germ.

Atlantic county, rare-Wenzel.

C. cratægi, Walsh.

Atlantic county, rare-Wenzel. New Jersey-Julich. Caldwell, common-Crane.

C. naso, Lec.

Atlantic county, rare-Wenzel.

C. posticatus, Boh.

Atlantic county, rare-Wenzel. Hudson county-Linell. Newark. New Jersey-Julich.

C. geminatus, Lec.

Atlantic county, rare-Wenzel. Westville, rare-Liebeck. Hudson county-Linell. New Jersey-Julich.

C. anaglypticus, Say.

Rather common throughout the State.

C. fissunguis, Lec.

Sea-shore, rather common-Liebeck. Cape May county, on Wild Hollyhock-Wenzel. 
RHYSSEMATUS, CheVr.

R. lineaticollis, Say.

I used to find this not rarely along the Palisades. On Asclepias -Julich. Caldwell, rare-Crane.

C. collaris, Horn.

CHALCODERMA, Sch.

Atlantic City-Castle.

A. spec. indet.

\section{ACALLES, Sch.}

Newark, in ants' nests-Bischoff. This most resembles the southern clavatus, but seems to differ from all the species in Dr. Horn's collection.

T. foveolatum, Say.

\section{TYLODERMA, Say.}

Generally distributed, rare-Wenzel. Westrille, rare-Liebeck. New Jersey-Julich. Newark-Bischoff.

T. fragariæ, Riley.

Arlington, Maplewood, under stones-Julich.

T. ærum, Say.

Westville, rare-Liebeck. New Jersey-Julich. NewarkBischoff.

P. undatus, Lec.

\section{PHYRDENUS, Lec.}

In cedar swamps-julich.

C. parochus, Host.

\section{CRYPTORHYNCHUS, Ill.}

On the Newark list. On Butternut-Julich.

C. bisignatus, Say.

Generally distributed, rare-Wenzel. Landisville, rareLiebeck. New Jersey-Julich.

C. fuscatus, Lec.

Newark. Determined by myself. In cedar swamps-Julich. 
C. pumilus, Boh.

New Jersey, in cedar swamps-Julich.

C. obliquus, Say.

Hudson county-Linell. Generally distributed, rare-Wenzel. New Jersey, in cedar swamps-Julich.

C. fallax, Lec.

Camden, rare-Wenzel. New Jersey-Julich.

C. minutissimus, Lec.

Hudson county-Linell. New Jersey-Julich.

C. tristis, Lec.

Newark-Bischoff.

C. ferratus, Say.

Gloucester, rare-Wenzel. Sea-shore, rare-Liebeck. Hudson county-Linell. New Jersey-Julich. Newark-Bischott. C. lapathi, Linn.

Newark. Determined by myself. Bergen-Julich.

B. cribratus, Lec.

BAROPSIS, Lec.

New Jersey-Collection Dr. Horn.

P. oculatus, Say.

PIAZURUS, Sch.

Westville, rare-Liebeck. New Jersey-Julich. NewarkBischoff.

C. operculatus, Say.

\section{COPTURUS, Sch.}

New Jersey-Julich.

C. quercus, Say.

Hudson county-Linell.

C. longulus, Lec.

Atco, one specimen-Wenzel.

C. binotatus, Lec.

Hudson county-Linell. Snake Hill, Fort Lee-Julich.

C. minutus, Lee.

Anglesea, rare-Wenzel. Anglesea, in July-Schwarz. 
A. suturalis, Lec.

\section{ACOPTUS, Lec.}

Hudson county_Linell. Nervark. Orange-Julich.

\section{TACHYGONUS, Sch.}

T. lecontei, Gyll.

Atco, Red Bank, on Pine, rare-Wenzel. Caldwell-Crane.

T. centralis, Lec.

Landisville, rather common-Liebeck.

T. tardipes, Lec.

Atlantic City-Castle.

MONONYCHUS, Germ.

M. vulpeculus, Fabr.

Generally distributed, rather common, on Blue FlagWenzel. Hudson county-Linell. Newark. New JerseyJulich.

C. inæqualis, Say.

CRAPONIUS, Lec.

West Hoboken-Julich.

CGLIODES, Sch.

C. curtus, Say.

Anglesea, not uncommon-Liebeck. Newark.

C. cruralis, Lec.

Hudson county-Linell. New Jersey-Julich.

C. nebulosus, Lec.

New Jersey_Julich.

C. flavicaudis, Boh.

Shrewsbury, on White Nettle-Julich.

C. acephalus, Say.

Common on the coast-Wenzel. Hudson county-Linell. Shrewsbury-Julich. 
A. ventricosus, Lec.

ACALLODES, Lec.

On the Newark list. Newark-Julich. Ocean countySmith.

C. rapæ, Gyll,

CeUTORHYNChUS, Germ.

West Hoboken-Julich.

C. sulcipennis, Lec.

Weehawken-Julich.

C. semirufus, Lec.

New Jersey-Julich.

C. septentrionalis, Gyll.

New Jersey-Julich.

P. sulcicollis, Fabr.

PELONOMUS, Thom.

Generally distributed, common-Liebeck. Camden and Gloucester counties, common-Wenzel.

CGLOGASTER, Sch.

C. zimmermanni, Gyll.

On the Newark list. South Orange, on Beggar's Nits-Julich.

C. cretura, Hbst.

New Jersey-Julich. Caldwell, rare-Crane.

R. pyrrhopus, Lec.

\section{REINONCUS, Sch.}

Generally distributed, rather common-Liebeck. Camden and Gloucester counties, not rare-Wenzel. Anglesea, in July -Schwarz. New Jersey-Julich.

R. longulus, Lec.

New Jersey—Julich.

RHOPTOBARIS, Lec.

R. nova species, Horn dixit.

Anglesea-Wenzel. 
B. umbilicata, Lec.

\section{BARIS, Germ.}

Atco, rare-Wenzel. Hudson county-Linell. Ocean county -Smith.

B. subænea, Lec.

Generally distributed, not rare-Wenzel.

B. confinis, Lec.

Ocean county-Smith.

B. ærea, Boh.

Atlantic City-Castle.

B. interstitialis, Say.

On Yarrow-Julich.

P. nigrina, Say.

\section{PSEUDOBARIS, Lec.}

Generally distributed, common-Wenzel. On SolidagoJulich.

O. rugicollis, Lec.

ONYCHOBARIS, Lec.

Atco, rare-Wenzel. On Asclepias-Julich.

M. undulatus, Say.

\section{MADARUS, Sch.}

Generally distributed, not common-Wenzel. Westville, rather common-Liebeck. Hudson county-Linell. New Jersey-Julich.

S. tubulatus, Say.

\section{STETHOBARIS, Lec.}

New Jersey-Julich.

CENTRINUS, Sch.

C. scutellum-album, Say.

Common throughout the State.

C. penicellus, Hbst.

Anglesea-Wenzel. 
C. picumnus, Hbst.

Found throughout the State; sometimes excessively abundant.

C. lineicollis, Lec.

New Jersey-Julich.

C. rectirostris, Lec.

South Orange-Julich.

C. confinis, Lec.

New Jersey—Julich.

Z. quadricolle, Lec.

ZYGOBARIS, Lec.

West Hoboken, one specimen only-Julich.

B. uniformis, Lec.

\title{
BALANINUS, Germ.
}

Newark. Determined by myself. New Jersey-Julich.

B. nasicus, Say.

Generally distributed, rare-Wenzel, Liebeck. Newark. Anglesea, in July-Schwarz. New Jersey-Julich.

B. caryæ, Horn.

New Jersey—Julich.

B. rectus, Say.

Generally distributed, rare-Wenzel, Liebeck. Newark. New Jersey-Julich. Caldwell, common-Crane.

B. quercus, Hớn.

Brigantine Beach, mainland, in September-Hamilton. New Jersey_Julich.

B. caryatrypes, Boh.

New Jersey-Julich.

\section{Family BRENTHID E.}

झ. minuta, Dru.

\author{
EUPSALIS, Lec.
}

Generally distributed, rare-Liebeck. New Jersey-Julich. 


\section{Family CALANDRID E.}

\section{RHODOB雨NUS, Lec.}

R. tredecimpunctata, Ill.

Generally distributed, not uncommon-Wenzel, Liebeck. Newark. Caldwell, common-Crane. Madison.

S. simplex, Lec.

\section{SPHENOPHORUS, Sch.}

New Jersey-Collection Dr. Horn; also Julich.

S. inæqualis, Say.

Rare on the shore-Wenzel. New Jersey-Collection Dr. Horn.

S. ochreus, Lec.

Generally distributed, rare-Linell. New Jersey-Julich. Orange Mountains-Hess.

S. pertinax, Lec.

Anglesea, in July-Schwarz. Sea-shore, common-Wenzel, Liebeck. Brigantine Beach, in September-Hamilton. Newark. Breeds in reed,-Calmus-Julich.

S. costipennis, Horn.

Sea-shore, rare-Wenzel. Brigantine Beach, in September-

Hamilton. New Jersey-Julich. Caldwell, rare-Crane.

S. cariosus, Oliv.

Brigantine Beach, in September-Hamilton. New JerseyJulich.

S. sculptilis, Uhler.

Sea-shore, common-Wenzel, Liebeck. New Jersey-Julich. Caldwell, rare-Crane.

3. melanocephalus, Fabr.

Sea-shore, rarę-Liebeck. Hudson county-Linell. New Jersey-Julich.

S. sayi, Gyll.

Anglesea, in July-Schwarz. 
S. placidus, Say.

Sea-shore, rare-Wenzel. Rather common-Liebeck. Brigantine Beach, in September, abundant-Hamilton. Hudson county-Linell. New Jersey-Julich. Newark-Bischoff.

S. parvulus, Gyll.

Generally distributed, rare-Liebeck. Sea-shore, commonWenzel. New Jersey-Julich.

S. retusus, Gyll.

Sea-shore, not common-Wenzel. Brigantine Beach, in September, abundant-Hamilton.

C. oryzæ, Linn.

\section{CALANDRA, Clairv.}

Generally distributed, common-Wenzel. Newark.

C. remotepunctata, Gyll.

Generally distributed, rather common-Liebeck. New Jersey -Julich.

C. granaria, Linn.

New Jersey-Julich.

DRYOPHTHORUS, Sch.

D. corticalis, Say.

Generally distributed, rare-Wenzel, Liebeck. New Jersey -Julich.

C. platalea, Say.

\section{COSSONUS, Clairv.}

Generally distributed, not common-Wenzel. New JerseyJulich.

C. concinnus, Boh.

New Jersey_Julich.

O. corticola, Say.

As before-Wenzel. Newark. New Jersey-Julich. Anglesea.

C. impressifrons, Boh.

Brigantine Beach, mainland and island, frequent-Hamilton. 
MESITES, Sch.

M. subcylindricus, Horn.

Anglesea, rare-Wenzel. Cape May, in July-Schwarz.

P. minor, Horn.

\section{PHLCOPHAGUS, Sch.}

Anglesea, in July-Schwarz. New Jersey-Julich.

WOLLASTONIA, Horn.

W. quercicola, Boh.

Landisville, rare-Liebeck. Sea-shore, rare-Wenzel. New Jersey-Julich.

R. brunneus, Mann.

RHYNCHOLUS, Germ.

New Jersey-Julich.

R. oregonensis, Horn.

Anglesea-Wenzel.

S. brevis, Boh.

STENOSCELIS, Woll.

Hudson county-Linell. New Jersey-Julich. Ocean county -Smith.

\section{Family SCOLYTIDE.}

MONARTHRUM, Kirsch.

M. fasciatum, Say.

Gloucester, rare-Wenzel: New Jersey-Julich.

M. mali, Fitch.

Dacosta, rare-Wenzel. New Jersey-Julich.

\section{PITYOPHTHORUS, Eich.}

P. minutissimus, Zimm.

New Brunswick, common in oak twigs-Smith. New Jersey -Julich. 
P. pullus, Zimm.

Atco, rare-Wenzel. New Jersey-Julich.

P. pulicarius, Zimm.

Cape May Court House, in July-Schwarz.

P. puberulus, Lec.

Cape May Court House, in July-Schwarz.

HYPOTHENEMUS, Westw.

H. eruditus, Westw.

Bred from Grape and Oak, New Brunswick. Anglesea, in July-Schwarz. New Jersey-Julich.

H. hispidulus, Lec.

Bred from Hickory and Oak. This is not the same as eruditus.

H. dissimilis, Zimm.

Bred from Grape and Oak. I consider this = eruditus. Anglesea.

H. erectus, Lec.

Bred from Hickory and Oak, New Brunswick.

X. politus, Say.

$$
\text { XYLOTHRUS, Er. }
$$

New Jersey-Julich.

X. pyri, Peck.

\section{XYLEBORUS, Eich.}

Anglesea-Wenzel.

X. celsus, Eich.

Dacosta, rare-Wenzel. New Jersey-Julich.

X. fuscatus, Eich.

New Jersey-Julich.

X. xylographus, Say.

Dacosta, not rare-Wenzel. Anglesea, in July-Schwarz. New Jersey-Julich.

X. pubescens,' Zimm.

Dacosta, not rare-Wenzel. On Oak-Julich. 
X. cælatus, Eich.

Generally distributed, not rare-Wenzel. New JerseyJulich.

D. granicollis, Lec.

\section{DRYOCETES, Eich.}

New Jersey-Julich.

T. calligraphus, Germ.

\section{TOMICUS, Latr.}

Generally distributed, common-Wenzel. Brigantine Beach, mainland, in September-Hamilton. New Jersey-Julich.

T. cacographus, Lec.

Same localities as before.

T. pini, Say.

Newark. Determined by myself. New Jersey-Julich.

M. asperula, Lec.

\section{MICRACIS, Lec.}

New Jersey—Julich.

M. opacicollis, Lec.

Boring in the pith of small oak twigs, New Brunswick.

SCOLYTUS, Geoff.

S. quadrispinosus, Say.

Generally distributed, not rare-Wenzel. Newark. New Jersey-Julich.

S. rugulosus, Ratz.

Peach and Wild Cherry-Julich.

C. icoriæ, Lec.

ChRAMESUS, Lec.

Hudson county-Linell. Common in hickory twigs, New Brunswick. New Jersey-Julich.

P. liminaris, Harr.

PHLGOTRIBUS, Latr.

New Jersey-Julich. 
P. frontalis, Oliv.

New Jersey-Julich.

HYLESINUS, Fabr.

H. aculeatus, Say.

On Ash, New Jersey—Julich.

H. opaculus, Lec.

New Jersey_Julich.

H. trifolii, L.

The clover-root borer. Bergen-Julich.

P. serratus, Lec.

PHLGOSINUS, Chap.

Anglesea, rare-Wenzel.

P. dentatus, Say.

Anglesea, in July-Schwarz. Brigantine Beach, in September-Hamilton. In Red Cedar-Julich.

C. bifurcus, Eich.

CARPHOBORUS, EIoh.

New Jersey_Julich.

D. terebrans, Oliv.

DENDROCTONUS, Er.

Generally distributed, common-Wenzel. Caldwell, common-Crane. New Jersey-Julich.

C. atomus, Lec.

\section{CRYPTURGUS, Er.}

New Jersey-Julich.

H. porculus, Er.

\section{HYLASTES, Er.}

Generally distributed, common-Wenzel.

\#. cavernosus, Zimm.

New Jersey-Julich. 
ㅍ. pinifex, Fitch.

\section{HYLURGOPS, Lec.}

New. Jersey-Julich.

The list is very incomplete in this family, because collectors have not generally sought for the species and they are difficult of determination.

\section{Family ANTHRIBIDE.}

E. fasciatus, Oliv.

\section{EURYMYCTER, Lec.}

On the Newark list. Sea-coast, rare-Wenzel. Orange, Snake Hill_Julich.

T. rectus, Lec.

TROPIDERES, Sch.

Sea-coast, rare-Wenzel.

ALLANDRUS, Lөc.

A. bifasciatus, Lec.

On Linden-Julich.

H. saltator, Lec.

HORMISCUS, Waterh.

Gloucester, rare-Wenzel. Anglesea, in July-Schwarz. New Jersey—Julich.

H. nova species, Schwarz dixit.

Anglesea, in July_Schwarz.

E. walshii, Lec.

\section{EUSPEYRUS, Lec.}

Gloucester, rare-Wenzel.

P. mixtus, Lec.

\section{PIEZOCORYNUS, Sch.}

New Jersey—Julich. 
P. moestus, Lec.

Sea-coast, rare-Wenzel. Brigantine Beach, in September, rare-Hamilton.

C. lunatus, Fabr.

CRATOPARIS, Sch.

Occurs throughout the State more or less commonly.

BRACHYTARSUS, Sch.

B. alternatus, Say.

Hudson county-Linell. New Jersey-Julich.

B. tomentosus, Say.

Gloucester, one specimen only-Wenzel. Hudson countyLinell. New Jersey-Julich.

B. variegatus, Say.

Generally distributed, not uncommon-Wenzel, Liebeck.

A. rotundatus, Lec.

ANTHRIBULUS, Lec.

Anglesea-Wenzel.

\section{Order LEPIDOPTERA.}

\section{Family NYMPHALID无.}

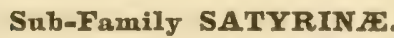

S. pegala, Fabr.

SATYRUS, Westw.

Rare along the coast of southern New Jersey. Seven Mile Beach, Mount Holly-Aaron.

S. alope, Fabr.

Common throughout the State.

Var. maritima, Edw.

Jamesburg, Ocean county, Cape May county, and there the common form; at Jamesburg it runs into the typical form. 
Form nephele, Kirby.

Occurs with and generally replaces the typical form in the northern counties. Warren county; common.

D. portlandia, Fabr.

DEBIS, Westw.

General throughout the State, but rather local. Newark. Caldwell, rare-Crane.

N. canthus, Bd.-Lec.

\section{NEONYMPHA, Westw.}

Mount Holly, Westville-Aaron. Newark. Quite generally distributed, but rare.

N. areolatus, Sm.-Abb.

Atlantic City, Seven Mile Beach-Aaron. MorristownEdwards. A southern species; its occurrence in the State occasional.

N. eurytris, Fabr.

Common throughout the State.

N. sosybius, Fabr.

Mount Holly-Aaron. Occasional in southern New Jersey.

\section{Sub-Family NYMPHALIN E.}

A. clyton, Bd.-Lec.

APATURA, Fabr.

New Jersey is included in the faunal map of this species, but I have no record of its capture.

L. ursula, Fabr.

\section{LIMENITIS, Fabr.}

Common throughout the State.

L. arthemis, Dru.

Schooley's Mountain-Aaron. Also recorded on the Newark list.

Var. proserpina, Edw.

On the Newark list, without definite locality. 
L. disippus, Gdt.

Common throughout the State.

GRAPTA, Kirby.

G. interrogationis, Fabr.

Both forms of the species-fabricii, Edw., and umbrosa, Lint.

- are rather common throughout the State.

G. comma, Harr.

Less common, but equally distributed throughout the State. Forms harrisii, Edw., and dryas, Edw.

G. faunus, Edw.

Schooley's Mountain-Aaron. A northern and mountain form.

G. progne; Cram.

Caldwell, common-Crane.

G. J-album, Bd.-Lec.

Schooley's Mountain-Aaron. Also recorded on the Nervark list. Caldwell, rare-Crane.

V. antiopa, Linn.

\section{VANESSA, Fabr.}

Common throughout the State, the larvæ often defoliating Willow.

$\nabla$. milberti, Gdt.

Schooley's Mountain-Aaron. Orange Mountains, rare. It is a northern form.

P. atalanta, Linn.

\section{PYRAMEIS, Doubl.}

Common throughout the State.

P. huntera, Fabr.

Common throughout the State.

P. cardui, Linn.

Common throughout the State. 
J. ccnia, $\mathrm{Hb}$.

\section{JUNONIA, Doubl.}

Common seasonally, south of Trenton-Aaron. Newark, also seasonally abundant. Caldwell, rare-Crane.

E. claudia, Cram.

\section{EUPTOIETA, Doubl.}

Cape May, Atlantic City, Mount Holly-Aaron. Occurs also northwardly, near the coast, and is on the Newark list.

A. vanillæ, Linn.

\section{AGRAULIS, Bd.-Lec.}

Cape May, Seven Mile Beach-Aaron. Camden county.

A. idalia, Dru.

\section{ARGYNNIS, Fabr.}

Found throughout the State; usually not common. Caldwell, common-Crane. Newark, in July-Seib.

A. cybele, Fabr.

Common throughout the State.

A. aphrodite, Fabr.

Schooley's Mountain-Aaron. Orange Mountains. Also on the Newark list, without definite locality.

A. myrina, Cram.

Common throughout the State. Abundant on cranberry bogs.

A. bellona, Fabr.

Found throughout the State; more common northwardly.

\section{PEYCIODES, Doubl.}

P. nycteis, Doubl.-Hew.

Gloucester, Mount Holly-Aaron. Also on the Newark list. Not common.

P. tharos, Dru.

Common throughout the State.

P. batesii, Reak.

Gloncester-Aaron. Not on the Newark list. 
M. phaeton, Dru.

MELIT丑A，Fabr。

Occurs all over the State, in fresh-water swamps.

M. harrisii, Scudd.

Schooley's Mountain-Aaron. Also on the Newark list.

D. archippus, Fabr.

DANAIS, Latr.

Common throughout the State. Larva on Asclepias.

\section{Sub-Family LIBY'THEIN EE.}

L. bachmanni, Kirtl.

LIBYTHEA, Fabr.

Gloucester-Aaron. Also on the Newark list. Common at Sandy Hook in 1886-Beutenmüller.

\section{Family LYCAENID五.}

\section{Sub-Family ERYCININ E.}

CALEPHELIS, Grt. \& Rob.

C. borealis, Grt. \& Rob.

Opposite Delaware Water Gap-Aaron. Not on the Newark list.

\section{Sub-Family LYCENIN在。}

T. halesus, Cram.

THECLA, Fabr.

Cape May, Gloucester, near Westville-Aaron. Also on the Newark list.

T. m-album, Bd.-Lec.

Atlantic City-Aaron. Not on the Newark list. 
T. favonius, Sm.-Abb.

On the Newark list, without definite locality.

T. humuli, Harr.

Quite generally distributed, but nowhere common.

T. melinus, Hüb.

On the Newark list, without definite locality. The State is included in Mr. Scudder's faunal map of this species.

T. acadica, Edw.

New Jersey is included in Mr. Scudder's faunal map of this species, but I have received no records of its capture.

T. edwardsii, Saund.

Recorded on the Nervark list, without definite locality.

T. calanus, Hüb.

Found throughout the State, but not common. Caldwell, rare-Crane. Newark, in July-Seib.

T. strigosa, Harr.

On the Newark list, without definite locality.

T. smilacis, Bd.-Lec.

Locally not rare in the Passaic Valley region, early in spring. Newark, in May-Seib.

T. augustus, Kirby.

Gloucester, Westville, Mount Holly-Aaron. Not taken by the Newark collectors.

T. irus, Godt.

Gloucester-Aaron. Westville. Also taken by the Newark collectors.

T. henrici, Grt. \& Rob.

Westville, local; also on the Newark list.

T. niphon, Hüb.

Gloucester, Mount Holly-Aaron. Westville, rare; also on the Newark list.

T. læta, Edw.

Atlantic City-Aaron. Not on the Newark list.

T. titus, Fabr.

Mount Holly-Aaron. Also on the Newark list. 
L. couperii, Grote.

\section{LYCA丹NA, Fabr.}

New Jersey is included in Mr. Scudder's faunal map of this species, and he has it recorded from the vicinity of New York

City. I know of no specimens from this State.

L. pseudargiolus, Bd.-Lec.

This species and its various forms and races are quite common throughout the State, but somewhat local.

L. comyntas, Godt.

Common throughout the State.

C. thoe, Bd.-Lec.

\section{CHRYSOPHANUS, Doubl.}

Schooley's Mountain-Aaron. Recorded on the Newark list. Said to be very local. Caldwell, rare-Crane. Newark, in July—Seib.

C. expixanthe, Bd.-Lec.

Dacosta, not rare-Aaron. Not on the Newark list.

C. hypophlcous, Bdv,-(americana, D'Urb.)

Common throughout the State.

F. tarquinius, Fabr.

FENISECA, Grt.

Mount Holly-Aaron. Also on the Newark list. Seems generally distributed, but local and nowhere common.

\section{Family PAPILIONID压。}

\section{Sub-Family PAPILIONINA.}

P. ajax, Linn.

PAPILIO, Linn.

Recorded on the Newark list, and said to be not rare seasonally and locally. There is considerable Paw-Paw in the State. 
P. philenor, Linn.

Atlantic City, Westville, Mount Holly-Aaron. Quite generally distributed throughout the State; not common.

P. brevicauda, Saund.

Pemberton-Aaron. Mr. Aaron marks the name with a (?). I have seen a specimen from Hightstown, which, with a different locality label, would pass very well for this species.

P. asterias, Fabr.

Common throughout the State.

P. troilus, Linn.

Common throughout the State.

P. turnus, Linn.

Common throughout the State. The dimorphic female, glancus, is rare.

P. cresphontes, Cram.

Trenton-Aaron. On the Newark list. Isolated specimens occur throughout the State. Caldwell-Crane.

\section{Sub-Family PIERIN死.}

C. eubule, Linn.

CALLIDRYAS, Bdv.

Mount Holly, Atlantic City-Aaron. Also on the Newark list. Long Branch-Edwards.

A. genutia, Fabr.

ANTHOCHARIS, BdV.

Westville, Mount Holly, Seven Mile Beach-Aaron. Timber Creek.

C. eurytheme, Bdv.

COLIAS, Fabr.

Mount Holly-Aaron. Occasionally taken by members of the Newark Society.

C. philodice, Godt.

Common throughout the State. 
T. nicippe, Cram.

\title{
TERIAS, Swains.
}

Mount Holly, Westville, Atlantic City-Aaron. I have seen it quite generally throughout the State, but nowhere common. Caldwell, rare-Crane. Newark, in September-Seib.

T. lisa, Bd.-Lec.

Not rare throughout the State. Newark, in October-Seib.

P. protodice, Bdv.

\section{PIERIS, Schr.}

Mount Holly, Westville-Aaron. Occasional throughout the southern part of the State.

P. rapæ, Linn.

The common cabbage butterfly; found everywhere.

P. oleracea, Bdv.

Orange Mountains; rare. Probably more common in the hilly north of New Jersey.

\section{Family HESPERID E.}

E. pylades, Scudd.

\author{
EUDAMUS, Swains.
}

Quite generally distributed, not common-Aaron.

E. bathyllus, Sm.-Abb.

Common throughout the State.

E. lycidas, Sm.-Abb.

Quite generally distributed, but rare. Taken both by the Philadelphia and Newark collectors. Caldwell, common-Crane. Taken in June-Seib.

E. cellus, Bd.-Lec.

Taken rarely by the Newark collectors.

E. tityrus, Fabr.

Common throughout the State. Taken in July-Seib. 


\section{S( GEOLOGICAL SURVEY OF NEW JERSEY.}

E. proteus, Linn.

Cape May-Aaron. Also on the Newark list.

N. brizo, Bd.-Lec.

NISONIADES, Speyer.

Gloncester-Aaron. Westville. Also on the Newark list. Newark, in May-Seib. Not rare.

N. icelus, Lint.

Opposite Delaware Water Gap-Aaron. Also on the Newark list.

N. lucilius, Lint.

The State is included in Mr. Scudder's faunal map of the species, but it has not been taken by collectors, so far as I know.

N. persius, Scudd.

This is in the same case as the preceding.

N. ausonius, Lint.

Said to occur in the State, but I have seen no positive records of the fact.

N. martialis, Scudd.

Taken in New Jersey-Aaron. Not on the Newark list.

N. juvenalis, Fabr.

Common near Philadelphia, and quite generally distributed throughout the State, in my experience. Newark, in JulySeib. Caldwell, rare-Crane.

N. horatius, Scudd.

Occurs in this State, according to Scudder's faunal map, but I know of no actual records.

N. terrentius, Scudd.

This is in the same case with the preceding.

P. catullus, Fabr.

PHOLISORA, Speyer.

Common throughout the State.

P. tessellata, Scudd.

PYRGUS, Westw.

Quite common throughout the State. 
P. centaureæ, Ramb.

Recorded from all land sides of the State and almost certain to occur here.

ANCYLOXYPHA, Feld.

A. numitor, Fabr.

Common throughout the State.

A. vialis, Edw.

\section{AMBLYSCIRTES, Speyer.}

Locally common throughout the State. Not on the Newark list.

A. samoset, Scudd.

Said to occur from Maine to Georgia, but has not been actually recorded from this State.

\section{PAMPHILA, Fabr.}

P. massasoit, Scudd.

Gloucester-Aaron. Swamps near Westville. Also on the Newark list. Not common.

P. zabulon, Bd.Lec.

Not rare throughout the State. The form hobomock is more common, while pocahontas is rare.

P. sassacus, Harr.

Trenton-Aaron. Also on the Newark list. CaldwellCrane.

P. metea, Scudd.

Schooley's Mountain-Aaron.

P. seminole, Scudd.

New Jersey-Edwards. Not taken by either the Philadelphia or Newark collectors.

P. leonardus, Harr.

Rare in the eastern part of the State. On the Newark list.

P. huron, Edw.

Mount Holly-Aaron. Also on the Newark list. 
P. phylæus, Dru.

Atlantic City-Aaron. I have taken this at Clifton, rarely. P. otho, Sm.-Abb.

Gloncester, \&c.-Aaron. Also on the Newark list. Not rare throughout the State. The form egeremet is more common.

P. peckius, Kirby.

Common throughout the State.

P. mystic, Scudd.

Trenton, Schooley's Mountain-Aaron. Also on the Newark list.

P. cernes, Bd.-Lec.

Common throughout the State.

P. manataaqua, Scudd.

Generally distributed, but not common. Taken by $\mathrm{Mr}$. Aaron, and also on the Newark list.

P. verna, Edw.

Recorded by Mr. Aaron, without definite locality.

P. metacomet, Harr.

Taken by Mr. Aaron, and also on the Newark list. Caidwell -Crane.

P. accius, Sm.-Abb.

Salem-Aaron. Not on the Newark list.

P. panoquin, Scudd.

Atlantic City-Edwards. New Jersey-Aaron. Not on the Newark list.

P. ocola, Edw.

Salem, rare-Aaron.

P. bimacula, Grt. \& Rob.

A specimen labeled "N. J." is in Mr. Aaron's collection; source unknown.

P. pontiac, Edw.

Westville-Aaron. "New Jersey"-Edwards. Not on the Newark list. 
P. delaware, Edw.

East bank of Delaware Bay, near Maurice River-Aaron.

P. viator, Edw.

Cape May-Aaron. Also on the Newark list.

\section{Family SPHINGID在.}

\section{SnT-Family MACROGLOSSINAE.}

H. tenuis, Grt.

HEMARIS, Dalm.

Not rare. Taken by the Newark collectors and generally distributed in the State.

H. diffinis, Bdv.

Common all over the State.

H. axillaris, Grt. \& Rob.

Morris Plains, rare-Neumoegen.

ㅍ. gracilis, Grt. \& Rob.

Not rare, but not taken by the Newark collectors.

H. thysbe, Fabr.

Common. Caldwell-Crane. Newark, in August-Seib.

Var. floridensis, Grt. \& Rob.

Morris Plains, rare-Neumoegen.

\section{Sab-Family CHCEROCAMPINA.}

A. tantalus, Linn.

AELLOPOS, Hüb.

An occasional visitor; a typically southern species, yet not infrequently taken along the coast. On the Newark list.

E. lugubris, Linn.

\section{ENYO, Hüb.}

Also a southern species which is occasionally taken in New Jersey. Not on the Newark list. 
A. nessus, Cram.

\section{AMPEION, Hüb.}

Common locally, but by no means generally distributed. On the Newark list. May and Juue-Seib.

T. abbotii, Swains.

THYREUS, Swains.

Usually common. The ugly larva on Grape is familiar to most. Caldwell, rare-Crane. May-Seib.

D. inscripta, Harr.

\section{DEIDAMIA, Clem.}

Rare. Seems to be generally distributed, but never obtrusive. Taken by the Newark collectors.

\section{DEILEPHILA, Ochs.}

D. gallii, var chamænerii, Harr.

Not common; seems local and rather more northern. Taken at Newark. Caldwell, rare-Crane.

D. lineata, Fabr.

Common throughout the State. The imago is especially fond of flying about the newly-opened flowers of (Enothera (Evening Primrose). July and August-Seib.

C. tersa, Linn.

\section{CHEROCAMPA, Dup.}

Rather a southern species, habitally. Taken by the Newark collectors. Caldwell, common-Crane. May, July and September-Seib.

\section{ARGEUS, Hüb.}

A. labruscæ, Linn.

An occasional visitor from southern climes. I have picked up a specimen on the beach. Not on the Newark list. 


\section{PHILAMPELUS, Harr.}

P. linnei, Grt. \& Rob.

Occasional along the coast. Not on the Newark list.

P. vitis, Linn.

Occasional along the coast. Taken by the Newark collectors.

P. pandorus, Hüb.

Common all over the State. The larva feeds on Grape. August-Seib.

P. achemon, Dru.

Common all over the State. The larva on Grape. AugustSeib.

AMPELOPHAGA, Brem. \& Grey.

A. chœrilus, Cram.

Common. Larva on Grape and Ampelopsis.

A. myron, Cram.

Common. Larva on Grape and Ampelopsis. August-Seib.

A. versicolor, Harris.

Rare. Local in occurrence and seldom in any numbers. Taken by the Newark collectors. Larva on "Button-ball."

D. ello, Linn.

\section{Sub-Family SPHINGIN王。}

DILOPHONOTA, Burm.

Rare. A visitor from the South, and sometimes in some numbers. Taken by the Newark collectors.

D. obscura, Fabr.

A very occasional visitor. Recorded on the Newark list. At home in the West Indies.

P. celeus, Hüb.

\section{PROTOPARCE, Burm.}

Not usually common. The larva on Potato, throughout the State. 
P. carolina, Limn.

Common. The larva is the well-known tomato worm, found everywhere in the State.

P. rustica, Fabr.

Not common. I have seen it from the State in some New York collection. Not taken by the Newark collectors.

P. cingulata, Fabr.

Rare. Generally distributed, but nowhere abundant. On the Newark list.

S. kalmiæ, S. \& A.

\section{SPHINX, Linn.}

Not rare. Generally distributed. Taken by Newark collectors. June-Seib.

S. drupiferarum, S.\& A.

Generally distributed. Taken by Newark collectors. Caldwell, rare-Crane. July and August-Seib.

S. gordius, Cram.

Not usually common. Generally distributed. It is on the Newark list. June-Seib. Caldwell, common-Crane.

S. Iuscitiosa, Clem.

Rare, and apparently very local; food-plant, Willow. Taken by Newark collectors.

S. chersis, Hüb.

Not usually common, somewhat local, but from all parts of the State. July-Seib.

S. eremitus, Hüb.

Not rare, and sometimes quite common. Recorded on the Newark list. Caldwell, rare-Crane.

S. plebeius, Fabr.

Not rare. Generally distributed. Taken by the Newark collectors. Caldwell, rare-Crane. In June-Seib.

D. hylæus, Dru.

DOLBA, Walk.

Generally distributed, but by no means common. Taken by the Newark collectors. Caldwell, rare-Crane. 
CHL FINOGRAMMA, Smith.

C. jasminearum, Bdv.

Rare. Taken by Newark collectors. Caldwell, rare-Crane.

C. amyntor, Hüb.

\section{CERATOMIA, Harris.}

Not rare. Generally distributed throughout the State. The larva feeds on Elm and Linden, and is readily recognized by the four thoracic horns in addition to the usual anal horn.

C. undulosa, Wlk.

Not usually rare. Quite generally distributed. Caldwell, rare-Crane. June and August-Seib.

E. harrisii, Clem.

\section{ELLEMA, Clem,}

Very rare.' Feeds, in the larva state, on Conifers. Taken by Newark collectors.

Đ. coniferarum, S. \& A.

Rare. Perhaps even more so than the preceding. Also on Conifers. It is on the Newark list.

\section{Sub-Family SMERINTHIN死。}

T. modesta, Harr.

TRIPTOGON, Brem.

Rare. One of the largest and the handsomest of our species. The larva on Poplar. Taken by Nervark collectors.

S. geminatus, Say.

\section{SMERINTHUS, Latr.}

Common. Generally distributed. On the Newark list. Caldwell, rare-Crane. In August-Seib.

P. excæcatus, S. \& A.

\section{PAONIAS, Hüb.}

Common throughout the State. 


\section{GEOLOGICAL SURVEY OF NEW JERSEY.}

P. myops, S. \& A.

Rare. Locally the larvæ are often somewhat common on Wild Cherry, Prunus serotina. Caldwell, rare-Crane. Newark.

P. astylus, Dru.

Very rare, and apparently very local. Taken by the Newark collectors. June and July-Seib.

CRESSONIA, Grt. \& Rob.

O. juglandis, S. \& A.

Not rare, yet usually by no means common. Generally distributed. Caldwell, common-Crane. Newark, in June-Seib.

\section{Family SESIID王.}

M. ceto, WVestw.

MELITTIA, Hüb.

Generally distributed. The larva bores in the roots and stems of Cucurbitacece. Caldwell, common-Crane. Newark, in July -Seib.

ALCATHOE, Ву. Edw.

A. caudatum, Harr.

Caldwell, rare-Crane.

TROCHILIUM, Scop.

T. apiforme, Linn.

Rare. Taken by Newark collectors.

BEMBECIA, Hüb.

B. marginata, Harr.

Rare. Generally distributed. The larva bores in canes of Blackberry.

F. denudata, Harr.

FATUA, Ву. Edw.

Morris Plains, rare-Neumoegen. 
P. syringæ, Harris.

\author{
PODOSESIA, Moeschl.
}

Common. The larva bores in Syringa.

S. exitiosa, Say.

\title{
SANNINA, Walk.
}

This is the well-known "Peach Borer," and occurs all over the State. May and June-Seib.

S. pictipes, Grt. \& Rob.

$$
\text { SESIA, Fabr. }
$$

Not common. Generally distributed. Taken by the Newark collectors.

S. pyri, Harr.

Larva in Apple and Pear; usually not common.

S. acerni, Clem.

Larva in Maple; often quite common.

S. tipuliformis, Linn.

Larva in Currant and Gooseberry; sometimes quite destructive.

S. albicornis, Hy. Edw.

Morris Plains, rare-Neumoegen.

\section{Family THYRID RE.}

T. maculata, Harr.

THYRIS, Illiger.

Not common. Taken occasionally on flowers, quite early in the season. Caldwell, rare-Crane.

T. lugubris, Boisd.

Not rare. Taken quite commonly in Ocean county and Atlantic county. Not taken by the Newark collectors. Morris Plains-Neumoegen. 


\title{
Family AGARISTID AE.
}

ALYPIA, Hüb.

A. octomaculata, Fabr.

Common about cities, on Grape. Quite rarely found in the open c untry. Sometimes quite destructive, in June-Seib.

P. epimenis, Dru.

$$
\text { PSYCHOMORPEA, Harr. }
$$

Rare. The larva on Grape. Taken by the Newark collectors.

E. unio, Hüb.

$$
\text { EUDRYAS, Boisd. }
$$

Not usually common. Local, but occurring all over the State. Larva on Grape. Caldwell, common-Crane. June-Seib.

E. grata, Fabr.

Rare; local. Larva on Grape. Caldwell-Crane.

\section{Family SYNTOMID里.}

L. pholus, Dru.

\author{
LYCOMORPHA, Harris.
}

Quite common late in summer, on Golden Rod.

\section{Family CTENUCHID王.}

S. fulvicollis, Hüb.

SCEPSIS, Walk.

Not rare. Generally distributed.

C. virginica, Charp.

CTENUCHA, Kirby.

Not common. Often taken on Spirea when in bloom. 


\title{
Family PYROMORPHIDE.
}

H. americana, Harr.

HARRISINA, Pack.

Common locally. The larva is sometimes quite destructive to Grape.

P. dimidiata, H-S.

PYROMORPHA, H-S.

Rare. I have taken two specimens in Ocean county. Not taken by the Newark collectors.

\section{Family LITHOSIID在。}

N. melanopa, Zell.

\author{
NOLA, Leach.
}

Not common. A few specimens at light.

Two species not satisfactorily determinable, taken by me this season (1889).

A. nigrofasciata, Zell.

Rare. Two specimens at light. Not on the Newark list.

C. albata, Pack.

\section{CLEMENSIA, Pack.}

Rare. Taken by Newark collectors.

H. fucosa, Hüb.

\section{HYPOPREPIA, Hüb.}

Common. Beaten from Pines; also in mossy meadows. July -Seib.

E. mendica, Walk.

EUPHANESSA, Pack.

Not rare. I have taken it in the Orange Mountains. On the Newark list. 


\section{Family ARCTIIDÆ.}

C. rubicundaria, Hüb.

CROCOTA, Hüb.

Not rare. Quite generally distributed. Taken by Newark collectors.

C. brevicornis, Walk.

I have taken this in Ocean county. Not on the Newark list.

C. ferruginosa, Walk.

Caldwell, rare-Crane.

C. opella, Grote.

I have taken this near Jamesburg.

U. bella, Linn.

\section{UTETHEISA, Hüb.}

Locally common. I have taken it on the beach at Sandy Hook.

\section{CALLIMORPHA, Latr.}

C. clymene, Brown.

Taken by the Newark collectors. Locally common.

C. militaris, Harris.

Taken by Newark collectors. Not rare.

O. contigua, Walk.

Recorded on the Newark list.

C. fulvicosta, Clem.

Taken by Newark collectors.

I have taken none of these forms in the State myself, but have taken them in the same faunal district. The species are locally common.

A. virgo, Limn ARCTIA, Schrank.

Not usually common. Generally distributed. Caldwell, common-Crane.

A. saundersii, Grt.

Rare. A single specimen has been taken near Newark. 
A. phyllira, Dru.

Not commonly taken by Newark collectors. Caldwell, common-Crane.

A. figurata, Dru.

Rare. Only a few specimens taken.

A. nais, Dru.

Common. Found all over the State. May and September-Seib.

A. decorata, Saund.

Not common. Taken by Newark collectors.

A. virguncula, Kirby.

Not common. It is on the Newark list.

A. arge, Dru.

Not common. More general in the northern parts of the State. It is on the Newark list. Caldwell, rare-Crane. May -Seib.

P. isabella, S. \& A.

PYRREARCTIA, Pack.

A common species all over the State. May-Seib.

\section{PHRAGMATOBIA, Harris.}

P. rubricosa, Harris.

Not common. Taken by Newark collectors. Caldwell, rare -Crane.

L. acræa, Dru.

$$
\text { LEUCARCTIA, Pack. }
$$

Common along the coast. Newark. Caldwell. Readily attracted by light.

S. virginica, Fabr.

SPILOSOMA, Steph.

Common throughout the State.

S. latipennis, Stretch.

Rare. Taken in fresh water-swampy localities.

S. antigone, Strk.

Rare. Taken near Newark. I have myself taken it on Staten Island, N. Y., but not as yet in New Jersey. Mr. Beutenmüller says the larva feeds in mushrooms. 
E. cunea, Dru.

HYPEANTRIA, Harris.

The parent of the common Fall Web Worm. Cummon throughout the State.

Đ. egle, Drury.

$$
\text { EUCHATES, Harris. }
$$

Common. Larva on Asclepias. June-Seib.

E. eglenensis, Clem.

More rare. Taken by Newark collectors.

E. oregonensis, Stretch.

Not recorded from New Jersey, but I have seen it from Long Island, and it is almost certain to occur with us.

E. collaris, Fitch.

Common. Generally distributed. Larva on Asclepias.

E. scribonia, Stoll.

$$
\text { ECPANTEERIA, Büb. }
$$

Not rare. The larva is more commonly seen than the imago, and is more abundant southwardly.

\section{HALESIDOTA, Hüb.}

H. tessellata, S. \& A.

Common throughout the State. The larva quite a nuisance on shade trees. June-Seib.

H. caryæ, Harris.

Common. Generally distributed. May-Seib.

\section{Family LIPARID瓜.}

O. leucosigma, S. \& A.

ORGYIA, Ochs.

Common throughout the State. The larra is an indiscriminate feeder on shade trees. 
O. obliviosa, Hy. Edw.

Probably only a variety of the preceding. Taken near the Hudson.

P. leucophæa, S. \& A.

PARORGYIA, Pack.

Not common. Recorded on the Newark list. Morris Plains, rare-Neumoegen.

P. clintonii, Grt. \& Rob.

Not common. Recorded on the Newark list.

P. parallela, Grt. \& Rob.

Not common. Recorded on the Newark list.

P. achatina, S. \& A.

Not common. Recorded on the Newark list.

P. cinnamomea, Grt. \& Rob.

I took a specimen of this species years ago near Jersey City.

L. crispata, Pack.

$$
\text { LAGOA, Harris. }
$$

Not rare. Generally distributed.

\section{Family LIMACODID正。}

E. querceti, H-S.

EUCLEA, Hüb.

Not rare. Generally distributed.

E. bifida, Pack.

Recorded on the Newark list.

E. pænulata, Clem.

Recorded on the Newark list.

P. chloris, H-S.

PARASA, Moore.

Not usually rare. Quite generally distributed. Caldwell, rare -Crane. 
P. fraterna, Grt.

Not rare. I have seen it only from the eastern part of the State.

E. stimulea, Clem.

$$
\text { EMPRETIA, Clem. }
$$

Common. Generally distributed. Larva on Pear, Cherry and Apple.

P. pithecium, S. \& A.

$$
\text { PEOBETRON, Hüb. }
$$

Not common. Generally distributed. Larva also on Pear.

L. Ecapha, Harris.

\section{LIMACODES, Latr.}

Not rare. Generally distributed. Rare at Caldwell-Crane.

L. biguttata, Pack.

Taken by Newark collectors.

L. Y-inversa, Pack.

Not rare. Generally distributed.

L. rectilinia, Grt. \& Rob.

I have had specimens from the northern part of the State, near the New York line.

L. fasciola, H-S.

Rather common. Generally distributed. Rare at CaldwellCrane.

$$
\text { SISYROSEA, Grt. }
$$

S. inornata, Grt. \& Rob.

Recorded by the Newark collectors.

A. spinuloides, H-S.

\section{ADONETA, Clem.}

Not rare. Quite generally distributed.

P. geminata, Pack.

$$
\text { PACKARDIA, Grt. \& Rob. }
$$

I have determined this species from New Jersey. It is not on the Newark list. 
P. ocellata, Grt.

Recorded on the Newark list.

P. albipuncta, Pack.

Recorded as taken near Newark.

P. nigripunctata, Good.

Recorded by the Newark collectors from that locality.

T. testacea, Pack.

TORTRICIDIA, Pack.

Not common. Generally distributed. On the Nerwark list.

\section{Family PSYCHID尼.}

P. confederata, Grt.

\section{PSYCHE, Ochs.}

Recorded on the Newark list.

THYRIDOPTERYX, Steph.

T. өphemeræformis, Steph.

The common "bag-worm." Often very injurious to Arbor vitæ, and feeding quite indiscriminately on shade trees.

PEROPHORA, Harris.

P. melsheimerii, Harr.

Rare. Generally distributed. It is on the Newark list, and I have it from Ocean county. June-Seib.

\section{Family PTILODONTID זE.}

I. inclusa, Hüb. ICHTHYURA, Hüb.

Common. Generally distributed.

I. albosigma, Fitch.

More rare. Recorded on the Newark list. June-Seib. 


\section{APATELODES, Pack.}

A. torrefacta, S. \& A.

Not common. Generally distributed.

A. angelica, Pack.

Rare. I have seen specimens from the State. Not on the Newark list. Lake Hopatcong-Palm.

D. ministra, Dru.

\section{DATANA, Walk.}

Common. The larva is the well-known yellow-necked apple tree caterpillar.

D. angusii, Grt. \& Rob.

Locally common. On the Newark list.

D. major, Grt. \& Rob.

Not common. Taken by the Newark collectors.

D. integerrima, Grt. \& Rob.

Not rare. Taken by the Newark collectors. Common at Caldwell-Crane.

D. contracta, Walk.

Locally common. Generally distributed.

D. perspicua, Grt. \& Rob.

Common. Generally distributed.

NADATA, Walk.

N. gibbosa, S. \& A.

Not common. Generally distributed. Caldwell, rare-Crane. August-Seib.

N. doubledayi, Pack.

Rare. On the Newark list.

HYPARPAX, Hüb.

H. aurora, S. \& A.

Not common. Generally distributed. Newark, in June, August and September-Seib. 
N. stragula, Grt. NOTODONTA, Ochs.

Not common. On the Newark list. Caldwell, rare-Crane. July and August-Seib.

N. basitriens, Walk.

Not on the Newark list, but I have had it from the State. Probably rare.

L. ferruginea, Pack.

LOPHODONTA, Pack.

On the Newark list. Not common.

L. angulosa, S. \& A.

Taken by the Newark collectors. June-Seib.

L. georgica, H-S.

Not common. Taken by the Nerwark collectors.

P. rimosa, Pack.

$$
\text { PEEOSIA, Hüb. }
$$

Rare. Taken near Newark. Also in Ocean county.

N. bidentata, Walk.

$$
\text { NERICE, Walk. }
$$

Not rare. Generally distributed. Caldwell, rare-Crane.

E. albifrons, S. \& A.

$$
\text { EDEMA, Walk. }
$$

Common at Newark. Readily attracted to light. Rare at Caldwell-Crane.

S. bilineata, Pack.

$$
\text { SEIRODONTA, Grt. \& Rob. }
$$

Not rare. Generally distributed. Not on the Newark list.

O. concinna, S. \& A. GEDMASIA, Pack.

Common. Generally distributed.

O. eximia, Grt.

Morris Plains, rare-Edwards. 
O. badia, Pack.

More rare. Taken near Newark. Morris Plains, rareEdwards.

D. anguina, S. \& A.

\section{DASYLOPEIA, Pack.}

Not common. I have taken it near Jersey City. Newark, in July-Seib.

D. interna, Pack.

Taken near Jamesburg. Not on the Newark list.

C. leptinoides, Grt.

CGLOD ASYS, Pack.

Newark-Augelman. Morris Plains, rare-Neumoegen.

C. unicornis, S. \& A.

Common, locally. On the Newark list.

C. apicalis, Grt. \& Rob.

Recorded on the Newark list.

C. biguttata, Pack.

Not rare. Generally distributed.

Var. cinereofrons, Pack.

With the type form, in equal numbers.

C. telifer, Grt.

Recorded on the Newark list.

I. lignicolor, Walk.

IANASSA, Walk.

Not common. Generally distributed. Not on the Newark list. Caldwell, rare-Crane.

H. obliqua, Pack.

HETEROCAMPA, Doubl.

Var. brunnea, Grt. \& Rob.

E. trouvelotii, Pack.

H. pulverea, Grt. \& Rob.

Caldwell, rare-Crane. Newark-Angelman. 
H. marthesia, Cram.

H. guttivitta, Walk.

H. biundata, Walk.

B. marina, Pack.

All the above are on the Newark list. The following in addition I know occur in the State :

H. cinerea, Pack.

H. unicolor, Pack.

Caldwell, rare-Crane.

H. subalbicans, Grt.

These I have either taken myself, or seen from the State.

C. borealis, Boisd.

CERURA, Schrank.

C. occidentalis, Lint.

C. cinerea, Walk.

C. multiscripta, Riley.

All of these are on the Newark list. I have taken borealis and cinerea only; multiscripta is rare.

\title{
Family PLATYPTERYGID
}

P. arcuata, Walk.

\author{
PLATYPTERYX, Lasp.
}

Not rare. Generally distributed. Newark, in August-Seib.

P. bilineata, Pack.

PRIONIA, Hüb.

Rare. I have taken it in Ocean county.

D. rosea, Walk.

$$
\text { DRYOPTERIS, Grt. }
$$

Not rare. Generally distributed. 


\section{Family SATURNIID王.}

Sub-Family ATTACINAE.

ATTACUS, Linn.

A. promethea, Dru.

Common all over the State.

A. angulifera, Walk.

Rare. Taken in small numbers all over the State.

A. cecropia, Linn.

Common. Sometimes injurious to Grape and small fruits.

S. cynthia, Drury.

SAMIA, Hüb.

Common along the main line of the Pennsylvania railroad, and for some distance around Jersey City and Newark. Feeds on the Ailanthus.

\section{Sub-Family SATURNIIN死。}

ACTIAS, Leach.

A. Iuna, Linn.

Not rare. Generally distributed.

TELEA, Hüb.

T. polyphemus, Cram.

Common all over the State.

HYPERCHIRIA, Hüb.

E. io, Fabr.

Common all over the State. The larva sometimes injurious to Corn. 


\section{Family CERATOCAMPIDEE.}

E. imperialis, Drury.

\section{EACLES, Ë̈̈b.}

Usually common throughout the State. Rare at CaldwellCrane. Newark, in July-Seib.

C. regalis, Fabr.

\section{CITHERONIA, Hüb.}

Not common. Generally distributed.

S. bicolor, Harris.

$$
\text { SPHINGICAMPA, Walsh. }
$$

I have taken this on the coast in a single specimen. Not on the Newark list.

A. stigma, Fabr.

ANISOTA, Hüb.

A. senatoria, S. \& A.

Caldwell, common-Crane.

A. virginiensis, Dru.

The latter is comparatively scarce, and is not on the Newark list. They are all generally distributed.

D. rubicunda, Fabr.

$$
\text { DRÝOCAMPA, Harris. }
$$

Common throughout the State. Sometimes quite injurious to Maple.

\section{Family LACHN AEID $A$.}

H. maia, Drury.

HEMILEUCA, Walk.

Rare in this State, but I have seen it in collections marked "New Jersey." 


\section{OLISIOCAMPA, Curtis.}

C. americana, Harris.

Newark, in June-Seib.

C. disstria, Hüb.

Both species are quite common all over the State.

GASTROPACHA, Ochs.

G. americana, Harris.

Rare. Generally distributed. On the Newark list. Caldwell, rare-Crane.

\section{A. punctistriga, Walk. \\ ARTACE, Walk.}

Rare. Taken by Newark collectors.

T. velleda, Stoll.

TOLYPE, Hüb.

Not common. Generally distributed. Caldwell, rare-Crane. Newark, in September-Seib.

\section{Family COSSID E⿸.}

C. reticulatus, Lint.

Cossus, Fabr.

Rare. Taken by Newark collectors.

P. robiniæ, Peck.

\section{PRIONOXYSTUS, Grt.}

Common. The larva bores in the Locust (Robinia). Rare at Caldwell-Crane. Newark, in June-Seib.

P. querciperda, Fitch.

Rare. Taken by Newark collectors.

Z. æsculi, Linn.

$$
\text { ZEUZERA, Latr. }
$$

Confined to the vicinity of Newark as yet, where it bores in the branches of Elm. A quite recent importation. 
H. auratus, Grt.

\section{HEPIALUS, Fabr.}

Recorded on the Newark list.

H. argenteomaculatus, Harr.

Caldwell, rare-Crane.

\section{Family NOCTUID E.}

The list in this family is largely compiled from my own notes of collections and recorded localities. The species are generally distributed except where otherwise noted, and I have starred (*) those not on the Newark list. To this family belong the cut-worms, and sufficient material is not at hand to indicate the more accurate limits of local species.

\section{Sub-Family CYMATOPHORINE.}

*L. dormitans, Gn. LEPTINA, Gn.

*L. doubledayi, Gn.

*T. pudens, Gn.

THYATIRA, Ochs.

PSEUDOTHYATIRA, Grt.

F. cymatophoroides, Gn.

Var. expultrix, Grt.

Caldwell, common-Crane.

H. scripta, Gosse.

HABROSYNE, Hüb.

\section{Sub-Family NOCTUIN玉.}

D. depilis, Grt.

DICOPIS, Grt.

D. muralis, Grt.

Newark-Hampsen. 
D. flavicornis, Smith.

DEMAS, Steph.

Newark ; rare.

C. deridens, Gn.

CHARADRA, Walk.

R. frater, Grt.

RAPHIA, Hüb.

F. jocosa, Gn.

FERALIA, Grt.

A rare species. Taken only by the Newark collectors. On Hemlock.

D. fallax, H-S.

DIPHTHERA, Hüb.

Caldwell, rare-Crane. Newark, in May-Seib.

A. vinnula, Grt.

AORONYCTA, Ochs.

Newark, in June-Seib.

*A. grisea, Walk.

A. tritona, Hüb.

A. occidentalis, Grt. \& Rob.

Caldwell, common-Crane.

A. lobeliæ, Gn.

Newark, in June and August-Seib.

*A. morula, Grt. \& Rob.

* A. radcliffei, Harv.

A. innotata, Gn.

A. betulæ, Riley.

A. americana, Harris.

Caldwell, common-Crane. Common also at New Brunswick.

*A. rubricoma, Gn.

A. brumosa, Gn.

Newark, in May-Seib. 
A. noctivaga, Grt.

Caldwell, rare-Crane.

A. superans, Gn.

Caldwell, rare-Crane.

A. clarescens, Gn.

Caldwell, common-Crane.

A. ovata, Grt.

A. hamamelis, Gn.

Caldwell, rare-Crane. Newark, in May-Seib.

*A, hæositata, Grt.

A. dissecta, Grt. \& Rob.

Caldwell, rare-Crane. Newark-Seib.

A. sperata, Grt.

A. lithospila, Grt.

*A. connecta, Grt.

A. oblinita, S. \& A.

Common at Caldwell-Crane.

ARSILONCHE, Led.

A. albovenosa, Goetze.

Anglesea. Newark.

HARRISIMEIMNA, Grote.

H. trisignata, Walk.

A rare and strikingly-marked species. Caldwell, one specimen-Crane.

MICROCGLIA, Gn.

M. diphtheroides, Gn.

Var. obliterata, Grt.

Caldwell, common-Crane. Newark-Seib.

*B. lepidula, Grt.

\section{BRYOPHILA, Tr.}

Caldwell, rare-Crane. 
*C. palliatricula, Gn.

\section{CHYTONIX, Grt.}

AGROTIS, Tr.

*A. sigmoides, Gn.

*A. perattenta, Grt.

A. phyllophora, Grt.

Newark, in May-Seib.

A. rubifera, Grt.

A. baja, S. V.

Caldwell, common-Crane.

A. normaniana, Grt.

Caldwell-Crane.

A. c-nigrum, Linn.

Caldwell, common-Crane. Found throughout the State.

A. bicarnea, Gn.

Caldwell, rare-Crane.

A. haruspica, Grt.

A. subgothica, Haw.

Caldwell, common-Crane. Found throughout the State.

A. tricosa, Lint.

A. herelis, Grt.

A. plecta, Linn.

Caldwell, rare-Crane.

A. cupida, Grt.

A. alternata, Grt.

Newark-Angelman.

*A. brunneicollis, Grt.

A. clandestina, Harris.

Caldwell, common-Crane. Newark, in Jume-Seib.

A. messoria, Harris.

A. murænula, Grt. \& Rob. 
A. bostoniensis; Grt.

A. pitychrous, Grt.

A. tessellata, Harris.

Caldwell, rare-Crane.

A. campestris, Grt.

*A. redimicula, Morr.

A. geniculata, Grt. \& Rob.

Caldwell, rare-Crane.

A. badinodes, Grt.

Caldwell, common-Crane.

*A. collaris, Grt. \& Rob.

A. velleripennis, Grt.

In the Newark collections.

A. pastoralis, Grt.

*A. morrisoniana, Riley.

*A. gladiaria, Morr.

Newark-Angelman.

*A. venerabilis, Walk.

*A. volubilis, Harv.

A. annexa, $\mathrm{Tr}$.

A. malefida, Gn.

A. ypsilon, Rott.

Common throughout the State.

A. saucia, Hüb.

Caldwell, rare-Crane.

A. incivis, Gn.

Caldwell, rare-Crane.

A. lubricans, Gn.

ANYTUS, Grt.

A. sculptus, Grt.

ADITA, Grt.

*A. chionanthi, S. \& A.

A rare species, but occurring in single specimens in the State. Not yet taken by the Newark collectors. 
M. purpurissata, Grt.

MAMESTRA, Ochs.

M. nimbosa, Gn.

Recorded on the Newark list. Caldwell, common-Crane.

M. imbrifera, Gn.

Recorded on the Newark list. Caldwell, rare-Crane.

M. latex, Gn.

M. adjuncta, Boisd.

Newark, in August-Seib.

M. lubens, Grt.

Newark, in June-Seib.

M. legitima, Grt.

M. lilacina, Harv.

Newark-Angelman.

M. rosea, Harv.

M. picta, Harris.

Caldwell, common-Crane. Newark, in June and AugustSeib.

M. grandis, Boisd.

M. subjuncta, Grt. \& Rob.

*M. distincta, Hüb.

Caldwell, common-Crane.

*M. confusa, Hüb.

Taken not uncommonly at sugar, by myself. Caldwell, rare -Crane. Newark-Seib.

*M. trifolii, Rott.

I have taken this during the day on flowers of Solidago. Caldwell, common-Crane.

M. pensilis, Grt.

*M. detracta, Walk.

Newark, in June-Seib.

M. laudabilis, Gn.

On the Newark list. I have never taken it myself. 
*M. olivacea, Mrorr.

I have taken this in Ocean county.

M. lustralis, Grt.

*M. meditata, Grt.

Not rare. Taken at New Brunswick this season (1889), and elsewhere in former years.

M. renigera, Steph.

*M. ectypa, Mrorr.

Very rare. A unique specimen of this species taken by Mr. Neumoegen, near the Orange Mountains, forms the type of $\boldsymbol{M}$. bella, Grt.

L. delicata, Grt.

LUCERIA, Von Hein.

L. passer, Gn.

\section{HADENA, Schrank.}

H. devastatrix, Brace.

The larva of this species is one of the most injurious cutworms we have in the State.

H. arctica, Boisd.

Caldwell, common-Crane. Newark, in September-Seib. Generally distributed.

*H. bridghami, Grt. \& Rob. State.

The type of this pretty and rare species was collected in this

H. sputatrix, Grt.

Caldwell, common-Crane.

H. suffusca, Morr.

*H. apamiformis, Gn.

*H. vultuosa, Grt.

H. lignicolor, Gn.

Caldwell, rare-Crane.

H. verbascoides, Gn.

Caldivell, rare-Crane.

*H. cariosa, Gn. 


\section{GEOLOGICAL SURVEY OF NEW JERSEY.}

*H. Sectilis, Gn.

*H. vulgaris, Grt. \& Rob.

*H. remissa, Hüb.

*H. finitima, Gn.

*H. impulsa, Gn.

*H. turbulenta, Gn.

This species I found quite abundant in Ocean county some years since.

H. miseloides, Gn.

Caldwell, rare-Crane. Newark, in June and August-Seib.

*H. modica, Gn.

Caldwell, rare-Crane.

*E. vulvivaga, Morr.

*H. fractilinea, Grt.

It is rather strange that the Newark list contains so few species of Hadena. All of the starred species are well recorded from the State, and many of them are not at all rare.

*O. festivoides, Gn.

\section{OLIGIA, Hüb.}

Taken not rarely at light, in Ocean county.

O. grata, Hüb.

Taken rarely. It is a southern species and common in the District of Columbia.

P. xanthioides, Gn.

\section{PERIGEA, Gn.}

Caldwell, common-Crane.

P. infelix, Gn.

Specimens are in the Newark collections.

P. luxa, Grt.

P. fabrefacta, Morr.

None of these species are really common, and $P$. infelix is rare, occurring only along the coast on a northern extension of its range, which is southward to Florida. 
D. scabriuscula, Linn.

DIPTERYGIA, Steph.

Caldwall, rare-Crane. Newark, in August-Seib.

H. xylinoides, Gin.

$$
\text { HYPPA, Dup. }
$$

Caldwell, rare-Crane. Newark, in August-Seib.

*V. grotei, Morr.

$$
\text { VALERIA, Gn. }
$$

A rare species; single specimens occurring each year in some part of the State. Not on the Newark list.

*D. stigmata, Grt.

$$
\text { DRYOBOTA, Led. }
$$

ACTINOTIA, Hüb.

A. ramosula, Gn.

Caldwell, rare-Crane.

- LAPHYGMA, Gn.

L. frugiperda, S. \& A.

$$
\text { PRODENIA, Gn. }
$$

P. commelina, S.\& A.

In Newark collections.

P. flavimedia, Harv.

In Newark collections.

P. lineatella, Harv.

In the Newark collections.

T. periculosa, Gn.

TRIGONOPHORA, Hüb.

Var. $\nabla$-brunneum, Grt.

E. lucipara, Linn.

EUPLEXIA, Steph. 
B. iris, Gn.

$$
\text { BROTOLOMIA, Led. }
$$

N. minians, Gn.

\section{NEPHELODES, Gn.}

Var. violans, Gn.

Caldwell, rare-Crane. This species is also sometimes quite injurious as a cut-worm. The imago flies during the day, and I have taken it in September, on Solidago.

\section{TRIOHOLITA, Grt.}

T. semiaperta, Morr.

Not common. Recorded on the Newark list.

HELOTROPHA, Led.

H. reniformis, Grt.

Caldwell, rare-Crane.

*A. purpuripennis, Grt.

APAMEA, Tr.

*A. sera, Grt. \& Rob.

A. nictitans, Bkh.

Caldwell, rare-Crane.

*A. immanis, Gn.

Purpuripennis is rare; sera is more common; nictitans is very abundant and variable throughout the State. Immanis is local and not common: in the hop-growing districts of New York it is a serious pest, the larva boring into the crown roots of the Hop and eating off the vine.

${ }^{*}$ G. rutila, Gn.

\section{GORTYNA, Hüb.}

G. harrisii, Grt.

Newark-Seib.

G. speciocissima, Grt. \& Rob.

On the Newark list. I have never seen it from the State. 
"G. limpida, Gn.

Newark, in August-Seib.

G. cerussata, Grt.

Newark, in September-Seib.

G. cataphracta, Grt.

Caldwell, rare-Crane.

G. nitela, Gn.

Bores in stalks of Corn, and sometimes quite injurious.

A. zeæ, Harris.

ACHATODES, Gn.

The larva is also a stalk borer. Rare at Caldwell-Crane.

ARZAMA, Walk.

A. obliquata, Grt. \& Rob.

Newark, in May and June--Seib.

A. diffusa, Grt.

The larvæ of both species bore in the stems of Typha, and the insects are of course confined to swampy localities where Cattails are abundant.

M. onusta, Grt.

MACRONOCTUA, Grt.

Newark-Stortz.

E. timais, Cram.

EUTHISANOTIA, Grt.

Rare. A southern species which occasionally finds its way northward.

S. liburna, Geyer.

SCOLECOCAIMPA, Gn.

Newark, in July—Seib.

EUCALYPTERA, Morr.

* E. bipuncta, Morr.

Found on salt marshes, where the larva probably bores into some of the reeds or grasses. 
D. acutaria, H-S.

\section{DORYODES, Gn.}

Found on salt marshes.

P. atriciliata, Grt.

PLATysenta, Grt.

Also a swamp species, but not, I believe, confined to salt marshes. Caldwell, rare-Crane.

O. lintneri, Grt.

ommatostola, Grt.

Anglesea, rare-Laurent.

L. pallens, Linn.

\section{LEUCANIA, Ochs.}

L. albilinea, Hüb.

Known as the "Wheat-head Army Worm" in the larva state; sometimes quite injurious. Caldwell, common-Crane.

L. phragmatidicola, Gn.

L. adonea, Grt.

L. commoides, Gn.

L. unipuncta, Haw.

This is the parent of the "Army Worm." Common all over the State.

L. pseudargyria, Gn.

Newark, in April and June. Caldwell, rare-Crane.

U. plicatus, Grt.

UFEUS, Grt.

Newark-Seib.

*C. multifera, Walk.

CARADRINA, Tr.

PYROPHILA, Hüb.

P. tragopogonis, Linn.

P. pyramidoides, Gn.

The larva of this species is sometimes quite abundant on Grape. Newark, in July and August-Seib. 
*O. infirma, Gn.

\section{ORTHODES, Gn.}

*O. cynica, Gn.

*O. enervis, Gn.

These species are not rare-infirma, indeed, is quite common, though it seems to have escaped the Newark collectors.

${ }^{*} \mathrm{~T}$. oviduca, Gn.

TAENIOCAMPA, Gn.

*T. modesta, Morr.

*T. alia, Gn.

Newark, in April-Seib.

*T. subterminata, Smith.

Newark, in April—Seib.

None of these appear on the Newark list, yet all are well recorded from New Jersey.

O. normani, Grt.

CROCIGRAPHA, Grt.

Newark, in April-Seib.

M. vomerina, Grt.

MORRISONIA, Grt.

Newark, in April and May-Seib.

C. orina, Gn.

CALYMNIA, Hüb.

I. pleonectusa, Grt.

IPIMORPHA, Hüb.

ORTHOSIA, Ochs.

O. ferrugineoides, Gn.

Var. bicolorago, Gn.

*O. aurantiago, Gn.

O. disticha, Morr. 
:1S GEOLOGICAL SURVEY OF NEW JERSEY.

O. conradi, Grt.

O. helva, Grt.

Caldwell, common-Crane.

O. lutosa, Andrews.

*G. inulta, Grt.

GLA两A, Hüb.

Caldwell, rare-Crane.

G. anchocelioides, Gn.

E. sericea, Morr.

EPIGLA A Art.

Fort Lee-Beutenmüller.

E. pampina, Gn.

EUCIRRGEDIA, Grt.

Caldwell, common-Crane. Newark, in September-Seib.

JODIA, Hüb.

J. rufago, Hüb.

Newark, in April-Seib.

S. libatrix, Linn.

SCOLIOPTERYX, Germ.

S. græfiana, Grt.

SCOPELOSOMA, Curtis.

Caldwell, rare-Crane. Newark, in April-Seib.

S. tristigmata, Grt.

S. ceromatica, Grt.

Recorded from New Jersey.

S. devia, Grt.

Newark, in April-Seib.

S. sidus, Gn.

Var. walkeri, Grt.

Newark, in April-Seib. 
X. petulca, Grt.

\section{XYLINA, Ochs.}

Caldwell, rare-Crane.

X. ferrealis, Grt.

New Brunswick, in April-Smith.

X. bethunei, Grt. \& Rob.

$X$. fagina, Morr.

$\mathrm{X}$. antennata, Walk.

Caldwell, rare-Crane. Newark, in September-Seib.

*X. laticinerea, Grt.

X. cinerosa, Grt.

$\mathrm{X}$. unimoda, Lint.

$\mathrm{X}$. thaxteri, Grt.

Newark-Seib.

C. nupera, Lint.

CALOCAMPA, Steph.

C. cineritia, Grt.

* O. curvimacula, Morr.

CUCULLIA, Schr.

C. convexipennis, Grt. \& Rob.

Caldwell, rare-Crane.

C. asteroides, Gn.

C. intermedia, Speyer.

The handsome larve of this genus are sometimes seen on Golden Rod.

*C. talidiformis, Gn.

CRAMBODES, Gn.

Favors swampy meadows.

N. malana, Fitch.

NOLOPHANA, Grt.

Caldwell, common-Crane. Newark, in May-Seib. 
*N. zelleri, Grt.

Newark, in May—Seib.

These two species are quite frequently confused, and this may account for its absence from the Newark list, though Mr. Seil has taken it there.

A. erosa, Hüb.

\section{ANOMIS, Hüb.}

Really a southern species, but found northwardly each year.

A. argillacea, Hüb.

ALETIA, Hüb.

The famous cotton moth. It does not breed in this State, so far as has been observed, but is found in considerable numbers almost every year, the imago emigrating from the South.

*M. ventilator, Grt.

MARASMALUS, Grt.

*M. histrio, Grt.

Caldwell, common-Crane.

I have seen both of these handsome species from the State, but the Newark collectors seem not to have run across them as yet.

I. abrostoloides, Gn.

INGURA, Gn.

I. delineata, Gn.

*I. oculatrix, Gn.

Caldwell, common-Crane.

The last-named is really the most common everywhere, but is not generally recognized as an Ingura.

C. canadensis, Beth.

CALPE, Tr.

\section{PLUSIODONTA, Gn.}

${ }^{*} \mathrm{P}$. compressipalpis, Gn.

One of our most beautiful species, and rare. It is rather more common to the north, and has not yet turned up near Newark. 


\section{PHIPROSOPUS, Grt.}

P. callitrichoides, Grt.

*H. hormos, Hüb.

HYPSOROPHA, Hüb.

Newark-Machesney. Taken in Ocean county; also near Jersey City.

T. cinereola, Gn.

\section{TELESILLA, H-S.}

Caldwell, common-Crane.

A. ovalis, Gn. ABROsTOLA, Ochs.

Newark-Seib.

*A. urentis, Gn.

I have collected this species on Long Island, and I have seen it from the vicinity of Philadelphia. It is certain to occur in New Jersey.

P. ærea, Hüb.

PLUSIA, Fabr.

Caldwell, common-Crane.

P. æreoides, Grt.

P. contexta, Grt.

Caldwell, rare-Crane.

P. putnami, Grt.

P. formosa, Grt.

Rare near Newark.

*P. verruca, Fabr.

This handsome form has been taken not rarely, near Greenville, by Mr. Loitloff. Newark, in May-Seib.

P. precationis, Gn.

Newark, in September-Seib.

P. laticlavia, Morr.

Newark, in October-Seib. 
P. brassicæ, Riley".

Sometimes quite injurions to Cabbages, in the larva state.

P. mortuorum, Gn.

Rare. Taken near Newark.

P. simplex, Gn.

Newark, in October-Seib. Caldwell, rare-Crane.

\section{PLAGIOMIMICUS, Grt.}

P. pitychromus, Grt.

S. trifascia, Hüb.

SCEINIA, Hüb.

Caldwell, rare-Crane.

S. nundina, Dru.

Taken on Spirca, near Jamesburg. Also on the Newark list.

S. spinosæ, Gn.

Sandy Hook-Beutenmüller.

A. rivulosa, Gn.

ANTHECIA, Gn.

A. lynx, Gn.

I have seen specimens in collections. One near Newark.

R. florida, Gn.

\section{RHODOPHORA, Gn.}

The larva feeds in the buds and seed capsules of CEnotherc.

P. umbra, Hüb.

PYRRHIA, Hüb.

Caldwell, rare-Crane. Newark, in June-Seib.

D. henrietta, Grt.

$$
\text { DERRIMA, Walk. }
$$

ㅍ. armiger, Hüb.

\section{HELIOTHIS, Hüb.}

The larva is the cotton-boll worm of the South, the corn worm of the North, and it varies its diet on oceasions by eating into Tomatoes. 
CIRREOPHANUS, Grt.

C. triangulifer, Grt.

Caldwell, rare-Crane. Newark-Hampsen. Philadelphia -Laurent.

T. aprica, Hüb.

TARACHE, Hüb.

T. erastrioides, Gn.

*T. candefacta, Hüb.

T. delecta, Walk.

T. patula, Morr.

THALPOCHARES, Led.

L. bellicula, Hüb.

LITHACODIA, Hüb.

C. cerintha, Tr.

CEAMYRIS, Gn.

Caldwell, rare-Crane. Newark, in June-Seib.

EUSTROTIA, Hüb.

E. concinnimacula, Gn.

Caldwell, rare-Crane.

${ }^{*}$ E. synochitis, Grt. \& Rob.

E. musta, Grt. \& Rob.

E. muscosula, Gn.

Caldwell, common-Crane.

E. carneola, Gn.

Caldwell, rare-Crane.

E. apicosa, Harv.

Caldwell, common-Crane. Newark, in July_Seib.

ㅍ. mollissima, $\mathrm{Gn}$ 。

HERRICHIA, Grt.

*H. monetifera, Gn.

I have taken this in Ocean county. Newark-Seib. 
*S. onagrus, Gn.

$$
\text { SPRAGUEIA, Grt. }
$$

A pretty little species, apparently rare here.

\section{XANTHOPTERA, Gn.}

*X. nigrofimbria, Gn.

X. semillava, Gn.

E. semicrocea, Gn.

EXYRA, Grt.

PROTEYMIA, Büb.

P. coccineifascia, Grt.

*P. rosalba, Grt.

M. obtusa, H-S.

METOPONIA, Dup.

Caldwell, common-Crane.

*G. hepara, Gn.

GALGULA, Gn.

${ }^{*}$ G. subpartita, Morr.

D. erechtea, Cram.

DRASTERIA, Eüb.

Caldwell, common-Crane. Newark, in April-Seib.

E. cuspidea, Hüb.

EUCLIDIA, Hüb.

S. graphica, Hüb.

SYNEDA, Gn.

Sandy Hook-Seib. Ocean county, in May-Smith.

S. jucunda, Hüb.

CATOCALA, Schrank.

As this is a favorite genus with collectors, the list is large, and perhaps fairly complete. All are on the Newark list, and I imagine but fer species will be added to it. All the species are quite gener- 
ally distributed, though each locality differs somewhat in the makeup of its fauna, and species rare in one district will be common in others.

C. epione, Dru.

C. lacrymosa, Gn.

C. viduata, Gn.

C. desperata, Gn.

Caldwell, common-C'rane.

C. retecta, Grt.

Caldwell, common-Crane.

C. flebilis, Gr.

Caldwell, rare-Crane.

C. robinsonii, Gr.

Caldwell, rare-Crane.

C. obscura, Strk.

Caldwell, rare-Crane.

C. insolabilis, Gn.

Caldwell, rare-Crane.

C. angusi, Grt.

C. residua, Grt.

C. tristis, Edw.

Caldwell, rare-Crane.

C. relicta, Walk.

Var. phrynia, Hy, Edw.

C. amatrix, Hüb.

Caldwell, rare-Crane.

C. cara, Gn.

Caldwell, common-Crane. Newark, in July-Seib.

C. concumbens, Walk.

Caldwell, common-Crane. Newark, in August-Seib.

C. unijuga, Walk.

Newark, in August and September-Seib.

C. briseis, Edw. 
C. faustina, Strk.

Caldwell, rare-Crane.

C. parta, Gn.

C. coccinata, Grt.

C. verrilliana, Grt.

C. ultronia, Hüb.

Caldwell, common-Crane. Newark, in August-Seib.

C. marmorata, Edw.

C. ilia, Cram.

Caldwell, common-Crane. Nervark, in July-Seib.

C. innubens, Gn.

C. cerogama, Gn.

Var. bunkeri, Grt.

Caldwell, rare-Crane.

C. neogama, S. \& A.

Caldwell, common-Crane.

C. subnata, Grt.

Caldwell, rare-Crane.

C. piatrix, Grt.

Caldwell, common-Crane. Newark, in August-Seib.

C. paleogama, Gn.

Caldwell, rare-Crane. Newark, in August and SeptemberSeib.

Var. phalanga, Grt.

C. habilis, Grt.

Var. basilis, Grt.

C. nebulosa, Edw.

C. muliercula, Gn.

C. consors, Gn.

C. antinympha, Hüb.

Caldwell, common-Crane.

C. badia, Grt. \& Rob.

C. serena, Edw.

Caldwell, rare-Crane. 
C. polygama, Gn.

Caldwell, rare-Crane.

C. pretiosa, Lint.

C. similis, Edw.

C. præclara, Grt. \& Rob.

Caldwell, common-Crane.

C. grynea, Cram.

Caldwell, common-Crane. Newark, in July_Seib.

C. gracilis, Edw.

Newark, in August-Seib.

C. minuta, Elw.

Var. parvula, Edw.

C. amica, Hüb.

Var. lineella, Grt.

Caldwell, common-Crane.
A. elonympha, Hüb.
ALLOTRIA, Büb.
Caldwell, rare-Crane.

P. nubilis, Hüb.

PARTHENOS, Hüb.

Caldwell, rare-Crane. Newark, in June-Seib.

P. atomaris, Hüb.

PHOBERIA, Hüb.

P. littera, Gn.

PSEUDOLIMACODES, Grt.

Newark-Hampsen.

O. frustulum, Gn.

CELIPTERA, Gn.

Caldrvell, common-Crane.

P. bistriaris, Hüb.

PARALLELIA, Hüb.

Caldwell, common-Crane. Newark, in May and June-Seib. 
A. anilis, Dru.

AGNOMONIA, Hüb.

P. carneicosta, Gn.

PANOPODA, Gn.

P. rufimargo, Hüb.

Caldwell, rare-Crane. Newark, in June-Seib.

Var. roseicosta, Gn.

PLEONECTYPTERA, Grt.

P. geometralis, Grt.

*R. latipes, Gn.

REMIGIA, Gn.

P. quadrifilaris, Hüb.

POAPHILA, Gn.

T. arrosa, Harv.

TRAMA, Harv.

E. odora, Linn.

EREBUS, Latr.

Z. horrida, Hüb.

ZALE, Hüb.

Caldwell, common-Crane.

*P. Iunifera, Hüb.

\section{PHEOCYMA, Hüb.}

E. edusa, Dru.

\section{HOMOPTERA, Boisd.}

Newark, in July-Seib.

Var. saundersii, Beth.

Var. lunata, Dru.

Caldwell, common-Crane. Newark, in September-Seib.

Var. nigricans, Beth.

H. unilineata, Grt.

H. obliqua, Gn. 
Y. undularis, Dru.

YPSIA, Gn.

Var. æruginosa, Gn.

Var. umbripennis, Grt.

P. coracias, Gn.

PSEUDANTHRCEIA, Grt.

H. tactus, Grt.

HOMOPYRALIS, Grt.

: Caldwell, common-Crane.

SPARGOLOMA, Grt.

S. umbrifascia, Grt.

P. decoralis, Hüb.

PANGRAPTA, Hüb.

P. lubricalis, Gey.

PSEUDAGLOSSA, Grt.

Caldwell, common-Crane.

*P. scobialis, Grt.

E. æmula, Hüb.

EPIZEUXIS, Hüb.

Caldwell-Crane. The larva of this species is said to feed on dry, dead leaves.

E. americalis, Gn.

Caldwell-Crane. The larva of this species lives in ants' nests. Food as yet not positively known.

*M. lituralis, Hüb.

MEGACHYTA, Grt.

${ }^{*}$ L. nubilifascia, Grt.

LITOGNATHA, Grt.

C. morbidalis, Gn.

ChYtolitA, Grt.

C. petrealis, Grt. 
*Z. lævigata, Grt.

ZANCLOGNATHA, Led.

*Z. ochreipennis, Grt.

R. propinqualis; Gn. RIVULA, Gn.

P. angulalis, Hüb. PALTHIS, Hüb. Caldwell-Crane.

*P. asopialis, Gn.

*P. rurigena, Grt.

PHAL AHOPHANA, Grt.

${ }^{*}$. discoloralis, Gn.

RENIA, Gn.

* $R$. brevirostralis, Grt.

${ }^{*}$ R. flavipunctalis, Geyer.

B. caradrinalis, Gn.

BLEPTINA, Gn.

HYPENULA, Grt.

ㅍ. opacalis, Grt.

HYPENA, Fabr.

*H. baltimoralis, Gn.

Caldwell-Crane. Newark-Seib.

*H. bijugalis, Walk.

*H. manalis, Walk.

*H. abalienalis, Walk.

*H. toreuta, Grt.

*H. scabra, Fabr.

Common everywhere in the State.

H. humuli, Harr.

Caldwell, common-Crane. 


\section{Family GEOMETRID王.*}

C. clemitaria, S. \& A.

CHGRODES, Gn.

Caldivell, common-Crane.

C. transversata, Dru.

A generally distributed and rather common species.

C. furciferata, 'Pack.

T. crocallata, Gn.

TETRACIS, Gn.

Caldwell, common-Crane.

T. lorata, Grt.

Caldivell, rare-Crane.

M. quercivoraria, Gn.

METANEMA, Gn.

M. inatomaria, Gn.

M. carnaria, Pack.

Caldwell, rare-Crane.

D. puber, Grt. \& Rob.

DREPANODES, Gn.

D. varus, Grt. \& Rob.

Found, not rarely, in pine woods.

D. hortularia, Hulst.

C. confusaria, Hüb.

CABERODES, Gn.

Occurs everywhere and in the greatest variety, though scarcely abundant.

C. majoraria, Gn.

Caldwell, rare-Crane.

\footnotetext{
* The material for the list in this family was furnished by Rev. Geo. D. Hulst, of Brooklyn, N. Y., who has made it a special study. It includes the list made by the Newark Society, and the whole is given without distinction by Mr. Hulst, as to source. All comments are my own, and from my own experience, except where otherwise stated.
} 
E. alniaria, Linn.

\section{ENNOMOS, Tr.}

Sometimes quite common locally.

E. subsignaria, Hüb.

$$
\text { EUDALIMIA, Büb. }
$$

Caldwell, common-Crane.

\section{SELENIA, EÜb.}

S. kentaria, Grt. \& Rob.

S. alciphearia, Walk.

A. hubnerata, Gn.

\section{AZELINA, Gn.}

Caldweil, rare-Crane.

E. serrataria, Dru.

ENDROPIA, Gn.

Caldwell, rare-Crane.

E. obtusaria, Hüb.

E. effectaria, Walk.

E. pectinaria, W. V.

E. bilinearia, Pack.

Caldwell, rare-Crane.

E. armataria, H-S.

E. amœnaria, Gn.

Caldwell, common-Crane.

E. madusaria, Walk.

Caldwell, rare-Crane.

E. marginata, Minot.

E. warneri, Harv.

E. hypochraria, H-S.

Caldwell, common-Crane.

E. duaria, Gn.

Caldwell, rare-Crane.

E. decoloraria, Hulst. 
Đ. obfirmaria, Hüb.

\section{EPIRRANTHIS, Hüb.}

Caldwell, rare-Crane.

T. fervidaria, Hüb.

THERINA, Hüb.

I have taken this at Jamesburg. Caldwell, rare-Crane.

T. endropiaria, Grt. \& Rob.

T. bibularia, Grt. \& Rob.

METROCAMPA, Gn.

M. margaritata, Linn.
A. pulveraria, Linn.
ANAGOGA, Hüb.

ANTEPIONE, Pack.

A. depontanata, Grt.

Caldwell, rare-Crane.

A. sulphurata, Pack.

Caldwell, rare-Crane.

S. macularia, Harr.

SIOYA, Gn.
A. crocataria, Fabr.
ANGERONA, Dup.
Caldwell, common-Crane.

N. filamentaria, Gn.

NEMATOCAMPA, Gn.

Not uncommon throughout the State.

P. rosaria, Grt. \& Rob.

PLAGODIS, Hüb.

P. Hloscularia, Grt.

P. keutzingaria, Grt. 
334 GEOLOGICAL SURTEY OF NEW JERSEY.

P. fervidaria, H-S.

P. phlogosaria, Gn.

P. alcoolaria, Gn.

H. amicaria, H-S.

\author{
HYPERETIS, Gn.
}

A common and extremely rariable species found throughout the State.

G. iridaria, Gn.

GEOMETRA, Linn.

Not common, but seems generally distributed.

A. rubrolinearia, Pack.

APLODES, Gn.

A. brunnearia, Pack.

A. mimosaria, Gn.

Caldwell, rare-Crane.

S. glaucaria, Gn.

SYNCHLORA, Gn.

N. subcroceata, Walk.

NEMORIA, Hüb.

Caldwell, rare-Crane.

N. gratata, Walk.

N. pistaciata, Gn.

Caldwell, rare-Crane.

E. chloroleucaria, Gn.

EUCROSTIS, Hüb.

Caldwell, common-Crane.

D. abortivaria, H-S.

DYSPTERIS, E-S.

Caldwell, rare-Crane.

E. pendulinearia, $\mathrm{Gn}$.

EPHYRA, Dup.

Caldwell, rare-Crane. 

A. ossularia, Hüb.
AOIDALIA, Tr.

A. granitaria, Pack.

A. insularia, Gn.

A. nivosata, Gn.

Caldwell, rare-Crane.

A. inductata, Gn.

A. punctofimbriata, Pack.

Caldwell, rare-Crane.

A. cacuminata, Morr.

A. enucleata, Gn.

One of the most common species of the genus; usually among Fern and Bracken, in woods.
A. albogilvaria, Morr.
ASTHENA, Hüb.

CALOTHYSANIS, Hüb.

C. amaturaria, Walk.

Caldwell, rare-Crane.

OALLEDAPTERYX, Grt.

C. dryopterata, Grt.

S. pustularia, Gn.

$$
\text { STEGANIA, Gn. }
$$

Caldwell, common-Crane.

G. basiata, Walk.

$$
\text { GUENERIA, Pack. }
$$

D. variolaria, Gn.

DEILINEA, Hüb.

D. erythemaria, Gn.

E. herminiata, Gn.

EUDEILINEA, Pack. 
C. vestaliata, Gn. CORYCIA, Dup.

Caldwell, rare-Crane.

C. semiclarata, Walk.

SEMIOTHISA, Hüb.

S. præatomata, Harv.

S. minorata, Pack.

S. enotata, Gn.

5. granitata, Gn.

S. ocellinata, Gn.

P. orillata, Walk.

PHASIANE, Dup.

P. mellistrigata, Grt.

MARMOPTERYX, Pack.

M. strigularia, Min.

THAMNONOMA, Led.

T. quadrilinearia, Pack.

T. wavaria, Linn.

T. subcessaria, Pack.

T. sulphuraria, Pack.

T. argillacearia, Pack.

LOZOGRAMMA, Steph.

L. lactispargata, Walk.

I. detersata, Gn.

L. delluata, Walk.

E. ribearia, Fitch.

EUfitChIA, Pack.

The gooseberry span worm; sometimes common. Caldwell, rare-Crane. 
C. divisata, Walk.

CARIPETA, Walk.

Caldwell, rare-Crane.

C. angustiorata, Walk.

F. truncataria, Walk.

FIDONIA, Tr.

F. notataria, Walk.

H. grataria, Fabr.

H开MATOPIS, Hüb.

Common throughout the State. Newark, in May-Seib.

C. cátenaria, Dru.

CATERVA, Grt.

Locally common. Not rare at Jamesburg. Caldwell, common -Crane.

T. rubiginosus, Morr.

TORNOS, Morr.

T. approximaria, Pack.

A. lintneraria, Pack.

ASPILATES, Tr.

A. coloraria, Fabr.

C. pulchraria, Minot.

CLEORA, Curtis.

H. unitaria, H-S.

HEMEROPHILA, Steph.

Caldwell, rare-Crane. Newark-Machesney.

E. hortaria, Fabr.

EPIMECIS, Hüb.

OYMATOPHORA, Hüb.

C. umbrosaria, Hüb.

C. polygrammaria, Pack. 
C. larvaria, Gn.

Caldwell, rare-Crane.

C. humaria, Gn.

Caldwell, rare-Crane.

C. pampinaria, Gn.

Caldwell, common-Crane.

C. crepuscularia, $\operatorname{Tr}$.

Quite common throughout the State.

T. canadaria, Gn.

TEPHROSIA, Bd.

Caldwell, rare-Crane.

T. cognataria, Hüb.

T. cribrataria, Gn.

Caldwell, rare-Crane.

P. subatomaria, Gn.

PARAPHIA, Gn.

Caldwell, rare-Crane.

E. cognataria, $\mathrm{Gn}$.

EUBYJA, Hüb.

E. pænulataria, Grt.

HYBERNIA, Latr.

H. tiliaria, Harris.

Caldwell, rare-Crane.

P. strigataria, Minot.

PHIGALIA, Dup.

P. olivacearia, Morr.

ANISOPTERYX, Steph.

A. vernata, Harris.

The spring canker worm. Seldom injurious in this State.

A. autumnata, Pack.

Also quite rare in my experience. 
O. boreata, Hüb.

\section{OPEROPHTERA, Hüb.}

HETEROPHLEPS, H-S.

H. harveiata, Pack.

H. triguttata, H-S.

A common species throughout the State.

H. cycladata, Grt. HELIOMATA, Grt.

BAPTRIA, Hüb.

B. albovittata, Gn.

LOBOPHORA, Curtis.

L. atroliturata, Walk.

L. anguilineata, Grt.

L. fuscifasciata, Walk.

H. undulata, Linn.

HYDRIA, Hüb.

PHIBALAPTERYX, Steph.

P. latirupta, Walk.

Caldwell, common-Crane.

P. intestinata, Gn.

OCHRIA, Hüb.

O. ferrugata, Linn.

O. munitata, Hüb.

PETROPHORA, Hüb.

P. diversilineata, Hüb.

Caldwell, common-Crane.

D. prunata, Linn. 
E. cambricaria, Curt.

EPIRRITA, Hüb.

E. dilutata, Borkh.

E. duodecimlineata, Pack.

P. fluviata, Hüb.

PLEMYRIA, Hüb.

P. multiferata, Walk.

GLAUCOPTERYX, Eüb.

G. cumatilis, Grt. \& Rob.

G. cæsiata, Borkh.

E. miserulata, Grt.

EUPETEECIA, Curtis.

E. interruptofasciata, Pack.

\section{Family PYRALID EE.}

Sub-Family PYRALIN $\boldsymbol{X E .}$

A. domalis, Gn.

AGLOSSA, Latr.

ASOPIA, Tr.

A. farinalis, Linn.

Often injurious to stored grain, and quite common.

A. costalis, Fabr.

The clover clay worm. Quite common throughout the State.

A. olinalis, Gn.

A. squamealis, Grt.

* Mr. IInlst has also kindly furnished the list of species in this family, of some parts of which he has made special study. No other lists have been available, and Ir. Inlst must be considered sole authority for all the species cited, except where I liave especially indicated another. The comments are, in all cases, my own. 
S. nobilis, Rob.

SIPAROCERA, Rob.

I have taken this rarely, in Ocean county.

MELANOMMA, Grt.

M, auricinctaria, Grt.

S. centuriella, S. V.

SCOPARIA, Haw.

S. libella, Grt.

T. pupula, Hüb.

THELCTERIA, Led.

I have seen this pretty species, not uncommonly.

BOTIS, Schrank.

B. octomaculata, Linn.

B. insequalis; Gn.

B. rufofimbrialis, Grt.

B. harveyana, Grt.

B. badipennis, Grt.

B. fodinalis, Led.

B. nelumbialis, Smith.

Bordentown. The larva bores in stems, \&c., of the Egyptian Lotus-Smith.

B. erectalis, Grt.

B. flavidalis, Gn.

B. oxydalis, Gn.

B. langdonalis, Grt.

B. citrina, Grt. \& Rob.

B. marculenta, Grt.\& Rob.

New Brunswick-Smith.

B. opilalis, Grt.

B. oscitalis, Grt. 
B. pertextalis, Led.

B. gentilis, Grt.

B. magistralis, Grt.

B. quinquelinealis, Grt.

B. feudalis, Grt.

New Brunswick, Jamesburg-Smith.

B. terrealis, $\mathrm{Tr}$.

B. illibalis, Hüb.

B. plectilis, Grt. \& Rob.

B. subolivalis, Pack.

B. niveicilialis, Grt.

B. ventralis, Grt.

E. sticticalis, Linn.

EURYCREON, Led.

E. cereralis, Zell.

Ocean county, May 20th-Smith.

E. chortalis, Grt.

Ocean county, May 20th-Smith.

E. rantalis, Gn.

I have found this quite common, yet not injurious.

N. noctuella, S. V.

NOMOPHILA, Hüb.

Common everywhere throughout the State.

M. rimosalis, Gn.

MESOGRAPHE, Hüb.

M. stramentalis, Hüb.

GROCIDOPHORA, Led.

C. tuberculalis, Led.

C. serratissimalis, Zell.

PANTOGRAPHA, Led.

P. limata, Grt. \& Rob. 
B. ranalis, Gn.

BLEPHAROMASTIX, Led.

Newark, at light_-Smith.

E. hyalinata, Linn.

$$
\text { EUDIOPTUS, Hüb. }
$$

A pretty species, not uncommon in Ocean county.

DESMIA, Westw.

D. maculalis, Westw.

CINDAPHIA, Led.

C. bicoloralis, Gn.

Not uncommon at light, at New Brunswick.

CONCHYLODES, Gn.

C. platinalis, Gn.

\section{Sub-Family HYDROCAMPIN王。}

OLIGOSTIGMA, Gn.

O. albalis, Rob.

$$
\text { HYDROCAMPA, Gn. }
$$

H. genuinalis, Led.

Not uncommon along ditches of running water, in Ocean county.

C. bifascialis, Rob.

$$
\text { CATACLYSTA, Hüb. }
$$

N. dispar, Grt.

NYMPH平ELLA, Grt. 


\section{Sub-Family HOMOPHYSIN 质.}

L. sicalis, Walk.

LIPOCOSMA, Led.

H. glaphyralis, Gn.

HOMOPHYSA, Gn.

H. sesquistrialis, Hüb.

\section{Sub-Family EPIPASCHIIN AE.}

E. superatalis, Clem.

EPIPASOHIA, Clem.

L. platanella, Clem.

LANTAPHE, Clem.

SALUDA, Hulst.

S. asperatella, Clem.

S. diluculella, Grt.

\section{Sub-Family PHYCITIN F.}

A. angusella, Grt.

ACROBASIS, Zell.

A. caryæ, Grt.

Quite common on Hickory, in Ocean county.

A. rubrifasciella, Pack.

A. vaccinii, Riley.

The "Cranberry Fruit Worm." Found on all the bogs, but in small numbers, and never seriously injurious.

A. indiginella, Zell.

Common at New Brunswick.

D. abietella, S. V.

DIORYCTRIA, Zell. 
N. ovalis, Pack.

NEPHOPTERYX, Hüb.

N. basilaris, Zell.

M. pravella, Grt.

MEROPTERA, Grote.

S. fusca, Haw.

SALEBRIA, Zell.

ZOPHODIA, Hüb.

Z. grossulariæ, Pack.

EUZOFEORA, Zell.

E. semifuneralis, Walk.

V. edmandsii, Pack.

VITULA, Rag.

P. pneumatella, Hulst.

PSOROSA, Zell.

Common at New Brunswick, larva on Elm-Smith.

H. oblitella, Zell.

HETEROGRAPHIS, Rag.

E. elutella, Hüb.

EPHESTIA, Hüb.

P. interpunctella, Hüb.

PLODIA, Gn.

Often injurious to grain, the larva eating out the kernel.

P. hæmatica, Zell.

$$
\text { PEORIA, Rag. }
$$

\section{Sub-Family GALLERIINA.}

G. mellonella, Linn.

GALLERIA, Linn.

The "Bee Moth." Larva infesting bee-hives, and sometimes very injurious. 
A. sociella, Linn.

APHOMIA, Hüb.

ACHREA, Hüb.

A. grisella, Fabr.

\section{Sub-Family CRAMBIDINAE.}

A. nivalis, Dru.

ARGYRIA, Hüb.

Found throughout the State. Hardly rare.

A. nummulalis, Hüb.

A. pulchella, Walk.

CRAMBUS, Fabr.

C. girardellus, Clem.

C. sericinellus, Zell.

C. præfectellus, Zinck.

O. leachellus, Zinck.

C. agitatellus, Clem.

C. saltuellus, Zell.

Ocean county, on cranberry bogs-Smith.

C. albellus, Clem.

Newark, Jamesburg-Smith.

C. bipunctellus, Zell.

C. laqueatellus, Clem.

Ocean county, in May-Smith.

C. topiarius, Zell.

Ocean county, on cranberry bogs, in May-Smith.

C. plejadellus, Zinck.

C. teterellus, Zinck.

C. elegans, Clem.

C. exsiccatus, Zell.

C. caliginosellus, Clem.

C. vulvivagellus, Clem. 

S. melinellus, Rob.
SCHENOBIUS, Dup.
S. clemensellus, Rob.

\section{Family TORTRICID王.}

In this family I have been unable to get at any collections made in New Jersey. The few species taken by myself form only a small part of the Tortricid fauna, and none of the local collectors to whose collections I had access, collected the family. I have therefore included in this list such species of Prof. Fernald's Catalogue of Tortricide as, from the distribution given, are likely to occur in this State. Where I have taken the species myself, I have, of course, indicated it.

T. subnivana, Walk.

\section{TERAS, Tr.}

Recorded from New York and Pennsylvania.

T. scabrana, Curt.

I have taken this near Jersey City.

T. hastiana, Linn.

Occurs all over the United States and Europe.

T. permutana, Dup.

Extends across the continent, but not recorded from New Jersey.

T. ferrugana, Schiff.

I have taken this near New Brunswick, and it is probably generally distributed in the State.

T. minuta, Rob. (vacciniivorana, Pack.)

This is the "Fire Worm," or "Old Vine Worm," so destructive on cranberry bogs.

T. oxycoccana, Pack.

Also said to be a Cranberry feeder. This name has usually been used to represent the preceding species. 
C. rosaceana, Harris.

CACCECIA, Hüb.

Common throughout the State. Often injurious to Roses.

C. purpurana, Clem.

I have seen this, taken in the State.

C. cerasivorana, Fitch.

Not rare. Generally distributed.

C. parallela, Rob.

Recorded from New York and Pennsylvania.

C. obsoletana, Walk.

C. transiturana, Walk.

Both of these are from New York and Pennsylvania.

C. argyrospila, Walk.

Recorded from the Atlantic to the Pacific.

C. semiferana, Walk.

I have seen the larva quite abundant on Oak, in Burlington county. I have not seen it near New Brunswick.

C. fervidana, Clem.

Recorded from New York and Pennsylvania.

C. fractivittana, Clem.

Recorded from Massachusetts to T'irginia, to Ohio and Illinoi-.

L. afflictana, Walk.

LOXOT FNIA, Steph.

I have taken several specimens in Ocean county.

P. persicana, Fitch.

$$
\text { PTYCHOLOMA, Steph. }
$$

Not rare. Generally distributed.

P.rmelaleucana, Walk.

I have taken this near Montclair.

P. lamprosana, Rob.

PANDEMIS, Hüb.

Recorded from New York and Pennsylvania. 
L. juglandana, Fern.

\section{LOPHODERUS, Steph.}

Not uncommon in Ocean county.

L. triferana, Walk.

Recorded from Maine to Texas. Dr. Packard gives Cranberry as a food-plant, but I have not found it on New Jersey bogs.

L. politana, Haw.

Recorded from Maine to District of Columbia.

L. velútinana, Walk.

New Brunswick, in April; common.

T. pallorana, Rob.

TORTRIX, Linn.

Not common. I have taken only a few specimens.

T. albicomana, Clem.

I have taken this, not rarely, in Ocean county.

T. peritana, Clem.

Recorded from New York and Pennsylvania.

T. fumiferana, Clem.

I have taken this in the Orange Mountains.

A. AMORBIA, Clem.

Recorded from New York and Pennsylvania.

Æ. unifasciana, Clem.

GNECTRA, Gn.

Recorded from New York and Pennsylvania.

๔.. xanthoides, Walk.

Recorded along the coast from Maine to Virginia.

O. reticulatana, Clem.

CENOPIS, Zell.

Not rare near Jersey City. 
350 GEOLOGICAL SURTEI OF NEW JERSEY.

C. cana, Rob.

Recorded from New York and Pennsylvania.

D. sulfureana, Clem.

DICHELIA, Gn.

Not rare. Generally distributed in my experience.

AMPEISA, Curt.

A. discopunctana, Clem.

Recorded from New York and Pennsylvania.

C. furcatana, Walk.

\section{CAPUA, Steph.}

Recorded from New York and Pennsylvania.

P. Havedana, Clem.

\section{PLATYNOTA, Clem.}

I have taken this in the State, but forget exactly where.

P. sentana, Clem.

New Brunswick; not common.

C. rutilana, Hüb.

\section{CONCEYLIS, Treits.}

I have received this from the western part of the State, as injurious to Trailing Juniper.

O. dorsimaculana, Rob.

I have taken this in Ocean, Middlesex and Monmouth counties, not rarely.

R. frustrana, Comst.

$$
\text { RETINIA, Gn. }
$$

I have taken this rarely in Ocean county.

E. botrana, Schiff.

EUDEMIS, Hüb.

Not rare along the base of the Orange Mountains. 
E. permundana, Clem. ECCOPSIS, Zell.

I have seen no New Jersey specimens, but feel confident it will be found in the State.

E. fasciatana, Clem.

E. inornatana, Clem.

Both of these are recorded from New York and Pennsylvania.

P. nimbatana, Clem.

PENTHINA, Treits.

Recorded from New York and Pennsylvania.

P. hartmanniana, Linn.

Newark; specimens taken by me.

P. hebesana, Walk.

Recorded from New Jersey, by Fernald.

P. chionosema, Zell.

New Brunswick; not common.

SERRICORIS, Tr.

S. auricapitana, Wlsm.

Recorded from New York and Pennsylvania.

S. coruscana, Clem.

I have taken this not rarely near Jersey City.

S. instrutana, Clem.

Recorded from New York and Pennsylvania.

PH丑OASIOPHORA, Grt.

P. confixana, Walk.

Recorded from New York and Pennsylvania.

P. juncticiliana, Wlsm.

P A ANDISCA, Tr.

Recorded from New York to California.

P. abbreviatana, Wlsm.

Recorded from New York and Pennsylvania. 
P. strenuana, Walk.

- New Brunswick; not common.

P. scudderiana, Clem.

I have seen the work of this species on Solidago, in Ocean and Atlantic counties.

P. dorsisignatana, Clem.

I have taken this near Montclair and in Ocean county, not uncommonly.

s. formosana, Clem.

\section{SEMASIA, Steph.}

I have taken this in Ocean county, May 20 th.

ฐ. striatana, Clem.

Recorded from New York and Penusylvania.

S. signatana, Clem.

Recorded from Maine to Virginia.

\$. argutana, Clem.

Recorded from Massachusetts to Texas.

P. spoliana, Clem.

PROTEOPTERYX, Wlsm.

New Brunswick, in April; common.

STEGANOPTYCHA, Steph.

S. fasciolana, Clem.

Recorded from New York and Pennsylvania.

T. ocellana, Schiff:

TMETOCERA, Lederer.

Not rare. Generally distributed in the State.

RHOPOBOTA, Lederer.

R. vacciniana, Pack.

Very injurious to Cranberries, and found wherever this fruit is grown. 
PHOXOPTERIS, Treits.

P. nubeculana, Clem.

I have this from several parts of the State, and it seems not rare. Ocean county, May 20th.

P. comptana, Frohl.

Widely distributed, but not recorded from New Jersey.

P. cornifoliana, Riley.

New Brunswick; rare.

G. caryana, Fitch.

GRAPHOLITA, Treits.

I have seen what I take to be the work of this species, in Ocean county.

G. interstictana, Clem.

Recorded from New York and Pennsylvania.

C. pomonella, Linn.

CARPOCAPSA, Treits.

The codling moth. Common all over the State.

D. simulana, Clem.

DICHRORAMPHA, Gn.

Recorded from New York and Pennsylvania.

\section{Family TINEIDEE.}

The list in this family, or rather aggregation of families, has been kindly furnished by $\mathrm{Mr}$. Wm. Beutenmïller, the Curator of Insects in the American Museum of Natural History, New York Cltyr.

Mr. Beutenmüller says "The list has been made up from personal observation, and not from published records; in fact, no species of Tineida, to my knowledge, have as yet been recorded from New Jersey." Small as is the list, the accuracy of the record and the 
notes on the food plants are very valuable. I have made fer additions to or comments in the list, and it is to be credited in its entirety to Mr. Beutenmïller.

C. pavonicella, Clem.

\section{CHOREUTES, Hüb.}

Rare. Food-plant and early stages unknown.

\section{ACROLOPHUS, Foey.}

A. plumifrontella, Clem.

Common. Food-plant and early stages unknown.

\section{PSEUDANOPHORA, Wlsm.}

P. arcanella, Clem.

Common. Food and early stages unknown.

A. effrenatella, Clem.

AMADRYA, Clem.

Not common.

T. biselliella, Hum.

$$
\text { TINEA, Linn. }
$$

Common. Larva very injurious to carpets, furs, woolens, de.

T. pellionella, Linn.

Common. Larva very injurious to furs, carpets, woolens, \&c.

T. granella, Linn.

Common. Larva injurious to grain.

B. ferruginella, Hüb.

\section{BLABOPHANES, Zell.}

Common. Early stages and food unknown.

B. dorsistrigella, Clem.

Common. Early stages and food unknown.

HYPONEUMEUTA, Zell.

H. multipunctella, Clem.

Not common. Early stages and food unknown. 


\section{CATALOGUE OF INSECTS.}

P. yuccasella, Riley.

\section{PRONUBA, Riley.}

Common. Larva infests the seed pods of Yucca.

P. cruciferarum, Zell.

\section{PLUTELLA, Schr.}

Common. Larva injurious to Cabbage.

E. packardella, Clem.

\section{EPIGRAPHIA, Steph.}

Rare. Early stages and food unknown.

\section{CRYPTOLECHIA, Zell.}

C. contrariella, Walk.

Not common. Early stages and food unknown.

C. tentoriferella, Clem.

Common. Larva in web on Oak, Cherry and Walnut.

C. schlægeri, Zell,

Common. Food, Wax Myrtle (Myrica) and Oak.

c. quercicella, Clem.

Not common. Food, Oak, Aspen.

D. atrodorsella, Clem.

Not common. Food, Beggar-tick (Bidens).

D. hilarella, Zell.

Not common. Food, Locust and Sanicula.

D. fulvipenella, Clem.

Not common. Food, Golden Rod (Solidago).

D. lecontella, Clem.

Common.

D: heracliana, De G.

Not common. Larva in stems of Parsnip and other umbelliferous plants. 
G. agrimoniella, Clem.

\section{GELECHIA, Zell.}

Not common. Food, Agrimonia.

G. alacella, Clem.

Not common. Early stages and food unknown.

G. bilobella, Zell.

Not common. Early stages and food unknown.

G. inscripta, Wlsm.

New Brunswick, in April, rare-Smith.

G. pinifoliella, Chamb.

Jamesburg, common in Pinus rigida-Smith.

G. flavicostella, Clem.

Not common. Early stages and food unknown.

G. atributella, Walk.

Common.

G. querciella, Chamb.

Common. Food, Oak.

G. rboifructella, Clem.

Common. Food, Poplar and Sumac.

G. rubidella, Clem.

Not common. Early stages and food unknown.

G. roseosuffusella, Clem.

Not common. According to Dr. Packard, the larva inhabits the fruit panicles of the Sumac. (Guide, p. 350, 8th ed.)

G. gallæsolidaginis, Riley.

Not common. Food, in stems of Golden Rod (Solidago), larva producing a fusiform stvelling.

B. bassettella, Clem.

\section{HAMADRYAS, Clem.}

Jamesburg, in July, rare-Smith.

S. cerealella, Oliv.

\section{SITOTROGA, Hein.}

Common. Larva in kernels of Corn, Wheat, de. 
S. emblemella, Clem.

\section{STROBISIA, Clem.}

Scarce. Early stages and food not known.

S. lepidella, Clem.

Rare. Early stages and food unknown.

YPSOLOPHUS, Fabr.

Y. pometellus, Harr.

Common. Food, Apple, Pear, Plum, \&c.

D. newmanella, Clem.

$$
\text { DASYCERA, Haw. }
$$

Rare. Early stages and food unknown.

\section{GCOPHORA, Zell.}

(F. argenticinctella, Clem.

Common. Early stages and food unknown.

B. impositellus, Zell.

\section{BUTALIS, Tr.}

Common. Food, various species of Aster.

B. basilaris, Zell.

Common. Early stages and food unknown.

B. glandulella, Riley.

Not common. Larva in Acorns.

\section{ARGYRESTHIA, Hüb.}

A. andereggiella, Dup.

Common. Early stages and food in this country unknown. Larva, in Europe, in buds of Hazel and Apple.

GRACILARIA, Zell.

G. sassafrasella, Chamb.

Comimon. Food, Sassafras. 
COLEOPHORA, Zell.

C. malivorella, Riley.

Common. Food, Apple, Plum, Cherry.

L. eloisella, Clem.

\section{LAVERNA, Curt.}

Scarce. Larva burrows in stalk of Primrose (Enothera).

L. phragmitella, Steph.

Common at light, in Newark. In Europe this feeds on Typha-Smith.

\section{COSMOPTERYX, Hüb.}

C. gemmiferella, Clem.

Rare. Early stages and food unknown.

\section{ANTISPILA, Hüb.}

A. nyssæfoliella, Clem.

Common. Food, Pepperidge (Nyssa sylvatica). Very destructive.

\section{ASPIDISCA, Clem.}

A. splendoriferella, Clem.

Common. Food, Apple.

TISCEERIA, Zell.

T. citripennella, Clem.

Common. Food, Oak.

\section{LITHOCOLLETIS, Zell.}

L. hamadryadella, Clem.

Very common. Food, Oak.

L. fitchella, Clem.

Common. Food, Oak.

L. robiniella, Clem.

Common. Food, Locust. 
L. caryæfoliella, Clem.

Common. Food, Hickory.

L. guttifinitella, Clem.

Very common. Food, Poison Ivy (Rhus radicans).

L. desmodiella, Clem.

Searce. Food, Desmodium viridiflorum.

LEUCANTHIZA, Clem.

L. amphicarpæfoliella, Clem.

Common. Food, Hog-peanut (Amphicarpa monoica).

PHYLLOCNISTIS, Zell.

P. vitiginella, Clem.

Common. Food, Grape.

\section{Family PTEROPHORIDI.}

PLATYPTILUS, Hüb.

P. ochreodactylus, var. bischoffii, Zell.

O. nigriciliatus, Zell.

OXYPTILUS, Zell.

Rare.

O. periscelidactylus, Fitch.

Common. Food, Grape.

PTEROPEORUS, Wallgr.

P. monodactylus, Linn.

Common.

\footnotetext{
* Mr. Meyrick considers the Pterophoridce as belonging to the Pyralidec rather than the Tineida, and $I$ am not sure but that he is right. In placing them at the foot of the series, I have followed both precedent and Mr. Beutenmüller's MSS.-J. B. S.
} 


\section{Order DIPTERA.}

\section{Family CECIDOMYIDEL.}

CECIDOMYIA, Meigen.

C. anthophila, O. S.

C. cornuta, Walsh.

C. culmicola, Morris.

C. destructor, Say.

The Hessian fly. Not destructive in New Jersey.

C. grossulariæ, Fitch.

C. ornata, Say.

C. salicis-brassicoides, Walsh.

I have seen the galls of this species not rarely.

C. vaccinii, J. B. Smith.

Common on Cranberry (Vaccinium) and Loose Strife (Lysimachia).

DIPLOSIS, LW.

D. caliptera, Fitch.

D. caryæ, O.S.

D. graminis, Fitch.

D. inimica, Fitch.

D. robiniæ, Hald.

D. tritici, Kirby.

Was reported as doing some damage in New Jersey during the season of 1889 .

ASPHONDYLIA, LW.

A. monacha, O.S.

A. recondita, O.S.

A. rudebeckiæ-conspicua, O.S. 
L. ventralis, Say.

LASIOPTERA, Meigen.

L. vitis, O.S.

I have seen the galls of this species not infrequently during the, present season (1889).

\section{Family MYCETOPHILID FE.}

MYCETOBIA, Meigen.

M. divergens, Walk.

D. euzona, Lw.

DITOMYIA, Winnertz.

P. lauta, Lw.

PLESIASTINA, Winnertz.

B. cinerea, Meigen.

BOLITOPHILA, Meigen.

M. formosa, Lw.

MAOROCERA, Meigen.

P. mendica, Lw.

PLATYURA, Meigen.

P. fragilis, Lw.

POLYLEPTA, Winnertz.

SCIOPHILA, Meigen.

S. appendiculata, Lw.

L. fasciata, Say.

LASIOSOMA, Winnertz.

E. obumbrata, Lw.

EUDICRANA; LW.

S. polyzona, Lw.

SYNTEMNA, Winnertz.

P. tanypus, Lw.

PHTHINIA, Winnertz. 
NEOGLAPHYROPTERA, O. S.

N. bivittata, Say.

N. melæna, Lw.

N. oblectabilis, Lw.

N. sublunata, Lw.

N. winthemi, Leh.

L. abbreviata, Lw.

LEJA, Meigen.

L. sororcula, Lw.

ALLODIA, Winnertz.

A. crassicornis, Stannius.

T. fœda, Lw.

TRICHONTA, Winnertz.

ZYGOMYIA, Winnertz.

Z. ignobilis, Lw.

Z. ornata, Lw.

E. pulicaria, Lw.

EPICYPTA, Winnertz.

M. paula, Lw.

MYCOTHERA, Winnertz.

MYCETOPHILA, Meigen.

M. extincta, Lw.

M. fallax, Lw.

M. ichneumonea, Say.

M. inculta, Lw.

M. mutica, Lw.

M. polita, Lww.

M. procera, Lw.

M. scalaris, Lw.

M. sigmoides, $L w$.

S. femorata, Say.

SCIARA, Meigen.

S. fuliginosa, Fitch. 
S. inconstans, Fitch.

s. mali, Fitch.

S. vulgaris, Fitch.

T. hebes, Lw.

TRIOHOSIA, Winnertz.

\section{Family SIIIULID平.}

There are several species of simulium in the rumning streams, but I have taken no imagos, and cannot even give a guess at what species we have, from published data.

\section{Family BIBIONID里.}

B. albipennis, Say.

\section{BIBIO, Geoff.}

I have taken this species in the State. Caldwell, commonCrane.

B. articulatus, Say.

B. femoratus, Wied.

I have taken this species in the State. Caldivell, commonCrane.

B. pallipes, Say.

B. rufithorax, Wied.

B. xanthopus, Wied.

D. dimidiatus, Lw.

DILOPHUS, Meigen.

D. orbatus, Say.

D. thoracicus, Say.

P. heteroptera, Say.

PLECIA, Wied.

S. atrata, Bay.

SCATOPSE, Geoff. 


\section{Family CULICID压.}

C. ciliatus, Fabr.

CULEX, Linn.

Caldwell, common-Crane. Taken quite frequently in New Jersey. One of the common mosquitos. It as frequently takes the collector.

C. consobrinus, R. Desv.

C. damnosus, Say.

Also quite abundant in New Jersey.

C. triseriatus, Say.

More rare, but still obtrusively abundant on occasion.

ANOPHELES, Meigen.

A. quadrimaculatus, Say.

Not common. I was taken by only a single specimen. Caldivell, common-Crane.

A ËDES, Meigen.

A. sapphirinus, O. S

CORETHRA, Meigen.

C. punctipennis, Say.

\section{Family CHIRONOMIDE.}

CHIRONOMUS, Meigen.

C. cristatus, Fabr.

C. geminatus, Say.

C. glaucurus, Wied.

C. lineola, Wied.

C. lobifer, Say.

C. modestus, Say.

C. tricinctus, Meigen. 
T. annulatus, Say.

TANYPUS, Meigen.

T. flavicinctus, Lw.

T. pinguis, Lw.

T. tibialis, Say.

T. tricolor, $\mathrm{L}$ w.

C. festivus, Lw.

Ceratopogon, Meigen.

C. longipennis, $\mathrm{L} w$.

C. lineatus, Lw.

C. plebejus, Lw.

C. rufus, Lw.

ㅋ. fasciata, Say。

HETEROMYIA, Say.

\section{Family ORPHNEPHILID $\not$.}

ORPHNEPHILA, Ealiday.

O. testacea, Ruthe.

\section{Family PSYCHODID瓜.}

P. alternata, Say.

PSYCHODA, Latr.

Common almost everywhere throughout the State.

\section{Family TIPULIDAE.}

D. brevirena, O.S.

DICRANOMYIA, Steph.

D. defuncta, O.S. 
366 GEOLOGICAL SURVEY OF NEW JERSEY.

D. globithorax, O.S.

D. immodesta, O.S.

D. liberta, O. S.

D. longipennis, Schum.

D. pubipennis, O.S.

D. rostrifera, O.S.

GERANOMYIA, Baliday.

G. canadensis, Westw.

G. rostrata, Say.

REIPIDIA, Meigen.

R. maculata, Meigen.

R. fidelis, O.S.

R. domestica, O.S.

L. cinctipes, Say.

LIMNOBIA, Meigen.

L. indigena, O. S.

L. triocellata, O.S.

RHAMPHIDIA, Meigen.

R. flavipes, Macq.

ELEPHANTOMYIA, O. S.

E. westwoodi, O. S.

TOXORREINA, LW.

T. magna, O.S.

Described from New Jersey specimens.

ANTOCHA, O. S.

A. opalizans, O.S.

ATARBA, O. S.

A. picticornis, O. S.

TEUCHOLABIS, O. S.

T. complexa, O. S. 


\section{REYPHOLOPHUS, O. S.}

R. holotrichus, Say.

R. innocens, O.S.

Recorded from New Jersey.

R. meigenii, O. S.

R. nubilus, O.S.

R. rubellus, O. S.

ERIOPTERA, Meigen.

E. chrysocoma, O.S.

E. chlorophylla, O. S.

E. septemtrionis, O.S.

E. straminea, O.S.

E. villosa, O.S.

E. vespertina, O.S.

E. armillaris, O.S.

E. venusta, O. S.

E. armata, O.S.

E. caloptera, Say.

E. parva, O. S.

Recorded from New Jersey.

E. hirtipennis, O. S.

Recorded from New Jersey.

SYMPLEOTA, Meigen.

S. punctipennis, Meigen.

GNOPHOMYIA, O. S.

G. tristissima, O. S.

GONOMYIA, Megerle.

G. blanda, O. S.

G. manca, O.S.

Recorded from New Jersey.

G. subcinerea, O.S.

G. sulphurella, O.S. 
C. indivisa, O. S.

$$
\text { CLADURA, O. S. }
$$

E. fascipennis, Say.

\author{
EPIPHRAGMA, O. S.
}

LIMNOPBILA, Macq.

L. adusta, O.S.

L. areolata, O.S.

L. contempta, O.S.

L. fuscovaria, O.S.

L. gracilis, Wied.

L. imbecilla, O. S.

L. lenta, O.S.

L. macrocera, Say.

I. montana, O.S.

L. quadrata, O. S.

L. recondita, O.S.

L. rufibasis, O. S.

L. tenuipes, Say.

L. ultima, O.S.

T. regelationis, Linn.

TRICHOCERA, Meigen.

PENTHOPTERA, Schiner.

P. albitarsis, O. S.

AMALOPIS, Haliday.

A. inconstans, O. S.

A. vernalis, O.S.

R. tenuipes, O.S.

RAPHIDOLABIS, O. S.

R. Haveola, O. S.

T. exsculpte, O.S.

TRIGOMA, Schiner. 
PTYCHOPTERA, Meigen.

P. quadrifasciata, Say.

P. rufocincta, O. S.

\section{BITTACOMORPEA, Westw.}

B. clavipes, Fabr.

Common along ditches of cranberry marshes in Ocean county, in May. Rare at Jamesburg, in June.

I. fitchii, O. S.

IDIOPLASTA, O. S.

TIPULA, Linn.

T. abdominalis, Say.

T. bella, Liv.

T. costalis, Say.

T. cunctans, Say.

T. dejecta, Walk.

T. fasciata, Lw.

Recorded from the Palisades, New Jersey.

T. fiavicans, Fabr.

T. fuliginosa, Say.

T. grata, Lw.

T. infuscata, Lw.

T. ignobilis, Lw.

T. maculipennis, Wied.

T. tetrocephala, Lw.

Recorded from New Jęrsey.

T. tricolor, Fabr.

T. trivittata, Say.

P. collaris, Say.

PACHYRRHINA, Macq.

P. ferruginea, Fabr.

P. incurva, Lw. 
P. macrocera, Say.

P. unifasciata, Lw.

P. virescens, Lw.

Recorded from New Jersey.

DOLICHOPEZA, Curt.

D. annulata, Say.

\section{Family RHYPHIDAE.}

R. alternatus, Say.

REYPHUS, Latr.

R. fenestralis, Scop.

R. punctatus, Meigen.

\section{Family XYLOPHAGID平.}

$\mathrm{X}$. lugens, Lw.

XYLOPHAGUS, Meigen.

$\mathrm{X}$, reflectens, Walk.

S. palipes, Lw.

SUBULA, Meigen.

\section{Family CCENOMYID死.}

C. pallida, Say.

CANOMYIA, Latr.

\section{Family STRATYOMYIDE.}

M. fuscitarsis, Say.

METOPONIA, Macq.

M. obscuriventris, $L \pi$. 
B. viridis, Say.

\author{
BERIS, Latr.
}

S. decorus, Say,

SARGUS, Fabr.

Common at Jamesburg.

S. elegans, Lw.

S. xanthopus, Wied.

C. viridis, Say.

CHLOROMYIA, Dunc.

Common throughout the State.

O. maculata, Oliv.

OXYCERA, Meigen.

O. unifasciata, Lw.

O. flavicornis, Oliv.

ODONTOMYIA, Meigen.

O. lasiophthalma, Lw.

Recorded from New Jersey.

O. nigerrima, Lw.
S. angularis, Lw.
S. flaviceps, Macq.
S. marginalis, Lw.
S. vicina, Macq.

STRATIOMYIA, LW.

N. pallipes, Say.

NEMOTELUS, Geoff.

\title{
Family TABANID坐,
}
P. chrysocoma, O.S.
P. pigra, O.S.
P. tranquilla, O.S.

PANGONIA, Latr. 
C. callidus, $0 . \mathrm{S}$.

CHRYSOPS, Meigen.

C. celer, O.S.

C. excitans, Walk.

C. fallax, O. S.

C. Havidus, Wied.

C. hilaris, O.S.

C. moechus, O.S.

C. niger, Macq.

Caldwell, not common-Crane.

C. obsoletus, Say.

C. plangens, Wied.

C. pudicus, O.S.

C. univittatus, Ma@.

C. vittatus, IVied.

Caldivell; common-Crane.

THERIOPLECTES, Zell.

T. cinctus, Fabr.

T. lasiophthalmus, Macq.

Caldwell, common-Crane.

T. trispilus, IVied.

TABANUS, Linn.

T. americanus, Först.

T. atratus, Fabr.

Common throughout the State.

T. catentatus, O.S.

T. cingulatus, Macq.

T. coffeatus, Macq.

T. costalis, Wied.

T. exul, O.s.

Recorded from New Jersey.

T. fulvulus, Wied.

T. giganteus, De G. 
T. lineola, Fabr.

The most common species in the State.

T. Iongulus, O.S.

I. melanocerus, Wied.

T. mexicanus, Linn.

Recorded from New Jersey.

T. nigrescens, Pal. Beauv.

Recorded from New Jersey.

T. nigrovittatus, Macq.

Recorded from New Jersey.

T. nivosus, O.S.

Described from New Jersey specimens.

T. pumilus, Macq.

Caldwell, not common-Crane.

T. reinwardtii, Wied.

T. stygius, Say.

T. sulcifrons, Macq.

T. trimaculatus, Pal. Beauv.

Caldwell, common-Crane.

T. variegatus, Fabr.
ATYLOTUS, O. S.

A. bicolor, Wied.

\section{Family LEPTIDA.}

T. fasciventris, Lw.

TRIPTOTRICHA, LW.

T. rufithorax, Say.

C. basilaris, Say.

CHRYSOPILA, Macq.

C. fasciata, Say.

Caldwell, not common-Crane. 
374 GEOLOGICAL SURVEY OF NEW JERSEY.

C. ornata, Say.

Caldwell, rare-Crane.

C. quadrata, Say.

C. thoracica, Fabr.

LEPTIS, Fabr.

L. albicornis, Say.

L. mystacea, Mracq.

Caldwell, rare-Crane.

L. punctipennis, Say.

L. plumbea, Say.

L. scapularis, Liv.

\section{Family ASILID王.}

L. flavipes, Lw.

LEPTOGASTER, Meigen.

L. histrio, Wied.

L. ochraceus, Schiner.

L. testaceus, Lw.

C. cruciatus, Say.

CERATURGUS, Wied.

D. albius, Walk.

DIOCTRIA, Meigen.

L. sexfasciata, Say.

LAPHYSTIA, LW.

Recorded from New Jersey.

E. formosa, Liv.

ECHTHOPODA, LW.

H. guttula, Wied.

HOLOPOGON, LW.

H. philadelphicus, Schiner. 
S. argenteus, Say.

STICHOPOGON, LW.

Sandy Hook, August. Anglesea, July 22d. Not rare.

S. trifasciatus, Say.

HOLCOCEPHALA, Jaenn.

ㅍ. abdominalis, Say.

N. politus, Say.

NICOCLES, Jaenn.

TARACTICUS, LW.

T. octopunctatus, Say.

D. discolor, Lw.

DEROMYIA, Phillipi.

D. umbrina, Lw.

D. winthemi, Wied.

A. glabrata, Say.

ATOMOSIA, Macq.

A. puella, Wied.

Caldivell, rare-Crane.

CEROTAINIA, Schiner.

C. macrocera, Say.

D. Alavicollis, Say.

DASYLLIS, LW.

D. posticata, Say.

D. thoracica, Fabr.

D. tergissa, Say.

ㅍ. atrox, Wied.

HYPERECHIA, Schiner.

D. thoracica, Fabr.

DASYLLIS, LW.

Caldwell, common-Crane. 
L sericea, Say.

LAPHRIA, Meigen.

L. bicolor, Wied.

LAMPRIA, Macq.

MALLOPHORA, Macq.

M. laphroides, Wied.

M. clausicella, Macq.

P. bastardi, Macq.

PROMACHUS, LW.

P. apivorus, Fitch.

Caldwell, common-Crane.

E. bastardi, Macq.

ERAX, Macq.

E. æstuans, Wied.

PROCTACANTHUS, Macq.

P. philadelphicus, Mac(p.

A. sericeus, Say.

ASILUS, Linn.

I have observed a few specimens of this species the present season. Caldwell, common-Crane.

A. femoralis, Macq.

A. tibialis, Macq.

N. ænobarbus, Lw:

NEOITAMUS, O. S.

T. annulipes, Macq.

TOLMERUS, Lw.

O. tibialis, Say

OMMATIUS, Illiger. 


\section{Family MIDAIDE.}

M. clavatus, Dru.

MIDAS, Fabr.

Not common. Taken at Jamesburg. Generally distributed. Caldwell, common-Crane.

\section{Family BOMBYLID}

EXOPROSOPA, Macq.

E. emarginata, Macq.

E. fascipennis, Say.

Caldwell, rare-Crane.

E. fasciata, Macq.

Caldwell, common-Crane.
ANTHRAX, Scop.

A. alternata, Say.

A. fulvohirta, Wied.

Caldwell, common-Crane.

A. gracilis, Macq.

A. sinuosa, Wied.

ARGYRAMCFBA, Schiner.

A. analis, Say.

A. cedipus, Fabr.

Caldwell, rare-Crane.

A. simson, Fabr.

Caldwell, common-Crane.

L. elongata, Say.

LOMATIA, Meigen. 
BOMBYLIUS, Linn.

B. atriceps, Lw.

B. fratellus, Wied.

Caldwell, common-Crane.

B. pygmæus, Fabr.

Caldwell, not common-Crane.

B. varius, Fabr.

$$
\text { SPARNOPOLIUS, LW. }
$$

S. fulvus, Wied.

P. sulphurea, Liv.

$$
\text { PHTHIRIA, Meigen. }
$$

Recorded from New Jersey.

G. calvus, Lw.

GERON, Meigen.

G. macropterus, Lw.

G. subauratus, Lw.

G. vitripennis, Lw.

S. macer, Lw.

SYSTROPUS, Wied.

TOXOPHORA, Meigen.

T. amphitea, Walk.

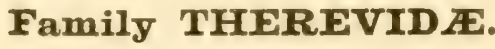

P. erythrura, Liv.

PSILOCEPHALA, Zett.

‥ melanoprocta, Lw.

P. nigra, Say.

T. candidata, Lw.

THEREVA, Latr.

T. gilvipes, Lw. 
T. fulvipes, Walk.

TABUDA, Walk.

Recorded from New Jersey.

\section{Family SCENOPINIDAE.}

ฐ. fenestralis, Linn.

SCENOPINUS, Latr.

క. lævifrons, Meigen.

\section{Family CYRTID AE.}

O. gagatinus, Lw.

OPSEBIUS, Costa.

O. pallidipennis, Lw.

ONCODES, Latr.

\section{Family EMPIDI.}

S. simplex, Walk.

SYNECHES, Walk.

S. thoracicus, Say.

E. longipes, Lw.

EMPIS, Linn.

Recorded from New Jersey.

E. varipes, Lw.

RHAMPEOMYIA, Meigen.

R. dimidiata, Lw.

R. fumosa, Lw.

R. gracilis, Lw.

R. scolopacea, Saý. 
38(1 GEOLOGICAI, SURVEY OF N゙EW JERSEY.

R. tristis, Walk.

R. umbilicata, L\%.

프. gracilis, Lw:

milara, Meigen.

트. nigriventris, $\mathrm{L} \pi$.

C. longipes, LN.

CYRTOMA, Meigen.

STILPON, LW.

S. varipes, $\mathrm{L} \pi$.

TACEYDROMIA, Meigen.

T. mesogramma, Lw.

T. pachycnema, Lw.

T. trivialis, Lw.

TACHYPEZA, Meigen.

T. fenestrata, Say.

H. notata, LN.

HEMERODROMIA, Meigen.

H. vittata, Lw.

C. lineata, Lw.

CLINOCERA, Meigen.

C. conjuncta, Lw.

C. maculata, $\mathrm{L} \pi$.

\section{Family DOLICHOPODID王.}

DOLIOHOPUS, Latr.

D. batillifer, $\mathrm{Lw}$.

D. bifractus, LN:

D. comatus, $\mathrm{Lw}$.

D. cuprinus, Wied.

D. funditor, $\mathrm{LW}$.

D. gratus, Lw.

Recorded from New Jersey. 
D. longipennis, Lw.

D. ovatus, Liv.

D. pachycnemus, Liv.

D. quadrilamellatus, Lw.

Recorded from New Jersey.

D. ruficornis, Lw.

D. scapularis, $\mathrm{Lw}$.

D. scoparius, Lw.

D. setifer, Lw.

GYMNOPTERNUS, LW.

G. albiceps, Lw.

G. barbatulus, Lw.

G. calacochrus, Lw.

G. debilis, LN.

G. despicatus, Lw.

G. exilis, Lw.

G. flavus, Lw.

G. frequens, Lw.

G. lævigatus, Lw.

G. minutus, Lw.

G. nigribarbus, Lw.

G. parvicornis, Lw.

G. subdilatatus, Lw.

G. ventralis, Lw.

PELASTONEURUS, LW.

P. cognatus, Lw.

P. vagans, Lw.

ARGYRA, Macq.

A. calceata, Lw.

A. calcitrans, Lw.

SYNARTHRUS, LW.

S. barbatus, Lw.

S. cinereiventris, Liv. 
PORPHYROPS, Meigen.

P. fumipennis, $L w$.

P. melampus, Lw.

DIAPHORUS, Meigen.

D. lamellatus, Lw.

D. mundus, Lw.

D. opacus, Lw.

D. sodalis, Lw.

CHRYSOTUS, Meigen.

C. affinis, Lw.

C. discolor, $\mathrm{L} \pi$.

C. longimanus, Lw.

C. validus, Lw.

S. lineatus, Lw.

SYMPYCNUS, LW.

CAMPSIONEMUS, Haliday.

C. hirtipes, Lw。

LIANOALUS, LW.

L. genualis, Lw.

SCELLUS, LW.

S. exustus, Walk.

HYDROPHORUS, Fallen.

H. parvus, Lw.

H. pirata, Lw.

MEDETERUS, Fischer.

M. nigripes, Lw.

CHRYSOTIMUS, LW.

C. delicatus, Lw.

C. pusio, Lw.

S. carbonifer, Lw.

SAUCROPUS, LW.

S. superbiens, Lw。

S. tenuis, Lw. 
P. bicolor, Lw.

PSILOPUS, Meigen.

P. comatus, Lw.

P. filipes, Lw.

P. inermis, Lw.

P. patibulatus, Say.

P. scintillans, Lw.

P. sipho, Say.

Common throughout the State. Caldwell, common-Crane.

\section{Family LONCHOPTERIDE.}

L. lutea, Panz.

LONCHOPTERA, Meigen.

L. riparia, Meigen.

\section{Family SYRPHID E.}

M. globosus, Fabr.

MICRODON, Meigen.

M. tristis, Lw.

M. rufipes, Macq.

C. laterale, Lw.

CHRYSOTOXUM, Meigen.

C. pubescens, Liv.

C. ventricosum, Lw.

P. angustifrons, Lw.

PARAGUS, Latr.

P. bicolor, Fabr.

P. tibialis, Fallen.

P. modesta, Lw.

PIPIZA, Fallen.

P. calcarata, Lw. 
384 GEOLOGICAL SURVEY OF NEW JERSEY.

P. salax, Lw.

P. nigribarba, Lw.

P. femoralis, Isw.

P. albipilosa, Will.

P. nigripilosa, Will.

P. buccata, Macq.

PSILOTA, Meigen.

CHRYSOGASTER, Meigen.

C. nigripes, Lw.

Recorded from New Jersey.

C. nitida, Wied.

C. pictipennis, Lw.

Recorded from New Jersey.

C. cyanescens, Lw.

CHILosia, Meigen.

MELANOSTOMA, Schiner.

M. obscurum, Say.

M. mellinum, Linn.

Jamesburg-Smith.

P. rosarum, Fabr.

PYROPH

P. ocymi, Fabr.

PLATYCHIRUS, St. F. \& Serv.

P. quadratus, Say.

P. hyperboreus, Staeger.

P. peltatus, Meigen.

S. arcuatus, Fallen.

SYRPHUS, Fabr.

S. diversipes, Macq.

S. ribesii, Linn.

S. torvus, O.S.

Caldwell, common-Crane. 
S. lesueurii, MIacq.

S. abbreviatus, Zett.

S. americanus, Wied.

S. xanthostomus, Will.

D. fuscipes, Lw.

DIDEA, Macq.

Collected by myself at Jamesburg.

X. felix, O. S.

XANTHOGRAMMA, Schiner.

$\mathrm{X}$. emarginata, Say.

X. flavipes, Lw.

$\mathrm{X}$. aqualis, $\mathrm{Lw}$.

ALLOGRAFTA, O. S.

A. obliqua, Say.

Caldwell, rare-Crane.

M. polita, Say.

MESOGRAPTA, Macq.

Caldwell, not common-Crane.

M. marginata, Say.

Cald well, common-Crane. Jamesbury-Smith.

M. geminata, Say.

N. globosa, Walk.

NEOASCIA, Will.

N. distincta, Will.

SPHEGINA, Moigen.

S. Keeniana, Will.

S. rufiventris, Lw.

S. lobata, Lw.

B. tarchetius, Walk.

BACCHA, Fabr.

Recorded from New Jersey. 
386 GEOLOGICAL SURVEY OF NEW JERSEY.

B. lugens, Lw.

B. fuscipennis, Say.

B. aurinota, Harris.

B. cognata, Lw.

M. nigra, Lw.

MYIOLEPTA, Newn.

R. nasica, Say.

RHINGIA, Scop.

V. evecta, Walk.

VOLUCELla, Geoff.

V. vesiculosa, Fabr.

S. militaris, Walk.

SERICOMYIA, Meigen.

S. chrysotoxoides, Macq.

E. tenax, Linn.

\section{ERISTALIS, Latr.}

I have taken this in New Jersey frequently.

E. æneus, Fabr.

E. dimidiatus, Wied.

Caldwell, not common-Crane.

E. saxorum, Wied.

New Brunswick, Jamesburg.

E. brousi, Will.

E. transversus, Wied.

Caldwell, not common-Crane. New Brunswick.

E. vinetorum, Fabr.

H. latifrons, Lw.

HELOPHILUS, Meigen.

H. similis, Macq.

Jamesburg, not common.

E. lætus, Lw.

H. chrysostomus, Wied.

H. distinctus, Will. 
H. conostomus, Will.

E. integer, Lw.

P. thoracicus, Lw.

PTERALLASTES, LW.

T. lituratus, Lw.

TEUCHOCNEMIS, O. S.

M. posticata, Fabr.

MALLOTA, Meigen.

M. barda, Say.

Caldwell, common-Crane.

M. cimbiciformis, Fallen.

T. curvipes, Wied.

TRIODONTA, Macq.

TROPIDIA, Meigen.

T. quadrata, Say.

Caldwell, rare-Crane.

C. verbosa, Harris.

CRIORHINA, Hoffm.

C. umbratilis, Will.

C. intersistens, Walk.

Recorded from New Jersey.

C. analis, Macq.

C. decora, Macq.

C. cyanogaster, Lw.

CRIOPRORA, O. S.

BRACHYPALPUS, Macq.

B. frontosus, Lw.

X. pigra, Fabr.

XYLOTA, Meigen.

X, bicolor, Lw.

X. ejuncida, Say. 
X. fraudulosa, Lw.

$\mathrm{X}$. angustiventris, Lw.

X. curvipes, Lw.

$\mathrm{X}$. chalybea, Wied.

X. elongata, Will.

X. quadrimaculata, Lw.

Caldwell, not common-Crane.

BENOGASTER, Macq.

s. comstocki, Will.

SYRITTA, St. F.\& Serv.

S. pipiens, Linn.

Common at Jamesburg.

S. longicornis, Lw.

SPILOMYIA, Meigen.

S. fusca, Lw.

S. hamifera, Lw.

s. quadrifasciata, Say.

TEMNOSTOMA, St. F. \& Serv.

T. bombylans, Fabr.

T. pictulum, ${ }^{\prime} \mathrm{Pa}$.

T. excentricum, Harris.

T. alternans, Lw.

M. ornata, Fabr.

MILESIA, Latr.

Caldwell, not common-Crane.

S. vittata, Wied.

SPEECOMYIA, Latr.

C. abbreviata, Lw.

CERIA, Fabr. 


\section{Family CONOPID E.}

C. genualis, $\mathrm{Lw}$.

CONOPS, Linn.

C. obscuripennis, IVill.

C. sagittarius, Say.

Caldwell, common-Crane.

C. sylvosus, Will.

Caldwell, rare-Crane.

C. tibialis, Say.

Caldwell, not common-Crane.

C. zanthopareus, Will.

S. stylatus, Fabr.

STYLOGASTER, Macq.

D. nigriceps, Lw.

DALMANIA, R. Desv.

M. fulvifrons, Say.

MYOPA, Fabr.

M. vesiculosa, Say.

\section{Family PIPUNCULID瓜.}

P. nigripes, Lw.

PIPUNCULUS, Latr.

\section{Family PLATYPEZIDF.}

C. divergens, Lw.

CALLOMYIA, Meigen.

C. notata, Liv.

P. flavicornis, Lw.

PLATYPEZA, Meigen.

P. obscura, Lw.

P. velutina, Lw. 


\section{Family CESTRIDAE.}

G. equi, Fabr.

GASTROPHILUS, Leach.

Caldwell, common-Crane.

G. hæmorrhoidalis, Linn.

G. nasalis, Linn.

Caldwell, not common-Crane.

All of these affect the horse, and the species are common to Europe and America.

H. bovis, DeG.

HYPODERMA, Clark.

Bots on oxen.

В. lineata, Villers.

Forming bots on sheep. Both are common to Europe and North America.

Ф. ovis, Linn.

ESTRUS, Linn.

Forming bots on sheep. Common to Europe and North America.

COTEREBRA, Clark.

C. americana, Fabr.

C. buccata, Fabr.

O. cuniculi, Clark.

C. emasculator, Fitch.

C. horripilum, Clark.

C. scutellaris, Lw.

\section{Family TACHINID}

HYALOMYIA, R. Desv.

H. triangulifera, $\mathrm{L} w$.

T. pennipes, Fabr.

TRICHOPODA, Latr. 
H. vivida, Harr.

HYSTRICIA, Macq.

Common throughout the State. Caldwell-Crane.

JURINIA, R. Desv.

J. algens, Wied.

J. aterrima, R. Desv.

J. boscii, R. Desv.

J. hystriz, Fabr.

GYMNOCH开TA, R. Dest.

G. alcedo, R. Desv.

MICROPALPUS, Macq.

M. distinctus, R. Desv.

NEMOR丑A, R. Dest.

N. leucaniæ, Kirkp.

Parasitic on the Army Worm, L. unipuncta.

EXORISTA, Meigen.

E. cecropiæ, Riley.

E. doryphoræ, Riley.

E. phycitæ, LeB.

MASICERA, Macq.

M. archippivora, Riley.

B. bifasciata, Fabr.

BELVOISIA, R. Desv.

D. lateralis, Macq.

DEGEERIA, Meigen.

S. lateralis, Macq.

SCOPOLIA, R. Desv.

E. tentatrix, Lw.

$$
\text { EUTHERA, LW. }
$$


P. americana, Macq.

\title{
PTILOCERA, Macq.
}

The Tachinid fauna of New Jersey, will, when studied, develop many times the number of species above listed. The imperfection of the list is caused not only by the fact that few of the species are recorded from New Jersey, but also because the entire family is very incompletely worked up.

\section{Family DEXID}
D. cerata, Walk.
DEXIA, Meigen.
D. harpasa, Walk.
D. punctata, R. Desv.

SERICOCERA, Macq.

S. pictipennis, Macq.

M. roralis, Linn.

MELANOPEORA, Meigen,

MICROPHTHALMA, Macq.

M. nigra, Macq.

\section{Family SARCOPHAGID王.}

S. carnaria, Linn.

\author{
SARCOPHAGA, Meigen.
}

Caldwell, common-Crane.

S. consobrina, R. Desv.

S. georgina, Wied.

\section{Family MUSCID}

S. calcitrans, Linn.

STOMOXYS, Geoffr.

Common everywhere in the State, and a great pest to cattle. 
H. serrata, R. Desv.

\section{HAMATOBIA, R. Dest.}

The "Horn Fly," "Buffalo Fly" or "Texas Fly." Has invaded all the southern and western counties, and is travelling east and north.

I. viridis, Wied.

IDIA, Meigen.

MESEMBRINA, Meigen.

M. resplendens, Wahlb.

CALLIPHORA, R. Dest.

C. ergthrocephala, Meigen.

C. vomitoria, Linn.

Common all over the State. Caldwell-Crane.

P. rudis, Fabr.

POLLENIA, R. Desv.

Not rare in houses in September. Less common earlier in the season.

LUCilia, R. Desv.

L. brunnicosa, R. Desv.

L. cæsar, Linn.

Common throughout the State.

L. consobrina, Macq.

L. cornicina, Fabr.

L. fraterna, Macq.

L. macellaria, Fabr.

L. philadelphica, R. Desv.

PYRELLIA, R. Dest.

P. cadaverina, Linn.

$$
\text { MUSCA, Linn. }
$$

M. domestica, Linn.

The common House Fly, abundant everywhere. 
C. stabulans, Fall.

\author{
OYRTONEURA, Macq.
}

MYOSPILA, Rond.

M. meditabunda, Fabr.

\title{
Family ANTHOMYIDE.
}

A. morioides, Zett.

\author{
ARICIA, R. Desv.
}

S. angelicæ, Mreigen.

SPILOGASTER, Macq.

S. urbana, Meigen.

H. armipes, Fall.

HYDROT册A, R. Dest.

H. dentipes, Meigen.

O. leucostoma, Wied.

OPHYRA, R. Desv.

LIMNOPHORA, R. Desv.

I. diaphana, Wied.

Caldwell, not common-Crane.

L. stygia, Meigen.

ANTHOMYIA, Meigen.

A. brassicæ, Bouché

On Cabbage. Locally very common and destructive.

A. campestris, R. Desv.

A. ceparum, Meigen.

On Onions. Locally common and injurious.

A. raphani, Harris.

On Radishes. Not reported in 1889.

A. zeas, Riley.

Injures Corn. Not recorded from New Jersey as yet. 


\title{
HOMALOMYIA, Bouché.
}

H. canicularis, Limn。

E. manicata, Meigen.

H. scalaris, Fabr.

H. tetracantha, Lw.

L. uliginosa, Fallen.

\author{
LISPE, Latr.
}

C. calopyga, Lw.

CENosia, Meigen.

C. nivea, Lrv.

C. fuscopunctata, Macq.

\section{Family CORDYLURID FE.}

C. adusta, Lw.

CORDYLURA, Fallen.

Recorded from New Jersey.

C. bimaculata, Lw.

C. latifrons, Lw.

C. pleuritica, Lw.

C. terminalis, Lw.

SOATOPHAGA, Meigen.

s. squalida, Meigen.

FUOELLIA, R Dest.

F. fucorum, Fallen.

\section{Family HELOMYZID}

H. lateritia, Lw.

BELOMYZA, Fallen.

H. longipennis, Lw.

E. plumata, Lw。 
⿷. fenestralis, Fallen.

\author{
FCOTHECA, Lw.
}

\title{
Family SCIOMYZIDA.
}

SCIOMYZA, Fallen.
S. albocostata, Fallen.
S. luctifera, Lw.
S. nana, Fallen.
S. obtusa, Fallen.
S. pubera, Lw.
S. tenuipes, Lw.
S. vittata, Haliday.

TETANOCERA, Latr.

T. arcuata, Say.

T. combinata, Lw.

T. Havescens, Lw.

T. pallida, Lw.

T. pictipes, $\mathrm{Lw}$.

T. plebeja, Lw.

T. plumosa, Lw.

T. saratogensis, Fitch.

T. sparsa, Lw.

DRYOMYZA, Fallen.

D. anilis, Fallen.

D. simplex, Lw.

Family PSILID Æ.

L. cylindrica, Say:

LOXOCERA, Meigen.

L. pleuritica, Lw. 
P. lateralis, Lw.

PSILA, Meigen.

P. sternalis, Lw.

\section{Family MICROPEZID压.}

calobata, Meigen.

C. antennipennis, Say.

C. lasciva, Fabr.

\section{Family ORTALIDÆ.}

P. undata, Wied.

PYRGOTA, Wied.

Caldwell, not common-Crane.

P. valida, Harris.

A. pertusus, Lw.

AMPHIONEPHES, LW.

RIVELLIA, R. Desv.

R. viridulans, R. Desv.

Caldwell, rare-Crane.

C. picta, Fabr.

CAMPTONEURA, Macq.

I. marginata, Say.

IDANA, LW.

T. humilis, Lw.

TEPHRONOTA, LW.

S. cribrum, Lw.

STIOTOOEPHALA, Lw.

S. corticalis, Fitch.

S. vau, Say. 
C. annulipes, Macq.

\section{CALLOPISTRIA, LW.}

S. Vibrans, Lim.

SEOPTERA, Kirby.

E. notata, Wied.

$$
\text { EUXESTA, LW. }
$$

CH开TOPIS, LW.

C. aenea, Wied.

\section{Family TRYPETID E.}

T. fratria, Lw.

TRYPETA, Meigen.

T. suavis, Lw.

T. longipennis, Wied.

Caldwell, common-Crane.

T. obliqua, Say.

T. polita, Iw.

T. cingulata, Lw.

Recorded from Long Branch, New Jersey.

T. pomonella, Walsh.

Locally injurious to Apple, but seems confined to very few varieties.

T. rotundipennis, $\mathrm{Lw}$.

T. sparsa, Wied.

T. comma, Wied.

T. latifrons, $\mathrm{Lw}$.

T. solidaginis, Fitch.

T. alba, Lw.

T. albidipennis, Lw.

T. vernoniæ, Lw:

T. seriata, Lw.

T. angustipennis, LW. 
T. clathrata, Lw.

T. geminata, Lw.

T. bella, Fitch.

T. festiva, Lw.

\section{Family LONCHAIDE.}

P. superba, Lw.

PALLOPTERA, Fallen.

L. polita, Say.

LONOHAA, Fallen。

L. rufitarsis, Macq.

\section{Family SAPROMYZID正.}

S. compedita, Lw.

SAPROMYZA, Fallen.

S. fraterna, Lw.

S. Iupulina, Fabr.

S. longipennis, Meigen.

S. philadelphica, Lw.

S. quadrilineata, Lw.

S. vulgaris, Fitch.

LAUXANIA, Latr.

L. cylindricornis, Fabr.

L. frontalis, Lw.

L. gracilipes, Lw.

L. manuleata, Lw.

L. obscura, Lw.

\section{Family PHYCODROMIDE.}

C. frigida, Fallen.

CELOPA, Meigen.

C. nitidula, Zett.

Both species are common to Europe and North America. 


\section{Family HETERONEURID压.}

HETERONEURA, Fallen.

ㅂ. albimana, Meigen。

Also common to Europe and North America.

\section{Family OPOMYZID巫.}

O. signicosta, Walk.

OPOMYZA, Fallen,

S. flava, Linn.

SCYPEELLA, R. Desv.

\section{Family SEPSID AE.}

S. similis, Macq.

SEPSIS, Fallen.

NEMOPODA, R. Desv.

N. cylindrica, Fabr.

N. minuta, Wied.

\section{Family PIOPHILD正.}

P. casei, Linn.

PIOPHILA, Fallen.

The common "Cheese Mite."

P. nigriceps, Meigen.

P. petasionis, L. Duf.

\section{Family DIOPSID王.}

SPHYRACEPHALA, Say.

S. brevicornis, Say. 


\section{Family EPHYDRIDAE.}

D. brevicauda, Lw.

Dichate, Meigen.

N. bella, Lw.

NOTIPHILA, Fallen.

N. carinata, Liv.

N. scalaris, Lw.

N. unicolor, Lw.

N. vittata. Lw.

PARALIMNA, LW.

P. appendiculata, Lw.

P. atra, Lw.

PSILOPA, Fallen.

P. scoriacea, Lw.

H. formosa, Lw。

HYDRELLIA, R. Desv.

H. hypoleuca, Lw.

H. ischiaca, Lw.

H. obscuriceps, Lw.

H. scapularis, Lw.

且. valida, Lw.

P. debilis, Lw.

PHILYGRIA, Stenh.

P. fuscicornis, Lw.

P. abbreviata, Lw.

PARYDRA, Stenh.

P. bituberculata, Lw.

P. breviceps, Lw.

P. paullula, Lw.

P. quadritriberculata, Lw. 
E. atrovirens, Lw.

EPHYDRA, Fallen.

E. subopacus, Lw.

E. obscuripes, Lw.

S. favillacea, Lw.

SCATELLA, R. Desv.

S. lugens, Lw.

S. quadrata, Fallen.

C平NIA, R. Dest.

C. spinosa, Lw:

I. spilota, Curt.

IL ҮTEEA, Ealiday.

\section{Family GEOMYZID王。}

D. pulchra, Lw.

DIAstata, Meigen.

\section{Family DROSOPHILIDF.}

PHORTIOA, Schiner.

P. leucostoma, Lw.

STEGANA, Meigen.

S. hypoleuca, Meigen.

S. nigra, Meigen.

DROSOPHILA, Fallen.

D. graminum, Fallen.

D. quinaria, L $\pi$.

D. transversa, Fallen. 


\section{Family OSCINID丝.}

G. anchora, Lw.

GAURAX, LW.

G. festivus, Lw.

O. atriceps, Lw.

OSCINIS, Latr.

O. dorsata, Lw.

O. umbrosa, $\mathrm{Lw}$.

MEROMYZA, Meigen.

M. americana, Fitch.

Common throughout the State, but not injurious.

S. obesa, Fitch.

SIPHONELLA, Macq.

CHLOROPS, Meigen.

C. versicolor, Lw.

C. crocota, $L w$.

C. grata, Lw.

\section{Family AGROMYZIDE.}

L. arcuata, Lw.

LOBIOPTERA, Wahlb.

AULACIGASTER, Macq.

A. rufitarsis, Macq.

L. simplex, $L w$.

$$
\text { LEUCOPIS, Meigen. }
$$

DESMOMETOPA, LW.

D. latipes, Meigen.

AGROMYZA, Fallen.

A. æneiventris, Fallen.

A. angulata, Lw. 
104 GEOLOGICAL SURVEY OF NEW JERSEY.

A. coronata, Lw.

A. magnicornis, Lw.

A. simplex, Lw.

A. tritici, Fitch.

A. virens, Lw.

PHYLLOMYZA, Fallen.

P. nitens, Lw.

\section{Family BORBORIDEE.}

BORBORUS, Meigen.

B. equinus, Fallen.

\section{Family PHORID王.}

GYMNOPHORA, Macq.

G. arcuata, Meigen.

$$
\text { PHORA, Latr. }
$$

P. atra, Fabr.

P. fuscipes, Macq.

P. rufipes, Meigen.

\section{Family HIPPOBOSCIDE.}

O. americana, Leach.

OLFERSIA, Wied.

Lives on Bubo virginianus and Buteo borealis.

O. albipennis, Say.

Lives on Ardea herodias.

O. ardeæ, Macq. 
O. avicularia, Linn.

ORNITHOMYIA, Latr.

O. nebulosa, Say.

O. pallida, Say.

O. confluens, Say.

L. depressa, Say.

LIPOPTENA, Nitsch.

M. ovinus, Linn.

MELOPHAGUS, Latr.

H. equina, Linn.

HIPPOBOSCA, Linn.

\section{Order ORTHOPTERA.}

For the list it this order, I am primarily indebted to Mr. Lawrence Bruner, the Entomologist of the Nebraska Experiment Station, and an authority in the present order. $\mathrm{He}$ is to be credited with the list in its entirety so far as systematic arrangement and general locality are concerned. I have, however, added Mr. Crane's authority for species taken by him, and have given also some notes of species taken by myself. I have also made use of Mr. William T. Dayis' list of the Orthoptera of Staten Island for dates of appearance, and sometimes for notes on habits.

\section{DERMAPTERA.}

\section{Family FORFICULID王.}

F. aculeata, Scudd.

$$
\text { FORFICULA, Linn. }
$$

F. auricularia, Linn.

The European " Ear Wig." An introduced species. 
SPONGOPHORA, Serv.

S. brunneipennis, Serv.

ANISOLABIA, Fieb.

A. maritima, Bon.

Common near the steamboat pier at Sandy Hook, but I found it nowhere else. This species was not on Mr. Bruner's list.

L. minor, Linn.

LABIA, Leach.

Common to this country and Europe. Not rare. Caldwell, rare-Crane.

\section{ORTHOPTERA.}

\section{Family BLATTID瓜.}

PHYLLODROMIA, Serv.

P. germanica, Linn.

The common small cockroach, water bug or croton bug. Disgustingly common in some localities.

P. borealis, Sauss.

I. unicolor, Scudd.

ISCHNOPTERA, Burm.

Under bark, June-Davis.

I. pennsylvanica, De G.

Under bark, June-Davis. Caldwell, common-Crane.

P. orientalis, Linn.

\section{PERIPLANETA, Burm.}

The "Black Beetle" or "Oriental Roach." A large, black species, common in houses around kitchen sinks. Newark, not common-Crane.

P. americana, Linn.

Caldwell, common-Crane. New Brunswick, rare-Smith. 


\title{
Family PHASMID电.
}

D. femorata, Say.

\author{
DIAPHEROMERA, Gray.
}

The "Walking Stick." I have taken a ferr specimens of this peculiar creature. Caldwell, not common-Crane.

\section{Family MANTIDAE.}

STAGMOMANTIS, Scudd.

S. carolina, Burm.

S. dimidiata, Burm.

\section{Family GRYLLIDA.}

TRIDACTYLUS, Oliv.

T. terminalis, scudd.

T. apicalis, Say.

I took a specimen of one of these odd little crickets in Ocean county the present season.

G. borealis, Burm.

GRYLLOTALPA, Latr.

The mole cricket. Lives in dams and along ditches, and has been recorded as injurious in potato fields. August-Davis. Caldwell, not common-Crane.

G. columbia, Scudd.

Habits like the preceding. August-Davis.

G. abbreviatus, Serv.

\section{GRYLLUS, Linn.}

Caldwell, common-Crane. Common also on cranberry bogs, where it is supposed to eat into the fruit. 


\section{GEOLOGICAL SURVEY OF NEW JERSEY.}

G. luctuosus, Serv.

Caldwell, common-Crane.

G. pennsylvanicus, Burm.

Newark, New Brunswick, Jamesburg, on cranberry bogsSmith.

G. neglectus, Scudd.

Caldwell, common-Crane, sub nom. niger. Ocean county, on cranberry bogs-Smith.

N. fasciatus, De G.

\section{NEMOBIUS, Serv.}

Jamesburg, on cranberry bogs-Smith.

N. vittatus, Harris.

Omitted by Mr. Bruner. Caldwell, common-Craue. Late June and July-Davis.

N. exiguus, Say.

In salt meadows, on Iva frutescens, in August-Davis.

\section{ANAXIPHUS, Sauss.}

A. pulicarius, Sauss.

Occurs in Pennsylvania and Delaware. It can be added to the list with some doubt-Bruner.

E. agitator, Uhl.

\section{ВАPITHUS, Uhl.}

OROOHARIS, Uhl.

O. saltator, Uhl.

๔. niveus, Serv.

\section{GCANTHUS, Serv.}

Common all over the State. Caldwell, common-Crane.

⿷. latipennis, Riley.

I have never taken a specimen of this.

๘. fasciatus, Fitch.

Newark, not rare-Smith.

ФE. angustipennis, Fitch. 
Æ. bipunctatus, De G.

Mr. Bruner does not give these three species. Mr. Davis records them all from Staten Island. I have myself taken them in New Jersey.

\section{Family LOCUSTID匣.}

OEUTOPHILUS, Scudd.

C. maculatus, Harris.

September-Davis.

C. lapidicolus, Scudd.

Caldwell, common-Crane.

C. uhleri, Scudd.

C. gracilipes, Hald.

CYRTOPHYLLUS, Burm.

C. concavus, Harr.

The well-known katydid. It is heard in August all over the State. Caldwell, common-Crane.

AMBLYCORYPHA, Stal.

A. oblongifolia, De G.

Newark.

A. rotundifolia, Scudd.

Both of these are found on Staten Island, in August-Daris.

A. uhleri, Bruner.

MICROCENTRUM, Scudd.

M. laurifolium, Linn.

M. retinervis, Burm.

Common on cranberry bogs. Does considerable damage by eating into berries. 
S. furculata, Bruner.

\section{SCUDDERIA, Stal.}

Caldwell, common-Crane. Jamesburg, on cranberry bogs -Smith.

S. pistillata, Bruner.

S. angustifolia, Harr.

S. curvicauda, De G.

Caldwell, common-Crane. August 6th-Davis. Jamesburg, on cranberry bogs-Smith.

S. furcata, Bruner.

Jamesburg, on cranberry bogs-Smith.

C. ensiger, Harr.

CONOCEPEALUS, Thunb.

July 9th, on Staten Island-Davis.

C. exilicanorus, Davis.

In salt meadows, on Spartina-Davis.

C. robustus, scudd.

Staten Island, in August-Davis.

C. retusus, Scudd.

Caldwell, rare-Crane. This is not on Mr. Bruner's list.

C. dissimilis, Serv.

'This is not on Mr. Bruner's list. Mr. Davis records it from Staten Island, in August, and it is very certain to occur with us.

O. vulgare, Harr.

\section{ORCHELIMUM, Serv.}

Staten Island, in July-Davis. Newark, Sandy Hook, Jamesburg-Smith. Common on cranberry bogs.

O. glaberrimum, Burm.

Caldwell, common-Crane.

O. concinnum, Scudd.

Staten Island, in July-Davis.

O. agile, De G. 
X. fasciatum, De G.

\title{
XIPHIDIUM, Serv.
}

Caldwell, rare-Crane. Staten Island, in August-Davis. Common at Jamesburg, on cranberry bogs-Smith.

X. brevipenne, Scudd.

Jamesburg, common on cranberry bogs-Smith.

X. saltans, Scudd. (?)

X. strictum, Scudd.(?)

T. dorsalis, Burm.

THYREONOTUS, Serv.

T. pachymerus, Burm.

\section{Family ACRIDID}

O. brachyptera, scudd.

\section{OPOMALA, Serv.}

T. brevicornis, Linn.

TRUXALIS, Linn.

S. admirabilis, Uhl.

\author{
SYRBULA, Stal.
}

This has been found in Delaware and in Pennsylvania, and will probably be found also in New Jersey-Bruner.

C. viridis, Scudd.

CHRYSOCHRAON, ฐcudd.

I have taken this in Ocean and Monmouth counties, on cranberry bogs-Smith.

S. lineata, Scudd.

STETHEOPHYM், Fisher.

C. conspersa, Harr.

CHLÖ̈ALTIS, Harr.

C. punctulata, Scudd. 


\section{2}

GEOLOGICAL SURVEY OF NEW JERSEY.

C. curtipennis, Harr.

Caldwell, common-Crane.

\section{STENOBOTHRUS, Fischer.}

S. maculipennis, Scudd.

Ocean Grove, not common-Crane. I also found this on cranberry bogs.

S. æqualis, Scudd.

Jamesburg, on cranberry bogs. Sandy Hook-Smith.

Var. bilineatus, Scudd.

S. propinquum, Scudd.

Caldwell, not common-Crane. This species is not on Mr. Bruner's list.

GOMPHOCERUS, Thunb.

G. carinatus, Scudd.

Taken in Penusylvania and Delaware, and will probably be found in New Jersey-Bruner.

P. atlantica, Scudd.

PAROXYA, Scudd.

Newark, Anglesea, Jamesburg, on cranberry bogs-Smith.

P. recta, Scudd.

Jamesburg, on cranberry bogs-Smith.

P. floridana, Thos.

Caldwell, not common-Crane. This is not on Mr. Bruner's list.

P. scudderi, Uhl.

PEZOTETTIX, Burm.

P. edax, Sauss.

Caldwell, not common-Crane. This is not on Mr. Bruner's list.

\section{MELANOPLUS, Stal,}

M. femur-rubrum, De G.

Common everywhere in the State. 
M. atlanis, Riley.

M. bivittatus, Say.

Caldwell, common-Crane. Common also on cranberry bogs in Ocean and Monmouth counties.

M. collinus, Scudd.

M. punctulatus, Uhl.

I have taken this on cranberry bogs in Ocean county.

ACRIDIUM, Burm.

A. alutaceum, Harr.

Caldwell, common-Crane. Common on cranberry bogs.

A. rubiginosum, Harr.

A. obscurum, Burm.

Newark, Caldwell-Crane.

\section{SCHISTOCEROA, Stal.}

S. americana, Dru.

Mr. Davis records this from Staten Island in November. Newark-Angleman.

CHORTOPHAGA, Sauss.

C. viridifasciata, De G.

Var. virginiana, Fabr.

Var. radiata, Harr.

Var. infuscata, Harr.

Caldwell, common-Crane. This insect in all its protean forms was very common this spring around and on cranberry bogs. It occurs throughout the State.

\section{ENCOPTOLOPHUS, Scudd.}

E. sordidus, Burm.

Caldwell, common-Crane. Newark, New BrunswickSmith. 


\section{GEOLOGICAL SURVEY OF NEW JERSEY.}

ARPEIA, Stal.

A. sulphurea, Fabr.

Caldwell, common-Crane. I have taken this also on cranberry bogs.

A. xanthoptera, Burm.

Caldwell, not common-Crane.

\section{HIPPISCUS, Sauss.}

H. tuberculatus, Beauv.

H. rugosus, Scudd.

Caldwell, rare-Crane.

E. phœnicopterus, Germ.

Caldwell, not common-Crane. New Brunswick-Smith.

P. fenestralis, Serv.

\section{PSINIDIA, Stal.}

Taken in August on Staten Island, by Mr. Davis.

P. eucerata, Uhl.

Ocean Grove, common-Crane. Also taken on cranberry bogs. This species is not on Mr. Bruner's list.

TRIMEROTROPIS, Stal.

T. maritima, Harr.

Ocean Grove, not common-Crane. Sandy Hook, in early August. Quite common and very shy.

CIRCOTETTIX, Scudd.

C. verruculatus, Kirby.

\section{SPHARAGEMON, Scudd.}

S. æquale, Scudd.

Ocean Grove, common-Crane. I have taken it on crauberry bogs at Jamesburg, not rarely. 
S. bolli, Scudd.

Caldwell, not common-Crane.

s. balteatum, scudd.

Jamesburg, on cranberry bogs.

S. collare, Scudd.

I have taken this on cranberry bogs at Jamesburg. It is not on Mr. Bruner's list.

\section{SCIRTETTICA, Bruner.}

S. marmorata, Harr.

Ocean Grove, not rare-Crane. Jamesburg, rare-Smith.

D. carolina, Linn.

DISSOSTEIRA, Scudd.

Common throughout the State.

B. cristata, Harr.

BATRICHIDEA, Serv.

Caldwell, rare-Crane.

B, carinata, Scudd.

Taken on Staten Island in April, by Mr. Davis.

T. lateralis, Say.

\section{TETTIGIDEA, Scudd.}

Taken on Staten Island in April and May, by Mr. Davis.

T. polymorpha, Burm.

Taken by Mr. Davis, on Staten Island, April to August.

T. triangularis, Scudd.

\section{TETTIX, Fischer.}

T. ornatus, Say.

Caldwell, common-Crane. April to September-Davis.

T. granulatus, Kirby.

A pril to September, on Staten Island-Davis.

T. cucullatus, Scudd. 


\section{Order HeMIPTERA.}

Any list of the species of this order must necessarily be largely tentative. There is not a single special collection of Hemiptera in the State, and few of the collectors ever pick up a specimen except where they mistake it for a beetle. The describers of species have therefore derived little of their material from this State, and seldom quote New Jersey among the localities. The result is that the list must be made up of those species known to occur on all sides of the State, and which may be therefore reasonably expected to be found with us. Mr. Crane's list and the few species taken by myself are the only positive records.

\section{SUB-ORdER HETEROPTERA.}

In this sub-order' Uhler's Check List (Brooklyn, New York, 1886,) has been my guide, and I have included those species which are quoted from the United States generally, from the Atlantic Stater, and from the Eastern States, the latter term including the Middle States, in Mr. Uhler's nomenclature.

\section{Family SCUTELLERIDA.}

HOM $\approx M U S$, Dallas.

H. grammicus, Wolff:

H. æneifrons, Say.

C. porosus, Germ.

CAMIRUS, Stal.

ACANTHOLOMA, Stal.

A. denticulata, Stal.

EURYGASTER, Lap.

E. alternatrus, Say. 


\section{Family CORIMEL ENIDAE.}

C. atra, Am. \& Serv.

CORIMEL 开NA, White.

C. nitiduloides, Wolft:

Caldwell, not common-Crane.

C. lateralis, Fabr.

C. pulicaria, Germ.

¿. marginella, Dall.

\section{Family CYDNIDA.}

PANG开US, Stal.

P. bilineatus, Say.

MELANÆ⿻彐丨UUS, Uhl.

M. robustus, Uhl.

M. picinus, Uh1.

M. ubleri, Sign.

A. spinifrons, Say.

AMNESTUS, Dall.

A. pusillus, Uhl.

L. anthracinus, Uhl.

LOBONOTUS, Uhl.

CANTHOPHORUS, Muls. et Rey.

C. cinctus, Beauv.

\section{Family PENTATOMID ZE.}

Sub-Family ASOPINAE.

PERILLUS, Stal.

P. circumcinctus, Stal.

P. exaptus, Say. 
REACOGNATHUS, Fieb.

R. americanus, Stal.

ZICRONA, Am. et Serv.

Z. cuprea, Dall.

PODISUS, H-S.

P. cynicus, Say.

P. placidus, Uhl.

P. serieventris, Uhl.

P. spinosus, Dall.

Caldwell, common-Crane.

P. modestus, Dall.

P. bracteatus, Fitch.

P. politus, Uhl.

L. humeralis, Uhl.

LIOTROPIS, Uhl.

Sub-Family HALYDIN

P. cinctipes, Say.

PODOPS, Lap.

BROCHYMENA, Am. et Serv.

B. arborea, Say.

Caldwell, common-Crane.

B. quadripustulata, Fabr.

B. annulata, Fabr.

B. laticornis, Say.

Sub-Family PENTATOMINA.

开LIA, Fabr.

A. americana, Dall. 
N. undata, Say.

NEOTTIGLOSSA, Kirby.

N. trilineata, Kirby.

C. carnifex, Fabr.

COSMOPEPLA, Stal.

Caldwell, rare-Crane.

E. pugnax, Fabr.

GBALUS, Stal.

MORMIDEA, Am, et §erv.

M. lugens, Fabr.

Caldwell, rare-Crane.

E. fissilis, Uhl.

EUCHISTUS, Dall.

E. servus, Say.

E. tristigmus, Say.

Caldwell, rare-Crane.

E. variolaris, Pal, Beanv.

Caldwell, common-Crane.

E. ictericus, Linn.

C. delius, Say.

CGNUS, Dall.

HYMENARCYS, Am. et Serv.

H. æqualis, Say.

H. nervosa, Say.

M. insertus, Say.

MENECLES, Stal.

L. senilis, Say.

LIODERMA, Uhl.

L. belfragii, Stal.

L. ligata, Say.

Caldwell, rare-Crane. 
TRICHOPEPLA, Stal.

T. semivittata, Say.

T. atricornis, Stal.

P. limbolaris, Stal.

\author{
PERIBALUS, Muls.
}

THYANTA, Stal.

T. custator, Fabr.

NEZARA, Am. et Serv.

N. pennsylvanica, De G.

Caldwell, common-Crane.

N. hilaris, Say.

I have taken a few specimens of this.

B. dimidiata, Say.

BANASA, Stal.

B. calva, Say.

\title{
Sub-Family ACANTHOSOMINAE.
}

AOANTHOSOMA, Curt.

A. cruciata, Say.

A. lateralis, Say.

A. nebulosa, Kirby.

\section{Family COREID}

CEARIESTERUS, Lap.

O. antennator, Fabr.

CORYNOCORIS, Mayr.

C. typhæus, Fabr.

C. distinctus, Dall.

ARCHIMERUS, Burm.

A. calcarator, Fabr. 
E. galeator, Fabr.

EUTHOCTHA, Mayr.

METAPODIUS, Westw.

M. femoratus, Fabr.

Caldwell, not common-Crane.

M. terminalis, Dall.

\section{LEPTOGLOSSUS, Guer.}

L. oppositus, Say.

L. corculus, Mayr.

ANASA, Am. et Serv.

A. tristis, De G.

The "Squash Bug." Common all over the State. CaldwellCrane.

ALYDUS, Fabr.

A. calcaratus, Fabr.

A. eurinus, Say.

Caldwell, common-Crane.

A. pilosulus, H-S.

A. quinquespinosus, Say.

A. rufipes, Westw.

PROTENOR, Stal.

P. belfragei, Hagl.

\section{Family BERYTID 2 .}

N. muticus, Say.

NEIDES, Latr.

J. spinosus, Say.

JALYSUS, Stal.

Caldwell, not common-Crane. 
HARMOSTES, Burm.

B. reflexulus, Stal.

Caldwell, rare-Crane.

E. fraterculus, Say.

\#. obliquus, Say.

C. lateralis, Say.

C. punctipennis, Dall.

C. novæ-boracensis, Sign.

C. nigristernum, Sign.

C. sidæ, Fabr.

Caldwell, rare-Crane.

\section{Family LYGAID ÆE:}

NYSIUS, Dall.

N. angustatus, Uhl.

O. producta, Uhl.

ORSILLACIS, Uhl.

BELONOCHILUS, Uhl.

B. numenius, Say.

ORSILLUS, Dall.

O. scolopax, Say.

ISCHNOREYNCHUS, Fieb.

I. didymus, Zett.

CYMUS, Hahn.

O. Iuridus, Stal.

O. angustatus, Stal.

BLISSUS, Burm.

B. leucopterus, Say.

The "Chinch Bug." Caldwell, rare-Crane. 
GEOCORIS, Fall.

G. fuliginosus, Say.

Caldwell, not common-Crane.

G. limbatus, Stal.

G. griseus, Dall.

G. borealis, Dall.

EDANCALA, Am, et Serv.

巴. dorsalis, Say.

C. disconotus, Say.

CROPHIUS, Stal.

LIGYROCORIS, Stal.

L. sylvestris, Linn.

I. constrictus, Say.

M. serripes, Oliv.

MYODOCHA, Latr.

HER AIUS, Stal.

\#. plebejus, Stal.

ㅍ. insignis, Uhl.

P. basalis, Dall.

P. vicina, Dall.

PAMERA, Say.

P. nodosa, Say.

PTOCHIOMERA, Sey.

CNEMODUS, B-S.

C. mavortius, Say.

TRAPEZONOTUS, Fieb.

T. nebulosus, Fall.

T. rufipes, Stal.

Đ. arenarius, Linn.

EMBLETHIS, Fieb.

P. fraternus, Uhl.

PERITRECHUS, Fieb. 
124 GEOLOGICAL SURVEY OF NEW JERSEY.

GONIANOTUS, Fieb.

G. marginepunctatus, Wolft:

EREMOCORIS, Fieb.

E. ferus, Say.

MICROTOMA, Lap.

M. carbonaria, Rossi.

MEGALONOTUS, Fieb.

M. unus, Say".

THAUMASTOPUS, Fitch.

T. alacris, Walk.

PELIOPELTA, Uhl.

P. abbreviata, Uhl.

MELANOCORYPHUS, Stal.

M. bicrucis, Say.

LYGÆUS, Fabr。

L. kalmii, Stal.

L. turcicus, Fabr.

Caldwell, common-Crane.

ONCOPELTUS, Stal.

O. fasciatus, Dall.

Caldwell, not common-Crane.

\section{Family PYRRHOCORID框。}

LARGUS, Hahn.

L. succinctus, Linn. 


\section{Family CAPSID王.}

BRACEYTROPIS, Fieb.

B. calcarata, Fall.

TRIGONOTYLUS, Fieb.

T. ruficornis, Fall,

MIRIS, Fabr.

M. affinis, Reut.

M. dorsalis, Say.

LEPTOTERNA, Fieb.

L. dolobrata, Linn.

RESTHENIA, Spin.

R. insitiva, Say.

R. nigricollis, Reut.

R. insignis, Say.

R. circumcincta, Say.

LOPIDEA, Uhl.

L. media, Say.

L. confluens, Say.

PHYTOCORIS, Fabr.

P. eximius, Reut.

P. puella, Reut.

P. pallidicornis, Reut.

P. scrupeus, Say.

P. colon, Say.

NEUROCOLPUS, Reut.

N. nubilus, Say.

N. inops, Say.

COMPSOCEROCORIS, Reut.

C. annulicornis, Reut.

DICHROOSCYTUS, Fieb.

D. rufipennis, Fall. 
C. rapidus, Say.

CALOCORIS, Fieb.

C. bipunctatus, Fabr.

MEGACCELUM, Fieb.

M. fasciatum, Uh].

M. grossum, Uhl.

ONCOGNATHUS, Fieb.

O. binotatus, Fabr.

L. pabulinus, Limm.

LYGUS, Bahn.

L. lucorum, Neyer.

L. pratensis, Linn.

L. belfragii, Reut.

L. invitus, Say.

L. chlorionis, Say.

CACCOBAPHES, ULl.

C. sanguinarius, Uhl.

TROPIDOSTEPTES, Uhl.

T. cardinalis, Uhl.

P. basalis, Reut.

PECILOSCYTUS, Fieb.

P. imbecillus, Say.

P. geminus, Say.

PECILOCAPSUS, Reut.

P. lineatus, Fabr.

Common throughout the State. Caldwell, common-Crane.

P. goniphorus, Say.

P. affinis, Reut.

P. marginalis, Reut.

C. nebulosus, Uhl.

C. grandis, Uhl.

CAMPTOBROCHIS, Fieb. 
DER A COCORIS, Kirsch.

D. capillaris, Fabr.

CAPSUS, Fabr.

c. ater, Limn.

PAMEROCORIS, Uhl.

P. anthocoroides, Uhl.

M. flicis, Linn.

MONALOCORIS, Dahl.

BRYOCORIS, Fall.

B. pteridis, Fall.

HYALIODES, Reut.

\#. vitripennis, Say.

STEENAROPS, Uhl.

S. chloris, Uhl.

S. malinus, Uhl.

ILNACORA, Reut.

I. stalii, Reut.

PILOPHORUS, Hahn.

P. bifasciatus, Fabr.

P. confusus, Kirsch.

P. Walshii, Uhl.

MALACOCORIS, Fieb.

M. irroratus, Say.

GLOBICEPS, Latr.

G. flavomaculatus, Fabr.

NABIDEA, Uhl.

N. coracina, Uhl.

EUCEROCORIs, Westw.

Đ. guttulatus, Uhl.

GARGANUS, Stal.

G. fusiformis, Say. 
S. stygica, Say.

$$
\text { STIPHROSOMA, Fieb. }
$$

ㅍ. bractatus, Say.

$$
\text { HALTICUS, Burm. }
$$

I. famelicus, Uhl.

$$
\text { IDOLOCORIS, D. \& Sc. }
$$

O. obliquus, Uhl.

$$
\text { ORECTODERUS, Uhl. }
$$

C. tenuicornis, Say.

$$
\text { CYLAPU̇, Say. }
$$

O. decolor, Fall.

$$
\text { ONCOTYLUS; Fieb. }
$$

RHINACLOA, Reut.

R. forticornis, Reut.

P. delicatus, Uhl.

$$
\text { PSALLUS, Fieb. }
$$

E. ornatus, Reut.

$$
\text { EPISCOPUS, Reut. }
$$

Not rare in Ocean county.

PLAGIOGNATHUS, Fieb.

P. grandis, Reut.

P. obscurus, Uhl.

AGALLIASTES, Fieb.

A. verbasci, H-S.

\section{Family ACANTHIID}

L. fitchii, Reut.

LYCTOCORIS, Hahn.

L. americanus, Dall. 
TRIPHLEPS, Fieb.

T. insidiosus, Say.

Common on grasses throughout the State.

CARDIASTETHUS, Fieb.

C. Iuridellus, Fieb.

c. pergandei, Reut.

ANTHOCORIS, Say.

A. musculus, Say.

А. antevolens, White.

ACANTHIA, Fabr.

A. lectularia, Linn.

The "Bed Bug." Found throughout the State. Caldwell, common-Crane.

\section{Family TINGITID $\mathbb{E}$.}

PIESMA, St. Farg. et Serv.

P. cinerea, Say.

C. ciliata, Say.

CORYTEUCA, Stal.

C. juglandis, Fitch.

LEPTOSTYLA, Stal.

I. oblonga, Say.

I. tabida, H-s̀.

PHEYSATOCHILA, Fieb.

P. plexa, Say.

LEPTOYPEA, Stal.

I. mutica, Say. 
T. clavata, Stal.

TINGIS, Fabr.

T. Iurida, Stal.

T. uniformis, Stal.

T. elongata, Uhl.

TELEONEMIA, Costa.

\section{Family ARADIDE.}

A. æqualis, Say.

ARADUS, Fabr.

A. similis, Say.

A. acutus, Say.

A. quadrilineatus, Say.

A. rectus, Say.

A. tuberculifer, Kirby.

A. affinis, Kirby.

A. inornatus, Uhl.

BRACHYREYNCHUS, Lap.

B. granulatus, Say.

B. simplex, Uhl.

ANEURUS, Curt.

A. inconstans, Uhl.

A. simplex, Uhl.

\section{Family PHYMATID}

P. Wolffii, Stal.

PEYMATA, Latr.

P. erosa, Guer.

Common throughout the State in my experience. CaldrellCrane.

MACROCEPHALUS, Swed.

M. cimicoides, Swed. 


\section{Family NABID王.}

NABIS, Latr.

N. fusca, Stein.

PAGASA, Stal.

P. nitida, Stal.

CORISCUS, Schrank.

C. subcoleoptratus, Kirby.

C. pallescens, Reut.

C. annulatus, Reut.

C. rufusculus, Reut.

C. ferus, Linn.

Caldwell, common-Crave.

C. kalmii, Reut.

C. roseipennis, Reut.

C. punctipes, Reut.

C. propinquus, Reut.

C. vicarius, Reut.

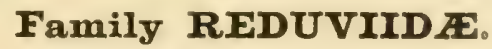

SINEA, Am, et Serv.

S. diadema, Fabr.

Caldwell, common-Crane.

AOHOLLA, Stal.

A. multispinosa, De G.

PRIONIDUS, Uhl.

P. cristatus, Linn.

A southern species, taken at Sandy Hook, in August. Common at Jamesburg-Angleman. I have also taken it there. 
MILYAS, Stal.

M. cinctus, Fabr.

Caldwell, rare-Crane.

APIOMERUS, Hahn.

A. crassipes, Fabr.

MELANOLESTES, Stal.

M. picipes, H-S.

M. abdominalis, H-S.

Caldwell, rare-Crane.

OPSICGTUS, Rlug.

O. personatus, Limn.

PYGOLAMPIS, Germ.

P. sericea, Stal.

ONCEROTRACHELUS, Stal.

O. acuminatus, Say.

\section{Family EMESID RE.}

EMESA, Fabr.

E. longipes, De G.

Caldwell, common-Crane.

BARGE, Stal.

B. annulipes, stal.

B. simplicipes, Uhl.

OERASCOPUS, Eeinek.

C. errabundus, Say. 
CATALOGUE OF INSECTS.

\section{Family LIMNOBATIDEE.}

L. lineata, Say.

LIMNOBATES, Burm.

\section{Family HYDROBATID}

H. remigis, Say.

HYGROTRECHUS, Stal.

H. conformis, Uhl.

L. marginatus, Say.

LIMNOTRECEUS, Stal.

LIMNOPORUS, Stal.

L. rufoscutellatus, Latr.

S. picta, H-S.

STEPHANIA, White.

M. hesperius, Uhl.

METROBATES, Uhl.

\section{Family VELIID}

HEBRUS, Curtis.

ㅍ. americanus, Uhl.

H. pusillus, Burm.

MESOVELIA, Mule.

M. bisignata, Uhl.

RHAGOVELIA, Mayr.

R, obesa, Uhl. 


\section{Family SALDIDE.}

\section{SALDA, Fabr.}
S. ligata, Say.
S. confluens, Say.
S. pellita, Uhl.
S. sphacelata, Uhl.
S. coreacea, Uhl.
S. anthracina, Uhl.
S. littoralis, Linn.
S. lugubris, Say.
S. deplanata, Uhl.
S. interstitialis, Say.
S. reperta, Uhl.
S. orbiculata, Uhl.
S. humilis, Say.
S. saltatoria, Linn.
S. separata, Uhl.

\section{Family GALGULID死.}

PELOGONUS, Latr.

P. americanus, Uh!.

GALGULUS, Latr.

G. oculatus, Fabr.

Caldwell, rare-Crane.

\section{Family NAUCORIDE.}

PELOCORIS, Stal.

P. femorata, Pal. Beauv. 


\section{Family BELOSTOMATIDEE.}

Z. fluminea, Say.

ZAITHA, Am. et Serv.

Z. aurantiacum, Leidy.

BELOSTOMA, Auct.

B. americanum, Leidy.

Caldwell, common-Crane.

B. griseus, Say,

BENACUS, Stal.

\section{Family NEPID王.}

N. apiculata, Uhl.

NEPA, Fabr.

Caldwell, common-Crane.

R. fusca, Pal. Beauv.

RANATRA, Fabr.

Caldwell, common-Crane.

\section{Family NOTONECTIDE.}

N. insulata, Kirby.

NOTONECTA, Linn.

N. undulata, Say.

Caldwell, not common-Crane.

N. irrorata, Uhl.

N. punctata, Fieb. 
A. platycnemis, Fieb.

ANISOPS, Spin.

P. striola, Fieb.

PLEA, Leach.

\section{Family CORISIDE.}

C. calva, Say.

CORISA, Geoff.

Caldwell, common-Crane.

C. tarsalis, Fieb.

C. signata, Fieb.

C. hieroglyphica, Duf.

C. verticalis, Fieb.

C. burmeisteri, Fieb.

C. interrupta, Say.

C. erichsonii, Fieb.

C. limitata, Fieb.

C. stigmatica, Fieb.

C. alternata, Say.

C. harrisii, Uhl.

C. kennicottii, Uhl.

\section{SUB-ORDER HOMOPTERA.}

In this sub-order, Mr. W. H. Ashmead kindly furnished the material. I know of absolutely no published list that would have been useful, and Mr. Ashmead's contribution is therefore an extremely valuable one. I have made but few additions to the list, and have added only Mr. Crane's records, and some notes of my own on species taken or observed by me. Mr. Ashmead is therefore authority for the entire list except for these few comments. 
Mr. Ashmead suggests that the list will be very much enlarged in the Aphididce and Coccide, and the same is probably true of all other families in the sub-order.

\section{Family CICADID正.}

\section{Sub-Family CICAdINA。}

TETTIGIA, Am. et Serv.

T. hieroglyphica, Say.

\section{TIBICEUS, Latr.}

T. septendecim, Linn.

The "Seventeen-year Locust" or "Periodical Cicada." Occurs at intervals in all parts of the State.

C. auletus, Germ.

CICADA, Linn.

C. variegatus, Fabr.

C. striatipes, Hald.

O. pruinosa, Say.

Caldwell, common-Crane. The "Dog-day Harvest Fly." Common throughout the State.

\section{Family FULGORIDE.}

Sub-Family ACONONINE.

ACONONIA, Am. et Serv.

A. serveillei, Spin.

CHLOROCHARA, Stal.

C. vivida, Fabr. 
O. pruinosa, Say.

\title{
Sub-Family FLATIN 2 .
}

ORMENIS, Stal.

Caldwell, rare-Crane. I have found it not uncommon near New Brunswick.

F. conica, Say.

\author{
FLATA, Fabr.
}

PCECILOPTERA, Latr.

P. nova, Say.

P. septentrionalis, Spin.

Caldwell, common-Crane.

AMPHISCEPA, Germ.

A. bivittata, Say.

I have taken this, not rarely, in the sweep net.

Sub-Family ISSIN正.

ISSUS, Fabr.

I. aciculatus, Uhl.

BRUCHOMORPHA, Newn.

B. oculata, Newn.

NASO, Fitch.

N. robertsonii, Fitch.

Sub-Family CALOSCELINF.

P. atra, Germ.

PHYLLOSCELIS, Germ.

P. pallescens, Germ. 


\section{Sab-Family DITYOPHORINA.}

S. sulcipes, Say.

\section{SOOLOPS, Schaum.}

I have taken this, not frequently, in Ocean county.

M. tabida, Spin.

\section{MONOPSIS, Spin.}

Sub-Family FULGORINA.

CALYPTOPROCTUS, Spin,

C. (?) elegans, Oliv.

\section{Sab-Family CIXIINA.}

OTIOCERUS, Kirby.

O. coquerbertii, Kirby.

O. degeerii, Kirby.

O. signoretii, Fitch.

O. stollii, Kirby.

O. wolfii, Kirby.

\section{ANOTIA, Kirby.}

A. bonnellii, Kirby.

A. robertsonii, Fitch.

A. Westwoodii, Fitch.

CIXIUS, Latr.

C. cinctifrons, Fitch.

C. coleopenne, Fitch.

C. albicincta, Germ.

C. impunctatus, Fitch.

C. pini, Fitch. 
C. 5-lineatus, Stal.

C. stigmatus, Say.

C. vicarius, Walk.

D. annulata, Fitch.

\section{Sub-Family DELPHACINAE。}

DELPHAX, Fabr.

D. albipes, Fitch.

D. arvensis, Fitch.

D. bicolor, Fitch.

D. dorsalis, Fitch.

D. tricarinata, Say.

\section{Family MEMBRACID}

\section{Sub-Family CENTROTINÆ.}

M. carjæ, Fitch.

\section{Sub-Family MEMBRACINA.}

ENCEENOPA, Am. et Serv.

E. curvata, Fabr.

Caldwell, common-Crane. Common throughout the State.

E. binotata, Say.

Caldwelì, common-Crane.

\section{Sub-Family HOPLOPHORIN死.}

PLATYCOTIS, Stal.

P. quadrivittata, Say.

Caldwell, common-Crane.

P. vittata, Fabr. 


\section{Sub-Family SMILIINA.}

S. inermis, Fabr.

STICTOCEPHALA, Stal.

S. festina, Say.

CERESA, Am. et Serv.

C. brevicornis, Fitch.

C. bubulus, Fabr.

Caldwell, common-Crane. Common throughout the State.

C. diceros, Say.

Caldwell, rare-Crane.

E. sinuata, Fabr.

EUTYLIA, Burm.

PUBLILIA, Stal.

P. concava, Say.

SMILIA, Germ.

S. camelus, Fabr.

S. vau, Say.

S. vittata, Am, et Serv.

C. fenestrata, Fitch.

CYRTOSIA, Fitch.

O. marmorata, Say.

THELIA, Am. et Serv.

T. acuminata, Linn.

T. belligera, Say.

T. bimaculata, Fabr.

Caldwell, not common-Crane.

T. cratægi, Fitch.

T. quercus, Fitch.

T. univittata, Harris. 
TELAMONA, Fitch.

T. ampelopsidis, Harr.

Caldwell, rare-Crane.

T. concava, Fitch.

T. coryli, Fitch.

T. fagi, Fitch.

T. querci, Fitch.

T. reclivata, Fitch.

T. tristis, Fitch.

T. unicolor, Fitch.

AROHASIA, Stal.

A. galeator, Fabr.

Sub-Family DARNINAE.

O. arcuata, Say.

OPHIDERMA, Fairm.

O. mera, Say.

O. salamandra, Fairm.

\section{Family CERCOPIDA.}

Sub-Family CERCOPINA.

MONECPHORA, Am. et Serv.

M. bicincta, Say.

\section{Sub-Family APHROPHORINAE.}

LEPYRONIA, Am. et Serv.

L. quadrangularis, Say.

Caldwell, not common-Crane. 


\section{APHROPHORA, Germ.}

A. parallela, Say.

A. quadrinotata, Say.

PHIL平NUS, Stal.

F. bilineatus, Say.

P. lineatus, Linn.

P. sarogotensis, Fitch.

P. spumaria, Germ.

Clostoptera, Germ.

C. achatina, Germ.

C. pini, Fitch.

C. proteus, Fitch.

C. obtusa, Say.

C. testacea, Fitch.

Caldwell, common-Crane.

C. xanthocephala, Germ.

\section{Sub-Family LEDRIN \&.}

LEDRA, Fabr.

L. perdita, Am. et Serv.

\section{Sub-Family GLYPONIN E.}

X. viridis, Fabr.

\section{XEROPHLFA, Germ.}

G. Iærilineata, Fitch.

GLYPONA, Germ.

G. octolineata, Say.

G. scarlatina, Fitch. 
P. peltata, Uhl.

PAROPHOLIS, Uhl.

P. atra, Fabr.

PEnThimia, Germ.

P. americana, Fitch.

\section{Snb-Family TETTIGONIN 卮.}

PROCONIA, Serv.

P. costalis, Fabr.

ONCOMETOPIA, Stal.

O. obtusa, Fabr.

O. orbona, Fabr.

O. undata, Fabr.

Of this latter.I have taken a few specimens.

HOMALODISCA, Stal.

H. coagulata, Say.

AULACIZES, Am. et Serv.

A. irrorata, Fabr.

DIEDROCEPHALA, Spin.

D. coccinea, Först.

D. flaviceps, Riley.

D. mollipes, Say.

Caldwell, not common-Crane. I have found it generally distributed and quite common.

H. communis, Fitch.

HELOCHARA, Fitch.

Caldwell, common-Crane.

EVACANTHUS, Serv.

E. orbitalis, Fitch. 
T. bifida, Say.

TETTIGONIA, Fabr.

T. trifasciata, Saý.

T. tripunctata, Fitch.

\section{Sub-Family ACOCEPHALINA.}

A. solidaginis, Harr.

ACOCEPHALA, Germ.

HECALUS, Stal.

H. fenestratus, Uhl.

PARABOLOCRATUS, Fieb.

P. viridis, Uhl.

SELENOOEPHALUS, Germ.

S. vitillinus, Fitch.

PLATYMETOPIUS, Burm.

P. acutus, Say.

P. albonotatus, Fitch.

\section{Family BYTHOSCOPID 포.}

PEDIOPSIS, Burm.

P. trimaculatus, Fitch.

P. viridis, Fitch.

B. pallidus, Fitch.

вттноOSCOPUS, Germ.

B. seminudus, Say.

AGALLIA, Curt.

A. sanguinolenta, Prov.

A. quadripunctata, Prov.

Common on cranberry bogs in Burlington and Monmouth counties. 
I. alternata, Fitch.

IDIOOERUS, Lewis.

I. lachrymalis, Fitch.

I. maculipennis, Fitch.

I. suturalis, Fitch.

\section{Family JASSID 压.}

\section{Sub-Family JASSIN}

C. olitoria, Say.

CELIDEA, Germ.

C. subbifasciata, Say.

Caldwell, rare-Crane.

\section{ATHYSANUS, Burm.}

A. fenestratus, Fitch.

A. minor, Fitch.

A. nigrinasi, Fitch.

A. variabilis, Fitch.

A. striatulus, Fallen.

Common on cranberry bogs everywhere.

J. clitellarius, Say.

JASSUS, Fabr.

Caldwell, common-Crane.

J. irroratus, Say.

Caldwell, common-Crane.

J. inimicus, Say.

J. unicolor, Fitch.

D. sayi, Fitch.

DELTOCEPHALUS, Burm. 
E. comes, Say.

\section{ERYTHRONEURA, Fitch.}

E. vitis, Harris.-

The common leaf hopper of the Grape.

E. vulnerata, Fitch.

E. querci, Fitch.

EMPOA, Fitch.

E. rosæ, Harris.

E. fabæ, Harris.

\section{Sub-Family TYPHLOCIBIN 2 .}

T. affinis, Fitch.

TYPHLOCYBA, Germ.

T. tricincta, Fitch.

\section{Family PSYLLID王.}

Sub-Family LIVIINA.

L. maculipennis, Fitch.

LIVIA, Latr.

L. vernalis, Fitch.

\section{Sub-Family APHALARIN $\boldsymbol{A}$.}

A. ilicis, Ashm.

APHALARA, Först.

Sub-Family PSYLLINAE.

C. nigripennis, Riley.

CALOPHYA, LW.

On Rhus sp.; quite common. 
P. annulata, Fitch.

PSYLLA, Geoffr.

P. carpini, Fitch.

P. quadrilineata, Fitch.

PAOHYPSYLLA, Riley.

P. celtidis-mama, Riley.

P. venusta, O.S.

BLASTOPHY3ૈ, Riley.

B. c-gemma, Riley.

Sub-Family TRIOZINA.

T. diospyri, Ashm.

TRIOZA, Först.

T. tripunctata, Fitch.

\section{Family APHIDIDE.}

Sub-Family APHIDINF.

SIPEONOPHORA, Koch.

S. asclepiadis, Fitch.

S. Jiriodendris, Mon.

S. pisi, Kalt.

S. rudbeckiæ, Fitch.

S. rosæ, Linn.

S. rubi, Kalt.

S. sonchi, Limn.

S. salicicola, Thos.

S. viticola, 'Thos. 
P. humuli, Schrank.

\title{
PHORODON, Pass.
}

The hop plant-louse. Occurs wherever Hop and Plum grow.

\section{RHOPALOSIPHUM, Koch.}

R. berberidis, Fitch.

M. solani, Thos.

\author{
MEGOURA, Buckt.
}

11. cerasi, Fabr.

MYZUS, Pass.

\section{DREPANOSIPHUM, Koch.}

D. quercifolii, Walsh.

A. brassicæ, Linn.

APHIS, Linn.

The cabbage plant-louse. Common everywhere.
A. cornifoliæ, Fitch.

A. cratægeifoliæ, Fitu.

A. diospyri, Thos.

A. mali, Fabr.

A. malifoliæ, Fitch.

A. maidis, Fiteh.

A. pinicolens, Fitch.

A. pruni, Koch.

A. prunifoliæ, Fitch.

A. rumicis, Linn.

A. salicicola, Thos.

A. sambuci, Linn.

A. sambucifoliæ, Fitch.

\section{Sub-Fami1y CALLIPTERINAE.}

MI. caryella, Fitch.

MONELLIA, Oestl. 
CALLIPTERUS, Koch.

C. betulæcolens, Fitch.

C. castaneæ, Fitch.

\section{Sub-Family LAGHNINA.}

LACHNUS, Burm.

L. abietis, Fitch.

L. alnifolii, Fitch.

L. laricifex, Fitch.

L. quercifoliæ, Fitch.

L. strobi, Fitch.

I. salicelis, Fitch.

P. fagi, Linn,

PHYLLAPEIS, Koch.

Sub-Family SCHIZONEURIN FE。

S. americana, Riley.

SCHIZONEURA, Hart.

S. imbricator, Fitch.

S. lanigera, Hausm.

S. strobi, Fitch.

S. ulmi, Limn.

S. tessellata, Fitch.

GLYPHINA, Koch.

G. ulmicola, Fitch.

VACUNA, Heyd.

V. spinosus, Shimer. 
Sub-Family PEMPHIGIN E.

P. populicaulis, Fitch.

PEMPHIGUS, Hart.

P. populiglobuli, Fitch.

P. populivenæ, Fitch.

P. rhois, Fitch.

\section{Sub-Family CHERMESIN Æ̇.}

C. laricifoliæ, Fitch.

CEERMES, Linn.

C. pinifoliæ, Fitch.

\section{Sub-Family PHYLLOXERIN A}

P. caryæ-caulis, Fitch.

PHYLLOXERA, Fonsc.

P. caryæ-foliæ, Fitch.

P. carjææ-चenæ, Fitch.

P. vastatrix, Planch.

\section{Family ALEURODIDE.}

ALEURODES, Am. et Serv.

A. abutilonea, Hald.

A. brassicæ, Walk.

A. corni, Hald.

\section{Family COCCID E.}

Sub-Family COCCIN王。

D. adonidum, Linn.

DACTYLOPIUM, Costa.

P. aceris, Geoff:

PSEUDOCOCCUS, Westw. 


\section{Sub-Family LECANINA.}

ORTHEZIA, Am. et Serv.

O. americana, Walk.

PULVINARIA, Targ-Toz.

P. innumerabilis, Rathv.

P. vitis, Linn.

L. cerasifex, Fitch.

LECANIUM; Burm.

I. fitchii, Sign.

I. hesperidum, Linn.

I juglandis, Bouché.

I. persicæ, Fabr.

L. quercicitronis, Fitch.

\section{Sub-Family DIASPIN.F.}

ASPIDIOTUS, Bouché.

A. abietis, Comst.

A. ancylus, Putn.

A. betulæ, Bärensp.

A. juglans-regiæ, Comst.

DIASPIS, Bremi.

D. circularis, Fitch.

D. rosæ, Sandb.

LEPIDOSAPHES, Shimer.

L. pormorum, Bouché.

O. furfurus, Fitch.

CHIONASPIS, Sign.

C. pinifolii, Fitch.

C. salicis, Einn. 


\section{Order neuroptera.}

\section{Family TERMITID尼。}

T. flavipes, Koll.

TERMES, Linn.

Common throughout the State. Caldwell, conamon-Crane.

\section{Family PSOCID压。}

A. divinatorius, Fabr.

ATROPOS, Leach.

Is common throughout the State.

P. signatus, Hagen.

PSOCUS, Latr.

P. pumilis, Hagen.

P. venosus, Burm.

P. contaminatus, Hagen.

P. striatus, Walk.

P. quietus, Hagen.

P. madidus, Hagen.

P. salicis, Fitch.

\section{Family PERLID ze.}

P. regalis, Newn.

PTERONARCYS, Newn.

P. nobilis, Hagen. 
454 GEOLOGICAL SURVEY OF NEW JERSEY.

P. abnormis, Newn.

PERLA, Geoff.

P. arida, Hagen.

P. coulonii, Pictet.

P. tristis, Hagen.

P. capitata, Pictet.

P. similis, Hagen.

P. xanthenes, Newn.

P. occipitalis, Pictet.

P. placida, Hagen.

P. ephyre, Newn.

I. cydippe, Newn.

ISOPTERYX, Pictet.

CAPNIA, Pictet.

C. pygmæa, Burm.

TANIOPTERYX, Pictet.

T. fasciata, Burm.

Caldwell, common-Crane.

T. similis, Hagen.

Caldwell, not common-Crane.

ז. maura, Pictet.

NEMOURA, Pictet.

N. albidipennis, Walk.

L. tenuis, Pictet.

LEUCTRA, Stephens.

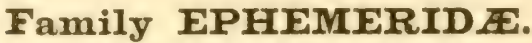

P. bilineata, Say.

PALINGENIA, Burm.

Caldwell, common-Crane.

P. limbata, Serv. 
E. decora, Walk.

EPHEMERA, Linn.

Caldwell, common-Crane.

B. vicaria, Walk.

BÄ̈TIS, Leach.

B. obesa, Say.

Caldwell, not rare-Crane.

B. fusca, Walk.

Caldivell, not rare-Crane.

B. canadensis, Walk.

Caldwell, not common-Crane.

B. noveboracana, Licht.

P. concinnus, Walk.

POTAMANTHUS, Pictet.

Caldwell, common-Crane.

P. nebulosus, Walk.

Caldwell, rare-Crane.

C. unicolor, Hagen.

CLÖ̈, Leach.

C. vicina, Hagen.

Caldwell, common-Crane.

C. amica, Hagen.

C Æ̇NIS, Stephens.

\section{Family ODONATA.}

Sub-Family CALOPTERYGINA.

C. apicalis, Burm.

CALOPTERYX, Leach.

O. maculata, Beauv.

Caldwell, common-Crane. 
C. virginica, Dru.

Caldwell, common-Crane.

\author{
HET AIRINA, Hagen。
}

H. americana, Fabr.

H. tricolor, Burm.

\title{
Sub-Family AGRIONIN压,
}

L. rectangularis, Say.

\section{LESTES, Leach.}

Recorded from New Jersey.

L. congener, Hagen.

L. eurina, Say.

L. unguiculata, Hagen.

Recorded from Bergen Hill, New Jersey.

L. hamata, Hagen.

Recorded from Bergen Hill, New Jersey.

A. irene, Hagen.

\section{AGRION, Fabr.}

Recorded from New Jersey.

A. iners, Hagen.

New Jersey specimens in Collection American Entomological Society.

A. ramburii, Sely's.

Recorded from Bergen Hill, New Jersey:

A. hastatum, Say.

Recorded from Bergen Hill, New Jersey.

A. saucium, Burm.

A. civile, Hagen.

A. violaceum, Hagen.

Recorded from New Jersey. 
A. apicale, Say.

A. aspersum, Hagen.

Recorded from Bergen Hill, New Jersey.

\section{Sub-Family GOMPHINE⿸}

G. armatus, Selys.

GOMPHUS, Leach.

Caldwell, rare-Crane.

G. adelphus, Selys.

G. fraternus, Say.

G. spicatus, Hagen.

Caldwell, common-Crane.

G. exilis, Selys.

H. brevistylus, Selys.

HAGENIUS, Selys.

CORDULEGASTER, Leach.

C. maculatus, Selys.

C. obliquus, Say.

P. thoreyi, Hagen.

PETALURA, Leach.

\section{Sub-Family FSCHNINA.}

A. junius, Dru.

ANAX, Leach.

Common in Ocean county, and generally distributed in the State. Caldwell, common-Crane.

平. clepsydra, Say.

ÆESCHNA, Fabr.

Aॄ. verticalis, Hagen. 
Æ. constricta, Say.

Caldwell, common-Crane.

A. grandis, Linn.

Recorded from Bergen Hill, New Jersey. I have taken it in Ocean county.

平, ingens, Ramb.

赵. heros, Fab.

Recorded from New Jersey. Generally distributed. Caldwell, not common-Crane.

A. quadriguttata, Burm.

Caldwell, common-Crane.

\section{Sub-Family CORDULINA.}

MACROMIA, Ramb.

M. tæniolata, Ramb.

DIDYMOPS, Ramb.

D. transversa, Say.

Mount Holly, New Jersey-Collection American Entomological Society.

D. obsoleta, Say.

C. lateralis, Burm.

CORDULA, Leach.

\section{Sub-Family LIBELLULIN E.}

T. carolina, Linn.

TRAMEA, Hagen.

Recorded from New Jersey.

T. lacerata, Hagen.

I took this in Ocean county luring the present season (1S89). 
C. eponina, Dru.

CELITHEMIS, Hagen.

New Jersey-Collection American Entomological Society.

\section{PLATYTHEMIS, Hagen.}

P. trimaculata, De G.

Common throughout the State. Caldwell, common-Crane.

\section{LIBELLULA, Linn.}

L. quadrimaculata, Linn.

L. semifasciata, Burm.

Recorded from New Jersey.

L. luctuosa, Burm.

Recorded from New Jersey. Caldwell, common-Crane.

L. pulchella, Dru.

Recorded from New Jersey. Caldwell, common-Crane.

L. auripennis, Burm.

Recorded from New Jersey. Specimens in Collection American Entomological Society.

I. incesta, Hagen.

New Jersey-Collection American Entomological Society.

L. lydia, Dru.

New Jersey-Collection American Entomological Society.

L. quadrupla, Say.

Recorded from New Jersey.

L. plumbea, Uhl.

Recorded from New Jersey.

\section{MESOTHEMIS, Hagen.}

M. simplicicollis, Say.

Recorded from New Jersey. Ocean Grove-Crane.

M. longipennis, Burm.

New Jersey-Collection American Entomological Society. 
D. costifera, Uhl.

\section{DIPLAX, Charp.}

D. vicina, Hagen.

Recorded from Bergen Hill, New Jersey.

D. semicincta, Say.

D. rubicundula, Say.

Recorded from Bergen Hill, New Jersey. Caldwell, common -Crane.

D. berenice, Dru.

Recorded from Bergen Hill, New Jersey, and common elsewhere in the State.

D. intacta, Hagen.

D. elisa, Hagen.

Recorded from Bergen Hill, New Jersey.

D. ornata, Ramb.

P. domitia, Dru.

\section{PERITHEMIS, Eagen.}

Recorded from New Jersey.

NANNOPHYA, Ramb.

N. bella, Uhl.

Recorded from New Jersey.

\section{Family SIALIDF.}

S. infumata, Newn.

SIALIS, Latr.

S. americana, Ramb.

CHAULIODES, Latr.

C. pectinicornis, Limn.

Caldwell, common-Crane. 
C. serricornis, Say.

C. maculatus, Say.

Caldwell, common-Crane.

C. cornuta, Linn.

CORYDALIS, Latr.

Common throughout the State. Caldwell-Crane..

\section{Family HEMEROBID IE.}

ALEURONIA, Fitch.

A. westwoodii, Fitch.

MICROMUS, Ramb.

M. insipidus, Hagen.

H. amiculus, Fitch.

HEMEROBIUS, Linn.

E. alternatus, Fitch.

H. stigmaterus, Fitch.

H. castanea, Fitch.

B. tutatrix, Fitch.

H. conjunctus, Fitch.

표. pinidumus, Fitch.

ㅍ. hyalinatus, Fitch.

POLYSTECHOTES, Burm.

P. punctatus, Fabr.

P. vittatus, Say.

Recorded from New Jersey.

M. brunnea, Say.

MANTISPA, Illig.

M. interrupta, Say. 
C. oculata, Say.

CHRYSOPA, Leach.

C. illepida, Fitch.

C. albicornis, Fitch.

C. chlorophana, Fitch.

C. fulvibucca, Fitch.

C. chi, Fitch.

O. ypsilon, Fitch.

C. latipennis, Schneid.

Caldwell, common-Crane.

C. nigricornis, Burm.

C. lineaticornis, Fitch.

C. 4-punctata, Burm.

C. ruflabris, Burm.

C. interrupta, Schneid.

C. emuncta, Fitch.

C. harrisii, Fitch.

C. plorabunda, Fitch.

C. Hava, Scop.

ACANTHACLISIS, Ramb.

A. americana, Dru.

MYYRMELEON, Linn.

M. gratus, Say.

M. obsoletus, Say.

M. abdominalis, Say.

Recorded from New Jersey.

M. nebulosus, Oliv.

M. immaculatus, De G.

Caldwell, rare-Crane.

ASCALAPHUS, Fabr.

A. hyalinus, Latr.

A. 4-punctatus, Burm. 


\section{Family PANORPIDE.}

P. rufescens, Ramb.

PANORPA, Linn.

Caldwell, common-Crane.

P. venosa, Westw.

P. debilis, Westw.

P. nebulosa, Westw.

P. maculosa, Hagen.

B. occidentis, Walk.

BITTACUS, Latr.

\section{Family PHRYGANIDID}

NEURONIA, Leach.

N. semifasciata, Say.

Recorded from New Jersey. Caldwell, common-Crane.

N. postica, Walk.

Caldwell, common-Crane.

L. rhombicus, Linn.

\section{LIMNOPHILUS, Leach.}

Caldwell, rare-Crane.

L. interruptus, Say.

Described from New Jersey. Caldwell, not common-Crane.

L. pudicus, Hagen.

E. subfasciata, Say.

ENOICYLA, Ramb.

E. lepida, Hagen.

N. pyraloides, Walk.

NOTIDOBIA, Steph.

S. candida, Hagen.

SETODES, Ramb. 
40. GEOLOGICAL SURVEY OF NEW JERSEY.

MACRONEMA, Pictet.

M. zebratum, Hagen.

HYDROPSYCHE, Pictet.

H. scalaris, Hagen.

H. morosa, Hagen.

Caldwell, common-Crane.

В. phalerata, Hagen.

PHILOPOTAMUS, Leach.

P. distinctus, Walk.

Caldwell, rare-Crane.

FOLYCENTROPUS, Curtis.

P. validus, Walk.

P. lucidus, Hagen.

CHIMARREA, Leach.

O. aterrima, Hagen. 


\section{CONCLUSION.}

In the foregoing pages 6,098 species are listed, to which future studies will undoubtedly add at least 20 per cent. more; they are distributed as follows :

\begin{tabular}{|c|c|c|c|}
\hline & & & \\
\hline Hymenoptera ........................... & 30 & 302 & 1,074 \\
\hline Coleoptera ................................. & 71 & 815 & 2,227 \\
\hline Lepidoptera ................................. & 28 & 484. & 1,140 \\
\hline Diptera ....................................... & 57 & 319 & 811 \\
\hline Orthoptera .................................. & 7 & 52 & 117 \\
\hline \multicolumn{4}{|l|}{ Hemiptera- } \\
\hline Heteroptera .......................... & 26 & 173 & 318 \\
\hline Homoptera ............................ & 10 & 101 . & 243 \\
\hline Neuroptera ............................. & 9 & 61 & 174 \\
\hline 'Total & 238 & 2,307 & 6,098 \\
\hline
\end{tabular}

Authors are not agreed as to the best way of making up catalogues. Some begin with the higher families, running down to the most degraded; others reverse this proceeding and begin with the least specialized forms, ending with the highest types. Of the lists followed in this catalogue, the Hymenoptera, Orthoptera and Neuropterc run the series from the lowest to the highest. In the Coleoptera, Lepidoptera, Diptera and Hemiptera the highest forms are placed at the head.

In adopting the Linnæan orders, rather than the more numerous divisions of Brauer or Packard, I have followed convenience and not conviction, believing that a catalogue of a restricted fauna is not the place to bring forward a classification not generally accepted. In a future edition of the catalogue I should expect to make the change. 


\section{ERRATA.}

THE FOLLOWING ESCAPED CORRECTION IN PROOF:

Page 172, for CGENIA read C ENIA.

Page 152, for P. serricorne read L. serricorne.

Page 216, for C. nsertus read C. insertus.

Page 370 , for $\mathbf{S}$. palipes read $\mathbf{S}$. pallipes.

Page 370, for CANOMYIA read CENOMYIA.

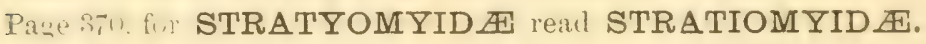

Pace :-:-, th: THERIOPLEOTES, Zell., read THERIOPLECTES, Zett.

Page 385 , for T. pictulum, Pa., read T. pictulum, Will.

Page 429, for LEPTOYPEA read LEPTOPHYA. 


\section{PRINCIPAL ABBREVIATIONS OF AUTHORS' NAMES.}

A.

Aaron..........Aaron, S. Frank.

Abb...........Abbot, John.

Ahr ............Ahrens, August.

Am. et Serv...Amyot \& Serville.

Ashm.........Ashmead, William $\mathrm{H}$.

Aubé...........A A ubé; Charles.

B.

Bärensp........Bärensprung, Felix.

Baly ............Baly, Joseph S.

Bass ............Bassett, H. F.

Bates...........Bates, Henry William.

Bdv.............Boisduval, Jean Alphonse.

Bd-Lec ....... Boisduval \& Leconte.

Beauv. ........ Beauvois, Palisot de.

Beth ...........Bethune, Charles J. S.

Billb... ........ Billberg, Gustav Johann.

Bkh ...........Borkhausen, Moriz B.

Blake.........Blake, Charles A.

Blanch .........Blanchard, E.

Bland..........Bland, James H. B.

Boh............Boheman, Carl H.

Boisd ...........see Bdv.

Bon............ Bonnelli, François André.

Bonr ........... Bonvouloir, Henry de.

Borkh........ see Bkh.

Bouché ........Bouché, Peter Friedrich.

Bourg ...........Bourgeois, J.

Brace...........Brace, John P.

Brem ..........Bremer, Otto.

Brem. \& Grey,

Bremer \& Grey.

Brend .........Brendel, Emil.

Brown ..........Brown, Peter.

Brullé..........Brullé, Auguste.

Bruner ......... Bruner, Lawrence.

Buck............Buckley, S. B.

Buckt..........Buckton, George B.
Buq........... Buquet, Lucien.
Burm........
$\begin{gathered}\text { Burmeister, Hermann Car }\} \\ \text { C. }\end{gathered}$

C.

Cam............Cameron, $\mathrm{P}$.

Cand............Candèze, E.

Casey...........Casey, Thomas L.

Chamb ... .....Chambers, Vactor Toucy.

Chd......... $\left\{\begin{array}{c}\text { Chaudoir, Baron Maxi- } \\ \text { milien de. }\end{array}\right.$

Chap...........Chapman, Thomas.

Charp ......... Charpentier, Toussaint de.

Chevr. ........ Chevrolat, Aug.

Clairv. .........Clairville, J. de.

Clark ......... Clark, Bracy (Diptera).

Clark .........Clark, Hamlet (Coleoptera).

Clem ...........Clemens, Brackenridge.

Comst..........Comstock, John Henry.

Costa ...........Costa, Achille.

Coup............Couper, William.

Cr..............Crotch, Geo. R.

Cram...........Cramer, Pieter.

Cress............Cresson, Ezra T.

Curtis.........Curtis, John.

D.

Dahl...........Dahlbom, Andres Gustav.

Dall ........... Dallas, William S.

Dalm ..........Dalman, Johann Wilhelm.

Davis.......... Davis, William $T$.

De G..........De Geer, Carl.

Dej........... \{ Dejean, Comte Pierre Fran-

Deis Marie Auguste.

Desv ........... Desvoidy, Robineau.

Doubl ...... Doubleday, Edward.

Doubl-Hew . Doubleday \& Hewitson.

Drap........... Drapiez, A.

Dru.............Drury, Drew. 
Duf Dufour, Leon.

Duft. Duftschmid, Caspar.

Dum........ \{ $\begin{gathered}\text { Duméril, André Marie Con- } \\ \text { stant. }\end{gathered}$

J)inc ........... Duncan, James.

Dup......... \{ $\begin{gathered}\text { Duponchel Philogène Au- } \\ \text { guste Joseph. }\end{gathered}$

D'Urb ...... D'Urban, William Stewart M.

\section{E.}

Elw. H........ Elwarls, Henry.

Edw........ $\left\{\begin{array}{c}\text { Edwards, W. H. (in Rho- } \\ \text { palocera). }\end{array}\right.$ Eich ............Eichhoff, W.

Fr ......... $\{$ Erichson, Wilhelm Ferdi-

Esch........ $\left\{\begin{array}{c}\text { Eschscholtz, Johann Fried- } \\ \text { rich. }\end{array}\right.$

\section{F.}

Fabr ........... Fabricius, Johann Christ.

Fairm......... Fairmaire, Leon.

Fall ............ Fallen, Carl Friedrich.

Feld............Felder, Cajetan.

Fern ...........Fernald, Chas. $H$.

Fieb............Fieber, Franz Xaver.

Fischer.... \{ $\begin{gathered}\text { Fischer, Johannes L. (Dip- } \\ \text { tera). }\end{gathered}$

Fischer.... \{ $\begin{gathered}\text { Fischer, Leopold H. (Orth- } \\ \text { optera). }\end{gathered}$

Fitch...........Fitch, Asa.

Först ........... Förster, Arnold.

Forel...........Forel, Albert.

Forst...........Förster, Johann Reinhold. Fondr ..... \{ Foudras, Antoine Casimir Fourcr ..... Fourcroy, Antoine FranFrohl........... Fuhlich, Jos. Alogs.

\section{G.}

G. \& H .......Gemminger \& Harold.

Gdt ............Goedart, Johann.

Geoff ...........Geoffroy, Etienne Louis.

Germ .........Germar, Ernst Friedrich.

Gey.............see Geyer.

Geyer........Geyer, Carl.

Gn .............Guenée, Achille.

Goetze..... $\left\{\begin{array}{c}\text { Goetze, Johann August } \\ \text { Ephraim. }\end{array}\right.$
Gorh...........Gorham, John.

Gory............Gory, Hippolyte Louis.

Gray........ $\left\{\begin{array}{c}\text { Gray, George R. (Orth- } \\ \text { optera). }\end{array}\right.$

Gray........ $\left\{\begin{array}{c}\text { Gray, John Edward (cisle- } \\ \text { optera). }\end{array}\right.$

Grav....... Gravenhorst, Johann Lud-

Grit..............see Grote.

Grt. \& Rob...Grote \& Robinson.

Grote ..........Grote, Augustus Radclifle.

Guer .........Guerin-Meneville, F. E.

Gyll......... Gyllenhal, Leonhard.

\section{E.}

Hagen .........Hagen, Hermann August

Hahn........Hahn, Carl Wilhelm.

Hald............Haldemann, S. S.

Haliday ....... Haliday, Alexis $\mathrm{H}$.

Harold.........Harold, Edgar von.

Harr ............ see Harris.

Harris ......... Harris, Thaddeus W.

Hartig .........Hartig, Theodore.

Harv ........... Harvey, Leon.

Hausm ..........Hausman, Johann F. L.

Haw ........... Haworth, Adrian Hardy.

Hbst... .... $\left\{\begin{array}{c}\text { Herbst, Johann Friedrich } \\ \text { Wilhelm. }\end{array}\right.$

Heer ............Heęr, Oswald.

Hein............Heinemann, H, von.

Heinek... .... Heineken, Carl.

Hellw ..... $\left\{\begin{array}{c}\text { Hellwig, Johann Christian } \\ \text { Ludwig. }\end{array}\right.$

Hentz..........Hentz, Nicholas Marcell.

Hothin..........Hotlmann, J. J.

Hoffm..........Hoffmeister, H. (Diptera).

Holmgr .......Holmgren, A ugust Emil.

Hope ........... Hope, Frederic William.

Horn ........... Hurn, 1 ieorge $H$.

Howard........ Howard, Leland O.

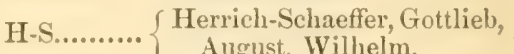

Hüb ... ........Hübner, Jacob.

Hulst ..........Hulst, George D.

Hum............Hummel, Arvid David.

Hy. Edw...... Henry Edwards.

I.

Illig......... $\left\{\begin{array}{c}\text { Illiger, Johann Carl Wil- } \\ \text { helm. }\end{array}\right.$ 
J.

Jaenn...........Jaennicke, F.

Jek. ..........Jekel, Henry.

Jur. ...........Jurine, Louis.

\section{$\mathrm{K}$.}

Kalt ............Kaltenbach, J. H.

Kies......... $\left\{\begin{array}{c}\text { Kiesenwetter, Ernst August } \\ \text { Hellmuth von. }\end{array}\right.$

Kirby .........Kirby, William.

Kirkp......... Kirkpatrick, John.

Kirsch.........Kirsch, Th.

Kirsch ....... Kirschbatu, C. L.

Kirtl........... Kirtland, Jared P.

K1 .......... $\left\{\begin{array}{l}\text { Klug, Joliann Christoph } \\ \text { Friedrich. }\end{array}\right.$

Knoch ......... Knoch, August Wilhelm.

Koch .......... Koch, C. L.

Koll ...........Kollar, Vincenz.

Kraatz..........Kraatz, Gustav.

Kug ............Kugelann, Johann Gottlieb.

Kunze ......... Kunze, Gustav.

\section{L.}

Lac......... $\left\{\begin{array}{l}\text { Lacordaire, Jean Theo- } \\ \text { dora. }\end{array}\right.$
Laf......... $\left\{\begin{array}{c}\text { Marquis de la Ferté-Sen- } \\ \text { ectere. }\end{array}\right.$

Lap.......... Laporte, F. L. de.

Lap. \& Gory..Laporte \& Gory.

Lasp .............Laspeyres, Jacob Heinrich.

Latr........... Latreille, Pierre Andre.

L. Duf..........Leon Dufour.

Leach .........Leach, William Elford.

Le B..........Le Baron, William.

Lec............. Leconte, John L.

Led ............Lederer, Julius.

Leidy. .........Leidy, Joseph.

Lewis ........... Lewis, K. H.

Licht ....... \{ Lichtenstein, Anton Au-

L. or Linn....Linnæus, Carl von.

Lintn.......... Lintner, James Albert.

Lw . ...........Loew, Hermann.

\section{M.}

MacL .........MacLeay, William S.

Macq ........... Macquart, Jean.
Mann........ $\left\{\begin{array}{c}\text { Mannerheim, Carl Gustav } \\ \text { von. }\end{array}\right.$

Mars ...........Marseul, S. A. de.

Marsh .........Marsham, Thomas.

Marsh ..........Marshall, T. A.

Math...........Natthews, A.

Mayr ........ Mayr, Gustar L.

Megerle .... $\left\{\begin{array}{c}\text { Megerle von Muelfeld, } \\ \text { Johann Karl. }\end{array}\right.$

Meigen,........Meigen, Johann Wilhelm.

Mell ............Mellié, J.

Mels ........ \{ $\begin{gathered}\text { Melsheimer, Friedrich } \\ \text { Ernst. }\end{gathered}$

Minot ..........Minot, Charles S.

Moeschl....... Moeschler, Heinrich Benno.

Mon............Monell, J. T.

Moore .........Moore, Frederick.

Morr............Morrison, H. K.

Morris ..... \{ Morris, Margaretta H.

Mots .............Motschulsky, Victor von.

Müll ........ $\left\{\begin{array}{c}\text { Müller, Philipp Wilbrand } \\ \text { Jacob. }\end{array}\right.$

Muls ..........Mulsant, Etienne.

Muls. et Rey...Mulsant et Rey.

N.

Nees........ $\left\{\begin{array}{c}\text { Nees von Esenbeck, Chris- } \\ \text { tian G. }\end{array}\right.$

Newn.......... Newman, Edward.

Nitsch .........Nitzsch, Christian L.

Nord ............Nordmann, Alexander von.

Norton..........Norton, Edward.

Nyl ............ Nylander, William.

\section{O.}

Ochs ...........Ochsenheimer, Ferdinand.

Oestl ............Oestlund, O. W.

Oliv ............ Olivier, Antoine Guillaume.

O-S............ Osten-Sacken, R. von.

\section{P.}

Pack...........Packard, Alpheus Spring.

Pal. Beauv...see Beauv.

Pall .......... Pallas, Peter Simon.

Panz ........ $\left\{\begin{array}{c}\text { Panzer, Georg Wolfgang } \\ \text { Franz. }\end{array}\right.$

Pasc ............Pascoe, Francis P. 


Pass ...........Passerini, Carlo.
Patton ........Patton, William H.
Payk ..........Paykull, Gustaf von.
Peck ..........Peck, William Dandridge.
Perty ........ Perty, Maximilian.
Phillipi ..... Phillipi, F. H. E.
Pict .......... Pictet, François Jules.
Poey ..........Poey, Phelipe.
Prov ... ........Provancher, L'Abbe.
Putn........ Putnam, J. D.
Putz..........Putzeys, H.

R.

Kag ...........Ragonot, Emile L.

Ramb. ...... Rambur, J. Pierre.

Rand........ Randall, John W.

Rathv..........Rathvon, J. H.

Ratz ....... \{ $\begin{gathered}\text { Ratzeburg, Julius Theodor } \\ \text { Christian. }\end{gathered}$

R. Desv...... Robineau Desvoidy.

Reak... ...... Reakirt, Tryon,

Kedt... ..... Redtenbacher, Ludwig.

Reichenb...... Reichenbach, Anton B.

Reitt... ....... Reitter, E.

Reut... ........ Reuter, O. MI.

Riley ....... Riley, Charles Valentine.

Rob ............Robinson, Coleman T.

Rog............Rogers, W. Frederick.

Rond ...........Rondani, Camille.

Rossi......... Rossi, Peter.

Rott ............Rottenburg, S. A. von.

Ruthe. ........Ruthe, Johann Friedrich.

S.

S. \& A ....... see Sm. \& Abb.

Sandb ..........Sandberg, Karl von.

Saund ........ Saunders, William.

Sauss.......... Saussure, Henri de.

Say .............Say, Thomas.

Sohäff ........ Schüffer, Jacob Christian.

Schaum...... Schaum, Hermann Rudolph

Schiff.......... Schiffermüller, Ignaz.

Schiner........ Schiner, J. R.

Schm ...... \{ $\begin{gathered}\text { Schmidt, Wilhelm Ludwig } \\ \text { Ewald. }\end{gathered}$

Schmp-Goeb $\left\{\begin{array}{l}\text { Schmidt-Goebel, Hermann } \\ \text { Max. }\end{array}\right.$

Schneid..... $\begin{gathered}\text { Schneider, Wilhelm Gott- } \\ \text { lieb. }\end{gathered}$
Schr............Schrank, Franz von Paula.

Schum .........Schummel, Theodore Emil.

Scop .......... Scopoli, Johann Anton.

Scriba ........ Scriba W.

Scud ............Scudder, Samuel H.

Seidl .......... Seidlitz, George.

Selys......... $\{\underset{\text { E }}{\text { Selys-Longchamps, Michel }}$

Serv........ \{ $\begin{gathered}\text { Audinet-Serville, Jean } \\ \text { Guilleaume. }\end{gathered}$

Shimer .........Shimer, Henry.

Shuck ......... Shuckard, W. E.

Sign ......... Signoret, Victor.

Sin. \& Abb....Smith \& Abbot.

Smith...... \{ $\begin{gathered}\text { Smith, Frederick (Hymen- } \\ \text { optera) }\end{gathered}$ Smith.... Smith, John B. (Col. et Lep.)

Sol .......... \{ $\begin{gathered}\text { Solier, Antoine Joseph } \\ \text { Jean. }\end{gathered}$

Speyer ....... Speyer, Adolph.

Spin ......... Spinola, Maximilian.

Staeger ....... Staeger, C.

St. Farg.... $\left\{\begin{array}{c}\text { St. Fargeau, Amédée Louis } \\ \text { Michel Le Peletier } \\ \text { Comte de. }\end{array}\right.$

St. F. \& Serv..Saint-Fargeau et Serville.

Stal ...........Stal, Carl,

Stenh.......... Stenhammar, Chr.

Steph......... Stephens, James Francis.

Stretch ....... Stretch, Richard H.

Strk ............Strecker, Hermann. .

Suffr........... Suffrian, E.

S. V........ \{ $\begin{gathered}\text { Schiffermüller, Verzeich- } \\ \text { niss. }\end{gathered}$

Swains......... Swainson, William.

Swed............. Swederus, Nils Samuel.

\section{T.}

Targ-'Toz.......Targioni-Tozetti.

Tasch ..........Taschenberg, E. L.

'Taylor .........Taylor, George W.

Thoms .........Thomson, C. G.

Thos............Thomas, Cyrus.

Thunb ... .... Thunberg, Carl Peter.

Tourn .......... Tournier, $\mathrm{H}$.

Tr..............Treitschke, Friedrich.

U.

Uhler..........Uhler, Philip R.

Urban ........ d'Urban, W. S. M. 


\section{CATALOGUE OF INSECTS.}

W.

Wahib........Wahlberg, P. F.

Wallgr ........Wallengren, H. D. J.

Waltl.........Waltl, Joseph.

Walsh .........Walsh, Benjamin Dann.

Waterh ........ Waterhouse, George Robert.

Web .............Weber, Friedrich.

Wesm..........Wesmael, Constantin.

Westw.........Westwood, John Obadiah.

White ......... White, Adam (Coleoptera).

White ......... White, B. (Hemiptera).

Wied ...... W Wiedemann, Christian R.

Will...........Williston, S. W.
Winnertz .... Winnertz, Johannes.

Walk..........Walker, Francis.

Wlsm......... Walsingham, Thomas.

Wolff ..........Wolff, Johann Friedrich.

Woll............Wollaston, T. Vernon.

W. V.........Wiener, Verzeichniss.

\section{Z.}

Zell. ...........Zeller, Philipp, Christoph.

Zett.......... Z Zetterstedt, Johann, Wil-

Ziegl... ........Ziegler, Daniel.

Zimm .,........Zimmermann, Christoph.

Zinck...........Zincken, Johann T. F. 



\section{INDEX OF GENERA.}

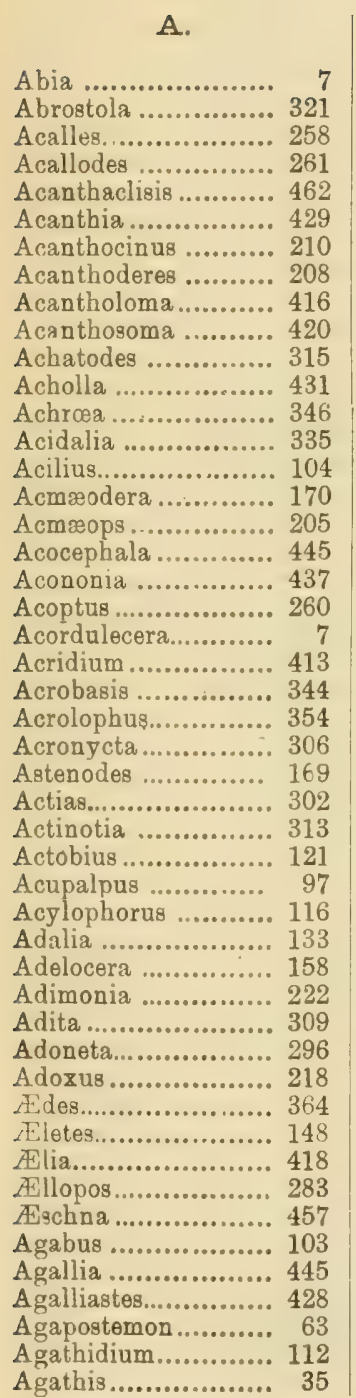

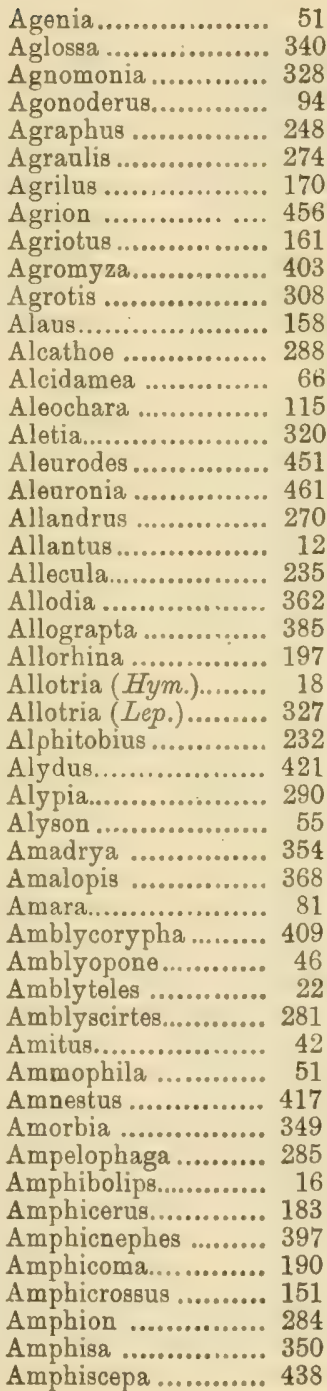

Anacrabro ............ 58

Anædus................ 233

Anagoga ................ 333

Anametis ............. 247

Anasa.................... 421

Anaspis................ 240

Anatis ................... 134

Anax................. 457

Anaxiphus............. 408

Anchodemus ........... 253

Ancyloxypha.......... 281

Ancyronyx............ 156

Andrena................ 63

Andricus................ 17

Androchirus............. 236

Aneurus.................. 430

Angerona .............. 333

Anisodactylus.......... 98

Anisolabia.............. 406

Anisops................ 436

Anisopteryx ........... 338

Anisosticta............. 132

Anisota.................. 303

Anisoxya.............. 238

Anomala............... 195

Anomalon ... ......... 25

Anomis .................. 320

Anomo2............... 215

Anomoglossus......... 93

Anopheles .............. 364

Anotia.................. 439

Antepione.............. 333

Anthaxia .............. 168

Antherophagus......... 142

Anthicus............... 243

Anthidium ........... 66

Anthocharis ........... 278

Anthocomus........... 177

Anthocoris.............. 429

Anthœcia ............... 322

Anthompia............. 394

Anthonomus ............ 254

Anthophora ............ 67

Anthrax.............. 377

Anthrenus ............. 144

Anthribulus ........... 271

Antispila ............... 358

Antocha................. 366

Anytus ................. 309

Apamea............... 314

$(473)$ 
Apanteles ............. 34

Apatelodes............. 298

A pathus................ 68

Apatura ............... 272

Apenes.................. 90

Aphenogaster ........ 46

Aphalara ............. 447

Apholinus.............. 40

Anbidus............... 37

Aphis.................. 449

Aphodius ............... 188

A rhomia.................. 346

Aphonus............... 196

Aphorista .............. 136

Aphrastus............. 249

Aphrophora ........... 443

Aphycus................ 39

A piomerus ............ 432

Apion.................... 249

A pis................... 68

Aplodes................... 334

Apocellus.............. 129

Apristus................ 89

Aptesis ................ 24

Aradus ................. 430

Aramigus .............. 249

Archasia ............... 442

Archimerus............. 420

Arctia .................. 292

Ardistomis ............. 76

Arenetra ............... 31

Argeus ................. 284

Argynnis ............... 274

Árgyra .................. 381

Argyramœba .......... 377

Argyresthia........... 357

Argyria ................ 346

Argyrophyes .......... 291

Arhopalus .............. 203

Aricia.................... 394

Arotes .................. 29

Arphia ................. 414

Arsilonche ............. 307

Artace................... 304

Arthrolips ............. 132

Arthromacra............ 236

Arzama................. 315

Asaphes ................... 165

Ascalaphus............ 462

Asclera.................. 239

Asemum ................ 199

Asilus.................... 376

Asopia................... 340

Asphondylia ........... 360

Aspidiotus ............... 452

Aspidisca.............. 358

Aspilates................ 337

Astata.................. 53

Asthena 335

Atr.njus ............... 187
Atarba................. 366

Athous.................. 164

Athysanus.............. 446

Atimia.................. $: 01$

Atomacera.............. 8

Atomaria............... 142

A tomosia . .............. 375

Atranus ................................ 86

Atropos ................ 453

Atta..................... 16

Attacus ................. 302

Attagenus .............. 144

Attalus................... 178

Attelabus............... 247

Atylotus............... 373

Augochlora ........... 62

Aulacigaster........... 403

Aulacizes ............. 444

Aulacus.................. 18

Auletes ................. 246

Aulonium.............. 139

Axinopalpus ......... 89

Azelina ................ 332

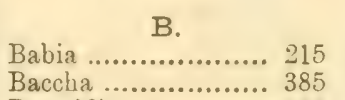

Bactridium............... 154

Badister.................. 83

Bä̈tis................... 455

Bagous ................. 253

Balaninus ............. 263

Balboceras............... 189

Banasa ................. 420

Baptria ................ 339

Barco.................... 432

Baris................... 262

Baropsis................ 259

Barytychius ........... 252

Bassareus ................ 215

Bassus ................. 29

Batrichidea ............. 415

Batrisus ............... 114

Batyle................. 203

Belonochilus .......... 422

Belonuchus .............. 118

Belostoma.............. 435

Belvoisia ................... 391

Bembecia............... 288

Bembex ................ 54

Bembidium ............. 76

Benacus................. 435

Beris ..................... 371

Berosus ................. 108

Betarmon .............. 162

Bibio .................... 363

Bidessus................... 101

Biorhiza................ 17

Bittacomorpha......... 369

Bittacus ............... 463
Blabophanes ........... 354

Blapstinus ............. 232

Blastophysa ........... 448

Blechrus ............... 89

Bledius .................. 128

Blennocampa.......... 11

Blepharida ............. 223

Blepharomastix........ 343

Bleptina................. 330

Blethisa ................ 73

Blissus ................ 422

Boletobius ............. 127

Boletophagus .......... 234

Boletotherus............ 234

Bolitophila ............ 361

Bombus................ 68

Bombylius ............. 378

Borborus.............. 404

Bostrichus .............. 183

Bothrideres ........... 139

Botis.................... 341

Brachyacantha ....... 134

Brachylobus ............ 93

Brachymyrmex........ 45

Brachynus............. 90

Brachypalpus......... 387

Brachypterus .......... 148

Brachyrhynchus....... 430

Brachys................ 171

Brachystylus ........... 248

Brachytarsus ........... 271

Brachytropis............. 425

Bracon ................. 33

Bradycellus ............ 97

Brathinus ............... i13

Brochymena............ 418

Brontes.................. 141

Brotolomia............. 314

Bruchomorpha......... 438

Bruchus ................. 229

Bryaxis.................. 114

Bryocoris .............. 427

Bryophila.............. 307

Bryoporus .............. 127

Buprestis .............. 167

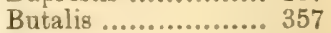

Byrrhus ................ 155

Bythoscopus ............ 445

Byturus ................ 143

\section{C}

Caberodes .............. 331

Uaccobaphes............ 426

Caccecia................... 348

Cacoplia................ 208

Cænia .................. 402

Cænis ..................... 455

Cænocara ............... 183

Cænomyia ............. 370

Cafius .................. 121 
Calandra................ 265

Calathus................ 83

Calephelis ............. 275

Caliroa ................... 11

Calledapteryx ........ 335

Callida .................. 89

Callidium .............. 200

Callidryas ............... 278

Callimorpha ........... 292

Calliopsis ............... 63

Calliphora .............. 393

Callipterus .............. 450

Calloides ................ 203

Callomyia............... 389

Callopistria ........... 398

Calobata ................ 397

Calocampa................. 319

Calochromus .......... 173

Calocoris ................ 426

Calophya.............. 447

Calopteron ............... 172

Calopteryx ............ 455

Calosoma .............. 72

Calothysanis ............ 335

Calpe .................... 320

Calymnia............... 317

Calyptoproctus ......... 439

Calyptus............... 36

Camirus.................. 416

Camponotus ........... 44

Campoplex............. 26

Campsicnemus ......... 382

Camptobrochis ......... 426

Camptoneura .......... 397

Canifa.................... 238

Canthon.................. 186

Canthophorus........... 417

Canthydrus ............ 100

Capnia................... 454

Capnochroa ............. 236

Capsus.................... 427

Capua ................... 350

Carabus................... 72

Caradrina .............. 316

Cardiastethus .......... 429

Cardiophorus............ 158

Caripeta................. 337

Carphoborus............ 269

Carpocapsa.............. 353

Carpophilus............. 149

Casnonia................. 86

Cassida .................. 229

Cataclysta.............. 343

Caterva.................. 337

Catocala................. 324

Catogenus................. 141

Cebrio ................... 166

Cecidomyia.............. 360

Cedius.................... 113

Celetes.................... 172
Celiptera ............... 327

Celithemis ............ 459

Cemonus ................ 56

Cenopsis.................. 349

Centeterus .............. 23

Centrinus ............... 262

Centrodera.............. 205

Centronopus ............ 231

Cephaloon .............. 239

Cephus .................. 15

Ceraphron .............. 41

Cerascopus .............. 43\%

Ceratina.................. 67

Ceratomia ............... 287

Ceratopogon ............ 365

Ceratosoma............. 27

Ceraturgus............... 374

Cerceris................. 55

Cercopeus ................ 248

Cercus .................. 149

Cercyon ................. 109

Ceresa................... 441

Ceria .................... 388

Ceropales................. 51

Ceroptres ............... 17

Cerotainia ............... 375

Cerotoma .............. 221

Ceruchus ................ 186

Cerura................... 301

Cerylon................. 139

Ceutophilus ............ 409

Ceutorhynchus........ 261

Chætocnema........... 226

Chætopis................ 398

Chalcis................... 38

Chalcoderma ........... 258

Chalcolepidius........... 158

Chalcophora............ 166

Chalepus................. 196

Chalybion............... 52

Chamyris ............... 323

Charadra............... 306

Chariessa ............... 180

Chariesterus ............ 420

Charistena .............. 228

Chauliodes................ 460

Chauliognathus........ 175

Chelonus................. 34

Chelymorpha ........... 229

Chermes ................. 45]

Chilocorus ............... 134

Chiloneurus ........... 39

Chilosia.................. 384

Chimarrha.............. 464

Chion .................... 200

Chionaspis .............. 452

Chironomus............. 364

Chlænius................ 91

Chlænogramma........ 287

Chlamys................ 215
Chloëaltig .............. 411

Chlorion................ 52

Chlorochara ........... 437

Chloromyia ............ 371

Chlorops ................ 403

Chœridium ............. 186

Chœrocampa .......... 284

Chœrodes ............... 331

Choleva................. 111

Choreutes................. 354

Chortophaga ........... 413

Chramesus ............. 268

Chrysis.................. 43

Chrysobothris.......... 169

Chrysochraon........... 411

Chrysochus............. 219

Chrysodina.............. 219

Chrysogaster ........... 384

Chrysomela ............ 220

Chrysopa................ 462

Chrysophanus ......... 277

Chrysopila .............. 373

Chrysops................ 372

Chrysotimus ............ 382

Chrysotoxum........... 383

Chrysotus ................ 382

Chytolita .............. 329

Chytonix ................ 308

Cicada .................... 437

Cicindela.................. 69

Cilissa ..................... 63

Cimbex................ 7

Cindaphia............... 343

Cinyra................... 168

Circotettix.............. 414

Cirrhophanus .......... 323

Cis ........................ 184

Cistela ................... 236

Citheronia ............... 303

Cixius..................... 439

Cladius.................. 8

Cladura.................. 368

Clemensia ............... 291

Cleora................... 337

Clerus.................... 178

Clinidium .............. 140

Clinocera ................ 380

Clisiocampa ............ 304

Clivina ................. 75

Cloë ....................... 455

Clostoptera............. 443

Clytanthus.............. 204

Cnemidotus ............. 99

Cnemodus............... 423

Coccidula ............... 135

Coccinella .............. 133

Coccophagus............ 40

Coeambus .............. 101

Colidea ................. 446

Coliodes................... 260 
Colioxys.............. 64

Cœlodasys............... 300

Cologaster.............. 261

Colopa.................. 399

Cœnia..................... 172

Cunosia.................. 395

Cœnus..................... 419

Colastus.................. 149

Colaspis .................. 220

Coleophora.............. 358

Colias .................... 278

Colletes ................ 62

Collops ................ 177

Colpognathus.......... 23

Colydium .............. 139

Colymbetes.............. 103

Compsocerocoris ...... 425

Conchylis ............... 350

Conchylodes............ 343

Conocephalus........... 410

Conops ................. 389

Conosoma ................ 126

Conotelus................. 149

Conotrachelus......... 257

Copelatus................ 102

Copidosoma ........... 39

Copris.................... 186

Coptera.................. 42

Coptocycla............. 229

Coptodera ............... 88

Coptotomus ........... 102

Copturus ................ 259

Cordula ................. 458

Cordulegaster.......... 457

Cordylura................ 395

Corethra................ 364

Corimelæna........... 417

Corisa... ................ 436

Coriscus .................. 431

Corizus .................. 422

Corphyra ............... 242

Corticaria............... 153

Corycia .................. 336

Corydalis ............... 461

Corylophus.............. 132

Corymbites............... 164

Corynocoris............. 420

Corytbuca.............. 429

Coscinoptera........... 215

Cosmopepla............ 419

Cosmopteryx .......... 358

Cossonus ............... 265

Cossus ................... 304

Cotalpa................. 195

Coxelus................. 139

Crabro..................... 57

Cræsus.................... 9

Crambodes............... 319

Crambus ............... 346

Craponius .............. 260
Cratacanthus.......... 94

Cratoparis.............. 271

Cregya ................ 180

Cremastochilus ......... 197

Cremastogaster ....... 47

Creophilus ............. 117

Crepidodera ............ 225

Cressonia ............... 288

Criocephalus............ 199

Crioceris................ 214

Crioprora ............... 387

Criorhina................ 387

Crocidophora .......... 342

Crocigrapha ............. 317

Crocota................. 292

Crophius .................. 423

Cryptarcha ............ 152

Cryptobium.............. 123

Cryptocephalus......... 216

Cryptohypnus.......... 159

Cryptolechia ........... 355

Cryptorhopalum....... 144

Cryptorhynchus....... 258

Crypturgus............. 269

Cryptus .................. 24

Cteniscus ................. 29

Ctenistes ................. 113

Ctenucha ................ 290

Cucujus .................. 141

Cucullia ................. 319

Culex.................. 364

Cupes..................... 184

Cuterebra................. 390

Cybister ................ 105

Cyclocephala........... 196

Cychramus............. 152

Cychrus .................. 71

Cylapus................... 428

Cyllene................... 203

Cylloceria .............. 31

Cymatodera............. 178

Cymatophora .......... 337

Cymindis ............... 90

Cymus ................... 422

Cynips................... 17

Cyphomimus ........... 249

Cyphon ................... 157

Cyrtinus.................. 207

Cyrtoma .................. 380

Cyrtoneura ............. 394

Cyrtophorus ............ 204

Cyrtophyllus............ 409

Cyrtosia.................. 441

Cytilus .................. 154

\section{D.}

Dacne................. 138

Dactylopium ........... 451

Dalmania ................389

Danais.................. 275
Dasycera .............. 357

Dasyllis................. 375

Dasylophia............. 300

Datana.................. 298

Debis .................... 272

Decarthron ............ 114

Decatoma................ 38

Dectes...................... 209

Degeeria................. 391

Deidamia ............... 284

Deilephila............... 284

Deilinea ................. 335

Delphax.............. 440

Deltocephalus ......... 446

Deltometopus .......... 158

Demas .................. 306

Dendroctonus . ........ 269

Dendroides ............ 244

Depressaria............ 355

Deræocoris.............. 427

Dermestes ............... 143

Deromyia.............. 375

Deronectes................ 101

Derrima ................ 322

Desmia.................... 343

Desmocerus............ 205

Desmometopa.......... 403

Desmopachria.......... 100

Dexia.................... 392

Diabrotica............... 222

Diachus.................. 218

Diaperis ................ 233

Diapheromera ......... 407

Diaphorus.............. 382

Diapria................ 42

Diaspis ................ 452

Diastata ............... 402

Diastrophus............ 16

Dibolia................. 227

Dicalus ................ 82

Dicerca................... 167

Dichrta ............... 401

Dichelia............... 350

Dichelonycha........... 191

Dichrooscytus ........ 425

Dichrorampha ........ 353

Dicopis.................. 305

Dicranomyia ........... 365

Didymops .............. 458

Didea..................... 385

Diedrocephala.......... 444

Dilophonota............ 285

Dilophus.................. 363

Dinentes ............... 106

Dinoderus............... 184

Diochus................ 122

Dicotria .................. 374

Diomorus ............. 39

Dioryctria .............. 344

Diphthera .............. 306 
Diplax................. 460

Diplochila.............. 82

Diplosis................. 360

Diplotaxis ............... 192

Dipterygia.............. 313

Dircæa.................. 237

Discoderus............... 94

Discothyrea............ 46

Disonycha .............. 224

Dissosteira.............. 415

Distenia ................. 204

Ditemnus .............. 177

Ditoma................... 139

Ditomyia .............. 361

Dolba .................... 286

Dolerus .................. 10

Dolichoderus ........... 45

Dolichopeza ............ 370

Dolichopus ............. 380

Dolopius ............... 161

Donacia................. 213

Dorcaschema............ 207

Dorcatoma.............. 183

Dorcus..................... 185

Dorymyrmex ......... 45

Doryodes................. 316

Doryphora............... 220

Dorytomus.............. 252

Drapetes ............... 166

Drasteria ................ 324

Drasterius................ 161

Drepanodes............ 331

Drepanosiphum ...... 449

Dromius................. 89

Drosophila............. 402

Dryobota .............. 313

Dryocampa ............. 303

Dryocostes ............... 268

Dryomyza .............. 396

Dryophanta............ 17

Dryophthorus ......... 265

Dryops................... 155

Dryopteris.............. 301

Dyschirius .............. 74

Dysphaga .............. 213

Dyspteris ................ 334

Dytiscus................. 104

E.

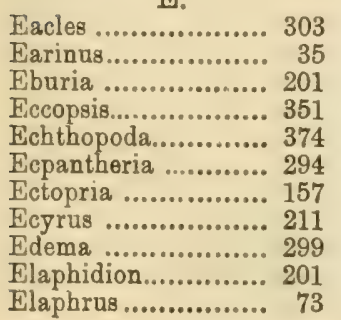

Elater .................. 159

Elephantomyia........ 366

Elis ..................... 49

Ellema .................. 287

Elleschus .............. 256

Ellychnia .............. 173

Elmis................... 155

Emblethis............... 423

Emesa ................... 432

Emmesa................ 237

Emphor ................ 67

Emphytus ............... 10

Empis................... 379

Empoa ................. 447

Empretia ............... 296

Enchenopa ............ 440

Enchodes ............... 237

Encoptolophus......... 413

Encyclops............... 205

Encyrtas............... 89

Endalus ................ 253

Endecatomus ........... 183

Endomychus ........... 137

Endropia ............... 332

Ennearthron ........... 185

Ennomos .............. 332

Enoicyla................ 463

Entechnia.............. 67

Enyo .................. 283

Epeolus.................. 64

Ephalus ................. 232

Ephemera............... 455

Ephestia ................ 345

Ephialtes .............. 30

Ephydra ............... 402

Ephyra ................... 334

Epicærus................. 247

Epicauta................. 245

Epicypta............... 362

Epierus ................... 147

Epiglæa ................. 318

Epigraphia.............. 355

Epilachna............... 136

Epimecis ................. 337

Epipaschia.............. 344

Epiphragma ............ 368

Epipocus................ 137

Epirranthis ............ 333

Epirrita.................. 340

Episcopus .............. 428

Epitragus ............... 230

Epitrix................ 226

Epizeuxis .............. 329

Epuræa .................. 150

Erax.................... 376

Erchomus .............. 126

Erebus ................. 328

Eremocoris ............. 424

Eretmocerus............ 42

Eriocampa.............. 11
Erioptera............. 367

Eristalis................. 386

Ernobius................ 181

Eros ...................... 172

Erromenus............ 28

Erycus .................. 252

Erythroneura........... 447

Euæsthetus............. 123

Eubadizon.............. 36

Eubyja .................. 338

Eucalyptera............. 315

Eucerceris .............. 55

Eucerocoris ............ 427

Euceros.................. 28

Euchætes .............. 294

Euchistus............... 419

Eucinetus ............... 157

Eucirrodia............. 318

Euclea................... 295

Euclidia ................ 324

Eucoila................. 18

Eucrada ................. 181

Eucrostis................ 334

Eudalimia............... 332

Eudamus .............. 279

Eudeilinea.............. 335

Eudemis................. 350

Euderces.................. 204

Eudicrana............... 361

Eudioptus............... 343

Eudocimus ............. 252

Eudryas................ 290

Eufitchia............... 336

Eugnamptus........... 246

Eulophus............... 41

Eumenes................. 59

Eupactus............... 182

Eupelmus ............. 39

Eupethecia ............. 340

Euphanessa ............ 291

Euphoria............... 197

Euphorus ............... 35

Euplectrus............... 41

Euplexia................ 313

Eupogonius............. 211

Eupristocerus........... 170

Eupsalis................ 263

Euptoieta .............. 274

Eurycreon............... 342

Eurygaster ............. 416

Eurylabus............... 23

Eurymycter ........... 270

Eurypogon ............ 156

Eurytoma.............. 38

Eusphyrus.............. 270

Euspongus................ 55

Eustrophus............ 238

Eustrotia .............. 323

Euthera ................. 391

Euthisanotia .......... 315 


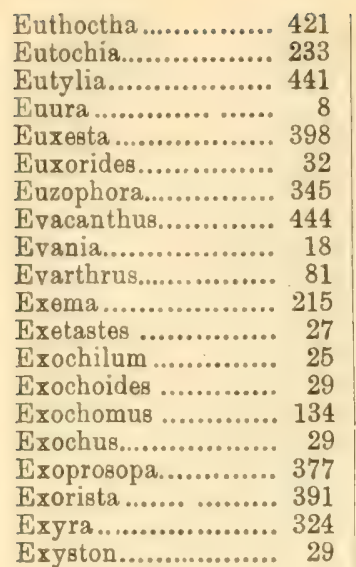

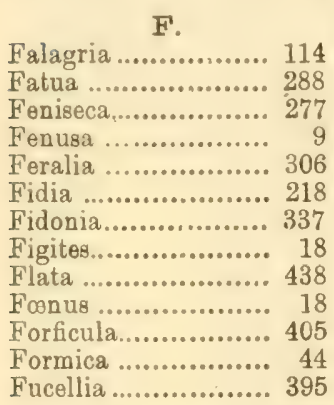

G.

Galerita................ 87

Galeruca ............... 222

Galgula ................. 324

Galgulus .............. 434

Galleria.................. 345

Garganus .............. 427

Gastroidea ............. 221

Gastropacha ............ 304

Gastrophilus............. 390

Gaurax.................. 403

Gaurotes................ 205

Gelechia.................. 356

Geocoris ................ 423

Geodromicus............ 129

Geometra .............. 334

Geopinus................ 93

Geotrupes .............. 189

Geranomyia ............ 366

Geron .................... 378

Glæa .................... 318

Glaucopteryz .......... 340

Globiceps .............. 427

Glyphina ............. 450
Glyphonyz............ 162

Glypona................. 443

Glypta.................. 31

Glyptina .............. 227

Glyptoma ............. 130

Glyptoscelis............. 218

Gnathocerus ............ 232

Gnophomyia ............ 367

Gnorimus................. 198

Goes..................... 208

Gomphocerus ........... 412

Gomphus................ 457

Gonianotus.............. 424

Gonomyia.............. 367

Gortyna ................ 314

Gorytes ................. 54

Gracilaria .............. 357

Graphisurus ............ 210

Graphoderus ........... 105

Grapholita............... 353

Graphops .............. 219

Grapta .................. 273

Grotea .................. 33

Gryllotalpa............. 407

Gryllus.................. 407

Gryptocentrus.......... 28

Gueneria.................. 335

Gymnetron.............. 256

Gymnochwta............ 391

Gymnophora............ 404

Gymnopternus ......... 381

Gymnoscelus............ 36

Gynandropus .......... 95

Gyrophæna............. 116

Gyrinus................. 105

H.
Habrosyne ............ 305

Hadena .................. 311

Hrmatobia............. 393

Hæmatopis ............. 337

Hadrobregmus ......... 182

Hagenius ............. 457

Halisidota .............. 294

Haliplus ................ 99

Halictus.................. 62

Hallomenus .............. 238

Haltica ................... 225

Halticus................... 428

Hamadryas ............. 356

Hapithus ............... 408

Haplandrus............. 231

Harmonia................ 133

Harmostes ............... 422

Harpalus ................. 95

Harpiphorus ........... 10

Harrisimenna ......... 307

Harrisina ................ 291

Hebras.................... 433

Hecabolug............... 33
Hecalus.................. 445

Hedychridium ......... 43

Hedychrum ........... 43

Helcon ................. 36

Heliomata ............. 339

Heliothis ................ 322

Helluomorpha ........ 90

Helochara ............. 444

Helodes................... 157

Helomyza ............... 395

Helophilus ............... 386

Helophorus ............ 106

Helops .................... 235

Helotropha ............. 314

Hemaris................... 283

Hemerobius............ 461

Hemerodromia.......... 380

Hemerophila............ 337

Hemileuca............... 303

Hemiptychus........... 183

Hemiteles .............. 24

Hepialus ................ 305

Herreus .................. 423

Heriades ................. 65

Herrichia ............... 323

Hetærina .............. 456

Hetærius ............... 147

Heterachthes............ 202

Heterocampa ............ 300

Heterocerus............. 156

Heterographis.......... 345

Heteromyia ............ 365

Heteroneura............ 400

Heteropelma ........... 25

Heterophleps ............ 339

Heterothops ............ 116

Hetomis ................ 208

Hilara.................... 380

Hippiscus ............... 414

Hippobosca ............ 405

Hippodamia ............ 133

Hippopsis ............... 211

Hister .................... 145

Holcaspis.............. 17

Holcocephala........... 375

Hololepta............... 145

Holopogon ............... 374

Homæmus .............. 416

Homalium............... 129

Homalodisca ........... 444

Homalomyia............ 395

Homolota ................ 115

Homophysa............ 344

Homoptera.............. 328

Homopyralis........... 329

Hoplia.................... 191

Hoplismenus ........... 22

Hoplisus ................ 54

Hoplocampa ............ 11

Hoplocephala........... 233 
Horistonotus .......... 159

Hormiscus ............. 270

Hormorus............... 247

Hyaliodes............... 427

Hyalomyia............. 390

Hybernia................ 338

Hydaticus ............... 104

Hydnocera ............ 179

Hydræna .............. 107

Hydrellia .............. 401

Hydria.................. 339

Hydrobius.............. 109

Hydrocampa............ 343

Hydrocanthus ......... 100

Hydrocharis ............ 107

Hydrochus ............. 106

Hydrocombus.......... 109

Hydrophilus .......... 107

Hydrophorus .......... 382

Hydroporus ............ 101

Hydropsyche ........... 464

Hydroctæa .............. 394

Hydrovatus.............. 100

Hygrotrechus............ 433

Hylastes ............... 269

Hylesinus ............... 269

Hylobius ................ 251

Hylotoma.............. 8

Hylotrupes.............. 200

Hylurgops ............. 270

Hymenarcys............ 419

Hymenorus ........... 235

Hyparpax .............. 298

Hypenula ............... 330

Hyperaspis.............. 135

Hyperchiria ............ 302

Hyperechia ............. 375

Hyperetis ............... 334

Hyperplatys ........... 210

Hyphantria ............ 294

Hypoderma .............. 390

Hypolampsis ........... 223

Hyponeumenta......... 354

Hypophlœus ............ 234

Hypoprepia ............ 291

Hypothenemus ........ 267

Нурра .................. 313

Hypsoropha ............ 321

Hyptia .................. 18

Hypulus ............... 237

Hystricia ............... 391

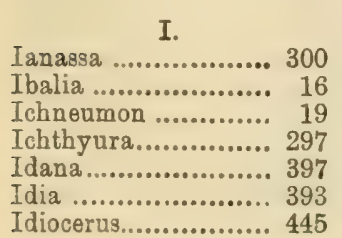

Idioplasta.............. 369

Idolocoris .............. 428

Ilnacora .............. 427

Ilybius .................. 102

Ilythea ................. 402

Ingura .................. 320

Ipimorpha ............. 317

Ips....................... 152

Ischnoptera........... 406

Ischnorhynchus....... 422

Ischyrus................. 138

Isodontia ............... 52

Isomira ................. 236

Isoptery x............. 454

Isosoma................. 38

Issus ................... 438

Ithycerus .............. 249

Jalysus ................ 421

Jassus..................... 446

Jodia ..................... 318

Junonia ................ 273

Jurinia................. 391

L.
Labena................ 33

Labia..................... 406

Labidia ................. 12

Laccobius ............... 108

Laccophilus............. 100

Lachnocrepis........... 93

Lachnosterna........... 192

Lachnus ................. 450

Ledra .................... 443

Læmophlœus .......... 141

Læmosaccus ............ 257

Lagor.................... 295

Lampria ................ 376

Lampronota ........... 32

Languria .............. 137

Lantaphe................ 344

Laphria .................. 376

Laphygma.............. 313

Laphystia.,............ 374

Largus ................. 424

Larra................... 53

Lasioderma ............ 182

Lasioptera .............. 361

Lasiosoma .............. 361

Lasius .................. 45

Lathrobium ........... 124

Lathropus ............... 141

Lauxania ............... 399

Laverna.................. 358

Lebia ................... 87

Lecanium .............. 45.

Leja....................... 362

Lema..................... 214

Lepidosaphes .......... 452
Leptacinus ........... $122^{\circ}$

Leptina................... 305

Leptis .................. 374

Leptogaster ............ 374

Leptoglossus ............ 421

Leptophya ............. 429

Liptostyla.............. 429

Leptoterna ............. 425

Leptostylus ............ 208

Leptotrachelus......... 86

Leptura ................ 206

Lepturges .............. 209

Lepyronia .............. 442

Lestes.................... 456

Leucania................. 316

Leucanthiza ............ 359

Leucarctia .............. 293

Leucopis ................ 403

Leucospis............... 37

Lenctra................... 454

Liancalus ............... 382

Cibellula............... 459

Libythea................. 275

Ligyrocoris.............. 423

Ligyrus.................. 196

Limacodes ............... 296

Limenitis .............. 272

Limneria ............... 26

Limnobates ........... 433

Limnobia............... 366

Limnophila .......... 368

Limnophilus ........... 463

Limnophora............ 394

Limnoporus ............ 433

Limnotrechus .......... 433

Limonius ............... 163

Lina .................. 221

Lioderma ............... 419

Liodes................... 112

Liopus................... 209

Liotropis ............... 418

Lipocosma ............ 344

Lipoptena................ 405

Lispe ................... 395

Lissorhoptrus.......... 253

Listotrophus............ 117

Listronotus............. 250

Litargus................. 143

Lithacodia .............. 323

Lithocolletis........... 358

Litocharis............... 124

Litochrus .............. 131

Litognatha ............ 329

Livia ................... 447

Lixus ................... 252

Loberus ................. 142

Lobloptera.............. 403

Lobonotus .............. 417

Lobophora............... 339

Lomatia ................ 377 
Iomechusa ............ 115

Lonchæa ................ 399

Lonchoptera ............. 383

Longitarsus ............ 227

Lopheros .............. 172

Lophoderus ........... 349

Lophodonta ........... 299

Lophyrus.............. 14

Lopidea .. ............. 425

Loxaulus ............. 17

Loxocera ................ 396

Lozogramma .......... 336

Loxotænia............... 348

Lucanus ................. 185

Luceria ................ 311

Lucidota ............... 173

Lucilia ................. 393

Ludius ................... 161

I.uperus ............... 221

Lycæna................. 277

Lycomorpha........... 290

Lycoperdina ............ 136

Lyctocoris ............... 428

Lyctus................. 184

Lyda................. 14

Lygæus ................. 424

Lygus ................... 426

Lymexylon ............ 184

Lyroda ................ 53

M.

Macratria .............. 242

Macrobasis ............... 244

Macrocentrus ......... 37

Macrocephalus,........ 430

Macrocera............... 361

Macrodactylus ........ 191

Macroglenes ............ 40

Macromia............... 458

Macronema............ 464

Macronoctua ........... 315

Macronychus.......... 155

Macrophya............. 12

Macrops ................ 251

Madarus .................. 262

Magdalis................ 254

Malacocoris ............ 427

Mallophora ............ 376

Mallota .................. 387

Malthinus.............. 177

Malthode8............... 177

Mamestra .............. 310

Mantispa .............. 461

Mantura ............... 226

Marasmalus ............. 320

Marmopteryx ......... 336

Masicera ................ 391

Mastogenius............ 170

Ifatus ................... 102

Mecynotarsus.......... 243
Medeterus.............. 382

Megachile............... 66

Megachyta............. 329

Megacœlum............. 426

Megalodacne .......... 138

Megalonotus............ 424

Megapenthes ........... 161

Megastilicus ............ 124

Megilla .................. 132

Megischus.............. 33

Megoura................. 449

Melanactes ............. 165

Melanæthus ............. 417

Melandrya .............. 237

Melanocoryphus ...... 424

Melanolestes ........... 432

Melanomma ............ 341

Melanophila............. 168

Melanophora............ 392

Melanoplus ............. 412

Melanostoma............ 384

Molanotus .............. 162

Melasis................ 157

Melissodes .............. 67

Melitæa................. 275

Melittia.................. 288

Meloe ...................... 244

Melophagus ........... 405

Menecles................. 419

Meniscus................. 32

Meracantha............ 235

Merinus ................ 230

Merisus ................... 40

Meromyza .............. 403

Meroptera................ 345

Mesembrina ............ 393

Mesites ................ 266

Mesochorus............. 27

Mesographe............. 342

Mesograpta.............. 385

Mesoleius.............. 28

Mesoleptus.............. 27

Mesostenus ............. 24

Mesothemis ........... 459

Mesovelia ............... 433

Messa ................... 9

Metabletus............. 89

Metachroma ............ 219

Metanema ................ 331

Metapodius ........... 421

Meteorus.............. 36

Metopius................... 29

Metoponia (Lep.)..... 324

Metoponia (Dipt.)..... 370

Metrobates ............ 433

Metrocampa............ 333

Miarus .................. 256

Micracis ................. 268

Microbembex .......... 54

Microcentrum ......... 409
Microcentrus ........... 440

Microcelia ............... 307

Microdon .............. 383

Microdus................ 35

Microgaster ........... 35

Micromus .............. 461

Micropalpus ........... 391

Microphthalma......... 392

Microplitis.............. 35

Microrrhagus .......... 158

Microrhopala .......... 228

Microtoma.............. 424

Microtonus ............. 239

Midas ................... 377

Milesia................... 388

Milyas .................. 432

Mimesa ................ 56

Miris ..................... 425

Molorchus ............. 202

Monachus.............. 218

Monalocoris ........... 427

Monarthrum .......... 266

Monecphora ............ 442

Monedula .............. 54

Monellia ................ 449

MIonobia ................ 59

Monocrepidius ......... 159

Monohammus ......... 207

Monomorium .......... 47

Mononychus ........... 260

Monophadnus ......... 11

Monopsis .............. 439

Monostegia............. 11

Monotoma............... 154

Mordella................ 240

Mordellistena........... 240

Mormidea............. 419

Morrisonia .............. 317

Musca .................... 393

Mutilla................... 48

Myas ..................... 79

Mycetina ................ 136

Mycetobia .............. 361

Mycetochares.......... 236

Mycetophagus ......... 142

Mycetophila............ 362

Mycetoporus .......... 127

Mycothera.............. 362

Mycotretus ............. 138

Mycterus ............... 238

Myiolepta.............. 386

Myllæna ............... 116

Myodocha ............. 423

Myopa.................. 389

Myospila................ 394

Myrmecina ............ 47

Myrmeleon............... 462

Myrmica ................. 46

Myrmosa ................ 48

Mysia .................... 134 


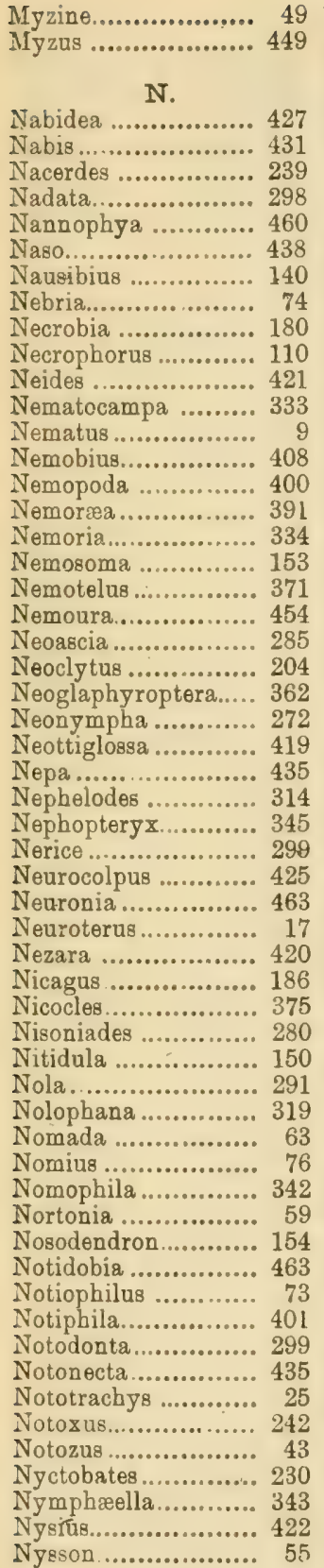

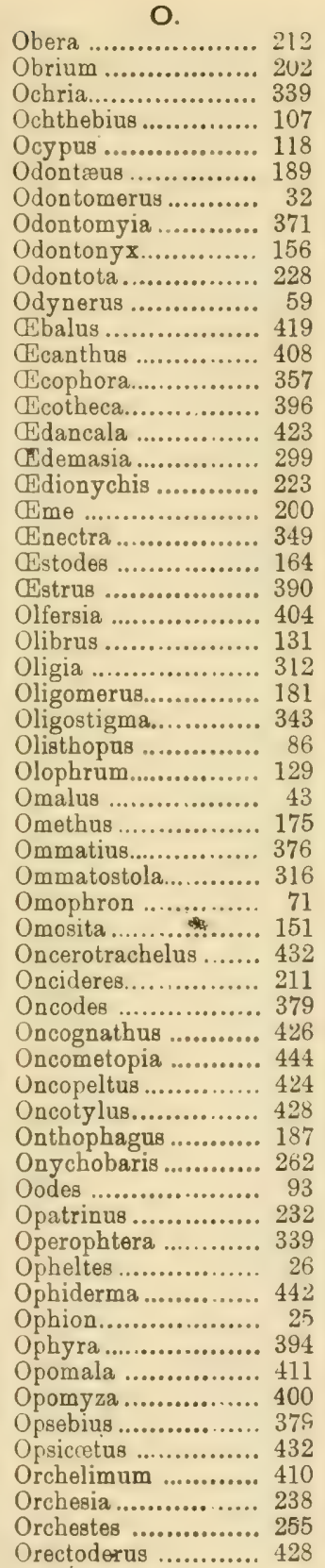

Orgyia............... 291

Ormenis................. 438

Ornithomyia .......... 405

Orocharis .............. 408

Orphilus ................ 145

Orphnephila........... 365

Orsillacis................ 422

Orsillus ............... 422

Orsodachna ............. 214

Orthaltica............... 225

Orthezia.................. 452

Orthodes ............... 317

Orthoperus ............. 132

Orthopleura .......... 180

Orthosia.................. 317

Orthosoma.............. 199

Oryssus ................ 15

Oscinis ..................... 403

Osmia.................... 65

Osmoderma ............ 198

Otidocephalus ......... 253

Otiocerus ............... 439

Utiorhynchus ......... 248

Oxacis ................... 239

Oxybelus .............. 58

Oxycera ................. 371

Oxycnemus ............ 151

Oxypoda................ 116

Oxyporus .............. 127

Oxyptilus............... 359

Oxytelus................. 128

Ozognathus ........... 181

P.

Pachybrachys ........ 217

Pachylobius ............ 251

Pachyprotasis ......... 13

Pachypsylla ........... 448

Pachyrrhina........... 369

Pachyscelus ............ 171

Packardia............... 296

Pæderus ................ 125

Pædisca................ 351

Pagasa .................. 431

Palaminus ............. 125

Palingenia.............. 454

Pallodes ............... 152

Palloptera............... 399

Palthis ................. 330

Pamera ................... 423

Pamerocoris ............ 427

Pamphila............... 281

Panagæus............... 76

Pandeletejus ........... 248

Pandemis................ 348

Pangæus ................ 417

Pangonia ................ 371

Pangrapta ............. 329

Paniscus ................ 26 
Panopoda.............. 328

Panorpa ................. 463

Panscopus ............... 248

Pantographa ........... 342

Paonias .................. 287

Papilio ................... 277

Parabolocratus........ 445

Paragus .................. 383

Paralimna.............. 401

Parallelia ............... 327

Parandra ............... 198

Paraphia................. 338

Parasa ............... 295

Paratenetus ........... 233

Paria ................... 219

Paromalus ............... 147

Paropholis ............. 444

Parorgyia ................ 295

Paroxya ................. 412

Parthenos .............. 327

Parydra.................. 401

Pasimachus ............ 74

Passalocus.............. 57

Passalus ................ 186

Patrobus .............. 79

Pediopsis.. .............. 445

Pelastoneurus........... 381

Pelecinus............... 42

Pelidnota............... 195

Peliopelta ............... 424

Pelocoris ................ 434

Pelogonus .............. 434

Pelonomus ............. 261

Pelorous .............. 51

Pemphigus.............. 451

Pemphredon............ 57

Pentaria................. 240

Penthe.................. 237

Penthelispa ............ 139

Penthimia .............. 444

Penthina................. 351

Penthoptera ............ 368

Pentilia.................. 134

Peoria.................... 345

Pepsis................... 51

Perdita.................. 63

Peribalus ............... 420

Periclistus............... 17

Perigea ................... 312

Perilampus.............. 38

Perillus ................. 417

Periplaneta........................406

Porithemis ............. 460

Peritrechus ............... 423

Perla ..................... 454

Perophora............... 297

Perothops ................ 166

Petalium................ 182

Petalura.................. 457

Petrophora
Pezomachus............ 24

Pezotettix .............. 412

Phrcasiophora........ 351

Phædromus ............. 223

Phrogenes............... 23

Phalacrus ............... 131

Phalænophana........ 330

Phaleria................ 233

Phanæus ............... 187

Phanerotoma.......... 34

Phasgonophora........ 38

Phasiane ............... 336

Pheidole ................. 47

Phellopsis .............. 230

Phenolia ............... 151

Pheocyma.............. 328

Pheosia ................ 299

Phibalapteryx ........ 339

Phigalia .................. 338

Philænus.............. 443

Phlampelus ............ 285

Philanthus ............ 55

Philourus ................ 197

Philhydrus ............. 108

Philontbus............ 118

Philopotamus........... 464

Philothermus .......... 140

Philygria ...............4 401

Phiprosopus ........... 321

Phløophagus........... 266

Phlossinus ......... 269

Phlosotribus.............. 268

Phoberia ............... 327

Phobotron............. 296

Phoenonotum.......... 110

Pholisora ............ 280

Phora .................... 404

Phorodon............. 449

Phortica................. 402

Photinns .............. 174

Photuris................. 174

Phoxopteris............. 353

Phragmatobia ......... 293

Phthinia ............... 361

Phthiria .................. 378

Phyciodes ............... 274

Phygadeuon............ 23

Phyletus ................ 234

Phyllaphis.............. 450

Phyllobænus ........... 180

Phyllobrotica........... 222

Phyllocnistis .......... 359

Phyllodecta............ 221

Phyllodromia......... 406

Phyllomyza ............ 404

Phylloscelis ........... 438

Phyllotreta............ 227

Phyllotrox............. 253

Phylloxera ............. 451

Phymata.................430
Pbymatocera........... 11

Phymatodes ............ 200

Phymophora .......... 136

Phyrdenus............. 258

Physatochila........... 429

Physocnemum ......... 200

Phytalus................ 194

Phytocoris............... 425

Phytodietus............ 32

Phyton ................. 202

Phytonomus........... 250

Phyzelis ............... 248

Piazorhinus ........... 256

Piazurus................... 259

Pieris................... 279

Piesma ................ 429

Piezocorynus............ 270

Pilophorus.............. 427

Pimpla .................. 30

Pinacodera ............. 90

Piophila ................. 400

Pipiza................... 383

Pipunculus ............. 389

Pissodes ............... 251

Pityobiug............... 164

Pityophthorus.......... 266

Plagiodera ............. 221

Plagiognathus ......... 428

Plagiomimicus........ 322

Plagionotus ........... 203

Plagodis................ 333

Planiceps .............. 51

Plateros............... 173

Platycerus ............ 185

Platychirus ............ 384

Platycotis .............. 440

Platydema .............. 234

Platygaster............... 42

Platylabus............. 23

Platymetopias ......... 445

Platynota ............... 350

Platynus............... 83

Platy peza............... 389

Platypteryx ........... 301

Platyptilus ............. 359

Platysenta ............. 316

Platystethus ............ 128

Platythemis............ 459

Platyura .................. 361

Plea..................... 436

Plecia ................... 363

Plegaderus.............. 148

Plemyria................ 340

Pleonectyptera ......... 328

Plesiastina .............. 351

Plocetes................. 256

Plochionus .............. 89

Plodia ............................. 345

Plusia.................... 321

Plusiodonta .......... 420 
Plutella............. 355

Poaphila ............... 328

Pocadius................. 151

Podabrus ............... 175

Podisus ................. 418

Podops ................ 418

Podosesia .............. 289

Pocilocapsus .......... 426

Prrcilonota ............. 167

P(rciloptera. .......... 438

Poeciloscytus ............ 426

Pogonocherus.......... 210

Pogonomyrmex ........ 46

Pogonus ................. 79

Polistes ................. 60

Pollenia ................ 393

Polyblastus ........... 28

Polycentropus ......... 464

Polyergus ............. 44

Polylepta............... 361

Polyphylla............ 194

Polysphincta.......... 31

Polystcechotes......... 461

Polystoma ............. 115

Pomphopcea........... 245

Pompilus............... 49

Ponera .................. 46

Porphyrops........... 382

Potamanthus.......... 455

Praon... ................ 37

Prasocuris.............. 220

Prenolepis ............ 45

Priocnemis.............. 50

Prionia ................ 301

Prionidus............... 431

Prionocbæta ........... 112

Prionomerus........... 256

Priononyx ............ 53

Prionoxystus........... 304

Prionus ............... 199

Priophorus ............. 8

Pristiphora ............. 8

Proconia .............. 444

Proctacanthus ........ 376

Prodenia............... 313

Promachus ............. 376

Prometopia............. 150

Pronuba................. 355

Prosopis ................ 62

Protenor ............... 421

Proteopteryz............ 352

Protheca ............... 183

Prothymia.............. 324

Protoparce............. 285

Psallus ................. 428

Pselaphus .............. 113

Psen

Psenocorus ............. 207

Psephenus.............. 155

Pseudaglossa .......... 329
Pseudanophora ...... 354

Pseudanthrœcia ....... 329

Pseudobrus ............ 177

Pseudobaris.............. 262

Pseudococcus.......... 451

Pseudolimacodes....... 327

Pseudothyatira......... 305

Psila ..................... 397

Psilocephala........... 378

Psilopa ............... 401

Psilopus.................. 382

Psilota................... 384

Psinidia................... 414

Psocus ................... 453

Psorosa .................. 345

Psyche................. 297

Psychoda................. 365

Psychomorpha........ 290

Psylla.................... 448

Psylliodes............... 227

Psyllobora .............. 134

Ptenidium ............. 130

Pterocolus ............ 247

Pteromalus .............. 40

Pteronarcys ........... 453

Pterophorus ........... 359

Pterostichus ............ 79

Pterrablastes........... 387

Ptilinus................ 183

Ptilium.................. 130

Ptilocera ................ 392

Ptilodactyla .......... 156

Ptinus................... 181

Ptochiomera............ 423

Ptomophagus .......... 112

Ptosima ................. 170

Ptycholoma ........... 348

Ptychoptera ........... 369

Publilia.................. 441

Pulvinaria............. 452

Purpuricenus ......... 202

Pygolampis ............ 432

Pyractomena ........... 174

Pyrameis .............. 273

Pyrellia ............... 393

Pyrgota .................................... 397

Pyrgus .................. 280

Pyrochroa .............. 244

Pyromorpha........... 291

Pyrophæna............. 384

Pyrophila ... ........... 316

Pyropyga ............. 173

Pyrrharctia ............ 293

Pyrrivia ............... $3 \& 2$

Pytho................... 23y

Q.

Quedius... 116
R

Ranatra.............. 435

Raphia ................. 306

Raphidolabis .......... 368

Remigia ................ 328

Renia.................. 330

Resthenia............. 425

Retinia................ 350

P.bacognathus.......... 418

Rhagium................ 205

Rhagovelia............. 433

Rhamphidia ........... 366

Rhamphomyia ......... 379

Rhanis ............... 136

Rhantus.............. 103

Rhinacloa .............. 428

Rhingia ................ 386

Rhinomacer........... 246

Rhinoncus............... 261

Rhinopsis............. 53

Rhipidia ................ 366

Rbipiphorus ........... 245

Rhizophagus............ 152

Rhodites ............... 16

Rhodobienus............ 264

Khodophora............ 322

Rhogas ................ 33

Rhopalophora.......... 202

Rhopalosiphum ........ 449

Rhopalum .............. 57

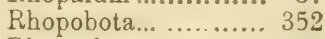

Rhoptobaris ............ 261

Rhopus................ 39

Rhynchites............. 246

Rhyncholus............ 266

Rhypholophus .......... 367

Rhyphus................ 370

Rhypobius.............. 132

Rhyssa'................ 29

Rhyssematus ........... 258

Rhyssemus ............ 187

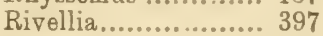

Rivula................. 330

Romaleum ............ 201

S.

Sacium ................ 131

Salda ... .............. 434

Salebria................ 345

Saluda................... 344

Samia ................. 302

Sandalus .............. 157

Sannina ................. 289

Saperda.................. 211

Saprinus ................. 147

Sapromyza.............. 399

Sarcophaga.............. 392

Sargus ................. 371 


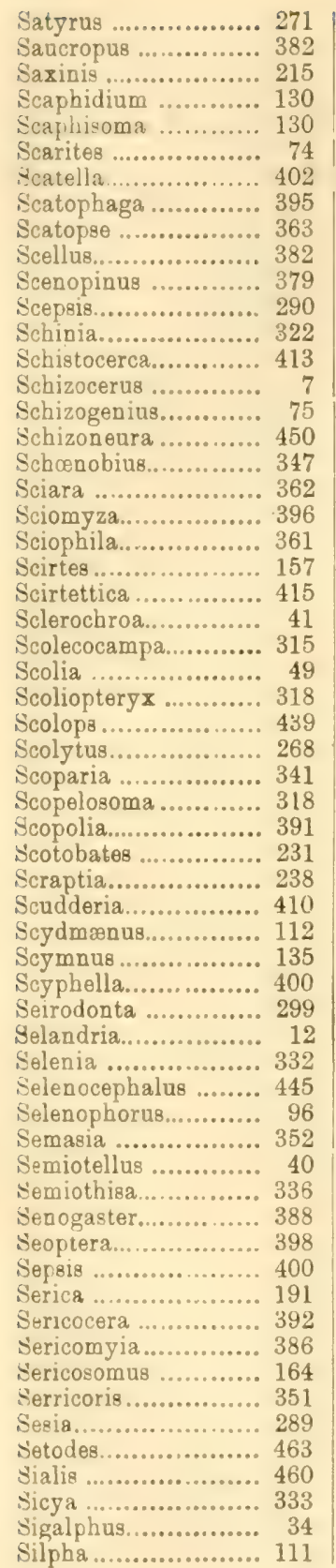

Silvanus................ 140

Sinea .................. 431

Sinoxylon............. 183

Siobla.................... 12

Siparncera ............. 341

Siphonella ............ 403

Siphonophora ......... 448

Sisyrosea ............... 296

Sitodrepa ............... 182

Sitones .................. 249

Sitotroga............... 356

Smerinthus............. 287

Smicra................... 37

Smicronyx............. 252

Smilia ................... 441

Smodicum.............. 149

Solenopsis............... 47

Sorronia................. 151

Spalangia.............. 40

Spargoloma ........... 329

Sparnopolius ........... 378

Spharagemon ......... 414

Sphærophthalma ...... 48

Spbæropyx ............. 34

Sphecius................. 54

Sphecodes ................ 62

Sphecomyia ........... 388

Sphegina................. 385

Sphenophorus ........ 264

Sphenostethus ........ 199

Sphex................... 52

Sphindus................ 185

Sphingicampa ......... 303

Sphinx ..................286

Sphyracephala........ 400

Spilogaster .............. 394

Spilomena.............. $56^{\circ}$

Spilomyia .............. 388

Spilosoma ............... 293

Spongophora.......... 406

Spragueia.............. 324

Stagmomantis ......... 407

Staphylinus............ 117

Statira.................. 236

Stegana ................. 402

Stegania ................. 335

Steganoptycha........ 352

Stelidota ............... 150

Stenamma ............. 47

Stenelmis.............. 155

Stenispa ............... 228

Stenobothrus .......... 412

Stenolophus ............ 97

Stenoscelis ............ 266

Stenosphenus .......... 203

Stenotarsus............. 137

Stenus ................ 122

Stephania ............ 433

Stephostethus........... 153

Stetheophyma......... 411
Stethobaris ........... 262

Sthenarops............. 427

Stichopogon ............ 375

Stictocephala (Dipt.).. 397

Stictocephala (Hemij).) 441

Stigmus................. $5 f$

Stilbus .............. 131

Stilicus................... 124

Stilpnus................ 23

Stilpon .................. 380

Stiphrosoma ........... 428

Stizus................ 54

Stomoxys............... 392

Strangalia............. 206

Strategus ............... 197

Stratiomyia ........... 371

Strigoderma ............ 195

Strobisia............... 357

Strongylium .......... 235

Strongylogaster....... 13

Strophisoma ........... 251

Stylogaster............. 389

Subula.................. 370

Sunius.................... 125

Symphora .............. 238

Sy.mplecta.............. 367

Sympycnus............ 382

Synarthrus ............. 381

Synchita................ 139

Synchlora.............. 334

Synchroa............... 237

Syneches ................ 379

Syneda ................. 324

Synergus ................ 18

Synota .................. 214

Syntemna.............. 361

Syrbula .................. 411

Syritta.................. 388

Syrphus ................. 384

Systena ................ 226

Systropus ............... 378

\section{T.}

Tabanus.,............. 372

Tabuda.................. 379

Tachinus................. 125

'Tachydromia ........... 380

Tachygonus .............. 260

Tachypeza.............. 380

Tachyporus ............ 126

Tachys .................. 78

Tachytes ............... 54

Tachyusa .............. 115

Tæuiocampa ............ 317

Tæn

Tanymecus ............. 248

Tanypus ................ 365

Tanysphyrus........... 253

Taphrocerus ............ 171

Tapinoma .............. 45 


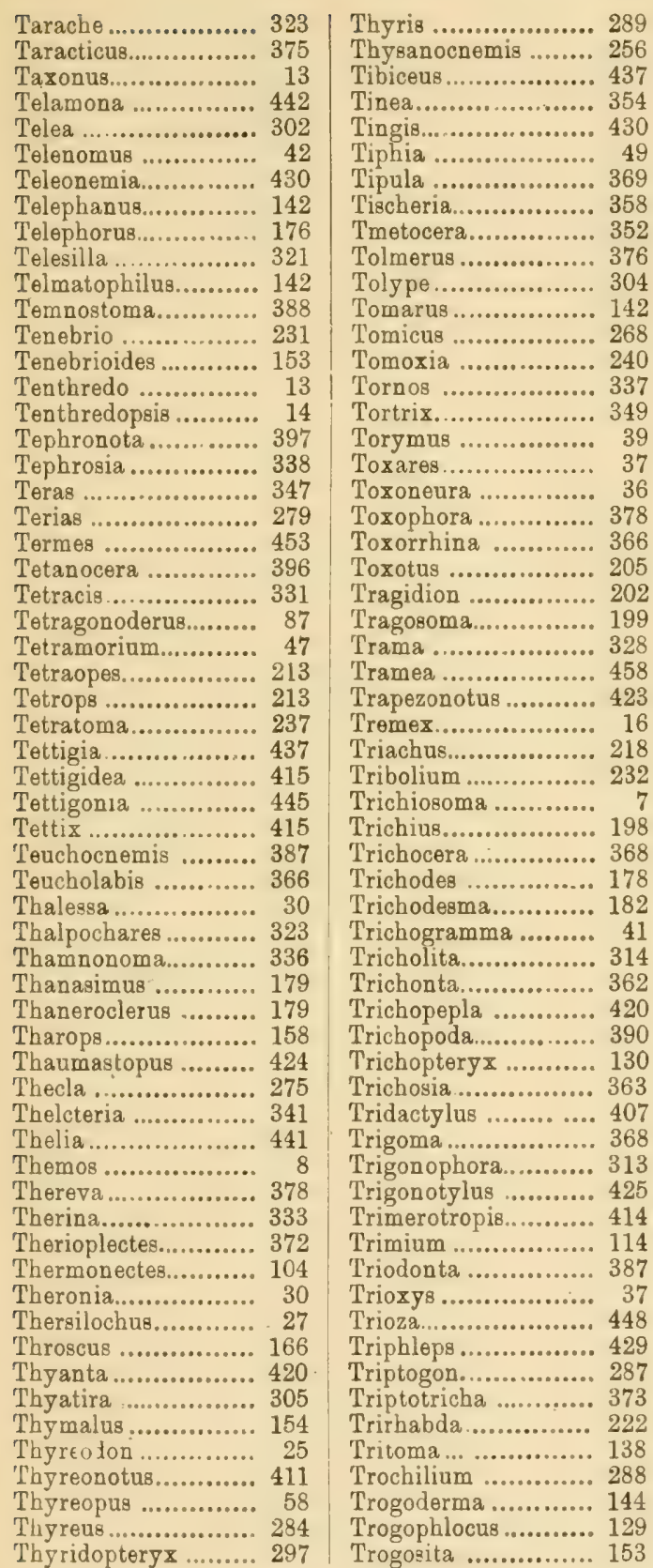

Trogus.................. 23

Tropideres ............. 270

Tropidia................. 387

Tropidosteptes ......... 426

Trox ................... 190

Truxalis ................. 411

Trypeta.................. 398

Trypherus ............... 177

Tryphon .............. 28

Trypopitys .............. 182

Trypoxylon........... 57

Tychius................. 256

Tyloderma............... 258

Tylonotus ............. 201

Tymnes................. 219

Typhlocyba ........... 447

Typhøa................... 143

Tyrus ..................... 113

Tytthonyx............. 174

U.

Ufeus................... 316

Uloma.................. 233

Upis....................... 230

Urocerus................ 15

Urographis............ 210

Utetheisa ............. 292

V.

Vacuna............... 450

Valeria ................. 313

Valgus ................. 198

Vanessa ................. 273

Vespa.................... 61

Vitula .................. 345

Volucella.............. 386

W.

Wollastonia ........... 266

X.

Xanthochroa ........... 239

Xanthogramma ....... 385

Xantholinus............ 121

Xanthonia............... 218

Xanthoptera........... 324

Xenoglossa ............ 67

Xenos.................... 245

Xerophlœa............... 443

Xiphidium............... 411

Xiphydria............... 15

Xyela ................... 15

Xyleborus.............. 267

Xyletinus .............. 132 
INDEX OF GENERA.

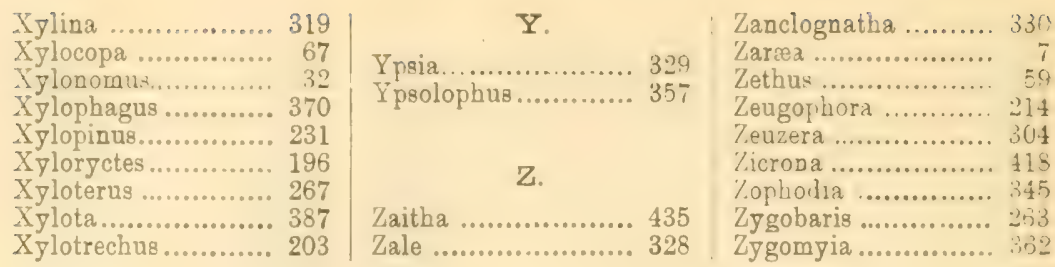




\section{DESCRIPTIVE CATALOGUE OF THE VERTEBRATES OF NEW JERSEY.}

BY JULIUS NELSON, PH.D. 



\section{DESCRIPTIVE CATALOGUE OF THE VERTEBRATES OF NEW IERSEY.}

(A revision of Dr. Abbott's Catalogue of 1868.)

PREPARED BY JULIUS NELSON, PH.D.

INTRODUCTION.

At the request of the late Dr. Cook, I herewith present a revision of Dr. Charles C. Abbott's Catalogue of the Vertebrated Animals of New Jersey, published as "Appendix E, Geology of New Jersey, 1868."

Owing to the numerous changes in nomenclature and classification which have been made within the last twenty years, the labor of merely revising the synonymy of Dr. Abbott's Catalogue has been great.

Before publishing his Catalogue, Dr. Abbott spent several years in acquainting himself particularly with the fauna of the State. The valuable knowledge thus obtained, he appended as notes to the name of each species. It has been thought best to retain this feature in the new Catalogue. Accordingly, all these notes have been inserted in quotation marks without change, except such as was called for in the inter-references among the species, due to their new arrangement. Wherever statements occur of a personal character or such as are given upon the authority of Dr. Abbott, and the truth of which I am able neither to controvert nor to confirm, I bave thought best to add the initials [C. C. A.] at the close of the paragraph containing such statements.

To increase the usefulness of the Catalogue I have added a description of each species, with particular reference to features distinguishing it from its allies, for purposes of identification. This seemed especially needful for species that are often confounded by the general observer. These descriptions bave been made more complete for the birds and fishes, because these tivo groups are most numerous in species, are of special interest to the sportsman and angler, and con- 
tain many forms which are only transient visitors to our State. The diagnoses have been prepared for persons of general education who may he interested in identifying species, rather than for the scientifir specialist. So far as possible, technical terms and anatomical characteristic have been avoided, although it was impossible to omit them entirely. Such terms are defined in any standard dictionary, and the symbols and abbreviations used are explained at the close of this Catalogue.

Professor Jordan's excellent "Manual of the Vertebrates of the Northern United States" * has been used in the preparation of the lists of Mammals, Reptiles and Imphibia. In numerous instances, the language of the Manual has been copied verbatim or nearly su, but much valuable matter has been necessarily omitted. The reader who desires fuller information is referred to the above work. For the birds, the recently-issued "Manual of the Birds of North America," by Robert Ridgway, has been used more freely, but in rare instances have any sentences been copied verbatim, and only a small portion of each of Mr. Ridgway's full descriptions has been used. But Prof. Jorlan's descriptions have been used wherever they appeared satisfactory to our purpose.

For the fishes, free use has been made of Jordan and Gilbert's "Synopsis of the Fishes of North America" (Smithsonian Collections, Vol. XXIV., 1883).

The general arrangement of the generic, specific and common names: of the groups of animals which was adopted by Dr. Abbott has been followed, except that in giving the scientific name of the species the generic name is repeated by initial only. The names of authors, usually abbreviated-see list of abbreviations at close of Catalogueare added in Roman type after the scientific name of the genus and the species or variety. Then come synonyms, added in brackets, and when following a generic term are generic names, and usually are of specific value if occurring after the specific designation; but it ofter happens that a particular species has been reterred to several different genera, and has had various specific names given by different authors that are now to be set aside; and, furthermore, a succeeding species belonging to the same genus as now adopterl has been referred to auother set of genera different from those applied to the former species. In all such cases the specific name is followed by the series

\footnotetext{
* Fourth edition. The fifth edition came to hand too late for use in this work.
} 
of generic and specific designations in parentheses-the generic terms being placed first, beginning with capitals, while the specific terms do not begin with capitals. No attempt has been made to indicate which specific terms have been coupled with each generic term.* In some cases every specific term is to be associated with each generic term. But the simple list of the different generic and specific terms that have been applied to an animal seemed sufficient for the general reader. After the scientific designations follow the common names, and then the descriptions, and finally Dr. Abbott's notes, to which additions have been made by the writer in several instances.

In this work the Classes of Vertebrata are arranged in what may be called the inverse order-that is, proceeding from the highest to the lowest.

\section{Mammals.}

BIRDS.

Reptiles.

Amphibians.

Fishes.

- Of these, the Orders, Families, \&c., of Mammals, Reptiles and Amphibians also follow the inverse order of arrangement, as in Jordan's Manual.

The Orders of Birds are also arrauged inversely, but the Families under each Order follow the plan of Ridgway's Manual. The fishes are arranged throughout according to the natural order, from lowest to highest, as in Jordan and Gilbert's "Synopsis."

It is hoped that persons using this Catalogue will communicate with the Biologist of Rutgers College, whenever specimens are found that do not appear to be in this list. Very nearly all the rare forms have been included, but it would unduly extend the work to include every migratory species that may, by some extremely infrequent accident, visit our State. So many of these accidental species have been included that the chance that any species will be found that are not described in this list, appears to the writer to be very small. This remark refers to forms well known elsewhere, but does not refer to species that are not thoroughly diagnosed, even where they are quite abundant. We will now give an example of such a case.

Among mammals it is particularly desirable to gain information concerning the number of species of shrew mice and their worth or

\footnotetext{
* To some extent these connections are shown in the index.
} 
destructiveness, and similarly of the field mice. The two are often confounded, although they belong to two separate orders, the Insectivora and Rodentia, respectively. The general characteristics of the former make them insect-eaters, while the latter are more destructive to grain, roots, fruits, de. In any individual case it is desirable to know if the good or bad qualities of the group are exemplified in the particular species.

So many of the birds are migratory and likely to be met with only temporarily, that we encounter peculiar difficulties in respect to making a catalogue of them. Yet, to the sportsman the migratory birds are of the greatest interest, and cannot be left out.

The reptiles form a class that is easily exterminated in a civilized community, and yet there are remote hiding-places in swamps and mountains where such forms may linger a long time and only rarely be seen. While, to the ordinary observation, certain species would be practically extiuct, it would be rash to say that they are actually extinct. The list must therefore be considered incomplete in this respect, and information concerning snakes and other reptiles that may be seen, not included in the present list, is earnestly desired.

It is the desire of the Biologist to make a collection of the fishes of New Jersey, in connection with which group of animals so much of the practical and scientific work of the biological department of the Experiment Station will lie. All public-spirited persons who are interested in having at the Station a representation of the various fishes of their locality are invited to send specimens to the Station. Such specimens can be sent packed in dry salt (in most instances), in receptacles convenient for the transport of fish. In cold weather no salt is needed.

The following synopsis (which may serve as a table of contents), shows the order in which the groups of Vertebrates are arranged in the Catalogue which follows, and the page where the consideration of each begins:

Ctass mamialia.

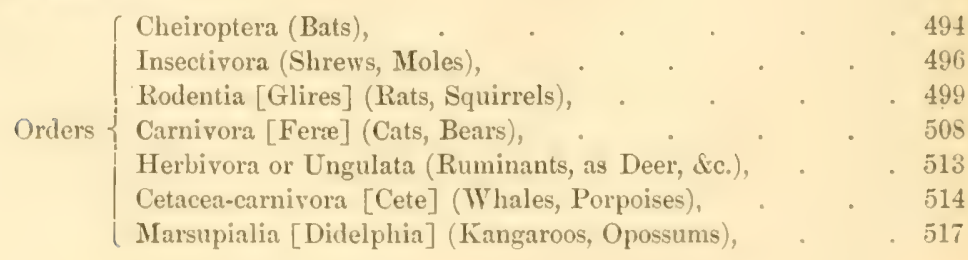


CLASS AVES (Birds).

3. Scansores (Climbing Birds).

(Pici (Woodpeckers), . . . . . . 518

Orders Cuculi [Coccyges] (Cuckoos, Kingfishers), . . 522

Cypseli [Macrochires] (Swifts, Humming-birds), . . 523

3. INSESSOREs (Perching Birds).

Order $\{$ Passeres (Sparrows, Crows, Larks, Swallows, dc.), . . 525

\{ Raptatores [Raptores] (Owls, Eagles, Birds of prey), . . 573

3. Cursores (Running Birds).

$\begin{cases}\text { Columbæ (Pigeons), } & 583 \\ \text { Rasores }\left\{\begin{array}{l}\text { Gallinæ (Fowls), } \\ {[\text { Crypturi (not represented in New Jersey)]. }}\end{array}\right. & 584\end{cases}$

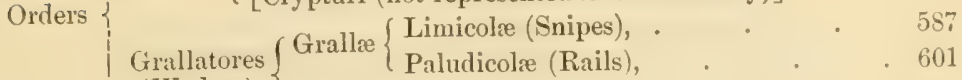

(Waders) \{ Herodiones (Herons), . . . 604

3. Natatores (Swimming Birds).

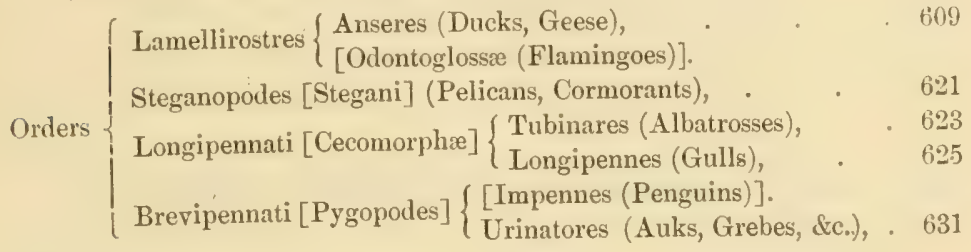

Class REPTILIA.

Chelonia (Turtles), . . . 637

Orders $\left\{\begin{array}{l}\text { Chelonia } \\ \text { Lacertilia [Saurii] (Lizards), . . . } .641\end{array}\right.$

Ophidia (Snakes), . . . . . . 643

CLASS AMPHIBIA [Batrachia].

Orders $\{$ Anoura, or Anura (Frogs), . . . . . 649

Orders $\{$ Urodela (Newts, Salamanders), . . . . 652

\section{Class PISCES (Fishes).}

Sub-Class Marsipobranchir [Cyclostomi].

$\{$ Hyperotreta (Hag-fishes), —. 057

Orders $\{$ Hyperoartia (Lampreys), . . . . . 657

Sub-Class Elasmobranchir (Selachians).

3. Plagiostomi.

$\left\{\begin{array}{l}\text { Squalides or Squali [Selachii] (Sharks), } \\ 059\end{array}\right.$

Orders \{ Rajides or Raire (Rays), . . . 663

Sub-Class Ganoider.

3. Chondrostei.

Order-Glaniostomi (Sturgeons), . . . . . 668 
\& Holostei.

Order-Ginglymodi (Gar-pikes), .

Sub-Class 'Tezeoster (Bony Fishes).

3. Рнтулоsтoiri.

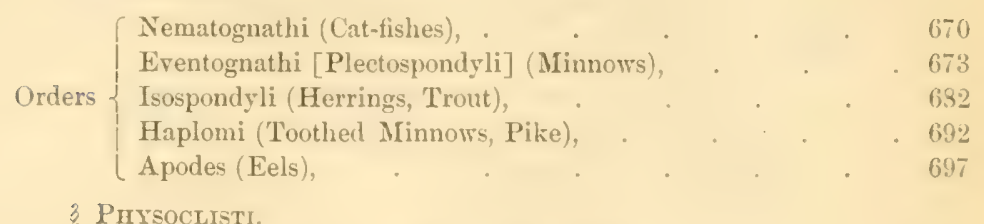

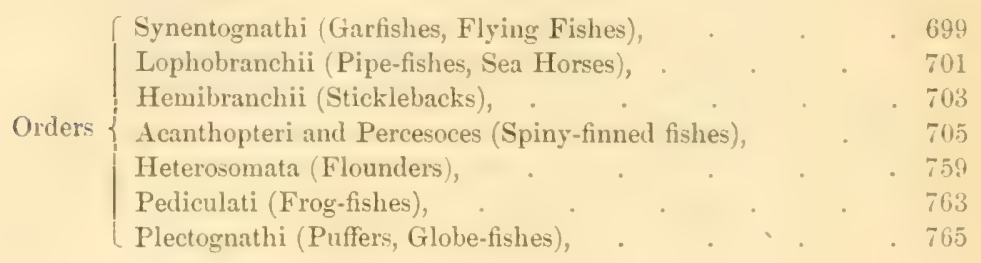

CATALOGUE OF VERTEBRATE ANIMALS.

CxASS IMAMIMATIA.

Mrmmals.

Order Cheiroptera.

Bats.

Family VESPERTILIONIDA.

Common Bats.

ATALAPHA, Raf.

(Lasiurus-Abbott's Catalogue.)

A. noveboracensis, Erxl. Red Bat.

Fur long and silky, reddish brown, mostly white at tip of hairs; lips and ears not edged with black; a white tuft at base of thumb. Spread of wing, 12 inches; length, 33 inches.

"Quite abundant. Appears to be less frequent in towns than others. Is first seen in April, when it leaves its winter quarters, 
having lain perfectly torpid since the preceding December. Feeds, as does all the tribe, exclusively on insects, and probably devours more than even the fly-catching birds."

A. cinerea, Beauv. (Vespertilio pruinosus, Say.) Hoary Bat.

Color rich chocolate brown, overlaid with white; lips and ears marked with black. Spread of wing, 14 inches; length, 5 inches.

"Not very abundant. First seen in May, having, like the preceding, been torpid during the winter. More generally met with hovering over creeks and about woods, than in the open country or in the city. Perfectly inoffensive."

\section{VESPERTILIO, Linn.}

(Scotophilus, Leach.)

$\nabla$. fuscus, Beauv. (Vesperugo, Keys. \& Bl,, serotinus, Schreb.), var. carolinensis, Geof. Carolina Bat. Dusky Bat. Long-eared Bat.

Wings naked; ears more or less turned outward; upper lateral incisors scarcely visible. 32 teeth. Spread of wing, 12 inches; length, 3 to 4 inches.

"Quite common. Common in eities, and not unfrequently flies into houses, probably in pursuit of common house flies. More frequently seen during the day than the preceding."

叉. fuscus, var. fuscus, Beauv. Brown Bat.

"Common. Is probably only a variety of the preceding, and in all respects appears the same in its habits."

V. noctivagans, Le C. (Vesperugo.) Silver-black Bat.

Fur long, silky, black, with silvery tips. Spread of wing, 12 inches; length, $3 \frac{1}{2}$ inches. 36 teeth.

"Not common. Have met with but few, in a very large collection, made during three summers." - [C. C. A.]

\section{$\nabla$. subulatus, Say. (lucifugus, Le C.) Little Brown Bat.}

Face small, fox-like, high forehead, pointed snout; ears large, oval; wings naked; face whiskered. 38 teeth. Spread of rvings, 9 inches; length, 3 inches. A variable species.

"Most abundant of all the species, and is everywhere to be met with throughout the State. Appear about the first of May, and as soon as it is dusk, commence a flight that lasts the greater part of the night, killing in the time an incredible number of insects. During the day they sleep, hanging to the small twig 
of a tree, generally sheltered from the sun's light. The females produce their young towards the end of June, three to five at at litter. In the winter they lie dormant, generally choosing a hollow tree for their winter quarters, many individuals occupying the same tree."

จ. subulatus, var, lucifugus, Le C. Blunt-nosed Bat.

In this case, and in that of $V$. fuscus, these varieties which stand as distinct species in the old Catalogue, perhaps scarcely merit the special designation we have given them.

"Appears to be more common during some summers than others. After a cold northeast storm in July, and while the air was still unseasonably cool, a 'festoon' of bats was found by the author, containing nine in all, two of which were of this species. These 'festoons' are not unfrequently met with during cool weather."-[C. C. A.]

\section{Order INSECTIVORA.}

\section{Family SORICID王.}

Shrews.

\section{SOREX, L.}

S. forsteri, Rich. Long-tailed Shrew.

Tail two-thirds length of head and body; snout slender; ears small. Length, $4 \frac{1}{2}$ inches.

"Not abundant, and have met with it only in the northern counties of the State, and once in Mercer county. Lives generally near water, and like the preceding, burrows a short distance below the sod, for a place of refuge and a nest. Feeds on larve of insects and on crickets." - [C. C. A. $]$

\section{BLARINA, Gray.}

B. brevicauda, Say. (talpoides, Gap.) [De Kay's Shrew.] Shorttailed Shrew. MIole Shrew.

Fur short and coarse; color dark ashy gray. Length, $4 \frac{1}{2}$ inches. 
"Frequents the banks of streams. Its nest is quite under the ground, smoothly lined with fine grass. Females litter in May and July. Feeds wholly on worms, larvæ of insects, and similar food. When disturbed, will dive readily, and swims easily. Probably devours the ova of the sunfish. Abundant."

There are probably other species of Shrews or Shrew-mice besides those noted above. Farmers should be on the lookout for the following (specimens of which will be gladly received at the Station):

\title{
SOREX.
}

S. platyrhinus, De K.

\author{
\% Teeth colored, 32- $\frac{20}{1} \frac{0}{2}$ (Sorex).
}

Ears very large for a shrew ; tail scant-haired; color chestnutty. Length, $3 \frac{3}{4}$ inches; tail, $1 \frac{1}{2}$ inches.

S. cooperi, Bach.

Same as preceding, except ears a little smaller and color chestnut brown.

S. personatus, Geof.

Smallest of our shrews. Length, $2 \frac{3}{4}$ inches; tail, 1 inch. Color and ears as in the preceding.

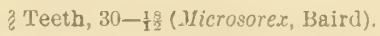

S. hoyi, Bd. Hoy's Shrew.

Very small and slender; ears large; olive brown. Length, 3 inches; tail, $1 \frac{1}{\frac{1}{4}}$ inches.

B. angusticeps, $\mathrm{Bd}$.

\section{BLARINA.}

Short-tailed Shrews.

Size intermediate; skull narrow; color uniformly leaden. Length, $3 \frac{1}{2}$ inches; tail, 1 inch.

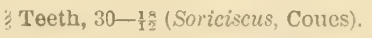

B. parva, Say (cinerea, Bach.)

Body stout ; iron gray, with brown gloss. Length, $3 \frac{1}{\frac{1}{t}}$ inches; tail, $\frac{3}{4}$ inch. 


\section{Family TALPID正. \\ Moles.}

Moles differ from shrews in having wore numerous teeth, in the presence of canines, in having concealed eyes, and in the peculiar development of the fore legrs, which are short, stout and adapted for digging.

\section{SOALOPS, Cuv.}

S. aquaticus, L. Common Mole.

Dark leaden color, paler below; feet full webbed; eyes not covered by skin; tail short, nearly naked. 36 teeth.

"Common everywhere, provided the soil is loose enough to permit its subterranean travels. Is probably more abundant in the moist meadow lands than in the high and dryer sections. Feeds almost wholly upon earth-worms, and destroys so many that unless they (the moles) are very abundant, are more useful than otherwise. Moles arrange their nests at a somewhat greater depth than they usually burrow at. The young are littered in May, seldom more than three being born at one littering. The prevalent idea that moles are blind is erroneous."

\section{SOAPANUS, Pom.}

(Scalops-Abbott's Catalogue.)

S. breweri, Bach. Hairy-tailed Mole.

Color dark leaden, with brown gloss. Tail short and very hairy. 44 teeth.

"Is much less abundant than the preceding, to which it bears a great resemblance. This mole seems to prefer wet, low grounds, even more than the preceding species, and burrows somewhat deeper. The nests are also further below the surface. They feed almost wholly upon the common earth-worm, and when placed in a box with a quantity of worms, they have been known to kill themselves by over-eating."

\section{CONDYLURA, Illig.}

C. cristata, L. Star-nosed Mole.

Color blackish; tail nearly as long as body. Long nose, fringed at end with a circle of fleshy projections. 44 teeth. 
"Not at all abundant. Prefers moist land, and is more frequently found burrowing in the banks of streams than elsewhere. Does not differ materially in its habits from the more common species. Is more frequently met with in the central than the northern or southern sections of the State."

\section{Order RODENTIA.}

\section{Family SCIURID FE.}

\section{Squirrels.}

"The true squirrel is arboreal. His home is in the trees, and his legitimate food their fruits and buds. Should he go to the ground, it is only in search of food; and this obtained, he returns to his airy dwelling-place. Here in summer he builds him a nest of leaves, taken from the branches at hand, and in a hole in the same tree, or in one that he can attain by springing from branch to branch without going to the ground, he has a more secure retreat, to which he can retire during inclement weather, or escape the attacks of an enemy, and in which the young are generally reared.

"'This class of squirrels possesses a muscular but light and graceful form, with the toes long and the nails strong and sharp, by which they are enabled to climb trees and take long leaps among the branches with wonderful ease. In these leaps, they are also aided by their large and bushy tails, which serve as rudders to steer by. They use their fore feet as hands, seizing their food with them, and stand upon their hind feet when eating. On the ground they either run or move by springs made mainly by the hind legs. Unlike most of the order, they move about by day, and keep in their retreats at night, to which they also retire for a few hours during the middle of the day. Though their food is properly vegetable, squirrels are known to eat insects. By a slighter departure from their natural food, they exhibit a fondness for corn, and more rarely wheat and other grains, which is highly prejudicial to their good standing in a community of farmers. In fact, these animals are much more injurious than is generally known.'-Kennicott. So far as the latter clauses of the above 
quotation are concerned, they are scarcely applicable to New Jersey, for no species is at present so abundant as to render its 'grain depredations' appreciable. Partly on aceount of a general cutting off' of large timber, and largely in consequence of the persistent shooting, at all times of the year, the squirrels have become, we may almost say, uncommon. In no county of the State could five hundred probably be found, during the proper shooting season. As they are, in so small a degree, insectivorous, it is perhaps of little moment whether they be numerous or otherwise, and probably their absence is more than compensated for by the true insectivorous birds (whose nests are frequently destroyed by squirrels), which are, when undisturbed by squirrels or men, really valuable beyond calculation."-[C. C. A.]

\section{SCIURUS, L.}

S. niger, L., var. cinereus. Fox Squirrel.

No cheek pouches; tail bushy, as long as body; ears long; no black stripes; color rusty gray, but very variable. Length, 26 inches; tail, 14 inches. The two following species of Abbott's Catalogue are merely varieties of $S$. niger.

"This squirrel is not an abundant species in the State, and is the largest of the squirrel tribe found with us. A pair or two, when this species is met with, are found inhabiting large trees, and waging determined war with the hudsonius and striatus, also with the following species. In Mercer county specimens of this squirrel have been quite frequently met with during the past three years. They seem to prefer a clump of large shell-bark hickories with open ground abont them, and do not wander far from the tree containing their nest. Are occasionally seen during a warm spell of weather in winter."

S. migratorius (Abbott's Catalogue). Gray and Black Squirrel.

A variety of $S$. niger.

"A greater number of this species are to be found in New Jersey than of the preceding, but as it frequents deep swamps and heavily-timbered tracts, away from houses, it is not more frequently seen in every-day life, and appears no more abundant. It is nowhere sufficiently numerous to be destructive to any extent." 
S. niger, L. (Abbott's Catalogue.) Black Squirrel.

Consider this as var. niger of S. niger, above.

"Very rarely met with, although probably only a variety of the preceding, which is an abundant species. Have seen but two specimens, both taken in Passaic county in December, 1860."

S. carolinensis, Auct. Gray Squirrel. Black Squirrel.

Varies from grizzly yellowish gray to pure black. Length, 24 inches; tail, 13 inches.

"It is not improbable that this, a southern species, may be occasionally met with in New Jersey, as one specimen has met my notice, known to have been shot in Essex county. There is a probability, however, of its having been a caged squirrel, escaped from its owner."

S. hudsonius, Pal. Chickadee. Red Squirrel. Chickaree.

Rusty red. Length, 14 inches; tail, $6 \frac{1}{2}$ inches.

"In many portions of the State this little squirrel, formerly very abundant, has become quite scarce. Such is the case throughout Mercer county in a marked degree. Before the large pine tracts in the southern counties were cut off, it was there found abundantly. Occasionally burrows quite deeply among the roots of trees. Lays up large stocks of food for winter use, and during this season is as lively as in midsummer."

\section{SOIUROPTERUS, CuV.}

(Pteromys, Cuv.)

S. volucella, Pal. Flying Squirrel.

Yellowish brown, creamy white below; a furred membrane extends along the sides from the fore to the hind legs. Tail flattened and densely furred.

"Quite common. Found only among large trees, especially large nut-bearing species. During the day they lie quietly in the hollow of a partially-decayed tree-frequently a half dozen together-and as the sun goes down make their appearance, sailing about from branch to branch, and seldom coming to the ground. The females produce two litters during the summer, three to five the usual number. The nests are in hollow trees, and occasionally a deserted bird's nest is occupied. The food of this species is that of squirrels generally, and unlike them, a 
certain amount is stored away in autumn for winter use, during which season they are very active. When barns are so situated that they can be reached by this species without their being compelled to travel over the ground, these squirrels are occasionally found in the mows, although it is not probable that the females ever make their nests there."

TAMIAS, Illig.

T. striatus, L. Ground Squirrel. Chipmunk.

With 3 to 5 black stripes along the back, with cheek pouches. and with the tail not bushy, but shorter than body. Length, 11 inches; tail, $4 \frac{1}{2}$ inches.

"Very abundant, and although a certain amount of yellow corn is eaten by them, are an inoffensive species. Live in burrows, and remain on the ground, or run along fences. They store up many nuts for winter use, and by the middle of October have generally crept into their burrows, where they remain in a state of semi-hibernation. Very rarely met with during the winter, even in long-continued mild weather."

\section{ARCTOMYS, Schr.}

A. monax, L. Ground-hog. Narmot. Woodehuck.

Thumb rudimentary; soles naked; grizzly gray to blackish. Body large, thick set.

"Very abundant in certain localities and very seldom met with in others throughout the State. The author has seen twelve killed along the bluffy banks of Crosswicks Creek, in Ocean county, during a three hours' hunt. Ground-hogs burrow very deeply, in open fields, on hill-sides, and in heavy timber land, though most frequently in open positions, so that when out of its burrows, the animal can see well about it. They are very wild and watehful, and never wander very far from their holes. The females have but one litter in a year, generally as early as. April, and the young are always sufficiently grown by autumn to take care of themselves. Ground-hogs, or woodchucks, are strictly herbivorous, and do more damage in their visits to clover fields than by any other habit. When their burrows are near gardens, they will oceasionally enter the gardens and eat largely 
of the vegetables there planted-peas and lima beans especially. Although not apparently a favorite locality, they burrow fre"quently on the banks of streams but little elevated." Besides, by means of trapping, woodchucks may be killed by putting a handful of rags, upon which a tablespoonful of bisulphide of carbon has been poured, into their burrows, and closing the opening by means of a sod.

\section{Family CASTORID $\mathbb{E}$.}

Beavers.

Aquatic rodents of large size; fore feet with five distinct toes and claws; hind feet webbed; tail broad, flat and scaly.

\section{CASTOR.}

C. fiber, L. (canadensis.) Beaver.

"Probably no longer found in the State, but may possibly stiil exist in very limited numbers about the northern boundary line. It was found in Cape May county twenty-five years ago occasionally, but in all probability has ceased to exist there. Was formerly very abundant, especially along the Assanpink Creek, Mercer county" (1868).-[C. C. A.]

\section{Family ZAPODIDE.}

\section{ZAPUS, Coues.}

(Jaculus, WVagl.)

Z. hudsonius, Zim. Jumping Mouse.

Yellowish brown; variable. Hind legs very long; fore legs short.

"Not very abundant. Frequents woods, but never goes very far from open ground. Occasionally it burrows, but not deeply, making a nest of fine grass. More frequently the nest is beneath the bark of a decayed tree. The young number from three to five in a litter, two litters generally being produced. Their 
food consists largely of seeds of plants and nuts. The 'chinkapin' or dwarf-chestnut they are extravagantly fond of, and they appear to store up quantities for winter use, but as they hibernate the nuts are not intended for such use, but are their 'stand-by' during November and so much of December as is sufficiently mild to warrant their remaining above the sod, for when it becomes really cold they burrow quite deeply down. They eat, too, little grain, and are too little abundant to be offensive." When animals are rare, it is a shame to wantonly destroy them.

\section{Family MURID}

Mice.

\section{MUS, L.}

M. decumanus, Pal. Brown Rat. Norway Rat.

Tail scaly, shorter than head and body; feet dusky white; fur mixed with stiff hairs. Introduced into America about 1775.

"Everywhere abundant, troublesome and boldly impudent. Very frequently met with in fields, burrowing and otherwise living as a strictly wild species. Their burrows are often very extensive, tortuous and deep, one large chamber frequently having several entries leading to it. They feed largely on grain when accessible, but are omnivorous."

M. rattus, L. Black Rat.

Tail not shorter than head and body; feet brown. Introduced into America about 1544, but now giving way to the preceding.

"Formerly an abundant species-is now nearly, if not quite extinct. The author has met with but a single specimen, which was taken in Essex county in 1846 and preserved as a curiosity." - C. C. A. $]$

M. musculus, $L$. Mouse.

"Abundant at all times and under all circumstances. More than it is generally believed of this species live out of doors. When thus living, they burrow quite extensively, generally under the shelter of corn-shocks, and still more frequently about the roots of trees, especially trees standing on the borders of fields. It lays up quite large stores of grain for its winter use." 


\section{NEOTOMA, Say.}

N. floridana, S. Wood Rat.

Tail scantily hairy; feet white, soles hairy. Length, 14 inches; tail, 6 inches. Should not be confounded with the brown rat, which has naked soles. This species ranges from the Gulf States to Massachusetts, and probably occurs in New Jersey.

\section{HESPEROMYS, Wat.}

E. leucopus, Raf. White-footed Mouse. Deer Mouse.

Yellowish brown; tail bicolor, closely hairy, about as long as head and body; fars large.

"Quite abundant, and a most interesting little animal. Frequently confounded with the 'jumping mouse,' but is easily distinguished by its lighter color and shorter tail. Found wholly in woods, living, nesting and gathering its winter store from the trees of the forest almost entirely. When grain-fields are skirted by timber land, they make incursions and gather corn and buckwheat, but do not travel any distance to secure grain if chestnuts and acorns are attainable in the woods. Do not hibernate. They build a nest not unlike a bird's nest, or use a deserted bird's nest. Three litters annually."

H. palustris, Har. Rice-field Mouse.

Blackish and ashy above, paler below; fur harsh and compact. A large, rat-like species of the Southern States, possibly likely to occur in Southern New Jersey.

\section{ARVICOLA, Lac.}

A. pennsylvanicus, Ord. (riparia.) Meadow Mouse.

Fore claws not longer than hind claws. Tail $\frac{1}{3}$ length of head and body, or more.

"The 'meadow mouse' of New Jersey. This species is quite abundant, and as its common name would suggest, lives almost wholly in marshy, meadow lands. They burrow generally beneath the roots of a small bush or tree, and occasionally in the decayed stump of a tree. They are also found in hollow, 
prostrate trees. The females have generally three litters during the spring and summer, probably a fourth. Do not libernate. Feed on seeds of grasses and some grain, and lay up considerable stores for winter use. Is very seldom met with in woods, and scarcely more frequent is it in grain-fields."

A. pinetorum, Le C. Field Mouse. Pine Mouse.

Tail $\frac{1}{t}$ length of head and body.

"Abundant. Frequents high and dry fields, and burrows and lives more in corn-fields than other localities. During the winter its nest is generally found under a fence, and very frequently close to the fence-post if it be at all rotten. Stores up large supplies of grain and roots, also beech-nuts, when the mice are nesting near beech trees."

\section{FIBER, Cuv。}

F. zibethicus, L. Muskrat.

The largest of our Muridce.

"Formerly was much more abundant than at present, but is still numerous. Strictly aquatic, in a measure gregarious, and at all times omnivorous. Muskrats feed largely upon Unios in the summer, and the roots of aquatic plants at other times. Occasionally suckers are eaught and devoured by them, they being abcut the only fish too sluggish in movement to easily escape pursuit. They build nests of hay in trees, a short distance above the water, and during the day lie on them, sunning themselves. These nests are used by them in winter, when they sleep the greater portion of the time. They also burrow into the banks of the streams, and frequently these burrows are but several entrances to one chamber. The opening is always under water. In the chamber the young are born, and it is in these burrows they spend most of their time during the summer; but if drowned out by freshets they take refuge in the winter nests in the trees. Although so frequently seen moving about during the day, they are strictly a nocturnal animal. The fur of the animal is valued sutficiently to render them worthy the trapping, and their flesh is by no means unpalatable, especially the tails." 


\section{Family LEPORID EE.}

Rabbits.

\section{LEPUS, L.}

L. americanus, Erxl. Northern Hare: White Rabbit.

Large size; hind feet longer than head; ears about equal in length to head; fur brown in summer, white in winter (at the tip of hairs). Lives in woods. Perhaps occurs in the northern counties.

L. eylvaticus, Bach. Rabbit. Gray Rabbit.

Size small; hind feet not longer than head; ears $\frac{2}{3}$ of head; color grayish, tinged with brown and black, white below. More southern than the preceding. It does not change to lighter color in winter.

"Abundant throughout the State. During the summer the majority of the rabbits remain in the woods and swamps and move about but little. The does have two litters in a year, the first dropped in May and the second in August. The nest is variously placed, and frequently is so exposed that not only the old fall victims to hawks, but the young to prowling mammals. Very frequently pigs come across the nests, and eagerly devour the occupants. Rabbits are quite tame during the latter part of the summer, and are found frequently in gardens; but later in the season they seem to know they are more prized by mankind, and they become wilder and seek less frequented localities. They are easily trapped by baiting a 'figure-of-four' box-trap with apple, especially during the winter, when the snow is over their favorite food. Rabbits frequently do serious mischief by gnawing the bark of young fruit trees, very generally killing the trees. During heavy snows rabbits make for themselves slight burrows and protect them overhead by overarching the grass. In this way they secure for themselves a comfortable little cave during the storm and while the snow lasts. They seem to be able to go a long time without food. Though very lively when disturbed during the day, rabbits are really nocturnal." 


\title{
Order carnivora.
}

\author{
Family FELIDEE。 \\ Cats.
}

LYNX, Raf.

L. rufus, Guld. Wild-cat.

Inner sides of legs with dark cross bands; tail with a black patch at end above, preceded by half rings.

"Very rare, and probably will be wholly extinct in a year or two. In the southern counties, among the still undisturbed swamps, there are yet, no doubt, perhaps two or three pairs still living. In Mercer, Middlesex, Essex, Hunterdon, \&c., they have been for some years extinct, and it is merely a matter of speculation as to whether or not they are found about the Blue Mountains and that portion of the State [1868].

"In 1852 a specimen came down the Delaware during a high freshet-was taken near Trenton, and although apparently dead when found, it revived. This may have come from the northeru part of the State, but it is by no means certain. The females have a single litter about May, the kittens shifting for themselves in August. Wild-cats frequent heavy timber land and prey upon birds principally, and also upon rabbits and squirrels. Domestic eats not unfrequently 'run wild,' and have, when tawny-colored, been mistaken for the Lynx rufus. The smaller size and longer tail of the former ought to readily undeceive any one."

\section{Family CANID $\mathbb{E}$. \\ Dogs.}

\section{VULPES, Bris.}

V. vulpes, L. (fulvus.) Red Fox. Cross Fox. Silver Fox. Black Fox. Chiefly red, with black feet and ears; tip of tail white; quite variable in color. 
"Formerly was very abundant throughout the State, but now is very rarely met with. Like the wolf and cougar, it has been too much persecuted to still add to the fame of our State, and were it not that its burrows rendered it less easily found, it would have long since been extinct. The last specimen seen in Mercer county was in 1850 , and it is doubtful if others are now living in that or the adjoining counties. The northern and extreme southern sections of the State are the favored localities, if they exist at all. They prefer heavily-timbered hillsides to any other locality, and at night make 'telling' raids on hen-roosts."

\section{UROCYON, Bd.}

U. cinereo-argentatus, Schr. (V. virginianus.) Gray Fox.

Fur dusky; hairs hoary at tip; tip of tail usually dark.

"In the southern counties that have salt-marsh and sea-coast boundaries, and in those localities where the timber and brush give sufficient shelter, the gray fox is still quite abundant. They do not appear to be found in the central portion of our State, or along the Delaware River. About May the bitches litter, producing generally five young. The gray fox feeds largely on crabs and fish ; it also robs the nests of the 'mud-hen,' Rallus repitans, and not unfrequently is sufficiently quick in its movements to capture the sitting bird. They are frequently caught and kept in hopes of their becoming tame, but they never become so far domesticated as to stay at home if they are left unchained" (1868).

\section{Family MUSTELID \\ Weasels.}

\section{MUSTELA, L.}

M. pennantii, Erxl. Fisher. Black Cat.

Color variable; belly, legs, tail and hind parts chiefly black; length more than two feet.

"Rarely met with. None exist in the central part of the State, probably none in the southern section. About the moun- 


\section{j11 GEOLOGICAL SURVEY OF NEW JERSEY.}

tains in the northern counties a few are still living, but in no appreciable numbers. Frequent water-courses, feeding largely upon fish. Seldom approach farm-houses, or attack poultry."

\section{PUTORIUS, Cuv.}

P. ermineus, Cuv. (noveboracencis.) Weasel. Ermine.

Color various; tip of tail usually black; white in winter. Length, 8 to 11 inches.

"Common. Known throughout the State and about equally abundant in the several counties, but still is nowhere actually numerous. Frequent timbered lands principally, but frequently met with in the open meadows, and when so found is a useful animal, as it now lives wholly on meadow mice. Weasels litter but once in the summer, usually May, producing generally five at a birth. Were it not for its ugly habit of raiding on poultry roosts and doing so much damage, the weasel could not be complained of, but under the circumstances merits the wrath of the farmer."

P. vison, Gap. Mink.

Brownish chestnut; tail black; length of body, 15 to 20 inches.

"Common. Probably equally abundant throughout the State, and in some localities is more numerous. Frequents meadow lands and the banks of streams principally, although frequently found in high, dry timber land. Minks litter but once during the summer, generally about the middle of June.

"If birds, meadow mice and 'chipmunks' are at all abundant in any neighborhood where minks are common, then the poultry is in a great measure free from their attacks; and only in midwinter do they ever do serious damage. In condemning them for their sins, so far as poultry is concerned, it may be as well to give them credit for the good they do-as valuable they really are, in the destruction of meadow mice."

LUTRA, L.

L. canadensis, Sab. Otter.

Color, liver brown; length, $4 \frac{1}{2}$ feet. 
"Not now abundant, although still found in the central counties of the State, but in the northern and southern sections they are still quite numerous. A water-loving animal, it is generally found about the banks and on the small islands of creeks and ponds, but occasionally in swamps, where there is but little running water. A creek traversing a thickly-grown maple and birch swamp is ever a favorite locality. About the Assanpink Creek they were, twenty-five years ago, very common, and a few still are found, this creek being the principal locality for them in the central third of the State. Otters live almost wholly on fish, and are nearly as much at home in the water as their prey. During the annual spring freshets the otter is very frequently carried down the river from its haunts, and in this way otters have made their appearance about Trenton and about New Brunswick, creating for a time no little excitement until they are captured, when the 'strange visitor' of the local columns of our papers proves to be-an otter."

\section{MEPEITIS, Cuv.}

M. mephitica, Shaw. Skunk.

Usually black, with tip of tail, the dorsal stripes and neck patch white; but it may be all black or sometimes nearly white.

"Is not very abundant in any portion of the State, nor yet entirely wanting in the fauna of any county. It appears to prefer" farms to uncultivated tracts, and yet is always found to live in timber land. Any small strip of heavy timber, within half a mile of a farm-house, very generally harbors at least one skunk. Occasionally they take up their abode in winter in a haymow, and a ruining of the hay is apt to be a consequence. They prey upon poultry occasionally, but are not very destructive in this respect. The skunk is nocturnal, or in a measure so, in its habits, prowling about during the dusk of the evening, and into the night when moonlight. In the northern counties of the State they do not appear to be as frequently met with as in the central and southern sections. Judging from old records, they were formerly very abundant, and looked upon as destructive." 


\section{Family URSIDEE.}

Benrs.

\section{PROCYON, Stor.}

P. lotor, L. Raccoon.

Slender, plantigrade, carnivorous; with well-developed tail, with black rings; snout elongated; color grayish white; hairs black at tip.

"Quite frequently met with in every county of the State, and yet is nowhere so abundant as to be looked upon as an animal of every-day occurrence. In the northern counties they are probably less numerous than in the southern, although more common than about the central third of the State. In Mercer county they are but little seen, and when found are generally net with about the Assanpink, which traverses in part swampy, overgrown land, such as 'coons' prefer. 'Coons,' when pursued, readily take to trees, and, indeed, are seldom met with at any great distance from heavy timber. The young are brought forth in May, from four to seven being in a litter. During the spring the raccoon is a valuable beast, as it at this time of year eagerly searches out and devours quantities uf' gruhs, and by this destruction of the larvæ of obnoxious insects largely compensates for the corn eaten by them in August. When the water-courses are strongly frozen up, and especially if there has much snow fallen, raccoons will burrow under haystacks, and less frequently under barns, living at such times in a great degree upon mice, and occasionally attacking poultry. It is doubtful if at any time they are so destructive as to warrant the persecution they seem doomed to sutter."

\section{URSUS, L.}

U. americanus, Pal. Black Bear. Brom Bear. Cinnamon Bear.

Color variable.

"Fast disappearing from the State. Now never met with in the central counties; in inappreciable numbers in the northern mountainous districts, and not more than half a dozen are anuually killed in the southern section of the State. The bear has been the last of the three large carnivorous animals of the 
State (panther, wolf and bear) to disappear before the settling and clearing off of the land. Of these three the bear is the least carnivorous and less roaming, thus giving it more of a chance while any thick swamps remained" (1868).

\title{
Order UNGULATA.
}

(HERBIVORA.)

\author{
Hoofed Mammals.
}

\section{SUB-ORDER RUMINANTIA.}

\section{Family CERVID正. \\ Deer.}

\section{OARIAOUS, Gray. \\ (Cervus, L.)}

\section{C. virginianus, Bod. Red Deer. Virginia Deer.}

Color chestnut red, grayish in winter.

"Found now only in a circumscribed locality in the southern portion of the State. Although frequently protected by law, they have never become very numerous, and the encroachments of agricultural interests upon the now wild lands will soon cause the deer entirely to pass away. Formerly they were very abundant throughout the whole State, and a century ago the central counties were, no doubt, the favorite haunts of this animal." 


\section{Order CETACEA=CARNIVORA.}

\section{SUB-ORder MYSTICETE.}

\section{Family BAL FNIDE:}

Whales.

BAL

(Eubalæna, Cope.)

B. mysticetes (ciscrtica). Right Whale. Whalebone Whale. Black Whale, dic.

Head very large; no teeth; 600 baleen plates in upper jaw ; no dorsal fin; 2 spiracles; eye above angle of mouth; length, 40 to 60 feet.

"Individuals of several species are occasionally cast ashore eastward, and some are known to enter New York harbor. They were formerly abundant about the mouth of the Delaware."-Cope, Proc. Acad. Nat. Sc. Phil., 1866. The finback whale (Dubertus or Gubartas) Sibaldius tectirostris, Cope, is abundant off Massachusetts. They swim so as to expose a part of the back: 'The sperm whale (Physeter macrocephalus, Lac.) was once abuudant on our coast. De Kay mentions two species of Rorquals, Rorqualus rostratus and $R$. borealis, as having been captured in New York Bay, 1822, and in the Delaware, 1804 , respectively. 


\section{Sub-Order odontocete.}

\section{Family DELPHINID FE. \\ Porpoises.}

\section{- TURSIOPZ, Gerv.}

T. tursio, Fabr. (Delphinus, Phocrna, metis, \&c.) Bottle-nosed Dolphin. Sea $\mathrm{Hog}$, \&c.

Beak moderate, tapering, marked off from forehead; dorsal and pectoral fins falcate; color greenish gray, white below, sometimes spotted; teeth, 22 in each half jaw; length, 9 feet. Not common on our coast.

\section{DELPHINUS, L.}

D. delphis, L. Sea Porpoise. "Dolphin."

Body slender; head slopes gradually into long beak; pectorals narrow; color black above, lighter below, with gray lateral bands; teeth, 46 to 51 in each half jaw; length, 7 feet. This species frequents the high seas; it should not be confounded with a true fish called the "Dolphin."

\section{PRODELPEINUS, Ger $\nabla$.}

(Delphinus.)

P. plagiodon, Cope. Spotted Dolphin.

Beak stout, shorter than preceding; color dark purplish above, with gray spots, and whitish below, with dark-gray oblong spots; teeth, 37 ; length, 7 feet. Southern-ranges northward to Cape Hatteras. Inserted here for sake of comparison.

P. frcenatus, F. Cuv. (D. clymene, Gro) True Dolphin.

Smaller than preceding; color of belly sharply separated from dark upper parts; spotted like former but smaller and more numerous above; teeth, 38 ; length, 6 feet. Rare. A specimen from our coast is in the Philadelphia Academy. 


\section{IJAGENOREYNCHUS, Gr.}

L. acutus, Gr. (perspicillatus.) Skunk Porpoise. Bay Porpoise.

Beak short, plowshare-like; body largest forward; flukes large; color black above, gray laterally, yellow patch on tail and white patch further forward, also irregular dark bands; teeth, 35 to 37 ; length, 8 feet. Abundant about Cape Cod.

\section{PHOCÆNA, Cuv.}

P. communis, Less. (D. brachycion.) Harbor Porpoise. Herring Hog. Common Porpoise.

Jaws equal, size small ; color blackish above, fading to whitish belly, sometimes with yellowish tinge; margin of lower jaw black; teeth, 26 ; length, 5 feet.

"This is the abundant species so common not only along the coast, but in the mouths of the rivers. They have been seen in the Delaware as high up as Trenton, and are common in the Hudson north of the New Jersey State line.

"They frequently are seen sailing along with a slow and measured motion, just appearing at the surface by elevating the crown of the head, and then diving short, so as to make their bodies describe the arc of a small circle, exposing themselves to view only from the crown of the head to a short distance behind the dorsal fin. Occasionally a troop of them may be seen scudiing along, rising in this manner in quick succession, as if auxious each to get in advance of the other, while again a single individual may be observed successively rising and falling in the same way, as if engaged in the act of catching a prey."

Have been known to kill schools of drumfish.

\section{GRAMPUS, Gr.}

G. griseus, Cuv. (D. globiocephalus.) . Grampus. Cowfish.

Head globular; lips beak-like; mouth oblique; dorsal fin high; pectorals long and falcate; flukes narrow; above dark gray and variegated, laterally, with yollowish and gray; whitish belly, with streaks; no teeth in upper jaw ; length, 10 feet.

True, in his "Review of the Delphinidr," Bul. No. 36, U. S. 
Nat. Mus., to whom I am indebted for this list of identifications, includes Atlantic City, New Jersey, in the habitat of this species. It is rare south of Cape Cod.

\section{GLOBIOEPHALUS, Gr。}

G. melas, Traill. (Phocæna, Delphinus, intermedius.) Blackfish. Black Whale. Social Whale. Pilot Fish.

Forehead protuberant; body deep at dorsal fin; uniformly black, except a white arrow-shaped line on belly; teeth, 10; length, 15 feet. Breed in summer about Cape Cod. Rare on New Jersey coast.

G. brachypterus, Cope.

Like preceding, but with shorter pectorals; dorsal fin far forward and color all black; teeth, 8. Rare.

ORCA, Gr.

O. gladiator, Lac. Gladiator Dolphin. Killer, \&c.

Dorsal fin very high in male; head broad and flat; no beak; pectorals short; color black, with a trident-shaped white mark on belly. Pelagic and of great size, and a terror to all other Cetaceans. Both jaws studded with conical teeth. Rare inshore.

\section{Order marsupialia.}

\section{Family DIDELPHID}

\section{DIDELPHYS, L.}

D. virginiana, Shaw. Opossum.

Tail long, nearly naked, scaly, with few hairs; toes prehensile; dirty white color; legs dark. Length, 35 inches; tail, 14 inches.

"Common, and about equally abundant in the several counties of the State. It frequents wooded tracts principally, and spends the greater portion of its time in trees, or in burrows at the roots of large trees. They are nocturnal in their habits, and it is 
selflom they are met with lluring the day, as they, when sleeping in trees, lie so closely to the branch on which they rest as to. escape observation. The opossum moves with great facility among trees, and not unfrequently captures birds while sitting on their nests. On birds and their eggs and young they rely mainly for food. 'The mother carries her young with her in a pouch peculiar to the order, and when the young fill this pouch to its utmost capacity, they still move freely about trees. Occasionally they hang from a limb, head downwards, holding on by a turn and a half of their tails. After the persimmons have been touched with the frost and lost their excessive astringency, the opossum feeds upon them very greedily, and a 'possum hunt' by moonlight is most successful when they are sought for among persimmon trees. Although it occasionally happens that poultry is attacked by these animals, such is so seldom the case that it is hardly just to them to say they are an offensive animal."?

CIASS AVES.

Birds.*

\section{Section SCANSORES. \\ Climbing Birds.}

\section{Order PICl.}

Family PICID FE.

Woodpeckors.

DRYOBATES, BOİ.

(Picus, L.)

D. villosus, L. Big Sap-sucker. Hairy Woodpecker.

Spotted and lengthwise streaked, but not banded; back black, with a long white stripe; outer tail feathers wholly white. Length, 9 inches; tail, $3 \frac{1}{2}$ inches. Male with a scarlet nuchal band.

\footnotetext{
* Ridgway's Manual of North American Birds has been followed in the nomenclature of the families and smaller groups.
} 
"Resident; everywhere abundant. Frequents apple orchards perhaps more than other places, and is in a measure destructive to the younger trees, and to all growing timber, by the innumerable perforations it makes in the bark, sometimes completely girdling the tree. Feeds exclusively on insects and their larvæ. Builds in decayed trees, in May."

D. pubescens, L. Downy Woodpecker. Little Sap-sucker.

Outer tail feathers black and white, barred. Length, $6 \frac{1}{2}$ inches; tail, $2_{4}^{3}$ inches. Otherrvise like preceding.

"Equally abundant, and with the same habits as the preceding. It has been suggested that this and the preceding species only perforated the bark of young trees when they have discovered larvæ of insects beneath; but such is not the case, as they perforate to see if larvæ are beneath, not knowing beforehand. The insects themselves are more injurious than the birds, many times over; and were only 'insect-ridden' trees visited by the woodpeckers, it would be our duty to defend them. Still, it is doubtful if the injury they inflict overbalances the good."

D. borealis, Vieill. Red-cockaded Woodpecker.

Black and white, spotted and crosswise banded, but not streaked; a red line on each side of the head in males. Length, $8 \frac{1}{2}$ inches; tail, 31 inches. A southern form inhabiting swamps, and ranging north as far as Pennsylvania. A few possibly may visit our southern swamps.

\section{SPHYRAPICUS, Bd.}

Sap-Sucking Woodpeckers.

S. varius, L. Yellow-bellied Woodpecker, or Sap-Sucker.

Black and white above; black on breast, chiefly yellowish below ; white wing patch ; crown red in the adult; chin scarlet in males. Length, $8 \frac{1}{4}$ inches; tail, $3 \frac{1}{3}$ inches. The young are of a mottled brownish tint. The adult female has the chin and throat white.

"More abundant during spring and autumn. Seldom seen during the summer, although a few breed in the northern hilly sections of the State. Strazglers occasionally seen during the 
winter about barns, in which they, not improbably, take refuge during the severer weather. The 'flicker' has also been known to do this."

\section{CEOPHLGUS, Cab.}

(Hylotomus, Bd.)

C. pileatus, L. Black Woodcock. Pileated Woodpecker. Black Logcock.

Black, with white streak down neck; males with crest and cheek patch scarlet; and general color may vary from black to slaty. Females with the head without scarlet, but color brownish gray. Length, 18 inches; tail, 7 inches.

"Stragglers occasionally seen; occasionally in the clark swamps of Cape May county; but more frequently in the mountainous portion of the State. This is one of a number of birds formerly very abundant, but now nearly extinct, being driven off by the destruction of the heavy timber, in which they lived."

\section{MELANERPES, Swains.}

M. erythrocephalus, L. Red-headed Woodpecker.

Head, neck and chest a rich crimson, with a black collar separating the white of breast from the crimson above; the back glossy blue black; lower back, rump, \&c., pure white; the inner secondaries spotted with black in the female. In young, the upper and forward parts brownish gray; the back dull grayish, barred with dusky gray; the secondaries crossed by black bands. Length, $9 \frac{1}{2}$ inches; tail, $3 \frac{1}{2}$ inches.

"Formerly a very abundant species, but now quite scarce. Have found two or three pairs breeding about Stony Brook, near Princeton, Mercer county. Partially migratory, probably twofifths of their numbers remaining in the State during winter. Occasionally hollows out a nest in sound timber-not otherwise objectionable. More abundant in the northern than southern and central portions of the State. Like the 'yellow-bellied woodpecker,' the 'red-head' has been found in hay-mows during severe winter weather, and noticed gathering up hibernating insects from beneath the weather-boards. Is more beneficial than the smaller species." - [C. C. A.] 
M. carolinus, L. (Centumes, Swains.) Red-bellied Woodpecker.

Grayish, much barred above with black and white; crown and nape crimson in male; crown ashy in female; belly reddish. Length, $9 \frac{3}{4}$ inches ; tail, $3 \frac{1}{2}$ inches.

"Not common; migratory; arrives in April, and generally passes on. Have seen but one nest of the species, which nest was in Ocean county, and when discovered contained young birds; the date of finding it was May 29th, 1861. In September they are generally more common, and often remain for six weeks, about old apple orchards principally. Have seen none in winter."-[C. C. A.]

\section{COLAPTES, Swains.}

C. auratus, L. Flicker. Golden-winged Woodpecker. Yellow Hammer. High-holer. Yarup.

Head ashy, with red nuchal crescent; back olivaceous, barred with black; rump white; below, pinkish shading into yellowish ; a black crescent and many round black spots on breast; shafts and under-surface of quills golden yellow; a black "mustache" in male. Length, $12 \frac{1}{2}$ inches; tail, $4 \frac{1}{2}$ inches.

"Resident and migratory. Very abundant. Flickers build almost always in decayed wood, and have this in their favor. Are very ravenous, and destroy more insects than all the other woodpeckers together. In August they become partially gregarious, and in a measure forsaking timber, frequent meadows, and feed largely upon crickets and grasshoppers. After the appearance of several severe frosts, they seek the timber again, and are especially abundaut about gum-trees, the berries of which they are very fond of. They are the most noisy of their tribe among us, and their guttural note has given rise to several names, as 'Yucker,' 'Wake-up,' 'Flicker,' \&c. They are also known as 'Yellow Hammers,' 'High-holes,' 'Claips,' \&c. The name 'High-hole' probably arises from their generally building at as great an elevation as the tree selected will admit. As has been stated, they frequent out-buildings in midwinter, especially barns, roosting in hay-mows." 


\section{Order cuculi.}

(COCCYGES.)

\section{Family CUCUIIDAE. \\ Cuclroos.}

\section{COCCYZUS, Vieill.}

C. americanus, L. Yellow-billed Cuckoo.

Bill yellow below; wings with much cinnamon red; middle tail feathers like back, olive gray; outer ones black, with hroad white tips. Length, 12 inches; tail, 6 inches. Inner and outer toes turn back.

"Makes its appearance in May, and remains till October. Feeds exclusively upon insects, generally caterpillars. Builks a loose nest of sticks, raising one brood only."

C. erythrophthalmus, Wils. Black-billed Cuckoo.

Bill chiefly black; little or no red on wings; tail feathers all brownish, obscurely white at tips. Length, $11 \frac{1}{2}$ inches; tail, $6 \frac{1}{4}$ inches.

"In its habits this cuckoo is similar to the above, but it is not as abundant a species, and is apparently more shy and frequents. less populated localities."

\section{Family ALCEDINID五.}

Kingfishers.

\section{CERYLE, Boie.}

C. alcyon, L. Belted Kingfisher.

Ashy blue above; a band across breast, bluish in male, chestnut in female; white below; tail transversely spotted with white. Length, 13 inches; tail, $3 \frac{1}{2}$ inches ; bill, 2 inches. 
"Although a migratory species, a ferw not unfrequently remain throughout the winter, and seem to find a sufficiency of food when the streams are frozen. It appears in numbers as early as February, if the weather is moderate, and seldom wanders far from fishing-grounds. Is an inoffensive species, except in the destruction of young pike."

\section{Order CYPSELI.}

(MACROCHIRES.)

\section{Family CAPRIMULGID FE.}

Goatsuckers.

\section{ANTROSTOMUS, Gould.}

\section{A. vociferus, Wils. Whip-poor-will. Night Jar.}

Grayish, much variegated; "the mouth is margined by enormous stiff bristles more than an inch long; the wings are short, not reaching the end of the tail, which is very broad and rounded. There are bars of rufous spots on the wing quills, but no white whatever. The tail is white beneath for its terminal half" in males, tawny in females. Length, 10 inches; tail, 5 . inches. Do not confound this with the next species.

"Migratory and in the extreme sections of the State, only, abundant. Their nests are shallow scooped holes in the dead leaves, two eggs being deposited. The food is exclusively insects. Habits nocturnal. Strictly inoffensive."

\section{CHORDEILES, Swains.}

(Popetue-Abbott's Catalogue.)

\section{C. virginianus, Gmel. Night Hawk. Bull Bat.}

Blackish, variegated; a $\mathrm{V}$-shaped blotch on throat-white in male, tawny in female; "the bristles of the bill are scarcely appreciable; the wings are sharp-pointed, longer than the tail, uniformly brown, with a broad spot of white across the middle of the long quills, and without any rufuus spots. The tail is rather 


\section{GEOLOGICAL SURVEY OF NEW JERSEY.}

narrow, forked" and with a square blotch or a bar of white near the end. Length, $9 \frac{1}{2}$ inches; tail, 5 inches.

"Migratory. Moderately abundant throughout the State. Sociable in their habits, when on the wing, Hying frequently low down through the streets of our towns. Semi-nocturnal. Their food consists exclusively of insects. Strictly inoffensive."

\section{Family CYPSELIDAE. \\ (Micropodidx.) \\ Swifts.}

CEATURA, Steph.

C. pelagica, L. Chimney Swallow, or Swift.

Sooty brown; throat paler. Length, 5 inches; tail, 2 inches.

"Abundant. Arrive early in April, remaining until late in October. Their nests, as is well known, are generally in chimneys. Not unfrequently they are in hollow trees, even near a town. They raise three broods generally. Their food is exclusively of insects. Strictly inoffensive."

\section{Family TROCHILIDAE.}

\section{Humming Birds.}

TROCHILUS, L.

T. colubris, L. Ruby-throated Humming Bird.

Bill long; tongue capable of great protrusion; wings long and pointed, the secondaries short, only six in number; rectrices ten; feet very small, with sharp claws; male, metallic green above, chin velvet black; a ruby-red gorget ; tail deeply forked. l'emale without red; tail double-rounded and variegated (green, white and black). Young male resembles adult female; young female like young male, but no streaks on throat, and tail more rounded. Length, $3 \frac{1}{4}$ inches; tail, $1 \frac{1}{ \pm}$ inches; bill, $\frac{2}{3}$ inch. 
"Arrive in May, and by twos or threes are seen hovering about flowers, or darting now and then among swarms of minute insects then beginning to fill the atmosphere. Humming birds are more sociable than they are supposed to be; and although their nests are generally in unfrequented positions, yet it is by no means always so, and the author has found them building in trees whose branches were in direct contact with the house. It may be that the flowers they most love are the cultivated ones, but this is by no means certain. The nest is built of fine grass, is lined with hair, and covered upon its exterior with lichen, rendering it very difficult to detect, as generally a scrubby oak is chosen, which has its branches frequently well covered with the same growth. The eggs are two in number. During incubation the males are very bold, and fearlessly attack any intruder. The author has had them to fly directly in his face, while inspecting their nests. They have generally disappeared by September 15th, but the writer has seen them after severe frostsone as late as October 19th. During some summers are much more abundant than others." - [C. C. A.]

\section{Section INSESSORES.}

Perching Birds.

\section{Order passeres.}

\section{Family TYRANNID}

Tyrant Flycatchers.

\section{MILVULUS, Swains.}

M. tyrannus, L. Fork-tailed Flycatcher.

Top of head deep black, with a concealed patch of yellow in middle of crown; back light bluish gray; lower parts white. Length, 15 inches; tail, 912 inches. Female somewhat smaller; the tail much shorter and less forked. No yellow crown spot or 
forked tail in the young, and colors duller. Tropical birds, accidentally found in New Jersey.

M. forficatus, Gmel. Scissor-tailed Flycatcher.

Tail feathers chiefly white; top of head ash gray; back tinged with red; scarlet crown patch (concealed); white parts below washed with salmon pink; hluish gray anteriorly. Length, 14 inches; tail, 9 inches. Female smaller and duller. Toung, no crown spot. Accidental in New Jersey.

\section{TYRANNUS, CUV.}

\section{T. tyrannus, L. (carolinensis.) Kingbird. Bee Martin.}

Blackish ash, white below; tail black, white tipped. Length, $8 \frac{1}{2}$ inches; tail, $3 \frac{1}{2}$ inches.

"Migratory. Very abundant from May till November. Were it not that they destroyed very many honey-bees would be very useful. But a single brood is raised in a season. The nest is generally in an apple tree."-[C. C. A. $]$ "Destroys a thousand noxious insects for every bee it eats." - Coues.

T. dominincensis, Gmel. Gray Kingbird.

Color leaden gray above; concealed orange crown patch. Accidental in Massachusetts (from the South), possibly also in New Jersey.

T. verticalis, Say. Arkansas Kingbird, or Flycatcher.

Belly yellow; tail deep black, white edged; ash gray above; concealed crown spot of yellow. Length, 9 inches; tail, 33 inches. Western-straying to New Jersey.

\section{MYIARGHUS, Cab.}

M. crinitus, I. Great-crested Flycatcher.

Throat and chest deep ash gray; belly bright sulphur yellow; back, \&c., decidedly olive; bright chestnut on wings and tail. "Scarcely crested." Length, 9 inches; tail, 4 inches. Uses cast-off snake skins in the construction of its nest.

"Migratory. Not numerous. This species is a solitary bird, only single specimens being found, except during incubation. They feed upon insects generally, and are not suthiciently numerous to aflect the bee colonies." 


\section{SAYORNIS, Bonap.}

S. phœbe, L. (fuscus.) Pee-wee. Phœbe. Pee-wit.

Olive brown; head and tail darker; yellowish or white below. Length, $6 \frac{3}{4}$ inches; tail, $3 \frac{1}{4}$ inches.

"Late in February or early in March, according to the weather, this little bird makes its appearance. It builds a nest generally about bridges or the eaves of a house, if sufficiently projecting, raising two broods. Strictly inoffensive."

\section{CONTOPUS, Cab.}

c. virens, L. Wood Pee-wee.

Rictal bristles half length of bill; olive brown above; pale or yellowish below; whitish or rusty bands on wings. Length, $6 \frac{1}{4}$ inches; tail, 3 inches.

"Very similar in general appearance to the above, but differing in its habits. It builds a.nest on the upper surface of a branch of a tree and covers it with lichen externally. The eggs are spotted with red, and not pure white as with the S. fuscus. Frequents orchards and woody districts, and is as solitary as the above is sociable. Feeds exclusively on insects, and is a valuable bird."

C. borealis, Swains. Olive-sided Flycatcher.

Rictal bristles short, $\frac{1}{4}$ length of bill ; tuft of cottony feathers on each side of rump, conspicuous; a white line along middle of belly, otherwise olive brown; paler below. Length, $7 \frac{1}{2}$ inches; tail, 3 inches. A northern form ranging as far south as New York, and should be looked for in our northern counties.

\section{EMPIDONAX, Cab.}

E. pusillus-traillii, Aud. Traill's Flycatcher.

Dull olive brown; bill pale below; lower parts tinged with yellow. Length, $5 \frac{3}{4}$ inches; tail, $2 \frac{1}{2}$ inches.

"Arrives in May, remaining till October. This flycatcher is restless and stays generally among the tops of tall trees. A single brood is raised in a season, the young leaving the nest in July. Strictly inoffensive." 
E. minimus, Bd. Least Flycatcher.

Olive gray; bill blackish below, length less than $\frac{1}{2}$ inch; wing-bands usually whiter than in preceding; middle toe half as long as tarsus (shorter than in preceding); otherwise difficult to distinguish from preceding.

"Numerous from May till October. Prefers tall trees, but is more sociable than the foregoing. Is frequently seen in towns, especially about old mulberry trees. Nidificate in May, raising one brood. Strictly inoffensive."

E. acadicus, Gmel. Blue-gray Flycatcher. Small Green-crested Flycatcher. Acadian Flycatcher.

Clear olive green, with buffy wing bands; whitish or yellowish below; yellow ring about eyes; bill pale below. Isength, 6 inches; tail, $2 \frac{3}{4}$ inches.

"Abundant everywhere from May till late in October. Like the foregoing, prefers tall trees, and is a sociable little bird, although abundant in secluded timber lands. Nidificate in May, and occasionally again in July."

E. flaviventris, Bd. Yellow-bellied Flycatcher.

Clear olive green; yellow below; bright yellow on belly; bill yellow below. Length, $5 \frac{1}{4}$ inches; tail, $2 \frac{1}{2}$ inches.

"Although numerous in the northern portions of the State, this bird generally is not an abundant species. Prefers unfrequented localities and is seldom seen in towns, as are the $\mathrm{fly}$ catchers generally."

\section{Family ALAUDID居.}

Larks.

\section{OTOCORIS, Bonap.}

O. alpestris, L. (Eremophila cormula.) Shore Lark. Horned Lark.

Tarsus sentellate in front and behind; nostrils concealed by tuft of feathers; a slight tuft of feathers over each ear. Nest imbedded in ground under shelter of grrass, dre. Pinki-h brown, thickly streaked; a black crescent on breast and strip under eye; 
chin, throat and line over eye more or less yellow ; less black in females; white below. Winter plumage with markings more obscure. Length, $7 \frac{1}{ \pm}$ inches; tail, 3 inches.

"Resident. Abundant. This lark is always found in flocks, except during the breeding season. They are equally numerous throughout the State. They feed upon insects principally, and in October become very fat. During a visit to Barnegat in November, 1862 , the author daily saw very many on the beach, moving about like sand-pipers."-[C. C. A.]

\section{Family CORVID}

\section{Crows.}

OYANOCITTA, Strick.

(Cyanura.)

C. cristata, L. Blue Jay.

Blue; collar and frontlet black; grayish below; wings and tail clear blue, barred; outer tail feathers and secondaries tipped with white. Length, 12 inches; tail, $5 \frac{3}{4}$ inches. Conspicuously crested.

"Resident. Common. The jay appears to be equally abundant throughout the State. During the summer they are shy and live entirely in secluded woods, where they breed, raising one brood. During the winter they are more sociable and oceasionally bold. They feed upon birds' eggs during the spring, and at other seasons are omnivorous. They occasionally peck at corn stored in cribs."

\section{CORVUS, L.}

C. corax principalis, Ridg. (carnivorus, Bartr.) Northern Raven.

Feathers of throat stiffened, elongated and narrow; tail shorter than the long-pointed wings. Length, 25 inches; tail, 10 inches. Nests among rocks.

"Though frequently seen along the sea-coast, the raven is a rare bird inland, in New Jersey. A few are occasionally above 
Trenton, about the Delaware, but no nests have been found. Their larger size, and loose, lace-like feathers of the neck, distinguish them from 'crows.'"

C.'americanus, Aud. (frugivorus, Bartr.) American Crow.

Feathers of throat short, broad, with their webs blended; gloss of plumage purplish violet; head and neck hardly lustrous. Length, 20 inches; tail, $7 \frac{1}{2}$ inches.

"Resident. Abundant. Crows are so numerous that from this fact alone they are supposed to be thoroughly understood by every one; in reality they are misunderstood and misjudged by nearly every one. Crows build in March, in tall trees, and raise generally two broods, the second leaving the nest in June. During the spring they are troublesome, on account of a habit of removing the lately-planted corn, but if any one will take the trouble to kill a crow after feeding on the corn, and examine the contents of the crop, he will find a large number of worms therein, and the corn that they have eaten, worm-eaten. Corn washed with coal-tar before being planted is always undisturbed, but the crows frequent the fields as numerously as ever, now carrying off worms only. Were this generally done, the crows now so persistently shot at would be soon appreciated and protected. Crows destroy annually many bushels of grain in the State, and at the same time destroy many millions of noxious worms. If these were left undisturbed, a thousand-fold more grain would be destroyed. During the summer, autumn and winter, crows are emphatically omnivorous, feeding upon whatever may come in their way. In very shallow water they gather mussels, and letting them drop from a height, they break the shells and devour the animal."

C. ossifragus, Wils. (maritimus, Bartr.) Fish Crow.

Gloss of plumage green and violet, evident on head and neck. Length, 16 inches; tail, 7 inches.

"Not abundant on the coast and very seldom seen inland. They are smaller than the common crow and have a rather more musical 'caw.' They feed upon fish, crabs and the debris of the beach, and are very inoffensive. During some seasons they are more numerous than others." 


\section{Family ICTERID FE. \\ Orioles.}

\section{DOLICEONYX, Swains.}

D. oryzivorus, L. Reedbird. Ricebird. Bobolink.

Male in spring black; neck buffy; shoulders and rump ashy white; back streaky; in autumn yellowish brown, streaked above. Female like fall male, dull yellow, resembling sparrows, but with acute tail feathers. Length, $7 \frac{1}{2}$ inches; tail, 3 inches. In autumn migrate southward to fatten in the rice swamps.

"Arrives early in May, and soon after nidification commences. But a single brood is reared. In August, after moulting, the males are feathered similarly to the females, and they now become gregarious. In flocks frequently of a thousand individuals, they frequent the reeds, and are then called 'reedbirds,' having been known as 'bobolinks' during the early summer. In September they are very fat, and are eagerly sought for as a delicate article of food. They remain on the reeds until the appearance of several sharp frosts, when they go south, migrating at night. The male birds during the spring have a varied, beautiful song, but in August it has changed, as has also the female's chatters, to a single note."

\section{MOLOTHRUS, Swains.}

M. ater, Bodd. (pecoris.) Cow Bird.

Male iridescent black; head and neck glossy brown; female smaller; dusky gray brown, with short blackish bill. Length (male), 8 inches; tail, 3 inches.

"Arrives early in April, and is found generally in meadows in loose flocks until May, when the females scatter through the country and deposit two or three eggs, one each in a nest of another bird. The warblers and sparrorss are the birds generally so favored. Later in the summer, after the young can fly, they become partially gregarious, and usually are found with the 'red-wings.' They are known throughout the State as 'sheep blackbirds.' Feed on insects and are strictly inoffensive." 


\section{XANTHOCEPHALUS, Swains.}

X. xanthocephalus, Bonap. Yellow-headed Blackbird.

Male black, with white wing patch; head and neck rich yellow; female smaller, browner and less yellow. Length, 10 inches; tail, $4 \frac{1}{2}$ inches. A western form straying occasionally to the Atlantic border from Massachusetts to Florida.

\section{AGELAIUS, Vieill.}

A. phœniceus, L. Red-winged Blackbird, or Starling. Swamp Blackbird.

Male glossy (not iridescent) black; lesser wing coverts scarlet, with buffy paler edgings; female dusky; plumage everywhere streaked; rusty tinge on throat. Length, 9 inches; tail 4 inches.

"Equally abundant throughout the central and southern portions of the State. Numerous about the northern, hilly sections. 'Red-wings' are migratory and do not, as is the case with 'grackles,' remain in scattered flocks during the winter, probably amounting to one-fourth of their number. Appearing in scattered twos and threes, often as early as March 1st, they frequent now only the meadows and vicinity of creeks, the males singing continually, and when courtship has ended, suitable localities for nidification are sought, and two broods are raised, the eggs of the second being deposited about a week after the previous brood has left the nest. The second brood is usually fully fledged by the middle of July. During the breeding season, the 'red-wings' live largely upon worms, grubs and aquatic insects, and after numerous examinations, it has been found that they do not feed their young upou grain, although at this time they are generally very attentive to corn-fields, and certainly do exhume a.considerable quantity, but it is seldom the case that corn has to be replanted solely in consequence of the previous planting having been taken up by 'red-wings.' In September, these birds collect in flocks, frequently numbering a thousand individuals, and frepuent now only the low marshy lands. In company with the ' reedbirds,' they are mostly found about the reeds, and feed almost wholly on the seeds of this plant, and insects. By No- 
vember 1st they have all gone south, frequenting rice plantations generally.

"Red-winged blackbirds are always looked upon as injurious to agriculture, and treated accordingly. The Patent Office Report for 1856-Agriculture-advocates their destruction as an injurious bird, but we doubt very much if the author of the article above referred to ever suffered from their attacks any more than he or any other has from the predatory visits of that largely useful and wholly inoffensive bird, the rose-breasted grosbeak, which also is considered as deserving of persecution. 'Red-wings' do take corn up when it is planted, and do feed upon it when in the milky state, but their diet of grubs, worms and noxious insects, throughout the greater part of the year, far more than compensates for any injury they do the corn-crop. The 'red-wing' following the plow in early spring, and careless of the plowman, devours the grubs the plow exposes, preserves more grain by each worm destroyed than the bird will itself eat, in August, an hundred times over. The 'red-wings' are about as frequently innocent as guilty, when accused of 'taking up' the corn, the grubs being the real offenders, and their destructiveness, when the corn is in a milky state, is largely exaggerated, and if they are killed at this time the contents of their crop will show that four-fifths of their food has been the insects always to be found on corn-stalks, and the angle-worms that the loose ground about the corn invariably contains." $-[$ C. C. A. $]$

\section{STURNELLA, Vieill.}

S. magna, L. Meadow Lark.

Brownish and much streaked above; chiefly yellow below; a black crescent on breast; bill long; tail short, with acute feathers; crown feathers bristle tipped. Length, 10 inches; tail, $3 \frac{1}{2}$ inches.

"Resident. In the spring they are in a measure gregarious, and frequent the meadows. About the middle of May they pair and build a nest of grass, on the ground, raising two broods, the young of the latter brood not flying before August 15th. About this time they become again partially gregarious, and in a measure forsake the meadows for the uplands, generally frequenting the stubble-fields. In October they are frequently 
very fat and afford excellent eating, but being, during the summer, a strictly insectivorous species, it is doubtful if it were proper to kill them."

\section{ICTERUS, Briss.}

I. spurius, L. Orchard Oriole.

Male black; rump, bend of wing and lower parts deep chestuut; bill acute, bluish; female yellowish olive; smaller than male; young yellow, with chestnut traces. Length, 7 inches; tail, 3 inches.

"Arrives in May and remains during the summer. Has no preference of locality, except in building its nest-as it chooses a tall tree and places the nest usually very near the top. Feeds largely upon insects. Seldom carries off any fruit. Returns south in October. Strictly inoffensive."

I. galbula, L. (baltimore.) Baltimore Oriole. Golden Robin. Fire Bird.

Male black; tips of greater wing coverts white; lesser and middle wing coverts, base and tip of tail, rich cadmium orange, orange red or lemon yellow; female variable, duller, olivaceous and yellow, spotted with black; white bands to most of wing feathers. Length, 7 inches; tail, 3 inches.

"Arrives in May, and remains during the summer. Is a more sociable bird than the preceding, and generally more abundant. Builds in willow and elm trees principally, raising but one brood. Refits the old nest, year after year, if undisturbed. Feeds on insects, and is very fond of cherries, though it generally takes the wormy in preference to the sound ones. Has generally gone by September 15th. Feeding so largely upon insects, is a valuable bird."

\section{SOOLECOPHAGUS, Swains.}

S. carolinus, Müll. (ferrugineus-Abbott's Catalogue.) Rusty Blackbird.

Wings longer than tail; plumage black, often obscured by brownish or rusty; no red or yellow; bill slender; male glossy black and rusty in autumn; female dusky and lusterless. Length, $9 \frac{1}{2}$ inches; tail, 4 inches.

"Arriver in New Jersey about the 1-it of April, occasionally soover, and in small flocks is dispersed generally throughout the State. Is nowhere abundaut, and among the people generally, 
passes as a 'crow blackbird,' as it indeed seems to be, when seen flying, or is in company with the Quiscali. There is no marked difference in the habits of this bird as compared with allied species, and in so far as usefulness and destructiveness are concerned, is upon a par with them. It is probable that this species is found in New Jersey only occasionally, as search for it has proved unsuccessful in about two summers of every five.[C. C. A.]

"Low meadow lands and the immediate neighborhood of our rivers and larger creeks, are their favorite haunts, and in trees, in such situations, they build their nests. Small fresh-water shells and spiders are eagerly devoured by them, and on such food they preferably subsist, when obtainable; at least, such is the case so far as their habits have been noticed by the author.

"This bird is easily distinguished from the grackle by the marked difference in the bill, aud the general ferruginous tint of the plumage. They seldom remain after the middle of September, appearing to be remarkably sensitive to atmospheric changes."

\section{QUISCALUS, Vieill.}

Q. quiscula, L. (versicolor.) Purple Grackle. Crow Blackbird.

Iridescent black; wings scarcely longer than tail; luster on head purplish, on body bronzy. Length, 13 inches; tail, $5 \frac{1}{3}$ inches.

"Purple grackles, or crow blackbirds, as they are more generally known, are very abundant throughout most portions of the State, from February 15 th until November; and not unfrequently single specimens or two or three together are met with during the winter. In proportion as meadow lands abound, especially when skirted by well-grown timber, they appear to be numerous, and during the whole of their stay they are gregarious, though never seen in such immense flocks as in the case of the 'red-wing.'

"About April 25th nidification commences, and generally a large number of nests are in close proximity; occasionally three upon the same tree, if the tree be large or bushy, as a cedar or hemlock. Very frequently an orchard will be the favored locality with the grackles, and the author has seen in an orchard of seventy trees one hundred and thirty-one nests, being.nearly two 
nests to a tree; the distribution was not very even, however, as one tree had five nests on, and nine trees none. Two broods are generally raised, the second leaving the nests about July 15 th.[C. C. A.]

"If the habits of this species, as well as some of the preceding, be studied during their whole stay in the State, conclusions will be arrived at that will be in a marked degree at variance with the one popular idea, that 'crow blackbirds' hurt the corn-crop' and ought to be exterminated. Without a doubt, these birds do destroy much grain, and prove a great annoyance to the farmer by causing a necessity for replanting, but the corn-hills very probably have suffered fully as much from grubs beneath the surface, as from birds above it. Not unfrequently has it proved to be the case that the stomachs of blackbirds killed upon cornfields, in May, have revealed masses of semi-digested grubs, and a mere trace of grain.

"If, as is recommended by many, a bounty be put upon every dozen blackbirds killed, and so favor their extermination, then nature's equilibrium will be destroyed, and the unavoidable excess of noxious worms will annihilate the corn-crops. It cannot be too emphatically announced or too persistently maintained, that birds as a tribe are useful, and those apparently least so are sufficiently so to warrant their protection rather than destruction. There is no bird of the many found in New Jersey that does not coufer actual benefit upon the agriculturist, the nearest approach to an exception being the 'cedar bird;' and when as in the case of the crow-blacks, at certain times, they are injurious to corn, it is the farmer's duty to devise means of frightening them off', for the time being, and not to destroy them, for it must be remembered that their services are of no mean value, when, following the plow in the spring, they gather up greater enemies to the crops than their necessities ever caused them (the blackbirds) to be."-[C. C. A. $]$

Q. quiscula æneus, Ridg. Bronzed Grackle.

Plumage of body brassy olive or bronze; neck blue, violet, purple or brassy green; wing coverts without metallic tints; wings and tail violet purple, never bluish; female smaller than male. Length, $12 \frac{3}{4}$ inches; tail, $5 \frac{1}{2}$ inches. Occasional in New Jersey, crossing the Alleghanies or from New England. 


\section{Family FRINGILIIDE.}

\section{Finches.}

A very large family. "One-eighth of all the North A merican birds are Fringillidce."-Jordan. "Any one locality of average attractiveness to birds has a bird fauna of over two hundred species, and if it be away from the sea-coast and consequently uninhabited by marine birds, about one-fourth of the species are Sylvicolidee and Fringillidce together, the latter somewhat in excess of the former."-Coues.

All are granivorous, feeding on seeds, and occasionally berries and insects. Nearly all sing; most are plain, but a few are brilliant of plumage. The bill is short, thick and conical, with the "corners of the mouth drawn down," as in the more slender-billed Icteride.

\section{PINICOLA, Vieill.}

P. enucleator canadensis, Cab. American Pine Grosbeak.

Male chiefly red; white wing bars; female brownish yellow on head and rump. Length, $8 \frac{1}{2}$ inches; tail, 4 inches. Northern form, coming south to northern United States in winter.

"Twice has been seen by the author in winter, but is a rare visitant. Those seen by the author were in cedar trees." [C. C. A.]

\section{CARPODACUS, Kaup.}

C. purpureus, Gmel. Purple Finch.

Tail feathers rounded and soft, none white; male flushed with red, most intense on head and neck, fading below and behind; female olive brown, with no red; bill stout. Length, 6 inches; tail, $2 \frac{1}{2}$ inches.

"Quite common. Irregularly abundant. Prefers hillsides with a southern exposure, and during the winter is found generally in small flocks. Inoffensive."

\section{LOXIA, L.}

(Curvirostra.)

L. curvirostra minor, Brehm. (Curvirostra americana-Abbott's Catalogue). Red Crossbill. American Crossbill.

Points of mandibles crossed, reddish; male brick red, wings unmarked; female brownish olive. Length, 6 inches; tail, $2 \frac{1}{2}$ inches. 
"A northern species that visits New Jersey in loose flocks about November, and remains throughout the winter. It has been -upposed to breed in the State, but it is doubtful. Strictly inoffensive." - [C. C. A.]

L. leucoptera, Gmel. White-winged Crossbill.

Iale rose red; white wing bars; female brownish olive, speckled with dusky; rump yellow. Length, $6 \frac{1}{\ddagger}$ inches; tail, $2 \frac{1}{2}$ inches.

"Not as common as the above, with which it is generally found associated. Like the above, it may breed in this State, but it is not probable. Graminivorous. Strictly inoffensive."

ACANTHIS, Bechst.

(悉giothus-Abbott's Catalogue.)

A. linaria, L. Lesser Redpoll Linnet.

Crown crimson in both sexes; throat, breast and rump rosy in male; chin blackish; much streaked above. Length, $5 \frac{3}{4}$ inches; tail, $2 \frac{1}{2}$ inches.

"A northern species that visits New Jersey during severe winters, and frequently in large numbers. In a measure gregarious. Graminivorous. Strictly inoffensive."

A. linaria rostrata, Cones. Greater Redpoll.

Colors darker and size larger than preceding. A Greenland form that comes south as far as the lower Hudson valley in winter.

A. brewsteri, Ridg. Brewster's Linnet.

With no red on top of head; rump rosy in male, yellow in female; is represented by a single specimen taken in Massachusetts in 1870, and is mentioned here that hunters in the northeastern parts of the State may be on the lookout. Should any specimens be found they will be of great scientific importance.

SPINUS, Koch.

(Chrysomitris, Boie.)

S. tristis, L. Yellow Bird. Thistle Bird. American Goldfinch.

Male rich yellow; rump whitish, white wing bars; black on crown, wings and tail; female more olivaceous; fall plumage 
pale yellow brown; young variously ochraceous, with yellow or not. Length, 5 inches; tail, 2 inches.

"Abundant. Throughout the year this finch remains in loose gangs, and after nidification they wander in flocks of from ten to fifty. Graminivorous. Inoffensive."

S. pinus, Wils. Pine Finch. Pine Linnet. Pine Siskin.

Sexes alike; plumage thickly streaked; no black on head; bill very sharp; in breeding season plumage suffused with yellow. Length, $4 \frac{3}{4}$ inches; tail, 2 inches. A northern species. Rare in New Jersey.

"In the depths of winter a few are occasionally seen about pine and cedar trees. Strictly inoffensive."

\section{CARDUELIS, Briss.}

C. carduelis, L. European Goldfinch.

Sexes alike; fore part of head crimson; hinder part of head black; rest of head white and buff; back brown, and upper tail coverts white; wings and tail black, marked with white and yellow; lower parts dull white; sides and flanks cinnamon brown. Length, 5 inches; tail, 2 inches. Introduced from Europe. It breeds in Central Park, New York City, and in parts of adjacent country.

\section{PASSER, BrisS.}

P. domesticus, L. European House Sparrow. English Sparrow.

Male chestnut brown above, thickly streaked; ashy below; throat, lores and chin black; female duller, without black; feet small ; vot streaked below; wing with two white bands. Length, 6 inches; tail, $2 \frac{1}{2}$ inches. Nest a bulky structure of dried grasses, lined with feathers, placed in nooks about houses, trees, \&c. Eggs four to seven, dull whitish, thickly speckled with dark brown and purplish gray. Introduced into the United States 185:3, is now so abundant in cities as to be a nuisance. The tree sparrow. also introduced with preceding, has a chestnut crown and is reported as being naturalized about St. Louis. As it is likely to spread, it is one of the forms to be on the lookout for. According to Bulletin No. 1, issued by the Division of Economic Orni- 
thology of the United States Department of Agriculture, the "tree sparrow" is a variety of house sparrow which has taken to trees from being crowded out by too great numbers from available nesting-places in the cities. Sparrors destroy young buds by wantonly picking them off. Their food is anything eatable, and they drive off useful insect-eating birds. The sparrow hawk (Falco sparverius), the northern shrike (Lanius borealis), the blue jay (Cyanocitta cristata), the purple grackle (Quiscalus quiscula), and other birds are its natural enemies, and should be encouraged. The hose should be turned on their nests, to wash and drown them out. They also make excellent pot-pic, and should be shot or trapped for this purpose. Poisoned wheat is an effective but risky destructive agent. Each pair of sparrows raises about twelve pairs of young per year, in about five broods.

\section{PLECTROPHENAX, Stejn.}

P. nivalis, L. Snowflake. Snow Bunting.

Bill small, with a ruff; hind claw long, but curved; color white in breeding season, with black on back, wings and tail; bill and feet black. In the United States this species is white, clouded with warm brown, and the bill is pale. Length, 7 inches; tail, 3 inches. A northern species, migrating south in winter.

"This beautiful bird is only occasionally seen during very severe winters. But two specimens have come under the author's notice, that were killed within State limits." - [C. C. A.]

\section{CALCARIUS, Bechst.}

O. lapponicus, L. Lapland Longspur.

Bill larger, without ruff; hind claw nearly straight; male with head and throat mostly black; a chestunt collar; back black and streaky, whitish below; outer tail feathers with white; legs aud feet black; female and winter birds with less black. I Length, $6 \frac{1}{1}$ inches; tail, 23 inches. A northern form; ranges south in winter, even to the Carolinas at times. 


\section{AMMODRAMUS, Swains.}

A. princeps, Mayn. (passerculus, Bonap.) Ipswich Sparrow.

Outer pair of tail feathers longer than middle pair; bill decidedly compressed; above pale grayish; top of head and back streaked with blackish, margined with pale brown; lower parts white, tinged with buff. Length, $6 \frac{1}{2}$ inches; tail, $2 \frac{1}{3}$ inches. Breeds in Nova Scotia; migrates south as far as the Gulf in winter.

A. sandwichensis savanna, Wils. (passerculus, Bonap.) Savanna Sparrow.

Sharply streaked; streaks blackish on back; edge of wing yellowish; yellowish stripe over eye. Length, $5 \frac{1}{2}$ inches; tail, 2 inches. Abundant on shores.

"Occurs in New Jersey in May principally. Probably does not breed within State limits. Few seen in September."

A. savannarum passerinus, Wils. (Corturniculus pusserinus.) Yellowwinged Sparrow. Grasshopper Sparrow.

Much streaked above; feathers edged with bay; breast buffy, unstreaked; wings and tail short; edge and bend of wing and line over eye, yellow. Length, 5 inches; tail, 2 inches. Noteis grasshopper-like.

"Quite common. Arrive in April. Frequents fields, especially those skirted by woodland. Nests are placed in low bushes, one brood being raised. None seen in winter."

A. henslowi. Henslow's Sparrow.

Smaller than preceding; more yellow above; black streaks on breast; bill stout; head and neck buffy olive, crown heavily streaked; hind neck narrowly streaked; back and wings chestnut, the feathers black in center and bordered with whitish; belly whitish; chest and sides buffy whitish. Winters in the Gulf States; breeds north of our region.

A. caudacutus nelsoni, Allen. Nelson's Sparrow. Sharp-tailed Finch.

Back sharply streaked; no yellow spot over eye; a bright buff stripe over eye. Length, 5 inches; tail, $1 \frac{3}{4}$ inches.

"Like the above, common in Cape May county and 'along 
the shore.' Occasionally seen along the Delaware. Has been killed at Trenton, Mercer county. Breeds in the salt meadows."

A. maritimus, Wils. Sea-side Finch, or Sparrow.

Olive gray; back obscurely streaked; a yellow spot over eye. Length, 6 inches; tail, 2 inches.

"Common in Cape May county and along the coast grenerally. Breeds in the salt marshes, raising two broods."

\section{POOCATES, Bd.}

P. gramineus, Gmel. Vesper Sparrow. Grass Finch. Bay-winged Bunting. Ground Bird.

Thickly streaked everywhere; slightly buffy below; outer tail feathers white; bend of wing chestnut; tail shorter than wings. Length, 6 inches; tail, $2 \frac{1}{2}$ inches.

"Abundant. Resident. This 'chippy' is a great lover of fences, and a sociable, lively bird. It builds a nest upon the ground, generally among dewberry vines, raising two broods during the summer. Graminivorous. Strictly inoffensive."

\section{CHONDESTES, Swains.}

O. grammacus, Say. Lark Sparrow, or Finch.

Streaked above, ashy below ; crown and ear coverts chestnut, hlackening on forehead; with whitish median and superciliary stripes; black lines through and below eye; a black line on each side of white throat; a black breast spot; middle tail feathers like back, the rest blackish and white tipped. Length, 6! inches; tail, 3 inches. A western songster, frequenting prairies and river bluff's; occasional on the Atlantic coast.

\section{ZONOTRICHIA, Swains.}

Z. leucophrys, Forst. White-crowned Sparrow.

Streaked above with but little chestnut; crown with broad white median band and a narrow white and narrow black band on each side of it; no yellow anywhere: throat like breast; young with crown rich brown. Length, 7 inches; tail, $3 \frac{1}{ \pm}$ inches.

"Not uncommon in April and in October. Two or three 
occasionally seen together. Does not breed within State limits. Less abundant in autumn than spring."

Z, albicollis, Gmel. White-throated Sparrow. Peabody Bird.

Much chestnut-streaked above; crown black, with white median stripe and white superciliary stripes; a yellow spot over eye and edge of wing; ashy below, whitening on throat; female duller. Length, 7 inches; tail, $3 \frac{1}{4}$ inches.

"More abundant than the above. They are freqently seen together. Arrive in April, and are then more abundant than in October, when they re-appear. None seen in summer."

\section{SPIZELLA, Bonap.}

S. monticola, Gmel. Tree Sparrow.

Streaked above; crown chestnut; bill black above, yellow below; line over eye, lower parts and neck, ashy gray; white wing bars; a dark pectoral blotch. Length, 6 ? inches; tail, 3 inches.

"Resident. Abundant. Though feeding principally on seeds, they not unfrequently prey upon small insects. Of decided value to the agriculturist."

S. socialis, Wils. (domestica, Bartr.) Chipping Sparrow. Chippy. Hair Bird.

Streaked above with dull bay ; crown chestnut ; bill, forehead and streak through eye, black; ashy below. Length, $5 \frac{1}{1}$ inches; tail, $2 \frac{1}{2}$ inches。

"Resident. Abundant. Graminivorous. The nest is built in trees generally, two broods being raised during the summer. Strictly inoffensive."

S. pusilla, Wils. (agrestis, Bartr.) . Field Sparrow.

Wing usually shorter than tail ; upper parts with more or less of rusty; no dusky streaks on top of head and hind neck, but two rusty lateral stripes on head; back streaked with black on a buffy-grayish ground; rusty spot on side of breast; lower parts whitish, tinged with gray or buff; bill reddish cinnamon; wing bands obscure; general color paler and duller than with S. monticola. Length, $5 \frac{1}{2}$ inches; tail, $2 \frac{1}{3}$ inches.

"Very abundant. Arrives as early as April 1st, and remains 
till late in October. Frequents uncultivated fields, and builds its nest in them, generally on the ground."

\section{JUNCO, Wagl.}

J. hyemalis, L. Snow Bird. Slate-colored Junco.

No white wing bands; slate gray, darker to blackish on head; female and young tinged with brown ; bill pinkish. Length, $6 \frac{1}{1}$ inches ; tail, 3 inches. Breeds in the Canadas.

"Makes its first appearance about the middle of November, and remains with us till the middle of March. Frequently their plumage becomes very mottled in March, giving them a handsome appearance. They are graminivorous. Entirely inoffensive. None breed in the State."

\section{MELOSPIZ A, Bd.}

M. fasciata, Gmel. (melodia.) Song Sparrow.

Much streaked above and on breast and sides; crown with an olscure pale median stripe; white below; pectoral streaks form a blotch. Length, $6 \frac{1}{2}$ inches; tail, 3 inches.

"Resident. Abundant. The song sparrow is too well known to need any remarks concerning it. It is found in all parts of the State, even close to the ocean. Strictly inoffensive."

M. lincolni, Aud. Lincoln's Finch, or Sparrow.

Everywhere thickly, sharply and narrowly streaked; breast with broad band of pale buffy or yellowish brown; sides washed with same. Length, $5 \frac{1}{2}$ inches; tail, $2 \frac{1}{2}$ inches. Very shy.

"Very rare, and seen only as a spring visitor. Have seen no specimens during the autumn. Never breeds in the State."[C. C. A.]

M. georgiana, Lath. (palustris, Wils.) Sramp Sparrow.

Crown chestnut; wings tinged with chestnut; few or no streaks on breast and below; tail shorter than in $M$. fasciata; browner in winter. Length, $5 \frac{3}{4}$ inches; tail, $2 \frac{1}{3}$ inches.

"Not uncommon, and it undoubtedly breeds annually in the Delaware meadows, about Bordentown, where it is frequently seen from April till October." 


\section{PASSERELLA, Swains.}

P. iliaca, Merr. Fox-colored Sparrow. Fox Sparrow.

Ashy above, overlaid and streaked with rusty red, which becomes bright bay on rump, tail and wings; white below, with large arrow-shaped spots and streaks, numerous on breast; feet stout, with long claws. Length, 7 inches; tail, 3 inches. Breeds in the Canadas; migrates early.

"This fine sparrow is more abundant in February than any other month, according to the author's observations. They remain in few numbers during the year, but no nests have yet been seen. Entirely inoffensive."-[C. C. A.]

\section{PIPILO, Vieill.}

P. erythrophthalmus, L. Chewink. Towhee Bunting. Marsh Robin.

Black; belly white; sides chestnut; white markings on tail and wing feathers; iris bright carmine red; in female, head, neck, chest and back brown instead of black. Length, 8.2 inc hes ; tail, 4 inches.

"Very abundant. Arrives in May, and remains during the summer. Frequents swampy grounds, and is nearly the whole of the time on the ground, except during incubation, when the male birds remain in the trees about the nest, which is always on the ground, and keep guard, warning the hen bird of the approach of danger. Are occasionally seen about gardens, especially where gooseberries are cultivated. Feed exclusively upon insects, and are very strictly an inoffensive species. Retires south in October."

\section{CARDINALIS, Bonap.}

O. cardinalis, L. (virginianus-Abbott's Catalogue.) Cardinal Grosbeak. Redbird.

Clear red; ashy on back; chin and forehead black; conspicuous crest; female ashy brown, washed with red. Length, $8 \frac{1}{2}$ inches; tail, $4 \frac{1}{2}$ inches. A brilliant songster.

"Resident. Known generally as 'winter redbird,' and as it frequents leafless bushes, after all other small birds almost have departed, appears to be more numerous in winter than at any 
other season. Build annually in cedar trees, raising but one brood. During the summer spends much of its time on the ground, scratching among the dead leaves. Were it not for its shrill whistle and bright plumage, would, like the 'tanager,' be difficult to detect."

\section{GUIRACA, Swains.}

G. corulea, L. Blue Grosbeak.

Male rich blue; feathers about bill, wings and tail, black; wing bars chestnut; female yellowish brown, with whitish wing bars. Length, 7 inches; tail, $2 \frac{3}{4}$ inches. A southern bird, locally rare in summer in our latitude.

\section{HABIA, Reich. \\ (Zamelodia, Coues.)}

H. ludoviciana, L. Rose-breasted Grosbeak.

Under wing coverts rose red in male, saffron yellow in female; male with head, neck and upper parts mostly black, with white on rump, wings and tail ; belly white; female olive brown, much streaked; head with whitish bands. Length, 81 inches; tail, 3 ! inches. Brilliant in plumage and in song.

"This magnificent bird arrives in May, remaining till October. Not abundant, and, as its plumage is so beautiful, they are eagerly sought after by taxidermists. Their nests are built in closely-leaved trees, one brood being raised. Their food consists of beetles principally, and seeds. They are strictly inotfensive, and should be protected."

\section{PASSERINA, Vieill.}

P. cyanea, L. Indigo Bunting.

Male indigo blue, clear on head, greenish behind; female plain, warm brown, obscurely streaked; a dusky line along the gonys. Length, $5_{4}^{3}$ inches; tail, $2 \frac{3}{4}$ inches. "A tireless songster."

"Arrives early in May, and is an abundant species. Nidificates in June, building its nest in briar-patches. Prefers unfrequented, woody districts, but is not unfrequently seen in towns. Strictly inoffensive. Disappears in September." 


\section{SPIZA, Bonap.}

S. americana, Gmel. Black-throated Bunting.

Grayish, and streaked above; wing coverts chestnut; line over eye, maxillary stripe, edge of wing, breast and part of belly, yellow; throat patch black; otherwise white below; female with little chestnut, and the black reduced to a few streaks. Length, $6 \frac{3}{4}$ inches; tail, $2 \frac{3}{4}$ inches.

"Rare. Appears in meadow lands in May, but none probably remain during the summer. Re-appears in September, and remains for several weeks, in few numbers."

S. townsendii, Aud. Townsend's Bunting.

Upper parts, head, \&c., slaty blue; no chestnut, and little yellow or black. Only one specimen known, found in Eastern Pennsylvania.

\section{CALAMOSPIZA, Bonap.}

C. melanocorys, Stejn (bicolor.) Lark Bunting. White-winged Blackbird.

Male in summer black, with slaty tint; white patch on wing; female, above brownish gray, streaked with dusky; lower parts white, streaked on breast and sides with dusky; patch on wing smaller. In winter, male is like female, though the feathers on belly show black beneath the surface when disarranged. Length, 7 inches; tail, 3 inches. Inhabits the Great Plains; accidental east of Alleghanies.

\section{Family TANAGRID王.}

\section{PIRANGA, Vieill.}

P. erythromelas, Vieill (rubra, L.) Scarlet Tanager. Fire Tanager.

Middle of cutting edge of upper mandible is toothed; male brilliant scarlet; wings and tail black; no wing bars; female clear olive green above; wings and tail grayish ; greenish yellow below. Length, $7 \frac{1}{3}$ inches; tail, 3 inches. Abundant in woodland. "A respectable songster."-Jordan. 
"Arrives about May 20th, and remains wholly among wellgrown trees. Is much more abuudant during some summers than others, although can never be said to be rare. Are shy, restless, and a silent bird. Were it not for the brilliancy of their plumage, would seldom be noticed. They build in trees, generally at considerable elevation, raising but the one brood. They feed prineipally upon coleopterons insects. Strictly inoffensive. Are largely destroyed by law-breaking 'bird-stuffers,' who well know their value when mounted in a 'case of birds.'" - [C. C. A. $]$

\section{P. rubra, L. (restiva, L.) Summer Redbird, or Tanager.}

Cutting edge of upper mandible not toothed; male bright rose red throughout; wings a little dusky; female dull brownish olive above, dull yellowish below; no wing bars. Length, $7 \frac{1}{3}$ inches; tail, 3 inches.

"During the past fifteen years this bird has been emphatically a rare bird, but up to 1850 was almost as numerous as the preceding. Without any decided alteration in the surface of the country generally, or material change in the climate, as compared with twenty years ago, to account for it, we have the statement to make that the summer redbird is now 'rare.' Were we writing in 1845 , we would record it as 'abundant.' The last specimen seen by the author was in June, 1862-a female-and although the most careful search was instituted, no other was detected in the neighborhood. On making inquiry in many and distant localities, I have been very frequently assured of their presence, but it has always proved that the 'cardinal' was the bird which they supposed was referred to.- [C. C. A.]

"Breeds in tangled briar-patches, raising a single brood. Have occasionally-not since 1855-found the mests in cedar trees. They feed largely upon coleopterous insects, and are in nowise injurious to fruit growers. Generally remained during September, though were not found after the appearance of a hard frost."

\section{P. Ludoviciana, Wils, Louisiana Tanager.}

The Louisiana tanager has been found accidentally in Massachusetts. 'The female is as in preceding, but has wing bars; the male is bright yellow, with black tail, and wing: black ; the head scarlet; yellow wing bars. 


\section{Family HIRUNDINIDAE.}

\section{Swallows.}

\section{PROGNE, Boie.}

\section{P. subis, L. (purpurea-Abbott's Catalogue.) Purple Martin.}

Lustrous blue black throughout; female duller; whitish and streaky below; bill stout, nearly hooked. Length, $7 \frac{1}{2}$ inches; tail, $3 \frac{1}{3}$ inches.

"Migratory. Abundant. The martin builds in boxes erected for his accommodation, but has been known to occupy a hollow tree for breeding purposes. They probably destroy more insects than any other one species. Arrive in May, and are generally all gone by the 20th of August."

\section{PETROCHELIDON, Cab.}

P. lunifrons, Say. Clifl' Swallow. Eaves Swallow.

Lustrous steel blue; forehead, sides of head, throat, rump, \&c., various shades of chestnut; belly whitish; a blue spot on breast. Length, $5 \frac{1}{2}$ inches; tail, $2 \frac{1}{3}$ inches.

"Abundant, and in some places seem to have taken the place of the barn swallow. Builds under the eaves of buildings, generally under barns and stables. Goes south earlier."

\section{CHELIDON, Forst.}

C. erythrogaster, Bodd. Barn Swallow.

Lustrous steel blue; pale chestnut below; forehead and throat deep chestnut; an imperfect steel-blue collar; tail deeply forked. Length, 7 inches; tail, $4 \frac{1}{2}$ inches.

"Very abundant, though probably less so than ten years ago [1858]. Arrive early in May, and remain till the 25th of August, after which they have generally disappeared. Build in barns, and raise generally two broods. Feed exclusively upon insects. Strictly inoffensive."-[C. C. A.]

\section{TACHYCINETA, Cab.}

T. bicolor, Vieill. White-bellied Swallow.

Lustrous green; pure white below ; female duller. Length, $6 \frac{1}{4}$ inches; tail, $2 \frac{2}{3}$ inches. 
"Abundant about the coast and along the rivers. Is the species that literally by the million skim over the rivers, crowd the bridges, and sometimes conceal a hundred yards of telegraph, by sitting upon the wires in one unbroken row."

\section{CLIVICOLA, Forst.}

(Riparia. Cotyle, Boie.)

C. riparia, L. Bank Swallow. Sand Martin.

Dark gray, not iridescent; white below; a shade of brown on breast. Length, $4 \frac{3}{4}$ inches; tail, 2 inches. A little tuft of feathers at base of hind toe.

"Abundant. A water-loving species, and builds its nest generally in the banks of the river, or about creeks, when far inland. Appears to be rather more abundant in the central and sonthern portions of the State than in the northern. Arrives late in May, and disappears early in August."

\section{STELGIDOPTERYX; Bd.}

(Cotyle, Boie.)

S. serripennis, Aud. Rough-winged Swallow.

Outer web of first primary saw-like, with a series of weak, small recurved hooks; no tarsal tuft; color brownish gray, darker on wings and tail; lower parts white. Length, $5 \frac{1}{2}$ inches; tail, $2 \frac{1}{4}$ inches.

"Not an abundant species, and in its habits does not differ from the above. Less seldom seen inland than the 'riparia,' but is more strictly a water-haunting species."

\section{Family AMPELID A.}

(Bombycillidr-Abbott's Catalogue.)

Wax-wings.

AMPELIS, L.

A. garrulus, L. Bohemian Wax-wing. Northern Wax-wing.

Tail short and square, tipped with yellow; wings long; color silky, ashy brown, with a red tinge; front and sides of head 
shaded with purplish cinnamon; a black band across forehead and around head; throat black; under tail coverts chestnut red; two white and broad wing bars; bill stout, flattened, notehed and hooked; with wide gape. Length, $7 \frac{1}{3}$ inches; tail, 3 inches.

"A northern species, that is occasionally shot as far south as New Jersey. The author has seen two specimens, one shot in Cape May county, the other in Morris county." - [C. C. A.]

A. cedrorum, Vieill. Cedar Bird. Cedar Wax-wing. Cherry Bird. Southern Wax-wing.

Similar to, but smaller than preceding; less cinnamon tinged; chin black; black stripe across face, bordered above by whitish ; belly yellowish; under tail coverts white; no wing bars; waxlike tips of the wing secondaries, \&c., small or absent in the female. Length, $6 \frac{1}{2}$ inches; tail, $2 \frac{1}{2}$ inches.

"A rambling, apparently useless bird. They remain the greater part of the year in flocks, and destroy large quantities of half-ripe cherries. They build a loose nest of sticks, generally in an apple tree, raising a single brood. They grow very fat in September, and are excellent eating."

\section{Family LANIID}

Shrikes.

\section{LANIUS, L.}

L. borealis, Vieill. Great Northern Shrike. Butcher Bird.

Clear bluish ash above; black bars on sides of head, not meeting in front, interrupted by white crescent on under eyelid; rump and shoulders whitish ; wings black; white below, waved with blackish; both mandibles notched; bill hawk-like. Length, $9 \frac{1}{2}$ inches ; tail, $4 \frac{3}{4}$ inches.

"Resident, but not numerous. During the winter they visit us from the north, and are occasionally very abundant. They feed upon small birds, and killing more than they require, impale them upon thorns." 
L. Iudovicianus, var. excubitorides, Swains. Loggerhead Shrike. White-rumped Shrike.

Clear ashy blue; a white superciliary line; black bars on sides of head meet across forehead; no crescent on under eyelid; white below, scarcely dark waved. Length, $8 \frac{1}{\ddagger}$ inches; tail, $4 \frac{1}{4}$ inches. Western; sporadic in northern New York. Scarcely to be expected in New Jersey.

L. ludovicianus, L. Loggerhead Shrike.

Slate colored above, darker than in preceding; the rump scarcely paler; black head stripe not bordered above by hoary. Length, $8 \frac{1}{4}$ inches; tail, $4 \frac{1}{2}$ inches. Southern; occasional as far north as Vermont.

\title{
Family VIREONID E.
}

\author{
VIREO, Vieill. \\ (Vireosylvia, Bonap.)
}

V. olivaceus, L. Red-eyed Flycatcher, or Vireo.

Bill much as in Lanius; wings long and pointed; slender build; no wing bars; color olive green, with ashy crown, edged with blackish; a white superciliary line, helow which is a dusky streak; below, olive shaded; eyes red. Length, $3 \frac{1}{3}$ inches; tail, $2 \frac{1}{2}$ inches. An energetic songster.

"Very abundant. Appears in May, and immediately commences nidification. Builds generally in birches or maples, high up in the trees. Have generally disappeared by September 15 th. Prefurs trees to bushes, and being strictly insectivorous, is a most valuable bird."

V. philadelphicus, Cass. Philadelphia Warbler, or Vireo or Greenlet.

Dull olive green, becoming ashy on crown; no black lines on head; a whitish line on eyebrow; below faintly yellowish, fading to white on throat. Length, $4 \frac{3}{4}$ inches; tail, $2 \frac{1}{4}$ inches. "Scarce."-Jordan.

"Probably not rare. Author has seen but two specimens. In habits very similar to the $V$. gilvus. Strictly inoffensive."[C. C.A.] 
$\nabla$. gilvus, Vieill. Warbling Flycatcher, or Vireo.

Colors like preceding, but has evidently ten primaries instead of nine apparent, as in the two preceding. Length, $5 \frac{1}{3}$ inches; tail, $2 \frac{1}{1}$ inches. Nests in trees at a considerable height.

"Abundant. Arrives in May, and a few remain during the summer. Re-appears in August and September. Sociable, being frequently seen in shade trees of the streets. Insectivorous."

V. flavifrons, Vieill. Yellow-throated Flycatcher, or Vireo.

Stout build; short bill and feet; white wing bars; rich olive green above, becoming ashy on rump; bright yellow below; belly white; yellow ring around eye. Length, $5 \frac{3}{4}$ inches; tail, 2 inches. Only nine primaries apparent.

"More common than the following. Arrives in May, and is found more frequently in open country than in secluded localities. Prefers deciduous to evergreen trees. They breed in June, building their nests at considerable elevation, in maple aud elm trees. Have generally disappeared by September 10 th. Insectivorous. Inoffensive."

V. solitarius, Wils. Blue-headed Flycatcher, or Vireo. Solitary Greenlet.

Ten primaries apparent; color bright olive green; crown and sides of head bluish ash ; stripe to and around eye white, a dusky line below it; white below, somewhat washed with pale yellow. Length, $5 \frac{2}{3}$ inches; tail, $2 \frac{1}{3}$ inches. Stout and handsome.

"Not numerous. More generally found in the northern hilly sections of the State. Arrives in May. Some few probably remain. Re appears in September. Prefers woodland."

V. noveboracencis, Gmel. White-eyed Flycatcher, or Vireo.

Wings short and rounded; bright olive green above; white below; sides and under tail coverts bright yellow; wing bars pale; stripe to and around eye yellow; eyes white. Length, 5 inches; tail, $2 \frac{1}{4}$ inches. Found in thickets.

"Uncommon. Seen occasionally in May and again in September. It probably breeds in the State. Strictly inoffensive." 


\section{Family MNIOTILTID王. \\ Wood Warblers. \\ MNIOTILTA, Vieill.}

M. varia, L. Black and White Warbler or Creeper.

Streaked; colors only black and white; a broad white stripe on crown; white wing bars; female somewhat grayer. Length, 5 inches; tail, $2 \frac{1}{\ddagger}$ inches.

"Migratory. Arrives from the South in May, and from the North during the last week in August and in September. Frequents the larger trees-deciduous rather than evergreens-and sings more than many of the migrating species. A few remain during the summer, and are then generally to be found in the dark, silent swamps."

\section{HELMITHERUS, Raf.}

표. vermivorus, Gmel. Worm-eating Swamp Warbler.

Wings longer than tail; olive green; head yellowish, with four black stripes; buffy below; sexes alike. Length, $5 \frac{1}{2}$ inches; tail, $2 \frac{1}{3}$ inches.

"Rare. Seen occasionally in May, but more frequently in September, when the warblers are generally returning to the South. Author knows of no instance of its breeding in the State."-[C. C. A.]

\section{HELMINTHO PHILA, Ridg.}

B. chrysoptera, L. Blue Golden-winged Warbler.

Tail feathers blotched with white; back and rump ashy blue; forehead, crown and wing bars bright yellow; throat and broad stripe through eye black; white below ; female duller. Length, 5 inches; tail, $2 \frac{1}{4}$ inches. Throat of female deep gray.

"Unusual. When warblers are more than ordinarily abundant, are occasionally detected. Several were shot in May of 1860, after a rain of two days' duration."

В. lawrencei. Lawrence's Warbler.

Supposed to be a variety of preceding; has wing bars white and narrower; yellow below; back and rump olive green; throat of female olive greenish. 
H. pinus, L. Blue-winged Yellow Warbler.

Olive yellow; crown and all under parts bright yellow ; wing bars whitish ; black stripe from eye to bill ; sexes alike. Length, $4 \frac{1}{2}$ inches; tail, 2 inches. Resembles a Protonotaria, or Golden Swamp Warbler, but is smaller. The latter belougs to the Lower Mississippi Valley, in willow swamps, and rarely visits the Atlantic coast north of Georgia.

"Not very rare. Seen generally in Cape May county when found in the State. Re-appears in September for a few days. Prefers large evergreen trees, keeping generally near their tops."

H. leucobronchialis, Brewst. Brewster's Warbler. White-throated Warbler.

Probably a variety of preceding, with back and rump ash gray; lower parts white; sides tinged ash gray; wing bands yellow or white, broad or narrow; varies by small gradations into the preceding ( $H$. pinus).

H. peregrina, Wils. Tennessee Warbler.

Olive green ; no crown patch; white or slightly yellow below; no white blotches on tail feathers. Length, $4 \frac{1}{2}$ inches; tail, $1 \frac{3}{4}$ inches.

"Rare. Arrives in May and again in September. Author shot a single specimen in July, 1863, but saw no others at that time. Thickly-tangled vegetation is its preferred haunt." [C. C. A.]

B. celata, Say. Orange-crowned Warbler.

Olive green; never ashy on head; orange-brown crown patch more or less concealed; greenish yellow below; female duller. Length, $4 \frac{3}{4}$ inches; tail, 2 inches. Migrates from Alaskan region south through Mississippi Valley. Rare east of Alleghanies.

H. ruficapilla, Wils. Nashville Warbler.

Olive green; ashy on head and neck; bright chestnut crown patch more or less concealed; bright yellow below ; ring around eye pale. Length, $4 \frac{2}{3}$ inches; tail, 2 inches.

"Moderately abundant. Arrives in May, and again in September. A few remain during the summer. Prefers large deciduous trees, keeping near the tops of them. Strictly inoffensive." 


\section{COMPSOTHLYPIS, Cab.}

(Chloris, Boie. Parula, Bonap.)

C. americana, L. Blue Yellow-backed Warbler. Parula Warbler.

Clear ashy blue; large golden-green patch on back; yellow below; belly white; brown band across breast; white wing 'bars; female paler. Length, $4 \frac{3}{4}$ inches; tail, 2 inches.

"Abundant from the beginning of May. Seldom remains during the summer. Returns in August. Prefers pines and cedars to other trees, and is not as restless as warblers generally are, but remains on one tree for a long time. Have found no nests of this species." - [C. C. A. $]$

\section{DENDROICA, Gr.}

D. tigrina, Gmel. (Perissoglossa, Baird.) Fringed-tongue Warbler. Cape May Warbler.

Olivaceous above, with darker streaks ; rump and sides of neck bright yellow; yellow below, streaked with black; crown nearly or quite black; a white wing patch; orange-brown ear coverts ; female duller, with no reddish or black about head. Length, 51 inches; tail 2 inches.

"Arrives in May, but is not an abundant species. Author has met with but two specimens. The common name would seem to suggest New Jersey as its principal 'habitat." - [C. C. A.]

D. æstiva, Gmel. Summer Warbler. Golden Warbler. Yellow Warbler.

Plumage chiefly yellow; wings and tail dusky, edged with yellow; back olive yellow; breast and sides with orange-brown 'streaks; female scarcely streaked. Length, $5 \frac{1}{ \pm}$ inches; tail, $2 \frac{1}{4}$ inches.

"Very abundant. Arrives in May, and remains during the summer. Builds in birch trees, especially those skirting streams, 'though by no means there exclusively. Is a sociable bird, and seldom seen in the woods or unfrequented swamps. Lives like all the tribe, exclusively on insects, and is a very useful bird to fruit-growers. Have generally all disappeared by Septemher 20th." 
D. cœrulescens, Gmel. (canadensis-Abbott's Catalogue.) Blackthroated Blue Warbler.

No wing bars; a white spot on primaries near their bases; color rich gray blue, with dusky streaks on back; black throat, neck and sides of body; white below; quills black, edged with blue; female obscurely marked, dull olive green. Length, $5 \frac{1}{2}$ inches; tail, $2 \frac{1}{4}$ inches.

"Arrives earlier than any of the warblers, and is a very common species. Has not been noticed breeding in the State. Reappears in September, and lingers with us till frost."

D. coronata, L. Yellow-rumped Warbler. Myrtle Warbler.

Throat white; crown and rump (and sides of breast) yellow ; white and streaked below; wing patch white; no white blotch on primaries; bluish ash above, streaked with black; female and young with less yellow on breast and head; brownish. Length, $5 \frac{3}{4}$ inches; tail, $2 \frac{1}{2}$ inches.

"Very abundant, arriving not unfrequently as early as March. Do not remain during the summer. Appears to prefer the neighborhood of small creeks, though is everywhere to be found, especially where there are large deciduous trees."

D. auduboni, Towns. Audubon's Warbler.

Similar to $D$. coronata, but throat yellow and sides of head dark leaden; no white streaks above and behind eye, but a white spot on each eyelid; male has a large white wing patch; female with two white wing bars, and chest ashy, spotted with black. Length, $5 \frac{1}{2}$ inches; tail, $2 \frac{1}{3}$ inches. A western species; rare in the east.

"Very rare. Single specimens have occasionally been taken; the last seen by the author was shot May 29th, 1860."-[C. C. A.]

D. malculosa, Gmel. Black and Yellow Warbler. Magnolia Warbler.

Rump yellow; crown clear ash; yellow and streaked below; back black, with olive skirtings; a white stripe behind eye; sides of head black; under tail coverts white; female more olivaceous, with less black. Length, 5 inches; tail, $2 \frac{1}{4}$ inches.

"Arrives early in May, and is one of the most active and restless of the warblers. Seems to have no preference of locality, and is abundant among the shade trees of the cities. None remain during the summer. Re-appears in September." 
D. cœrulea, Wils. Corulean or Blue Warbler.

Spots at end of nearly all tail feathers ; crown and back blue, with black streaks; white below; no yellow; female greenish above; slightly yellow below. Length, $4{ }_{4}^{1}$ inches; tail, 2 inches.

"Like the castanea, is a rare species, and only to be met with once or twice in a series of springs. Author has killed but one." - [C. C. A. $]$

D. pennsylvanica, L. Chestnut-sided Warbler.

Much streaked; blackish above; crown clear yellow; black about eye; pure white below; chestnut streaks along sides; wing patch yellowish (never pure white); female has less hlack and chestnut. Length, 5 inches; tail, $2 \frac{1}{4}$ inches.

"Common. Arrives about May 1st, and many remain during the summer. Prefers sivamps to open ground, and haunts, where it builds its nest, low, tangled vines and bushes."

D. castanea, Wils. Bay-breasted Warbler. Autumn Warbler.

Back black and olive; thickly-streaked forehead and sides of head black, enclosing a deep chestuut crown patch; chin, throat and sides, dull chestnut; otherwise pale; buffy below; female more olivaceous, with less chestnut; young nearly like young of D. striata, but more buffy below. Length, 5 inches; tail, $2 \frac{1}{2}$ inches.

"Rarely seen. During the month of May, occasionally a severe northeast storm detains the warblers generally, and when such is the case, the above, with several others, are sometimes seen."

D. striata, Forst. Black-poll Warbler.

Crown pure black; general color black and olivaceous, everywhere streaked; female more olivaceous, and slightly yellow below. Young male olive green, streaked; rump gravish, white and olive; olive yellow below ; flanks rusty; female not streaked, and flanks not rusty. In second year general color is dull gray, streaked; a dull white below, spotted with black. Length, $5 \frac{3}{4}$ inches; tail, $2 \frac{1}{ \pm}$ inches. The last to migrate.

"Very abundant, frequenting elm trees in preference to all others, and remains longer during both spring and autumu, hut none have been noticed to remain during the summer." 
D. dominica, L. (superciliosa-Abbott's Catalogue.) Yellow-throated Warbler.

Some yellow on crown; back ashy blue; cheeks black; throat yellow; belly white. Length, 5 inches; tail, $2 \frac{1}{3}$ inches. Southern. Very rare in New Jersey. Last one seen by C. C. A. was shot May 29th, 1860.

D. blackburniæ, Gmel. Orange-throated Warbler. Blackburnian Warbler. Hemlock Warbler.

Black above, with whitish streaks; brilliant orange crown patch and throat, fading into yellowish on belly; outer tail feathers white edged externally; female has olive instead of black, and yellow instead of orange. Length, $5 \frac{1}{2}$ inches; tail, $2 \frac{1}{4}$ inches. A most brilliant species.

"Not abundant. Arrives about May 10th, and frequents maple and elm trees principally, keeping among the higher branches. May occasionally remain during the summer. Reappears in September, frequenting deciduous trees."

D. virens, Gmel. Black-throated Green Warbler.

Clear yellow olive; outer tail feathers white edged; sides of head rich yellow; whole throat, breast and sides jet black; whitish below; throat feathers sometimes edged with yellow; especially in the female and winter birds. Length, 5 inches; tail, $2 \frac{1}{4}$ inches.

"Arrives early in May, and frequents city and country alike. Is partial to elm trees. Seldom seen during the summer, though a few breed in the State. Re-appears in September for a few days."

D. vigorsii, Aud. (pinus,Wils.) Pine-creeping Warbler. Pine Warbler.

Yellow olive above; yellow below; wing bars white; white oblique tail spots at end of two outer feathers only ; female more grayish. Length, $5 \frac{2}{3}$ inches ; tail, $2 \frac{1}{3}$ inches.

"Arrive in April, and are most abundant in the southern counties of the State, though numerous everywhere, where pine trees are to be met with. Remains during the summer."

D. kirtlandi, Bd. Kirtland's Warbler.

Ashy blue above; yellow and streaked below; lores black; back brownish gray, streaked with black; wings aud tail black, with brownish edgings; in female, the gray on head, rump, \&c., 
is duller. Length, $5 \frac{2}{3}$ inches; tail, $2 \frac{1}{3}$ inches. Winters in the Bahamas. Summer residence unknown. Rare. Seen during migration.

D. discolor, Vieill. Prairie Warbler.

Olive yellow; patch of red spots on back; forehead, wing bars and belly, yellow; streaked below; sides of head black; sexes alike. Length, $4 \frac{3}{4}$ inches ; tail, 2 inches. Chiefly in evergreen thickets.

"Not very abundant. More numerous during some years than others. Always remains during the summer. Frequents old, uncultivated fields, spending much of its time upon the ground. Sings more, and with a greater variation of notes, than warblers generally. Remains till October."

D. palmarum, Gmel. Yellow Redpoll Warbler. Palm Warbler.

Brownish olive above, somewhat streaked; rump brighter; crown bright chestnut; under parts yellow, with brown streaks; no obvious wing bars (brownish); sexes alike; tail spots square and at ends of two outer tail feathers only; sides reddish streaked. Length, 5 inches; tail, $2 \frac{1}{1}$ inches.

"Arrives early in April, and in loose flocks roam restlessly about dwarfish trees and blackberry briars, frequently in company with other species. None remain during the summer. Re-appear late in August and during September, when they are more scattered and frequent wet, marshy grounds."

D. palmarum, var. hypochrysea, Ridg. Yellow Palm Warbler.

Larger and more brightly colored; entire lower parts bright yellow; upper parts less grayish, but richer olive than in preceding. Length, $5 \frac{1}{2}$ inches; tail, $2 \frac{1}{3}$ inches. Breeds in the Labrador region; southward to Gulf States in winter.

\section{SEIURUS, Swains.}

s. aurocapillus, L. Golden-crowned Thrush. Oven Bird.

Bright olive green; white below; sharply spotted on breast and sides; crown orange brown, with two black stripes. Length, $6 \frac{1}{ \pm}$ inches; tail, $2 \frac{1}{2}$ inches. Builds on the ground or in old logs, stumps, \&c., an oven-shaped nest; has a loud, ringing note; is largest of true warblers; lives in thickets, but spends " most of its time on the ground."-Jordan. 
"Migratory. Abundant. Arrives in April and remains till October. They live along streams of water or about marshes, but spend much of their time in the trees. They are seldom seen on open ground. Strictly inoffensive. Is the most abundant of the three species of Seiurus." - [C. C. A.]

S. noveboracensis, Gmel. (novius, Bodd.) Water Wagtail. Water Thrush.

Dark olive brown above; pale yellowish beneath; thickly spotted with color of the back; feet dark; bill, $\frac{1}{2}$ inch. Length, 6 inches; tail, $2 \frac{1}{3}$ inches.

"Arrives in May, and occasionally in April, frequenting banks of creeks, and in movements similar to the more abundant 'tiltup.' Breeds in June. Have disappeared by October 1st."

S. motacilla, Vieill (hudovicianus.) Long-billed Water Thrush. Louisiana Water Thrush.

Same general color (less brownish) as preceding, but white or pale buffy below, and less sharply spotted; bill, 3 inch; feet pale. Length, $6 \frac{1}{2}$ inches; tail, $2 \frac{1}{3}$ inches.

"Less numerous than the preceding, but in every way is similar to it in habits. Seldom see more than one of this species, where we find twenty of the noveboracencis."

\section{GEOTHLYPIS, Cab.}

G. agilis, Wils. (Oporornis, Baird.) Connecticut Warbler.

Olive green; ashy on head; brownish ash on throat and breast; yellow below. In fall more olive. Length, $5 \frac{3}{4}$ inches; tail, $2 \frac{1}{4}$ inches. A shy bird.

"Arrives in May, and re-appears in September. Very rare. Author has seen but two specimens. They were taken at different seasons, but upon the same cypress tree. Probably prefers cedar swamps and similar localities, which may account for its so seldom being detected."-[C. C. A.]

G. formosa, Wils. Kentucky Warbler.

Clear olive green; bright yellow below ; crown and sides of head and neck black, with rich yellow superciliary stripe, which bends around eye behind. Length, $5_{4}^{3}$ inches; tail, $2 \frac{1}{4}$ inches. In low thickets in eastern part of Mississippi Valley ; rarer east of Alleghanies. Nests on the ground. 


\section{G. philadelphia, Wils. Mourning Warbler.}

Bright olive; clear yellow below; head ashy; throat and breast black, the feathers ashy skirted, "as though the bird wore crape." When not in full plumage, both sexes resemble G. agilis, except wing is not longer than tail.

"Arrives in May, and re-appears in September. Rare. Is similar in its movements to $G$. trichas, but seems to prefer low bushes and dwarfed trees rather than the ground. Have detected none during the summer. During the spring of 1860, when warblers were unusually abundant, saw several, but have seen few since."-[C. C. A.]

G. trichas, L. Maryland Yellow Throat. Black-masked Ground Warbler.

Olive green; jet-black mask over forehead, sides of head and neck, bordered behind with clear ash; under parts yellow, clear on throat and breast; female without black mask; with less yellow, and with obscure markings. Length, $4 \frac{1}{2}$ inches; tail, $2 \frac{1}{4}$ inches.

"Very abundant. This beautiful bird frequents wet, swampy localities, and passes the greater portion of its time upon the ground. In its movements resembles very much the wren. Builds a nest always upon the ground, raising but a single brood. Sings but little. Have generally all disappeared by September 15th. Like all warblers, is strictly insectivorons, and destroys an incredible quantity during every twenty-four hours."

\section{ICTERIA, Vieill.}

I. virens, L. Yellow-breasted Chat,

Olive green; throat and breast bright yellow; belly abruptly white; lores black; white line on eyebrow; tail plain; tarsus nearly "booted." Length, $7 \frac{1}{8}$ inches; tail, $3 \frac{1}{3}$ inches.

"Very abundant. Arrives early in May, and remains during the stummer. Frequents tangled, bushy vegetation, spending a great portion of its time upon the ground. Is sociable, and frecuently seen in gardens, in town, hopping ahout gnoseberry and currant bushes. Breeds in the haunts above mentioned, raising but one brood. Later in the summer, when the young are fully Hedged, retire to the woods and swamps, and sing much less than during incubation. The chat is largely known throughout the 
State as the 'yellow mocker,' a name to which it is in no way entitled, as it has no trace of mimicking in its varied notes. Feeds largely upon insects, and is very active and eager in the pursuit of spiders, frequently lying in wait for the large spiders having nests in-to the chat-inaccessible places. They have generally all disappeared by the middle of September."

\section{SYLVANIA, Nutt.}

(Myiodioctes, Aud.)

S. mitrata, Gmel. Hooded (Flycatching) Warbler. Yellow-masked Warbler.

Bright yellow olive; crown and neck jet black, enclosing a broad golden mask; bright yellow below; white blotches on tail ; female with olive instead of black. Length, 5 inches; tail, $2 \frac{1}{2}$ inches.

"Rare. Arrives in May, and prefers apparently evergreen trees. Re-appears in September and makes a longer stay. Always remains high up among the branches, so is difficult to detect."

S. pusilla, Wils. Wilson's Warbler. Green Black-capped Flycatching Warbler. Green Black-cap Flycatcher.

Clear yellow olive; crown glossy black; remainder of head and under parts bright yellow; wings and tail unblotehed; female with less black. Length, $4 \frac{3}{4}$ inches; tail, $2 \frac{1}{4}$ inches.

"Less rare than the preceding, and unlike it in habits, as it prefers dark, swampy thickets. Has been seen in July, and so may possibly breed here. Re-appears in September for a short time."

S. canadensis, L. Canadian (Flycatching) Warbler. Canada Flycatcher.

Bluish ash; crown speckled with black; under parts clear yellow; under tail coverts white; lores black, continued under eye, and as a chain of black streaks down side of neck, encircling breast like a necklace; wings and tail plain; female with less black. Length, $5 \frac{1}{3}$ inches; tail, $2 \frac{1}{2}$ inches. Very handsome.

"Most abundant of the three species. Arrives in May, and prefers oak woodlands to the open country. None remain during the summer. Re-appear in September." 


\section{SETOPHAGA, Swains.}

S. ruticilla, L. American Red Start.

General color black; orange-red blotches on wings and tail and sides of breast; belly white, tinged with red ; female olive; similarly marked with reddish yellow. Length, $5{ }_{4}^{1}$ inches; tail, $2 \frac{1}{2}$ inches.

"Abundant. Arrive early in May. A few remain during the summer. They re-appear more numerous than ever late in August and September. Are sociable and as frequent in town as in the country. Show no preference as to the trees they haunt, provided they can supply them largely with insects. Have all gone by October."

\section{Family MOTACILLID FE.}

Wagtails.

\section{ANTHUS, Bechs.}

A. pennsylvanicus, Lath. (ludovicianus-Abbott's Catalogue.) American Pipit. Brown Lark. Titlark.

Dark brown, slightly streaked; under parts butfy ; breast and sides streaked; outer tail feathers more or less white. Length, $6 \frac{\mathrm{I}}{2}$ inches; tail, 3 inches.

"Migratory. Not abundant. Occur during the months of May and October and November. Do not breed in the State. Gregarious. Frequent plowed fields in May, stubble fields in October."

\section{Family TROGLODYTIDE.}

Wrens.

MIMUS, Boie.

M. polyglottus, L. Mocking Bird.

Ashy brown above; wings blackish, with white wing bars; tail blackish, outer feathers white. Length, 91 inches; tail, 5 
inches. Tail longer than wing and rounded; tarsus distinctly scutellate.

"Formerly was quite a common summer visitor, but of late years is seldom met with. Author has seen but few specimens during the past seven summers, and has found but the one nest, which has been occupied for three successive summers, and probably by the same pair." - [C. C. A.]

\section{GALEOSCOPTES, Cab.}

G. carolinensis, L. Catbird.

Dark slate color; crown and tail black; under tail coverts brownish chestnut. Length, $8 \frac{3}{4}$ inches; tail, 4 inches.

"Arrives in May and remains until October. Abundant everywhere, and at all times. Builds in trees or bushes, and occasionally on the ground, raising two broods. Feeds largely upon insects and wormy fruit. The catbird is considered very generally a great nuisance by fruit growers, and undoubtedly does carry off much good fruit; but without the shadow of a doubt, it is the wormy fruit that it prefers, and when that is to be had the sound berries or cherries are left undisturbed. If fruit is known to be healthy, it would be better to protect it by fluttering strips of red flannel, or by little flags, than to destroy the catbirds."

\section{HARPOREYNCHUS, Cab.}

E. rufus, L. Brown Thrasher. Sandy Mocking Bird. Brown Thrush.

Cinnamon red above; lower parts thickly spotted; bill nearly straight, shorter and more curved than in allied species of this genus. Length, 11 inches; tail, $5 \frac{1}{\ddagger}$ inches. "A brilliant songster:"-Jordan.

"Arrives in May and remains in summer. Prefers woody districts, and is as retired as the catbird is sociable. Builds its nest generally on the ground. Feeds largely upon insects and worms, and is not offensive to the gardener or fruit grower. They sing but seldom, except early in the morning. Return South in October." 


\section{THRYOTHORUS, Vieill.}

\section{T. ludovicianus, Lath. Carolina Wren.}

Reddish brown above, brightest on rump; whitish superciliary stripe, bordering a blackish stripe; wings narrowly barred with dusky; pale rusty spots on quills; chin whitish; lower parts tawny. Length, 6 inches ; tail, $2 \frac{1}{3}$ inches.

"Rare, and frequenting secluded, tangled thickets. Is but seldom met with, even when several may be in the seeker's neighborhood. Have seen them only in Camden county."[C. C. A.]

T. bewickii, Aud. Bewick's Wren.

Grayish brown; two middle tail feathers barred. Length, $5 \frac{1}{2}$ inches; tail, $2 \frac{1}{2}$ inches. Belongs to the south and eastern portion of the Mississippi Valley.

"Like the above, this wren is but seldom met with in New Jersey. Appears to be more abundant, however, during some seasons than during others."

\section{TROGLODYTES, Vieill.}

T. ä̈don, Vieill (domesticus, Bartr.) House Wren. Wood Wren.

Color brown; brightest behind; rusty below; everywhere more or less waved with darker, especially on the wings, tail, \&c. Very variable. Length, 5 inches; tail, 2 inches.

"Arrives early in May, and is everywhere abundant, unless it be in dark, unfrequented swamps, for the wren is eminently a social bird, and intelligent above many of its race. Builds in boxes erected for his accommodation, in deserted woodpeckers' nests-anywhere that affords a certain amount of shelter. Ten eggrs are froguently laid, eight always, and two broods are generally raised. Feeds exclusively upon insects, and is as active in their destruction as any of the 'flycatcher' tribe. Have all disappeared by October 15th."

The following is doubtless a mere variety:

"Troglodytes americanus [Abbott's Catalogue]. Wood Wreu.

"In all respects, in plumage, movements, and habits generally, is similar to the preceding species, but inhabits the unfrerpenter woody districts. Alrives and disappears with the aëdon." 
T. hiemalis, Vieill. Winter Wren.

Deep brown, waved with dusky; belly, wings and tail strongly barred. Length, 4 inches ; tail, $1 \frac{1}{4}$ inches.

"During the spring and summer this wren is found only about thick woods, and especially swampy districts. In its movements, restlessness, and apparent love of the ground is much like the common 'house wren,' and like it, feeds exclusively upon insects and spiders, hunting diligently for the latter amorg dead leaves. About October, or later, the winter wren leaves the woods, and in a measure occupies the lately-deserted haunts of $T$. aëdon, remaining about our yards, even in town, during the winter. Occasionally a deep snow drives them to the sheltered swamps, but they promptly re-appear on the disappearance of the snow. The three above-mentioned species of wrens are all inoffensive, and worthy the care and protection of all interested in fruit culture."

\section{CISTOTHORUS, Cab.}

C. palustris, Wils. Long-billed Marsh Wren.

Bill slender, as long as head; a white superciliary line; color clear brown; a black patch, with white streaks, on back; otherwise not streaked above; crown blackish ; rump brown. Length, 5 inches; tail, $1 \frac{3}{4}$ inches.

"Not abundant. Arrives in May, and is found only in the meadow lands, generally in the marshy, wet tracts that are undisturbed throughout the year. Breeds in June, and raises two broods generally. Are most frequently met with in September, when they may be seen flitting about the reed;, apparently careless of the shooting so incessant about them at this time."

C. stellaris, Licht. Short-billed Marsh Wren.

Bill half as long as head; no white superciliary line; color dark brown, head and back darker; entire upper parts with white streaks. Length, $4 \frac{1}{2}$ inches; tail, $1 \frac{3}{4}$ inches.

"More abundant than the preceding, and frequents the same localities. Builds a large globular nest of grass, supported by firm bulrush stalks. Raises two broods in a season, laying frequently ten eggs. This and the above feed exclusively upon 
insects, and are very active in the pursuit of them. Arriving in May, they settle down immediately in the meadows, and do not leave them till a hard white frost has come."

\section{Family CERTHIID压。}

\section{Creepers.}

\section{CERTEIA, L.}

C. familiaris americana, Bonap. American Creeper.* Brown Creeper.

Bill slender, as long as head; without notch or bristles; claws long and curved; tail feathers stiff and pointed, almost woodpecker-like. Plumage dark brown, much barred and streaked; rump tawny. Length, $5 \frac{1}{2}$ inches; tail, $2 \frac{3}{4}$ inches.

"Resident. Although really numerous at all times, is apparently more abundant from October to March than at other times. They usually occupy a deserted woodpecker's nest to breed in. Raise but one brood. Insectivorous. Inoffensive."

\section{Family PARIDEE.}

\section{Titmice.}

\section{SITTA, L.}

S. carolinensis, Lath. White-breasted [or White-bellied] Nuthatch. [Sap-sucker.]

Ashy blue above; white below; under tail coverts washed with rusty brown; crown and nape black, unstriped; middle tail feathers like back, others black, blotehed with white; female. with less or no black on head. Length, $5 \frac{1}{2}$ inches; tail, 2 inches.

"Resident. Common. Prefers large trees, but is always to

* The term American Creeper is now not strictly applicable. Ridgway distinguishes a Mexican and two Western forms of this bird as races distinct from our Eastern species. 
be found in greater or lesser numbers in old apple orchards, in which they usually build their nests. Feeds exclusively upon insects and their larvæ. Strictly inoffensive."

S. canadensis, L. Red-breasted [or Red-bellied] Nuthatch.

Ashy blue, brighter than preceding; rusty brown below; crown glossy black in male, bluish in female, bordered by white and black stripes. Length, $4 \frac{1}{2}$ inches; tail, $1 \frac{1}{2}$ inches.

"Resident. Not as numerous as the preceding species. Appears to be more abundant in the winter, but the leafless condition of the trees and the scarcity of birds generally is the reason. Like the above, it feeds only on insects and their larvæ."

\section{PARUS, L.}

P. atricapillus, L. Black-cap Titmouse. Black-capped Chickadee.

Grayish ash; wings and tail plain, with whitish edging; crown, nape, chin and throat black; no white line above eye. Length, 5 inches; tail, $2 \frac{1}{2}$ inches.

"Very abundant everywhere, at all times of the year. Seems to prefer no locality, and is as abundant on exposed upland fields as marshy meadows. Feeds exclusively on insects and their larvæ, and is strictly inoffensive."

P. bicolor, L. Tufted Titmouse.

Forehead alone black; whitish below; sides washed with reddish; general color lead gray; a conspicuous crest. Length, $6 \frac{1}{4}$ inches; tail, $3 \frac{1}{4}$ inches. Has a loud, ringing note.

"Very common during the greater part of the year. Has been shot as late as December 3d. Prefers the tallest trees, though not found exclusively in them. Strictly inoffensive."

\section{Family SYLVIID王.}

Sylvias.

REGULUS, Cuv.

R. satrapa, Licht. Golden-crowned Kinglet. Golden-crested Wren.

Tarsus booted; wings longer than tail; color olivaceous; crown with a yellow patch, bordered with black (orange red in 
center in male); front of forehead and line over eye whitish ; a tiny feather over each nostril. Length, 4 inches; tail, 13 inches.

"Resident. Common. This species and the next are more abundant during the summer in the northern hilly regions of the State-during the winter equally uumerous throughout the State. Both species are inoffensive."

R. calendula, L. Ruby-crowned Kinglet [or IVren].

Olivaceous; scarlet patch on crown in both sexes, wanting the first year ; no black about head; no nasal feather. I Length, $4 \frac{1}{ \pm}$ inches; tail, $1 \frac{3}{4}$ inches.

"Resident. Common. During the winter, when birds generally are few in numbers and speries, this and the preceding are freyuently seen flitting through the leafless branches. During the summer they are shy, and breed in secluded woods."

\section{POLIOPTILA, Sclat}

P. cærulea, L. Blue-gray Fly-[or Gnat-]Catcher.

Clear ashy blue, brightest on head; whitish below; male with forehead and sides of crown black; outer tail feathers chiefly white. Length, $4 \frac{1}{3}$ inches; tail, $2 \frac{1}{4}$ inches. A fine singer; ordinary note squeaky; manner sprightly.

"Not abundant. Generally to be found, however, on careful search during the summer. Haunts lofty trees."

\section{Family TURDID EE.}

Thrushes.

TURDUS, L.

T. mustelinus, Gmel. Wood Thrush.

Tarsus booted; wings longer than tail ; color cinnamon brown, brightest on head, shading into olive on rump; breast with large, distinct, dusky spots. Length, 8 inches; tail, 3 inches. An "exquisite songster."

"Abundant from May till October. Prefers thickly-overyrown hillsides, and near water courses, although occasionally 
seen in town. They nidificate in May and raise two broods. They feed exclusively on insects, and are strictly inoffensive. During September, when about to migrate, become slightly gregarious, and generally disappear simultaneously."

T. fuscescens, Steph. Wilson's Thrush. Tawny Thrush. Veery.

Uniform tawny above; breast and throat washed with brownish or pinkish yellow, and marked with small, indistinet, brownish spots. Length, $7 \frac{1}{2}$ inches; tail, $3 \frac{1}{5}$ inches.

"Arrives about May 1st, occasionally earlier, and remains during the summer. Abundant Frequents small trees and bushes, and unlike the following, passes but little of its time upon the ground. Builds a neat nest on or very near the ground, the eggs being laid during the third week in May. Appears less abundant late in the summer, and during September. This is on account of their remaining more in woodlands and tangled thickets than when on their first arrival; they are abundant in the open country. They have generally left by October 15th."

T. aonalaschkæ pallassii, Cab. Hermit Thrush.

Olive brown above, becoming rufous on rump and tail; breast with numerous, rather distinct, dusky spots; a whitish ring around eyes. Length, 7 inches; tail, 21 inches.

"During the month of May, 1859, and in each successive spring, this interesting bird has appeared abundantly in the State, nor has it, as its name would seem to associate, sought only the most secluded localities, but has hopped fearlessly and familiarly about, searching for insects and spiders among the dead leaves, on which insects it exclusively feeds. As it remains during the summer, it undoubtedly breeds with us, but the author has as yet found no nests. During the past summer it has been much less abundant. Although a magnificent singer, the author has heard nothing but a weak chirp issue from its throat, and that seems to be but seldom uttered." - [C. C. A.]

T. ustulatus swainsonii, Cab. Swainson's Thrush. Olive-backed Thrush.

Uniform olive above; breast and throat thickly marked with large, dusky, olive spots; breast and sides of head strongly buffy tinted; a conspicuous buffy orbital ring. Length, $7 \frac{1}{4}$ inches; tail, 3 inches. 
"Quite common, arriving early in May. Are seen occasionally during the summer, and are more abundant in October, when, after a few days' stay, they all disappear. Formerly were more abundant, and the 'hermit' was seldom seen, even as a migratory species. 'Olive-backs' were more abundant during the past summer than for several years" (1867).

\section{MERULA, Leach.}

M. migratoria, L. American Robin, or Red Breast.

Bill bright yellow, notched; sexes alike; olive gray above; head and tail blackish; throat white, with black streaks; under parts chestnut brown; breast, \&e, rufous. Length, 93 inches; tail, $4 \frac{1}{2}$ inches.

"Resident. Abundant, but at certain seasons only. As the specific name indicates, is migratory-perhaps it would be better to say, wandering. Semi-gregarious. Although not uncommon during winter, it is not until the middle of February that they show themselves in numbers. At this time they fly in close flocks, and spend a large portion of their time, if the ground be clear of snow, upon the ground. From now (February) until they pair, their food consists of angle-worms and larve of insects; and they remain largely insectivorous during the whole summer, feeding principally upon grasshoppers in August. Nidification takes place in May, two broods being usually raised. In October they have become again gregarious, and feed largely upon the berries of the gum and cedar. At this time they associate to some extent with 'flickers;' a flock of the former numhering fifty, will be accompanied probably by ten or a dozen of the latter. Are least abundant in December and January. Are in no way objectionable to fruit growers."

\section{HESPEROCICELA, Bd.}

H. nævia, Gmel. Varied Thrush. Oregon Robin.

Bill not notched; throat unstreaked; sexes unlike; male with a black collar; general color slate; orange brown below; chin, throat and breast orange, rufous or ochraceous. Length, 93 inches; tail, 4 inches. Hab.-Pacific Slope. Accidental in New Jersey. 


\section{SIALIA, Swains.}

S. sialis, L. Bluebird.

Bright blue above; throat and breast reddish brown; belly white; female duller, with a brownish tinge on back; young are usually spotted. Length, $6 \frac{3}{4}$ inches; tail, 3 inches.

"The 'bluebird' is much less migratory now than in the days of Wilson and Audubon. They are frequently to be seen during the depths of winter, flying from fence-post to post in the country, and singing as cheerfully as in May. They build in 'boxes' or woodpeckers' nests, raising two broods."

\section{Order RAPTORES.}

\section{Family CATHARTIDE.}

(Vulturidæ.)

Vultures.

\section{CATHARTES, IIl.}

O. aura, L. Turkey Buzzard, or Vulture.

Head and part of neck bare; bill lengthened, slender, slightly hooked; wings long and strong; toes somewhat webbed; claws weak; a tuft of bristles in front of eye; plumage black, lustrous above; skin of head and neck red. Length, 30 inches; tail, 12 inches; wings, 22 inches. Voracious scavengers, feeding on carrion and animal refuse of all sorts.

"From Trenton and from New Brunswick, southward, these birds are more or less abundant, becoming more numerous as we approach Delaware Bay and the ocean. Breeds mostly in Cape May county, in unfrequented localities. The opinion entertained by many that lambs and poultry are attacked occasionally by them is not unfounded." 


\section{CATHARISTA, Vieill.}

C. atrata, Bartr. Black Vulture. Carrion Crow.

Wings short; skin of neck corrugated; no bristles in front of eye; uniform dull black. Length, 24 inches; tail, 8 inches; wings, 17 inches. Southern; strays northward. Rarely visits New Jersey.

\section{Family FALCONID}

\section{Falcons.}

\section{ELANOIDES, Gray.}

E. forficatus, L. Swallow-tailed Kite.

Lustrous black; head, neck and lower parts white; tail widely forked, outer feathers twice as long as middle ones. Length, 19 to 25 inches ; tail, 14 inches. Southern ; accidental on our coast.

\section{CIRCUS, Lac.}

C. hudsonius, L. Marsh Hawk. Marsh Harrier.

Face with a slight ruff; color pale bluish or brown; rump and under parts whitish. Length, 18 inches; tail, 9 inches.

"Known also as 'bog-trotter.' 'This very abundant hawk prefers meadow lands and appears to be especially abundant along the Delaware River, from Trenton to Cape May. They feed upon mice principally, but are also very active in picking up the wounded reedbirds and 'red-wings' which the gunners fail to gather. 'The nest of this species is placed upon the groumd, in tangled marshy thickets, the same being often userl several seasons."

\section{ACCIPITER, Briss.}

(Nisus, Cur.)

A. velox, Wils. (fuscus, Gmel.) Sharp-shinned Hawk. Pigeon Hawk.

Tarsus feathered less than one-third down front, the feathers widely separated behind; tarsus "booted" in male; general color dark brown. Length, 12 inches; tail 6 inches. 
"The habits of this species vary but little from that of the next. It is less disposed to attack poultry, preferring mice, and is generally found about swamps and woodland. They breed yearly within State limits."

A. cooperi, Bonap. Cooper's Hawk. Chicken Hawk.

Bare tarsus shorter than middle toe; tail round; back bluish gray; top of head black; female duller in color than male. Length, 18 inches; tail, 8 inches.

"During the spring and early summer is not frequently seen, but from July till midwinter is an abundant, bold and destructive hawk. As is the case with the pigeon hawk, this species is more destructive to poultry than larger species."

A. atricapillus, Wils. American Goshawk.

Tarsus feathered half way down in front; feathers scarcely separated behind; color slate blue, with white stripe over eye; tail with four dark bars. Length, 24 inches; tail, 11 inches.

"Occasionally abundant, but most frequently very scarce; the goshawk appears to be nowhere well known. It seldom frequents the barnyards, but is not unfrequently seen sailing over overflown meadows, especially in March and April. If it breeds within State limits, it is probably in the northern mountainous sections."

\section{BUTEO, Cuv.}

B. borealis, Gmel. Red-tailed Hawk, or Buzzard.

Tail bright chestnut red above; general color dark brown, mụch barred and streaked. Length, 23 inches; tail, $8 \frac{1}{12}$ inches.

"Known as the 'henhawk,' as well as 'red-tail.' This is the most abundant species found in the State.

"This hawk will never molest poultry if mice are to be caught by them, which is always or nearly so the case, and for this reason this species should be as carefully preserved as it is now persistently destroyed. Fifteen mice have been found in the digestive tract of a single specimen. Breeds in heavy timber, frequently raising two broods."

B. latissimus, Wils. (pennsylvanicus, Wils.) Broad-winged Hawk.

Brown above, whitish below, variously streaked and barred; dark cheek patches; tail with a few broad dark bands, alter- 
nating with narrower pale ones, white tipped. Length, 18 inches; tail, 7 inches.

"This species appears to be much more numerous during some seasons than others, but being a wary, restless bird, they are frequently more numerous than suppo-ed to be. They breed every season in the hilly, wooded districts."

B. lineatus, Gmel. Red-shouldered Hawk, or Buzzard.

Length, 22 inches; tail, 9 inches.

"Adult.-Shoulders bright red, breast and belly paler, with transverse bands and spots of white. Tail black, with five white bands. Thus plumaged, is known as 'red-shouldered hawk.'

"Young.-Breast and belly yellowish white, with longitudinal bands and spots of brown. Tail brown, with numerous bands of rufous white. Thus plumaged, is known as 'winter falcon.'

"This showy hawk makes its appearance about meadows and imall streans generally about October 1st, and is abundant till May, when but few are to be seen. Like B. borealis, this hawk prefers mice to chickens, and should be protected."

\section{ARCHIBUTEO, Brehm.}

A. lagopus, vur. sancti-johannis, (imel. American Rough-legged Hawk. Black Hawk.

Tarsus feathered to the toes, with a narrow unfeathered strip behind; chiefly whitish and rusty, but sometimes entirely black, except forehead and narrow bands on tail. Length, 24 inches; tail, 10 inches.

"From November till April, about meadows and watercourses, this lazy hawk is frequently seen. They are less constantly on the wing than many of the other large hawks. It preys upon mice and rabits, also poultry, when pressed with hunger. They are sometimes found in gangs, and hunt in company frequently for field and meadow mice.

"Formerly this noble bird was more abundant, but is still by no means rare. The uplands, and especially corn-fields, seem to be favorite haunts of this hawk during autumn, but as winter approaches, especially if there is snow on the ground, they come nearer to the farm-houses, and carry off many and frequently full-grown chickens."

The above species was formerly considered as two species, the 
lagopus and the sancti-johannis. The latter was supposed to be black when adult (and was known as the black hawk), and its young to resemble the lagopus. We now know that the melanistic condition affects certain individuals, both young and old, and that all gradations from black to light are found.

\section{AQUILA, Briss.}

A. chrysaëtos, L. Golden Eagle.

Tarsus entirely feathered to toes; plumage glossy, purplish brown; head and neck golden brown; quills blackish. Length, 36 inches; tail, 16 inches. A northern species.

"Occasionally on the sea-coast, and still more rarely inland, a specimen of this eagle is seen or taken. The young or 'ringtailed eagle' is generally seen during winter on the coast, but they are few in numbers. A specimen was seen by the author near Trenton in April, 1863."-[C. C. A.]

\section{HALIÆ̈ËTUS, Savig.}

\section{ㅍ. leucocephalus, L. Bald Eagle.}

Dark brown; head, neck and tail white after the third year. Length, 36 inches; tail, 14 inches. Feeds on fishes, which it often takes by robbing the osprey, or fishing eagle. "Notorious as the emblem of the Republic."-Coues.

"More abundant on the sea-coast than elsewhere within the limits of the State; and breeding in secluded swamps, never very far from good fishing grounds.

"In Mercer county two or three pairs are generally seen every year, but no nest has as yet been found within the last ten years. They are not an offensive bird to the farmer, and would probably be more abundant were they not so eagerly pursued when seen inland."

\section{FALCO, L.}

F. peregrinus, var. anatum, Bonap. Duck Hawk. Peregrine Falcon.

Upper mandible toothed, lower notched; nostrils circular (as in all falcons); tarsus scarcely feathered below the joint; plumage blackish ash, with paler waves, whitish, and barred below ; black cheek patches. Length, 16 inches; tail, 7 inches. 
"Preferring the sea-coast to inland localities, this bird, letter known as 'duck hawk,' is a not unfrequent species. Has been found breeding in Cape May county, the young leaving the nest as early as May 20th."

F. columbarius, L. Pigeon Hawk. American Merlin.

Inner webs of quills distinctly barred with whitish ; tail bands distinct; ashy blue or blackish above, variegated below; female and young whitish or buffy below. Length, 13 inches; tail, 5 inches.

"Not abundant. Is found generally throughout the State, and breeds annually within its limits. This hawk is much more destructive to poultry, especially during the spring, than many of the larger species."

F. sparverius, L. American Sparrow Hawk. Rusty-crowned Falcon.

Back tawny; wings bluish and black; seven black blotches about head; tail chestuut, with a broad black band in male and a narrow terminal one of white; below white or tawny; female more streaky. Length, 11 inches; tail, 5 inches.

"Very abundant, remaining throughout the year. Building a rude nest in the hollow of a tree, two broods are raised during the spring and summer. Though small birds are frequently attacked, mice constitute the bulk of its food."

\section{PANDION, Savig.}

P. haliä̈tus, vur. carolinensis, Gmel. American Osprey. Fish Hawk.

Plain grayish brown above; tail more grayish, tipped with white and barred with dusky; head, neck and lower parts pure white, or nearly so, in male; always spotted or blotched with brown in female; feet very large. Length, 24 inches; tail, 10 inches.

"The 'fish hawk' is probably more abundant along the Delaware river than elsewhere throughout the State, except on 'the shore.' It appears along the river in March or late in February, following the herring (Chupea harengus), which then throng the river. They rebuild the nest of the former season, and raise but the one brood generally. The nest is usually at some distance from the parent birds' favorite haunt. During August and through the autumn the fish hawk seeks its food in 
creeks, preying upon pike principally, and in this way only are they objectionable, as occasionally they destroy nearly all the pickerel of a stream that has heretofore afforded the angler excellent sport."

\section{Family STRIGIDÆ. \\ Barn Owls.}

STRIX, L.

S. pratincola, Bonap. American Barn Owl.

Inner toe as long as middle toe; middle claw pectinate; iris black; tarsus naked, or nearly so; no ear tufts; face elongated, reddish or tawny, and variegated with bars and spots.

"Until within a few years this owl was the rarest of the seven resident species. It lives and nidificates in hollow trees, and lives almost exclusively on mice. It is not only an inoffensive, but a most useful bird, and should be carefully protected."

\section{Family BUBONID}

Horned Owls, \&c.

Inner toe shorter than middle, whose claw is not pectinated; feathers on hinder part of tarsus point downward.

\section{ASIO, Briss.}

A. wilsonianus, Less. American Long-eared Owl. Cat Owl.

Ear opening very large; ears asymmetrical; head with ear tufts; bill dark; face ochraceous; mottled, dusky upper parts; lower parts whitish and irregularly barred. Length, 15 inches; tail, 6 inches. Nest usually the deserted one of a crow or other bird of similar size.

"This owl is probably better known as the 'cat owl.' They are generally found in woody districts and away from meadow 
lands. They feed upon mice, and also capture hirds while roosting. They have been known to kill chickens, but such is seldom the case."

A. accipitrinus, Pall. Short-eared Owl.

Ear tufts small ; two outer primaries emarginate (one only in preceding); ground color tawny to butfy, striped, but not barred, with brown; face blackish around eyes, eyebrows whitish. Length, 15 inches; tail, 6 inches. Nest on ground.

"Unlike the preceding species, the 'short-eared owl' appears to be found about meadow lands, preying upon the mice generally there so abundant. They fly in broad daylight with apparent ease when disturbed. Not offensive to the agriculturist."

\section{SYRNIUM, Savig.}

S. nebulosum, Forst. Barred Orvl. Swamp Owl.

Bill yellow; no evident ear tufts; iris black; toes not concealed; color olive brown, barred with white above; breast barred and belly streaked. Length, 30 inches; tail, 12 inches.

"Better known as the 'swamp owl.' This species is more abundant in Cape May county than elsewhere within the limits of the State. Shy, and seldom approaches barnyards or poultryroosts. The nest is in a hollow tree, generally at a considerable height. Mice are their principal food."

\section{SCOTIAPEX, Swains.}

s. cinereum, Gmel. Great Gray Owl.

Iris yellow; six outel primaries emarginate; toes concealed by. long feathers; ashy brown above, waved with white; breast streaked, belly barred. Length, 30 inches; tail, 12 inches.

"A single specimen has been taken in Sussex county, in December, 1859. Only a very rare visitor."

\section{NYCTALA, Brehm.}

N. acadica, Gmel. Saw-whet Owl.

No ear tufts; iris yellow; nostrils prominent, nearly circular, open anteriorly; brown above, spotted with white; white below, 
striped with reddish brown; feet whitish buff. Length, 8 inches ; tail, $2 \frac{3}{4}$ inches.

"This is now a rare species of owl. It is generally found in cedar trees, and flies very readily when disturbed. It feeds exclusively upon insects, and is a strictly inoffensive species; but, being an owl, a disgraceful prejudice on the part of most people prompts to its destruction."

\section{MEGASCOPS, Kaup.}

M. asio, L. Screech Owl. Little Red Owl. Gray Owl.

Speckled and barred; the ground color gray or bright red, the two colors bearing no relation to age, sex or season. Length, 10 inches; tail, $3 \frac{1}{2}$ inches.

"This is the best known of all the owls, and has several names besides the one above, as 'little red owl,' 'gray owl,' \&c. The two conditions of plumage, red and gray, give rise generally to the belief that they are two distinct species. This, however, is erroneous. The screech owl is more frequently found in orchards than elsewhere, but is everywhere abundant. The nest is always in a hollow tree. They fly about during the day very frequently. The food is mice and insects. They are entirely inoffensive."

\section{BUBO, Dum.}

B. virginianus, Gmel. Great Horned Owl.

Bill blackish; conspicuous ear tufts, of blackish feathers; iris yellow; plumage dark colored, black, gray and buffy; no stripes; lower parts barred; above variegated ; usually a whitish half collar. Length, 22 inches; tail, 10 inches.

"In the northern and southern sections of the State this owl is not uncommon. In the central counties it appears only as 'stragglers.' They haunt secluded swamps, near water-courses, and not unfrequently visit poultry-yards, coming a great distance."

\section{NYCTEA, Steph.}

N. nyctea, L. (scandiaca, nivea, dc.) Snowy Owl.

Iris yellow; bill black; toes concealed by long feathers; facial disk incomplete; plumage pure white, with blackish bars. 
Length, 23 inches; tail, 10 inches. A northern form, ranging south in winter. The female has only the front aspect white, the other parts more heavily barred with dark than in male.

"The snowy owl visits New Jersey almost every winter, and not unfrequently they remain throughout the year. Their diurnal habits, large size and snowy plumage render them an easy prey to the gunner, however, and they are soon all destroyed. Their food is mice."

\section{SURNIA, Dum.}

S. ulula, L. (funerea), var. caparoch, Müll. American Hawk Owl. Day Owl.

No ear tufts; iris and bill yellow; plumage brown, much speckled and barred; whitish below. Length, 16 inches; tail, 7 inches. A northern species.

"This is, as the 'great gray owl,' a very rare winter visitor. The author knows of but two instances of its being taken in the State-in Mercer county, in 1858, and in Middlesex county, in 1861."-[C. C. A.]

\section{SPEOTYTO, Gloger.}

S. cunicularia, var. hypogæa, Bonap. The Burrowing Owl.

With nearly naked tarsus; imperfect facial disk; simple middle claw; spotted and variegated brown plumage. Length, 10 inches; tail, 4 inches. Belongs to the western plains, living in the burrows of the prairie dog, and has been accidentally conveyed to New York and Massachusetts; might possibly also, at times, be found in New Jersey. 


\title{
Section CURSORES.
}

\section{Order Columba.}

\author{
Pigeons.
}

\section{Family COLUMBID}

Doves.

\section{ECTOPISTES, Swains.}

E. migratorius, L. (macrura.) Passenger Pigeon. Wild Pigeon.

Tarsus feathered at the heel (tibio-tarsal) joint; tail of twelve feathers, long and wedge shaped; plumage bluish, with reddish and violet tinges; reddish below. Length, 17 inches; tail, 8 inches.

"The wild pigeon is much less abundant than formerly. A few can generally be found where there is a preponderance of beech timber, which is always a favorite sort. Incubation takes place during May and June, occasionally three broods being raised. They appear in flocks of from fifty to five hundred, during August and September, and when they are ripe they live largely upon beech-nuts. The decrease in their numbers has been steady during the past ten years, and they will probably be among 'the things that were,' in this State" (1868).

\section{ZENAIDURA, Bonap.}

Z. macroura, L. (carolinensis.) Turtle Dove. Carolina Dove. Mourning Dove.

Tarsus bare; tail of fourteen feathers; plumage brownish olive, glossed with blue and wine color; with metallic luster. Length, 12 inches; tail, $6 \frac{3}{4}$ inches.

"Resident. Abundant. The dove is not apparently very numerous till the grain is harvested, then they are found in loose flocks on the stubble, and are very fat. Though a grain-eating species and at times very numerous, they are not offensive." 


\section{COLUMBA, L.}

C. livia. Rock Dove. Domesticated Dove.

Of numerous varieties and breeds, whose description does not belong to a catalogue of this sort.

\section{Order Rasores}

(OR GALLINAE.)

\section{Family TETRAONIDE.}

\section{Grouse,}

\section{COTURNIX, Bonnat.}

(Tetrao, L.)

C. coturnix, L. European Quail:

Tarsus naked nearly to joint; sides of toes not pectinated; cutting edge of lower mandible without serrations; tail very short; above light brown, streaked with buff bordered by black, on back and rump; wing coverts barred with dusky and buffy; breast cinnamon brown, with dusky spots; buffy below; a dark patch on throat (absent in female). Length, 7 inches.

\section{COLINUS, Less.}

\section{(Ortyx, Steph.)}

C. virginianus, L. Quail. Bob White (known as "Partridge," South.)

Nostrils unfeathered, protected by naked scale; tarsus bare and scutellate; head not crested; plumage generally chestmut red, barred and streaked; forehead, line through eye, chin and throat, white in male, brownish yellow in female. Length, $9 \frac{1}{2}$ inches; tail, 3 inches. Similar to grouse, but smaller.

"Resident. Abundant. Quails couple about the first of May, and huild a large nest of grass, on the ground, laying from ten to fifteen eggs. A second brood is not usually raised. Weasels are the most destructive enemies they have, not only eating the eggs, but frequently killing the hen bird. 'The young are on the wing by August, although their flight is feeble till the middle of 
September. Two broods frequently associate and as a 'covey' remain in the neighborhood of the nests the greater part of the fall, unless driven off and thinned out by the gunners. Severe winters are very destructive to quails, and deep snows have done much probably towards "thinning them out." "

\section{BONASA, Steph.}

B. umbellus, L. Ruffed Grouse. Partridge (North). Pheasant (South).

Tarsus feathered half way; tail of eighteen soft, broad feathers; head crested; sides of neck with ruff of dark feathers (smaller in female); plumage variegated, reddish or grayish brown, with blackish and pale. Length, 18 inches; tail, 7 inches.

"Resident. Gradually being exterminated. The pheasant is probably most abundant in Monmouth and Ocean counties, but the law protecting them being totally disregarded, they are not numerous in those localities. The grouse pair off in May, and raise one brood, which are weak on the wing in August, but nevertheless are eagerly pursued by pot-hunters. Numbers from other localities have occasionally been 'planted' in New Jersey, but certain gentlemen (?) who have no idea beyond their bellies, frustrate these attempts to stock the State, by 'out of time' shooting." - [C. C. A.]

\section{TYMPANUCEOS, Glog.}

(Cupidonia, Reich.)

T. cupido, L. Prairie Hen, or Chicken; more properly, Heath Hen.*

Scapulars with large terminal spots of buffy white (no such spots in T. americanus); neck tufts of male sharply pointed, lanceolate (rounded in americanus); beneath neck tufts a patch of bare red skin, capable of great inflation; plumage black, tawny and white, barred and streaked; female smaller, with rudimentary neck tufts. Length, 17 inches; tail, 4 inches. Now left only on Martha's Vineyard, where it is in danger of extermination. Formerly abundant along Atlantic coast.Ridgway.

"A few only remain in Monmouth county and in Ocean

\footnotetext{
* The true prairie chicken is $T$, americanus, and does not range east of Indiana.
} 
county, but so very few that it is perhaps hardly correct to consider it as any longer represented in the State fauna. Formerly it was very abundant throughout the State. Several attempts have been made to restock the State with this species, and in a measure these attempts would be succesful, but it appears impossible to prevent them from being shot during May, when they are breeding, and are comparatively tame" (1868).

\section{Family PHASIANID}

Turkeys.

\section{MELEAGRIS, L.}

M. gallopavo, L. Wild Turkey.

Glossy, coppery black. Length, 48 inches; tail, 18 inches. Now extinct, or nearly so, in the more-settled regions of the Atlantic coast. Our domestic turkey is descended from a Mexican variety.-Jordan.

G. bankiva.

\section{GALLUS.}

The jungle fowl of India, supposed to be the ancestral stock from which our domestic fowls ( $G$. domestica) have been derived. A description of the races and breeds is foreign to this list. Other species commonly kept in a domesticated state and derived from Asiatic or African species, are Puvo cristatus, the peacock; Numida meleagris, the guinea fowl; Phasianus colchicus, common pheasant. 


\section{Order Grallatores.}

Wading Birds.

\section{Sub-Order GRALLA-LIMICOLAE. \\ Shore Birds.}

\section{Family PHALAROPODID王.}

\section{Phalaropes.}

\section{PHALAROPUS, Briss.}

\section{P. tricolor, Vieill. (Steganopus wilsoni, Sab.) Wilson's Phalarope.}

Snipe-like; toes with narrow, plain lobes; ashy above, variegated; rump and under parts white; sides of neck with black stripe, which changes to chestnut below ; swimmers; northern; male smaller and duller than female; winter plumage different. Length, $9 \frac{3}{4}$ inches ; wings, $5 \frac{1}{ \pm}$ inches ; tarsus, $1 \frac{1}{3}$ inches.

"Rare. Specimens of this phalarope are very seldom taken in the State; when taken, it is as a single specimen, and always on the sea-board. A specimen killed at Deal, Monmouth county, and one at Atlantic City, are the only two that the author bas met with." - [C. C. A.]

P. lobatus, L. (Lobipes hyperboreus.) Northern Phalarope.

Bill awl shaped; toe membranes scalloped; plumage grayish black, variegated with buff; stripes on back; wings dusky, greater coverts tipped with white; rump and under parts white; sides of neck with a chestnut stripe; northern. Length, $7 \frac{1}{2}$ inches ; tarsus, $\frac{3}{4}$ inch.

"More frequently met with, and occasionally seen inland, a specimen having been shot by the author on the Delaware, at the mouth of the Rancocas Creek. When found, it is generally in company with other birds of similar habits, especially on the sea-shore."-[C. C. A.] 


\section{CRYMOPHILUS, Vieill.}

C. fulicarius, L. Red Phalarope.

Bill flattened; membranes of toes scalloped; lower parts purplish cinnamon; sides of head white; top of head dark (streaked with buffy in male); back butfy, striped with black; male smaller than female. Length, 8 inches; tail, $2 \frac{3}{4}$ inches; tarsus, $\frac{4}{5}$ inch; bill 1 inch. Breeds far northward. In winter, ranges south to Middle States and Ohio Valley, and then plumage is different; lower parts white; head white; back uniform pearl gray.

"About as numerous as the preceding. It arrives on our seaboard in May, and soon suddenly disappears, to re-appear in August, during which month they are most numerous. Author has seen a specimen, shot June 27th, 1863, on the Hackensack River."-[C. C. A.]

\section{Family RECURVIROSTRID IE.}

Arocots.

\section{RECURVIROSTRA, L.}

R. americana, Gmel. American Avocet. Blue Stocking.

Legs blue, long; bill slender, recurved, flattened and tapering to a needle point; toes four, full webbed; plumage white, marked with cinnamon on wings; head tinged with gray in winter. Length, 18 inches; tail, $3 \frac{1}{2}$ inches; tarsus, $3 \frac{3}{4}$ inches.

"Common along the sea-board, more especially at Egg Harbor. Frequents shallow pools in the salt meadows. Breeds in the Jong grass, generally selecting a tuft in which to place the nest. Never seen inland, nor about the bay shore. Known frequently as 'blue-stockings.'"

\section{HIMANTOPUS, Briss.}

H. mexicanus, Müll. (nigricollis-Abbott's Catalogue.) Black-necked Stilt. Long-shanks. Lawyer.

Toes three, semipalmated; bill nearly straight, not flattened; legs pink; forehead, cheeks and lower parts white; iris crim- 
son ; tail ashy; rest of body glossy greenish black. Length, 15 inches; tail, 3 inches; tarsus, 4 inches.

"Not as numerous as the preceding species, but by no means rare. Arrives in May, and is again more plentiful in August. Some few breed in the salt marshes, building a nest of grass, in grass. They are similar to the preceding in their habits. Known often as 'lawyers."

\section{Family SCOLOPACID}

Snipe.

\section{PHILOBELA, Gray.}

P. minor, Gmel. American Woodcock.

Toes not webbed; bill straight, longer than head; first three primaries attenuate; eye high and far back; plumage variegated brown, gray, russet, with black spots; below warm brown. Length, 11 inches; bill, 3 inches; tarsus, $1 \frac{1}{4}$ inches.

"Very abundant in some sections of the State. Never found very far from farm-houses. Builds a nest of grass, nearly on the ground, sometimes as early as March. Raises two broods, the young of the latter brood not often able to fly by July 5 th, when wise (?) legislation permits them to be shot. Disappear and moult in August. Re-appear in September, a wary, strong bird. In the summer, haunt willow hedges. In October, drier ground, generally hillsides."

\section{SCOLOPAX, L.}

S. rusticola, L. European Woodcock.

First primary, only, attenuate; general appearance of preceding, but larger. European. Accidental on Atlantic coast.

\section{GALLINAGO, Leach.}

G. delicata, Ord. (wilsoni, Temm.) Wilson's Snipe. American Snipe.

Toes not webbed ; primaries not attenuate; bill straight, about twice as long as head; back blackish, varied with bay; crown 
black, with pale median stripe; tail feathers sixteen. Length, 11 inches; bill, 2.1 inches ; leg, naked, 3 inches ; tail, 21 inches. "Arrive in March, frequenting meadows exclusively. At this time, generally in loose flocks. The 'killdeer' always heralds their arrival. The greater part pass on to the North, but numbers remain, building nests in long grass, most frequently about springs in the upland, raising but one brood. Returning from the North, they reach us during the latter part of September and in October. A few not improbably remain during the winter."

\section{MAORORHAMPUS, Leach.}

M. griseus, Gmel. Gray Snipe. Brown-back Dowitcher, \&c.

Toes webbed at base; rump white and barred; tail slaty, barred with white; sides of neck, chest, \&c., light cinnamon, speckled with dusky; belly white; top of head streaked with buffy and dusky; back variegated with pale cinnamon and dusky; in winter plumage is more whitish and ash gray. Length, 10.1 inches; tarsus, $1 \frac{1}{3}$ inches. Breeds in Northeastern North America. Sometimes confused with next.

M. scolopaceus, Say. Red-breasted Snipe. Long-billed Dowitcher, \&c.

General characters same as preceding, but entire belly and breast bay in summer, white in winter; sides barred with dusky. Length, 12 inches; tarsus, 1․․․ inches. Breeds in Northwesteru North America. Bill, 23: inches (culmen); longer than in preceding.

"Called 'dowitcher' very generally along the shore. Arrives in April, and frequents the beach, and bog meadows. They reappear late in July, and are found in great numbers till late in September. Author has found them most abundant about Tuclierton. Frequently called 'brown-backs." - - C. C. A. $]$

These are considered as two species by Ridgway, as one by Jordan, Abbott, \&c.

\section{MICROPALAMA, Bd.}

M. himantopus, Bonap. Stilt Sandpiper.

Toes webbed at base; tail not barred; bill straight, nearly twice as long as head; upper parts blackish, varied with gray and bufl; top of head dusky, streaked with white; lower parts 
whitish, barred with dusky ; winter plumage ashy gray. Length, 9 inches; tail, $2 \frac{1}{1}$ inches ; culmen, $1 \frac{3}{4}$ inches.

"Not numerous. Are seen generally in company with allied species. Single specimens have been killed in the Delaware at Trenton, accompanying 'jack snipe.' Do not breed in the State."

\section{TRINGA, L.}

T. canutus, L. Robin Snipe. Knot. Red-breasted Sandpiper.

Tarsus not shorter than middle toe; tibia bare below; bill straight; plumage brownish black above, brownish red below; Length, 11 inches; tail, $2 \frac{1}{2}$ inches.

"Arrive in May, and after a few days spent upon the beach, they have all gone, to re-appear in August, when they make a longer stay. Have sometimes found this species inland."

T. maritima, Brünn. Purple Sandpiper.

Tarsus shorter than middle toe; tibia feathered (Sub-genus Arquatella); color ashy black, with purple reflections; feathers with pale edgings; lower parts mostly white; bill nearly straight. Length, 9 inches; tail, $2 \frac{2}{3}$ inches; bill, $1 \frac{1}{\frac{1}{4}}$ inches.

"Very rare in New Jersey. Prefers rocky sea-coast to the sandy beach. Author has seen but one specimen. It was found dead upon the beach, near Absecom lighthouse."-[C. C. A.]

T. maculata, Vieill. Pectoral Snipe, or Sandpiper. Jack Snipe. Grass Snipe.

Bill, tarsus and middle tue (with claw) of about equal length (Arctodromas); throat ashy and sharply streaked; above light clay color, broadly striped with black; lower parts and chin white; chest buffy gray and streaked; crown unlike neck; upper tail coverts dark. Length, 9 inches; bill, $1 \frac{1}{8}$ inches.

"Arrives in April. Re-appears in August. Very abundant, and known as 'fat-bird.' Frequently seen in flocks on the Delaware, at Trenton."

T. fuscicollis, Vieill. Bonaparte's Sandpiper. White-rumped Sandpiper.

Upper tail coverts all white, sometimes marked with dusky; in winter, upper parts plain brownish gray, with indistinct streaks; in summer, top of head buffy, broadly streaked with black; back brownish gray and buffy, tinged with rusty and 
striped with black; lower parts white. Length, 7!s inches ; tail, $2 \frac{1}{4}$ inches.

"Abundant both on the coast and inland. During spring freshets frequents the overflowed meadows of the Delaware though in August is found only on the river shore."

T. minutilla, Vieill. Least Sandpiper. Peep.

In winter, plain brownish gray, with dusky streaks; chest pale gray, streaked, and lower parts white; in summer, top of head rusty ochraceous, streaked with black; chest brownish white, streaked; rump and upper tail coverts brownish black. Length, 6 inches; tail, 2 inches.

"Very abundant both on the coast and inland. Arrives in May, and re-appears in August. When found in spring or autumn, is always in flocks ranging from ten to fifty."

T. bairdii, Coues. Baird's Sandpiper.

Colors of preceding, but larger; throat but little streaked. Length, $7 \frac{1}{2}$ inches; tail, $2 \frac{1}{4}$ inches. Rare east of Mississippi River.

T. alpina, var. pacifica, Coues (var. americana, Cass.) Red-backed Sandpiper. American Dunlin. Oxbird. Black-bellied Sandpiper.

Bill slightly decurved; tibia bare below; plumage chestnut brown above; belly, in summer, with a black area; breast white. Length, 9 inches ; tail, $2 \frac{1}{3}$ inches; bill, 13 inches ; tarsus, 1 inch.

"Arrives in April, but makes a limited stay only. Re-appears in August, and throughout September is very plentiful. Has been shot on the Delaware, at Trenton."

T. ferruginea, Brünn. (Ancylocheilus subarquata-Abbott's Catalogue.) Curlew Sandpiper.

Tarsus one and a half times as long as middle toe; upper tail coverts entirely white; head, neck and lower parts rufous in summer; upper parts varied with blackish and rusty; in winter, upper parts plain brownish gray. Length, 8 inches; tarsus, $1 \frac{1}{5}$ inches. European, but occasional on this side of Atlantic.

"Like the maritima, this is a rare species, though not to the same extent. Specimens have been found at Tuckerton and Cape May. Never seen along the rivers, nor on the shores of Delaware or Raritan Bays." 


\section{EREUNETES, III.}

E. pusilius, L. Semipalmated Sandpiper. Peep.

Grayish brown, tinged on sides of head, \&c., with pale buffy ciunamon; chest narrowly streaked with dusky; white below.

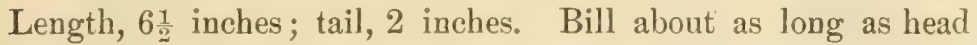
(culmen, $\frac{3}{4}$ inch); middle toe webbed at base.

"Arrive in New Jersey early in May, occasionally in April, and although many go north, a great number remain during the summer. Abundant on the coast. Numerous inland. Prefer meadow lands inland to the river shore, but are more abundant on the beach, on the coast. Go south in October."

E. occidentalis, Lawr. Western Sandpiper.

Summer adult with upper parts rusty, the feathers spotted centrally with black; stripe of rusty on head; chest and breast marked with broad streaks; bill longer in female, where culmen is 1 inch. Breeds in Northwestern North America; occasional on Atlantic coast during migrations; probably confused with preceding.

\section{CALLIDRIS, Cuv.}

C. arenaria, L. Sanderling. Ruddy Plover.

Form of $T$. canutus, but with only three toes, the hinder one absent; belly very white; above variegated rusty, white and dusky ; more grayish in winter. Length, 8 inches ; tail, 21 inches.

"Never appears on our coast as abundantly in spring as in autumu. Prefers the border of the ocean to meadows, and goes in flocks, or in company with sandpipers. On the Delaware River, at Trenton, and on the Raritan, at New Brunswick, they are frequently killed in August and September. When thus found, they are accompanying sandpipers."

\section{LIMOSA, Briss.}

L. fedoa, L. Great Marbled Godwit. Marlin.

Toes somewhat webbed at base; tail barred crosswise with light and dark colors; no pure white, but cinnamon brown, variegated above with bars and spots; uniform below; head and 
neck streaked. Length, 16 to 22 inches; tail, $3 \frac{1}{2}$ inches; bill, $4 \frac{1}{2}$ inches.

"Known generally as the 'marlin.' Arrives in May, and re-appears in September. Flies always in flocks, and is a wild bird. Frequents the bays rather than beach. Never seen inland."

L. hæmastica, L. (hudsonica-Abbott's Catalogue.) Hudsonian Godwit. [Improperly, Black-tailed Godwit.] Ring-tailed Marlin.

'Tail black, white at base and tip; head and neck pale chestnut, streaked with dusky; lower parts deeper chestnut, barred; back blackish, variegated with buffy; winter plumage brownish gray above; head and lower parts grayish white. Length, 15 inches ; tarsus, $2 \frac{1}{2}$ inches ; bill, $3 \frac{1}{2}$ inches.

"Known as the 'ring-tailed marlin.' Arrives also in May, and re-appears in September. Is not as abundant as the preceding, whose habits are the same as the species under consideration."

\section{TOTANUS, Bechs.}

T. melanoleucus, Gmel. Greater Yellow-legs. Greater Tell-tale. Yellow-shanks. Stone Snipe.

Legs long, yellow; tarsus, $2 \frac{3}{4}$ inches; inner web of toes very small; bill very slender, $2 \frac{1}{4}$ inches, not curved; rump grayish, spotted with dusky; flanks barred with dusky ; in summer, grayish, spotted with white above, barred with dusky below (except on belly); in winter, lighter in color. Length, $12 \frac{1}{2}$ inches ; tail, $3 \frac{1}{1}$ inches.

"Arrive in May, and a few remain during the summer. Are abundant again in August. Frequent the Delaware, and occasionally very large flocks are seen on the river, but generally they are associated with the following species."

T. flavipes, Gmel. Lesser Tell-tale. Yellow-legs. Yellow-shanks.

Colors as in preceding; smaller; legs longer (proportionally). Length, 11 inches; tail, $2 \frac{1}{2}$ inches; bill, $1 \frac{3}{4}$ inches; tarsus, 2 inches.

"Very abundant. Arrive along our coast and rivers in May ; a few remain during the summer, and re-appear in August. Generally fly in immense flocks. On the Delaware are most numerous in August, and are then much wilder than in May. None seen after October 15th." 
T. solitarius. Solitary Tattler, or Sandpiper.

Inner web of toes rudimentary; legs blackish; bill straight and slender; white below, breast with dusky suffusion; above olive brown, streaked and speckled with whitish. Length, 9 inches; tail, $2 \frac{1}{2}$ inches; bill, $1 \frac{1}{4}$ inches.

"Arrives about the 1st of May, and single specimens are scattered over meadow lands throughout the State. Is much more abundant during some seasons than others. Builds a nest of grass on the ground, raising but one brood. Congregate on river shores in August, and have all gone by September 15th."

\section{SYMPHEMIA, Raf.}

s. semipalmata, Gmel. Willet. Semipalmated Tattler.

Legs dark or bluish; toes distinctly webbed at base, even hetween inner and middle toe; quills blackish, with basal half white, producing a white patch at base of spread wing; in summer, plumage brownish gray above, varied with dusky; below whitish, varied with dusky on chest and sides; in winter, ash gray above, white below. Length, 12 to 16 inches; tail, 3 inches; bill, $2 \frac{1}{2}$ inches.

"Arrive in May. Abundant. Breed in the salt marshes, building a nest of grass. Are very noisy, especially during incubation. Are easily decoyed by imitating their whistle. Fly in large flocks, and seldom associate with other birds. Have never seen specimens on our rivers."

\section{PA VONCELLA, Leach.}

(Machetes, Cur.)

P. pugnax, L. Ruff (male). Reeve (female).

Web at base of toes; plumage black, buff and gray above; white below and on sides of rump, varied on chest; middle tail feathers barred; great variation of color in male, scarcely two alike; provided with a "cape," which is usually black, but may vary to whitish ; also has a "ruff," usually chestnut, either plain, streaked or barred; face bare; no ruff or cape in the female; head completely feathered; plumage barred with black, buff, white and rusty; white below. Length, 12 inclies; tail, $2 \frac{1}{2}$ inches; tarsus, $1 \frac{3}{4}$ inches; bill, $1 \frac{1}{4}$ inches. A North European form, occasional on our eastern coast. 


\section{BARTRAMIA, Less.}

B. longicauda, Bechs. (Actiturus bartramius-Abbott's Catalogue.) Bartramian Sandpiper. Field Plover. Upland Plover.

Above light brownish, barred with blackish ; crown blackish, with median line of buff; neck ochraceous, streaked behind, and plain white on throat; onter tail feathers light butf, tipped with white, \&c.; lower parts whitish buff, deeper in winter. Length, 13 inches; tail, 4 inches ; bill, $1 \frac{1}{t}$ inches.

"Appears in May, but is not at all abundant until August, when considerable flocks are to be found, especially in red-clover fields. If undisturbed, a flock will remain about a single field for several weeks. They feed largely upon grasshoppers, and in September are frequently very fat. They are shy, and when flushed fly to a great height, and whistle continually while on the wing."

\section{TRYNGITES, Cab.}

T. subruficollis, Vieill. (rufescens.) Buff-breasted Sandpiper.

Toes not webbed; upper parts grayish buff, varied with blackish; lower parts buff, speckled on breast with dusky; quills speckled with dusky on a white ground. Length, 8 inches; tail, $2 \frac{1}{t}$ inches.

"Comparatively rare. Strictly a sea-board species. Two or three, or more frequently a single specimen is seen. Appear to be more wary than sandpipers generally, and alighting only on the smooth beach, are difficult to approach."

\section{ACTITIS, Boie.}

(Tringoides, Bonap.)

A. macularia, L. Spotted Sandpiper. Teeter-tiltup. 'Tip-up. Teetertail.

Lustrous drab above, varied with black in summer; pure white below, with round black spots in summer. Length, 8 inches; tail, 2 inches; bill, 1 inch.

"Arrives with $T$. solitarius, but is a more sociable and more abundant species. Frequents the river and creek shores unti] June 1st, when nidification commences, and they are then scattered over the uplands. In August, congregate alio on the river shores, and have generally left by October 1st." 


\section{NUMENIUS, Briss.}

N. longirostris, Wils. Long-billed Curlew. Sickle-bill.

Pale cinnamon, varied above with blackish, dusky and gray. Length, 24 inches; tail, 4 inches; bill, 5 to 9 inches.

"Arrive in May, and are with us till late in September. They" fiy in flocks of about twenty, sometimes more, and usually have a 'leader ;' their whole appearance while on the wing not unlike the Canada goose. Single specimens have frequently been killed inland. One at Trenton, in 1859."

N. hudsonicus, Lath. Hudsonian Curlew. Jack Curlew.

Similar to preceding, but paler; secondaries and quills darker ; crown with a narrow, median light stripe, besides broad lateral stripes. Length, 18 inches ; tail, $3 \frac{1}{2}$ inches; bill, $3 \frac{1}{2}$ inches.

"Arrive in May. Not as abundant as the preceding, and have not been found inland. Frequent mud-flats and go in small companies. Have generally all disappeared by August 15th."

N. borealis, Forst. Esquimaux Curlew. Dough Bird.

Crown narrowly streaked and without median light stripe; plumage more reddish; breast with $\mathrm{V}$-shaped marks of dusky. Length, 14 inches; tail, 3 inches; bill, $2 \frac{1}{2}$ inches. Breeds in Northern North America; in winter, migrates as far as southern end of South America.

"Not very abundant. Makes its appearance very late in the summer, and is seen as late as November 1st. Frequents meadows, and feeds largely upon grasshoppers."

\section{Family CHARADRIIDE.}

Plovers.

CEARADRIUS, L.

C. dominicus, Müll. (virginicus-Abbott's Catalogue.) American Golden Plover. Frost Bird.

Bill soft and flexible, fitted for probing in mud; no hind toe; plumage dark and grayish above, profusely speckled, some of the spots bright yellow; grayish below (black in breeding season, in 
female). Length, $11 \frac{1}{2}$ inches; tail, 3 inches; bill, $1 \frac{1}{ \pm}$ inches; tarsus, 2 inches.

"Is seen inland in May, in quite large flocks. They remain but a short while, however, and none are seen until August, when with their young, they are moderately abundant. They prefer high open lands, are very wild, and stay in flocks of twenty to fifty. If undisturbed will frequent the same field during their autumnal stay. A few are found on the river, with sandpipers."

C. squatarola, L. (Squatarola, Cuv.), (helvetica, L.) Black-bellied Plover. Ox-eye.

A rudimentary hind toe; most of lower parts black in summer, white in winter; under tail coverts, \&c., and forehead white; "1pper parts spotted with dusky and white in summer, grayish in winter. Length, $11 \frac{1}{2}$ inches; tail, 3 inches; bill, $1 \frac{1}{4}$ inches; tarsus, 2 inches.

"Arrives along the sea-board early in May, and remains but a short time, but in August they return from the North with their young, and are frequently abuudant. They are mostly very wild, and usually found in company with other birds. A straggler is occasionally found high up our rivers."

\section{झ્FIALITIS, Boie.}

I. vocifera, L. Killdeer. Plover.

Bill black, rather long; three toes with basal web; plumage brown; rump orange brown; tail with black, white and orange; two black bars across breast and one above white forehead; black collar around neck; white collar around back-neck. Length, $9 \frac{1}{2}$ inches; tail, $3 \frac{1}{2}$ inches.

"Arrives early in March, appearing to accompany the 'snipe." Frequents meadows and river shore till May, when, after pairing, they go upon the upland, and build or rather scratch a nest, on the ground, in fields. Are sociable, noisy and strictly inoffensive. In August, again frequent the meadows and river shore."

EF. wilsonia, Ord. Wilson's Plover.

Tail not projecting much, if any, beyond folded wings ; rump' same color as back, brownish gray; only one band across chest (black in male, brownish in female); forehead and lower parts white. 
"Common on the coast, but less seldom seen along our rivers than the following two species. Accompany other birds, and during the summer are generally seen by twos and threes. More gregarious as the season advances. During violent northeast storms are sometimes driven up the rivers, but make as short a stay as practicable. Author found them on the beach, off Barnegat, as late as November 12th, in 1862. They were in company with 'sanderlings' and 'red-backed sandpipers." $-[$ C. C. A. $]$

A\&. semipalmata, Bonap. King Plover. Semipalmated Plover. Ringneck Plover.

Bill black tipped, short and stout; feet webbed at base ; plumage dark ashy brown, with forehead, hind-neck ring and lower parts white; a broad band across breast, black in summer and grayish brown in winter; lighter in female. Length, 7 inches.

"In May, in company with Actodromas bonapartei (Tringa fuscicollis), this beautiful bird frequents the Delaware and Raritan Rivers, and although found throughout the summer, is less abundant in June and July than in May, and more plentiful in August than at any other time. They breed within State limits, but author has found no nests as yet. Seldom are seen far from running water, and generally in company with other birds."

止. meloda, Ord. 'Piping Plover.

Toes slightly webbed, or web absent between middle and inner toes; upper parts brownish gray; white below, and on forehead and hind-neck collar; black patch on each side of chest; in female and in winter male this patch duller. Length, $66_{4}^{3}$ inches.

"Arrives on the coast in May, but do not appear to remain for any length of time, although some breed in the immediate neighborhood of the ocean. About the middle of May, they appear on the Delaware in large flocks, but are very uncertain in their movements, being one day as abundant as the following they are scarce. In August, both inland and on the coast, they are more abundant. Are generally very numerous about $\mathrm{New}$ Brunswick, on the Raritan, in August." 


\section{Family APHRIZIDE.}

Surf Birds.

ARENARIA, Briss.

(Strepsilas, Morinella.)

A. interpres, L. Turnstone.

Toes four, not webbed; tarsus scutellate in front, and as long as the sharp-pointed bill; chest deep black; head and throat mostly white, upper parts dusky varied with rufous; tail coverts, wing coverts, \&c., white. Length, $S_{\frac{1}{2}}^{1}$ inches; tail, $2 \frac{1}{2}$ inches.

"Arrives along our sea-coast in May, and passes on generally to the North, to return again in August, and then remains till October. It probably remains with us during the summer, in small numbers, as twice following violent storms, in the last week of June, in company with certain other strictly marine species, they have been shot at Trenton, on the Delaware. When birds are thus weather-driven so far from the ocean, it is probable they fly across the State to reach it again, thus accounting for their being seen inland."

\section{Family HAMATOPODIDEE.}

\section{Oyster-catchers.}

\section{EसPMATOPUS, L.}

H. palliatus, Temm. American Oyster-catcher.

Legs short, stout and bright colored; three toes, which are webbed at base; bill red, woodpecker-like; tarsus reticulate and shorter than bill; upper parts blackish; white beneath; rump, \&c., dusky; tail coverts white. Length, 18 inches; tail, $4 \frac{1}{2}$ inches; bill, 3 inches.

"Frequents the sandy beaches of the State, and is never seen inland. About June 1st deposits its eggs in a little basin, hollowed out in the sand; but one brood only is raised. They feed on the small crustacea. Two or three are generally seen together, but they are nowhere nor at any time abuudant in the State." 


\section{Sub-Order GRALLE-PALUdicolef.}

\section{Family RALLID王.}

Rails.

RALLUS, L.

R. elegans, Aud. King Rail. Fresh-water Marsh Hen.

Wings and tail short; hind toe elevated; front toes long; forehead feathered; bill decurved, longer than head; brownish black above; chestnut below and on wing coverts; white bars on flanks. Length, 18 inches; middle toe, $2 \frac{1}{4}$ inches. Frequents fresh-water marshes.

"Arrives in May, and is abundant in meadows skirting our rivers. They build a nest of grass, in the grass, raising but the 'one brood. In July the young are strong upon the wing. They are very swift of foot, and run long when pursued by dogs. Have generally disappeared by October 1st."

R. longirostris, rar. crepitans, Gmel. [Mud Hen. See Fulica ameri cana.] Salt-water Marsh Hen. Clapper Rail.

Above olive brown, variegated with ashy; breast cinnamon buff, ashy tinged; flanks grayish brown, with white bars. Length, 15 inches; tail, $2 \frac{1}{x}$ inches; bill, $2 \frac{1}{2}$ inches; female smaller.

"Very numerous on the marsh meadows of the sea-board, where they arrive early in spring. They build in the long grass of the islands studding the bays, and raise two broods usually. Their eggs are an article of diet on the shore, being numerous and easily gathered."

R. virginianus, L. Virginia Rail.

Above olive brown, striped with black; wing coverts reddish; breast cinnamon; flanks dusky, barred with white; lower parts mixed with black in immature specimens. Length, 10 inches; tail, $1 \frac{1}{2}$ inches; bill, $1 \frac{1}{2}$ inches. Like $R$. elegans, but smaller.

"Not an abundant species. Arrive in May, and nidificate as in the case of $R$. elegans. In August and September they are generally found in company with the 'sora' on the river flats. Occasionally every eighth or tenth bird will be this species, but 
it is seldom they are thus abundant. Have been known to remain during the winter, but this is probably an exceptional case."

PORZANA, Vieill.

P. carolina, L. Rail. Sora. Ortolan.

Bill straight, shorter than head; flanks barred with white and slate; neck to breast leaden, without spots; throat, \&c., black; top of head olive brown, with median black stripe; back streaked; belly barred. Length, 9 inches; tail, 2 inches.

"Much tendency appears to exist among people generally to enshroud this common bird with mystery, when in reality there is nothing very strange about it. Very many make their appearance along the Delaware early in May, and remain quietly in the meadows (unlooked for, and therefore unnoticed) until August, when they go in large numbers to the reeds on the flats, and remain there till the appearance of several severe frosts. It is not true that they suddenly and wholly disappear on the first appearance of frost. 'The 'rail' is a bird of very strong powers of Hight, and migrates, flying for a great distance without requiring rest. As we have stated, many appear early in May, and these breed, building a nest of grass, in long grass, raising two broods. In August they congregate along water-courses, and the number annually hatched in May and June along the Delaware meadows is fully sufficient to explain the origin of the incredible numbers usually killed on the Delaware in September. Being a bird also of great locomotive powers, it is not improbable that the sudden accession to their numbers which has been noticed, should simply be a 'batch' from a neighboring river."

P. jamaicencis, Gmel. L Little Black Rail.

Head and lower parts dark slate; belly brownish black, barred with white; back dark brown, speckled with white. Length, $5 \frac{1}{2}$ inches.

"Its habits are very similar to the 'sora,' and is about as abundant as the 'yellow rail.' Have not found it breeding in the State, although it very probably does so."

P. noveboracencis, Gmel. Yellow Rail.

Head and breast, inclusive, ochraceous; flanks dusky, barred with white; under tail coverts cinnamon; secondaries white; 
upper parts ochraceous, broadly striped with black and narrowly barred with white. Length, 7 inches.

"Rare. A few of these birds are generally killed during the 'rail season,' but when compared with the numbers of 'soras,' are emphatically rare. Have not found any breeding, or noticed them, except on the river, and during September."

\section{CREX, Bechs.}

C. crex, L. Corn Crake.

Above light brown, black striped; wings rusty, with a few white spots; head ashy, crown brownish; white below; chest drab; brown and white bars on sides and under tail coverts. Length, 10 inches. A North European form, accidental on this side of the Atlantic.

\section{IONORNIS, Reich.}

I. martinica, L. Purple Gallinule.

Forehead covered with a horny frontal plate; toes not lobed; nostril nearly circular; tarsus more than two inches long; plumage olive green above and purplish blue below and on head; bill reddish; under tail coverts white. Length, 12 inches; tail, 3 inches.

"Has been more frequently noticed than G. galeata, though like it, must be looked upon as a rare visitor only. Specimens have been taken about Tuckerton, on the Hackensack, near Newark, and on the meadows of the Delaware at Trenton. The author has met with five specimens in all, from the three mentioned localities, during the past seven summers. The latest specimen observed was killed on the $2 \mathrm{~d}$ of November, 186t, near Trenton." - [C. C. A. $]$

\section{GALLINULA, Briss.}

G. galeata, Licht. Florida Gallinule.

Nostrils linear; frontal plate, bill and a ring around tibia, red ; tarsus little more than two inches; grayish black on head and below; above brownish olive ; white stripes on flanks; in winter, belly suffused with white. Length, 14 inches; tail, $3 \frac{1}{2}$ inches. A southern form, straying north. 
"Single specimens have occasionally been met with. Author has seen but one, which was killed in July, 1862, on the meadows skirting the Delaware, below Trenton. It was seen wading in a shallow ditch; as though fishing." - [C. C. A.]

\title{
FULICA. L.
}

F. americana, Gmel. American Coot. Mud Hen.

Toes lobate, edged with broad flaps; bill white, tinged blue at end and there bearing a brown spot; frontal shield brown; sooty above; belly slaty; in winter, belly suffused with white. Length, 14 inches; tail, 2 inches. Frequents reedy marshes and shores.

"Generally are first seen about the middle of April, swimming leisurely about ponds and creeks. Are not common on the rivers. When disturbed, they usually make but short flights, and not unfrequently endeavor to escape notice by creeping upon the shore or among bushes skirting the water's edge. They breed in the State, but the author has found no nest as yet. They feed largely upon small fish and aquatic insects, and are totally unfit for food. They have generally all disappeared by October, although single specimens have been met with in midwinter." [C. C.A.]

\section{SUB-ORdER HERODIONES.}

Herons, \&c.

\section{Family IBID王.}

\author{
(Tantalidœ.)
}

Ibises.

GUARA, Reich.

G. alba, L. White Ibis.

(Eudocimus, Wagl.)

Groove in side of upper mandible; bill slender, cylindrical and bent downwards; head naked iu front, crown with short feathers; plumage pure white; tips of longer quills greenish black; young grayish brown above, white below. Length, 25 
inches; tarsus, 3 to 4 inches; bill, 7 inches; tail, 4 inches. Belongs to Tropical America; casual as far north as Connecticut.

\section{PLEGADIS, Kaup.}

P. autumnalis, Hass. (falcinellus, L.), (Ibis ordii-Abbott's Catalogue.) Glossy Ibis.

Head feathered, crown feathers lanceolate, and forming a crest when erected; tarsus scutellate; bill curved as above; feet long; claws nearly straight; plumage rich chestnut, with metallic tiuts. Length, 24 inches ; tail, 4 inches; bill, $4 \frac{1}{2}$ inches. Southern.

"Stragglers only of this species are seen in New Jersey, and none ever breed here. When seen it is generally near the coast, although occasionally they follow the course of our rivers. Author has seen a specimen killed on the Hackensack River, and saw a second on the meadows skirting the Delaware, a few miles above Bordentown, in Mercer county." - [C. C. A.]

\section{Family CICONIID A.}

\section{Storks and Wood Ibises.}

TANTALUS, L.

T. loculator, L. Wood Ibis.

Tarsus reticulate; bill stout, curved upwards ; toes long; top of head covered by a smooth plate; plumage white; quills and coverts black; naked part of head bluish. Length, 40 inches; bill, 9 inches; tarsus, 8 inches ; middle toe, 4 inches. Southern; casual as far north as New York.

\section{Family ARDEIDAE.}

Herons.

\section{BOTAURUS, Steph.}

B. lentiginosus, Montag. American Bittern. Indian Hen. Stake Driver.

Hind toe at same level as front ones; claws long, narrow, curved, and middle one pectinated; bill narrow and pointed; 
tail feathers ten, short and not very stiff; outer toe shorter than inner one; color ochraceous, mottled with brown and black above; quills slate, tipped with cinnamon; lower parts buff, striped with brown; dark spot on sides of neck. Length, 23 to 34 inches; tail, $4 \frac{1}{2}$ inches; bill, 3 inches; tarsus, $3 \frac{1}{2}$ inches; middle toe, $3 \frac{1}{2}$ inches.

"Very numerous. Appear in March, and are not unfrequently seen as late as November. They are most abundant on the edges of dense swamps, and when frightened take refuge by flying : short distance over and then dropping into them. Are largely nocturual in their habits, and about sundown make their neighborhood hideous with their coarse, peculiar croak. Do not frequent the river shores to any extent. Are abundant in the neighhorhood of the ocfan. Breed in swamps, raising one brood only. Feed largely upon frogs, and have been seen turning over stones in the bottom of brooks, evidently in search of salamanders. Are known as 'stake drivers' in some localities. Strictly inoffensive."

B. exilis, Gmel. (Ardetta, Gr.) Least Bittern.

Male glossy greenish black above, brownish yellow below; sides of neck and shoulders with chestnut; female with purplish chestnut instead of black. Length, 14 inches; tail, $1 \frac{3}{4}$ inches; bill, $1 \frac{3}{4}$ inches; tarsus, $1 \frac{3}{4}$ inches.

"This beautiful little bird is more sensitive to cold weather, and seldom is seen before May 1st. It frequents meadows, and is generally found walking about in grass much taller than itself. It is rather shy, but when flushed, flies but a short distance. Does not take readily to trees. Although more abundant in the southern and central portions of the State, is generally to he found wherever one may look if it be marshy, open ground. They feed largely upon insects and the small fish that wander from the creeks into the ditches that drain meadow lands. Strictly inoffensive."

\section{ARDEA, L.}

A. herodias, L. Great Blue Heron.

Tail feathers twelve, stiff; feet black; outer toe not shorter than inner one; claws short and much curved; bill long and narrow; tibia chestuut brown, bare for two or more inches; 
color grayish blue; dusky below and black on sides of head; white on crown and white stripes below; back of head crested in breeding season. Length, 48 inches; tail, 7 inches; bill, $5 \frac{1}{2}$ inches; tarsus, $6 \frac{1}{2}$ inches; female much smaller.

"Are first seen in April, but never appear to be as numerous as in August and September. They are equally abundant throughout the State, unless it be in the northernmost counties. Breed in swamps, but few in number, in the central portion of the State, and more frequently in Cape May county. During early spring and nidification remain inland the greater part of the time, but congregate about rivers and larger creeks in August. They feer on fish and reptilia, and are strictly inoffensive. The three lastmentioned species were formerly very abundant."

A. egretta, Gmel. (Herodias, Gr.) American Egret. White Heron. Great White Egret.

Pure white; head without lengthened feathers; a long train on back in breeding season. Length, 40 inches; bill, 5 inches; tarsus, 6 inches.

"Arrive a little earlier generally than the preceding, and are at all times more common, but never abundant. Frequeut meadow lands and the skirts of.swamps rather than the river shore, and are less shy. Build in trees, at considerable elevation, but so slightly is the nest put together that the young generally destroy it when but a few days old, and are compelled to sit upon branches, if they have been lucky enough not to have fallen to the ground. Their food is fish and frogs principally. Strictly inoffensive. This and the above species are semi-nocturnal in their habits."

A. corulea, L. (Florida, Bd.) Little Blue Heron.

Legs blackish or bluish; plumage slaty blue; young white; no dorsal plumes, but head with elongated feathers. Length, 24 inches; bill, 3 inches ; tarsus, 4 inches.

"Occasionally are found as early as March 15th, if the weather be at all moderate. Vary very greatly in a series of years as to their abundance in the State. During the summer of 1860 they were very abundant along the Delaware, as high up as Belvidere, and very many bred along Crosswicks and Watson's Creeks, tributaries of the Delaware, in Mercer county. They were quarrelsome with allied species, and drove oft' the night-herons, 
generally so abundant. In their habits they are similar to the preceding species, but spend less time upon the wing, and become apparently more attached to a circumscribed neighborhood for the -eason. Occasionally specimens are found throughout the winter. Feed on fish generally, but go 'snail-hunting' frequently."

A. candissima, Gmel. (Garzetta, Bonap.) Little White Egret. Snowy Egret. Snowy Heron.

Legs black and yellow; plumage pure white at all times; head and neck with long plumes in the breeding season. Length, 24 inches; tail, 4 inches; bill, 3 inches.

"Arrives about the 20th of April, if the weather is moderate, and is equally numerous throughout the State, though nowhere at all abundant. Annually two or three pairs visit the Delaware, about Trenton, and sometimes alight on the gravel-beds of the river. They are thus seen at all parts of the State. They build in high trees, in secluded positions, raising but the one brood. Are extremely shy, and feeding almost always in open meadows, are difficult to approach. They associate with allied species, more particularly the $A$. herodias. Feed upon fish and frogs. Strictly inoffensive."

A. tricolor, var. ruficollis, Gosse. ' Louisiana Heron.

Moderate crest on back of head; upper parts bluish slate; plumes maroon purplish; white streaks on fore-neck; train light drab ; lower parts white. Length, 23 to 28 inches; tarsus, 4 inches. Southern; occasional in New Jersey.

A. virescens, L. (Butorides, Bonap.) Green Heron.

Tibia bare one inch or less; bill more than thrice the length of its height; crown, back and wings lustrous dark green; neck purplish cinnamon, crested; back with lengthened feathers. Length, 18 inches; bill, $2 \frac{1}{2}$ inches.

"The most abundant of all the Ardeidx in New Jersey. Is generally known by either one or the other of the meaningless names of 'shite-poke' or 'fly-up-the-creek.' Arrives in May, and remains with us till October. Equally abundant 'up hill and down dale,' and in the driest positions is occasionally found in numbers. Breets generally in maples or birches that skirt some small stream, generally raising but the one brood. Feed on fish exclusively when haunting water, but on the uplands devour large quantities of insects. Strictly inoffensive." 


\section{NYCTICORAX, Steph.}

N. [grisea, L.] nycticorax, var. nævius, Bodd. (Nyctiardle gardeniAbbott's Catalogue.) Black-crowned Night Heron. Squawk, \&c.

Bluish gray; crown and shoulders glossy green; two or three long, white occipital plumes; lower parts, \&c., white or yellowish; young light brown, speckled with white. Length, 24 inches; bill, 3 inches; tarsus, 3 inches.

"Arrives in April, and seldom goes south before November, and it is not an unusual occurrence to find them in midwinter. At such times they frequent spring-holes, but what they there find to subsist upon deponent saith not. During the daybeing strictly nocturnal-they remain in the swamps and woorllands, and fly to their feeding-grounds after the sun is fairly down. They feed exclusively upon fish, unless it be in winter. From their note, which is a coarse, guttural sound, they have received the name of 'qua' or 'quok,' or from some the equally meaningless 'qua-bird.' They build among large trees, at less elevation than herons generally choose, raising but a single brood. Strictly inoffensive."

\section{Section NATATORES.}

Swimmers.

\section{Order LAMELLIROSTRES.}

\section{Sub-Order ANSERES.}

Ducks, \&c.

\section{Family ANATID 2 E. \\ Ducks.}

\section{MERGANSER, Briss.}

M. americanus, Cass. (Mergus merganser, L.) American Merganser.

Goosander. Fish Duck. Shelldrake.

Bill narrow, not black, with fine teeth along edge of mandibles, and at front, pointing loackwards; head greenish black, bearing 
a crest; lower parts creamy white or salmon; rump and tail ash gray; back pied black and white; in female, head is cinnamon; upper throat white; upper parts grayish, with white on wings, and lower parts buffy white; both sexes have a black bar across the white of wings. Length, 26 inches; tarsus, 2 inches ; middle toe, $2 \frac{1}{2}$ inches; culmen, 2 inches; female smaller.

"Arrives early in October, flying in very large flocks for a few weeks, then, splitting up into small companies, disperse through the bays. Found frequently associated with other ducks, especially 'broad-bills.' Occasionally met with ou the Delaware, about Trenton."

M. serrator, L. Red-breasted Merganser. Pied Shelldrake. Fish Duck.

Similar to preceding, but smaller and more crested; male with throat reddish brown, black streaked; wing with two black bars ; nostrils near base of bill. Length, 20 inches.

"Not as abundant as the preceding, but more frequently met with on the Delaware, especially in April, when the meadows are overflowed. None seen during summer."

\section{LOPHODYTES, Reich.}

L. cucullatus, L. Hooded Merganser. Shelldrake. Crested Diver.

Serrations of mandibles short and blunt; bill black; crest white; head and upper parts black; white below; cinnamon, waved with black, on sides; in female, crest reddish; upper parts grayish brown; belly and upper throat white.

"Not abundant. Are more frequently met with along our river-courses than either of the two preceding species. It is generally known inland as 'pond sawbill.' Occasioually it probably breeds within State limits."

\section{ANAS, L.}

A. boschas, L. Mallard, or Mallard Duck. Tame Duck.

Bill flattened, distinct lamellæ in lower mandible; hind toe not bordered by membrane; in male, head and upper neck glossy green, a white ring below; breast purplish chestnut; wing coverts tipped with black and white; female dull ochraceous, streaked with dark brown. Length, 24 inches; tarsus 
$1 \frac{1}{2}$ inches, less than middle toe. The original of our domestic varieties.

"Common, making its first appearance in April and remaining in small numbers during the summer. It has been found breeding in Mercer county. In September and October is more numerous than at other times of the year."

A. obscura, Gmel. Black, or Dusky Duck.

Resembles female of mallard, but darker, and no decided white except under wings; sexes alike in plumage. Length, 23 inches.

"Abundant during the spring and summer, inland, and also abundant on the coast during autumn. Frequents ponds along 'the shore,' and inland is partial to birch and maple-grown meadows, when overflowed by spring freshets."

A. discors, L. (Querquedula, Steph.) Blue-winged Teal.

Male with head and neck blackish plumbeous, darkest on crown; a white crescent in front of eye; under parts pale chestnut, thickly spotted with black; female (and male in breeding season) dusky and buffy above; head, neck and lower parts brownish white; head streaked; belly spotted, or, in younger birds, pure white. Length, 16 inches; tail, 3 inches. Known by blue on wings.

"Common. Equally abundant with $A$. crecca. Less wary, and often caught asleep. Occasionally breeds in the State. Associates but little with other ducks. Is most abundant in September, and prefers the open river to narrow creeks."

A. carolinensis, Gmel. (Nettion, Kaup.) Green-winged Teal.

Male with broad white bar on breast; head, \&c., reddish chestnut, with patch of metallic green behind eye; neck black above and waved with black and white below and on back; female, upper parts grayish, varied by buffy bars; head, neck and lower parts brownish white, speckled with dusky on head, \&c.; belly speckled or white in younger birds. Length, 15 inches; tail, $3 \frac{1}{2}$ inches.

"Common. A few breed in the State. Pass through the State in April, and return as early as September. Are a wild, shy bird; are difficult to approach, and seldom caught napping. Somewhat more abundant on the river than creeks." 
A. crecca, L. European (English) Teal.

Male similar to that of preceding, but no white bar on breast; black and white undulations on side, \&c., coarser, otherwise not distinguishable from the green-winged teal.

"Have seen a single specimen that was killed in the State. Taken on meadows of Delaware River, near Trenton, April 21st, 1861. Occasionally killed on the coast." - [C. C. A.]

A. strepera, L. (Chaulelasmus, Gr.) German Duck. Gadwall.

Speculum white; wing coverts chestnut and black; male, head and neck whitish brown, speckled with black; white and black cresceuts on crop; slate, with white undulations, on back, \&c.; tail coverts black; bill blue black; iris brown; legs orange yellow and webs dusky; in breeding season the crown is rusty, rump and breast tinged with rusty and under parts more spotted; female brownish, varied with dusky above and white below; belly white; chestnut of wings nearly rudimentary. Length, 22 inches; female smaller.

"A species belonging to the Sunthwestern States, and but seldom met with. A few seen in autumn and spring about Egg Harbor, but not regularly. Known as 'gadwell.'"

A. penelope, L. (Mareca, Steph.) European Widgeon.

Winter male, crown, belly and tail coverts white; tail spot green and velvet; back and sides waved with black; head and neck reddish; male after breeding season, tail coverts ashy blue; back, \&c., dark ashy gray; head and neck pale rusty, barred with dusky; female, head and neck as in summer male; tail spot grayish; white on wings reduced; upper parts dusky brown. variegated; tail coverts barred; lower parts white. Length, 22 inches; tail, 5 inches. Frequent in Alaska; occasional on our eastern coast.

"A rare bird in the State. Has been killed at Barnegat, but the author bas met with none taken about the rivers. Appears to be more frequent on Long Island."-[C. C. A.]

A. americana, Gmel. (Mureca.) American Widgeon. Baldpate.

Male, head and neck white, flecked with black (except on crown); a bright green patch on sides of head; back grayish white and sides reddish, all waved with black; female, head and 
neck white, streaked with dusky; upper parts dusky grayish brown, barred with dull white. Length, 20 inches; tarsus, $1 \frac{1}{2}$ inches.

"Abundant in spring and again in autumn. Both a 'shore" and inland species. When seen inland, are usually accompanied by 'sprig-tails.' Are easily stooled by imitating their whistlelike call. A few breed in the State."

\section{ȘPATULA, Boie.}

S. clypeata, L. Shoveller. Spoon-bill Duck.

Bill much widened towards tip; male, head and neck dark bluish green; breast white; lower parts chestnut; under tail coverts greenish; wing coverts bluish; tail speculum green; bill black; iris yellow; feet orange red; female, wings as in male, rest of plumage grayish brown, varied with whitish; head and neck brownish white and streaked; lower parts spotted with dusky; bill brown and orange. Length, 19 inches; bill, $2 \frac{3}{4}$ inches.

"Not abundant, single specimens generally being found with other ducks. Most abundant during May and October. Does not breed in the State. Is more frequently seen inland than along the sea-board."

\section{DAFILA, Steph.}

D. acuta, L. Sprig-tail. Pin-tail.

Male, head and neck brown; hind-neck black; back and sides waved with white and dusky; speculum green to purple; a cinnamon bar on grayish wing coverts; tail pointed. Length, 28 inches. In breeding season, much like female. Female, lower part of head dull white, streaked with dusky ; lower parts chiefly white; upper parts grayish dusky, with irregular yellowish bars: neck whitish, streaked with black. Length, 22 inches; tail, 9 inches or less.

"During the spring, on their way to the breeding-grounds, and on their return in autumn, they scatter about the State inland and along the shore. They associate with other ducks, and seldom fly in large flocks of their own kind." 


\section{AIX, Boie.}

A. sponsa, L. Wood Duck. Summer Duck.

Hind toe not bordered by a membrane; head crested; tip of bill formed entirely of "nail ;" male, head green, purple and violet, with white lines and throat patch; upper parts velvet black, with metallic tints; chest chestnut, with white spots; bars on sides of breast; belly white; bill variously colored (in life). Length, 20 inches. Female, head gray, with greenish crown and crest, and white feathers at base of bill and backwards; throat white; chest brown and spotted; upper parts grayish brown. Length, 18 inches; tail, 5 inches.

"Arrives early in April, and is abundant in certain localities during the summer. Prefers small, quiet streams, hedged in by large trees. Builds in trees, and sits much upon the branches. Occasionally met with during the winter, but such is seldom the case."

\section{A YTEYA, Boie.}

A. vallisneria, Wils. Canvas-back.

Bill a: long as middle toe without claw, end flattened, tip slightly hooked. (Sub-genus Aristonetta, Bd.) Male, head blackish on top and reddish brown below, with neek, chest, upper back and tail coverts with lower rump, black; rest of plumage, except 'fuills, whitish, with dusky vermiculations; female, head, neek, chest and upper back brownish; fore-neck, \&c., whitish. Length, 22 inches; bill, $2 \frac{1}{2}$ inches or more, its width one-third length.

"Not abundant, although annually killed, not only on the sea-board but occasionally on the Delaware River, as high up as Trenton. Have been killed on meadows during freshets."

A. americana, Eyt. (ferina, L.) Red-head. Pochard.

Male, head and upper neck chestnut, glossed with purple; belly white; rest of plumage black, except back, shoulders, sides and flanks, which are black and white (vermiculated); female, head and neck grayish brown, nearly white on throat; duller brown on back, chest and sides; bill shorter than head. Length, 20 inches.

"Arrives about the 1st of November, and is more or less common on the sea-board till March. Is less seldom seen inland 
than the 'broad-bill' or ' red-neck,' being taken on the Delaware regularly about Bordentown."

A. marila, var. nearctica, Stejn. (Fulix, Sund.) American Scaup Duck. [Broad-bill.] Blue Bill. Raft Duck. Big Scaup Duck.

Culmen as long as outer toe, with claw; bill wider (1 inch) at end than at base ( $\frac{4}{5}$ inch) (Sub-genus Fuligula); speculum white, tipped with black. Male, bill, in life, grayish blue, with black nail; head, neck and chest black; wing coverts grizzled with grayish white. At end of breeding season more like female, but richer colors. Female white at base of bill, rest of head and neck snuff brown; belly white, graduating into the decided brown of sides; upper parts brownish dusky. Length, 20 inches.

"Abundant. Arrives along the sea-board about the 15th of October. Flies in large flocks, and is one of the most common species. Are occasionally met with on the Delaware as high up as Trenton."

A. affinis, Eyt. (Fulix, Sund.) Lesser Scaup Duck. Pond Broad-bill.

Similar to preceding, but smaller, with flanks vermiculated with blackish, and black of head of male glossed with purplish instead of green. Length, 16 inches; bill nearly 1 inch wide.

"Arrives about the 1st of October, and frequents small creeks rather than the bay, and is more frequently met with inland than the preceding. Seldom seen in summer."

A. collaris, Donov. (Fulix, Sund.) Ring-necked Duck. Red-neck.

Speculum bluish gray. Male black, with violet gloss on head, a chestnut collar, and with white spot on chin; bill transversely banded; female no collar; upper parts brown, shading into white of throat, chest and belly. Length, 18 inches.

"Arrives in October. Goes in small flocks. Is much more abundant during some seasons than others. Is very scarce generally in the spring. Occasionally seen inland, keeping on the rivers. Associates but little with other ducks."

\section{GLAUCIONETTA, Stejn.}

G. clangula, rur. americana, Bonap. (Clangula, Flem., Bucephalit-Abbott's Catalogue.) American Golden-eye. Garrot. Whistler.

Male, head and upper neck greenish black, with white spot on lores; white wing patch uninterrupted by black bars; lower 
parts white; upper parts pied; female, head brown; white collar of neck broader; chest grayish; wings dusky. Length, $16 \frac{1}{2}$ inches. Length of male, $18 \frac{1}{2}$ to 23 inches.

"Not very abundant. Generally found on the sea-board from November to March, and inland. Many were formerly killed on the Delaware, above Bordentown."

\section{CHARIONETTA, Stejn.}

C. albeola, L. (Clangula, Bucephala.) Bufle-head. Dipper. Butterball. Spirit Duck.

Male, head, \&c., rich dark green, bronze and violet purple, with large white patch behind eyes; back black; nearly all the rest of plumage white; female, head and upper parts grayish brown; belly white, graduating into gray on sides, front and posteriorly; inner secondaries, ear coverts, \&c., white. Length, 13 inches. Length of male, 15 inches.

"Common. More abundant on the sea-board than inland, although one of the more common of the river ducks. Occasionally met with during the summer."

\section{CLANGULA, Leach.}

C. hyemalis, L. (Harelda, Leach,) (glacialis-Abbott's Catalogue.) Old Squaw. Old-wife. Long-tailed Duck. South-southerly:

Male, in winter, lower parts white, grayish on sides; upper parts and breast black; upper back and chest, head and neck, white; sides of head and neck grayish and dusky; in summer, forehead pale gray; behind eyes white; head, neck and upper parts sooty brown or blackish, shading into the white of lower parts; female, in winter, head, neck and lower parts white; top of head dusky; chest grayish; upper parts dusky brown; in summer, head and neck dark grayish brown; white space on sides of neck and around eyes. Length, $15 \frac{1}{2}$ inches; of male, 22 inches; middle tail feathers, 8 inches.

"Common, though more abundant during some seasons than others. Is properly a marine species, but is occasionally seen inland. Following a very violent northeast storm in February, a large flock appeared on the Delaware, near Trenton, and fully one hundred were killed. This was in 1860, and they have not been seen since in the same locality" (1867).-[C. C. A.] 


\section{HISTRIONICUS, Less.}

H. histrionicus, L. (torquatus-Abbott's Catalogue.) Harlequin Duck. Male, in winter, speculum dark violet blue; plumage in general bluish, much varied with white; sides bright rufous; in summer, much duller; speculum, under tail coverts, sides, \&c., grayish brown; female like summer male, but head, neck and chest grayish brown, with some white on head. Length, 17 inches.

"Very rare, and seen only on the sea-board. Young birds appear to be met with only. Is a northern species. Know of but two specimens, both killed off Tuckerton."-[C. C. A.]

\section{OAMTOLAIMUS, Gray.}

C. labradorius, Gmel. Labrador Duck. Sand-shoal Duck.

Male black, with head, neck, chest, scapulars and wings (except quills) white; female brownish gray. Length, 22 inches. Now (1889) practically extinct.

"Not abundant. Arrives in October, and in small flocks is found along our sea-board generally. Leaves in April " (1867). $-[$ C. C. A. $]$

\section{SOMATERIA, Leach.}

S. dresseri, Sharpe (mollissima, L.) American Eider Duck.

Male, in breeding plumage, white, with under parts, rump, quills and crown, black, bordered by pale green on head; female reddish brown, streaked and barred; bill with long, club-shaped frontal processes. Length, 24 inches.

"Rare. Appears in November, and straggling single birds occasionally shot during the winter, especially about Barnegat."[C. C. A.]

S. spectabilis, L. King Eider.

Male chiefly black; - top of head bluish gray; front parts white, with a $V$-shaped black mark on throat; frontal processes broad and out of line with culmen; female brownish streaked and barred, as in other species of Somateria, but with the feathering on forehead reaching to the nostril. Length a little smaller than preceding. Its southern range in winter is marked by our northern boundaries. 


\section{OIDEMIA, Flem.}

O. americana, Sw. \& Rich. [Surf Scoter.] American Black Scoter.

Male black; basal part of bill yellowish; female grayish brown, paler below and on throat; bill all black. Length, 20 inches.

"Called 'coot' and sometimes 'butter-bill.' Passes its time at sea. This and the above arrive about November 1st, and remain till April."

O. deglandi, Bonap. (Melanettu relvetinu-Abbott's Catalogue, O.fusca (I.), Sw.) White-winged Scoter, or Coot. [White-winged Surf Duck. Velvet Scoter (?)]

$O$. deglandi and $O$. fusca are separate species, according to Ridgway, the latter being the velvet scoter, a European species accidental in Greenland. The two species seem to have been confounded by some previous writers. Our species has a much narrower space between the nostrils and the loral feathering. The male has the swollen lateral base of upper mandible unfeathered, and sides of bill more reddish yellow. The plumage is much as in the European form, black or brownish black, with a white spot on wings and back of eyes; female is sooty brown or grayish, darkest above and with no white on head. Length, 22 inches.

"Arrives off our coast about the middle of October, and remains until the middle of April. Stays outside the beach always, and spends much of its time swimming."

O. perspicillata, L. (Pelionetta.) Surf Scoter. Surf Duck. Sea Coot.

Forehead feathering extends further forward than the loral feathering; the sides of bill at base have a naked swollen portion; no white on wing; male black, with red bill, black on swollen portions of base; a white spot on hind-neck, or on forehead. Length, 21 inches. Female, bill dusky, hardly -wollen at base; upper parts dusky ; lower parts grayish brown. Length, $18 \frac{1}{2}$ inches.

"The 'coot' is, like the above, an ocean-haunting species, and is never found in the bays except when driven in by the storms." 


\section{ERISMATURA, Bonap.}

E. rubida, Wils. Ruddy Duck.

Male, top of head black; lower parts whitish (brownish gray beneath surface); upper parts reddish chestnut; female and young male, above grayish brown, mottled with buff; top of head darker; rest of head grayish white, with brownish stripe on sides. Length, 16 inches or less.

"More abundant during some years than others. Not unfrequent in Chesapeake Bay, where it is known as 'salt-water teal." "

\section{NOMONYX, Ridg.}

N. dominicus, L. Masked Duck. San Domingo Duck.

Accidental in various parts of Eastern United States; differs from the above in having a larger nail at tip of bill, not bent back at tip, but nearly all visible from above; there is a white spot on wings, and young male and the female have two stripes on sides of head. Length, 14 inches or less.

\section{CHEN, Boie.}

C. hyperborea, var. nivalis, Forst. (Anser.) Greater Snow Goose.

Pure white (or washed with reddish grayish in young); quills black: Length, 30 to 38 inches. An arctic form, migrating south in winter. Bill, $2 \frac{1}{2}$ inches, robust, with prominent lamellæ.

"Rare. Two or three together occasionally met with along the coast in winter. Never seen inland, or on Delaware Bay."

\section{ANSER, Briss.}

A. albifrons, var. gambeli, Hartl. American White-fronted Goose. Speckle-bill. [Laughing Goose.]

Head grayish brown, forehead white; lower parts grayish white, spotted with black; tail coverts white; bill yellowish; feet light colored; back dark. Length, 27 to 30 inches.

"Like the preceding, is a rare species, met with only as a straggler, in winter. Have seen one specimen, killed at Barnegat." - [C. C. A.] 


\section{BRANTA, Scop. \\ (Bernicla, Steph.)}

Generic characters-Lores feathered; feet, bill and neck black (with white patches); tail and quills black; tail coverts white; upper parts brownish; paler or grayish below.

B. canadensis, L. Canada Goose. Wild Goose.

Length, 35 to 43 inches; tail, $7 \frac{1}{2}$ inches. Lower parts light brownish gray; white throat patch extending on sides of head.

"Abundant during autumn and till spring. In March is not unfrequently met with inland, and has been known to alight and familiarize with the domestic geese. Do not breed in the State, except in a state of domestication. According to Smith's History, were much more abundant a century ago."

B. leucopsis, Bechst. Barnacle Goose.

Head nearly all white; chest (and back, sometimes) black; bluish gray above; grayish white below. Length, 26 inches. A European species accidental on our coasts.

B. bernicla, L. (brenta-Abbott's Catalogue.) Brant Goose.

Head all black; white streaks on sides of neck; upper parts brownish gray; grayish below, abruptly ehanging to black on chest.

"Abundant, from autumn till spring, along the coast. Are killed by thousands about Egg Harbor, during the shootiug season. Vary, during a course of years, as to abundance."

B. nigricans, Lawr.

The black brant of Northwestern North America has been found accidently at Long Island. It has a white collar; indistinct in young; upper parts are sooty brown; lower parts slate. Length, 22 to 29 inches.

\section{OLOR, Wagl.}

\section{(Cygnus, L.)}

O. columbianus, Ord. (americanus, Sharpless.) Whistling Swan.

Tail twenty-feathered; bill with a yellow spot. Length, 50 inches.

"Swans appear along the coast during winter, entering the bays. Are killed every winter on the Delarrare Bay, and on the 
Chesapeake especially. Never seen inland, unless it be a stray specimen "flying over.' "'

O. buccinator, Rich. Trumpeter Swan.

Bill without yellow spot, longer than in above, and with nostrils nearer base. Length, 60 inches or more. Is rare on the Atlantic coast, and may scarcely be considered as belonging to a catalogue of the birds of New Jersey. It is mentioned here (as are other rare forms), as it might possibly be seen.

\section{Order STEGANOPODES.}

\section{Family SULID}

\section{Gannets.}

SULA, Briss.

S. bassana, L. Gannet.

- Hind toe connected by web with other toes, which are of unequal length; the lower jaw is feathered; legs, \&c., black; color of plumage white, buffy on head; quills brown. Length, 30 to 40 inches.

"Are rare off the coast of New Jersey. Fly in quite large flocks, and frequent rocky sea-boards, resting upon the rocks when not fishing. Never seen in the bays."

\section{Family PHALACROCORACID E.}

Cormorants.

\section{PHALACROCORAX, Briss.}

(Graculus-Abbott's Catalogue.)

P. carbo, L. Common Cormorant.

Bill strongly hooked; wings short (13 inches); tail large and stiff ( $7 \frac{1}{2}$ inches), of fourteen feathers; legs set far back; plu- 
mage lustrous black; back and wing coverts brownish ; in breeding season with crest and long white plumes on back of neck. Length, 34 to 40 inches. Colors of young paler, inclining to white.

"Appears off the coast during autumn, staying out at sea the greater part of the time. Is a much more common species than the following, though it varies as to its numbers very much during a course of years."

P. dilophus, Sw. \& Rich. Double-crested Cormorant.

Tail feathers twelve; wings aud back slaty brown, otherwise greenish black; two curly black crests in adult; pouch bright orange. Length, 29 to 33 inches.

"Appears off the coast in November, and is seen very frequently during the winter. Fishes at sea, and after being well stuffed, comes to shore and sits on sandelift's, awaiting the prorcess of digestion."

\section{Family PELECANID E.}

\section{Pelicans.}

PELECANUS, L.

P. erythrorhynchus, Gmel. (trachyrhynchus, Lath.) American White Pelican.

Large fish-eating birds, with long bills, ending in a hook; a large sac between the branches of lower jaw ; nostrils abortive; wings long; tail short; live in flocks; color white, with black on wings. In breeding season a yellowish crest, red bill and feet. In winter more yellowish. Length, 60 inches; bill, 12 inches; weight about 17 pounds. Nest a rude mound of gravel and rubbish on some shore, usually inland.

"Is but seldom met with, though was probably a numerous species. Author saw three flying off Sandy Hook, in February, 1864 , and has seen one mounted specimen said to have been killed near Tuckerton." - [C. C. A. $]$ 


\title{
Order LONGIPENNATI.
}

(CECOMORPHAE.)

\section{SUB-Order TUBINARES.}

\section{Family PROCELLARIID五.}

\author{
Petrels.
}

FULMARUS, Leach.

F. glacialis, L. (Procellaric meridionalis-Abbott's Catalogue.) Fulmar.

Nasal tubes long proportionately and close together; bill short and stout, and dusky or brownish; head, neck and lower parts white; upper parts bluish gray, the quills darker, or whole plumage may be gray. Length, 19 inches.

"Met with, but not abundantly, during the spring and again in autumn, off the coast. At neither season do they make any prolonged stay. Occasionally, but very seldom, have been killed in the bays."

\section{PUFFINUS, Briss.}

P. puffinus, Brünn. (anglorum-Abbott's Catalogue.) Manx Shearwater.

Bill cylindrical; nostrils separated widely and visible frọm above; plumage sooty blackish; lower parts white; lower tail coverts white and dusky. Length, 14 inches; tail, 3 inches; wing, 9 inches.

"Rare. Appears off the coast about the middle of November, and is seen occasionally until March. The author met with several off Sandy Hook in December, 1863."-[C. C. A.]

P. major, Faber. Greater Shearwater.

Throat white, abruptly separated from dusky of top and sides of head and neck; bill blackish; upper tail coverts white; belly clouded with gray. Length, 20 inches; wings, 13 inches. Inhabits the Atlantic Ocean generally. 
P. stricklandi, Ridg. Sooty Shearwater.

Lower parts dusky; bill brownish; under wing coverts gray, mottled with white at tips. Length, 16 inches; wings, 12 inches. Inhabits American side of North Atlantic.

P. auduboni, Finsch. Audubon's Shearwater.

No white tips to wing coverts; lower tail coverts dusky; above sooty black; white of under side head extends nearly to eye. Length, 11 inches; wings, 8 inches; tail, $3 \frac{1}{2}$ inches; tarsus, $1 \frac{1}{2}$ inches. Inhabits warmer parts of Atlantic; casual on coast of New Jersey.

\section{ASTRELATA, Bonap.}

E. hastata, Kuhl. Black-capped Petrel.

Cutting edge of lower mandible concave; upper parts dusky ; upper tail coverts white; head and neck white; head blackish on top. Length, 15 inches; wings, 11 inches; tail, 5 inches. Inhabits Middle Atlantic aud striggles occasionally to our coasts (Florida to Long Island).

\section{OOEANODROMA, Reich.}

\section{O. leucorhoa, Vieill. Leach's Petrel.}

Upper tail coverts white (or grayish), without black tips; plumage sooty, darker above; a grayish band across chest. Length, 8 inches; wings, 6 inches; tail, 4 inches, forked for nearly one inch. Feet black. Inhabits the oceans of northern hemisphere.

\section{OCEANITES, Kөyser. \& Bl. \\ O. oceanus, Kuhl (Thalassidroma wilsoni). IVilson's Petrel (incor- rectly, the Stormy Petrel, $P$. pelagica, which does not range south of Banks of Newfoundland, on our side of Atlantic).}

Secondaries ten; claws narrow and pointed; belly and flanks dusky; sooty black above; tail and quills black; upper tail coverts white; web of feet yellowish; tail not forked. Length, 7 inches; wings, 6 inches; tail, 3 inches.

"Not uncommon off the coast. Occasionally during severe storms is driven across the State and up the Delaware and other rivers, but makes no longer stay inland than practicable. Does not breed in the State." 


\section{Sub-Order LONGIPENNES.}

General characters-Feet palmate ; hind toe small and elevated ; bill long; wings long and pointed.

\section{Family STERCORARIID㞋.}

Skuas and Jaegers.

\section{STERCORARIUS, Briss.}

S. pomarinus, Temm. (pomatorhinus.) Pomarine Jaeger.

Covering of upper mandible in three distinct pieces (a terminal hook, and basal cere of separate pieces); middle tail feathers project and are broad at ends; plumage in two phases; light phase, upper parts sooty; lower parts and front of head and neck white; dark phase, no white. Both phases grade into each other. Length, 20 inches; wings, 15 inches.

"When, as is the case during one winter in every ten, coast birds are unusually numerous, this among others may sometimes, but very rarely, be met with in midwinter."

S. parasiticus, L. Parasitic Jaeger. Arctic Jaeger.

General color dark brown, with two extremes as above; middle tail feathers pointed, project four inches. Length, 18 inches; wings, 13 inches.

"This species is little less abundant than the preceding, and like it, only met with during the winter."

S. longicaudus, Vieill. Long-tailed Jaeger.

With middle tail feathers projecting eight or ten inches; probably gets as far south as New Jersey, in winter, extremely rarely, although a very cold season favors an extension of its migration. 


\title{
Family LARID王.
}

Gulls and Terns.

\author{
RISSA, Leach.
}

R. tridactyla, L. Kittiwake Gull.

Legs and feet dark; hind toe rudimentary; plumage in summer white, with black of cills and tip of tail; in winter with hind-head and neck suffused with gray; mantle pearl gray; more dark patches in young. Length, 17 inches; wings, 12 inches.

"This gull is common off the coast from November to April, but is never seen inland or along the Delaware. Seldom observed in summer. Does not breed in the State."

\section{LARUS, L.}

L. marinus, L. Great Black-backed Gull. Coffin-carrier. Saddleback.

Hind toe perfect; mantle dark slate; primaries black; rest of plumage white, streaked with dusky on head in winter; young dusky above and head streaked. Length, 28 to 31 inches; wings, 18 inches; tarsus, 3 inches.

"The young of this species are those generally met with off" the coast and in the rivers of this State. Does not ascend the Delaware above Philadelphia, and is there met with very rarely. None breed in the State."

L. glaucus, Brünn. Glaucous Gull. Ice Gull. Burgomaster.

No black on wings; bill yellow, with red spot on lower mandible. Length, 30 inches. Its southern limit is Long Island.

L. leucopterus, Faber. Iceland Gull. White-winged Gull.

Similar, but length 23 inches. Limits nearly the same as preceding.

L. argentatus, var. smithsonianus, Coues. American Herring Gull. Common Gull.

Feet flesh colored; mantle grayish blue or lighter; no black spots on bill; red spot on lower mardible; young grayish; bill dark. Length, 22 to 27 inches; wings, 17 inches. 
"Off the coast from November 15th or thereabouts until March. Probably does not ascend the rivers any distance. Appears to prefer the open sea to the bays. Go north to breed in March. Are not as abundant at any time as the following species."

L. delawarensis, Ord. Ring-billed Gull.

Plumag like preceding; feet olivaceous; webs yellow; bill yellowish, with black band at tip. Length, 20 inches; wings, 15 inches.

"Nakes its first appearance about October 1st, and is abundant on our sea-board and along our rivers until April, when they have all left for their breeding-grounds. This gull is very abundant on the Delaware, as far up as Philadelphia, but seldom ascends farther."

L. atricilla, L. (Chrococephalus, Eyt.) Black-headed, or Laughing Gull.

Bill and feet"dusky carmine; tarsus longer than middle toe; lower parts white, roseate in breeding season; head sooty slate, white in winter; mantle leaden; five outer primaries black, rest of quills gray; young brownish and white. Length, 15 to 17 inches; wings, 13 inches; tail, 5 inches.

"Abundant, not only on the coast but in Delaware Bay. Seldom ascends farther up the river than Philadelphia. Breeds in Cape May county. Is first seen about April 1st, and generally have all disappeared by the middle of October."

L. philadelphia, Ord. Bonaparte's Gull.

Tarsus not longer than middle toe ( $1 \frac{1}{2}$ inches); bill deep black; plumage generally white; head dark gray in summer, white in winter; mantle pearl gray; quills white and pearl gray, tipped with black; feet orange red, paler in winter. Length, 13 inches; wings, 10 inches.

"This gull is abundant on our coast and along our rivers from April 1st, but does not make a prolonged stay, and never breeds within State limits. This species ascends the Delaware as far as Trenton more frequently than any other species. Are not seen during the winter." 


\section{XEMA, Leach.}

X. sabinii, Sab. Sabine's Gull. Forked-tail Gull.

Much like above, but with a black collar and hood; more black on quills; mantle deeper bluish gray; bill tipped with orange. Length, $13 \frac{1}{2}$ inches; tail, $4 \frac{3}{4}$ inches, forked for nearly

1 inch. Ranges south to New York, casually further south.

\section{GELOOHELIDON, Brehn.}

G. nilotica, Hass. (anglica, Mont.,) (Sterna aranea-Abbott's Catalogue.) Marsh Tern. Gull-billed Tern.

Tail forked; feet black; bill stout (1 $\frac{1}{2}$ inches); top of head, \&c., black in summer, white in winter; upper parts pearl gray, otherwise white. Length, 15 inches; wings, 12 inches; tail, $5 \frac{1}{2}$ inches.

"Arrive about A pril 15th. Breed along the coast. Not found inland. Do not associate with other species."

\section{STERNA, L.}

S. tschegrava, Lepech. (Thalasseus caspius, Pall.) Caspian 'Tern.

Tail forked for less than a fifth of its length; adult in spring, top of head glossy black; feet black; bill red; plumage white, pearl gray above; after pairing season, white, speckled on the black of head; winter arlult white or grayish, streaked on head; dark colors more extended in young. Length, 20 inches; wings, 17 inches; tail, 6 inches.

"A northern species, only occasionally met with. Is more rarely seen than the sooty tern. Is met with in winter."

S. maxima, Bodd. (T. regius, Gamb.) Royal Tern.

Bill orange; tail forked for half its length; adult in spring, top of head and occipital crest and feet, black; after pairing season, only occipital region black; in winter, white, mixed with black of occiput; bill paler; young like winter adult, but upper parts spotted. Length, 20 inches; wings, 15 inches; tail, 8 inches. More slender body than preceding.

"Like the preceding, is a rare species. Visits us from the South during the summer. Does not breed in the State." 
S. sandvicensis, var, acuflavidus, Cabot. Cabot's Tern.

Bill deep black, with whitish tip; otherwise much like preceding. Length, 15 inches; wings, $12 \frac{1}{2}$ inches; tail, 6 inches, forked for 21 inches; bill, 21 inches. A southern form ranging north on the Atlantic coast to Southern New England. Rare. Same as Thalasseus cantiacus, Sandwich Tern.

S. trudeaui, Aud. Trudeau's Tern.

Mantle bluish gray; no black on head, but a dusky stripe on each side; general color white and pearl gray; lower parts pure white in winter; bill yellowish, with black middle in summer, with yellow tip, only, in winter. Length, $15 \frac{1}{2}$ inches; wings, 10 inches; tail, 5 inches or more, forked for about one-third of its length. Inhabits "Atlantic coast of South America; casual on Atlantic coast of United States (New Jersey)."-Ridgway.

"Met with rarely, in winter only, being a northern species." - [C. C. A.] Probably refers to the aretic tern.

\section{S. forsteri, Nutt. Forster's Tern.}

Inner web of outer tail feather dusky towards end, outer web all white; in summer, above pearl gray; white below; top of head black; bill orange, with dusky tip ; feet reddish orange; in winter, top of head white; sides of head striped; tail less forked; bill with more dusky; feet paler. Length, $14 \frac{1}{2}$ inches; wings, 10 inches; tail, 5 to 8 inches, forked for $2 \frac{1}{2}$ to 5 inches.

"Occasionally met with during the winter, but rarely."

S. hirundo, L. (wilsoni, Lawr.) IVilson's Tern. Common Tern. Sea Swallow.

Inner web of outer tail feather all white; outer one dusky; summer plumage, lower parts grayish white; upper parts pearl gray; top of head black; tail mostly white; bill red, blackening towards tip; feet rich orange vermilion; in winter, white encroaches on black of head from the front; lower parts pure white; bill and feet duller. Length, 13 to 16 inches; wings, 10 inches; tail, 5 to 7 inches, forked about half way.

"Appears off the coast A pril 15th. Called 'sheeps-head gull.' Breeds along 'the shore,' depositing its eggs on the drift-grass. Is found along the rivers Delaware, Raritan and Hackensack."

S. paradisæa, Brünn. (macrura, Naum.) Arctic Tern.

Bill carmine throughout; tail and tips of secondaries white, in sharp contrast with grayish cast of rest of plumage. Length, 
$1 \pm$ to 17 inches; wings, 10 inches ; tail, $6 \frac{1}{2}$ to $8 \frac{1}{2}$ inches, forked for 4 to 5 inches. Breeds south to Massachusetts.

S. dougalli, Montag. (paradisea-Abbott's Catalogue.) Roseate Tern.

Both webs of outer tail feathers all white; in summer, silvery gray above, pinkish below (fades to white in dried specimens); top of head black; bill black, with red base; feet red (in life); in winter, less black on fore part of head.

"This species visits us during the summer, from the South. Is always a rare bird in New Jersey, but is more common during some summers than others."

S. fuliginosa, Gmel. (portlandica, Ridg.) Sooty Tern.

Mantle and middle tail feathers blackish, outer ones white; forehead, sides of head and lower parts white; upper parts, bill, and feet black; less white in young. Length, 15 to 17 inches; wings, 12 inches; tail, 7 inches, forked nearly half way. A tropical species.

"Rare. Is seldom seen at any time, and only during the summer, off the coast. Does not breed in the State."

S. antillarum, Less. (superciliaris, frenata.) Least Tern.

In summer, pearl gray above; white below, and a crescent on forehead; top of head and lateral stripes black; bill yellow, with dark tip; feet orange yellow ; in winter, yellows paler, and black of head gives way to white anteriorly. Length, 9 inches; wings, $6 \frac{1}{2}$ inches; tail, $3 \frac{1}{2}$ inches, forked half way.

"Arrive about middle of April. Breed, depositing eggs on the sand. Ascend our rivers. Disappear by October 1st."

\section{BYDROCHELIDON, Boie.}

H. nigra, var. surinamensis, Gmel. (plumbea.) American Black Tern.

Toes not full webbed; head and lower parts all black in summer, white in winter; upper parts leaden, more brown in young. Length, 10 inches; wings, 8 inches; tail, 31 inches, forked less than 1 inch.

"Very abundant during the summer, not only about our seaboard, but inland. Are more numerous inland, about Raritan Bay, than in the Delaware. Breed in the salt meadows about 
Newark probably. Seldom ascend the Delaware very far, and bave never been seen by the author above Burlington, Burlington county."

\title{
Family RYNCHOPIDEE. \\ Skimmers.
}

\section{REYNCEOPS, L.}

R. nigra, L. Black Skimmer. Cutwater. Shearwater.

Lower mandible longer than upper, compressed like a knifeblade; tail white, with middle feathers dusky; secondaries tipped with white; in summer, forehead, sides of head and lower parts white; upper parts, \&c., black; base of bill, feet, \&c., red; in winter, black is more brownish, and there is a white collar across hind-neck; the young are buffy above. Length, 17 to 20 inches; wings, 15 inches; tail, $5 \frac{1}{2}$ inches, forked about a fifth of length. Upper mandible nearly 3 inches; lower one, 3 to 4 inches.

"Arrives off" the coast in May, and remains during the summer. Breed mostly-in Cape May county. They come from the South in the spring, and return in August. Are very rarely seen on the rivers, even near the mouths, where the water is brackish. Never seen during the winter."

\section{Order Pygopodes.}

Divers.

Legs set far back; feet webbed or lobed; position of bird when standing, nearly erect; hind toe small; wings small.

\section{Family PODICIPID王.}

\author{
Grebes.
}

COLYMBUS, L.

(Podiceps, Latham.)

C. auritus, L. (P. comutus, Gmel.) Horned Grebe.

Bill slender, black, tipped with yellow, shorter than head; breast brownish red; head black; general color dark brown; 
vchraceous crest of soft feathers on each side of occiput. Length, 14 inches; wings, 6 inches; bill, $3 \frac{3}{4}$ inches.

"About as frequently met with as the crested species; and as in that case, generally the young birds are met with. Ascends the rivers more than the 'red-necked' species."

C. cristatus, L. Crested Grebe.

Bill about as long as head; lower parts white, not mottled; muptial plumage, throat and chin buffy white, becoming reddish on ruff; top of head and occipital crests black, rest of plumage dark brown; secondaries white. Length, 23 inches; wings, 7 inches; bill, 2 inches. "Nearly cosmopolitan, but no authentic records for any portion of America."-Ridgway. "Not American."-Jordan.

"Much less common than the red-necked grebe. Met with only in winter, and nearly all young birds. Has been found on the Raritan, above New Brunswick."-[C. C. A.] Possibly varieties or younger birds of $C$. auritus have been mistaken for cristatus.

C. holbœlii, Reinh. (P. griseigena-Abbott's Catalogue.) Real-necked Grebe. Holboll's Grebe.

Lower parts mottled white or ash; nuptial plumage, top of head black, rest of head gray; neck brownish red; crests and ruffs not large. Length, 18 to 20 inches; wings, 8 inches; bill, 2 inches. Northern.

"This species is only a winter visitor, and is never abundantly met with. Is found about Delaware Bay, but seldom 'up the river.'"

PODILYMBUS, Less.

P. podiceps, L. Devil Diver. Pied-billed Grebe. Diedapper. Helldiver. Water-witch. Dab-chick, \&c.

Bill stout, hooked; no ruff or crest; brownish above, silvery ash below; nuptial plumage, chin, throat, cheek, black; rest of head brownish gray; spotted with dusky below; bill whitish, with dark band; in winter, black replaced by dull white; no spots below; bill brownish; no black band; sides of head striped with brown, in young. Length, 14 inches; wings, 5 inches; bill, 1 inch.

"Very common, and known under a legion of names, but 
devil diver is probably that most generally used. Arrives early in April, and is found in all our creeks, mill-ponds, de.-in nearly all water that contains small fish. Remains until the middle of October, and breeds within the State. Is by many erroneously considered the female of the 'coot,' Fulica americana."

\section{Family URINITORIDEE.}

(Eudytidæ.)

\section{Loons.}

\section{URINATOR, Cuv.}

(Eudytes, Illig.)

U. imber, Gunn. (immer, Brünn.,) (Colymbus torquatus-Abbott's Catalogue, glacialis, L.) Diver. Great Northern Loon.

Hind toe present, but small; no ruffs or naked spaces on head; can hardly walk, but good flyers; voice sharp and wild; plumage blackish above, whitish below; in summer, upper parts spotted with white; throat, \&c., black, with white streaks on sides of neck; head, \&c., glossed with green; in winter, and in young, white spots above absent; fore-neck white. Length, 36 inches or less; wings, 15 inches; tarsus, 3 inches ; bill, 3 inches.

"Probably not a resident, as it has not been found breeding in the State, and is very seldom seen during the summer months. They are abundant on our sea-board and about our rivers from October till the middle of April. Seldom seen off our rivers when inland, unless compelled to take to flight, which they seldom do."

U. arcticus, L. Black-throated Diver, or Loon.

Similar to preceding, but, in summer, hind-neck grayish, foreneck black, with white streaks on sides between the black and the gray. Length, 28 inches; wings, 13 inches; bill, $2 \frac{1}{2}$ inches. Northern boundary of United States marks its southern limit.

"Young specimens of this diver are very rarely taken, probably, on our sea-board. But only one such instance has come to the notice of the author. Is the rarest of rare visitors."

U. lumme, Gunn. (septentrionalis.) Red-throated Diver, or Loon.

Head and neck gray, streaked with white behind and chestnut on fore-neck in summer, white in winter; upper parts black- 
ish, with white spots; lower parts white. Length; 27 inches or less; wings, 11 inches; bill, 2 inches.

"Young specimens of this rare bird have been occasionally taken, not only on the coast, but in Delaware Bay. Met with only during the depths of winter. Have seen but one adult specimen killed in the State."-[C. C. A.]

\section{Family ALCID王。}

Anks.

\section{FRATERCULA, Briss.}

F. arctica, L. Aretic Puffin.

No hind toe; deciduous basal shields on bill not white; horny processes on eyelids short; upper parts and neck band blackish; sides of head gray; whole throat grayish in breeding season; lower parts white. Length, 11 to 13 inches; bill, $1 \frac{3}{4}$ inches. Breed south as far as Bay of Fundy.

"Occurs off the coast in winter, and is seldom met with. This bird, like the razor-bill, remains wholly at sea, never heing met within the outer beach."

\section{CEPPEUS, Pal.}

C. mandtii, Licht. MIandt's Guillemot.

Greater wing coverts all white; rest of plumage black; in winter all except wings white, with black markings above. Length, 13 inches; wings, 7 inches; bill, 1 inch. An arctic form, breeding as far south as Labrador. Comes south as far as New Jersey in winter.

C. grylle, L. Black Guillemot.

Much like above, except that basal half of white wing coverts is black and bill is stouter. Breeds south to Maine.

"Much more frequently met with than the aretica and torda, and flies nearer the beach, but very seldom over it to the bay. Noticed only during winter." 
URIA, Briss.

U. troile, L. Ifurre. Foolish Guillemot.

Upper parts dusky; 'white below; secondaries tipped with white; bill compressed; upper mandible notched near tip; chin, throat, fore-neck and sides of head velvety brown in summer, white in winter, but sides of head not white in young; top of head and hind-neck smoky brown. Length, 15 to 18 inches; wings, 8 inches; bill, $1 \frac{3}{4}$ inches. Breeds from Nova Scotia northward.

"About as abundant as the preceding. Met with during autumn and winter, and seldom after the middle of March. Remains always at sea."

U. ringvia, Brünn. Murre.

Same as above, but white ring around eye connecting with a white streak behind eye. Perhaps not a distinct species.

"Rather more abundant than the preceding, appearing of" the coast in November, and remaining until March. Like the preceding, remains at sea."

U. lomvia, L. Brünnich's Murre.. Thick-billed Guillemot.

Top of head and hind-neck sooty black; basal portion of cutting edge of upper mandible light colored; sides of head, fore-neck, \&c., snuff brown in summer. Length, 14 to 18 inches; wings, 8 inches; bill, $1 \frac{1}{2}$ inches.

"Is probably not as common as the preceding, but is very generally to be met with during the winter. Have seen them quite abundant off Sandy Hook (December, 1863)."- [C. C. A.]

\section{ALCA, L.}

A. torda, L. Razor-billed Auk.

Bill deep, much compressed, and shorter than head; tail feathers pointed; wings strong; upper parts black; tips of secondaries and lower parts white; in summer, head and neck (except on top) velvety suufl' brown; white line (except in young) from bill to eye; bill crossed by white bar in middle, and with basal lamina; in winter, no lamina, no white line to eye, and snuff brown replaced by white. Length, 15 to 18 inches; wings, 8 
inches; tail, $3 \frac{1}{2}$ inches; bill, $1 \frac{1}{t}$ inches, nearly 1 inch deep. Breeds from Eastern Maine northward.

"Stragglers make their appearance off the coast in winter, but are rarely met, however. Like many allied birds, is more frequent during some seasons than others, and occasionally has been seen as early as October."

\section{ALLE, Link.}

A. alle, L. (Nergulus-Abbott's Catalogue.) Dovekie. Little Auk.

Bill short and broad; head, neck and upper parts black; secondaries tipped with white; white below; flanks and scapulars streaked; in summer the sides of head, neck, chest, \&c., are dark sooty brown; in winter white. Length, 7 to 9 inches; wings, $4 \frac{1}{2}$ inches; bill, $\frac{1}{2}$ inch.

"Known in some localities as 'sea-dove.' Appears off the coast about the middle of November, and is seen until the beginning of March. They sit out some distance from the beach, generally two or three at a time. Never are met with in the bays. None breed in the State."

The Great Auk, Plautus. impennis, L. (length, 28 to 30 inches,) of coasts of North Atlantic south to Massachusetts Bay, has not been abundant since 1844 , and is now believed to be extinct. 


\section{CLASS REPTILIA.}

\section{Order CHELONIA.}

(TESTUDINATA.)

\section{Family EMYDID王. \\ Pond Turtles. \\ CISTUDO, Flem.}

C. carolina, L. (virginea.) Common Box Turtle, or Tortoise.

Carapace very convex; plastron divided by transverse hinge into two or more movable pieces; toes hardly webbed; colors variable, chiefly blackish, variegated with yellow. Live in dry woods.

"A very abundant species, that should be encouraged in every garden in the State, as they wage an unending war against a multitude of noxious creatures. The habit of cutting initials upon the shell of this animal has resulted in proving it to be an animal of long life. Instances of this, showing the animal to have been from fifty to eighty years of age, have come under the notice of the writer."-[C. C. A.]

\section{CHELOPUS, Raf.}

C. muhlenbergii (Schw.), Cope (Calemys-Abbott's Catalogrue). IIuhlenberg's Tortoise. Water Turtle.

Carapace elongated, arched; plastron immovable; toes short, with small web; habits semi-aquatic; size small; no round spots on shell; upper jaw deeply notched; orange spot on each side of neck; plastron black, with central yellow; carapace brown, with yellow markings. Length, $4 \frac{1}{2}$ inches.

"Equally abundant with $N$. guttatus, and generally found associated with it. They feed upon fish, and are inoffensive in every way." 


\section{GEOLOGICAL SURVEY OF NEW JERSEY.}

C. insculptus, Le C. (Glyptemys, Ag.) Wood Tortoise, or Terrapin.

Upper jaw broad at end; width of jaw less than forehead; tip of lower jaw curved up; shell marked with concentric strie and radiating lines; a black patch on each plate of plastron. Length, 8 inches.

"This reptile does not appear to be an abundant species. It is less aquatic than the preceding species, and is generally met with in woodlands."

\section{NANEMYS, Ag.}

N. guttatus, Schn. Speckled Tortoise. Spotted Turtle.

Upper jaw slightly notched; shell not carinated; black, dotted with orange; plastron yellow, blotched with black. Length, 4. inches.

"A very abundant species, inhabiting the creeks throughout the State, and occasionally met with in swampy land which has no running water."

\section{OERYSEMYS, Gray.}

C. picta, Herm. Mud Turtle. Painted Turtle.

Carapace flattish; plastron broadly united at sides to carapace ; toes broadly webbed; hind legs stouter than fore legs; upper jaw notched in front; head with yellow lines; red on neck, tail, legs, dc.; large plates of earapace plain; marginal plates with red markings; greenish black above; yellow below. Length, 8 inches.

"This handsomely-marked species is not very abundant. About equally numerous in the various counties, except where salt water prevails."

\section{MALACOCLEMMYS, Gray.}

M. gøographicus, Le S. (Graptemys, Ag.) Map Turtle.

Upper jaw not notched; carapace keeled, notched behind; lower jaw with spoon-shaped dilatation; head with horny skin; plastron yellowish ; color above dark olive brown, with greenish and yellowish reticulations, especially on edge of carapace, legs, neck, de.

"More common than $P$. migosa, and more generally distri- 
buted throughout the State. The creeks of the central counties generally contain them, associated with the more common species."

M. palustris, Gmel. Terrapin. Salt-marsh Turtle. Diamond-back.

Sheath of jaws straight; concentric dark stripes on plates of both carapace and plastron; color greenish to dark olive.

"The eagerness with which this species is sought, in consequence of the value set upon it as an article of food, has tended to render them scarce. The sea-board counties of the State now furnish but few in comparison with twenty years ago (1868)."

\title{
PSEUDEMYS, Gray.
}

P. rugosa, Shaw (Ptychemys, Ag.) Red-bellied Terrapin.

Jaws serrated; neck with yellow stripes; plastron red or partly yellow; marginal plates of carapace with much red; general color above dusky, with red markings.

"Not an abundant species. This and $M$. geographicus have no apparent peculiarities in habits from the tribe to which they belong."

P. hieroglyphica, Holbr. (Trachemys, Ag.) Hieroglyphic Turtle.

Jaws not serrated ; olive brown, with broad, reticulated, yellow lines; head small. Habitat-Eastern United States. It is desirable to obtain information about this turtle, which may be mistaken for preceding.

\section{Family CINOSTERNID尼.}

\author{
Stink-pots.
}

\section{CINOSTERNUM, Wagl.}

C. pennsylvanicum, Bosc. (Thrynosternum, Ag.) Small Box, or Mud Turtle.

Anterior lobes of plastron nearly equal, and both capable of closing the shell; the posterior one emarginate; carapace highest posterior to center; dusky brown; light stripes and yellow dots on head and neck. Length, 4 inches.

"This species, notwithstanding its specific name, is not an abundant one in New Jersey. More common in the central and southern than northern counties." 


\section{AROMOCHELYS, Gray.}

A. odoratus, Latr. (Ozotheca, Ag.) Mrusk Turtle. Stink-pot.

Head large; jaws strong; lobes of plastron incapable of elosing shell, though movable; posterior lobe narrower, longer and truncate, with pointed angles; carapace dusky, clouded or spotted; two yellow stripes on each side of head; musky odor. Length, 6 inches.

"This disagreeable species is probably the most abundant representative of the turtle tribe in the State. Every creek and mill-pond seems to abound in them, much to the annoyance of the angler."

\section{Family CHELYDRIDA. Snappers.}

CHELYDRA, Schw.

C. serpentina. Common Snapping Turtle.

Shell highest near front; head and neck large; jaws hooked and powerful; tail with a crest of tubercles; plastron small, cross shaped, with narrow bridges; fierce and voracious.

"This species is abundant throughout the State wherever the water is quiet, the mud deep and soft-finned fishes abundant. Mill-ponds and creeks, formed by the draining of extensive meadow lands, are their favorite localities; although they are frequently met with in small brooks and ditches, at a great distance from any water-course of any size. They have no habits that make them obnoxious to the farmer."

\section{Family TRIONYCHIDE.}

Salt-water Turtles.

Soft-shelled Turtles.

ASPIDONECTES, Wagl.

A. spinifer, Le S. Common Soft-shelled Turtle.

Bolly flat, round; carapace not ossified to margins, covered hy a leathery skin; head long, pointed, with flexible snout; feet 
broadly webbed; only three toes with claws; nostrils terminal, crescent shaped; plastron white; head, \&c., olive green, with stripes; legs mottled; back olive brown, with dark spots; male with tubercles on front of carapace, smaller than in female; body also longer.

"This salt-water turtle is quite abundant on our sea-board, but is nowhere very numerous. They are found in all the saltwater rivers and creeks."

- $A M Y D A$, Ag.

A. mutica, Less. Leathery Turtle. Soft-shelled Turtle.

Nostrils under tip of snout; a depression along middle of carapace; no spines on anterior margin, \&c.; feet not mottled.

"Very rare. An occasional specimen has been met with in the Raritan River. None appear to be found in the Delaware. Occasionally seen in the Hudson."

\section{Order LACERTILIA.}

(SAURII.)

\section{Family IGUANID $F$.}

SCELOPORUS, Wieg.

S. undulatus, Harl. (tropiclolepis.) Tree Swift. Pine-tree Lizard. Fence Lizard.

Head broad, not spinous; greenish, bluish or bronzed, with black, wavy cross-bands above; throat and sides of belly with blue or green; dorsal scales carinated; tail slender, brittle. Length, 7 inches. Varies much in color.

"This and the following are the only true lizards found within State limits, and the present species is much the more commonly met with of the two. It appears to be about equally distributed throughout the State, and disappears from localities in proportion as the timber is cut off. The popular appellation of 'fence 
lizard' is well chosen, as they seem exceedingly partial to rough worm-fences that enclose unfrequented fields. The food of this attractive little animal consists wholly of insects and their larve, as found beneath the decayed bark of prostrate trees or fence rails. They are incapable of inflicting any wound, when captured, and are wholly free from the venomous sting not unfrequently attributed to them. Their habits render them a valuable animal, and they should be free from the molestation so common."

\section{Family SCINCID}

\section{Skinlrs.}

\section{EUMECES, Wieg.}

(Plestiodon.)

E. fasciatus, L. (P. striatus-Abbott's Catalogue.) Blue-tailed Lizard.

Head sub-quadrangular; body fusiform; ear large; color blackish, with five yellowish streaks, the middle one forked, on head; tail blue; old specimens reddish. Length, 8 to 11 inches. Prof. Frank L. Nason reports having seen this secretive animal on a mountain ridge three miles west of Midvale, near Wanaque mine.-J. N.

"This beautiful skink is less generally distributed throughout the State, being most usually met with in the dense swamp: of the southern counties. They are extremely shy and seminocturnal in their habits, so that unless diligently sought for, are not often seen. The food of this species is insects and their larva, which they hunt for diligently under the decaying bark of trees; in which locality, too, they themselves generally rest during the day. The motions of this little animal are the most rapid of any creature of the State fauna. They are very difficult of capture. They, like the preceding, camnot bite so as to inflict a wound, and are not venomous." 


\section{Order OPHIDIA.}

SERPENTS.

\section{Family COLUBRID}

Harmless Snakes.

"The species belonging to this family are not all harmless, but so far as the family is represented in this State, are so without any exception. They are all of great value to the agriculturist, and the popular prejudice against serpents of all kinds should be done away with, so far, at least, as the following species are concerned."[C. C. A.]

\section{BETERODON, Beauv.}

B. platyrhinus, Latr. Adder. Blowing Viper. Hog-nose Snake.

Brownish, with twenty-eight dark dorsal blotches, besides lateral ones and half rings on tail ; sometimes all black. Length, 30 inches; ventral plates (gasterosteges), 125 to 150 ; number of rows of scales, 25.

"This abundant species is generally known as the 'adder,' and in consequence of its habit of flattening its head and swelling its neck, when surprised, it is looked upon as very venomous, but is in reality very harmless. The species is sometimes found almost entirely black, and is generally looked upon as a different animal."

\section{TROPIDONOTUS, Kuhl.}

T. sipedon, L. Water Snake. Water Adder.

Brownish; back and sides with each a series of large, square, dark blotches, alternating with each other. Length, 30 to 50 inches; gasterosteges, 130 to 150 ; number of rows of scales, 23.

"Very abundant. When fully grown is about five feet in length, and appears to be a dangerous reptile, but such is not the case. It feeds upon fish and frogs."

T. leberis, L. Leather Snake. [Garter Snake.]

Chestnut brown; a yellow lateral band and three narrow, black dorsal stripes; scales all carinated. Number of rows of scales, 19 ; gasterosteges, 140 to 150 ; length, 24 inches. 
"This well-known species is similar in all respects to $E$. sirtalis, and equally merits the good will of the gardener. Thiand the sirtalis are very frequently met with in the yards of our cities."

\section{TROPIDOCLONIUM, Cope.}

T. kirtlandi, Kenn. Kirtland's Snake. Little Red Snake.

Head shiny black; general color brown; belly salmon, with a row of black spots on each side; scales carinated. Number of rows of scales, 19 ; gasterosteges, 115 to 140 ; length, 8 inches. "Ohio to Illinois." - Jordan.

"A single specimen of this beautiful little snake was captured by the writer in 1859, and a second has been seen, that the author failed to secure. These only are known to have ever been met with. The specimen was described from specimens taken in Ohio." - [C. C. A.] Perhaps refers to the following.

\section{STORERIA, Bd. \& Grd.}

S. occipitomaculata, Stor. Red-bellied Snake.

Grayish or chestnut brown, paler on middle of back, with lots; obscure dots ou side; three pale blotches on occiput; belly salmon red. Number of rows of scales, 15; gasterosteges, 120 to 125 ; length, 12 inches. United States; chiefly eastward. Abundant.

S. dekayi, Holbr. (Tropidonotus.) De Kay's Brown Snake. [House Snake. $]$

Grayish brown; clay-colored dorsal band bordered by dotted lines; grayish below; body thickish, tapering towards the small head. Number of rows of scales, 17; gasterosteges, 125 to 130 ; length, 12 inches.

"This lively little snake is not a very abundant species, and is frequently met with in yards, about pumps, sinks and other moist places. It feeds largely upon grasshoppers, insects, \&c."

EUT ENIA, Bd. \& Grd.

E. sirtalis, L. Common Garter Snake. Striped Snake.

Olivaceous dorsal stripe narrow; lateral stripes broad but faint. Gasterosteges, 130 to 160 ; number of rows of scales, 19. Very variable. The prominent varieties are: 
Var. ordinata, L.

Stripes dull, but spots distinct.

Var. dorsalis, Bd. \& Grd.

With broad dorsal stripe and row of distinct spots above lateral stripe.

"This numerous species is exceedingly abundant, and is of value to the gardener, from the fact of feeding, during the summer season, very largely upon grasshoppers."

E. saurita, L. Swift Garter Snake. Riband Snake.

Body more slender, with longer tail; brown, with three yellow stripes; colors bright. Gasterosteges, 150 to 160 ; length, 36 inches. Chiefly east of Alleghanies.

BASCANIUM, Bd. \& Grd.

B. constrictor, L. (Coryphodon, Dum. \& Bib.) Black Snake.

Pitch black; greenish below; chin and throat white; young olive, with rhomboid patches; large and slender. Number of rows of scales, 17 to 19 ; gasterosteges, 170 to 200 ; length, 50 to 60 inches.

"This well-known serpent appears to be growing less abundant every year. They are not as numerous in the northern as in the central and southern counties. The fully-grown specimens measure over six feet. Perfectly harmless."

\section{PITYOPHIS, Holbr.}

P. melanoleucus, Daud. Pine Snake. Bull Snake.

White, with chestnut-brown blotches margined with black, besides other markings. Number of rows of scales, $29^{\circ}$; gasterosteges, 220 to 230 ; length, 60 inches. Pine woods, New Jersey to Ohio, and southward.-Jordan.

\section{COLUBER, L.}

(Scotophis, Bd. \& Grd.)

C. obsoletus, Say (alleghaniensis, Holbr.) Pilot Snake. Racer.

Black; some scales white edged. Number of rows of scales, 27 ; gasterosteges, 235 ; length, 50 to 75 inches. Massachusetts to Illinois and Texas. Possibly often mistaken for B. constrictor, above. 


\section{\$46 GEOLOGICAL SURVEY OF NEW JERSEY.}

C. vulpinus, Bd. \& Grd. Fox Snake.

Light brown, with quadrate, chocolate-colored blotches. Number of rows of scales, 25 ; gasterosteges, 200 to 210 ; lengrth, 60 inches. Massachusetts to Kansas and northward.-Jordan. If this occurs at all in New Jersey it must be in the northern counties.

\section{PHYLLOPHILOPHIS, Garm.}

(Opheodrys - Abbott's Catalogue.)

P. æstivus, L. Summer Green Snake.

Head conical; neck small; yellowish below; clear green above. Number of rows of scales, 17 ; gasterosteges, 150 to 160 ; length, 30 inches. Southern; northern limit, New Jersey. Abundant in mountains.

"Perhaps is rather more abundant than the following. Their appearance in towns is occasionally noticed, when their uniform green color and active movements attract very general attention."

\section{CYCLOPHIS, Günth.}

(Liopeltis-Abbott's Catalogue.)

O. vernalis, De K. Green Snake. Grass Snake. Spring Snake

Head elongate; neck slender; eyes large; yellowish below; otherwise uniformly green (bluish in spirits). Number of rows of scales, 15; gasterosteges, 130 to 140 ; length, 20 inches. More northerly than preceding.

"This and the preceding species are neither abundant, and appear to be about equally distributed throughout the various sections of the State. The food consists wholly of the larger insects."

\section{DIADOPHIS, Bd. \& Grd.}

(Ablabes, Dum. \& Bib.)

D. punctatus, L. Ring-necked Snake.

Head depressed; eye large; blue black above; pale orange below; each plate with black spots; yellow occipital ring conspicuous. Number of rows of scales, 15; gasterosteges, 140 to 160 ; length, 15 inches.

"Not an abundant species. In Mercer and the central counties they are but seldom met with, but are found in greater 
numbers in Sussex and Warren counties. They feed upon very young mice and the eggs of birds, in the spring." - [C. C. A.]

OPHIBOLUS, Bd. \& Grd.

(Coronella. Iampropeltis.)

O. getulus, L. Chain Snake. Thunder Snake. King Snake.

Black, with narrow yellow lines forking on flanks, each fork embracing a large black spot; belly checkered. Number of rows of scales, 21 ; gasterosteges, 210 to 225 ; length, 50 inches. Maryland and South.-Jordan.

"This large serpent is found only in the southern counties. It is perfectly harmless. It is called also 'pine snake."

O. doliatus, L. Red Snake. Corn Snake. Calico Snake.

Red, with twenty to twenty-five pairs of black rings, each set enclosing a yellowish one; head red. Number of rows of scales, 21; gasterosteges, 180 to 210 ; length 30 to 50 inches. Maryland and South. Very variable, and grades into following species or variety.

"Very similar to the next in all its habits. Perhaps not as frequently met with. The food of this and the following species renders them of value to the agriculturist, in many ways."

Var. triangulus, Boie (C. eximia, De K.) Milk Snake. House Snake. Spotted Adder.

Grayish, with three series of brown, rounded blotches bordered by black; about fifty of them in the dorsal row; an arrowshaped occipital spot. Scales, \&c., as in preceding. Ranges more northerly.

"Not very abundant, and is a stupid, inoffensive species. It feeds principally upon mice and moles."

\section{CARPHOPHIOPS, Gerv.}

(Celuta, Bd. \& Grd.)

C. amœnus, Say. Ground Snake. Milk Snake.

Chestnut brown, glossy; belly salmon red; head small. Number of rows of scales, 13 ; gasterosteges, 120 to 130 ; length, 12 inches.

"This common little snake is well known to farmers as having 
a decided predilection to dairies and cellars. Beyond the trouble caused by their fondness of milk, however, they are of no harm. They feed also upon grasshoppers."

\section{Family CROTALID}

\section{Poisonous Snalios.}

These snakes are known by the triangular head, which has a pit between the nostril and eye. There are three American genera, two of which occur on the Atlantic side of the Alleghanies.

\section{CROTALUS, L.}

C. horridus, L. Banded or Northern Rattlesnake.

Tail provided with a rattle of horny epidermal rings; scales on top of head small, the largest in front; general color sulphur brown in various shades, with two rows of confluent, brown, lozenge-shaped spots; tail black; scales carinate. Number of rows of scales, 23 to 25 ; gasterosteges, 165 to 170 ; length, 40 to 60 inches.

"This dreaded serpent is found only in the southern counties of the State, and is not abundant except in a few limited localities. No specimens have been taken north of Trenton or New Brunswick during the past fifty years" (1868).-[C. C. A.]

\section{ANCISTRODON, Beauv.}

(Toxicophis. Trigonocephalus, Holbr.)

A. contortrix, L. Copperhead.

Hazel brown; top of head coppery; back with a series of twenty-five dark blotches of the form of $\mathrm{Y}$; yellowish below, with dark blotches. Number of rows of scales, 23 ; gasterosteges, 150 to 160 ; length, 35 to 40 inches.

"This venomous species is rare within State limits, and only to be met with in the northern mountainous districts. The author has seen a single specimen, which was killed near Newton, Sussex county, in November, 1864."-[C. C. A.] 


\section{CuAss AIMPHIBIA.}

(Batrachia.)

\section{Batrachians.}

These were, of old, classed with the reptiles, but are now seen to be more closely allied to the fishes, constituting the group Ichthyopsida, while the true Reptilia are included with the birds (Aves) in the group Sauropsida.

\section{Order ANURA.}

\section{Family RANID 2 .}

\section{Frogs.}

RANA, I.

R. virescens, Kalm (halecina-Abbott's Catalogue.) Leopard Frog. Shad Frog. Common Frog.

General color greenish, sometimes brassy, with many paleedged dark spots in two irregular rows on the back; usually two large spots between the eyes; legs barred above; belly pearly or yellowish; each side of back with a well-marked fold.

"Very abundant. Found in greater numbers along the banks of the larger streams than in the swamps and meadow lands."

R. palustris, Le C. Pickerel Frog.

Brownish, with square spots in four rows; young golden green; two glandular folds on each side.

"Numerous. This species is among the first to give notice of the approach of spring, by its monotonous 'singing."

R. clamata, Daud. (fontinalis, Le C.) Green Frog. Spring Frog.

Bright green, darker on flanks; everywhere spotted with small dots ; white below.

"The most common species of the small frogs. The common name is aptly chosen, as it is essentially a clear-water, springloving creature.

"R. horiconensis, Holbr. 
"Not as abundant as some others of the 'frog' family. Useful as a mosquito killer." To be considered as only a variety of the foregoing species, $R$. clamata.

R. catesbiana, Shaw (pipiens, Auct.) Bull Frog.

Greenish, of various shades, with numerous small, indistinct, larker spots; head usually bright pale green; glandular folds not as marked as in preceding. Size large, sometimes over 12 inches.

"Abundant wherever there is sufficient quiet water to warrant the growth of water lilies. Eagerly sought for by epicures."

R. silvatica, Le C. (cantabrigensis, Bd.) Wood Frog.

Reddish brown; a dark band on each side of head through eye; size small; searcely aquatic.

"This handsome frog does not appear to be as numerous as its predecessors. It is found wholly in moist spots in timber land, where it feeds upon the numerous insects found among dead leaves." $R$. cantibrigensis is a distinct variety.

\section{Family SCAPHIOPIDE.}

Spade Foots.

SCAPHIOPUS, Holbr.

S. holbrookii, Harl. (solitarius, Holbr.) Solitary (or Hermit) Spade Foot.

Heel bears a sharp-edged spur; color olive brown; a pale yellow streak on each side; burrows in the ground.

"This little frog is not abundant, and is generally met with, when found, in the southern counties of the State."

\section{Family HYLID E.}

Tree-tonds.

HYLA, Laur.

ㅍ. versicolor, Le C. Common Tree-toad. Green Tree-toad, \&c.

Small-sized arboreal frogs, with toes expanded into disks and noted for their shrill voices. The disks are round, well devel- 
oped; toes one-third webbed ; very variable in color, green, gray or brown, with irregular dark spots.

"Very abundant throughout the State, although not easily discovered, as the animal is so generally the precise color of the tree it rests upon."

Var. viridis (of $H$. versicolor, above). Green Tree-toad.

"Quite abundant in the central and southern counties. Generally found in swampy lands."

H. pickeringii, Holbr. Pickering's Tree-toad.

Yellowish brown, with dusky rhomboid spots and lines, sometimes arranged in the form of a cross.

"Very common. It is one of the most numerous species of this family found in the State. The 'song' is more melodious than the generality of sounds made by tree-toads. Frequents swampy grounds. The food of all these species consists of insects."

H. andersonii, Bd. Anderson's Tree-toad. Green and Yellow Treetoad.

Color pea green, with irregular yellow spots on sides; a purplish band on sides of head. Rare.

"A southern species, a single specimen of which was found (by Dr. J. Leidy) in Camden county, in 1863." Rev. Dr. John E. Peters, of Pleasantville, N. J., reports finding a specimen June 1st, 1888, at May's Landing, N. J., in a wet place on the border of a pine barren. Its voice consists of a repetition of a short note (or "peep") three or four times (see Am. Nat., Jan., 1889). Abbott describes its note in captivity as a "keck," nearly like that of the Virginia rail (Am. Nat., Feb., 1890).

\section{ACRIS, Dum. \& Bibr.}

A. gryllus, var. crepitans, Bd. Cricket Frog. Savannah Cricket.

Disks small; webs only on hind feet; tympanum indistinct; brownish above; middle of back and head green, with dark triangle between eyes; sides with three oblique blotches; white line from eye to ear.

"Not an abundant species, and more usually met with in the southern third of the State." 
CHOROPHILUS, Bd.

C. triseriatus, Cope. Little Tree Frog.

Toes not webbed; tympanum distinct. Abundant near Gloucester (Cope, Bul. 34, U. S. Nat. Mus., 1889).

\section{Family BUFONIDE. \\ Toads.}

BUFO, Laur.

B. lentiginosus, var americanus, Le C. American Hop-toad.

Brownish olive, with yellowish vertebral line and some brownish spots; adults warty; young nearly smooth. Very variable.

"One of the most abundant, if not quite so, of the 'reptiles' of the State's fauna, and probably the combined benefits derived from the other reptiles would not equal that conferred by the toads. It is safe to say that from May 1st to September 1st the toads destroy daily, in our State, one million of flies, or in the time mentioned, one hundred and twenty-three millions. This alone should, and does in a measure, protect this creature from the uncalled-for, unchristian prejudice against the Reptilia as a class, all of which, save the two venomous snakes, are of value to the farmer; and the dead snakes especially so frequently seen upon farms, are in all cases dead losses; and it is hoped that all those who have it in their power to decrease the ignorance of the value of animal life, will use it to the prompt, inestimable advantage of our agricultural interests."

\section{Order URODELA.}

\section{Family SALAMANDRID王.}

Newts, or Salamnnders.

DIEMYCTYLUS, Raf.

(Notophthalmus, Raf.)

D. viridescens, Raf. Spotted Triton. Newt. Evet. Eft. [Salamander.]

Outer and inner toes of hind feet rudimentary; above olive green of varying shades; lemon' yellow below; sides with large 
vermilion spots, each surrounded by a black ring; back with a pale streak; belly with dots.

"We have frequently found this salamander in the many brooks that run into the Delaware, on the Jersey side, from Trenton to Manunka Chunk. They lie upon flat stones, frequently out of water, to which they betake themselves on heing pursued."-[C. C. A.]

D. miniatus, Raft. Red Eft, or Evet.

Color vermilion red of various shades; paler or yellowish below; markings and habits same as preceding, of which it may be a variety.-Cope. Come out after a rain.

"This and the preceding species of reptiles, improperly called 'lizards,' are more or less abundant throughout the State. The present species is not as abundant as the foregoing."

\section{Family DESMOGNATHID里.}

\section{DESMOGNATHUS, Bd.}

D. ochrophœa, Cope. Yellow Desmognath.

Brownish yellow, with brown shade on side; dorsal band yellowish; few spots on back, none on belly; tail rounded. Alleghanies of New York and southward.-Jordan. Should occur in our northern counties. Hard to distinguish from the salamanders (Plethodontida).

D. fusca, Raf. Dusky Salamander. Water Lizard.

Brown above, with gray or purplish spots; becomes blackish with age ; marbled below; eyes prominent ; tail compressed and keeled, as long as head and body; fourteen costal folds.

"This is the most abundant species of the family under consideration. Every brook with a pebbly bottom appears to have any quantity of them. Early in the spring, they may frequently be found some distance from the brook, lying under flat stones. The ground is always moist, however, when they are thus met with. The common name of water lizard is a misnomer, the animal not belonging to the lizard tribe." 


\section{Family PLETHODONTID}

American Salamanders.

\section{HEMIDACTYLIUM, Tschudi.}

H. scutatum, Schl. (melanosticta, Gibbes.) Four-toed Salamander.

Ashy brown above; snout yellow; silvery below, with dots "like inkspots;" tail slender, nearly twice as long as body; head blunt. Rhode Island to Illinois and south.

\section{PLETEODON, Tschudi.}

P. cinereus, var. erythronotus, Green. Red-backed Salamander.

Leaden above, with red dorsal band; belly marbled; body very slender; tail rounded; inner toes rudimentary; costal folds, 16 to 19.

"About as frequently met with as P. glutinosus. The impression that this class of creatures are venomous is erroneous."

P. cinereus, var. cinereus, Green. Gray Salamander.

A variety without dorsal red band.

"Found about rapid streams where there are flat stones, under which it can conceal itself when pursued. The food of these animals is small insects."

P. glutinosus, Green. Viscid Salamander. Blue-spotted Salamander.

Black, with gray lateral blotches and smaller dorsal spots; body stout; tail rounded; inner toes well developed; like the preceding, spends much time out of water.

"Not unfrequently met with in the hilly sections of the State. Very moist land and the bottoms of brooks where it is generally met with."

\section{SPELERPES, Raf.}

S. bilineatus, Green. Two-striped Salamander. Stripe-backed Salamander.

Yellow, with a dark line along each side of back; belly unspotted; tail not keeled. Costal folds, 14; size small.

"Not abundant. More numerous in the northern hilly sections of the State. This and the following are very scarce in the central counties." 
S. longicaudus, Green. Cave Salamander. [Slender Salamander.]

Lemon yellow; many black spots on sides, also a median series on back, none on belly; tail keeled, very long, spotted or barred with black. Size large; costal folds, 13.

"Not abundant. Frequents similar rocky land as the above, and is found associated with it."

S. ruber, Daud. (Pseudotriton, Bd.) Red Triton.

Vermilion red, with black or brown spots; head wide. Costal folds, 15 ; size large. A variable species.

"Not as abundant as the next, and found in the same portions of the State."

\section{GYRINOPHILUS, Cope.}

G. porphyriticus, Green (S. salmonea, Stor.) Purple Salamander. [Y Yellow Triton.]

Uniform purplish gray above; head broad; tail rounded at base, not finned; size large; aquatic. "It suaps fiercely but harmlessly, and throws its body into contortions in terror."Cope. Alleghany system.

"Not abundant. This species is met with about Trenton and the central portions of the State." I should judge from the name "Yellow Triton," bracketed above, that the S. longicaudus was intended.-J. N.

\section{Family AMBLYSTOMID压.}

Big Salamanders.

AMBLYSTOMA, Tschudi.

A. opacum, Grav. (fasciata, Green.) Opaque Salamander.

Black above, with bluish-gray bars; belly dark blue; no dorsal furrow nor enlarged pores on head. Tail, $2 \frac{1}{2}$ inches in length ; body stout; costal grooves, 11.

"About as abundant as A. tigrinum, and is more generally distributed, although not as abundant in Sussex and Warren counties as in Cape May county." 
A. punctatum, L. (venenosa, subviolacea.) Large Spotted Salamander. Crimson-spotted Triton.

Black above, with series of yellow spots on each side of back; hody large, broad, depressed and swollen; skin with small pores, through which a whitish fluid exudes; several groups of enlarged pores on head; a strong dorsal groove. Tail, $2 \frac{1}{3}$ inches: costal grooves, 11.

"Quite an abundant species in some localities. This species is the one so frequently seen in aquaria, where it shows to great advantage, by its graceful movements and the brilliancy of its coloring. 'The food of this and of the preceding, and of A. jeffersonianum, is flies."

A. conspersum, Cope. Smaller Spotted Salamander.

Lead colored; one or two series of small yellow spots on

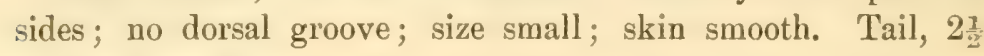
inches; costal grooves, 11.

"The author has only met with a single specimen of this species in New Jersey. It was discovered lately by $\mathrm{Mr}$. Cope, in Chester county, Pennsylvania."-[C. C. A.]

A. tigrinum, Green (ingens). Tiger Salamander, or Triton.

Brownish, with many yellow spots; body thick; head long and narrowish; tail shorter than head and body; color varies from brown to yellow. Costal grooves, 12 ; two tubercles on sole of foot.

"Found only, apparently, in the southern counties of the State. The only specimen ever captured by the writer was in Cape May county, in a dense cedar swamp."-[C. C. A.]

A. bicolor, Hallow. Two-colored Salamander.

Olive brown, yellowish below, rising in blotches on sides; a few large spots above; legs banded; tail yellow, with brown spots; soles with two tubercles. Costal grooves, 11. New Jersey.-Jordan. Beesley's Point, N. J.-Cope.

A. jeffersonianum, Green. Triton. Jeffersen's Salamander.

Dark leaden, variable, sometimes with bluish spots ; size small. Costal grooves, 12 , but not two tubercles on sole.

"We have not met with this species very frequently. 'The localities in which such animals are found, and the absence of 
any benefit conferred by them upon the agricultural interest, however, renders the absence of any fact concerning them of no importance."-[C. C. A.]

\section{Class PISCES.}

Fishes.

\section{SUB-CLASS IMARSIPOBRANCFII.}

(Cyclostomi.)

Eel-shaped fishes, without limbs, ribs, jaws; nasal aperture single and mouth suctorial (circular).

\section{Order hYPEROTRETA.}

Nostril tube-like, penetrates palate; snout with eight barbels; two comb-like series of teeth on tongue; gill apertures far from head. Burrow into the flesh of other fishes.

\section{Family MYXINID \\ Hagfishes.}

MYXINE, L.

M. glutinosa, L. (limosa, Grd.) Hagfish. Borer. Sleepmarken.

No eyes; two rows of mucous glands below, secreting much slime; blue above, whitish below. Not abundant on our shores.

\section{Order hYPEROARTIA.}

Nasal duct does not penetrate the palate.

\section{Family PETROMYZONTIDE.}

\section{Lampreys.}

Borly naked, cylindrical anteriorly and compressed behind; mouth armed with horny teeth, resting on papillæ; eyes present; seven 
separate gill openings on each side; the young are toothless and have rudimentary eyes.

\section{AMMOCGTES, Dum.}

Maxillary tooth single; lingual teeth not pectinated.

A. appendix, De K. (Ichthyomyzon, Grd.) Lamprey.

Brown, tinged with blue; fins pale amber; one large double tooth in lower side of mouth; dorsal fin begins in front of middle of body; vent near posterior third of body, with conspicuous "appendix" in males in spring. Streams of Southern New England and New York, representing A. niger, small black lamprey, of region west of Alleghanies (length, 6 to 10 inches), which, however, is distinguished by having dorsal fin start further back.

"This small species is very abundant in the majority of our creeks that communicate directly with the rivers. It is very similar in all its habits to the lamper eel."

\section{PETROMYZON, L.}

Maxillary teeth two or three; lingual teeth pectinate.

P. marinus, L. (americanus, Le S.) Great Sea Lamprey.

Head scarcely longer than gill region; numerous teeth on large buccal disk, arranged in oblique series; color olive brown, mottled with blackish patches; dull brownish below. Length, 24 to 36 inches. Enters streams in spring, to spawn.

"This species is quite common in spring along our coast, entering the bays and rivers. It is valued as an article of food, and many are taken and offered for sale in our fish-markets."

P. marinus, var. nigricans, Le S. Lamper Eel. Large Black Lamprey.

Head one-third longer than "chest;" color plain bluish black above, pale below. Length, 12 inches. Usually described from a distinct variety (dorsotus) found in Cayuga I Lake, New York, which has head a little longer and a theshy ridge on hack in front of fin. Our nigricans is supposed to be the young of the preceding species.

"An allied species that is found wherever the previous one is met with." 


\section{SUB-CIASS ELASIMOBRANCFII.}

Fishes with cartilaginous skeleton; heterocercal tail; no air-bladder; embryo with deciduous external gills.

\section{Section SELACHII.}

(Plagiostomi.)

\section{Order SQUALI.}

Sharks.

\section{Famly SPINACID E. \\ Dogfishes.}

Body elongated; head depressed; eyes lateral, without nictitating membrane; mouth and nostrils inferior; five gill openings on each side; two dorsal fins with spines; no anal fin.

\section{SQUALUS, L.}

(Acanthias, Risso.)

S. acanthias, L. (americanus, Stor., sucklii, Grd.) Spiked Dogfish. Bone Dog. Skittle Dog. Hoe.

Body slender; snout pointed; head, $6 \frac{1}{2}$ inches; slate color above, with white spots on back; pale below; teeth small, alike in both jaws; spiracles wide, just back of eyes; gill openings narrow. Length, 12 to 36 inches; weight, 5 to 15 pounds. Their livers valued for oil.

"This is a common species along our coast, and according to Storer, are so numerous at Cape Cod as to form an important fishery for the oil they furnish." 


\section{Family CARCHARIID压.}

Two dorsal and an anal fin, without spines; eyes with nictitating membranes.

\section{MUSTELUS, CUV.}

M. canis, Mitch. (hinnulus, Blainv., mulgaris.) Dogfish. Dog Shark. Smooth Hound.

Mouth with labial folds; teeth flat, without cutting edges; no pit at root of tail; no placenta in development. Smallest of our sharks.

"Quite common, and met with as the thresher."

\section{GALEOCERDO, M. \& H.}

G. tigrinus, M. \& H. Tiger Shark.

Teeth with sharp edges, serrated; a pit at root of tail; a double notch on caudal fin; color brown, with dark spots; caudal fin about one-third of whole length; rather large. Ranges from Cape Cod to the Indian Ocean.

\section{CAROHARIAS, Raf.}

(Cynocephalus. Squalus. Prionodon. Eulamia.)

\section{C. obscurus, Le S. (Platypodon, Gill.) Dusky Shark.}

No spiracles; teeth serrated, upper ones oblique, notched on outer margin, in lower jaw clavate; first dorsal fin large, close behind the pectoral; color dark, clear blue above, white below; large, reaching ten feet. "Frequently taken on our coast." Jordan.

"Not a common species." - [C. C. A.]

O. coruleus, De K. (milberti, caudata, De K.) Small Blue Shark.

Length of snout equal to width of mouth; color slate blue, white below; fius with black tips; pectorals rather small; "pper teeth serrate, not notched; size much as preceding.

"Prof. Baird reports this species quite numerous at Beesley's Point. It is about equally abundant along our coast. Specimens occasionally wander up Delaware Bay, but do not leave the salt water." 


\section{ISOGOMPHODON, Gill. \\ (Carcharias. Prionodon.)}

I. limbatus, M. \& H. Spotted-fin Shark.

Teeth scarcely serrated, narrow in both jaws; suout short and pointed ; gill openings wide; upper edge of pectorals four times length of lower margin; some black on fins. Tropical; straying north.

\section{SCOLIODON, M. \& H.}

(Squalus. Carcharias.)

S. terræ-novæ, Rich. Sharp-nosed Shark.

Teeth flat and oblique, with points turned to right or left away from center; pectoral fins large; ventrals small; color gray; tail fin black edged. Size rather small. Nerfoundland to South America.

\section{Family SPHYRNID王.}

Hammerheads.

\section{SPEYRNA, Raf.}

(Squalus. Cestracion, \&c.)

S. tiburo, L. (Section Reniceps.) Shovel-head Shark. Bonnet-head.

Head kidney shaped; eyes far separated, with nostrils near; front margin of head a semicircle; ashy color. Length, 3 to 6 feet.

"Professor Baird met with this species at Beesley's Point."

S. zygæna, L. (Section Sphyma), (malleus, subarcuatus.) Hammerhead.

Head more truly hammer shaped, width twice its length. Common from Cape Cod southward. Size large.

"Only occasional specimens of the 'hammerhead' are met with along our coast, but this species is more usually seen than the spiked dogfish."

\section{Family ALOPIID}

(Lamnoidea in part.)

Thresher Sharks.

Body moderately elongate ; snout short ; teeth alike, flat, triangular, not serrated ; the third upper tooth much smaller than rest; no nicti- 
tating membrane; spiracles behind and near eye; first dorsal fin large; tail fin as long as body, with a pit at its root and a notch near tip.

\section{ALOPIAS, Raf.}

(Squalus. Alopecias.)

A. vulpes, Gmel. Thresher. Fox Shark. Swingle-tail. Long-tail Sharks, \&c.

For characteristics, see family characters.

"This is a common species, frequently taken on hooks baited for other fish."

\section{Family ODONTASPIDE.}

\section{Sand Sharks.}

Iouth wide; teeth large, long and narrow; gill openings all in front of pectorals; dorsal fins nearly equal ; pectorals short ; no nictitating membrane; spiracles pore-like.

\section{ODONTASPIS, Ag.}

(Carcharias.)

O. littoralis, Mitch. (americanus.) Sand Shark. Shovel-nose.

Teeth awl-like; no basal cusps on first and fourth upper teeth and first lower; body elongate; head pointed; fins small ; color gray. Length, 4 to 6 feet. Voracious.

"This species, described in full by the author, was taken off Beesley's Point."-[C. C. A.]

\section{Family LAMNID}

The Porbeagles.

Size large; body stout; mouth wide; teeth large; lobes of tail fin nearly equal; first dorsal and pectorals large; second dorsal and anal very small; spiracles minute or absent; gill openings wide and lateral. 


\section{ISURUS, Raf. \\ (Oxyrhina. Isuropsis.)}

I. dekayi, Gill. (punctata, De K., glaucus.) Mackerel Shark. Porbeagle.

Snout long and pointed; teeth long, lanceolate, with entire edges without basal cusps; first dorsal inserted well behind the pectorals; dark bluish gray above, white below; middle teeth longest. Length, 10 feet. I. glaucus is the Asiatic species, with shorter pectorals.

"This large species is not unfrequently seen and taken along our coast. It chases the schools of mackerel generally, and is seen on our coast frequently or not, as the latter fish are abundant or otherwise."

\section{Family CETORHINID正.}

Basking Sharks.

Very large, with wide gill openings that reach nearly to middle of throat; teeth small and conical; spiracles small, above corners of mouth ; first dorsal large and midway between the large pectorals and the ventrals.

\section{OETOREINUS, BlainV.}

(Squalus. Selachus.)

C. maximus, Gunner. Basking Shark.

Skin very rough; head and eyes small; nose blunt; teeth in six or more rows of two hundred in each row ; largest of sharks. Length, 40 feet at times.

"Occasionally, in August and September, a specimen of this species is seen, but they are seldom captured. They are a northern species that are seen on our coast only as stragglers."

\section{Order RAife.}

(RAJIDES. BATOIDEI.)

Five pairs of gill openings on the lower surface; no anal fin ; dorsal fin on tail ; body flat, formed laterally of the expanded pectorals; tail slender, with small fin. 


\section{Family TORPEDINID EE.}

Electric Rays.

Body smooth, sharply marked off from thickish tail ; rayerl caudal fin: longitudinal fold on each side of tail ; two dorsal fin-; spiracles well behind eyes; electric organs present.

\section{TORPEDO, Dum.}

T. occidentalis, Stor. Crampfish. Torpedo. Numbfish.

Nouth small, with pointed teeth; first dorsal fin more than twice as large as second ; edges of spiracles smooth ; color black, with obscure darker spots. Atlantic coast. Not common.

\section{Family RAIID正.}

\section{Slkates.}

Disk rhombic, rough ; tail long, spiny ; pectorals extend to snout; ventrals large; eggs laid in horny cases with two "horus" at each end.

\section{RAIA, L.}

R. erinacea, Mitch. (eglanteria.) Common Skate, Hedge-hog Ray. Little Skate. Tobacco-box.

No angle to disk at snout; about fifty rows of teeth; large, close-set, hooked spines on front of pectorals; middle of back nearly smooth; groups of small scales on each side of vent, in females; middle teeth sharp in males, blunt in females; color light brown, with small darker spots; females larger. The smallest of our skates; abundant northward.

"This species is rare. Dr. Mitchill found one on our coast, which is the only specimen recorded as having been seen from New Jersey."

R. ocellata, Mitch. (diaphanes in part, Stor.) Big Skate Ray.

Much like last, but attains length of three feet and has more spines on back, and nearly one hundred rows of teeth. 
"Not uncommon. They are mostly taken in the spring, and are occasionally eaten, but are not prized as an article of food."

$\boldsymbol{R}$. radiata, Donov. (americana, De K.) Starry Ray. Prickly Ray.

Disk forms an obtuse angle at tip of snout ; about forty rows of teeth; besides spines as above, are strong spines with expanded plate-like bases, one or two in front of eye, one between eye and spiracle, a pair on shoulders and fourteen in a dorsal row ; teeth hooked in male; females larger and more spinous.

"Rare. The writer has never met with a specimen, and De Kay reports having seen but one, taken at Staten Island."[C. C. A.]

R. eglanteria, Lac. Brier Ray.

With acute snout; color brown, with bands, bars, blotches, \&c.; with small, very sharp prickles and larger spines in various regions; two rows on each side of tail. Length, 2 feet. Not common.

R. lævis, Mitch. Barndoor Skate.

Angle at tip of snout much produced and shovel-like; rows of teeth nearly forty; spines few and small, most spines on female, as usual; color variable, brownish, with paler spots. Virginia northward.

"Not uncommon. In 1860 a specimen was taken in the Delaware River, above Philadelphia, and exposed in the Trenton market for sale. It was captured in May, in a shad-net, and lived five days out of water, and was afterward kept alive several weeks in a tank made for it."

\section{Family TRIGONID平.}

\section{Sting Rays.}

Disk broader than long; pectorals confluent in front; tail usually whip-like, never bears two dorsals, and usually with a vertical fold and a retrorsely-serrated spine (or several), capable of inflicting a serious wound; sexes alike; ovoviviparous. 


\author{
TRYGON, Adan. \\ (Dasybatis, Walbaum. Dasyatis, Raf.)
}

T. centrura, Mitch. (hastata.) Common Sting Ray. Clam-cracker. Stingaree.

(T. sayi, Le S., is a more southerly species.) Tail more than twice length of disk (less in sayi); round on top, compressed, with lateral series of large tubercles; snout not prominent ; teeth small; color brownish. Length, 8 feet. T. sayi is supposed to be young of other species. Varieties of centrurc (perhaps young in different stages), with shorter tails, smoother skin, dce, have heen distinguished. This species is designated T. sayi by C. C. A.

"Lesseur describes a specimen of ray from New Jersey, in the Journal of the Philadelphia Academy, which is reported by Prof. Baird to have been very abundant at Beesley's Point. It inflicts a poisonous wound with its tail, if not handled with care."

\title{
Family MYLIOBATIDE.
}

Eagle Rays.

Disk broad; pectoral fins not continued to end of suout, but are replaced here by two fleshy "cephalic fins;" tail very slender; fin near its root and a spine; skull raised so eyes and spiracles are lateral; teeth large, hexangular; sexes alike.

\section{MYLIOBATIS, Dum.}

M. freminvillei, Le S. (acuta, Stor., bispinosus, Dum.) Eagle Ray.

Median teeth very broad; disk broad, equal to length of tail; skin smooth; a white prominence over eye; small teeth in three rows at sides of median ones; color reddish brown, with black tail. Cape Cod to Brazil. Not uncommon.

\section{RHINOPTERA, Kuhl.}

R. quadriloba, Le S. Cow-nosed Ray.

Disk emarginate on "snout," which bears two lobed "cephalic 
fins" below ; teeth in seven rows, middle teeth not so large as in preceding; skin nearly smooth; brownish. Attains a large size.

"This is quite common along our coast, especially in September. It feeds largely upon clams, having jarss and teeth sufficiently powerful to crush the shells."

\section{Family CEPHALOPTERID王.}

\section{Sea Devils.}

Very large; disk broader than long; pectorals not extended on sides of head, but anterior part developed as two long, ear-like appendages; mouth wide; teeth small, in many series; eyes well separated, also nostrils; skin rough ; sexes alike; ovoviviparous.

MANTA, Banc.

(Ceratoptera, M. \& H.)

M. birostris, Walf. (vampyrus, Mitch.) Sea Devil. Devil Fish.

Disk broad, with acute exterior angles and concave posterior margins of pectorals; head truncate, with long cephalic fins; teeth present in lower jaw only; tail whip-like, without spine, as long as width of disk ; teeth, one hundred longitudinal series ; skin rough, brownish. Attains a width of 20 feet. Tropical; northward occasionally.

"A specimen of this monster is reported to have been taken in Delaware Bay about 1810. There have been no captures along the coast since, that have been recorded. It is seen along the southern coasts occasionally, but is rare everywhere" (1868). 


\section{SUB-CLASS GANOIDEI.}

Fishes having many structural characters similar to the Elasmobranchs, but with bony plates in skin instead of scales.

\section{Section CHONDROSTEI.}

\section{Order GLANIOSTOMI.}

\section{Family ACIPENSERID王.}

Sturgeons.

Bodly nearly cylindrical, armed with five rows of bony bucklers, each terminating in a spine; mouth small, without teeth, but with barbels; eyes small; gills four besides the opercular gill; no branchiostegals; head covered by bony plates united by sutures; tail heterocereal.

\section{ACIPENSER, L.}

A. sturio, var. oxyrhynchus, Mitch. American Sturgeon.

Snout conical, sharp, depressed; a small spiracle over eye; mouth inferior; barbels between mouth and snout; plates on sides of tail ; not so many lateral plates (twenty-seven to twentynine) as in European sturio. Ascend rivers of Atlantic coast in spring to spawn.

"This is the more common of the two species of sturgeon met with in the Delaware River. They were formerly much more abundant than at present, and it would seem as though they then were generally of much greater dimensions. They are taken in the Delaware as far up as Port Jervis, N. Y."

A. brevirostris, Le S. Short-nosed Sturgeon.

Snout one-fourth length of head; bony plates smaller and further apart. 
"This species is met with in the Delaware in proportion to the other, at about five to one. It never is taken of as large a size. As an article of food it is equally good."

\section{Section HOLOSTEI.}

\section{Order GINGLYMODI.}

\section{Family LEPIDOSTEID正.}

Gar Pikes.

Tail heterocercal ; body covered with rhombic plates, imbricated in oblique series running downward and backward; jaws beak-like, the upper the longer; maxillary bones divided into several; lower jaw of several pieces; mouth armed with series of small and of large teeth, the latter set in a groove and having pulp eavities; no spiracles; pseudobranchiæ, four gills and an additional slit present; air-bladder lung-like, with a glottis; dorsal fin nearly opposite anal.

\section{LEPIDOSTEUS, Lac.}

L. osseus, L. (huronensis, oxyuris.) Common Gar Pike. Billish. Long-nosed Gar. Bony Gar.

Only one row of large, several rows of small teeth; snout slender, more than twice length of head; olivaceous, pale silvery below; posterior part of body with round black spots; a black lateral band in very young. Length, 2 to 5 feet.

"This, the largest of the river fish found in the State, with the exception of the sturgeon, is not abundant in any of the streams, but appears to be more numerous in the Delaware River than elsewhere within State limits. It remains in the river probably throughout the year, and during the summer secretes itself in the patches of tape-grass that grow on the bottom of the stream, and from it dart out ever and anon, to seize some one of the many mammoth chubs that are ever moving about.

"The young of this species are beautifully spotted, with round markings of a dark brown, and until over two feet in length, 
they are the most beautiful of the fresh-water fishes of the State. The young, however, are seldom met with, more seldom, indeed, than adult specimens, which seems to show that the species does not spawn in fresh water, at least not in the Delaware, unless it is in the bay, and that only the grown specimens come, as a general thing, into strictly fresh water.

"This species has been seen in the Delaware at Water Gap, hut" generally they do not go above Trenton."

L. platystomus, Raf. (crassus.) Short-nosed Gar Pike.

Beak a little longer than rest of head. West of Alleghanies; more abundant southward. Fresh water. Doubtful if same as crassus referred to in following.

"Prof. Cope, in the Proceedings of the Academy of Natural Sciences of Philadelphia, makes mention of this species with the following note: 'The type specimen was probably taken in brackish water at Bombay Hook, near the mouth of the Delaware River.' This will indicate a species of gar which must be very rare in the Delaware, as among many specimens nothing agreeing with it has been met with by the writer. In habits it is probably very similar to the preceding, which, however, is a fresh-water fish."

\section{SUB-CLASS TELFOSTEI."}

(Skeleton bony.

\section{Section PHYSOSTOMI.}

Fishe having an open duct hetween the air-bladder and the gullet.

\section{Order NEMATOGNATHI.}

No sub-opercle nor symplectic; supra-oceipital and parietals anchylosed, also (n-ossification of anterior vertebre; precoracoid present; skin naked or with bony plates.

*All the Physostomes except the orders Nematognathi and Apodes, and all the Physoclists except the Pediculati, Plectognathi and Lophobranchii, are often grouped into one order, the T'eleocephali. 


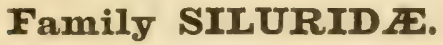 \\ Catfishes.}

Anterior part of head with two or more barbels, the bases of the longest formed by the modified maxillaries; margin of upper jaw formed by the premaxillaries only ; an operculum is present; an adipose fin usually; anterior rays of dorsals and pectorals spinous; airbladder connected with ear by means of auditory ossicles. Our species belong to the division Protopterce, in which the dorsal fin has not more than twelve soft rays.

\section{NOTURUS, Raf.}

N. flavus, Raf. (occidentalis, platycephahus.) Yellow Stone Cat.

Anterior and posterior part of nostril widely separate, the latter provided with a barbel; three other pairs of barbels; head depressed, vomer and palatines toothless; mouth large; eyes small; teeth in a wide band; branchiostegals nine; dorsal with seven branched rays; adipose fin notched, not free posteriorly; tail fin obliquely truncate, ventral edge shortest ; poison gland connected with pectoral spine; color yellow brown, blackish above; fins yellow edged; dorsal spine short; attains length of a foot. Vermont to Virginia and westward; common.

N. gyrinus, Mitch. (sialis, Jord.) Tadpole Stone Cat.

Pectoral spines half as long as head; color pale yellowish brown, with dark streaks on sides; slender; almost ribbon shaped behind; thirteen rays in anal. Common in lake region of New York. Doubtful if in New Jersey.

\section{AMIURUS, Raf.}

(Pimelodus.)

A. catus, L. (atrarius, De K.) Bull-head. Black Catfish. Horned Pout. Small Catfish. Schuylkill Cat, dc.

Adipose fin free posteriorly; head flat, wedge shaped; skin thick; branchiostegals, eight to eleven; dorsal fin higher than long, with six branched rays; lateral line incomplete; caudal fin truncate; color varies from nearly black to yellowish; anal fin about twenty-one rays. Length, 18 inches.

"This fine species is not frequently met with, and only in the 
rivers, where occasionally specimens are captured, associated witl the following common species."

A. vulgaris, Thomps. (dekayi, ailurus.) Long-jawed Cat. Common Catfish.

Lower jaw projects beyond the upper; head longer than broal and narrowed in front; profile steep and convex; color dark reddish or blackish; size of foregoing.

"This is the most abundant species of the catfish found in the State. It is a lover of quiet water's, with a deep deposit of mud on the bottom of the stream. It would not be a misnomer to desiguate it as the 'mud' catfish. They afford moderate sport to the angler, and, except in July and ingust, are a fair article of food. They are less abundant in the smaller creeks of the northern part of the State."

A. natalis, Le S., var. cupreus, Jord. (Silurus lividus, Raf., \&c.) Yellow Cat. Chubby Cat.

Body stout, with large head; upper jaw projecting; color yellowish brown. This may possibly occur in the valley of the Delaware, but it is difficult to distinguish species so variable.

\section{ICTALURUS, Raf.}

I. albidus, Le S. White Catfish. Channel Cat of the Potomac.

Body slender, compressed ; head conical ; branchiostegals eight to nine; six rays in dorsal fin; caudal deeply forked; mouth rather narrow, upper jaw longer; rays of anal fin about twentyone; pale olive bluish above and silvery. below. Length, 18 inches.

"This, as an article of food, is the finest of our catfish species. They are very abundant in tide-water streams, often associated with the white perch, and afford excellent sport to the angler. Large quantities appear in our markets."

I. punctatus, Raf. (Pimelodus corrulescens and many others.) Common Channel Cat. Blue Cat. White Cat, \&c.

Eye large; anal fin short; a complete bony ridge from occiput to dorsal fin; color bluish silvery, with small, round, dark spots ; spines long; skin thin; anal fin short; attains a weight of over twenty pounds. Variable. Probably to be found in the Delaware. 
ARIUS, Cuv. \& Val.

(Ariopsis, Gill.)

A. felis, L. (milberti, Cuv. \& Val.) Sea Catfish.

Anterior and posterior nostrils close together; lower jaw has four barbels; skull with fontanelle; dorsal fin short, rays seven; adipose free behind; tail forked; bony bucklers in neck region; steel blue above, silvery below; mouth small. Length, 24 inches. Cape Cod to Florida; common southward.

"It is somewhat doubtful if this species is met with on our coast, although said to have been taken at New York."

\section{AfLURICHTHYS, Bd. \& Grd.}

F. marinus, Mitch. Oceanic Catfish. Gaff-topsail.

Lower jaw with two barbels; maxillary barbels long; large fontanelle; spines end in a filament. Cape Cod to Mexico.

"This large ocean species is at times very common along our" coast, and is frequently met with of immense size. It has been known to ascend our rivers, but not farther up the Delaware, we believe, than Philadelphia."

\section{Order EVEnTOGNATHI.}

(PLECTOSPONDYLI.)

Physostomes with opercular bones all present, and a symplectic; no interclavicle; four anterior vertebræ co-ossified.

\section{Family CATOSTOMID王.}

Suckers.

Jaws toothless; brain case extends between the orbits; numerous pharyngeal teeth ; maxillaries form part of upper jaw ; head conoid; mouth protractile, with fleshy lips; branchiostegals three; four gills and a posterior slit; head naked; body with cycloid scales; dorsal fin long; anal short; caudal forked; air-bladder with transverse constrictions; flesh full of small bones and of poor flavor. 


\section{ICTIOBUS, Raf.}

(Carpiodes.)

I. cyprinus, Le S. (C. velifer, Cope.) Silvery Carp Sucker. Skim-back.

Sailfish. Spearfish. Quill-back.

Dorsal fin long, rays twenty-six; fontanelle present; scales large: mouth small and horizontal, with thin lips; muzzle conic obtuse; eye large. Chesapeake Bay to Mississippi Valley.

\section{CATOSTOMUS, Le S.}

(Cyprinus. Hylomyzon, Ag.)

C. commersoni, Lac. (teres, bostoniensis, communis.) Common Sucker.

White Sucker. Brook Sucker. Fine-scaled Sucker.

Fontanelle present; body elongate, heavy at shoulders, with large head, flat above; dorsal fins short, rays nine to fourteen; mouth inferior, with thick lips, the lower with two lobes; color olivaceous; males in spring with rosy lateral bands; young brown, mottled. Length, 18 inches.

"The sucker is found generally in the rivers and larger creeks baving easy communication with them. Early in the spring they accumulate in great quantities at the mouths of creeks, and are taken in great numbers from such localities. At this time of year they are an excellent article of food, but as the waters are warmer they grow soft, and have a muddy taste."

C. nigricans, Le S. (Hypentelium.) Hog Sucker. Black Sucker. Stone

Roller. Mud Sucker. Crawl-a-bottom. Hammerhead. Hog Molly. Toter. Stone Lugger, \&c.

Head flat and concare between eyes; upper lip very thick and with eight to ten series of papillæ on its free margin; pectoral fins very large; dorsal ten to eleven rays; eye rather small; olivaceous, with brassy luster on sides; white below; back brown, with blotches; young variegated. Attains a length of two feet. Ascend streams in spring to spawn.

"This species is nowhere abundant in the State, but is met with generally in company with the following species. It is a lover of mud and quiet water, and is less active and restless than the mullet. The writer has met with more black suckers in Crosswicks Creek, Burlington county, than elsewhere in the State."-[C. C.A.] 
ERIMYZON, Jord.

(Moxostoma, Ag.)

E. sucetta, Lac. (Mr. oblongum.) Creekfish. Chub Sucker. Mullet.

Lateral line wanting; body short and deep; dusky above, brassy on sides and below; young with bands and bars; spring males with six tubercles on head; variable; fins rarely reddish. Length, 10 inches or less.

"This species, in a majority of our streams, is the most abundantly represented of any of the family. Although met with in the rivers in summer, they are never so common as in smaller creeks having quiet waters. It is strictly a mud-loving species, and like C. commersoni, is worthless as an article of food, except during the winter and early spring."

\section{MINYTREMA, Jord.}

M. melanops, Raf. Spotted Mullet. Striped Sucker.

Each scale has a black spot, which forms stripes along sides; adults only show traces of lateral line; spring males with many small tubercles on head; dorsal fin high, with twelve rays; dusky above, silvery coppery below. Length, 18 inches. Usually confused with preceding. Should be looked for.

\section{MOXostoma, Raf.}

(Ptychostomus, Ag.)

M. macrolepidotum, Le S. (robustus, oneidı, \&c.) Eastern Red Horse. Lake Mullet. White Sucker. Large-scaled Sucker.

Lateral line complete, scales large, fontanelle present; airbladder in three parts; lower lips not deeply cleft; body compressed; dorsal fin thirteen rays; lips plicate; lower fins red; back smoky; sides reflect brownish and golden. Length, 2 feet. Vermont to South Carolina (and westward as a distinct variety). 


\section{Family CYPRINIDAE. \\ Carps and Minnows.}

Margin of upper jaw formed by premaxillaries only; head naked; branchiostegals three; gills four, slits five, with a pseudobranch; ventral fius abdominal; air-bladder large, often constricted into two lobes.

CHROSOMUS, Raf.

(Luxilus. Leuciscus.)

C. erythrogaster, Raf., var, өos, Cope. Red-bellied Dace.

Lateral line incomplete; dorsal fin well back, short, without spine; sides of body with two black stripes, faint in female; head pointed; mouth terminal and oblique; fins and scales small; color brownish olive, with dusky line on back; silvery on sides and belly, scarlet in males in spring, and fins yellow.

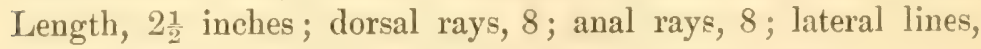
77. Susquehanna basin ; possibly also Delaware basin.

\section{НYBOGNATHUS, Ag.}

\#. argyrites, Grd. (nuchalis, osmerinus, Cope, regius.) Silvery Minnow.

Lateral line complete; mouth oblique; dorsal over ventrals; scales large; eye large; olivaceous green above; sides silvery; head large; upper jaw heavy, lower thin; fins unspotted. Dorsal rays, 8; anal rays, 7 ; length, 5 inches or less. Var. nuchalis, Ag., ranges west, is smaller and has mouth horizontal ; var. regius, Grd., is larger and more southerly.

\section{HYBORHYNCEUS, Ag.}

H. notatus, Raf. (Minnilus, Raf., perspious, Grd.) Blunt-nosed Minnow.

First ray of dorsal short and spine-like; head short; mouth small and inferior, upper jaw protractile; alimentary canal lones; fins short, a black spot on dorsal; males with about fourteen large tubercles on snout in spring; lateral line complete; body elongate; brownish or bluish. Length, 3 to 4 inches. Var. superciliosus, found associated with it, has a broader head and a distinct barbel at each angle of mouth. New York to Tennessee. 


\section{HEMITREMIA, Cope.}

H. bifrenata, Cope (Hybopsis). Eastern Hemitremia. Minnow.

Lateral line incomplete; intestine short; dorsal over ventrals ; scales large; teeth hooked, with grinding surface; body slender ; snout obtuse; jaws oblique; eye large; straw colored, with a black band on sides, silvery below. Dorsal rays, 8 ; length, $1 \frac{1}{2}$ to 2 inches.

"Not as abundant as the following."

\section{OLIOLA, Grd.}

C. procne, Cope (Hybognathus, Hybopsis, Leuciscus). Minnow.

Lateral line complete; dorsal behind ventrals; males in spring prickly, with white and red on fins; body slender; muzzle obtuse; mouth small, inferior, horizontal ; eye large; olivaceous ; a dark dorsal line and leaden lateral band overlying black pigment. Length, $2 \frac{1}{2}$ inches; lateral lines, 32 to 37.

"This and the foregoing allied species are more or less numerous in the Delaware and Raritan Rivers and the inflowing creeks. Their habits are similar and uninteresting."

C. hudsonia, Clint. (Cluper, Hybopsis, Leuciscus, Hudsonius funiatilis.) Silvery Minnow. Spawn-eater.

Head short; muzzle blunt, decurved; top of head flattened, somewhat concave between eyes; jaws horizontal; a dusky spot at base of caudal in young; sides with a broad silvery band; tail fin long. Length, 4 to 8 inches.

"This species is rare, although the writer has met with it in several widely-separated streams. Not numerous in the Delaware River."-[C. C. A.]

C. analostana, Grd. (Cyprinella, Luxilus, Hypsilepis kentuckiensis, Leuciscus, Photogensis spilopterus.) Silver-fin. Shiner.

Teeth serrate, with narrow grinding surfaces; body somewhat compressed, gently arched above and below; mouth small and oblique; lower jaw received within upper; eye small; color leaden silvery; blue in males; a dark vertebral line; fins charged with white pigment in males in spring, also head and front covered with small tubercles. Dorsal and anal rays, 8 ; length, 4 inches; dorsal fin with black spot. 
"This species is numerically ahead of any cyprinoid in the State, if we except the chub. Thousands swarm every brook, and often actually crowd each other to their destruction. Found in the rivers and creeks as well as brooks."

\section{MINNILUS, Raf.}

(Luxilus, Hypsilepis. Lythrurus, \&c.)

M. cornutus, Mitch, var. cornutus (chrysocephalus, Plergyrus uryentutus. dc.) Common Shiner. Red-fin. Dace. Rough-head.

Teeth with narrow grinding surface; scales large, but only narrowly exposed; abdomen rounded; males in spring with red (not white) fins, and with tubercles on head; snout blunt; body compressed and growing deeper in front with age; mouth nearly horizontal; dorsal over ventrals in young, further back with age; steel blue above, with golden bands; sides silvery (rosy in spring males); twenty-two to twenty-five scales in front of dorsal fin; fewer in western and southern varieties. Length, 5 to 8 inches.

"Very abundant in all the streams of flowing, cool water, but apparently more numerous as we ascend into the northern counties of the State."

M. chalybæus, Cope (Hybopsis). Pigmy Minnow.

Body with abruptly-elevated back; head flat above, narrow, with pointed muzzle; mouth oblique, lower jaw the longer; eye large; eighteen scales in front of dorsal; brownish above, a broad, black lateral band; belly straw colored; orange in spring males. Length, $1 \frac{1}{2}$ to 2 inches.

"Quite a common species, generally found associated with the Clinostomus and the many-banded minnows."

\section{REINICETHYS, Ag.}

(Argyreus, 8c.)

R. cataractæ, Cuv. \& Val. (nasutus, Ceratichthys, Leuciscus, Gobio.) Long-nosed Dace.

Body not much compressed; mouth small, upper jaw not protractile; a barbel on maxillary; teeth hooked, without grinding surface; scales small ; dorsal behind ventrals; head long, muzzle flat, narrow and prominent; pectoral fins enlarged in male; color olivaceous, paler below, with dusky points; back nearly black 
or mottled; a black spot on operele; no black lateral bands; spring males with lips, cheeks and lower fins crimson. Dorsal rays, 8 ; length, 5 inches. In clear and boisterous streams.

"This less handsome species is not as abundant anywhere in the State as the next, and is generally found associated with it."

R. atronasus, Mitch. (Cyprinus.) Black-nosed Dace.

Barbel minute; dusky silvery below, with a dark lateral band from snout to tail fin; in spring males this (or sometimes whole body) crimson; in summer orange. Dorsal rays, 7; lateral lines, 64 ; length, 3 inches.

"This is a very common species, found in all the spring-water brooks of every county of the State. Its habits present nothing peculiar."

\section{CERATICHTHYS, Bd.}

(Nocomis. Hybopsis.)

C. biguttatus, Kirt. (Semotilus, nebrascensis, cyclotis, stigmaticus.) Horny-head. Horned Chub. Jerker, River Chub.

Barbel on maxillaries; dorsal nearly over ventrals; body robust; head large ; snout conical and blunt; mouth large, lower jaw the shorter; eye small; eighteen scales in front of dorsal; bluish above; sides with coppery and green; belly pale, not silvery, rosy in spring males; fins pale orange, without black spot; a crimson spot on side of head in spring males; sort of crest on head, covered with tubercles. Length; 6 to 9 inches. The most widely diffused of Cyprinidce; everywhere abundant from Pennsylvania to Utah. Not quoted from the Atlantic coast (?).

\section{SEMOTILUS, Raf.}

(Leucosomus. Chilonemus. Cyprinus.)

S. corporalis, Mitch. (dorsalis, cephalus, atromaculatus, speciosus, \&c.) Common Chub. Horned Dace.

Body robust; head large; upper jaw protractile; a small harbel on maxillary; dorsal well back on tapering part of body; scales small and crowded anteriorly; a black spot on base of dorsal; eye small; dusky blue above; band on side in young; belly whitish (rosy in spring males); dark vertebral line; dusky har back of opercle; snout coarsely tuberculate in spring males. Length, 10 inches. 
"This, the northern and Susquehamna species, is rery seldom net with in the Delaware River, or elsewhere within State limit.. It is represented by the next, which may be distinguished therefrom by its much smaller scales. The largest specimens are found in the rivers and large creeks, as the Rancocas. The young generally remain in the smaller, clear-water, rapid rivulets, where they are met with during the spring and summer in abundance."

S. bullaris, Raf. (rhotheus, pulchellus, argenteus.) Rose-colored Chub. Fallfish. Silver Chub. Dace. Roach.

Dorsal nearly above ventrals; scales nearly alike over body; no black dorsal spot; twenty-two scales in front of dorsal ; steel blue above; sides and belly silvery; in spring males rosy below ; largest of our eastern Cyprinida.

"This very common species was long confounded with the northern species, and was first properly named by Prof. Cope. It is the Delaware representative of the corporalis of the Sus(fuehauna, and the pulchellus of the North. It is, when large, a river-frequenting species, but spawns generally in small brooks, where the young remain until five or seven inches long. It is subject to many variations of color, which is dark or light, according to the character of the water in which they are found.

"Dr. Mitchill described a chub as the atromaculatus, which is generally now considered to be the young of this species.

"The largest chub that the writer has succeeded in procuring" weighed three pounds; and this is probably the maximum growth of the species.

"As an article of food they are not much prized, and are sought for only by boys, to whom they afford yuite good sport hy their readiness to take a hook, if well baited.

"In the river they seem to prefer rocky bottoms and swift water, and in the autumn they follow the schools of perch, as though they sought food that these fish left after them.

"The Lepidosteus, or 'Gar,' feeds principally upon the chub, seizing it about the middle, and frequently cutting it entirely in two, when it catches the two pieces and devours them." [C. C. A.] 


\section{SQUALIUS, Bonap.}

(Telestes. Clinostomus. Tigoma, \&c.)

S. funduloides, Grd. (carolinus.) Gold-thread Roach. Rosy Dace.

Teeth compressed, close set, hooked, two-rowed, two teeth in lesser row; teeth without grinding surface; mouth wide and oblique; lower jaw projecting; dorsal fin well backward; head moderate; eye large; dusky above; a dark lateral band below a paler streak; yellowish below, red in spring males.

"This handsome little 'shiner' was found by the writer to be very abundant in the Delaware where the Assanpink Creek enters it; but no specimens were taken in any of the small creeks flowing into the river." $-[$ C. C. A. $]$

S. margaritus, Cope (Leuciscus). Gold-thread Shiner. Pearly Dace.

Body stout; head blunt; mouth small, oblique; eye large; scales small ; fins large; dorsal posterior; dusky olive above; sides silvery; belly white; crimson in spring males. Length, 3 inches; lateral lines, 58 . Susquehanna-basin.

"Associated with the preceding were several specimens of this allied species, which has been lately discovered and described by Prof. Cope, of Haverford College" (1868).

\section{NOTEMIGONUS, Raf.}

(Stilbe. Abramis. Cyprinus.)

N. chrysoleucus, Mitch. (americanus, versicolor, Leuciscus, Leucosomus, Luxilus, \&c.) Golden Shiner. Bream. Roach.

Teeth one-rowed, serrate, with grinding surfaces; lateral line decurved, continuous; abdomen rounded; belly keeled behind vent; tail not keeled; head small, conic; mouth small, oblique, without barbels; dorsal fin well back; clear greenish above; sides silvery and gold; fins yellowish, tipped with orange in spring males. Length, 12 inches; anal rays, 13. Has some resemblance to shad.

"The roach is everywhere met with in New Jersey, preferring still waters, with an excessive growth of vegetation upon the bottom of the stream. In these masses of vegetation it conceals itself from the attacks of the pike, which latter feed almost exclusively upon them." 


\section{CARASSIUS, Nils. \\ C. auratus, L. (Cyprinus.) Goldfish.}

Scales large; no barbels; dorsal long, third ray a spine; anal short, with spine; ventrals well forward; olivaceous, orange and variegated in domestication. Length, 12 inches, variable. China and Japan; now naturalized in many of our eastern streams.-J. \& G.

\section{CYPRINUS, L.}

C. carpio, L. European Carp.

Body robust, compressed; mouth with four long barbels; snout blunt; dorsal long (23 rays), with a stout spine; anal short (8 rays), with spine; olivaceous. Length, 18 inches. Domesticated in Europe and America from Asia. Now many varieties. Six-pound carp have been taken in the Delaware, escaped from private ponds.

\section{Order ISOSPONDYLI.}

No interclavicles nor auditory ossicles; gills four, with slit behind fourth; anterior vertebrie distinct; precoracoid, symplectic and parietals present.

\section{Family ALBULID E.}

\section{Lady-fishos.}

Tail diphycercal; maxillaries help form upper jaw; head naked; dorsal in front of anal; mouth small, horizontal; back of tongue and roof of mouth covered with coarse, pavement-like teeth; boly covered with small, brilliaut scales; snout shaped like that of a pig ; eye large; pseudobranchire present; branchiostegals about fourteen ; belly flattish and scaled; caudal fin widely forked.

\section{ALBULA, Gronov.}

A. vulpes, L. (Esox, L., conorhynchus, Günth.) Lady-fish. Bonefish.

Brilliantly silvery; olivaceous above, with faint streaks aloug the rows of scales; upper lobe of caudal the longer; a peculiar 
band of scales along the back. Dorsal rays, 15; length, 18 inches. Cape Cod to tropics, in all oceans. Not of great food value, but beautiful and gamey.

\section{Family ELOPID王.}

Big-eyed Herrings.

Mouth large; teeth all pointed; body with cycloid scales; mouth broad, with lower jaw prominent; branchiostegals twenty to thirtyfive; dorsal little behind ventrals.

ELOPS, L.

E. saurus, L. Big-eyed Herring.

Body elongate, covered with thin, small, silvery scales; dorsal fin depressible into a sheath of scales; anal smaller and also depressible. Dorsal rays, 20 ; length, 24 inches. Not rare on Atlantic coast.-J. \& G.

"This is a rare fish along our coast, and only straggling specimens are met with. De Kay reports but a single specimen having been seen by him, which was taken in the harbor of New York."-[C. C. A.]

\section{MEGALOPS, Lac.}

M. atlanticus, Cuv. \& Val. Tarpum. Jewfish.

Dorsal behind ventrals; anal fin larger than dorsal; scales large, except on belly; anal with sheath of scales; uniform silvery; back darker. Dorsal rays, 12 ; anal rays, 20. Atlantic Ocean, entering fresh water. Common southward. Extralimital to New Jersey fauna.

\section{Family CLUPEID平.}

Herrings.

No lateral line; body more or less compressed; head naked; jaws equal; maxillaries in three pieces on each side; teeth feeble; pseudobranchiæ present; anal fin long; caudal forked. 
ETRUMEUS, Bleek.

E. teres, De K. (Alosa.) Round Herring. Slender Herring.

Body fusiform; snont pointed; scales cycloid, deciduous; branchiostegals fifteen; anal small; dorsal in front of ventrals; silvery ; olivaceous above ; eye large ; fins small. Dorsal rays, 13.

"This is a rare species of the herring tribe, that occasionally is met with along our coast. The writer found a single specimen at Barnegat 'in the edge of the surf,' as Prof. Baird relates he met with 'a number of specimens' at Beesley's Point. Occasionally it is seen in Delaware Bay." - [C. C. A. $]$

CLUPEA, L.

(Alosa. Pomolobus, \&c.)

C. harengus, L. (elongata, Le S.) Common Herring. "Whitebait" (young).

Bluish; silvery below; body compressed; scales loose; lower jaw projecting; dorsals in front of middle of ventrals ; abdomen serrated in front of and behind ventrals. Dorsal rays, 18. Vomer has an ovate patch of teeth ; spawns in sea.

"The herring is very abundant at times, and then will be almost unknown to the coast."

C. mediocris, Mitch. (mattowacca, lineata.) Hickory Shad. Tailor Herring. Fall Herring.

Bluish silvery; sides with faint stripes; head elongate; body more elliptic, less heavy forward; lower jaw projecting; upper emarginate. Dorsal rays, 15 ; anal rays, 21 ; a few teeth on tongue; ventral scutes prominent, $20+16$. Newfoundland to Florida; of little value as a food fish.

"This is not unknown to our coast, but is only met with in small numbers, during the autumn months."

C. vernalis, Mitch. (pseudoharengus, Wils., tyranmus, Stor.) Alewife. Branch Herring. Gaspereau.

Blue above; sides silvery, with stripes; a black spot behind opercle; body deep and heavy forward; head short; lower jaw projects a little, upper emarginate; eye large; lower lobe of tail fin the longer; dorsal high, 16 rays; anal, 19 rays; ventral scutes, $21+14$. Enters streams to spawn.

"This herring precerles the shad in the Delaware, and is after- 
ward associated with it. It enters the various creeks and many thousands are occasionally taken by nets, in the creeks they have overstocked."

C. æstivalis, Mitch. (A. cyanonoton, Stor.) Glut Herring. Blueback.

Like preceding, but with lower fins and smaller eyes; has peritoneum black; of less value as a food fish; appears later than $C$. vernalis.

C. sapidissima, Wils. (Alosa, prestabilis, De K.) Common Shad.

Bluish above; sides silvery; a dark spot behind opercle, and sometimes others along line dividing the darker back from the sides; body deep; mouth large, jaws equal, the lower fits into notch of upper; cheeks much deeper than long; fins small; dorsal nearer snout than base of caudal; no teeth (except a ferv on jaws, deciduous); preopercle scarcely prolonged anteriorly below. Dorsal rays, 15 ; anal rays, 21 ; ventral scutes, $21+16$.

"The principal shad river in our State is the Delaware, and in this stream they are not now as abundant, nor met with as large as twenty years ago. Many causes have been suggested for the decrease in the yield, and the destruction of the fishery by the erection of dams has been discussed in all its bearings. The diminution of their numbers is dependent, in all probability, upon the marked increase of rockfish, which devour in immense numbers the young shad that in September descend the river to seek winter quarters in the ocean. The attacks of the rockfish also will explain, in a measure, the scarcity of the large specimens occasionally taken, and known as 'brass-backs.'

"The erection of dams above Trenton would not destroy the fisheries if such dams were erected with a 'fish-way' that would enable them to pass up stream, without necessitating them to make an actual leap, which the salmon considers no objection.

"The diminution of the annual catch of shad may also be explained by the prevalence of immense gill-nets in the lower part of the river, which are occasionally so numerous and so completely across the river that it is impossible for any shad to pass them.

"Shad spawn about the 'falls' opposite Trenton, more or less frequently, every summer, but the ova are probably always devoured by the swarms of rockfish and white perch that are ever on the alert for the eggs or the young. The shad appears 
late in February or early in March, according to the weather, and until the end of the season allowed for catching them, they are met with more or less abundantly, going up stream. Above the Delaware Wrater Gap they are seldom plentifully met with.

"Although not generally credited, the shad in May will take the hook, if attractively baited with maple blossoms or insects. The hook must be floated upon the surface of the water and drawn slowly along. If the line is long, so that the boat the angler is in does not scare them, the hook is pretty sure to be seized if there be any shad 'passing up.'"-[C. C. A.]

The shad-catch from the Delaware is now worth nearly half a million dollars annually. Since the government has begun stocking the river, the increase in the run of shad has been remarkable in spite of rockfish, which are thought to prey on the young shad.-J. $\mathbf{N}$.

\section{OPISTHONEMA, Gill.}

(Clupea.)

O. thrissa, Osbeck. Thread Herring.

Bluish above, silvery below; an indistinct bluish shoulder spot; scales fixed; each scale on back with a dark spot, forming longitudinal lines; body compressed, obloug; belly serrate; tongue with small teeth; lower jaw slightly projects; dorsal in front of middle, with a filament. Dorsal rays, 19 ; anal rays, 24 ; scutes, $17+14$. Atlantic; mostly southward. Sometimes poisonous.

"Never abundant, but appears annually along our coast in September. Occasionally they enter Delaware Bay, hut never come to strictly fresh water."

\section{BREVOORTIA, Gill.}

(Clupea.)

B. tyrannus, Latrobe (C. aurea). Menhaden. Mossbunker. Bonyfish. Whitefish. Bugfish. Yellow-tail. Flat-back.

Fins, head, dc., comparatively short; dorsal a little behind ventrals; scales strongly serrated, arranged irregularly; bluish above; sides silvery, with brassy luster; fins yellowish; a large shoulder bloteh, hehind which are often smaller spots. Dorsal 
rays, 19 ; anal rays, 20 ; no teeth; ventral plates, $20+12$; length, 12 to 18 inches. Very abundant on our southern coast; spawns in the sea; the young canned as sardines; adults used for oil and manure.

\section{Family DOROSOMATID $F$.}

Gizzard Shads.

Body short, deep, much compressed, covered with thin, cycloid, deciduous scales; belly sharp edged, serrated; head naked, short; mouth small, inferior, oblique; no teeth; maxillary in two pieces, forming only a small part of jaw; no lateral line; anal fin long and low; caudal forked; stomach like a fowl's gizzard.

\section{DOROSOMA, Raf.}

(Chatoëssus, Cuv.)

D. cepedianum, Le S. (ellipticus.) Gizzard Shad. Hickory Shad.

Silvery; bluish above; young with shoulder spots; dorsal with last ray filamentous; lower lobe of caudal the longer. Dorsal rays, 12 ; anal rays, 31 ; scutes, $17+12$; length, 15 inches. Abundant along our southern shore. Handsome, but not valuable for food.

"Generally preceding the 'shad' in its passage up the river, this large but worthless species appears in greater or less numbers, and entering the various creeks, creates quite a commotion among the juvenile fishermen who may chance to come across them. Occasionally the 'gizzard shad' is carried by a freshet into inland streams, usually having very small outlets, and thus imprisoned they thrive very well. A pond near Trenton was in 1857 thus stocked with them, and is now full of specimens, some weighing five pounds apiece. Along the coast they are not abundant, and like the true 'shad,' they appear to come from the South, to spawn in the fresh waters of the northern rivers." 


\section{Family ENGRAULIDID百.}

Anchovies.

Body elongate, somewhat compressed, covered with thin eycloid seales; mouth extremely large, overlapped by the pig-like snout; the maxillary long and slender, extending backwards; premaxillaries small, firmly joined to maxillaries; teeth small, fine and even, in a single row usually; eye large and far forward; pseudobranchice present; no lateral lines; belly rounded; size small.

\section{STOLEPHORUS, Lac.}

(Engraulis, Cuv.)

S. browni, Gmel. (vittatus, mitchilli, Günth., hiulcus, G.\& B.) Anchovy.

Olivaceous; sides silvery, with a distinct silvery band; snout yuite projecting; teeth strong; dorsal nearer caudal than snout; anal with a sheath of scales; belly has a faintly-serrated edge. Dorsal rays, 12 ; anal rays, 20 ; length. 4 to 6 inches.

"This really valuable little fish appears annually along our coast in extensive schools, and is easily taken."

S. mitchilli, Cuv. \& Val. (duodecim, Cope, vittatus, Stor.)

Very pale; translucent; silvery lateral stripe narrow ; snout and caudal yellowish, with many dark points; a stripe of dark points along back; both jaws toothed; cheeks triangular; anal high (26 rays); dorsal over anal (18 rays). Length, $2 \frac{1}{2}$ inches.

"This is not as common as the preceding, which is so very abundant during August and September."

S. perfasciatus, Poey.

Body quite slender; belly not serrated; head not so deep as browni, more pointed; eye small; maxillary teeth well developed: mandibular ones slender; scales deciduous; lateral silvery stripe broad, bordered above by dusky streaks. Dorsal rays, 12 ; anal rays, 20; length, 4 inches. West Indies; occasional northward.

\section{Family SCOPELIDAE.}

Mouth wide; entire margin of upper jaw formed of premaxillatries; maxillawies small; pseudobranchice present ; cheeks and opercles 
commonly scaly ; adipose fin often present; dorsal of soft rays only ; skeleton weakly ossified; air-bladder small or wanting; intestine short; an oviduct present.

\section{SYNODUS, B. \& S.}

(Saurus, Cuv.)

S. fœtens, L. Lizard-fish. Soury. Sand Pike.

Teeth on palate in a single row on each side; olivaceous; yellowish below; back mottled; head brownish, vermiculated; inside of mouth yellowish; scales, seven rows on cheek, five on opercle; pectoral fin short, ventrals long; scales cycloid; body nearly terete; head depressed, with triangular pointed snout; premaxillary with knife-like teeth, the inner and large ones depressible; also depressible teeth on tongue. Branchiostegals, 12; anal and dorsal rays, 11; length, 12 inches. Common southivard. Not valued as food.

"Rare. Baird found a specimen in Toms River in 1854."

\section{Family SALMONID王.}

\section{Salmonoids.}

Body elongate, covered with cycloid scales; head naked ; maxillary with supplemental bone, forms part of upper jaw margin ; adipose fin present, caudal forked; pectorals placed low; lateral line present; abdomen rounded; air-bladder large; no oviduct.

\section{OSMERUS, L.}

(Salmo. Atherina.)

O. mordax, Mitch. (viridescens, Le S.) American Smelt.

Transparent greenish above, silvery on sides; some dark points on body and fins; body rather slender; head large, long pointed, with large mouth, having strong, fang-like teeth on tongue and vomer; small teeth on maxillary; other teeth on palatines, \&c.; mandible projecting; scales deciduous; dorsal fin begins over ventrals. Branchiostegals, 8 ; dorsal rays, 10 ; anal rays, 15; 
length, 12 inches. (European smelt has larger scales.) Atlantic coast from Virginia northward, entering rivers; sometimes landlocked. Sometimes sold as "frost-fish."

"The Raritan River produces the greater quantity of smelt taken in the State, although they are found in autumn in the Hackensack, Passaic, Hudson and the Delaware. Those found in the Delaware are generally larger, are fewer in number, and are not as highly prized by epicures."

\section{ONCORHYNCHUS, Suckl.}

(Salmo.)

O. tchawytcha, or chouicha, Walb. (quinnat, orientalis.) Columbia River Salmon. Sacramento Salmon, \&c.

Dusky above, silvery below; head darker than body; back, dorsal fin and tail with many black dots; male in October blackish, blotched with reddish; head conic and pointed; vomerine teeth weak; males in fall have jaws elongated and hooked, with large anterior teeth; color darker and body deeper at shoulders; flesh red; paler in fall at breeding season. Dorsal rays, 11 ; anal rays, 16 ; length, 36 inches. Introduced into eastern rivers, attain a weight of 16 to 18 pounds, in California much more; move up river in summer, often a great distance. 30,000,000 pounds are taken yearly in the Columbia River. The Raritan and Delaware Rivers (and tributaries) were stocked with 2:35,000 of the fry of this speeies by Dr. J. H. Slack, in 1874, but have not flourished, though specimens have been seen occasionally (?).

\section{SALMO, L.}

\section{S. salar, L. (sebago, gloveri.) Common Atlantic Salmon.}

Body symmetrical; head low; scales comparatively large, silvery and well imbricated in young, becoming imbedded in adult males; back brownish; many black spots on sides of head, body and fins; red patches in males; the young ("parrs") with eleven dusky cross-bands besides red patches and black spots. Bands, 11; dorsal rays, 11; anal rays, 9. Anadromous, with vomerine teeth little developed; breeding males with lower jaw hooked upwards; upper jaw emarginate. Var. sebago applied to land-locked forms. 
"The Delaware River no longer produces salmon, but the occasional capture of an isolated specimen, warrants the addition of this species to our list of the State's ichthyic fauna. Three several endeavors have been made to 'plant' the salmon in the Delaware, but without success, which cannot be well accounted for, as the water generally is very clear from Trenton upwards, and trout are not unfrequently met with" (1868).

The Delaware, the Raritan and the Passaic have been re-stocked (1874), with similiarly unfavorable results, as in case of preceding species. The water is claimed to be "too muddy."

S. fontinalis, Mitch. (immaculatus, canadensis, hudsonicus.) Brook Trout. Speckled Trout.

Live in fresh water nearly permanently; mouth and eye large; red spots on sides; back mottled with dark patches; dorsal and caudal fins barred; belly in males often red. Var. canadensis refers to specimens that run to sea- "salmon trout"which then are plain silvery. Many local varieties. Dorsal rays, 10 ; anal rays, 9 ; length, 18 inches.

"The mountain streams in the northern portions of the State generally abound in trout, and those brooks that empty directly into the Delaware, in Sussex county, produce very large specimens, which latter are found in the river in midsummer, near the mouths of the small streams."

\section{Family PERCOPSID AE.}

Lateral margins of upper jaw formed by the premaxillaries bearing villiform teeth; mouth small; bones of head cavernous; scales, ctenoid. Branchiostegals, 6 ; dorsal rays, 11 ; anal rays, 8 .

\section{PERCOPSIS, Ag.}

P. guttatus, Ag. Trout Perch.

Pale olivaceous, with silvery stripe along lateral line; obscure dots or spots above; head slender and conical. Length, 6 inches. Spawns in spring. Delaware River, northward and westward. 


\section{Order HAPLOMI.}

No precoracoid nor interclavicles; mouth with teeth; ventral fins abdominal; no adipose fin; symplectic present; parietals separated by the supra-occipital; scapular arch attached to cranium.

\section{Family CYPRINODONTIDE.}

\section{Toothed Minnows.}

Margin of upper jaw formed by premaxillaries only, freely protractile; vent abdominal; body depressed behind, compressed forward, covered with large cycloid scales; no lateral line; head scaly; no pseudobranch; caudal fiu not forked; sexes usually unlike; fins largest in males; many are ovoviviparous.

\section{CYPRINODON, LAc. :}

(Lebias, Cuv.)

C. variegatus, Lac. (ovinus, bovinus, eximius.) Mummichog. Killiefish.

Oviparous; intestine short; carnivorous; teeth incisor-like, notched, in one row; body stout; dorsal rays, 10 ; back arched; male dusky, traces of bars; caudal, dusky bar at base; tips of dorsal and anal dusky; scales with small tubercles in breeding season; female olivaceous; sides silvery, with dark bars, \&c.; a dark spot on dorsal; caudal as in male; dorsal fin behind ventrals. Anal rays, 10 ; rows of scales, 25 ; male, $2 \frac{1}{2}$ inches; female, $1 \frac{1}{2}$ inches. Brackish water.

"This little fish is abundant everywhere, where there is sufficient salt water to sustain them. They wander about in large schools, and are of little value." 


\section{FUNDULUS, Lac.}

(Hydrargyra. Xenisma.)

F. majalis, Walb. (Esox flavulus, Cobitis.) Mayfish, Large Killifish. Rockfish.

Teeth pointed, in bands; dorsal begins in front of anal; branchiostegals six; mouth very oblique; anal very high in males; black cross bars and black dorsal patch in males; females with longitudinal black stripes; size larger than males. Dorsal rays, 12 ; anal rays, 10 ; length, 5 to 6 inches. Largest of our Cyprinodonts; 36 scales in length (along lateral line).

"This is a very common species in the various bays, but is not so numerous as the following."

F. swampinus, Lac.

A southern variety of preceding, with scales a little smaller; color greenish olive, with silvery longitudinal band and twelve to fifteen vertical blackish streaks. Dorsal rays, 14 ; anal rays, 12 ; in lateral line, 43 scales.

"This abundant species is met with along our coast generally, especially along the beach and at the inlets. It goes in large schools, and does not associate much with other species."

F. diaphanus, Le S. (multifasciata.) Spring Minnow.

Body slender; head flat above; fins not large; olivaceous, with sides silvery; fifteen to twenty-five black cross bars; back spotted with black; fins plain; outer teeth not much enlarged. Dorsal rays, 13 ; anal rays, 11 ; lateral line, 40 scales; depth, 12 rows; length, 4 inches.

"This species is abundant in the rivers generally, and in many" creeks."

F. nigrofasciatus, Le S.

Body short and deep; snout obtuse; anal fin short; fins immaculate; males with nine to ten silvery cross bars; female with nine to ten black bars. Dorsal rays, 10 ; anal rays, 9 ; length, $2 \frac{1}{2}$ inches. With next, not common.

F. heteroclitus, L. (Esox, pisculentus, zebra, grandis, floridensis.) Common Killifish. Mummichog. Salt-water Minnow.

Body thick set; back elevated, broad in front; head blunt, flat on top; dorsal further back in female, opening of oviduct 
near tip of anterior ray of anal; teeth in broad bands; males dull green; belly yellow; sides with silvery spots and bars; vertical fins dark, with pale spots; dorsal with dark spot; anal and ventrals and under part of head yellow; young males with dark bars; females plain olivaceous, lighter below. Dorsal rays, 11 ; anal rays, 11 ; scales, $36 \times 13$; length, 3 to 5 inches. Grandis is a larger southern variety, and pisculentus has wider head. Most abundant of Cyprinodonts for United States.

"This is not a very abundant Cyprinodont. It is found associated with allied species. They have no habits peculiar to themselves."

\section{ZYGONECTES, Ag.}

(Micristius.)

Z. cingulatus, Cuv. \& Val. (Fundulus, Hydragyra, Haplochilus, lucix.) Top Minnow.

This genus differs from the preceding in the smaller size, dorsal farther back and smaller; swim on the surface and feed on insects (not exclusively); body short and deep; anal larger than dorsal; ten to twelve vertical dark bars on sides; a black behind a white spot on dorsal; other fins immaculate. Dorsal rays, 8 ; anal rays, 9 .

"Prof. Baird discovered this species at Beesley's Point. It proves to be quite common in the brackish waters of the State, generally."

\section{LUCANIA, Grd.}

L. parva, Bd. \& Grd. (Cyprinodon.) Little Killifish, or Top Minnow.

Elongated; head less than one-fourth the length ; female plain light olive; male, dorsal and caudal bright yellow; anal orange and each margined with black; dorsal with black spot at base. Dorsal rays, 11 ; anal rays, 9 ; rows of scales, 26 to 28 ; very small.

"This species was first made known to naturalists by the description of Baird, who distinguished its specific characters as distinct from the preceding, from specimens taken at Beesley's Point." 


\section{Family UMBRID王.}

Mud Minnows.

Carnivorous; live in mud or among weeds; mouth small ; teeth villiform and equal; lower jaw the longer; scales cycloid, cover head also; caudal fin rounded.

\section{UMBRA, Müll.}

(Melanura, Ag.)

U. limi, Kirt. (annulata, pygmea.) Mudfish. Dogfish. MIud Minnow. Mud Dace.

Dark brown, with white longitudinal streaks, sometimes with cross bars; a black bar at base of caudal; head rather large. Dorsal rays, 13 ; anal rays, 7 ; rows scales, $35 \times 15$; length, 2 to 4 inches; no lateral line; bars, 6 . Eye small; anal shorter than dorsal; mucous pores on preopercle.

"Found in the streams of the State, except in very rapid water."

\section{Family ESOCID在。}

\section{Pikes.}

Head long, with long snout; mouth large, with long eleft, lower jaw the longer; maxillaries form most of margin of upper jaw ; premaxillaries, \&ce., have broad bands of cardiform movable teeth; lower jaw with strong teeth of different sizes; a band of small teeth on tongue; head naked above; scales small.

\section{ESOX, L。}

E. americanus, Gmel. (hucius, niger, fasciatus, ornatus.) Banded Pickerel. Tront Pickerel. Pike.

Cheeks and opercles scaly; body robust; head heavy; snout blunt and short; eye large; dark green, with twenty blackish, curved bars; a bar below eye. Bars, 12 to 13 ; dorsal rays, 11 ; anal rays, 11 ; lateral line, 105 scales; length, 12 inches. 
"This species is generally looked upon as the same with $E$. reticulatus, although so very dissimilar in its markings, and uniformly smaller size. This pike is very generally associated with the reticulatus, and in all its habits is identical. The smaller specimens are generally found in small streams and ditches, with the true 'ditch pike,' feeding on the swarms of small fish that frequent such waters to avoid the attacks of the yellow and white perch. They appear to be uniformly abundant throughout the State, specimens being found in the streams of every county, including Cape May county, where they are met with in abundance and of large size."

Var. porosus, Cope (cypho). Hump-back Pickerel. Ditch Pike.

Has a more arched back, \&c.; sometimes confused with E. umbrosis, the "little pickerel," which has body moderately stout ; eye large; color greenish gray, with eurved bars or reticulations, variable; a dark bar downward from eye and one forward. Dorsal rays, 11 ; anal rays, 11 ; lateral line, 105 scales; length, 12 inches. Mississippi Valley. Extra-limital to New Jersey.

"This small pike prefers small ditches with overhanging banks, yet that have a steady, gentle flow of pure, cool water. In its habits generally it resembles the preceding, and not unfrequently is met with in waters abounding in the larger species. It appears, from the author's observation, to prey principally upon the 'mud minnow', which is itself a ravenous, pike. resembling species. It is not as abundant as the foregoing or the succeeding, and has been found by the writer only in Mercer county."-[C. C. A.]

E. lucius, L. (estor, boreus, deprandus.) Great Lake Pike. Northern Pickerel.

Lower half of opercle bare; light spotted on a darker ground in rows; color greenish gray or bluish gray; black spots on fins. Bands, 15 ; dorsal rays, 17 ; anal rays, 14; lateral line, 123 scales; length, 2 to 4 feet. Common in the East and Great Lake region. Not found in Atlantic coast system of rivers.

E. reticulatus, Le S. (affinis.) Green Pike. Common Eastern Pickerel.

Head prolonged; snout long; eye small; caudal well forked ; green, with golden luster on sides, marked with dark lines and 
streaks, mostly horizontal, producing a reticulated effect; fins plain; a dark band below eye. Bands, 15 ; dorsal rays, 14; anal rays, 13 ; lateral line, 125 scales; length, 2 feet.

"This fine fresh-water fish is abundant throughout the State, inhabiting pretty much every stream and pond, avoiding rapid currents, and delighting in still, deep waters, with a sufficient growth of spatter-dock to conceal them from the sun's rays and general observation, while they lie in wait for any unlucky minnow, shiner, roach or chub that may approach within a limited number of feet of them."

\section{Order APODES. \\ (ENCHYLYCEPHALI. HOLOSTOMI. COLOCEPHALI.) \\ Eels.}

Scapular arch free from cranium; no precoracoid; no ventral fins; increased number of vertebræ; no pseudobranchiæ.

\section{Family ANGUILLID王。}

Eels.

Body serpent shaped ; head conical ; maxillaries wanting or united with premaxillaries; gill openings separate. Includes more than the Anguillidce of Günther.

ANGUILLA, Thun.

(Muræna, L.)

A. rostrata, Le S. (tenuirostris, bostoniensis, tyrannus.) Common American Eel.

Tongue free anteriorly; pectorals present; body with small scales; lower jaw projecting; teeth in bands; head pointed and not short; dorsal one-third of length from snout; distance from front of anal to front of dorsal about equal to length of head; pectoral shorter than mandible; color brown, with yellowish tinge. Length, 50 inches. 
"This, the 'common eel,' is abundant everywhere, and seems equally at home in the rivers and small rivulets, with scarcely sufficient water to cover them."

A. vulgaris, Raf. (acutirostris, Risso.) European Eel.

Distance from snout to dorsal less; from anal to dorsal more; head shorter, and pectoral as long as mandible. Accredited by Günther to New Jersey.

\section{LEPTOCEPHALUS, Gmel.}

(Conger. Murøna.)

L. conger, L. (niger, vulgaris, C., occidentalis and Isognatha oceanicaAbbott's Catalogue.) Conger Eel. Sea Eel.

Jaws equal ; skin scaleless ; lateral line present ; gill opening= large; short patch of teeth on vomer; dorsal close behind pectorals; cleft of mouth deep; pectorals one-third as long as head. Length, 4 to 8 feet; darker above than $A$. rostrata.

"This sea eel is not abundantly met with anywhere along our coast."

SIMENOHELYS, Gill.

S. parasiticus, Gill. (A. macrocephala-Abbott's Catalogue.) Bullheaded Eel (?). Pug-nosed Eel.

Differs in having head blunt at snout; gill opening very short; teeth rounded, none on vomer, \&c.; buries in flesh of halibut. New Foundland banks. It is doubtful if following refers to this and not to a variety of one of preceding.

"Occasionally a heavy-headed species of eel is taken in the Delaware River and brought to the markets. A specimen of this description was purchased by the writer in Trenton market in August, 1865."-[C. C. A.] 


\section{Section PHYSOCLISTI.}

No open connection between gullet and air-bladder; ventral fins near head, often spined; other fins usually spiny; premaxillaries normally form the entire border of upper jaw.

\section{Order SYNENTOGNATHI.}

Scapula united to cranium by a post-temporal bone; lower pharyngeals united; fins without spines; ventral fins abdominal ; no interclavicle ; no distinct supraclavicle.

\section{Family SCOMBEROSOCID EE.}

\section{Garfishes and Flying-fishes.}

With cycloid scales; lateral line low; head scaly; premaxillaries not protractile; pectorals inserted high; lower lobe of caudal the longer; nostrils large and near eye; air-bladder large; carnivorous.

\section{TYLOSURUS, Cocco.}

(Belone, Cuv.)

T. marinus, Bl. \& Schn. (B. truncata, longirostris.) Garfish. Billish. Needle-fish.

Jaws prolonged, forming a beak, with sharp, wide-set teeth; body slender; scales small, deciduous ; bones green ; one ovary ; color green above, silvery below; a silvery lateral stripe; a dark spot above root of pectorals; head flat above, not rugose ; caudal not cleft. Dorsal rays, 15 ; anal rays, 18 ; length, 4 feet.

"This interesting species is more or less abundant in the principal rivers of the State. In the Delaware they are numerous, and entering the Delaware and Raritan Canal at Bordentown, find their way into the basins, where they are left in winter when navigation is closed and the water in the canal is drawn off." 


\section{SCOMBERESOX, Lac.}

(Sayris, Raf.)

S. saurus, Walb. (scutellatum, Le S.) Billfish. Saury. Skipper.

Jaws form a beak, with feeble teeth; lower jaw longer; pectorals and ventrals small; dorsal and anal with finlets; size small, eighteen inches; air-bladder large; color olive brown above, bordered sharply by silvery band; silvery below; head broad above, narrow below, tapering to slender, and pointed beak; caudal forked.

"Occasionally a specimen of this species is caught in the bays, but it does not appear to ever have been abundantly met with."

\section{HEMIREAMPHUS, Cuv.}

H. unifasciatus, Ranz. Half-beak.

Upper jaw short; lower prolonged to beak, red at tip; scales large, deciduous; large plates on head; color greenish, with narrow silvery band. Dorsal rays, 14; anal rays, 15; length, 12 inches. Common southward; run in schools. Cape Cod to Panama and eastward.

\section{HALOCYPSELUS, Weinl.}

H. evolans, L.

Much like next, but with smaller pectorals; olivaceous above, with specks; silvery blue below, pectorals black, with lower border whitish. Dorsal rays, 13; anal rays, 13; 20 scales in front of dorsal. Spawns on Atlantic coast in summer. Not common.

\section{EXOCGTUS, L.}

E. rondeletii, Cuv. \& Val. Flying-fish.

Head blunt; mouth small; teeth feeble; eyes large; scales large, deciduous; no finlets; caudal widely forked; pectorals very long, serving as organs of flight, not by flapping, but as parachutes, the motion having been acquired by strokes of tail before leaping from the water. This species has black ventrals. Dorsal rays, 11 ; aual rays, 11. 
E. noveboracensis, Mitch. Flying-fish.

Dark blue above; pectorals blackish at tip; ventrals white. Dorsal rays, 14 ; anal rays, 9. More common than preceding.

"This species can only be looked upon in the light of a straggler, A specimen, taken at Beesley's Point, is in the museum of the Academy of Natural Sciences, at Philadelphia."

E. exiliens, Gmel. Flying-fish.

Ventrals nearly plain; head not very blunt. Dorsal rays, 11 ; anal rays, 12. Young with five broad transverse bars; pectorals banded; body very slender. E. exiliens was originally applied to the young, E. melanurus to the adults of this species. Occasional on our coast.

\section{CYPSELURUS, Swains.}

C. furcatus, Mitch. (nuttallii.) Double-bearded Flying-fish.

Size small, with two ribbon-like barbels; young with three bands on belly; pectorals marbled with black; dorsal very high. Dorsal rays, 13 ; anal rays, 9.

"This species is not unfrequently seen, but is by no means abundant."

C. comatus, Mitch. Single-bearded Flying-fish.

Greenish above, paler below ; ventrals dusky; eye very large ; barbel very long, with small accessory barbels at its base. Dorsal rays, 12 ; anal rays, 9 ; length, 8 inches. Rare.

"This may be an occasional visitor to our waters, but very rarely does it appear, if at all."

\section{Order LOPHOBRANCHII.}

Gills in tufts; no superior branchihyals, pharyngeals or basihyals; post-temporal co-ossified with cranium; snout produced, having a small, toothless mouth at end; opercle one plate; skin with bony plates; no ventrals. 


\section{Family SYNGNATHID里.}

Pipefishes.

Body long and slender; suout tube-like; gill openings reduced to a small aperture; tail long, with small caudal; males with egg pouch below tail or on abdomen.

\section{SIPHOSTOMA, Raf.}

(Syngnathus.)

S. fuscum, Stor. (peckianus, fasciatus, \&c.) Common Pipefish.

Body six or seven angled, not compressed; tail long; anals minute; lower jaw projecting; breast shields not covered by skin; sides blotched; muzzle shorter than rest of head; dorsal rays, 35 to 40 , fin covering $4+5$ rings; length, 10 inches.

"This is not common in New Jersey, but has been met with in the Hackensack, Passaic and Raritan Rivers. It is much more common in the Hudson."

\section{Family HIPPOCAMPIDE.}

\section{Sea Horses.}

With tail prehensile, without caudal fin; head at right angles to body axis, horse-like in appearance; body compressed ; held vertically in water.

\section{HIPPOCAMPUS, Raf.}

(Syngnathus.)

ㅂ. heptagonus, Raf. (brevirostris, lavicaudatus.) Mediterranean (?) Sea Horse (antiquorum).

Body has tuberculated rings; head with occipital crest; neck curved; egg pouch a sac at base of tail in male; color yellowish brown, with radiating brown lines on cheeks; white band across snout; sides with pale spots (in European specimens, not in American); some of tubercles on back longer than intermediate ones; crest high, with five tubercles and filaments. Dorsal rays, 18 ; anal rays, 4 ; length, 5 inches. Rare. 
H. hudsonius, De K. Common Sea Horse.

Dusky, without spots, but with gray blotches, some on neck, \&c., the most distinst forms an hour-glass figure, extending down each side of back; spines short and blunt, those on head cirrated and weak: Dorsal rays, 19.

"This species is abundant in the brackish waters of the State, but appears to be less so as we proceed south."

\section{Order HEMIBRANCHII.}

Ventral fins abdominal; superior branchihyals and pharyngeals reduced in number; mouth bounded by premaxillaries only ; shoulder girdle and skull differ from ordinary Acanthopteri, with which they are often classed; gills pectinate.

\section{Family FISTULARIIDE.}

\section{Trumpet-fishes.}

Body long, slender, depressed; no scales; bony plates present in skin; head very long, with long, tubular snout, terminating in a narrow mouth; both jaws with minute teeth ; tube capable of dilation ; dorsal without spines, behind ventrals; caudal forked, with middle ray produced into a filament; vertebræ numerous.

\section{FISTULARIA, L.}

(Solenostomus-Abbott's Catalogue.)

F. tabaccaria, L. Trumpet-fish. Pipefish.

Reddish brown, with blue spots; lower jaw longer. Dorsal rays, 14 ; anal rays, 13 . Tropical. Occasional northward.

"Has been seen in our waters, but is very rare."

F. serrata, Cuv. Pipefish.

Skin without dermal plates; grayish; head silvery below; blue spots along back and sides; much like preceding, but broader and more depressed; edges of snout serrated. Dorsal 


\section{GEOLOGICAL SURVEY OF NEW JERSEY.}

rays, 14; anal rays, 13. Rare northward. Perhaps same as preceding.

"This species has also been met with, but very rarely. Northward and to the south they are more frequently seen."

\section{Family GASTEROSTEID E.}

\section{Sticklebacks.}

Head long, but no tubular snout; teeth sharp, in a narrow band, none on vomers; premaxillaries protractile; suborbital plate large; branchiostegals three; no true seales, only bony plates; dorsal with two or more spines; anal and ventral fins with spine; build nest for young, which is defended by male. Destroy eggs and fry of other fishes.

\section{GASTEROSTEUS, L.}

(Pygosteus, Brev.)

G. pungitius, L. (occidentalis, dekayi.) Nine-spined (Many-spined) Stickleback.

Olivaceous above, punctate and barred; silvery below; body slender, compressed, tapering to slender, keeled tail; skeletal plates not all covered by skin; snout blunt; anal spine larger than dorsal. Anal rays, 8 ; length, 3 inches.

"Not an uncommon species in the streams of the State flowing into salt water. The writer has met with them at Trenton."[C.C.A.] The following note concerns a variety of this species: "Pygosteus dekayi.

"Not an uncommon species, resembling in habits the above" (G. pungitius).

G. biaculeatus, Shaw. Two-(Three)-spined Stickleback.

Body mailed; tail naked, not keeled; male blackish in spring, with coppery luster; body short and deep. Soft rays of dorsal, 12 ; of anal, 9 . Northern; probably a variety of next.

"This is a common species about Toms River, and is found in the Delaware River at Philadelphia." 
G. aculeatus, L. (noveboracensis, biaculeatus, niger, trachurus, \&c.) New York Stickleback. Burnstickle. Common Stickleback.

Dark greenish above; sides yellowish; ventrals often red; head long; tail keeled and slender; dorsal spines hinged to plate; large naked area in front of pectorals. Thirteen rays and three spines in dorsal; nine soft rays in anal. Length, 4 inches.

"This is an abundant species, met with along the coast generally:"

\section{APELTES, De $\mathrm{K}$.}

A. quadracus, Mitch. Four-spined Stickleback.

Back elevated ; tail very slender, not keeled; skin naked ; ventrals, when depressed, enclosed by bony ridge ; free dorsal spines three, directed to different sides, first longest; brownish olive; mottled; silvery below; male nearly black; ventrals red in spring. Length, $1 \frac{1}{2}$ to $2 \frac{1}{2}$ inches; 11 soft rays in dorsal ; 8 in anal.

"This species appears, from the writer's investigations, to be the most abundant species of the five. He has taken it in small streams in the interior of the State, at considerable distance from the river, and fully one hundred and fifty miles from the ocean."-[C. C. A.]

\section{Order ACANTHOPTERI.}

\section{Spiny-rayed Fishes.}

Maxillary distinct from premaxillary, which latter forms boundary of mouth; bones of jaws separate, and cranium normal. The most extensive order of fishes, sometimes including also the Hemibranchii, Opisthomi and Pediculati; or sometimes more restricted, the Atherinidce and Mugilidce being classed as Order Percesoces; and the Gadida, Lycodide, Ophidiide, Ammodytidee and Fierasferidce forming the Order Anacanthini. By some authors (European), the Anacanthini also include the Synentognathi and Heterosomata: the group being considered to include fishes with no spines in dorsal and $v \in \mathbf{n}$ trals, the latter being jugular in position. 


\section{Family MUGILID}

\section{Mullets.}

Body oblong, compressed; covered with large cycloid scales; no lateral line; mouth small; teeth feeble; premaxillaries protractile; sill openings wide; branchiostegals five or six; pseudobranchice large; two dorsal fins, the first with four spines; three anal spines; ventrals abdominal; caudal forked; vertebra twenty-four; feed on mud.

\section{MUGIL, L.}

M. albula, L. (lineatus, plumieri.) Striped Mullet. Spotted Mullet.

Head large and blunt, scaled; mouth small; jaws toothless, but cirrated; gizzard connected with stomach; body subterete; dark bluish above; sides silvery, with stripes; a dusky patch at base of pectorals; scales medium; eight soft rays in dorsal or anal; scales, $42 \times 13$. Valued as a food-fish where abundant (South).

"This species is not as numerous as the following. Specimens have been found in Delaware Bay, near the ocean."

M. brasiliensis, Ag. (petrosus, lineatus.) Liza. White Mullet. Rock Muliet.

Scales larger; no stripes; body compressed; dorsal and anal partly scaled; nine soft rays in anal.

"Never abundant along our coast, although annually appearing in August and September, and a few remain through the winter."

\section{Family ATHERINID E.}

Silversides.

Carnivorous, with feeble teeth and with more than twenty-four vertebre; no lateral line; scales cycloid, not large; spines flexible; branchiostegals five or six. 


\section{MENIDIA, Bonap.}

(Argyrea. Labidesthes.)

M. notata, Mitch. Silversides.

Premaxillaries protractile, broad posteriorly, with curved edge, with filiform teeth in a band, none on vomer; lower jaw short; color transparent green, with a lateral silvery band as wide as the large eye; first dorsal of four spines; second with one spine and eight soft rays; anal, one spine and twenty-three rays. Length, 5 inches.

"An abundant species found everywhere along our coast, both in the open sea and the many bays and inlets."

\section{Family SPHYR ENIDEE.}

\section{Barracudas.}

Ventrals abdominal; dorsals well separated ; vertebre twenty-four ; body subterete, with small cycloid scales; head pike-like, scaly ; jaws large, lower projecting; large, sharp teeth present; air-bladder forked in front; lateral line well developed; branchiostegals seven; first dorsal of five stout spines.

\section{SPHYR FINA, Bloch.}

S. spet, Haüy (borealis, vulgaris). Barracuda.

Olivaceous; silvery below; dusky blotches above in young; body slender, with rather large scales; first dorsal inserted some way behind end of pectorals; nine soft rays in second dorsal; anal, 1 spine, 9 soft rays. Length, 24 inches.

"This small fish is generally to be met with in the small streams of the coast counties of the State. There is nothing of interest connected with it, its numbers not making it noticeable except to the collector."

S. guaguancho, Cuv. \& Val.

Differs from preceding in having first dorsal farther forward. Anal, 2 spines and 8 rays; length, 18 inches. Probably the species referred to in remarks appended to preceding. 


\section{Family AMMODYTID死.}

\section{Sand Launces.}

Scales small, cycloid; head long; mouth large; no teeth; gill openings very wide; psendobranchs large; premaxillaries very protractile; spinous part of dorsal nearly absent; soft part extends along nearly whole of back; no ventrals; no air-blarlder; size small : swim in schools and often bury in sand.

\section{AMMODYTES, L.}

A. americanus, De K. Sand Launce (or Lance). Sand Eel. Lant.

Body lanceolate, with twenty-five transverse, oblique folds of skin having cross series of small cycloid scales between them; a fold of skin along each side of belly; color olivaceous above, silvery below; sides with a steel-blue stripe. Dorsal rays, 60 ; anal rays, 28.

"This curious fish is not unfrequently met with in our waters, but does not appear to be abundant at any time."

\section{Family ECHENEIDID更.}

Remoras.

Body fusiform, with minute cycloid scales; mouth wide, with villiform teeth on jaws, vomer, dc. ; premaxillaries not protractile; lower jaw projects beyond upper; spinous dorsal modified into a sucking disk on top of neck, by which the fishes attach themselves to Hoating objects; ventrals thoracic; no air-bladder.

\section{EOHENEIS, L.}

E. naucrates, L. (albicauda, lineata, holbrooki, \&c. Refer to varieties with long disk and twenty-one lamine, \&c.) Pegador.

Body slender; thirty vertebræ; brownish; belly like back; sides with a black stripe edged with white; tail fin black, whitish at outer angles; other fins black, with white edges; lower jaw 
with flexible tip; disk with twenty-one to twenty-six laminæ. Soft rays, 32 to 41 ; in anal, 32 to 38 .

"Echeneis naucrates. Indian Remora.

"It is doubtful if this species has been met in the waters of New Jersey.

"Echeneis albicauda. White-tailed Remora.

"The more usually met with of the three species. Specimens have occasionally been met with in the Delaware, at Philadelphia." A variety, only, of $E$. naucrates.

E. remora, Gill. (Remora squalipeta, Dald., jacobca.) Remora.

Body robust; vertebræ twenty-seven; dorsal rays twentythree, with eighteen lamellæ in disk; tail compressed; head broad; tip of lower jaw not produced. Anal rays, 25. Usually found attached to sharks. Color uniform dark brown.

"This is a less species, less frequently met with than the preceding. In its habits it is. identical."

E. (or Remora) brachyptera, Lowe. Fourteen-laminated Remora.

Uniform light brown, with paler fins; disk shorter than base of dorsal, rather broad, with fourteen to sixteen laminæ; upper jaw angular. Dorsal rays, 30 ; anal rays, 26. Warm seas north to Massachusetts.

\section{RHOMBOOHIRUS.}

R. osteochir, Cuv. (E. tetrapturorum.) Stiff-finned Remora.

Pectoral fins short, broad, with flat, broad rays ossified and stiff, otherwise like preceding, except paler under head; mouth larger; disk broader and rougher, extending forward over tip of snout, and with sixteen lamellæ. Dorsal rays, 21; anal rays, 20. West Indies to Cape Cod. Parasitic on species of Tetrapturus.

\section{Family ELACATIDË.}

Crab-eaters.

Body fusiform, with small, smooth scales; head broad, pike-like; mouth wide, with bands of short, sharp teeth on jaws, vomer, palatines 
and tongue; first dorsal of eight spines; two anal spines; ventrals thoracic; no air-bladder; caudal forked; branchiostegals seven; vertebræ more than twenty-four.

\section{ELACATE, Cuv.}

E. canada, L. (atlanticus, niger.) Crab-eater. Cobia. Sergeant-fish. Snooks. Ling.

Olive brown, with broad, dark band on sides, bounded above and below by an indistinct band; below silvery; head much depressed; pectorals falcate; upper lobe of caudal a little the longer; lateral line wavy and irregular. Dorsal rays, 26 ; anal rays, 25 ; length, 60 inches.

"A very rare fish, that occasionally is met with on our coast, and in Delaware Bay."

\section{Family XIPHIID匡。}

\section{Swordfishes.}

Large fishes, with upper jaw much prolonged to form the "sword;" teeth small or wanting; dorsal fin, in adults, in two parts, the anterior the larger; anal similarly divided; caudal widely forked ; air-bladder and pseudobranchice present; branchiostegals seven. Toung ditfer: from adults in having both jaws prolonged to form a beak, in having dorsal fins high and continuous, and in having spines on head.

\section{XIPHIAS, L.}

X. gladius, L. Sworlfish.

Teeth none (except in young); ventrals none; anterior dorsal above gill openings, high and falcate, the second small and above the second anal; skin naked (rudimentary scales in young); pelvic arch obsolete; color dark blue above, dusky below; "sword" nearly black above. Dorsal rays, $40+4$; anal rays, $18+14$; vertebræ, $14+12$. Often attain a large size, and are valuable for food.

"On the coast of New Jersey this interesting species is not abundant ever, although more numerous during some years than 
others. Specimens have been seen by the writer taken at Barnegat and Atlantic City. They were all small, the largest measuring about four feet." - [C. C. A. $]$

\section{TETRAPTURUS, Raf.}

T. indicus, Cuv. \& Val. (albidus, herschelii, brevirostris.) Speartish. Billfish, \&c.

With small teeth; ventrals represented by spines; dorsals low; skin with rudimentary scales; double caudal keel; sacculated air-bladder; caudal fin forked at seventy-five degrees; color dark blue above, whitish below; fins like back. Dorsal rays, III $+39+6$; anal rays, II $+13+6$; length, 7 to 8 feet. Not rare on our coast from Cape Cod to West Indies.

\section{Family TRICHIURIDEE.}

\section{Hair-tails.}

Ventrals thoracic, imperfect; body very long, compressed and naked; mouth wide and toothed; dorsal long, low, continuous, and with equal and similar rays.

\section{TRICHIURUS, L.}

(Lepturus, Art.)

T. lepturus, L. (argenteus.) Hair-tail. Silver Eel. Ribbon-fish. Silver-fin, \&c.

Tail tapers to a fine point; four barbed teeth in upper jaw ; lower jaw longer; vertebre, $39+120$; color silvery; ventrals absent in adult; snout pointed. Dorsal rays, 135 ; anal rays, 100.

"This is not a common species; though more frequently met with during some years than others. A specimen, measuring twenty-two inches, was captured by the writer at Barnegat, in November of 1862, and others have been seen from Cape May and Atlantic City."-[C. C. A.] 


\section{Family SCOMBRIDE.}

\section{Mackerols.}

Bondy not much compressed, covered with minute cycloid scales (or naked); head conical; jaws with sharp teeth; dorsal fins two, the first of weak spines depressible in a groove; tail slender, keeled; cauclal fin falcate; ventrals thoracic; vertebre more than twenty-tive.

\section{SCOMBER, L.}

S. pneumatophorus, Delar. (grex, dekayi, colias?* \&c.) Chub Mackerel. Fall Mackerel. Easter Mackerel. Tinker Mackerel.

Body fusiform; two small keels on each side of tail ; one row of slender teeth in jaws; first dorsal of nine slender spines; quite a space in front of second, which is followed by a series of five finlets ; aual similar; color blue, with twenty wavy, blackish streaks and reticulations, enclosing pale blue spots; silvery below. Lateral line, 200 scales; length, 1 foot.

"Quite abundant on the coast during October and November. Straggling specimens occasionally met with in the bays and inlets."

S. scombrus, L. (vernalis.) Common Mackerel.

Lustrous dark blue above, with thirty-five wavy streaks; silvery below; base of pectorals dark; snout long, pointed; ventrals and pectorals short. Length, 18 inches.

"This well-known species is quite abundant during the fishing season on the banks off Barnegat, where they were caught by the writer in 1862." - [C. C. A.]

\section{AUXIS, Ouv.}

A. thazard, Lac. (rochei, vulgaris, bisus, \&c.) Frigate Mackerel.

Body plump, naked behind; small scales anteriorly ; a "corselet" of large scales in pectoral region; mouth small; teeth small; tail slender, with large keel on each side; seven to eight finlets behind second dorsal and anal; vertebræ thirty-nine,

* S. colices is the Spanish mackerel of Europe, which has been introduced upon our coast hy the U.S. Fish Commission. 'I'his has a longer hend, lower dorsal fin; the dark bands are narrower and belly is not immaculate. May be considered as a distinct species rather than a rariety. 
modified as in Euthynnus; variegated blue and darker; belly silvery; an Old-World fish lately become abundant upon our coast, but of little value for food.

SCOMBEROMORUS, Lac.

S. maculatus, Mitch. (dekayi.) Spanish Mackerel. Spotted Mackerel.

Body elongate, without a corsélet; head pointed and short; teeth knife shaped; fourteen to eighteen feeble spines in low first dorsal, white at base; soft dorsal short, followed by eight to nine finlets; anal similar; ventrals small; vertebræ normal; bluish and silvery above, with metallic reflections; numerous bronze spots on sides; mouth obliqne; caudal keel with accessory keels.

"This is not an abundant species, although usually met with in twos or threes during a fishing excursion of a week or more. Its flesh is excellent, and deservedly prized."

S. regalis, Bloch. (plumieri, acervum, dekayi?) Cero. [Spanish Mackerel (?). Spotted Mackerel ?]

Silvery; sides with a brownish, broken, longitudinal line above and below, on which are numerous brownish spots; base of dorsal black; pectorals scaly. Dorsal rays, XVII-I, 15VIII; anal rays, II, 15-VIII. Cape Cod to Brazil ; not common. May attain a weight of twenty pounds.

"Prof. Baird reports but two specimens being taken at Beesley's Point in 1854, during his stay. The writer has met with the species at Barnegat, but not abundantly." (Possibly refers to the preceding?)

SARDA, CuV.

(Pelamys, Cuv. \& Val.)

S. mediterranea, Bl. \& Schn. ( pelamys, sarda.) Bonito. Skip-jack, \&c.

Scales small, except pectoral corselet; tail strongly keeled; head large, pointed; mouth large; teeth strong and conical; first and second dorsals not far separated; followed by seven to eight finlets; first dorsal with twenty-one stout spines, posterior shortest; color steel blue, with oblique dark stripes; silvery below. Length, $2 \frac{1}{2}$ feet.

"This species is an occasional visitor in our waters. A specimen has been seen by the writer from Cape May." 


\section{ORYCNUS, CuV.}

(Thynnus.)

O. thynnus, L. (secundo-dorsalis, vulgaris, \&e.) Horse Mackerel. Tunny. Albicore.

Body robust; tail slender; an obscure corselet; pectorals do not reach beyond end of first dorsal; color dark blue above; below grayish, with silvery spots; mouth large. Dorsal rays, XIV-I, 13-IX; anal rays, I, 12-VIII. Attains a length of 10 feet or more.

"The writer has never seen a specimen of this large fish from New Jersey, but it is fair to suppose it occasionally is met with, as it is taken off Long Island frequently." - [C. C. A.]

\section{Family CARANGID}

\section{Pilot-fishes.}

Body compressed, with prominent occipital keel; usually with small cycloid scales; teeth generally small ; premaxillaries protractile; spinous part of dorsal weak; anal always with two spines; airbladder often forked behind; vertebræ about twenty-five.

\section{DECAPTERUS, Bleek.}

D. punctatus, Ag. (Caranx.) Scad. Spotted Caranx. Round Robin. Cigar-fish.

Body spindle shaped; head short; mouth small, with feeble teeth: premaxillaries protractile; scales enlarged along posterior straight part of lateral line; one finlet after second dorsal and anal; bluish above; silvery below, with a dark opercular spot; pectorals short; eye small. Length, 12 inches; dorsal rays, VIII-I, 30-I; anal rays, II-I, 24-I.

"This is a seldom-met-with species of Caranx, that is to be included in our list from a specimen taken near Cape May, and now in the museum of the Philadelphia Academy." 
D. macarellus, Cuv. \& Val. Nackerel Scad.

Silvery; leaden below; small spot on opercle; a few more rays in dorsal and anal than in above. From Cape Cod southward. Scarce.

\section{CARANX, Lac.}

(Paratractus. Trachurops. Carangus, \&c.)

C. crumenophthalmus, Bloch. Goggler. Big-eyed Scad.

Small scales, with larger plates on lateral line, especially on tail ; each plate armed with a spine; preopercle serrate in young; small, uniform teeth present; body elongate, spindle shaped; bluish olive above, silvery below; opercular spot faint; head pointed; lower jaw projecting; a patch of teeth on tongue; adipose eyelid; cheeks and breast scaly; lateral line nearly straight, its plates weak and little carinated. Dorsal rays, VIII -I, 26; anal rays, II-I, 22 ; scutes, 35 .

"The writer has never met with a species of this fish accredited to our coast, or rather the coast of the whole Atlantic." - [C. C. A.]

C. chrysus, Mitch. (hippos, pisquetus.) Hard-tail. Jural. Crevallé. Yellow Caranx.

Body ovate, nearly fusiform; greenish olive above, golden yellow below; a black blotch on opercle; teeth comparatively large, one series in lower, two in upper jaw ; top of head naked, with mucous pores; scutes developed whole length of lateral line. Dorsal rays, VIII-I, 24 ; anal rays, II-I, 19 ; scutes, 50 ; length, 12 inches.

"Paratractus hippos.

"Not uncommon during the summer along our coast."

The following remark probably refers to a variety of preceding species :

"Carangus chrysos. Yellow Caranx.

"This species is not an abundant one on our coast, although more so during some seasons than others."-[C. C. A.]

C. amblyrhynchus, Cuv. \& Val. (falcalus.)

Greenish above, with blue reflections; sides and belly golden or silvery; tail fin yellow; body ovate, deeper than preceding; mouth very small and oblique; eye large; lateral scutes strong; teeth strong, in one series; cheeks naked; lateral line strongly arched; scaly sheaths of dorsal and anal well developed; pec- 
torals falcate, reach anal. Dorsal rays, VII-I, 28; anal rays, II-I, 25; lateral-line scutes, 50. West Indies northward. Not common.

C. hippos, L. (defensor, caninus, carangus, chrysos, esculentus, \&ce.) Horse Crevallé. Southern Caranx.

Olivaceous above; sides and below golden or silvery; a black blotch on opercle; anterior edge of dorsals black; head large and deep; back strongly arched; teeth in upper jaw in a broad band; distinct canines in lower jaw ; arched part of lateral line three-fourths that of straight part; breast naked; scales in front of ventrals only; about thirty lateral-line scutes. Dorsal rays, VIII-I, 20; anal rays, II-I, 17. Cape Cod to West Indies. Common southward.

"This species is much more numerous during some seasons than others, but is generally to be met with in August and September in small companies."

\section{BLEPHARIS, Cuv.}

B. crinitus, Akerly (Zeus, Caranx sutor). Shoemaker.

Body rhomboid, much compressed; apparently naked, with large scales on posterior part of lateral line; bands of villiform teeth in mouth; first dorsal with rudimentary spines, disappearing with age; generic characters otherwise much as in Caranx; bluish above, golden below; blotch on opercle on dorsal and anal ; mouth oblique in young; first rays of dorsal filamentous; soft rays of second dorsal and anal, nineteen and sixteen respectively.

"This species is very rare on our coast, single specimens being met with at long intervals."

\section{SELENE, Lac.}

(Argyriosus.)

S. vomer, L. (Zeus, capillaris, argentea, pacificus.) Rostrated Dory. Hair-finned Silver-fish. Moonfish. Horsehead, \&c.

Body much compressed, with nearly circular profile, very steep in front; premaxillaries protractile; tongue narrow, free; teeth minute; spines filamentous in young; lateral line unarmed; bluish above, below golden silvery; soft rays, dorsal and anal, twenty-two and twenty. Different varieties or stages 
of development are referred to in the following three notes by C. C. A. :

"Argyreiosus capillaris. Hair-finned Silver-fish.

"Specimens of this fish are met with along our coast vearly every summer, but they are never abundant. They appear during August and September, and prefer the open sea.

"Argyreiosus vomer. Rostrated Dory.

"This is a very rare species in our waters. The writer has never met with a specimen except from southern waters.

"Selene argentea.

"Described by Brevoort, in Annals Lyceum Nat. Hist. N. Y., Vol. V. No specimen has been seen by the author."-[C. C. A.]

S. setipinnis, Mitch. (Vomer, browni, curtus.) Horsefish. Blunt-nosed Shiner.

Greenish above, golden silvery below; body less rounded, more oblong, than in preceding, but profile nearly vertical, highest over eye; young with a blotch at origin of straight part of lateral line; snout somewhat protruding; mouth oblique; ventrals minute; dorsal and anal very low, no long rays in the adult; second dorsal and anal soft rays, twenty-one and seventeen.

"Specimens of this fine fish are taken every summer along our coast. It does not appear to have favorite haunts, but it is about equally distributed from Sandy Hook to Cape May."

\section{OHLOROSCOMBRUS, Grd}

(Micropteryx. Seriola.)

C. chrysurus, L. (cosmopolita, chloris, caribbæus.) Yellow-tail.

Body ovate, compressed, not elevated ; belly more convex than back; tail very narrow, caudal forked; scales small, smooth; head nearly naked ; mouth small, oblique; upper jaw protractile ; teeth feeble; eye large ; first dorsal of eight feeble spines ; second and anal low, with twenty-six rays; strong anal spine. Common southward.

"This is not a common species in our waters." 
TRACHYNOTUS, LAc.

(Bothrolæmus. Doliodon.)

T. carolinus, L. (pampanus.) Common Pompano. Carolina Lichia. Spiny Dory (?).

Body ovate, compressed; abdomen not trenchant ; head blunt ; snout abruptly truncate; mouth nearly horizontal; teeth villiform, deciduous; first dorsal of six spines, united in young, separate in adult, and often disappearing; three stout spines in anal; no caudal keel; preopercle armed in young with three spines; bluish above; sides silvery, becoming golden with age; body without dark bands, and no black(?) on vertical fius; fins silvery or dusky. Soft rays, dorsal, 25; anal, 23 ; length, 18 inches.

"This little fish is very abundant on our coast, and was met with by Prof. Baird in large numbers about Beesley's Point." A species with four vertical black bands under the dorsals, known as T. glaucus, Gaff-topsail Pompano, ranges scarcely as far north as New Jersey. The following is probably a stage of preceding :

"Trachynotus spinosus. Spinous Dory.

"This species was found by Prof. Baird associated with $T$. carolinus in very small numbers."

\section{NAUCRATES, Raf.}

(Nauclerus, Cur.)

N. ductor, L. (noveboracensis.) Pilot-fish. Romero.

Differs from next only in having first dorsal of four or five low, uncounected spines (connected in young); bluish, with five to seven dark vertical bars; little compressed, but elongate; mouth small and oblique. Soft rays, dorsal, 26 ; anal, 16. More abundant southward.

"This species, although abundant elsewhere, and well known, is not often seen in our waters. A specimen from Beesley's Point is in the museum of the Philadelphia Academy."

\section{SERIOLA, CuV.}

(Halatractus, Gill.)

\section{S. carolinensis, Holb. (zonata, steamsii.) Amber-fish.}

Occiput and breast not treuchant; head conical; mouth large, with broad bands of villiform teeth; lateral line nearly straight, 
forming a keel on tail ; scales on sides of head ; first dorsal with seven low, connected spines; much like Naucrates; bluish above; a greenish-yellow band along side; white below; fins greenish; body spindle shaped; one median and two lateral series of teeth on tongue; head naked; cheeks with small scales: soft rays of dorsal, 36 ; of anal, 19 ; no sharp keel at occiput. Gulf of Mexico. Rare northward. The following note probably refers to aged specimens of following species, or possibly to S. fasciata :

"Halatractus carolinensis.

"Specimens of this species are occasionally met with associated with the following."

S. zonata, Mitch. (Zonichthys, carolinensis, without vertical bands, due, perhaps, to increased age.) Banded Leriole. Rudder-fish.

Ditfers from preceding in having six broad, black bars (darker in young than in previous cases); body deeper, with occipital keel; spinous dorsal and ventrals black. Rays, dorsal, 38; anal, 21 ; length, 30 inches.

"This species is quite abundant along our coast. Specimens have been met with by the anthor at each of the principal points along our coast." - [C. C. A.]

S. fasciata, Bloch. (Zonichthys.) Amber-fish.

Greenish above, with sixteen brown, narrow cross bands, arranged in pairs, and running into the dorsal and anal ; head deeper than long. Dorsal rays, 30 ; anal rays, 20. Coast of South Carolina. Extra-limital to New Jersey.

\section{OLIGOPLITES, Gill.}

(Scombroides, Lac.)

O. saurus, B1. \& Schn. (Scomber, occidentalis.) Leather-jacket.

Body compressed, nearly lanceolate; tail slender, not keeled; head short, acute; occipital keel sharp; mouth with sharp teeth on jaws, tongue, \&c. ; upper jaw not protractile ; maxillary narrow, without a distinct supplementary bone; scalss small and very narrow; dorsal spines $5+1$, strong; second dorsal mostly broken up into finlets; anal longer, also with finlets posteriorly; pterygoids toothless; bluish above, bright silvery below; fins yellow; caudal deeply forked; twenty soft rays in dorsal and anal. Tropics to New York. Not rare southward. 


\section{Family POMATOMIDE.}

\section{Bluefishes.}

Scales weakly etenoid; mouth large and oblique, with premaxillaries protractile; lower jaw projects; supplementary bone to maxillary; teeth strong, unequal, a triangular patch on the vomer; occipital keel strong; free edge of operele serrated; branchiostegals seven; cheeks and opercles scaled; anal and soft dorsal scaly; first dorsal of seven low spines; ventrals thoracic; vertebræ as in Carangide.

\section{POMATOMUS, Lac.}

(Temnodon, Cuv.)

P. saltatrix, L. (Perca, Gasterosteus.) Bluefish. Greenfish. Skip.jack.

Bluish or greenish above and silvery below; a black bloteh at base of pectoral; body robust, slightly compressed; belly with blunt edge; top of head naked. Rays in dorsal and anal, 25; scales in lateral line, 95 ; length, 3 feet. Voracious and destructive to other fishes. Valued for fuod.

"This is a well-known and exceedingly abundant species found along our coast generally. Isolated specimens wander up the Delaware occasionally as high as Bordentown, Burlington county."

\section{Family STROMATEIDAE.}

Broad Shiners.

Scales minute, eycloid; profile of body blunt in front; mouth small; no teeth on vomers or palatines; œesophagus armed with horny, hooked teeth; dorsal fin single, long, spines weak; anal with three spines; usually no air-bladder.

\section{STROMATEUS, L.}

(Poronotus. Peprilus.)

S. paru, L. (Rhombus longipinnis, gardenii.) Rudder-fish. Harvest-fish.

Body ovate; tail slender; scales loosely inserted; ventrals represented by a spine; pectorals narrow, nearly half as long as 
body; first rays of dorsal and anal high; caudal forked. Dorsal rays, 45 ; anal rays, 40 ; lateral-line scales, 90 ; vertebræ, $15+15$. Commonest southward.

"This is a rare species, said to be met with occasionally in our waters."

S. triacanthus, Peck (Rhombus cryptosus). Harvest-fish. Dollar-fish. Butter-fish. La Fayette.

Dorsal and anal not very high in front, with a series of large pores along base of dorsal. Dorsal rays, III, 45 ; anal rays, III, 38 ; length, 10 inches.

"This is not a common species, and is met with almost entirely during July and August. The writer has seen single specimens from various points along the coast." $-[$ C. C. A. $]$

\section{LIRUS, Lowe. \\ (Palinurichthys. Palinurus.)}

L. perciformis, Mitch. (Pammelas, Leirus, Mupus, \&c.) Pilot. Rudderfish.

Body elongate-ovate and a little compressed; profile very blunt; opercular bones finely serrated; scales more fixed than in preceding; cheeks scaly; six to eight short but strong spines in dorsal; vertical fins scaly at base; ventrals $(I, 5)$ large and thoracic; dark green; belly not silvery; eye large, with adipose eyelid; top of head naked, with mucous pores; pectorals long. Dorsal rays, 21 ; anal rays, 16 ; lateral-line scales, 75 ; length, 12 inches.

"This species is not unfrequently met with during the summer months some seasons, but as a general thing is not met with in our waters. Isolated specimens have been seen by the writer from Sandy Hook, Barnegat and Atlantic City." - [C. C. A.]

\section{Family CORYPHANID正.}

Dolphins.*

Body elongate, compressed, covered with small cycloid scales; cleft of mouth wide, oblique; lower jaw projecting; teeth cardiform, some

\footnotetext{
* These fishes should not be confounded with aquatic mammals of the same name.
} 
on vomer, \&c.; villiform teeth on tongue; skull with a high erest; dorsal fin along entire back nearly; no distinct spines; pectorals short; caudals widely forked; no air-bladder nor pseudobranchs.

\section{CORYPEA A}

(Lampugus.)

C. equisetis, L. (immaculata punctulatus.) Spotted Dolphin, or Lampugus. Small Dolphin.

Bluish above, paler below, and yellowish; sides sometimes sprinkled with small blue spots, larger at base of dorsal; dorsal blue, wavy, with rows of spots; none on anal; profile of snout does not become vertical with age. Dorsal rays, 51 to 56 ; anal rays, 24 to 26 ; length, $2 \frac{1}{2}$ feet.

"The writer has not met with this species. Said to have been caught at the mouth of the Hudson River."-[C. C. A.]

C. hippurus, L. (guttata, sueuri) Great Dolphin.

Colors brilliant when captured, changing suddenly at death; brownish olive above, golden below, with bright blue spots; dorsal purplish, with lines; other fins tinged blue; caudal yellow, pale, with blackish spots in preserved specimens; profile becomes vertical with age; male with a crest, female with blue spots on each side of tail.-Poey. Dorsal rays, 58 to 64 ; anal rays, 26 to 30 ; length, 6 feet. Common in warmer seas.

"This handsome and interesting species is not abundant along our coast, although specimens are met with every summer at the various coast villages, as Long Branch, Tuckerton, Toms River, \&c." - [C. C. A.]

\section{Family APHREDODERIDEE.}

Pirate Perches.

Body oblong, elevated at hase of doral, compresed hehind, with head thick aud depresed ; lower jaw projecting ; teeth in villiform bands: opercle with a spine, some of hones scrrated; hones of skull saveruous; branchioctegals six; sales ctenoid, atherent: lateral line 
imperfect; vent moves forward towards opercular region with age; ventrals thoracic; anal small ; air-bladder adherent to walls of abdomen.

\section{APHREDODERUS, Le S.}

(Scolopsis, Gilliams.)

A. sayanus (gibbosus, cookianus, mesotrema, isolepis, \&c.) Pirate Perch. Mud Perch.

Dark olive, much speckled with dark points; two blackish bars at base of caudal, between which is a light bar. Dorsal rays, III, 11 ; anal rays, II, 6 ; lateral-line scales, 47 to 58 ; length, 5 inches.

"Met with in Mercer, Burlington, Camden and Atlantic counties. No species is perhaps less known, of all our freshwater fishes, than the above. Being strictly nocturnal in its habits, will account in a measure for this, but its numbers are great in those streams where it is found at all, and only its peculiar habit of lying semi-dormant during the day, will aceount for the fact of its being a 'rara pisces' to the community generally. Smali streams with dense vegetation upon the bottom, and with overhanging banks, are its favorite, if not exclusive haunts. Among the roots of some neighboring tree, whose tangled rootlets extend out into the stream, the 'pirate' is sure to be found in streams containing them, but it requires skill and patience to secure them, when thus protected. No species in the State's fauna is perhaps as voracious as this under consideration. Even its own young are not exempt from attack, and indeed they seem to be somewhat of a favorite article of food. So greedy are they at times, that not unfrequently the tail of the captured fish may be seen protruding from the mouth of its captor, who seeks his favorite haunt after seizing his prey, and there, lazily flapping his pectoral fins to and fro to give his body a gently swaying motion, devours the swallowed victim at his leisure.

"The 'pirate' makes a nest after the manner of the sunfish, and with the female, guards it and afterward the young, till they reach a size of one-third of an inch, when they are left by their parents, and become exposed to the attacks of the larger carnivorous fish, including their own species.

"The largest specimens met with have measured about five inches in length. De Kay's figure is a correct representation." 


\section{Family CENTRARCHID $\not$.}

\section{Sunfishes.}

Compressed; body deep, not very long; mouth well toothed with villiform teeth in bands; premaxillaries protractile; opercle ends in two flat points or a black flap; branchiostegals six (or seven); body fully scaled (etenoid, rarely cycloid); usually ten spines in dorsal; intestine short; vertebre about thirty, number changes with age; pseudobranchs rudimentary; sexes alike; voracious. Valued for food according to size.

\section{POMOXYS, Raf.}

(Labrus. Centrarchus.)

P. sparoides, Lac. (heỉucanthus, nigromaculutus.) (Grass̊ Bass. Barfish. Calico Bass. Strawberry Bass.

Snout projecting; month large, oblique; few teeth on tongue; seales large; anal fin larger than dorsal ; opercle with two points; dorsal spines seven or eight, not six; scales on cheeks in six rows; fins very high; color silvery olive, mottled with olive green in small bunches over whole body; anal marked with reticulations and spots like dorsal. Dorsal rays, 15 (soft); anal rays, 17 ; lateral-line scales, 41 ; length, 12 inches. Chiefly in lowland streams and lakes.

\section{AMBLOPLITES, Gill.}

(Lepomis. Bodianus.)

A. rupestris, Raf. (æneus, cavifrons?) Common Rock Bass. Red-eye. Goggle-eye. Mud Sunfish.

Mouth large; lower jaw projecting; lingual teeth in one patch; opercle with two points; scales large; dorsal larger thau anal, with ten to eleven low spines; six spines in anal; scales on cheek in six to eight series; color olive green, brassy, with dark mottlings; the young irregularly barred and blotehed black; adult has a dark spot on each scale; black opercular spot. Soft rays, dorsal, 10 ; anal, 10 ; length, 12 inches.

"The writer captured a specimen of this northern species in October of 1867 , in Mercer county. It is the only one met with."-[C. C. A.] 
ACANTHARCHUS, Gill.

(Centrarchus.)

A. pomotis, Bd. (Ambloplites-Abbott's Catalogue.) Mud Sunfish.

Body oblong, not much compressed nor elevated; mouth wide, with short gape; lower jaw projecting; pharyngeal teeth sharp; scales large, cycloid; dorsal spines low, eleven; anal five; caudal fin rounded; cheeks with five rows of scales; color dark green, with five indistinct longitudinal bands on sides; also bands on cheeks ; an opercular spot ; fins plain. Soft dorsal and anal rays, 10 ; length, 4 inches.

"This is a less abundant species than the one following, but in its habits is somewhat similar. Specimens kept by the writer in an aquarium, devoured many small cyprinoids and wounded the other large fish so that many of them died." - [C. C. A.]

\section{ENNEACANTHUS, Gill.}

(Hemioplites. Copelandia.)

E. obesus, Bd. (Pomotis, Bryttus, fasciatus, guttatus.) Spotted-finned Sunfish.

Body short, deep, compressed; mouth small, with welldeveloped supplementary bone; no teeth on tongue; opercle with two points; anal large, but smaller than dorsal; scales large; opercular spot more than half as large as eye; cheeks with four rows of scales; color olivaceous, with five to eight dark cross bars and purplish-golden spots on body and fins; lines and spots on eheeks; bar below eye. Dorsal rays, IX, 10 ; anal rays, III, 10 ; scales, $32 \times 10$; length, 3 inches.

"This species is very abundant in many tributaries of the Delaware, in Mercer and Camden counties. It is likewise a lover of sluggish water, and is found usually in the midst of a mass of weeds, from which it must be dragged with a net, as it does not ever, or very seldom, bite at a hook."

E. simulans, Cope (margaratis, guttatus, piniger-last, southern variety, larger and brighter).

Body comparatively elongate; mouth very oblique; soft rays of dorsal elevated in male, lower in female; color dark olive, with traces of vertical bars in young; ear flap small, with blue 
border and a pearly spot in front; a dark bar below eye; males much spotted with blue, fainter in females. Dorsal rays, IX, 10 ; anal rays, III, 9 (varies). Abundant near the coast.

\section{MESOGONISTIUS, Gill}

M. chrtodon, Bd. (Pomotis.) Black-banded Sunfish.

Differs from preceding genus in having ten dorsal spines; small supplemental bone; anal much smaller than dorsal ; dorsal with anterior spines longest; body suborbicular; mouth very small; lateral line continuous; cheeks three to four rows of scales; dirty straw color, clouded with olive; six to eight vertical bars on sides. Lateral-line scales, 28 ; length, 3 inches.

"This interesting species is a lover of weedy, sluggish streams and ponds, and is never met with in tide water. The writer has seen it from Mercer and Burlington counties, but could not find it in Warren, Sussex or Morris counties. It was first met with in Atlantic county by Prof. Baird." - [C. C. A.]

\section{LEPOMIS, Raf.}

(Ichthelis. Eupomotis. Apomotis, \&c.)

L. phenax, Cope \& Jord. (Apomotis, Bryttus, \&c.) Sunfish.

Body ovate; supplementary bone strong; teeth on vomer and palatines; dorsal with ten short and strong spines; opereular spot larger than eye; seven rows of scales on cheek; no black spot on dorsal or anal; color olive green, dark in adults; more silvery in young. Dorsal rays, 10 ; anal rays, 9 ; scales, $43 \times$ 14; length, 6 inches. Beesley's Point.

L. auritus, L. (Labmus, Bryttus unicolor, Pomotis rubicauda, appendix.) Long-eared Sunfish. Black-eared Sunfish.

Gill rakers short and thick; ear flaps long and narrow; body elongate; seven rows of small scales in cheek; scales of breast very small; palatine teeth few and large; dorsal spines low; color olive, belly orange red; scales on sides with red spots on a blue ground; vertical fins yellowish; head with bluish stripes. Dorsal rays, 11 ; anal rays, 9 ; lateral-line scales, 47 ; length, 8 inches.

The two following notes by C. C. A. refer doubtless to varieties of the above species: 


\section{"Ichthelis rubicauda. River Sunfish.}

"This beautiful fish is distinguishable by its ruddy tail and lower fins. It attains a greater size than the others, and is met with most usually in the rivers. In the Delaware they are abundant, and reach a length of several inches very frequently.

"Pomotis appendix. Black-eared Sunfish.

"This species is larger bodied and much less brilliantly colored, but in its habits is in all respects similar to the next. It is less abundant than the next, and like it, prefers quiet ponds and slowly-moving streams to the river or tide water. The black appendix easily distinguishes it from the following. As articles of food the two species are of very little value."

L. gibbosus, L. (Perca, Sparus, Pomotis, vulgaris.) Common Sunfish. Pumpkin Seed. Bream.

Body short and deep; profile steep; head and mouth small; dorsal spines high, soft rays higher; seales large, four rows on cheek; greenish olive; sides spotted with orange; belly yellowish; blue, wavy streaks on cheeks; lower part of opercular flap bright scarlet in adult. Dorsal rays, $\mathrm{X}, 11$; anal rays, III, 10 ; lateral-line scales, 47 ; length, 8 inches.

"This is probably the best-known species of all our inland fishes. It appears to be uniformly abundant in every section of the State. Its colors are brightest in the spring, when they may be seen in shallow water, making nests and guarding them from every*intruder."

\section{MICROPTERUS, Lac.}

(Huro. Grystes. Lepomis, \&c.)

M. salmoides, Lac. (Labrus, pallida, Cichla floridana, nigricans, \&c.) Large-mouthed Black Bass. Oswego Bass. Green Bass. Bayou Bass [erroneously Trout (South).]

Body oblong, compressed; head long; mouth large and oblique; supplementary bone well developed; lower jaw prominent; opercle with two flat points ; scales weakly etenoid; dorsal divided by deep notch; spines low, not strong, same number as in sunfish; ten rows of scales on cheek; young dark green above, silvery below; a dark stripe on side and three on cheek; caudal blackish in middle; lateral stripe indistinct and general tone darker in adult. Dorsal rays, 13; anal rays, 11 (soft); scales, $68 \times 16$; length, 1 to 2 feet. Fresh water. Introduced 
by New Jersey authorities into Greenwood Lake, 1871. This and the following have lost in size, from lack of fresh stock for interbreeding, according to the belief of the fishermen.

M. dolomiei, Lac. (Bodinnus achigem, Grystes sulmoides, fusciutus, punctulatus, obscurus, \&c.) Small-mouthed Black Bass.

Head large, but mouth not as large as in preceding; scales on cheek small, seventeen rows; young golden green, with bronze luster; spots or vertical bars on sides, but no longitudinal stripe ; three bands on cheeks; adults dead green ; scales, $74 \times 17$. Cool, clear and rapid streams. Introduced by authority of State of New York into Greenwood Lake, 1866.

\section{Family PERCID平.}

(Etheostomatidæ.)

\section{Perches.}

Body elongate, terete or compressed, covered with small, adherent stenoid scales; two dorsals, the first spiny ; many characters in common with the foregoing family, but body more slender; anal spines one or two ; pseudobranchiæ small or none; skull bones not cavernous.

\section{BOLEOSOMA, De K.}

(Etheostoma. Estrella, \&c.)

B. olmstedi, Stor. (tessellatum, maculaticeps, \&c.) Tessellated Darter.

Body sleuder, little compressed, not translucent; head small, pointed; cheeks and opercles scaly; scales large; breast naked; fins high ; color olivaceous, tessellated above, sides with blotches and rigzag markings; fins speckled or barred; head not speckled, dusky in males. Dorsal spines, 9 ; soft rays, 14; anal, 9 ; lateral-line scales, 50 ; length, 31 inches. Breast closely scaled in var. atromaculatum.

"This is the most numerous of the described species of 'darters.' No stream appears to be too small for them, and many specimens have been found by the writer in the 'belly' of shad-nets, tangled in the vegetation and trash drawn from the bottoms of our rivers." 


\section{PERCINA, Hald. \\ (Perca. Scimna, \&c.)}

P. caprodes, Raf. (Etheostoma, Pileoma semifasciatum, carbonaria, \&c.)

Banded Darter. Log Perch. Rockfish. Hogfish.

Body compressed, with long, pointed head, depressed above; cheeks, opercles and neck scaly; chest naked; fins low; color yellowish green, with about fifteen long cross bands on sides, alternating with short ones; fins barred. Dorsal rays, XV15; anal rays, II-9; lateral-line scales, 92 ; length, 6 to 8 inches. Mouth overlapped by a pig-like snout.

"This species I have only met with in the Delaware, and there it is a by-no-means-abundant species. It appears to move about more than the other species, sustaining itself for a greater length of time in the water."

\section{ETHEOSTOMA, Raf.}

(Catonotus, Ag.)

E. flabellare, Raf. (humeralis, fasciatus.) Fan-tailed Darter.

Head naked; lateral line short and nearly straight; spinous dorsal low, ending in fleshy knobs in males; color olivaceous, dusky above, with obscure bars; scales with brown spot forming obscure lines; head narrow ; mouth oblique; fins barred. Dorsal rays, VIII-12; length, $2 \frac{1}{2}$ inches. Western New York and southward. Possibly extra-limital to New Jersey.

\section{PACILIOHTHYS, Ag.}

(Oligocephalus. Boleichthys. Aplesion. Alvarius. Astatichthys. Hololepis, \&c.)

P. cœruleus, Stor. (variatus, Jord.) Blue Darter. Rainbow Darter. Soldier-fish.

Body robust; back elevated; head large, compressed; neck, cheeks and breast usually naked; opercles scaly; fins large, dorsals close together; males olivaceous, tessellated and blotched; sides with twelve indigo-blue bars, separated by orange spaces; caudal and anal deep orange, edged with blue; soft dorsal blue at base ; spinous crimson; ventrals and cheeks blue; throat, \&rc., orange; females with little blue or red; vertical fins barred, \&c. Dorsal rays, $\mathrm{X}-12$; anal rays, II -7 ; scales, $45 \times 8$; 
length, $2 \frac{1}{2}$ inches; lateral lines, developed for 35 scales, nearly straight.

"With perhaps one exception, this is the most abundant of the species of this family found in the State. Flat rocks in shallow water, or sandy flats among rougher bottoms, are the favorite haunts of this restless species."

P. fusiformis, Grd. (Hololepis, Boleosoma.) Fusiform Darter.

Strongly compressed; head long and narrow, with short, decurved muzzle; eye large; strong opercular spine; lateral line from twelve to fifteen scales; cheeks, neck, belly aud throat scaly; olivaceous, dotted with dusky points; soft vertical fins, speckled. Dorsal rays, $\mathrm{X}-9$; anal rays, $\mathrm{II}-7$; lateralline scales, slightly curved, 55 ; length, 2 inches.

"In Cape May county, and at Bound Brook, Somerset county, this species is more or less abundant.

"The want of a good monograph of this family has prevented the writer from giving a complete list of the family. Occasional specimens have been frequently met with, not referable in all respects to the published descriptions, and are probably as yet undescribed species, but as this is to a certain extent doubtful, the writer did not feel justified in giving names to what might be only varieties."-[C. C. A.]

P. erochrous, Cope. Red-sided Darter.

Dorsal outline of body curved, ventral straight; head long, decurved and narrow in front; lateral line on sixteen scales; blackish above, with notched, dark band on sides; no red dots. Dorsal rays, IX -10 ; anal rays, II -7 ; lateral-line scales, 43 ; length, 2 inches. Streams tributary to Chesapeake and Delaware Bays.-J. \& G.

\section{MICROPERCA, Putn.}

M. punctulata, P'utn. Least Darter.

Body short and deep; cheeks naked; opercles somewhat scaly; opercular spine very small; neck and chest naked; no trace of lateral line; scales ctenoid, large; anal spines strong; color olivaceous; sides speckled and with vague bars and markings; some of fins barred. Dorsal rays, VI-VII, 10; anal rays, II, 6 ; lateral-line scales, 34 ; length, $1 \frac{1}{2}$ inches. 
"Generally found in protected corners of rapid streams, resting on a flat stone or the level sand. In its movements it is very similar to $P$. coeruleus. Concerning its breeding habits the writer has gathered no particulars." - [C. C. A.]

\section{PEROA, L.}

P. americana, Schranck (Bodianus flavescens, acuta, gracilis, fluviatilis). Yellow Perch. American Perch. Ringed Perch.

Back dark olive; sides yellow, with six to eight bars; belly pale; lower fins red or orange; cheeks closely scaled, scales imbricated; opercles naked, armed with one spine, preopercle serrated. Dorsal rays, XIII-1, 14 ; lateral line complete.

"This well-known species is found more or less abundantly throughout the State. In the Delaware River, specimens of unusual size have been taken, weighing over four pounds."

\section{STIZOSTEDIUM, Raf}

(Lucioperca.)

S. vitreum, Mitch. (americana, salmonea.) Wall-eyed Pike. Dory. Glass-eye. Yellow Pike. Blue Pike (Var.) Jack Salmon. Susquehanna Salmon.

Pseudobranchs developed; branchiostegals seven; preopercle serrate; canine teeth in jaws and on palatines; body slender, fusiform; dark olive, finely mottled with brassy; lower jaw flesh color; belly and lower fins pinkish; black bloteh on spinous dorsal. Dorsal rays, XIII-I, 21 ; anal rays, II, 12 ; lateral-line scales, 90 ; reaches a length of nearly three feet and a weight of ten to twenty pounds. Some have been put into the Delaware by Pennsylvania authorities.

\section{Family SERRANIDFE.}

(Percidæ.)

Sea Bass.

Body oblong, compressed; with usually ctenoid scales; mouth horizontal, posterior part of maxillary not slipping under edge of 
preorluital; no incisors nor molars, but often canines; pseudobranchs large; opercle with one or two points; anal short, with three spines; vertehrse twenty-five; air-bladder adherent to abdominal walls.

\section{ROCCUS, Mitch.}

(Labrax, Cuv.)

\section{R. lineatus, Bloch. Striped Bass. Rockfish.}

Anal spines strong; branchiostegals seven; teeth villiform, some on base of tongue in two patches; caudal forked; dorsal divided; no supplemental maxillary; first dorsal with nine spines; lower jaw projecting; olivaceous silvery, white or brassy below; sides with seven or eight dark bands, one on lateral line; young slender; mouth large and oblique; twelve soft rays in dorsal and anal. Lateral-line scales, 65 ; length, 3 to 4 feet.

"Numerous in the various rivers of our State, and probably most so in the Delaware. Although met with during the greater part of the year in the rivers, it nevertheless appears to be a marine species that ascends in the spring for breeding purposes, and in the fall is again met with seeking the head-waters, this time to meet the outgoing shad, that are now making their way to the ocean to pass the winter. Many 'rockfish' winter in the salt creeks, but the majority seek the deep sea-water."

R. americanus, Gmel. (Morone, mucronata, rufus.) White Perch.

Sides not striped with black; olivaceous, with silvery sides and faint lighter streaks; back arched; head depressed and pointed; mouth small, oblique; dorsal fins united. Lateralline scales, 50 ; length, 12 inches (maximum).

"This well-known fish is abundant in the rivers of the State, and wandering from the rivers, enters the various creeks, and is to be met with in great abundance in tide-water streams in the neighborhood of flood-gates, where they congregate to catch the thousands of minnows that are swept through the gates at the 'turn of the tide.' No finer sport is to be had than fishing for 'white perch' at this time.

"This fish is abundant on the coast during the late autumn and winter, and from the brackish streams and various fishinggrounds it is brought at this time of year to the markets. They rarely reach over a foot in length, if ever. The largest specimen preserved at Philadelphia measures one foot." 


\section{SERRANUS, CuV.}

(Centropristis. Perca.)

S. nigrescens, Bl. \& Schn. (atrarius.) Northern Black Sea Bass. Blackfish.

Canine teeth of outer row small; caudal fin trilobed; color dusky, more or less mottled, with traces of pale longitudinal streaks along the rows of scales; young greenish, often with dark lateral band, sometimes cross bars; dorsal with whitish spots; body robust; head large, little compressed; top of head naked; about eleven rows of scales on cheeks; mouth oblique, low; dorsal spines strong; pectorals as long as ventrals (longer in southern variety, atrarius). Dorsal rays, $\mathrm{X}, 10$; anal rays, III, 7; lateral-line scales, 50; length, 12 inches.

"This species is the best known of our coast fish to the marketpeople. During the spring and summer it is brought in great numbers from our coast generally. The species never reaches a very great size, the largest specimeris met with by the author measuring fifteen inches."

\section{CREOLUS, J. \& G.}

(Paranthias. Brachyrhinus, \&c.)

O. furcifer, Cuv. \& Val. (Serranus.)

Is a revision of the following:

"Epinephelus oxypteras. Sharp-finned Corvina.

"A specimen of this fish is described in De Kay's Report, as having been met with in New York. The writer has not seen a living specimen." - [C. C. A.] Its occurrence on our coast is still doubtful.

\section{TRISOTROPIS, Gill.}

T. stomias, G. \& B. Black Grouper.

Dark gray, freckled with paler, but no distinct spots; fins tipped with black; mouth large; body slender; scales smooth, with many accessory scales. Lateral-line scales, 140. Rare north of Virginia. The following note seems to refer to a variety of the next species:

"Epinephelus moris. Groper.

"There is but one specimen preserved from the coast of New Jersey known to the writer. A southern species." 


\section{EPINEPHELI尺, BIoch.}

E. morio, Cuv. (erythrogaster.) Red Grouper.

Brownish, marked with ash; salmon below; fins margined with blue; scales of lateral line triangular, cycloid; elsewhere small and ctenoid; medium crest of cranium developed; opercle with two spines. Dorsal rays, XI, 17 ; anal rays, III, 9; lateral-line scales, 106. Southeru.

"Occasionally met with along the coast. - The writer has seen a specimen taken at Beesley's Point." - [C. C. A.]

\section{DULES, Cuv.}

D. auriga, Cuv. \& Val. Coachman. Charioteer.

This genus is distinguished by having third dorsal spine filamentous. Doubtful if ever taken on our coast.-J. \& G.

"A specimen of this fish is preserved in the museum of the Acudemy of Natural Sciences of Philadelphia, labeled 'Cape May, N. J.' The writer has seen no other specimen from State limits."- [C. C. A.]

\section{Family SPARID}

Scales ctenoid, sometimes nearly cycloid ("sparoid"); head large; premaxillaries protractile; maxillary without supplemental bone, and slipping under preorbital for its whole length; pseudobranchs well developed.

\section{LUTJANUS, Bl. \& Schn.}

(Mesoprion. Diacope, \&c.)

L. caxis, Bl.\& Schn. (griscus, Neomanis emarginatus.) Yelting. Gray Snapper.

Head long; mouth large; jaws with bands of villiform teeth, with well-developed canines in upper jaw, an anchor-shaped patch of teeth on vomer and one patch on tongue; caudal fin lunate; color greenish olive, each scale with a brown spot; cheeks with six rows of scales. Dorsal rays, $\mathrm{X}, 14$; anal rays, III, 8 ; lateral-line scales, 48. 
"This small species was first described by Prof. Baird in 1854, he having procured specimens at Beesley's Point. It is an abundant species in the salt rivers on the southern portion of our coast, frequenting the grassy-grown coves, and seldom seen where the water is free of vegetation."

POMADYS, Lac.

(Pristipoma, Cuv.)

P. fulvomaculatus, Mitch. (Orthopristis, Labrus, Hrmulon.) Speckled Red-mouth. Hogfish. Sailor's Choice.

Vomer, palatines and tongue toothless; dorsal fin continuous; body not much elevated; head long, with conical snout; mouth low and small, outer teeth slender and short; dorsal and anal naked to base, where is a sheath of scales; posterior spines lower than soft rays and anterior spines; caudal forked; color light brown, silvery below, orange-yellow spots on sides, in rows, oblique above lateral line, horizontal below; head blue and spotted. Dorsal rays, XII, 16; anal rays, III, 12 ; lateralline scales, 57 ; length, 12 inches.

"During the summer of 1865 , numbers of this fish were taken off Sandy Hook, and the writer has seen specimens since, caught near the mouth of the Delaware River. It is a visitor to our coast, however." - [C. C. A.]

P. virginicus, L. (Anisotremus, trniatus, Sparus.)

Golden olive above; a dusky bar from nape through eye, and from dorsal downward, behind which are several light-blue, narrow stripes; body ovoid, compressed and elevated; outer teeth strong; eye large; second anal spine longer than third. Dorsal rays, XII, 17 ; anal rays, III, 9.

"An occasional specimen of this fish has been taken on our coast, and the writer met with a specimen in the fish-market at Trenton, said to have been received from Barnegat." - [C. C. A.]

\section{DIABASIS, Desm.}

(Hæmulon, Cuv.)

D. plumieri, Lac. (Perca formosa, H. arcuatum.) Black Grunt. Squirrel-fish.

Brownish above, lighter below; head with twelve or more wavy lines of blue; fins dusky blue; body highest at dorsal; 
profile very convex to base of snout; second anal spine much enlarged; inside of mouth red ; soft part of fins scaled; caudal forked. Dorsal rays, XII, 17; anal rays, III, 9 ; lateralline scales, 55 .

"A single specimen of this fish was taken in Delaware Bay, in July, 1867, and is now in the possession of the writer. It is a rare visitor to our waters."

D. aurolineatus, Cuv. \& Val. (chrysopterus, quadrilineatum.) Yellowfinned Red-mouth.

Olive brown above; sides silvery; mouth large, red; back less elevated than in preceding; profile nearly straight; a narrow bronze band from snout throngh eye to caudal, and three or four stripes on head and anterior part of body; vomer, \&ce, toothless; soft part of fins scaled; dorsal continuous. Dorsal rays, XIII, 15 ; anal rays, III, 8 ; lateral-line scales, 55.

"This species is more frequently met with than the preceding, but is only a visitor to our waters. The writer has seen them exposed for sale in the Trenton fish-market."-[C. C. A.]

\section{LOBOTES, Cuv.}

(Holocentrus, Bloch.)

L. surinamensis, Bloch. (auctorum, erate.) Flasher. Black Triple-tail.

Blackish above, becoming silvery gray on sides, often blotched and tinged with yellow; fins dusky; head small, profile concave in front, convex from occiput to dorsal ; scales on opercle large, small around eye; pectorals shorter than ventrals, spines lower than soft dorsal ; caudal fin convex; jaws with bands of villiform teeth, in front of which are a series of larger ones; none on vomer. Dorsal rays, XII, 16 ; anal rays, III, 11 ; lateralline scales, 47 ; length, 2 to 3 feet.

"This is not a common species in our waters. 'The museum of the Philadelphia Academy contains specimens from Beesley's Point, and from Cape May."

\section{STENOTOMUS, Gill.}

(Sparus. Pagrus.)

S. chrysops, L. (aculeatus, argyrops.) Southern Porgee. Gilt-head.

Differs from following in having body larger, less elevated, more elongated, with coarser molar teeth; color silvery, with 
reddish tinge and golden streaks; head large; two rows of nolars, the inner series the larger; six strong, canine-like teeth in front of upper jaw ; five rows of scales on cheek and four on opercle; fins reddish. Dorsal rays, XII, 12; anal rays, III, 11 ; scales $7-48-14$; length, 18 inches.

"This species is included in our list, from the fact of various authorities making mention of it, but the author has not met with it." - [C. C. A.]

S. versicolor, Mitch. (argyrops, Sargus ambassis.) Scuppaug. Porgee. Sand Porgee (?). Northern Scup.

Brownish, silvery below; everywhere with blue reflections; vertical fins mottled; young faintly barred; body compressed; back elevated; head deep; mouth small ; incisors very narrow; molars in two rows above; cheeks with four rows of scales. Dorsal rays, XII, 12 ; anal rays, III, 11 ; scales $8-49-16$; length, 12 inches.

"Found generally along the coast, more abundantly after July. They enter the bays in large numbers, and are also caught at sea in very deep water. They are prized as a market fish, and are largely sold throughout the country and in towns not too remote to render transportation impracticable."

The following note probably refers to a variety of $S$. versicolor, or possibly of S. chrysops.

"Stenotomus arenosus. Sand Porgee.

"This is not an abundant species on the coast. They are generally met with in. August and September. Author has caught them near Tuckerton and Atlantic City."-[C. C. A.]

\section{LAGODON, Holbr.}

L. rhomboides, L. (Sparus, Sargus.) Pinfish. Bream. RhomboidaI Porgee.

Brownish, white below; sides with horizontal light-blue and golden stripes, and half a dozen faint, dark, vertical bands, disappearing with age; vertical fins yellowish, wich bluish stripes; body elliptical; head sharp; mouth small and upper jaw protractile; incisors broad and notched; cheeks with five to six rows of scales; a procumbent spine before dorsal, latter in spiny part high. Dorsal rays, XII, 11 ; anal rays, III, 11 ; seales, $8-66$ -18 ; length, 12 inches. 
"This species the author has seen a specimen of, in a small collection made at Beesley's Point, and now in the museum of the Philadelphia Academy."-[C. C. A.]

\section{DIPLODUS, Raf.}

(Archosargus, Gill.)

D. probatocephalus, Walb. (ovicephalus, Gill., Sparus, Sargus ovis.) Sheepshead.

Grayish, with eight vertical black bands; fins dark; body robust, very deep in old examples; back compressed and elevated; profile very steep; mouth low, horizontal; incisors broad, serrated in young; cheeks with six rows of scales; scales on breast small and crowled ; dorsal spines high ; soft dorsal low ; second anal spine strong. Dorsal spines, XII, 12 ; anal spines, III, 10 ; scales, $7-45-16$; length, 30 inches.

"This fine fish is quite abundant and most eagerly sought after. They are found on the coast from June or July, according to the season, until October. Opposite the village of Baruegat this species is met with quite abundantly, and many are taken by the professional fishermen during the summer months."

\section{OYPHOSUS, Lac.}

(Pimelepterus, Lac.)

\section{C. bosqui, Lac. (flavolineatus, Perca sectatrix.)}

Dusky, with about twenty-five light stripes following the rows of scales; scales of back and belly smaller than on sides; soft dorsal and anal very low, the latter short; caudal with lower lobe longer; top and sides of head and fins finely scaled; incisors lanceolate, with backward projecting processes. Dorsal rays, XII, 12; anal rays, III, 11; scales, $10-66-20$; vertebrr, $9+16$. Massachusetts to Panama. Common southward.

\section{Family SCI IENID FE.}

Cronkers.

Skull cavernous; head scaly; no teeth on vomers, \&c.; lateral line extends on to the caudal tin; scales thin and ctenoid; mucous 
pores much developed; ear bones large; dorsal fin not continuous; air-bladder large, perhaps used in producing peculiar grunting sounds, by squeezing air into lateral horns.

\section{POGONIAS, Lac.}

(Labrus.)

P. chromis, L. (fasciatus, Holb.) Big Drum. Banded Drum.

Grayish silvery, with four to five broad, dark, vertical bars that disappear with age (once considered as two species as to whether "banded" or not; the young are banded, large examples not); body compressed, oblong, with steep profile; scales large (except on breast); pectoral fins large; head scaly on top ; outline of belly not much curved ; upper jaw longest ; teeth small ; lower pharyngeals united, armed with paved teeth; lower jaw with short barbels; second anal spine very large. Dorsal rays, X, I, 20 ; anal rays, II, 6 ; lateral-line scales, 50. Abundant southward. Occasionally schools of them raid the planted beds of the oystermen and make sad havoc.

"Pogonias chromis. Big Drum.

"This is by no means as common as the succeeding species, but is nevertheless not a rare species. They are met with from Sandy Hook to Cape May, during the summer and early autumn.

"Pogonias fasciatus. Banded Drum (young of preceding).

"This well-known species is abundant in the bays along the coast, and is frequently found on the beach after a storm, killed by the violence of the waves."

\section{SCI 平NA, L。}

S. chrysura, Lac. (punctata, argyrolencus, Homoprion xanthurus, Bodiunus, Perca, Corvina, Bairdiella.) Silver Perch. Yellow-tail, \&c.

Greenish above, silvery below, each scale with a group of dark points in center; fins plain, caudal yellow; body robust; head conical ; preopercle serrated at its angle; jaws with stout teeth ; region between eyes narrow and normal; anal fin small and far back; pectorals short, pharyngeals separate, with sharp teeth; chin with pores, no barbels; teeth in jaws in one main series, bands narrow. Dorsal rays, XI, I, 22; anal rays, II, 9; lateral-line scales, 50. 
"This species is not very abundant, although specimens are not difficult to procure, if searsh is male for them where fishing is actively carried on."

S. ocellata, L. (Perca, Corvina, Scirnops.) Redfish. Red Bass. Channel Bass. Red Horse.

Grayish silvery, iridescent; scales with dark spots; at least one spot on caudal ; pectorals short; teeth in both jaws in broad bands; preopercle serrate; outer teeth in upper jaw considerably enlarged. Dorsal rays, $\mathrm{X}-\mathrm{I}, 25$; anal rays, $\mathrm{II}, 8$; lateralline scales, 50 ; attains 20 to 50 pounds.

"An occasional visitor to our waters, and seldom met with but as a straggler with other scieænoids."

\section{LIOSTOMUS, Lac.}

L. xanthurus, Lac. (Sciæna, Mugil, obliquus.) Spot. La Fayette. Oldwife. Goody.

Bluish above, silvery gray below, with fifteen dark, oblique bands; fins plain, caudal not yellow ; profile steep, snout blunt ; anal spines small; teeth feeble, permanent in upper jaw only. Dorsal rays, X, I, 32 ; anal rays, II, 12 ; lateral-line scales, 60 ; length, 12 inches.

"This is a well-known species, visiting the coast in summer, and in great numbers. It is known at Cape May as the 'Cape May Goody." "

The variety obliquus has bars and spots, and is probably old adults; the var. xanthurus is plain, hence following note:

"Liostomus obliquus.

"This is not as common a species as the preceding, but is occasionally met with in large numbers. During the summer of 1865 many were taken near Barnegat, and the writer saw them exposed for sale in the Trenton fish-market." - [C. C. A.]

\section{MICROPOGON, Cuv. \& Val.}

M. undulatus, L. (Perca, lineatus.) Croaker.

Bright grayish silvery; sides and back with narrow undulating lines of dots, three lines of dots along base of dorsal; head long; preopercle serrate or spiny; second anal spine weak; lower jaw toothless; teeth weak in upper jaw. Dorsal rays, $\mathrm{X}$, 
I, 32 ; anal rays, II, 12; lateral-line scales, 60 ; length, 12 inches. Cape Cod to Florida. Valued for food.

"This is a very rare species on our coast, and can scarcely be considered as a member of the fauna."

\section{MENTICIRRHUS, Gill.}

M. nebulosus, Mitch. (Umbrina.) Kingfish. Whiting. Barb.

Irregular dark bars, those in front run backward and downward, those further back the reverse; fins all dusky; body terete, elongate; snout very blunt; eyes small; lower jaw with one thick barbel; no air-bladder; only one anal spine; teeth in both jaws; dorsal spines high; soft dorsal low and long. Dorsal rays, $\mathrm{X}-\mathrm{I}, 26$; anal rays, $\mathrm{I}, 8$; lateral-line scales, 68.

"This fine fish is abundant on our coast, but is not frequently met with in the markets, or the wagons of traveling fishmongers. As an article of food it has no rival."

\section{CYNOSCION, Gill.}

(Cestreus, Gronow.)

O. regale, Bl. \& Schn. (Johnius, Otolithus.) Weakfish. Gray Trout. Squeteague.

Silvery, darker above, blotched, and with oblique undulating lines; second dorsal and caudal dusky and scaly; lower fins yellow or speckled; teeth sharp, in narrow bands; pectorals short; one or two canines in upper jaw only; lower jaw projecting; vertebræ, $14+10$; body elongate, little compressed; mouth large; anal spines feeble, one or two; caudal not forked. Of high rank as food-fishes.

"This is a very abundant species, well known along our coast. It affords excellent sport from the manner of seizing the hook, but is of little value as an article of food."

o. maculatum, Mitch. (Labrus squeteague, var. maculatum, Otolithus comolinensis, drummondii.) Spotted Sea Trout.

Bright silvery, darker above; back with numerous black spots, also on dorsal and caudal fins ; pectorals short. Dorsal rays, X-I, 25; anal rays, I, 10 ; lateral-line scales, 90 . Southern.

"This is an uncommon species on our coast, but is occasionally met with in company with allied species." 


\section{Family GERRID王.}

Mouth very protractile, descending when protruded; no supplementary maxillary ; spine from premaxillary ascends to above the eye ; surface of maxillary silvery, like rest of head; base of mandible scaly; teeth villiform; pseudobranchiæ concealed.

\section{GERRES, Cuv.}

G. gula, Cuv. \& Val. (Diapterus, Eucinostomus argenteus.)

Silvery, without spots or streaks; young sometimes barred; mouth small; scales large; soft dorsal extends further back than usual; second spines of dorsal and anal only a little enlarged; soft and spiny part of dorsal of similar extent; preopercle entire; anterior part of premaxillary groove on top of head, scaled. Dorsal rays, IX, 10 ; anal rays, III, 7 ; scales, 4-45-9; depth two-fifths of length; third dorsal spine twice the length of second anal.

"This species was first made known by Prof. Baird in 1854, he having taken specimens at Beesley's Point. The writer has seen many specimens from the same locality, and from South Amboy, Atlantic City, \&c. They are most abundant in September and later, until winter."-[C. C. A.]

G. homonymus, G. \& B. (Diapterus, Eucinostomus argenteus.)

Silvery, brownish above, center of scales with a dark spot; a spot on spinous dorsal; young with transverse bars; depth half of length; third dorsal spine about equal to second anal. Dorsal rays, IX, 10 ; anal rays, III, 8 ; lateral-line scales, 40 ; otherwise like preceding. Atlantic coast. Abundant southward.

\section{Family LABRIDA.; \\ Wrasse-fishes.}

Pseudobranchs well developed; slit behind last gill small or obsolete; scales cycloid; no supplemental maxillaries; premaxillaries moderately protractile; teeth strong, often soldered together into 
plates; lower pharyngeals completely united into one without median suture; lips thick and plicate; ventrals thoracic; most feed on mollusks, having teeth adapted for crushing shells.

\section{CTENOLABRUS, Cuv. \& Val.}

C. adspersus, Walb. (Tautogolabrus, Labrus, Uurgall, cornuleus.) Cunner. Chogset. Blue Perch. Bergall.

Pharyngeal teeth not confluent; teeth all conical, set in a band; the outer enlarged; no posterior canines; body slender, compressed; head pointed; cheeks with small scales, opercles with large ones; preopercle serrate; lateral line abruptly bent near posterior part of dorsal ; spiny part of dorsal the longer; anal spines strong; pectorals short; color brownish blue, with brassy luster; young variegated with black blotch on dorsal. Dorsal rays, XVIII, 10; anal rays, III, 9 ; lateral-line scales, 45 ; length, 12 inches.

"This is a numerous species, found about the coast generally, and not prized as an article of food. It has many common names, as 'nibbler,' 'conner,' \&c."

\section{BIATULA, Lac.}

(Tautoga, Mitch.)

H. onitis, L. (Labrus, americana, gardeniana, hiatula.) Blackfish. Tautog. Oyster-fish.

Preopercle entire; cheeks scaly, but opercles naked; teeth in two series, strongest in front; eye small, high up; head large; mouth small; dorsal low and long; spines with cutaneous appendage at tip; caudal short and truncate; branchiostegals five; color blackish; young greenish, with three pairs of irregular, chain-like bars; pectorals short. Dorsal rays, XVI, 10 ; anal rays, III, 8 ; lateral-line scales, 60.

"Found more or less abundant along the coast during the summer and autumn. They are prized as a market fish, and are brought to the various towns of the State throughout the winter. They occasionally are found in the rivers where the water has ceased to be brackish." 


\section{Family EPHIPPID 压.}

Angel-fishes.

Dorsal fin divided; vertical fins sealy; teeth bristle-like, in many rows; gill openings restricted to sides; body compressed, greatly elevated, with steep profile; scales etenoid; mouth small ; premaxillaries protractile; maxillary short, withont supplemental bone; preopercle usually finely serrate; pectorals short and ventrals long, thoracic $(\mathrm{I}, 5)$; air-bladder large, often forked in front and with two slender horns behind.

\section{CH开TODIPTERUS, Lac.}

(Parephippus, Gill.)

O. faber, Brouss (Chæotodon, Ephippus, Zeus, quadratus, gigas, zonatus). Angel-fish. Porgee.

Grayish, dusky band across eye to throat; similar bands on body, obscured with age; ventrals black; third dorsal spine prolonged; a row of pores on chin; body nearly orbicular in outline, much compressed; scales small. Dorsal rays, VIIII, 20 ; aual rays, III, 18 ; lateral-line scales, 60 ; length, 2 feet. Excellent for food.

"This peculiar fish is met with during the summer on our coast, but never abundantly; and during some seasons it does not make its appearance." Old individuals of large size, without bands, and with thick, bony masses on occipital crest, \&c., have by some been considered to be distinct species, as follows:

"Ephippus gigas.

"Has been caught in the Hudson River. Very rare."

\section{Family CHAETODONTIDE.}

Differs from last family in having the dorsal fin continuous; pseudobranchs very large; colors bright. 


\section{POMACANTHUS, LAc.}

(Chætodon: Holacanthus.)

P. ciliaris, L. Angel-fish. Isabelita.

Preoperculum with a strong spine at its angle; brownish olive; each scale with a crescent of lighter shade; nape with a dark-brown spot, enclosing blue center; cobalt-blue markings on various fins, spines, \&c.; yellow also on fins; scales ciliate; soft dorsal and anal with anterior rays prolonged as long streamers. Dorsal rays, XIV, 20 ; anal rays, III, 20 ; scales, $8-$ $50-30$.

"This beautiful species is seldom met with along our coast. A specimen is in the Philadelphia Academy's museum, that was taken in Delaware Bay. It is a southern species."

\section{Family ACANTHURIDEE.}

(Teuthidæ.)

\section{Surgeons.}

Teeth in one row, incisor-like; tail with one or more movable spines or bony plates on each side; mouth small, low; eye high up; premaxillaries movable, but not protractile; gill rakers obsolete; a gill slit behind fourth arch; gill openings restricted to the sides; pelvic bone long; ventrals thoracic. Herbivorous fishes.

\section{AOANTHURUS, BI. \& Schn.}

(Acronurus, Gunth.)

A. nigricans, L. (Chxtodon, phlebotomus.) Surgeon-fish.

A movable, lancet-like spine on each side of tail ; body ovateoblong, covered with minute ctenoid scales; operculum short; branchiostegals five; vertebræ, $9+13$; color brownish ; opercle with a black margin; sides with very narrow transverse bands; body not much elevated; profile somewhat convex and snout longish; fins high; caudal emarginate. Dorsal rays, IX, 25 ; anal rays, III, 23.

"This species is very rare upon our coast, and can only be 
looked upon as an occasional visitor. A single specimen has been seen, taken at 'Tuckerton in 1860."

These species are West Indian, and only rarely come northward. 1. chirurgus differs from preceding in having a less convex profile, shorter snout, vertical bars on sides wider, and vertical fins with oblique streaks. Besides this, there is the "blue surgeon," A. cceruleus, marked with bluish lines; profile concave, caudal forked, and body very deep; soft rays two or three more. A form more like nigricans is A.tractus, distinguished by deeply-forked caudal, with long upper lobe, which ends in a white thread; fins, but not body, streaked.

\section{Family URANOSCOPID EE.}

Star-gazers.

Anal fin elongate; pectorals broad; eyes small, on top of front of head; body terete, largest at back of head; scales small, in oblique series; lateral line feeble; mouth vertical; lips fringed; premaxillaries protractile; gill openings wide; branchiostegals six; gills three and a half, a small slit behind last. Carnivorous fishes, living on sea-bottom.

\section{ASTROSCOPUS, Brev.}

(Agnus. Upselonphorus.)

A. anoplus, Cuv. \& Val. (guttatus-Abbott's Catalogue.) Star-gazer.

Month large; teeth of jaws depressible; nostrils fringed; a Y-shaped projection on top of head; a naked space in front of the $\mathrm{Y}$, between eyes; belly mostly naked; sides with fine scales; brownish, covered with small white spots; candal striped; a broad, naked, electric area on each side of the Y. Dorsal rays, IV-13; anal rays, 12; lateral-line scales, 113. Young said to be naked.

"This species is not abundant, but is generally to be found if" hunted for, from Navesink to Cape May."

The following is evidently a stage in the growth of the preceding: 
"Upsilonphorus guttatus. Star-gazer.

"This species is about as abundant as the preceding, and for some time was confounded with it. The first description and figure published was by the writer, in the Proceedings of the Philadelphia Academy of Natural Sciences, 1860."-[C. C. A.]

\section{Family GOBIID压.}

\section{The Gobies.}

Gill openings restricted to the sides; no lateral line; body not elevated; spinous dorsal weak; inner rays of ventrals longest; premaxillaries protractile; nsually no air-bladder. Carnivorous fishes, living on the bottom, usually, of warm seas.

\section{GobIosoma, Grd.}

(Gobius, L.)

G. bosci, Lac. (alepidotum, Schn.) Goby.

Body naked; no canines; teeth in bands; ventral fins united; body oblong, depressed in front, compressed behind; eyes high, anterior, close together; color olive brown, with seven to eight paler transverse bars; caudal fin pointed and with curved bars; mouth small. Dorsal rays, VII-14; anal rays, 11.

"This is a very rare fish along the coast of New Jersey. Isolated specimens are occasionally met with in the loays and inlets, and one was taken in 1867 in Delaware Bay."

\section{Family SCORP AINID压.}

\section{Rockfishos.}

Suborbital, with a bony stay (" cottoid" character); body elongate, compressed behind; head large, often with spiny ridges; opercles with spines (five on preopercle, two on opercle); gill openings wide; ventrals thoracic, with branched rays (I, 5). Many of this family are viviparous. 


\section{SEBASTES, CUV.}

S. marinus, L. (Perca norwegicus.) Red Sea Perch. Redfish. Rosefish.

Snapper. Hemdurgan.

Orange red, sometimes with vague dusky bars; back elevated; belly profile nearly straight; top of head evenly scaled; concave between two low interorbital ridges; nasal spines present; opercular spines long and sharp; eye very large; mouth large, oblique; tip of lower jaw projecting; pseudobranchs large; caudal fin narrow and forked; scales weakly ctenoid; vertebræ, $12+19$; palatine teeth present. Dorsal rays, $\mathrm{XV}-13$; anal rays, III, 7 ; lateral-line scales, 85 ; tubes, 40 . North Atlantic; south to Cape Cod.

"A specimen of this northern species was taken off Sandy Hook in August, 1865, and presented to the writer."-[C. C. A.]

The following is a littoral variety or sub-species of the above having similar range :

Subsp. viviparus, Kröyer.

Brownish red, mottled, with black blotch on opercle, and brown spots on body; pectorals a little longer, body smaller.

\section{Family COTTID}

\section{Sculpins.}

Head broad, depressed; body tapering backward; eyes high up and close together; a bony stay connects suborbital and preopercle; upper angle of preopercle with spines; body never uniformly scaled ; caudal rounded; air-bladder usually wanting.

\section{HEMITRIPTERUS, CuV.}

H. americanus, Gmel. (Scorprna, Cottus, acadianus.) Sea Raven.

Spinous dorsal deeply notched, anterior spines highest; skin rough with prickles, \&c.; teeth on vomer and palatines; no slit behind last gill; head large, uneven; mouth very wide; preopercle with blunt spines; color reddish brown, marbled with darker and variegated; yellow below; prickles on back tubercle- 
like; two occipital spines on each side. Dorsal rays, IV, XII -I, 12 ; anal rays, 13 ; lateral-line scales, 40.

"An occasional specimen met with, but the species appears in our waters only as a straggler."

\section{URANIDEA, De K. \\ (Cottus. Cottopsis.)}

Ð. richardsoni, Ag., vur. meridionalis, Grd. Miller's Thumb. Blob. Muffle-jaw. Bullhead. Fresh-water Sculpin. Little Stargazer.

Body fusiform; head feebly armed; no slit behind fourth gill; branchiostegals six; dorsals nearly separate; skin mostly smooth; preopercular spine sharp and directed upward, and more or less concealed by skin; below this, two small spines; palatines with teeth; olivaceous, barred or speckled with darker, especially on fins; body relatively robust, tapering backwards; first dorsal low ; pectorals long. Dorsal rays, VI to VIII-16 or 17; anal rays, about 12; length, 3 to 7 inches. Abundant in Pennsylvania.

The following is also found in Pennsylvania :

U. viscosa, Hald.

Palatine teeth obsolete; ventrals, I, 3; anals, 14 or 15 ; spinous dorsal edged with orange; body stout, with many mucous pores on head; mouth small. Dorsal rays, VI-18.

The following is abundant in New York:

U. gracilis, Heckel (gobio, quiescens.)

Anal rays, 11 or 12 ; upper edge of spinous dorsal red in life; body slender, fusiform; preocular spine concealed; mouth large. Dorsal rays, VIII -16 .

\section{COTTUS, L.}

(Acanthocottus, Grd.)

\section{C. octodecimspinosus, Mitch. (A. virginianus.) Bullhead.}

Body slender, covered with thick skin, without true seales; head large; villiform teeth on jaws and vomer, none on palatines; preopercle with two strong, straight spines above and one below; color olivaceous, with transverse bars; fins barred and mottled; ventrals plain; tail very slender; head long and nar- 
row; upper preopercular spine more than four times as long as the spine next below; occipital ridges end in spines; eye large ; vertex flat; a series of concealed plates along lateral line; spinous higher than soft dorsal; no slit behind last gill. Dorsal rays, IX -15 ; anal rays, 14 .

"This species does not appear to be abundant in our waters, although met with along our whole extent of sea-board."

O. æneuø, Mitch. (mitchilli, Gunth.) Grubby. Least Sculpin.

Grayish olive, much variegated with darker, no paler spots; broad, dark bars on back and sides and fins; belly pale; head broad; preopercular spine about twice as long as next one below. Dorsal rays, IX -13 ; anal rays, 10 ; length, 6 inches.

"This is a much more numerous species than the preceding." The following is a variety of this species:

"Acanthocottus mitchilli. Sculpin.

"Not as abundant as the preceding" (oneus).

\section{Family AGONID}

Alligator-fishes.

Body elongate, angular, with a coat of mail of eight rows of bony plates; head externally entirely bony; eyes large, high up; mouth low, often with barbels; teeth small, in villiform bands; gills three and one-half, no slit behind last ; pseudobranchs very large; ventrals thoracic (I, 2 or 3 ); spinous dorsal small; caudal narrow; no airbladder. Feed mainly on Crustacea.

\section{ASPIDOPHOROIDES, Lac.}

(Cottus. Anoplagonus.)

A. monopterygius, Bloch.

No spinous dorsal ; body very long and slender, tapering to a six-sided tail, which forms two-fifths of whole length; plates keeled, not spiny; fins small; nasal spines very strong; color brownish, obscurely banded with darker; fins mottled; head triangular, narrowed in front. Dorsal rays, 5; anal rays, 6; length, 6 inches. North Atlantic.

"A specimen was taken off Sandy Hook in the summer of 1864." 


\section{Family TRIGLID王.}

Gurnards.

Differs from preceding family in having ventrals far apart and more rayed ( $I, 4$ or 5$)$; plates on head armed with spines; a large slit behind fourth gill; spinous dorsal present; caudal narrow ; pectorals large.

\section{PRIONOTUS, Lac.}

(Trigla, L.)

P. palmipes, Mitch. (Ornichthys, pilatus, carolinus.) Spiny Gurnard. Sea Robin.

Snout broad, flat; eyes close together, high up; head bony, rough; body scaly; opercles with spines, teeth on jaws, vomer and palatines; pectoral with three lower rays detached and thickened at tips; body robust, brownish above, clouded ; throat dark; a distinct black blotch on spiny dorsal and with light streaks; pectorals short; mouth small. Dorsal rays, $\mathrm{X}-13$; anal rays, 12 ; lateral-line scales, 58.

"This is an abundant species, found generally along the coast."

P. tribulus, Cuv. \& Val.

Mouth large; sides with spots; belly pale; blotch on spiny dorsal not ocellated; pectorals with bars, detached rays tapering; head shorter and broader than in next. Dorsal rays, $\mathrm{X}, 12$; anal rays, 11 ; lateral-line scales, 50. South Atlantic of United States. Rarer in our latitude.

\section{P. sarritor, L. (evolans.)}

Similar to P. strigatus (lineatus), but spotted also with white; pectorals black, with pale edgings longer; body and head stouter, plates rougher and scales larger, in about fifty-five series. Atlantic coast. Common southward.

P. strigatus, Cuv. \& Val. (lineatus.) Flying-fish.

Olive brown above, mottled and spotted with blackish; whitish below; a narrow black streak on lateral line and a broader one below it, ending behind in dots; lower jaw sometimes orange; pectorals black and orange and dark lines; black 
blotches on dorsal; ventrals and anals orange. Dorsal rays, $\mathrm{X}$, 12 ; anal rays, 11 ; lateral-line scales, 60 .

"This species is not abundant on our coast, although met with every summer by collectors."

\section{OEPHALACANTHUS, Lac.}

(Dactylopterus.)

C. volitans, L. (Gasterosteus spinarella, L.) Flying Gurnard.

Head blunt, quadrangular; body tapering backward; bones on top of head united into a shield, prolonged backward as two ridges to dorsal; preorbitals form a projecting roof above jaws; a long, rough spine on preopercle; cheeks and opercles with small seales; mouth small; no teeth on vomer and palatines; scales keeled; two knife-like, serrated appendages at base of tail; pectorals in two parts, the anterior of six rays about as long as head, the posterior large, and reaching nearly to caudal in the adult; air-bladder with two lateral parts ; vertebræ, $9+$ 13 ; color greenish brown and olive, paler below, marked with red and yellow; blue on pectorals; brownish-red markings on caudal; variable. Dorsal rays, II-IV, 8 ; anal rays, 6 ; length, 12 inches. Can fly like true flying-fish, but not so far.

"Although not numerous, this fish is well known to the shore fishermen. Specimens are met with along the coast and in our bays, and occasionally in the river's mouth, heyond the reach of strictly sea-water."

\section{Family CYCLOPTERIDEE.}

\section{Lump Suckers.}

Body short and thick; mouth small ; teeth slender, in bands, none on vomer or palatines; gill openings on sides, narrow; dorsal long, spiny in front, hidden by a fleshy lump in the adult; ventrals thoracic, rudimentary, forming the center of a sucking disk. 


\section{CYCLOPTERIS, L.}

C. lumpus, L. (Lumpus anglorum, De K.) Lumpfish. Lump Sucker.

Ventral disk small; head heavy, nearly round; skin with tubercles and seven rows of spiny plates; olivaceous, with darker markings. Dorsal rays, VII-10; anal rays, 10.

"This species belongs to the northern seas, and is very seldom met with as far south as the coast of New Jersey. A specimen taken at Sandy Hook in 1866, warrants our placing it in the State's fauna."

\section{Family BATRACHIDA.}

Toadfishes.

Body robust, depressed in front, compressed behind; head large, with mucous channels; mouth very large, with strong teeth ; psendobranchs none; ventrals large, jugular.

\section{BATRACHUS, Bl. \& Schn.}

B. tau, L. Toadfish. Sarpo. Oyster-fish.

Body scaleless; no lateral line; young with tufted cirri on back and sides; color dusky olive, with irregular bars on sides, \&c. ; belly lighter ; fins barred ; teeth largest posteriorly ; tip of snout with cirri ; subopercle ends in a long, sharp spine. Dorsal rays, III-27; anal rays, 24.

"This unattractive fish is very abundant along our coast, and is to be met with outside the beach, and never or very seldom in the inlets or bays.

"The flesh is said by those who have been able to overcome their aversion to the fish, to be very sweet and palatable."

\section{Family BLENNIDAE.}

\section{Blennies.}

Body oblong; cheeks not mailed; ventrals jugular ; caudal rounded, diphycercal ; air-bladder usually wanting. 


\section{CHASMODES, Cuv. \& Val. \\ (Blennius.)}

C. bosquianus, Lac. (Pholis, novemlineatus.)

Body naked; head triangular in profile, with pointed snout; mouth large; premaxillaries not protractile; teeth in one row, long and comb-like; gill openings very small; color in male olive green, with three horizontal, narrow blue lines; orange opercle and a stripe through spinous dorsal; anal fin dark rays with white tips; in female, head dotted with black; dark bars and narrow green lines on body. Dorsal rays, XI, 19; anal rays, 20. Rare on our coast; abundant southward.

"The writer has never met with a species of this fish; said to be an inhabitant of our range of coast."

\section{BLENNIUS, L.}

B. fucorum, Cuv.\& Val. Blenny.

Body oblong, compressed, naked; head short, profile rounded ; mouth small, with one series of long, close-set, curved teeth ; strong canines in both jaws; gill openings wide; color olive green, darker above, with numerous brown spots on cheeks and on sides of body; below faintly reddish; orbital cirri nearly as long as head. Dorsal rays, XI, 17 ; anal rays, 18.

"Not unfrequently met with out at sea, but does not appear to be abundant in the ocean, and less so along the coast."

\section{MUR AॄNOIDES, Lac.}

(Centronotus, Bloch.)

M. gunnellus, L. (Blennius, Ophidium mucronatum, Gunnellus macrocephalus, \&c.) Butter-fish.

Body band shaped; head small; scales small; no lateral line; dorsal long and low, composed of spines; anal has two spines; caudal small; ventrals rudimentary; color olive brown; sides with obscure bars; ocellated spots at base of dorsal; mouth oblique. Dorsal rays, LXXVIII ; anal rays, II, 38 ; vertebræ, 85 ; length, 12 inches.

"This species is abundant in New York Harbor, and is less numerous as we proceed down the coast of our State. Specimens have been taken in Delaware Bay." 


\section{ANARRHIOHAS, L.}

\section{A. lupus, L. (vomerinus, Stor.) Wolf-fish.}

Body elongate, covered with rudimentary scales; head compressed, scaleless, narrow above profile; decurved strongly; mouth wide, oblique; jaws with strong teeth in front; vomer thick, with two series of molars; palatines similarly; no lateral line; dorsal all spines, high; no ventrals; pectorals broad, low down ; color brown, with nine to twelve dark bars on sides, also spots, dc. ; fins dark; caudal tipped with reddish. Dorsal rays, LXII; anal rays, 42.

"Not unfrequently met with, but they are nowhere along our const abundant."

\section{Family LYCODID王.}

\section{Eelpouts.}

Body eel shaped; head large; mouth large, with conical teeth; bones of head unarmed; pseudobranchs present; dorsal and anal fins very long, without spines, not separate from caudal ; pectorals small; ventrals rudimentary, jugular; lateral line nearly or quite obsolete; viviparous, living on bottom of sea.

\section{ZOAROES, Cuv.}

Z. anguillaris, Peck (Enchelyopus, lubrosus, fimbriatus; Blennius ciliatus, the large-mouthed variety). Eelpout. Mutton-fish. Mother of Eels. Conger Eelpout.

Reddish brown, mottled with olive; dorsal marked with darker; pectorals two-thirds length of head; ventrals one-fifth head; some short spines in posterior part of dorsal. Dorsal rays, 95, XVIII, 17 ; anal rays, 105 ; length 20 inches. Anguillaris and ciliatus are by some treated as distinct species.

"Quite abundant in early spring, found associated with the common cod." 


\section{Family OPHIDIID EE.}

Body compressed, eel shaped, with small scales in oblique series; head large; gill openings wide; pseudobranch rudimentary; candal isocercal, confluent, with long, non-spined vertical fins.

\section{OPHIDIUM, L.}

O. marginatum, De K.

Scales not imbricated; head nearly naked; teeth on vomer and palatines blunt, on jaws fixed, for the outer series; color brownish ; vertical fins margined with black; air-bladder short, with foramen below.

"Rare. Prof. Baird reports a specimen taken at Beesley's Point."

\section{Family GADID正. \\ Codfishes.}

Body elongated, compressed behind; tail usually isocercal ; seales cycloid, small ; gill openings very wide; no spines; dorsal very long, often divided; ventrals jugular; no pseudobranchs.

ONOS, Risso (Ayres).

(Motella. Rhinonemus.)

O. cimbrius, L. (M. candacuta.) Four-bearded Rockling.

Brownish; posterior part of vertical fins abruptly black, also inside of mouth ; snout high ; mouth large, four barbels ; lateral line interrupted at intervals ; first ray of dorsal free and as long as head; no canines; dorsals two. Dorsal rays, 50 ; anal rays, 43 ; ventral rays, 5 ; length, 12 inches. North Atlantic.

PHYOIS, Bl. \& Schn.

P. regius, Walb. (Blennius, punetatus, Enchelyopus, regalis, Urophycis, Gill.) Spotted Codling.

Brownish and yellow; lateral line brown, with white spots; inside of mouth white; first dorsal black, edged with white; 
second dorsal spotted; pectorals dusky; ventrals white; sides of head spotted; body stout; mouth large; barbel on chin; palatines toothless; dorsals two; ventrals filamentous, separated. Dorsal rays, 8-43; anal rays, 45 ; lateral-line scales, 90 . Said to be electric.

"Rare. The writer knows it only from the work of De Kay." - [C. C. A. $]$

P. chuss, Walb. (Blennius, Enchelyopus americanus, filamentosus.) Ling. Codling. Squirrel-hake.

Brownish above; sides tinged with yellow, and punctulate with darker; lateral line not dark; body slender; eye large; first ray of dorsal filamentous, two-sevenths as long as body; ventrals long. Dorsal rays, $9-57$; anal rays, 50 ; lateral-line scales, 110.

"This is seldom met with along our coast, although very abundant northward. A specimen was taken in Delaware Bay, at Salem, N. J., in 1867."

P. tenuis, Mitch. (dekayi, Gadus.) Codling. White Hake. Squirrelhake.

Body lighter below; fins very dark; snout longer and narrower than preceding; filamentous dorsal ray two-thirds length of head; scales much smaller than in preceding. Dorsal rays, $9-57$; anal rays, 48 ; lateral-line scales, 138 . With the preceding.

\section{BROSMIUS, Cuv.}

B. brosme, Müll. (Gadus, flavescens, vulgaris.) Cusk.

Brownish, mottled; young uniform slate color, or with transverse yellow bands; vertical fins black, white bordered; upper jaw longer; head flattened; scales very small; chin with a barbel; branchiostegals seven; dorsal continuous (98 rays); anal rays, 71 .

"A rare species that is only met with as a straggler. The writer has seen but two, both from Cape May."

\section{GADUS, L.}

G. æglifinus, L. (Melanogrammus, Gill.) Haddock.

Dark gray above, whitish below; lateral line black; a dark blotch above pectorals; dorsal and caudal dusky; snout long 
and narrow, overlapping small month; teeth strong, in one row in lower jaw, and in band in upper; occiput with a high erest; eye very large; skull depressed, thinner in texture aud broader as compared with next; anterior rays of first dorsal elevated; second dorsal over vent; caudal lunate; scales very small; chin with a barbel; three dorsals and two anals; ventrals well developed, seven rays. Dorsal rays, $15-24-21$; anal rays, $23-21$.

"This is a very common species, offered for sale in large numbers in our markets, and when fresh is a moderately good fish for the table."

G. callarias, L. (morrhua, Morrhua americana, macrocephalus, ogak, auratus.) Common Codfish.

Lateral line pale; mouth large; color greenish brown (variable), sometimes yellowish or reddish, with many round brown spots; fins dark; occipital crest moderate; teeth in lower jaw, in band, the inner ones enlarged. Dorsal rays, $14-21-19$; anal rays, 20-18. Many varieties; dependent on locality.

"The cod is not by any means as common on our coast as farther north, but yet it is sufficiently abundant about several bars, as off Barnegat, and affords most excellent fishing. Fresh cod from Barnegat are offered for sale in Trenton market, in large quantities."

G. tomcod, Walb. (Microgadus, Morrhua pruinosa.) Tomcod. Frostfish.

Olive brown, blotched with darker; back and sides punctulate; snout rounded; mouth short; barbel small; ventrals filamentous, not reaching vent; second dorsal behind vent. Dorsal rays, $13-17-18$; anal rays, $20-17$; length; 11 inches.

"This is a very common little fish, more or less abundant throughout the year. As an article of food they are of little value."

G. virens, L. (carbonarius, Pollachius, Merlangus purpureus.) Pollack. Green Cod. Coalfish.

Greenish brown; silvery below; lateral line and fins pale; body elongate, compressed; snout sharp, conic; mouth oblique; teeth nearly equal; barbel rudimentary; vent under first dorsal ; pectorals and ventrals short; lower jaw projecting. Dorsal rays, 13-22-20; anal rays, 25-20; lateral-line scales, 150 ; vertebre, 54 . 
"This is not a common species on our coast, and when met with is associated with allied species. As an article of food they are not much prized."

MERLUCIUS, Raf.

M. bilinearis, Mitch. (Stomodon, Gadus, albidus.) Hake.

Grayish ; darker above, silvery below ; inside of mouth dusky blue; top of head with $\mathrm{W}$-shaped ridges; teeth not very large; pectorals and ventrals long; scales larger than in allied species; excavation on forehead; eye somewhat large; edge of preopercle free; mouth large, oblique; lower jaw longer, with slender teeth in two series, the inner movable, no barbel; branchiostegals seven; second dorsal and anal deeply emarginate. Dorsal rays, $13+41$; anal rays, 40 ; lateral-line scales, 100 to 110 . Large and voracious. Of little value for food.

"A rare species, that is, as an apparent straggler, found associated with the common cod and the haddock."

\title{
Order heterosomata.
}

\author{
Flat Fishes.
}

\section{Family PLEURONECTIDED.}

\section{Flounders.}

Cranium anteriorly twisted to allow both eyes on one side; dorsal long; body very flat, oval in outline; blind side plain and lowermost; cranium symmetrical in young, becoming twisted during development, and at same time the horizontal position of body is assumed; sometimes one eye moves through the cranium to reach the opposite side; no air-bladder; vent near head; scales small; lateral line usually extends on to caudal fin; pectorals and ventrals near together. 
BOTHUS, Raf.

(Rhombus. Pleuronectes.)

B. maculatus, Nitch. (aquosus, Lophopsetta.) Spotted Turbot. Sand Flounder. Window-pane.

Light olive brown, nearly translucent, marbled with paler, and with blackish blotches; body rhomboid; eye large; mouth large; teeth in one lateral series in both jaws; scales well-dereloped cycloid; no bony tubercles; dorsal and anal scaled; lateral line arched in front; dorsal begins on snout; left side uppermost. Dorsal rays, 65 ; anal rays, 52; lateral-line scales, 85 ; length, 18 inches.

"Occasionally this species is seen in our waters, but it is rare, and only taken associated with allied species."

\section{CITHARICHTHYS, Bleek.}

(Hemirhombus. Metoponops. Orthopsetta.)

C. arctifrons, Goode.

Light brown; body comparatively elongate; scales cycloid, deciduous; lateral line straight; eyes close together; dorsal begins over eye; pectoral on colored side twice the length of other. Dorsal rays, 83 ; anal rays, 67 ; left pectoral rays, 10 ; right, 7; lateral rays, 40 ; length, 6 inches. Gulf Stream, otf Rhode Island; probably referred to in following note, which designates a tropical species:

"Citharichthys microstomus.

"This is a rare species, met with occasionally, with other" flounders, and in its habits generally resembles them."

The following is associated with the preceding, but less abundant.

O. unicornis, Goode.

Ashy gray; eyes black; lateral line dark; body deepest over pectorals; strong ridge between eyes, ending in spine on snout; teeth minute, closely set, stronger on blind side. Dorsal rays, 74; anal rays, 60 ; right pectoral rays, 4 ; left, 10 ; lateral-line scales, 40 ; length, 3 inches. 


\section{HIPPOGLOSSUS, Cuv.}

स्H. vulgaris, Flem. (americanus, Pleuronectes hippoglossus.) Halibut.

Nearly uniform dark brown; blind side white; body deepest mesially, and tapering both ways; eyes large, separated by broad, flat area; eyes and color on right side; teeth in one series in lower, two in upper jaw; scales small, cycloid. Dorsal rays, 105 ; anal rays, 78 ; sometimes reaches a weight of 400 pounds.

"Halibut are seldom taken off the New Jersey coast, but occasionally they are met with in small schools. The markets are generally supplied from northern waters."

PARALICHTHYS, Grd.

(Chænopsetta, Ancylopsetta and Uropsetta, Gill.)

P. ocellaris, De K. (Platessa, Pseudorhombus, ophryas.) Oblong Flounder.

Brownish gray, mottled; fins dusky, with dark blotches; body elongate, thickish; mouth oblique; teeth in one row, the front ones canine-like; scales very small, not ctenoid, with accessory smaller ones; rather narrow-ridged space between eyes; eyes on left side; lateral line strongly curved anteriorly ; caudal doubly concave; both ventrals lateral. Dorsal rays, 88 ; anal rays, 67 ; lateral-line seales, 90. Common from Cape Cod to Florida.

P. dentatus, L. (Pleuronectes, Platessa, Pseudorhombus, Chrnopsetta, ocellaris, melanogaster, oblonga.) Common Summer Flounder.

Blackish olive, mottled and blotched with darker; pectorals barred; mouth wide, oblique; mandible heavy and projecting; eight to ten teeth on each side of lower jaw; anterior teeth strong and long; eyes small and not far separated; scales small, cycloid; ventrals small; fins all scaly. Dorsal rays, 85 to 93 ; anal rays, 65 to 73 ; lateral-line scales, 100 .

"This is a very common species, found everywhere along the coast, especially in warm weather, and is called 'summer flounder.'"

\section{HIPPOGLOSSOIDES, Gotts.}

(Psettichthys. Pomatopsetta.)

B. platessoides, Fabr. (Pleuronectes, dentata.) Rough Dab.

Reddish brown, nearly uniform; upper jaw with one series of teeth; mouth oblique, with a knob at chin; snout thick, scaled; 
eyes large; interorbital space rough, with scales. Dorsal rays, 80 to 93 ; anal rays, 64 to 75 ; 90 pores in lateral line. North Atlantic; abundant northward. The southern variety (limandoides) has a smaller number of fin rays.

\section{PLEURONECTES, L.}

P. ferrugineus, Stor. (Limauda, Platessa, Myzopsetta, rostrate.) Sand Dab. Fluke.

Lateral line arched in front; scales ctenoid; a strong anal spine; body ovate-elliptical, very flat, brownish olive, with many red spots; left side lemon yellow ; teeth small, conical, close set. in one series; snout projecting; eyes separated by a high, narrow ridge; eyes on right side. Dorsal rays, 85 ; anal rays, 62 ; lateral lines, 100.

"This is a rare ocean-loving species, that is met with occasionally associated with the preceding."

P. glaber, Stor. (Platessa, Liopsetta, Euchalarodus putnami.) Plaice.

Grayish brown, mottled with darker; black spots on fins; body oblong; eyes small, separated by a naked ridge; jaws with interrupted series of twenty incisor-like teeth, besides an inner row sometimes; right side of both jaws toothless; scales small, not imbricate, cycloid in female, ctenoid in male; anal spine present; lower pharyngeals broad, with paved teeth. Dorsal rays, 55 ; anal rays, 40 ; lateral line, 70 pores; length, 10 inches. Atlantic coast, chiefly northward.

P. americanus, Walb. (Pseudopleuronectes, Bleek.) Common Winter Flounder. Mud Dab.

Dark, rusty brown, spotted or nearly plain; young more olive and spotted; body elliptical; head covered above like body, with imbricated ctenoid scales; blind side of head nearly naked; eyes well separated; teeth close set, incisor-like; right side of both jaws toothless. Dorsal rays, 65 ; anal rays, 48 ; lateralline scales, 83 .

"This species is quite common along our coast generally, and is deservedly prized as an article of food. They are generally exposed for sale in the fish-markets, and are usually known as the "winter flounder.'" 


\section{AOHIRUS, Lac.}

A. lineatus, L. (mollis, Pleuronectes, lineatus, Solea, achirus.) Sole.

Olive brown, with six narrow, vertical, black lines and numerous spots and clouds; left side white, mottled or barred; form oval; scales on ehin, \&c., three or four times size of others; fins scaly on both sides; nostril of blind side and lip of colored side fringed; teeth small, on blind side only; head scaled; no anal spine; both pectorals absent. Dorsal rays, 55 ; anal rays, 41 ; lateral-line scales, 75 ; length, 6 inches.

"This little species is abundant along our coast and in the various bays and inlets. Although much more abundant during the spring and summer, they are met with throughout the year. They are known at Beesley's Point as the 'hog-choker.'"

\section{Order Pediculati.}

Carpal bones of pectorals elongate, forming a sort of arm; gill openings reduced to a foramen, more or less posterior to the pectorals; ventrals, if present, jugular; no scales; first vertebra united to cranium ; no interclavicles.

\section{Family LOPHIID $\not E$.}

\section{Fishing-frogs.}

Head wide, large, depressed; body tapering rapidly backward; mouth very large, opening into an enormous stomach; upper jaw protractile, lower projecting; teeth in both jaws strong and unequal; gill openings comparatively large in lower axil of pectorals ; pseudobranchs present; no gill rakers; spinous dorsal of three tentaclelike spines on head and three smaller ones behind; ventrals far apart.

\section{LOPHIUS, L.}

L. piscatorius, L. (americanus.) Angler. Fishing-frog. Monkfish. Goosefish. Allmouth. Bellows-fish.

Brownish, mottled; white below; pectorals and caudals black at tip; body scarcely longer than head; head surrounded by a 
fringe of barbels; spines on top of head in young. Soft rays of dorsal and anal, 10 and 9 ; length, 3 feet.

"This species is quite common along our coast. It is occasionally found in the Delaware River, in the vicinity of fresh water."

\section{Family ANTENNARIIDE.}

\section{Frog-fishes.}

Mouth oblique, almost vertical; gill openings small, pore-like; pectorals with elbow; ventrals near together; dorsal with three tentacular spines; can float by inflating stomach.

\section{PTEROPHRYNOIDES, Gill.}

(Antennarius, Lac.)

P. histrio, L. (Lophius, Pterophryne, A. marmoratus, Chironectes lavigatus.) Mousefish. Toadfish.

Body compressed, deep through occiput; mouth oblique; ventrals long; skin with fleshy tags; eye small; first dorsal spine tentaculate, second and third covered with fleshy filaments; soft dorsal high and long; anal short; color yellowish, marbled with brown; three bands from eye; vertical fins barred; white spots below. Dorsal rays, 14 ; anal rays, 7 ; ventral rays, 5 . Tropical; oceasionally northward. Different varieties referred to as different species in the two following of C. C. A. :

"Antennarius variegatus. Mousefish.

"Not common. The writer has seen but a single specimen, which was taken at Beesley's Point.

"Antennarius gibbus. Mousefish.

"Specimens of this species are more frequently met with than are the preceding."

\section{Family MALTHID王.}

\section{Batfishes.}

Head depressed and broad, with elevated snout and short, slender trunk ; mouth not large ; gill openings behind upper part of pectorals ; 
body and head covered with bony tubercles and spines; spinous dorsal reduced to a small retractile tentacle on head; angle in pectorals near base; branchiostegals five.

\section{MALTHE, Ouv.}

(Lophius, L。)

M. vespertilio, L. Batfish.

Pale grayish brown above, reddish below ; forehead produced into a conical process. Dorsal rays, 4 ; anal rays, 4 ; length, 6 inches. Chiefly southern. (II. cubifrons, associated with this, differs in having a shorter snout and heavier tail.)

"Occasional specimens are no doubt to be met with in our waters, but they have escaped the writer's detection." - [C. C. A.]

\section{Order Plectognathi.}

Scapula attached to cranium by a post-temporal; premaxillaries usually united to maxillaries; interoperculum a slender rod; skeleton weakly ossified; vertebræ few ; ventrals rudimentary.

\section{Family OSTRACIIDE.}

\section{Trunkfishes.}

Body angular, covered by a carapace of firmly-united, six-sided plates; the tail, jaws and fins free, and covered by naked skin; mouth small, with long, narrow teeth; gill opening a slit behind eye; no ribs; anterior vertebræ long, posterior very short.

\section{OSTRAOIUM, L. \\ (Ostracion. Artedi.)}

O. quadricorne, L. Cowfish. Cuckold. Trunkfish.

Brown, yellow, blue or green, with irregular blue blotches; carapace trigonal; adults with a broad, low ridge on each side of back; ventral surface flat; a stout spine over each eye ; carapace closed behind dorsal fin and anal. Common in southern waters of Atlantic. Probably referred to in following: 
"Tetrasomus camelinus. Trunkfish.

"The writer has never met with specimens of this fish, except one in a private cabinet, labeled 'Atlantic City, N. J.' '

\section{Family BALISTID $\mathbb{E}$.}

Trigger-fishes.

Body oblong, covered with rough scales or scutes, not united into a carapace; mouth small, with incisor-like teeth; eye near occiput; gill openings small slits, not behind pectorals; ventrals absent; one to three spines in first dorsal.

\section{BALISTES, L.}

B. capriscus, Gmel. (fuliginosus, De K.) Leather Jacket. Filefish.

Brown; second dorsal and anal with lines; caudal mottled and with dots; third dorsal spine stouter, but shorter than second; plates on head like those on body, rough; a groove in front of eye; tail compressed. Dorsal rays, III-27; anal rays, 25 ; lateral-line scales, 51 to 57 . Gulf of Mexico.

"This is a very rare species on our coast, but has been met with at Tuckerton and at Cape May."

\section{MONACANTEUS, Cuv.}

M. occidentalis, Gunth.

Brownish, mottled with paler; a broad band across middle of abdominal flap; scales small; tail with spines; snout pointed; dorsal spine with two rows of barbs behind; soft rays thirty; abdominal flap greatly developed, with rough scales. West Indies. Occasional on southern coast of United States.

M. hispidus, L. (broceus, massachusettensis, setifer", Stephanolepis, Canthorinus, Balistes.) Foolfish. Filefish. Thread Filefish.

Dull greenish, mottled with darker; fins olivaceous and blotched; body deep ; eyes large ; dorsal spine barbed; pectorals small; pelvic bone long, ends in a spine; abdominal flap short; each seale with three prickles; no spines on tail. Soft rays, 32, 
first one filamentous in some specimens; length, 6 inches. Referred to in following three species of C. C. A.'s list:

"Canthorinus broccus. Foolfish.

"This is an abundant species, found along our coast generally.

"Canthorinus massachusettensis. Filefish.

"This species is frequently met with during the summer months, along our coast generally.

"Canthorinus segnifer. Thread Filefish.

"Not abundant. Stragglers have been taken at Sandy Hook and at Cape May."

M. pullus, Ranz. (Cantherines, pardalis.)

Has two pairs of spines on sides of tail ; ventral spine fixed; dorsal without barbs; scales minute; skin velvety. Soft rays, dorsal, 35 ; anal, 31 . Rare north of Florida.

\section{ALUTERA, Cuv.}

\section{(Balistes.)}

A. schœpffi, Walb. (aurantiacus, cuspicauda, Ceratacanthus.) Unicornfish. Filefish.

Dull green, marbled; lower lip dusky; eye small; gill slit long, below eye; pectorals short; caudal long in young; scales shagreen-like; lower jaw projecting so teeth point obliquely backward; pelvic bones without spine. Soft rays, $36+38$; length, 16 inches. Referred to in following two notes of C. C. A. :

"Alutera cuspicauda. Unicorn-fish.

"This fish is very frequently met with along our coast, and is uniformly abundant from New York to Cape May. They are often abundant in Great Egg Harbor Bay, and many specimens are in the Philadelphia Academy, from Beesley's Point.

"Ceratacanthus aurantiacus. Orange Filefish.

"This species is only a straggler on our coast, and is very seldom met with. A specimen from Beesley's Point is in the Philadelphia Academy's museum."

A. scripta, Osbeck.

With blue spots and lines and small, round, black spots ; snout long, concave in profile; part of gill opening in front of eye; pectoral below eye; caudal long. Soft rays, dorsal, 46 ; anal, 50. Is rare north of South Carolina. 


\section{Family TETRODONTID}

\section{Puffers.}

Body broad; belly capable of great inflation; skin prickly (without scales); teeth confluent, to form sort of beak in each jaw; lips full ; no spines in fins; no ventrals.

\section{LAGOCEPHALUS, Swains. \\ (Gastrophysus.)}

L. Iævigatus, L. (Tetrodon.) Tambor. Smooth Pufier.

Olive green; silvery white below ; tail slender ; belly prickly, with spines well separated and equal; sides of tail with folds of skin. Dorsal rays, 14 ; anal rays, 12 . Tropics to Cape Cod.

"Only a straggler occasionally of this species is met with in our waters."

\section{TETRODON, L.}

T. turgidus, Mitch. Puffer. Swell-toad. Blower.

Olivaceous above, marbled with black; sides with black bars; a blotch below pectorals; fins plain; profile depressed in front of eyes; skin with three-rooted spines, longest on back and belly ; eyes small ; no fold on tail ; only one nasal tube on each side, but with two openings; dorsal and anal short. Dorsal rays, $\bar{T}$; anal rays, 6 ; length, 12 inches.

"Specimens of this fish are always to be met with in our coast-waters during the summer. At Atlantic City, in 1864, they were very abundant, and were readily taken with a hook."

\section{TRICHODIODON, Bleek.}

T. pilosug, Mitch. (Diodon.) Balloon-fish. Hairy Boxfish.

Brownish above, ashy below; spines golden; dark oblong spots on sides and above; body cuboid; skin spiny or bristly. Dorsal rays, 12 ; anal rays, 14 . North Atlantic. Rare. Perhaps following refers rather to next (or its young, var. fuliginosus):

"Diodon pilosus. Balloon-fish.

"This little fish is occasionally met with along our coast, most frequently, however, at the mouth of the Hudson." 


\section{CEILOMYOTERUS, Bibr.}

C. schœpfi, Walb. (geometricus, Bl. \& Schn., Diodon, maculostriatus.) Rabbit-fish. Spotted Balloon-fish. Swell-toad.

Greenish; belly pale; a round spot above pectorals, several posterior and dorsally; back and sides with black stripes, horizontal and oblique; eyes large; nine spines between eye and tail; fins small; spines with three roots (two in Diodon proper). Dorsal rays, 12 ; anal rays, 10 ; length, 6 inches.

"This species is not uncommon along our coast, entering the bays. It is generally met with in summer, and never in cold weather."

Subsp. fuliginosus.

Dark brownish olive, with wavy lines; belly black; bases of its spines orange; probably a young form of preceding.

\section{Family ORTHAGORISCID EE.}

(Molidæ.)

\section{Headfishes.}

Body short and deep, truncate behind; mouth small ; teeth united to form a beak; dorsal and anal confluent around posterior end of body; no ventrals; no pelvic bone; pectorals present; belly not inflatable; no air-bladder. Tropical fishes looking as if "all head," to which fins had been attached.

\section{MOLACANTHUS, Swains.}

M. nummularis, Walb. (Diodon, Acanthosoma, carinatum, pallasi.) Globefish.

Olive brown above, silvery below; vertically-oval body, higher than long; spines scattered on the deep orbicular body; striated on sides; vertical fins not confluent posteriorly; spines on tail in place of caudal. Dorsal rays, 25 ; length, 2 inches.

"Occasionally met with in our waters, but never abundant. Specimens are preserved in Philadelphia Museum, labeled 'New Jersey.'” 


\section{MOLA, Cuv.}

M. mola, L. (rotunda, Cuv., Tetrodon, Orthagoriscus analis.) Head-fish. Sunfish. Mola (a millstone).

Body in young shaped much as in preceding, but becoming longer with age; depth always more than half the length; a "nose" develops with age; skin thick, without spines, but granular; vertical fins high in front, confluent with the low caudal; color dark gray; sides brownish, with silvery; belly dusky; a broad, blackish bar along bases of vertical fins. Dorsal rays, 17 ; anal rays, 16.

"Specimens of this curious species are only occasionally met. The writer found a specimen partially decomposed, on the beach at Barnegat, in November, 1862."-[C. C. A.]

"This concludes the list of the marine and fluviatile species of fish found in the New Jersey waters, with whatever notes the author has made, during his study of their habits, since 1859" (1868).- [C. C. A.]

Note.-It is but just to Dr. Abbott, as well as to the reviser, to add that this Catalogue should have been enriched by the addition of the facts concerning the distribution of the Vertebrates of New Jersey, which have accumulated since 1868 (not incorporated into the general works mentioned in our Introduction); but unfortunately the time neediful for this further research too far exceeded the limits set for publication. It is hoped that in its present form, the Catalogue will be more efficient in stimulating accurate observation and in facilitating the gathering and organizing of all seattered information for the use of a future reviser.-Julius Nelson. 


\section{AंDDENDA.}

To facilitate inter-reference between this Catalogue and Jordan's Manual, these Addenda are added, the words being incorporated into the Index.

Pace 497. Sorex platyrhinis is common in the Northern United States; S. cooperi has nearly the same range. S. personatus ranges from Pennsylvania southward. $S$. hoyi is extra-limital to New Jersey. Blarina angusticeps has been found in Vermont. $B$. parva is common southward from Pennsylvania.

Page 498. Add (americanus, Bartram) as synonym to $\mathbf{S}$. breweri.

Page 501. Add (volans, L.) as synonym to S. volucella.

Page 505. Add (Calomys) as synonym to HESPEROMY S.

$H$. palustris occurs in New Jersey.

Page 507. The HYSTRICIDEE, Porcupines, represented by Erethizon (Cuv.) dorsatus, L., the Canada Porcupine, belong to the extinct fauna of New Jersey.

Page 508. The PHOCIDEE, Seals, represented by Phoca (L.) vitulina (L.), the Harbor Seal of the Banks of New Foundland, should be added to the list of occasional visitants.

Page 512. The Raccoons are separated from the other Ursidx, by Jordan, as a distinct family, Procyonidx.

Page 514. Add (CETE) as synonym for CETACEA.

Page 515. Add (DENTICETE) as synonym for ODONTOCETE. Tursiops tursio is abundant at Cape May. Tursiops erebennus, Cope, the Black Dolphin of the Atlantic, may be added to our list of dolphins, though extra-limital. P. plagiodon is occasional on our New Jersey coast.

Page 516. Add (phocæna) to synonymy of P. communis, and Snuffer, Puffing Pig, to common terms.

Page 554. Add (Sylvicolidæ) as synonym to MNIOTILTID $\mathbb{E}$.

Page 576. Add Winter Falcon to local names of B. lineatus.

Page 590. The note by C. C. A. accompanying M. scolopaceus properly belongs with M. griseus. 


\section{2}

Page 623. The note by C. C. A. accompanying P. puffinus refers most probably to $\mathrm{P}$. borealis, which is more common, and should properly replace $P$. puffinus in our Catalogue.

Page 624. [P. pelagica] is Procellaria pelagica.

Page 632. Add nigricollis, Brehm, Eared Grebe, to synonomy of C. cristatus.

Page 638. Add (Chelopus, Raf.) to synonymy of NANEMYS.

Page 641. The following Sea Turtles should have appeared in the list of

\section{TESTUDINATA: CHELONIID瓜,}

Thalassochelys (Fitzinger); caretta (L.), Loggerhead Turtle; Atlantic, north to Massachusetts. Reaches 400 pounds. DERMOCHELYDID EE, Dermochelys (Blainv.); coriacea (Vandelli), Leather Turtle, Trunk-back; differs from the former in having no scales on feet.

Page 643. Add "Spreading Adder" to local names of H. platyrhinus. Add (Regina) to synonymy of T. leberis.

Page 649. Add (SAlientia) as symonym to ANURA.

Page 652. Add "Swamp Tree-frog" to C. triseriatus.

Add (Pleurodelide) as synonym to SALAIMANDRID E.

Page 653. Add D. nigra (Green), Black Salamander, found in mountain springs of Pennsylvania, to extra-limital faunal list.

Page 654. Add erythronotus as synonym to P. cinereus.

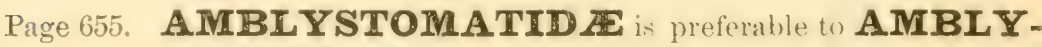
STOMID ZE.

Page 656. Extra-limital to New Jersey ocur the PROTEIDA

family PROTEID FE, Mud Puppies; Necturus (Raf.). maculatus (Raf.), the Water Dog or Mud Puppy, abundant in the great lake region, but also occurring in the Alleghany system. (Menobranchus) is synonym of NECTURUS. These are salamanders with external gills through life. Sometimes called Water "Lizards."

Page 657. The Amphioxus or Lancelet, a minute sea-fish and the simplest organized of all vertebrates, properly must be included in our List. It forms Class or Sub-Class Leptocardii, Order Cirrostomi, Family Branchiostomatidæ, Genus Branchiostoma (Costa), Species caribæum (Sundevall.) 
Page 658. Add (branchialis) as synonym to A. appendix.

Page 660. Add (Galeorhinidæ) as synonym to CARCHARIID 2 E.

Add (Galeus, Raf.) as synonym to MUSTELUS, Cuv.

Add (maculatus, Ranzani) as synonym to G. tigrinus.

Add (Carcharinus, Blainv.) as synonym to OARCHARIAS.

Add (Lamna) as synonym to C. coruleus.

Page 661. I. limbatus is extra-limital.

Page 662. Add (Squalus) as synonym to O. littoralis.

Page 663. The note by C. C. A., accompanying I. dekayi, refers probably to Lamna (Cuv.), cornubica (Gmel:), Porbeagle, or Mackerel Shark. First dorsal fin close behind pectorals; snout sharp; back elevated. Length, 8 feet. Frequently north to Cape Cod.

Page 666. The Southern Sting Ray, or "Whiparee," Dasyatis sayi (Le S.), is synonym of $T$. sayi, and is occasional on our coast. To this form, the note by C. C. A., appended to T. centrura, is intended to refer.

Add (bonasus, Mitch.) to R. quadriloba as synonym.

Page 667. Add (Mantidæ) as synonym to CEPHALOPTERID $\mathbb{E E}$. Add (cephaloptera, Raia.) to M. birostris as synonym.

Page 671. AMEIURUS is preferable to AMIURUS.

N. insignis (Rich.) has a flat and thin head with projecting upper jaw, and is perhaps more common than N. gyrinus in our region. The latter is found in the Hudson.

Add (nebulosus, Le S.) to synonymy of A. catus. Closely allied to this form and found in New York is A. melas. Adult very plump; pectoral spines very short.

Page 672. Add (Ameiurus) to synonymy of D. albidus.

Page 673. Add (Tachysurus, Lac., Galeichthys, Cuv.) to synonymy of ARIUS.

Page 676. Add (Pimephales, Raf.) as synonym to BYBORHYNCHUS.

Page 677. HEMITREMIA, CLIOLA, and MINNILUS are sections of genus NOTROPIS in Jordan's Manual.

Page 678. Add (megalops, Notropis) to synonymy of M. cornutus.

Page 679. Add (Kentuckiensis, Raf.) to synonymy of C. biguttatus.

Page 680. Add (Leuciscus) to synonymy of S. bullaris. 


\section{4}

GEOLOGICAL SURVEY OF NEW JERSEY.

Page 681. Add (Phoxinus, Ag.) to synonymy of Squalius, Bonap.

Page 683. M. atlanticus is occasional in our region.

Page 684. Add (Sadina, Mitch.) as synonym to E. teres

Page 685. Add "Summer Herring," Black-belly, to local names of C. æstivalis.

Page 686. Add (oglinum, Le S.) to synonymy of O. thrissa.

Page 687. Add (Clupeidæ) as synonym to DOROSOMATID RE.

Page 688. Add stolephoridx as synonym to ENGRAULIDID FE。 Add (argyrophanus, C. \& V., eurystole, Swain \& Meek.), to synonymy of $\mathbf{S}$. perfasciatus.

Add ' Synodontide) as synonym to SCOPELID FE.

Page 689. Osmerus is separated from the other Salmonoids by Jordan to constitute family ARGENTINID $\boldsymbol{A E}$.

Page 693. F. swampinus is a variety of F. majalis. F. nigrofasciatus is a variety of $\mathbf{F}$. heteroclitus.

Page 694. L. parva is also known as Rainwater-fish.

Page 695. Add var. pygmæa to U. limi.

Page 696. Add vermiculatus as synonymous with $E$. umbrosus.

Page 697. A. rostrata may stand as A. anguilla, var. rostrata.

Page 69S. Add (Echelus, Raf.) as synonym of LEPTOCEPEALUS.

Page 699. Add (Exocotidx) as synonym of SCOMBEROSOCID AE. Add (Esox), Silver Gar, to synonymy of T. marinus.

Page 700. The following allies of the flying-fish frequent the ocean in our latitude, besides those noted in the Catalogue: Euleptorhampus (Gill), longirostris (Cuv.) Lower jaw much prolonged; body and pectorals long and slender. Length, 18 inches. Pelagic; occasional north to Cape Cod. Parexocœtus (Bleek.), mesogaster (Bloch.) Jaws short; roof of mouth with teeth; dorsal fin very high. Length, 6 inches. Pelagic; ranges north to Rhode Island. Exocctus (Artedi), vinciguerræ (Jord.\& Meek.) Anal fin with 11 rays; ventrals black; no black on dorsal fin. Length, 12 inches. Atlantic north to Grand Banks. E. volitans, L. Differs from preced. ing in having smaller scales (lateral-line scales, 55), and ventrals are nearly white. E. heterurus, Raf. Anal fin short, with 9 rays; white band on pectorals. Lateral-line scales, 58 . Commonest species. 
Page 701. F. exsiliens, Müll., takes precedence of exiliens, Gmel., as name of this species.

Jordan includes CYPSELURUS in EXOCGTUS.

Add (E. gibbifrons) as synonym of C. comatus.

Page 702. Add (S. hippocampus) to synonymy of H. hөptagonus.

Page 704. Perhaps G. pungitius and $\mathrm{G}$. biaculeatus are but varieties of $\mathrm{G}$. aculeatus.

Page 706. Add (cephalus) as synonym of M. albula.

Add (curema) as synonym of M. brasiliensis (Günth.), not Ag.

Page 709. E. remora is also called Sucking-fish. E. brachyptera is also called Swordfish Remora. R. osteochir is also called Spearfish Remora.

Page 711. TETRAPTURU s may be separated as Family ISTIO. PHORIDEE.

T. lepturus is also termed Scabbard-, or Cutlass-fish.

Page 712. S. pneumatophorus is also called Thimble-eye.

Page 713. S. regalis is also called Pintado. Sierra.

Page 714. Add (Albacora) as synonym to ORYONUS.

Page 715. Add (latus) as synonym to O. amblyrhynchus.

Add C. gallus, L. (crinitus, Mitch.), Threadfish, to list of forms occasional in our region. Body very ovate; scales very small; scutes feeble. Length, 2 feet.

Page 716. Add (Scomber).to synonymy of C. hippos.

Page 717. Add Moonfish to local names of $\mathbf{S}$. (or Vomer) setipinnis. Add Bumper, Casabe, to local names of C. chrysurus.

Page 71s. Add T. falcatus, L. (ovatus, rhomboides), Round Pompano, Palometa, to list of forms occasional in our limits. Depth of body more than half length.

Page 722. Add Dorado to local names of C. hippurus.

Page 723. Add (Asternotrema) to A. sayanus as synonym.

Page 724. Add (Centrarchus) to A. rupestris as synonym.

Page 72s. Add (Calliurus) to M. dolomiei as synonym.

Page 729. Add (Oligocephalus) to E. Alabellare as synonym. Add (Etheosoma) to P. cæruleus as synonym. 
Page 733. Add (striatus) as synonym to S. nigrescens.

C. furcifer has small scales, covering also jaws and head; snout short; color reddish, with three small violet spots on side of back and one on tail. Tropical.

Page 734. Add (cerna) as synonym to E. morio.

Add "Mangrove Snapper" to local terms of L. caxis.

Page 736. Add (Chrysophrys) to synonymy of S. chrysops.

Page 7::T. Add (Sparus) to synonymy of S. versicolor.

l'age 741 . Add (saxatilis) to synonymy of M. nebulosus.

Add (nebulosus) to synonymy of C. maculatum.

Page 742. The GERRID $\boldsymbol{F}$ include the Moharras.

Page 747. Upsilonphorus (Gill), guttatus, should stand as U. y-græcum (C. \& V.), a distinct species with no barbel on mouth.

Page 750. Acanthocottus (Grd.), scorpius (L.), var. greenlandicus (C. \& V.), Big Sculpin, or Daddy Sculpin, is occasional as far south as New York; extra-limital to New Jersey.

Page 755. ANARREICHAS Jordan puts into a family by itself.

Yage 756. Add (Rhinonemus, Ayres) as synonym to Onos.

Page 761. Add (oblongus) to synonymy of P. ocellaris.

Add P. lethostigma, J. \& G. Southern Flounder. Occasional north to New York; has a nearly plain, dusky-olive color. This properly belongs in our list.

Platophrys (Swains.), ocellatus.(Ag.), (nebularis), is rarer north to Long Island; color grayish.

P'age 762, Add (glacialis) to synonymy of P. glaber.

Page 763. Add (fasciatus) to synonymy of $\mathbf{A}$. lineatus.

Page 766. Add (carolinensis) to synonymy of B. capriscus.

Page 768. Add (Orbidus) to synonymy of TETRODON (or Tetraodon.) 


\section{ERRATA.}

Page 501. For S. hudsonius, Pal., read S. hudsonicus, Erxl.

Page 505. For N. floridana, S., read N. floridana, Say \& Ord.

Page 510. For (noveboracencis), read (noveboracensis).

For L. canadensis, Sab., read L. hudsonica, L. (Mustela canadensis, Turton.)

Page 514. For B. mysticetes (cisarctica), read B. cisarctica, Cope (mysticetus, L.)

For Sibaldius, read Sibbaldius.

Page 516. For (D. Globiocephalus), read (Delphinus, Globicephalus).

Page 517. For O. gladiator, Lac, read O. gladiator, Bonnaterre (orca).

Page 526. For T. dominincensis, read T. dominicensis.

Page 527. For E. pusillus-traillii, read E. pussillus, var. traillii.

Page 541. For (Corturniculus passerinus), read (Coturniculus passerinus).

Page 553. For $\nabla$. noveboracencis, read $\nabla$. noveboracensis.

Page 557. For D. malculosa, read D. maculosa.

Page 555. For D. cœrulea, read D. cærulea.

Page 571. For T. aonalaschkæ pallassii, read T. aonalaschkæ, var. pallasi.

Page 584. For C. livia, read C. livia, Briss., Sub-species domestica

Page 585. For TYMPANUCHOS, read TYMPANUOHUS.

Page 586. For G. bankiva, read G. bankiva, Sub-species domestica. Bankiva Jungle Fowl. Domestic Fowl.

Page 602. For P. jamaicencis, read P. jamaicensis.

For P. noveboracencis, read P. noveboracensis,

Page 604. For Family IBIDEs, read Family IBIDID $F$. 


\section{GEOLOGICAL SURVEY OF NEW JERSEY.}

Page 622. For P. erythrorhynchus, read P. erythrorhynchos.

Page 624. For स. hastata, read F. hæsitata.

Page 628. For GELOCEELIDON, Brehn, read GELOCHELIDON, Brehm.

Page 632. For C. holbœlii, read C. holbœlli.

Page 641. For A. mutica, Less., read A. mutica, Le S.

For 8. undulatus, Harl. (tropidolepis), read S. undulatus, Daudin (tropidolepis).

Page 650. For R. silvatica, read $R$. sylvatica

Page 652. For C. triseriatus, Cope, read C. triseriatus, Wied.

Page 653. For D. miniatus, Raft., read D. miniatus, Raf.

Page 659. For SQUALUS, L., read SQUALUS, Artedi.

Page 664. For RAIA, L., read RAIA, Artedi.

Page 667. For M. birostris, Walf, read M. birostris, Walb.

Page 668. For A. brevirostris, read A. brevirostrum.

Page 676. For H. argyrites, read H. argyritis.

Page 679. For $\mathbf{S}$. corporalis, Mitch, read $\mathbf{S}$ corporalis, Auct.

Page 684. For OLUPEA, L., read CLUPEA, Artedi. •

Page 686. For Flat-back, read Fat-back.

Page 689. For SYNODUS, B. \& S., read SYNODUS, Gronow.

Page 695. For ESOX, L, read ESOX, Artedi.

Page 706. For MUGIL, L., read MUGIL; Artedi.

l'ace 7i. For SPEYRZENA, Bloch, read SPEYR丑NA, Artedi.

I'ice 7ls. For A. americanus, read A. tobianus, var americanus. For ECEENEIS, L., read EOEENEIS, Artedi.

Page 710. For (niger), read (nigra).

Page 731. For PERCA, L., read PERGA, Artedi.

Page 734. For (griseus), read (griseus) in synonymy of L. caxis. For EPINEPHELIS, Bloch, read EPINEPHELUS, Auct. (Cerna, Bonap.) 


\section{STATISTICS.}

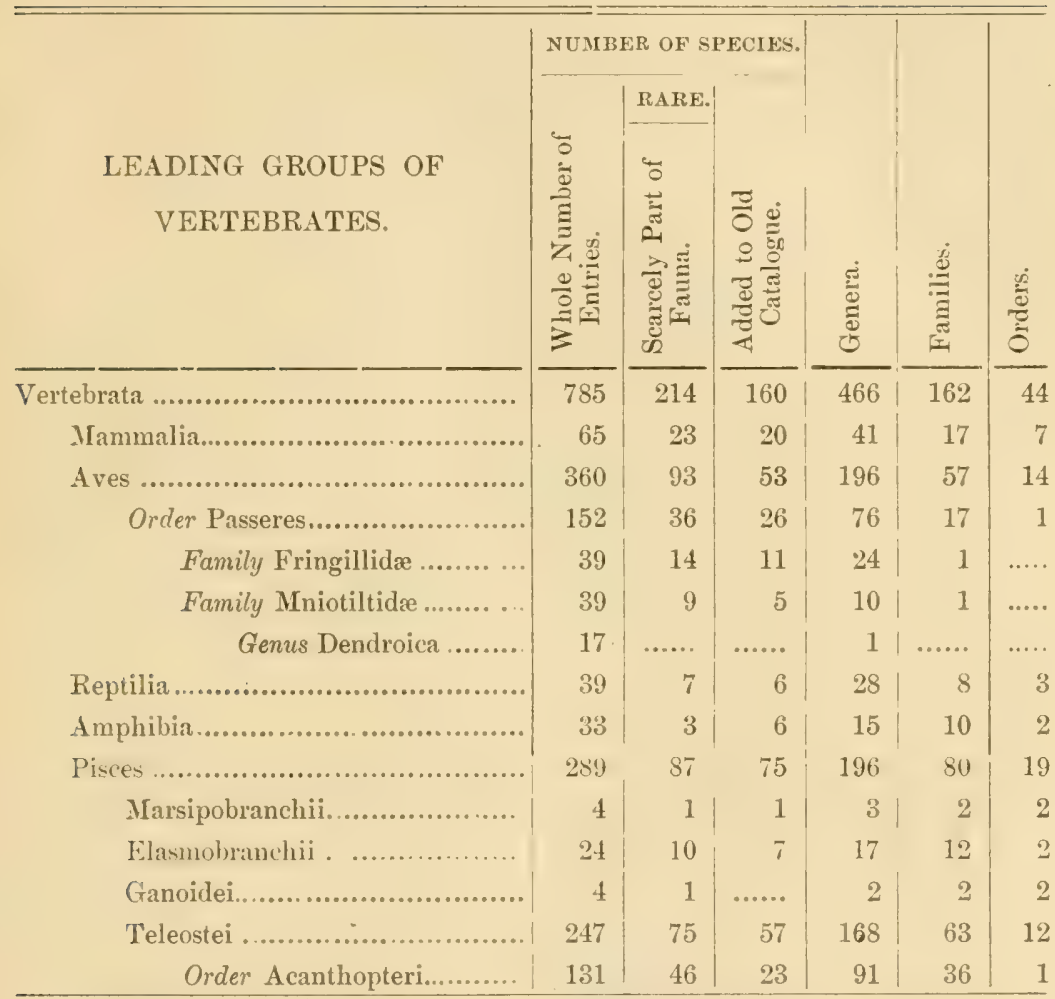

In this table the fifteen additions made in the Addenda are included. Of the additions made in the Addenda, the fishes receive the bulk; the mammals and reptiles nearly all the others. Nearly all the additions to the old catalogue go to swell the number of rare, extra-limital, occasional, doubtful or extinct species. In the column headed "rare" are not included any species that are ordinarily known as rare to collectors, provided the claim of such a species to a place in the fauna of the State is well established. The table shows at a glance that only about six hundred species of Vertebrates properly belong to our fauna, and probably less than five hundred of these are abundant or common. 



\title{
ABBREVIATIONS.
}

\author{
(List of Authors.)
}

The figures show approximately the relative (not absolute) frequency with which the abbreviations occur (synonyms not counted).

A.

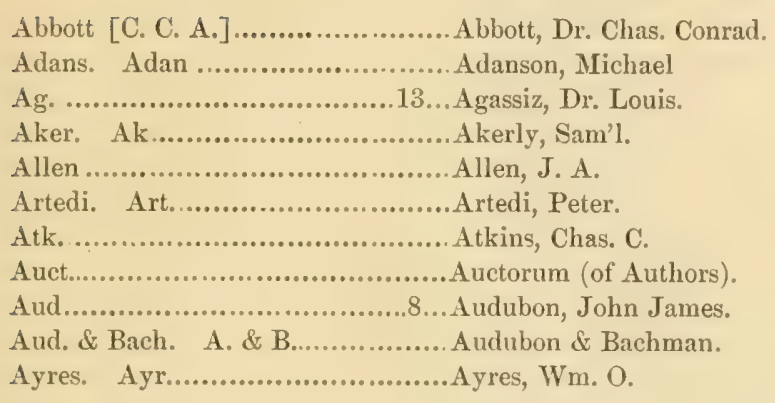

B.

Baird. Bd......................23...Baird, Spencer Fullerton.

Bd. \& Grd. B. \& G..............10...Baird \& Girard.

Bach... ............................... Bachman, John.

Bartr...............................Bartram, Wm.

Banc..................................Bancroft, Edward.

Beauvois. Beauv......................Beauvois, Palisot de.

Bechst. Bechs..........................Bechstein, Johann Natth.

Bean. B...........................Bean, Tarleton H.

Bewick.............................. Bewick, Thos.

Bibr. Bib ..........................Bibron, Gabriel.

Blainv.............................. Blainville, Marie Henri Ducrotay.

Bloch. Bl. B.................. 8...Bloch, Mark Elieser.

Blochm..............................Blochmann, J.

Blas. Bl............................ Blasius, Johann Heinrich

B1. \& Schn. B. \& S..............10... Bloch \& Schneider.

Bleek ................................4...Bleeker, Pieter Van.

Bodd. Bod........................4...Boddaert, Petrus.

Boie.............................12... Boie,

Bosc................................... Bosc, Louis Augustin Guillaume.

Bonnat. Bonn. Bon..................Bonnaterre, Pierre Jean l'Abbé. 
Bonay. Bp …................ 21... Bonaparte, Chas. Lucien.

Brayt .............................. Brayton, Alembert Winthrop.

Brewst ............................ Brewster, Wm.

Brandt ............................... Brandt, J. Franz.

Brevoort. Brev .......................Brevoort, Jas, Carson.

Brehm ..............................Brehm, Chr. Ludwig.

Briss. Bris ......................19...Brisson, Mathurin Jacque.

Brouss. Bruts ........................Broussonet, Pierre Auguste Marie.

Brunn. Brun ........................Brunnich, Martin Thos.

C.

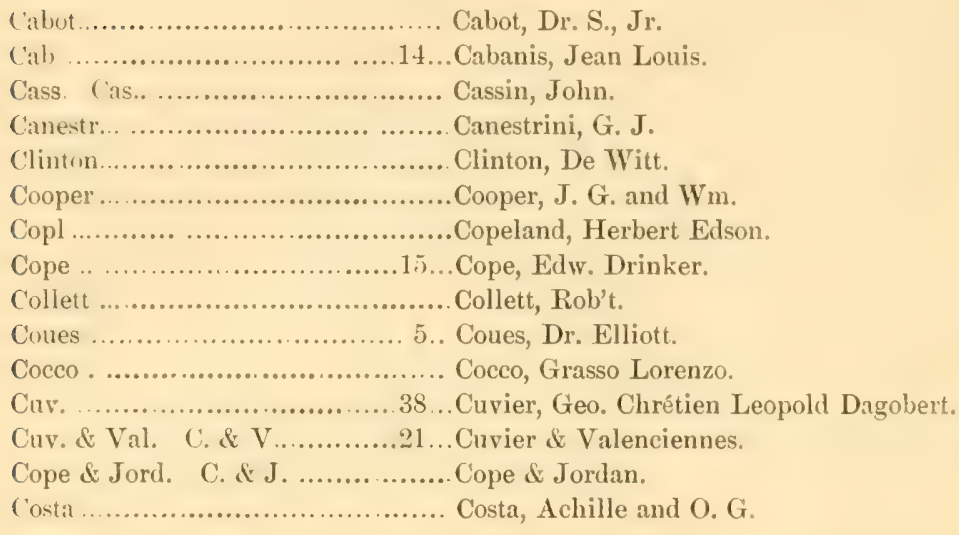

D.

Dalit

Daldorf,

Dant .

4...Daudin, Francois Marie.

De K. or Dek....................12...De Kay, James Ellsworth.

Desm . .............................. Desmarest, Gaetan Anselm.

Delar.............................. Delaroche,

Domov ................................ Donovan, Edward.

I)resi. . ... ............................ Dresser, Henry E,

Dumer. [um ...................5...Duméril, André Mariè Constant and Aug.

Dum. \& Bibr. D. \& B. ......... 3...Duméril \& Bibron.

E.

Erxl................................... Erxleben, Johann Christ. Polycarp.

Eyt ................................. Eyton, T. C.

F.

Faber. Fab..........................Faber, Johann.

Fabr.

$2 . .\left\{\begin{array}{c}\text { Fabricius, Geo. Christ. and Otho (Northem } \\ \text { Fishes). }\end{array}\right.$

Finsch Finsch, Otto. 
Fitzing: Fitz. Fitzinger, Leopold Joseph Franz.

Flem.................................. Fleming John.

Forst.............................7...Forster, Johann Reinhold.

Freminv, Frem........................Freminville, Christ. Paul de.

G.

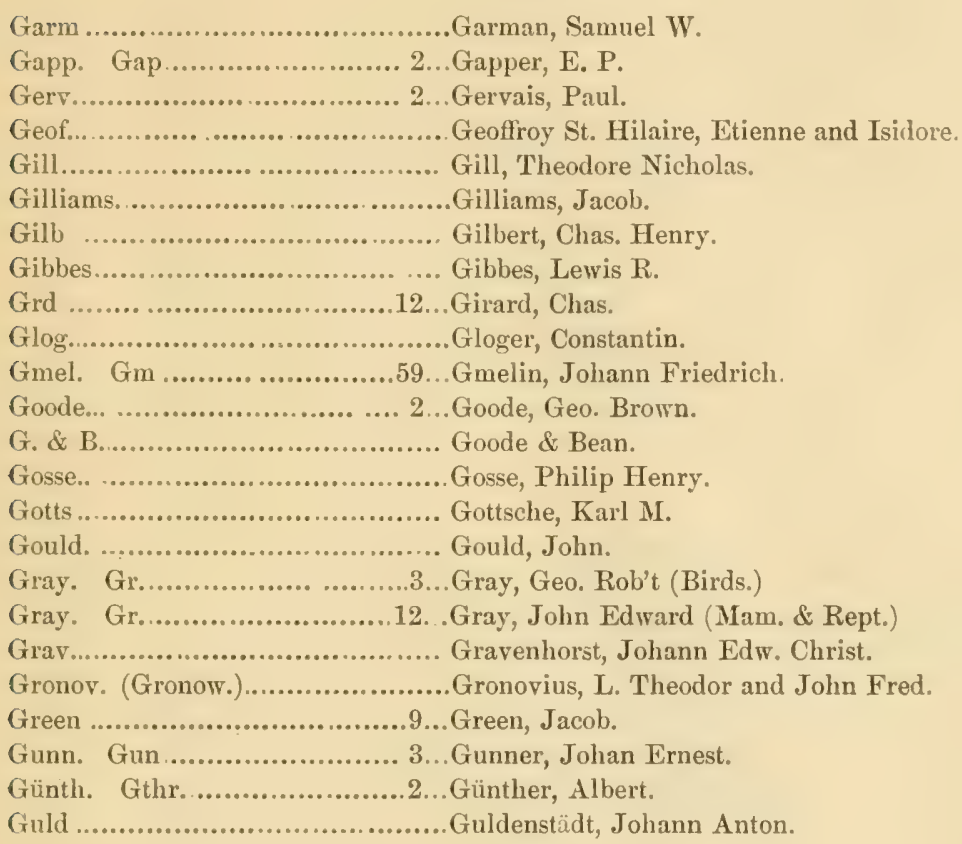

\section{H.}

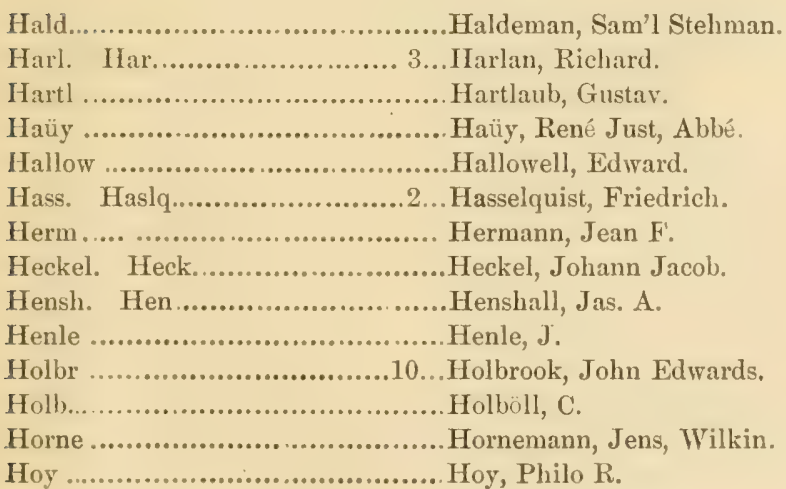

\section{I.}

Illig. Ill .4...Illiger, Johann Carl Wilhelm 
J.

Jord. Jor..............................Jordan, David Starr.

J. \& G....................................Jordan \& Gilbert.

J. \& M....................................Jordan \& Meek.

$\mathrm{K}$.

Kalm .................................Kalm, Pehr.

Kaup.................................... Kaup, Johann Jakob.

Keyser. Keys. K....................Keyserling, Alex. B.

Keyser. \& Bl. K. \& B................. Keyserling \& Blasius.

Kirtl. Kirt............................Kirtland, Jared Potter.

Koch..................................... Koch, Carl Ludwig.

Kram................................. Kramer, Wm. Henry.

Kröy.....................................Kröyer,

Kuml .................................Kumlien, Ludwig.

Kuhl................................Kuhl, Heinrich.

L.

Lat ....................................Latrobe, Benj. Henry,

Lac................................42...Lacepède, Bernard Germain.

Lafres. Laf............................Lafresnaye, Etienne.

Lath................................5... Latham, John.

Latr.....................................Latreille, Pierre Andre.

Lawr..................................Lawrence, Geo. N.

Laur....................................Laurentini, Joseph Nicolas.

Le C...............................10...Le Conte, John L.

Le S................................21...Le Sueur, Chas. Alex.

Less. Les...........................7...Lesson, René Primevère.

Lepech.............................Lepechin, Iwanowitch.

Leach..............................10...Leach, William Elford

Link....................................ink, J. H.

Licht................................ 4...Lichtenstein, Anton August Heinrich.

Linn. Lin. L.............. 292... Linnæus, Carl von.

Lowe.....................................Lowe, R. $\mathrm{T}$.

Lütk. Lüt.......................Lütken, Chr. F.

M.

Mayn................................... Maymard, C. J.

Merr. Mer...........................Merrem, Blasius.

Mitch.............................41....Mitchill, Sam'l Latham.

Meek.................................Meek, Seth E.

Montag. Mont....................2... Montagu, George.

Mü̈ll. Mül......................6...Müller, Otto Friedrich and Johannis.

M. \& H................... 廿.........4...Müller \& Henle. 
N.

Naum................................ Naumann, Carl Friedrich and Joh. Andreas.

Nels .....................................Nelson, Edw. W.

Nils................................. Nilsson, Sven.

Titt.............................. Nuttall, Thos.

O.

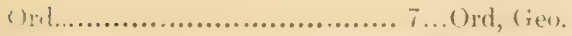

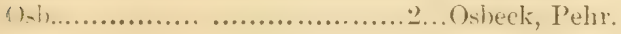

P.

Pall. Pal........................6...Pallas, Peter Simon.

Peck.................................Peck, W'm. Dandridge.

Pom.................................. Pomel, A.

Putn............................... 2...Putnam, Fred. Ward.

Poey................................Poey, Felipe.

$R$.

Rat ............................. Ratinerflue, Cuntantine sim'l.

Ranz................................ Ranzani, Camillo.

Reich............................... Reichenbach, Heinrich Gustav Lnelwig.

Feinh. Rein....................... Reinhardt, J.

Ridg................................. Ridgway, Rob't.

Rice............................ Rice, Frank C.

Rich............................... Richardson, Sir John.

Risso. Riss. Ris.................... Risso, Antonio.

S.

Sab.............................. 2...Sabine, Edw.

Savig. Sav...........................Savigny, Marie Jules Cesar Lelorgne de.

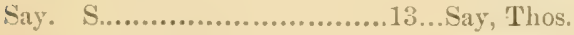

Schl.................................Schlegel, Hermann.

Schr................................. Schreber, Johann Christopher Daniel von.

Schn ................................... Schneider, Johann Gottlob.

Schranck ..........................2...Schranck, Franz von Paula.

Schw .............................. 3...Schweigger, August Friedrich.

Scop ..................................Scopoli, John Anton.

Schöpff..................................Schöpft, Johann David.

Sclat. Scl........................... Sclater, Phil. Lutley.

Smith, H.............................Smith, Hamilton L.

Sharpe ............................... Sharpe, Richard Bowdler.

Shaw ............................. 5...Shaw, Geo.

Sharpl ..............................Sharpless, J. T.

Sprague...............................Sprague, Isaac.

Stor................................... Storer, Horace Rob't and David Humphrey. 
Strickl. Strick........................Strickland, Hugh.

Steph .................................Stephens, Jas. Francis.

Stejn ................................... Stejneger, Leonhard.

Steind ................................ Steindachner, Franz.

Suckl.................................Suckley, Geo.

Sund......................................Sundevall, Charles James.

Sw. \& Rich. S. \& R..............2...Swain \& Richardson.

Swains. Sw....................23... Swainson, Wm.

Swain .............................. Swain, J.

\section{T.}

Temm ............................. 2...Temminck, Conrad Jacob.

Towns ....................................Townsend, J. K.

Thomps, Thom...................... Thompson, Rev. Zadock.

Tschud. Tsch.......................... Tschudi, Johann Jakob.

Traill ................................... Traill, Thos. Stewart.

Thunb. Thun.. ....................... Thunberg, Carl Peter.

Turt .................................... Turton, Wm.

Tunst.................................. Tunstall, Marmaduke.

V.

Val................................. Valenciennes, Achille.

Vaillant. Vaill...................... Vaillant, Francois Le.

Vieill...................................Vieillot, L. P.

Vig.................................. Vigors, Nicholas Aylwarl.

Vand...................................Vandelli, Domenico.

W.

Walb.............................12...Walbaum, Johann Jul.

Wagl..............................4...Wagler, John.

Wils...........................24...Wilson, Alex

Wath. Wat...........................Waterhouse, Geo. Rob't.

Wied..................................Wied, Max. Alex. Phil.

Wieg.................................... Wiegmann, Arend Friedrich Aug.

Weinl. Wein........................Weinland.

Z.

Zimmer, Zim........................ Zimmermann, Eberhard Aug, Wilh. 


\section{GENERAL ABBREVIATIONS.}

The numerical measurements given with each specific description are only averages, and considerable variations are likely to be found. In the fishes the Roman numerals indicate stiff rays, and the Arabic soft rays in tins. When the figures are separated by a dash or plus, the fin is composed of corresponding distinct parts. Posterior finlets are also represented by a Roman numeral indicating their number. The number of scales along the lateral line (or in its absence, along an imaginary line) are indicated, and when the scales are unlike on different parts of body, the number is broken by dashes or otherwise. 



\section{INDEX.}

This Index refers to the Catalogue as emended according to the Addenda and Errata.

A.

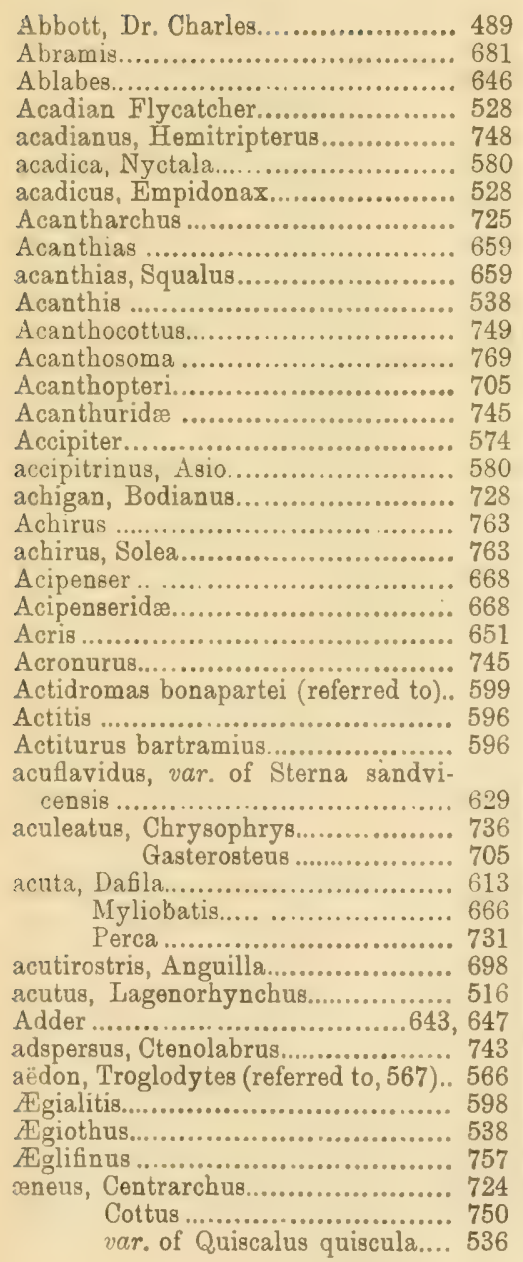

æstiva, Dendroica...................... 556

Piranga............................ '548

æstivalis, Clupea........................ 685

æstivus, Phyllophylophis................ 646

Estrelata ................................... 624

Ettobatidø.............................66 666

affinis, Aythya.......................... 615 Esox ................................ 696

Agelaius ............................... 532

agilis, Geothlypis......................... 561

Agnus ................................. 746

Agonidæ .................................. 750

agrestis, Spizella......................... 543

Ailurichthys............................6 673

ailurus, Pimelodue...................... 672

Aix ....................................... 614

Alaudidæ ..................................... 528

alba, Guara.............................. 604

Albacora....................................... 714

albeola, Charionetta.................... 616

albicauda, Echeneis..................708, 709

albicollis, Zonotrichia.................. 543

Albicoro................................. 714

albidus, Ameiurus...................... 672

Gadus ............................ 759

Ictalurus...................... 672

Tetrapturus.................. 711

albifrons, var. gambeli, Anser......... 619

Albula.................................. 682

albula, Mugil,.............................. 706

Albulidæ ................................ 682

Alca ....................................... 635

Alcedinidx........................... 522

Alcidæ ..................................... 634

alcyon, Ceryle............................ 522

alepidotus, Gobius....................... 747

Alewife ..................................... 684

Alle ........................................6 636

alle, Alle......................................... 636

alleghaniensis, Coluber................. 645

Alligator-fishes ............................. 750

Allmouth ................................... 763

Alopiidø ................................... 661

alpestris, Otocoris........................ 528

alpina, var. pacifica, Tringa............ 592

Alopecias................................. 662

Alopias .................................. 662

(789) 
Alosa

684,685

Alvarius................................. 729

Alutera................................ 767

ambassis, Sargus......................... 737

Amber-fish ............................. 718

Ambloplites .......................724, 725

amblyrhynchus, Caranx................ 715

Amblystoma............................. 655

Amblystomatidø......................... 655

Amblystomidæx......................... 655

Ameiurus... .............................. 671

Rmericana, Anas...................... 612

Aythya ..................6.6 614

var. of Certhia familiaris, 568

Compsothlypis ............. 556

Curvirostra.................. 537

Fulica....................6 604 var. of Glaucionetta clan-

gula .....................6.6. 615

Lucioperca ................ 731

Morrhua ..................... 758

Oidomia .................... 618

Perca......................... 731

Raia.........................664 664

Recurvirostra.............558 58

Stilbe.....................6 681

Spiza ...................... 547

Tautoga.................. 743

var. of Tringa alpina...... 592

American Avocet ........................ 588

Barn Owl................... 579

Bittern ....................... 605

Black Scoter............... 618

Black Tern...................6 630

Coot......................... 604

Creeper ....................... 56. 5

Crossbill...................... 537

Crow ............................ 530

Dunlin .................... 592

E $\theta 1 . . . . . . . . . . . . . . . . . . . . . . .6697$

Egret....................... 607

Eider Duck................. 617

Golden-eye Duck........... 615

Golden Plover.............. 597

Goldfinch.................... 538

Goshawk.................... 575

Hawk Owl................. 582

Herring Gull.................. 626

Hop-toad.................... 652

Long-eared Owl............ 579

Merganser..................... 609

Merfin........................ 578

Osprey ....................... 578

Oyster-catcher............... 600

Perch....................... 731

Pine Grosbeak.............. 537

Pipit ......................... 564

Red Breast.................. 572

Robin ......................... 572
American Rough-legged Hawk...... 576

Salamanders .................. 654

Scaup Duck................6 615

Smelt ......................... 689

Snipe ......................... 589

Sparrow Hawk.............. 578

Sturgeon ................... 668

White-fronted Goose....... b19

White Pelican............... 622

Widgeon .................... 612

Woodcock .................... 589

americanus, Abramis ................... 681

Acanthias................... 659

Ammodytes................ 708

var. of Bufolentiginosus, 652

Coccyzus.................... 522

Corvus ..................... 530

Cygnus ...................... 620

Enchelyopus, Phycis..... 757

Esox........................ 695

Hemitripterus ............. 748

Hippoglossus ............. 761

Lepus ....................... 507

Leucosomus ..............6.68 681

Lophius ................... 763

Merganser ................. 609

Odontaspis ................ 662

Petromyzon ...............6.658

Pleuronectes .............. 762

Roccus .................... 732

Scapanus .................. 498

Squalus.................... 662

var. of Troglodytes aëdon 566

Tympanuchos ............ 585

Ursus .................... 512

Amiurus ................................... 671

Ammocœtes .............................. 658

Ammodrainus ............................. 541

Ammodytes.............................. 708

Ammodytidit ............................ 705

amœnus, Carphophiops................. 647

Ampelidæ ................................... 550

Ampelis................................... 550

Amphibia ..........................4492, 649

Amyda.................................. it it

Anacanthini......................... 705

analis, Orthagoriscus................... 770

analostana, Cliola...................... 677

Anarrhichas............................. 755

Anas...................................... 610

Anatidx............................... 6C9

anatum, var. of Falco peregrinus.... 577

Anchories.............................. 588

Ancistrodon.............................. 648

Ancylocheilus subarquata.. .......... 592

Ancylopsetta............................ 761

andersonii, Hyla....................... 651

Anderson's Tree-toad....................6 651

Angel-fishes............................ 744

Angel-fish .......................744, 745 
Angler

anglorum, Lumpus...................... 753 Puffinus......................6 623

Anguilla.............................6.67, 698 var. rostrata, Anguilla....... 697

anguillaris, Zoarces....................... 755

Anguillidx ............................. 697

angusticeps, Blarina...................... 497

Anisotremus.............................. 735

annulata, Melanura..................... 695

Anoplagonus........................... 750

Anoura.................................. 649

anoplus, Astroscopus.................... 746

Anser ...................................... 619

Anseres..................................6 609

Antennarius.............................. 764

Antennariidæ............................ 764

Anthus.................................. 564

antiquorum, Hippocampus........... 702

antillarum, Sterna.................... 630

Antrostomus ............................. 523

Anura ................................. 649

aonalaschkæ, var. pallassii, Turdus... 571

Apeltes................................... 705

appendix, Ammocootes..................66 658

Pomotis..................726, 727

A ņhredoderidæ ......................... 722

Aphredoderus ............................ 723

Aphrizidæ................................6 600

Aplesion ..................................... 729

Apodes..................................... 697

Apomotis .................................. 726

aquaticus, Scalops........................ 498

Aquila.................................... 577

aquosus, Rhombus....................... 760

aranea, Sterna.......................... 628

Archibuteo .............................. 576

Archosargus............................ 738

arctica, Fratercula....................... 634

Arctic Jaeger........................... 625

Puffin ............................. 634

Tern ................................6 629

areticus, Urinator....................... 633

arctifrons, Citharichthys.................. 760

Arctodromas............................ 591

Arctomys................................. 502

arcuaturn, $\mathrm{H}$ iemulon....................... 735

Ardea ..................................... 606

Ardetta ....................................6 606

Arenaria....................................66 600

arenaria, Callidris ........................ 593

arenosus, Stenotomus................... 737

Ardeidæ ................................. 605

argentatus, Plargyrus .................. 678 var. smithsonianus, Larus 626

argentea, Selene....................716, 717

Argentinidæ ............................ 689

argenteus, Eucinostomus .............. 742

Leuciscus...... argenteus, Trichiurus................. 711

Argyrea ................................ 707

Argyreus.................................. 678

Argyriosus ..........................716, 717

argyrites, Hybognathus................ 676

argyroleucus, Corvina, Bodianus...... 739

argyrophanus, Stolephorus............. 688

argyrops, Sparus, Pagrus, Stenoto-

mus....................... 737

Stenotomus.................... 736

Ariopsis ...................................... 673

Aristonetta............................ 614

Arius ........................................ 673

Arkansas Flycatcher.................... 526

Arromentird....................... 526

Aromochelys ........................... 640

Arvicola.................................... 505

Asio..................................... 579

asio, Megascops.......................... 581

Aspidonectes............................ 640

Aspidophoroides ........................ 750

Astatichthys............................. 729

Asternotrema ............................. 723

Astroscopus ............................. 746

Atalapha .................................. 494

ater, Molothrus......................... 531

Atherina................................ 689

Atherinidæ............................ 706

atkinsii, Gasterosteus................... 704

Atlantic Salmon.......................... 690

atlanticus, Elacate..................... 710

Megalops.................... 683

atrarius, Pimelodus..................... 671

Serranus................................ 733

atrata, Catharista....................... 574

atricapillus, Accipiter.................. 575

Parus...................... 569

atricilla Larus......................... 627

atromaculatum, var. of Boleosoma olmstedi........... 728

Cyprinus...............6 679

atronasus, Rhinichthys................ 679

auctorum, Lobotes........................ 736

auduboni, Dendroica..................... 557

Puffinus. ..................... 624

Audubon's Shearwater................. 624

Warbler........................ 557

Auks ...................................... 634

aura, Cathartes.......................... 573

aurantiacus, Balistes...................... 767

Ceratacanthus ............... 767
auratus, Carassius................... 682

Colaptes ...................... 521

Gadus ............................ 758

aurea, Clupea............................. 686

aurocapillus, Seiurus................... 560

aurolineatus, Diabasis.................... 736

auriga, Dules........................... 734

auritus, Colymbus (referred to, 632)... 631 
auritus, Lepomis....................... 726

autumnalis, Plegadis.................... 605

Autumn Warbler....................... 558

Auxis................................... 712

Aves.................................... 518

Avocets .................................... 588

Aythya.................................. 614

\section{B.}

Bairdiella 739

Baird's Sandpiper........................ 592

bairdii, Tringa........................ 592

Balmaa.............................. 514

Balænidæ ............................... 514

Bald Eagle............................ 577

Bald pate................................ 612

Balistes ............................766, 767

Balıstidr................................ 766

Balloon-fish............................... 768

baltimore, Icterus....................... 534

Baltimore Oriole....................... 534

Banded Darter........................... 729

Drum ......................... 739

Leriole........................... 719

Pickerel.......................... 695

Rattlesnake................... 648

Barnacle Goose........................ 620

Barn Owls................................ 579

Swallow.......................... 549

bankiva, var, domestica, Gallus...... 586

Bank Swallow........................... 550

Barb ..................................... 741

Barred Owl............................. $5 \varepsilon 0$

Barfish................................. 724

Barndoor Skate ....................... 665

Barracudas .............................. 707

Bartramia ........................... 596

Bartramian Sandpiper................ 596

Bascaniun ........................... 645

Basking Sharks.......................... 663

Bass .......................... 727, 732, 740

bassana, Sula.......................... 621

Battishes .............................. 764

Batfish.................................. 765

Batoidioi............................. 6633

Batrachia............................... 649

Batrachians.............................. 649

Batrachid............................. 753

Batrachus .............................. 753

Biats ............................... 494

Bay Porpoise.......................... 516

Bayou Bass............................. 727

Bay-breasted Warbler................... 558

Bay-winged Bunting................... 542

Bears.. ................................... 512

Beaver .................................... 503

Bee Martin............................... 526

Pelted Kingtialer................... 522
Bellows-fish ............................ 763

Bergall.................................... 743

bernicla, Branta........................ 620

bewickii, Thryothorus .................. 566

Bewick's Wren........................ 566

biaculeatus, Gasterosteus...........704, 705

bicolor, Amblystoma ................... 656

Calamospiza .................... 547

Parus ........................... 569

Tachycineta .................... 449

bifrenata, Hemitremia ................. 677

Big Drum................................. 739

Big-eyed Herrings...................... 683

Scad ........................... $71^{\circ} 5$

Big Salamanders....................... 655

Sapsucker .......................... 518

Scaup Duck......................... 615

Skate Ray........................... 664

biguttatus, Ceratichthys............... 679

bilinearis, Merlucius ..................... 759

bilineatus, Spelerpes .................... 654

Billfish ........................669, 700, 711

Birds.................................. 518

birostris, Manta......................... 667

Raia..........................6.6. 667

bispinosus, Myliobatis ................ 666

bisus, Auxis .......................... 712

Bitterns.................................. 605

Black and Whito Creeper................ 554

Warbler ............ 554

Yellow Warbler.............. 557

Black-banded Sunfish................... 726

Black Bear............................... 512

Black-bellied Plover..................... 598

Sandpiper.............. 592

Black.billed Cuckoo.................. 522

Blackbird ............................532-535

Black Brant.............................. 620

blackburniæ, Dendroica ................ 559

Blackburnian Warbler................. 559

Black-capped Chickadee................ 569

Petrel ................... 624

Black-cap Titmouse................... 569

Black Cat .................................. 509

Catfish .......................... 671

Dolphin ......................... 515

Duck.............................. 611

Black eared Sunfish...................... 720

Blackfish (mammal). ................. 517 (fighes)..................732, 743

Black Fox............................ 508 Grouper......................... 733

Grunt.............................. 735

Guillemot...................... 634

Black-headed Gull..................... 627

Black Hawk............................ 57

Logcock ......................... 520

Black-masked Ground Warbler....... 562

Black-necked Stilt....................... 588

Black-nosed Dace..................... 679 
Black-poll Warbler

558

Black Rat

Skimmer

Snake.

Squirrel

Blacks-tailed Godwit..

Black-throated Blue Warbler........ 557

Bunting................ 547

Diver ................ 633

Green Warbler........ 559

Loon 633

Black Sucker ............................ 674

Triple-tail......................... 736

Vulture.......................... 574

Whale .......................514, 517

Woodcock................. 520

Blarina.............................496, 497

Blennies................................ 753

Blennius.................754, 755, 756, 757

Blenniidæ.............................. 753

Blenharis ................................. 716

Blob .............................. 749

Blower .................................... 768

Blowing Viper.......................... 643

Blue-back Herring....................... 685

Blue-bill Duck........................... 615

Bluebird 573

Blue Catfish.............................. 672

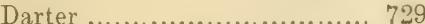

Bluefishes ............................... 720

Blue Golden-winged Warbler......... 554

Blue-gray Flycatcher..............528,570

Gnatcatcher................. 570

Blue Grosbeak.......................... 546

Blue-headed Flycatcher................ 553

Vireo ..................... 553

Blue Jay (referred to, 540)........... 529

Perch .......................... 743

Pike ................................ 731

Blue-spotted Salamander............. 654

Bluo Stocking,........................ 588

Blue-triled Lizard...................... 642

Blue Warbler............................. 558

Blue-winged Teal..................... 611

Yellow Warbler......... 555

Blue Yellow.backed Warbler.......... 556

Blunt-nosed Bat....................... 496

Minnow.................... 676

Shiner.................. 717

Bobolink ................................ 531

Bob White........................... 584

Bodianus ...............724, 728, 731, 739

Bog-trotter ......................... 574

Bohemian Wax.wing.................. 550

Boleichthys ........................... 729

Boleosoma .......................728, 730

Bombycillidæ............................ 550

Bonaparte's Gull........................ 627

Sandpiper.................. 591 bonasus, Rhinoptera ................... 666

Bone Dog ............................. 659

Bonefish................................... 682

Bonito.................................. 713

Bonnet-head Shark...................... 661

Bony-fish.................................. 686

Bony Gar.................................... 669

borealis, Buteo .......................... 575

Contopus ...................... 527

Dryobates .................. 519

Lanius (referred to, 540).... 551

Numenius ...................... 597

Puffinus..................... 623

Rorqualus (referred to)...... 514

Sphyræna .................... 707

Borer................................... 657

boreus, Esox............................. 696

boschas, Anas........................... 610

bosci, Gabiosoma...................... 747

bosqui, Cyphosus....................... 738

bosquianus, Chasmodes................. 754

bostoniensis, Catostomus.............. 674

Muræna ................... 697

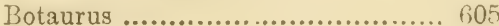

Bothrolæmus ........................... 718

Bothus ................................ 760

Bottle nosed Dolphin.................... 515

bovinus, Cyprinodon................... 692

Bow.head Whale........................ 514

Box Tortoise............................... 637

Turtle........................... 637

brachycium, Phocæna................. 516

brachyptera, Echeneis................. 709

Remora..................... 709

brachypterus, Globicephalus.......... 517

Brachyrhinus ......................... 733

Branch Herring........................ 684

branchialis, Ammocotes............... 658

Branta .................................... 620

Brant Goose............................ 620

brasiliensis, Mugil.......................... 706

Bream ......................727, 737, 651

brevicauda, Blarina.................... 496

brevirostris, Acipenser................ 668

Hippocampus............. 702

Tetrapturus .............. 711

Brevoortia.......................... 686

breweri, Scapanus......................... 498

brewsteri, Acanthis....................... 538

Brewster's Linnet...................... 538

Warbler ................... 555

Brier Ray............................ 665

Broad-bill Ducks (referred to, 610) .. 615

Broad Shiners.......................... 720

Broad-winged Hawk.................. 575

broccus, Balistes......................... $\$ 66$

Banthorinus.................. 767

Bronzed Grackle.................... 536

Brook Sucker............................. 674

Tront.......................... 691 
brosme, Brosmius...................... 757

Brosmiur.............................. 757

Brown-back Dowitcher................ 590

Brown Bat ................................. 495

Bear ........................... 512

Creeper ......................... 568

Brown crowned Night Heron......... 609

Brown Lark............................. 564

Rat (referred to, 505)......... 504

Thrasher........................ 565

Thrush .......................... 565

browni, Stolephorus..................... 688

Vomer ........................... 717

Bryttus ............................725, 726

Brinnich's Murre.........................6 635

Bubo .................................... 581

Bubonidæ................................ 579

buccinator, Olor........................ 621

Bucephala........................615, 616

Buff-breasted Sandpiper............... 596

Bufonida................................ 652

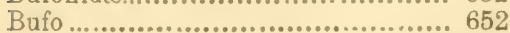

Bugfish... ................................ 686

bullaris, Semotilus...................... 680

Bull Bat............................... 523

Bull Frog.................................. 650

Bull-head ..........................671, 749

Bull-headed Eel......................... 698

Bull Snake............................... 645

Bumper................................. 717

burgall, Ctenolabrus.................... 743

Burgomaster ........................... 626

Burnstickle.............................. 705

Butcher Bird........................... 551

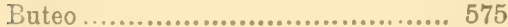

Butorides................................ 608

Butter-bill ............................ 618

Butter-fish ...............................721, 754

I3uzzard .............................. 575

C.

Cabot's Tern.............................. 629

cerulea, Ardea................................ 607

Dendroica ...................... 558

Guiraca........................... 546

Polioptila ........................ 570

Cerulean Warbler........................ 558

cerulescens, Dendroica.................. 557

Pimelodus ................6 672

caruleus, Acanthurus (referred to)... 746

Carcharias (r................ 660

Ctenolabrus.................... 743

Pœcilichthys .................. 729

('alamosuriza . ............................. 547

Calcarius.................................. 540

Calemys ...................................... 637

calendula, Regulus....................... 570

Calico Bass ................................ 724
Calico Snake ........................ 647

Calomys................................ 505

callarias, Gadus,n....................... 758

Callidris..................................... 593

Calliurus .. ............................. 728

camelinus, Tetrasomus..................... 766

Camtolaimus ........................... 617

canada, Echeneis.......................... 710

Canada Goose ........................... 620

Porcupine ...................... 507

canadensis, Branta................... 620

Castor ....................... 503

Dendroica ................ 557

Lutra..................... 510

var, of Pinicola enucleator ..................... 537

Salmo .......................6.69 691

Sitta ...................... 569

Sylvania ................... 563

Canadian Flycatcher .................... 563

Warbler ......................... 563

candissima, Ardea ........................ 608

Canidie .................................... 508

caninus, Caranx ........................ 716

canis, Mustelus. ...................... 660

cantabrigensis, Rana..................... 650

Cantherines.............................. 767

Canthorinus.........................766, 767

cantiacus, Thalasseus...................... 629

Canvas-back............................. 614

canutus, Tringa............................ 591

caparoch, var. of Surnia ulula ....... 582

Cape May Goody...................... 740

Warbler.................... 556

capillaris, Argyreiosus................... 717 Zeus............................... 716

Caprimulgidæ ............................ 523

capriscus, Balistes.............................. 766

caprodes, Percina......................... 729

Carangidæ .................................... 714

Carangus .............................. 715

carangus, Scomber.................... 716

Caranx .........................714, 715, 716

Carassius................................. 682

carbo, Phalacrocorax................... 621

carbonaria, Pileoma. .................... 729

carbonarius, Pollachius..................... 758

Carcharias ..........................660, 662

Carchariidæ ................................... 600

Cardinal Grosbeak........................ 545

Cardinalis...................................... 545

cardinalis, Cardinalis...................... 545

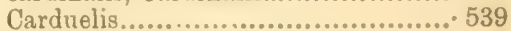

carduelis, Carduelis........................ 539

caretta, Thelassochelys................. 640

Cariacus ................................... 513

caribbæus, Chloroscombrus............ 717

carinatum, Acanthosoma ................ 769

Carnivora ................................ 508

carnivorus, Corvus........................... 529 
Carolina Bat........................... 495

carolina, Cistudo........................ 637

Carolina Dove........................... 583

Lichia...................... 718

Porzana........................ 602

Wren .......................... 566

carolinensis, Anas ...................... 611

Balistes.................... 766

Galeoscoptes.............. 565

Halatractus.............. 719

Otolithus ................ 741 var. of Pandion haliaë. tus...................... 578

Sciurus.................... 501

Seriola ................718, 719

Sitta.................... 568

Tyrannus ................. 526

Vespertilio .............. 495

var. of Vespertilio fus-

cus....................... 495

Zenaidura................. 583

carolinus, Clinostomus.................. 681

Melanerpes................... 521

Prionotus..................... 751

Scolecophagus.............. 534

Trachynotus ................. 718

Carp ......................................... 682

Carps ........................................ 676

carpio, Cyprinus.......................... 682

Carriodes................................. 674

Carphophiops........................... 647

Carpodacus ............................ 537

Carrion Crow.............................. 574

Caspian Tern ........................ 628

caspius, Thalasseus....................... 628

castanea, Dendroica..................... 558

Castor ..................................... 503

Castoridre.............................. 503

cataractæ, Ceratichthy8................. 678

Rhinichthys...............6 678

Catbird................................... 565

catesbiana, Rana....................... 650

Catfishes ................................... 671

Catfish................................... 672

Cathartes ................................ 573

Cathartidæ............................... 573

Catharista................................. 574

Catonotus ................................. 729

Catostomidre............................. 673

Catostomus................................ 674

Cat Owl................................. 579

Cats ....................................... 508

catus, Amiurus........................... 671

caudacuta, Motella..................... 756

caudacutus, var, nelsoni, Ammo-

dramus ............................... 541

caudata, Lamna........................... 660

Cave Salamander........................ 655

cavifrons, Ambloplites.................... 724

caris, Lutjanus....................... 734
Cecomorphr........................... 623

Cedar Bird ............................... 551

Wax wing ....................... 551

cedrorum, Ampelis....................... 551

celata, Helminthophila................. 555

Celuta...................................... 647

Centrarchidre........................... 724

Centrarchus .........................724, 725

Centronotus.............................. 754

Centropristis ............................... 733

centrura, Trygon........................666 666

Centurus .................................. 521

Ceophlous .............................. 520

cepedianum, Dorosoma................ 687

Cephalacanthus ........................... 752

Cephalopteridæ......................... 667

Cephalopterd.............................. 667

cephalus, Mugil......................... 706

Semotilus ................... 679

Cepphus................................. 634

Ceratacanthus ........................... 767

Ceratichthys ........................6 678, 679

Ceratoptera .............................. 667

Cerna..................................... 734

Cero...................................... 713

Corthia .................................... 568

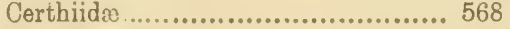

Cervide.................................. 513

Cervus.................................... 513

Ceryle .................................... 522

Custracion................................. 661

Cestreus ................................. 741

Cistudo.................................... 637

Cetacea-Carnivora........................ 514

Cetaceans................................. 514

Cete ..................................... 515

Cetorhinide ............................... 663

Cetorhinus ............................... 663

Chænopsetta................................. 761

Chætodipterus ............................. 744

Chætodon.........................744, 745

chætodon, Mesogonistius.............. 726

Chætodontidæ ............................ 744

Chrtura ............................... 524

Chain Snake ............................ 647

chalybæus, Hybopsis...................... 678

Minnilus .................. 678

Catfish......................... 672

Charionetta............................ 616

Charadrius .............................. 597

Charadriidæ ............................ 597

Charioteer.................................. 734

Chasmodes................................. 754

Chatoëssus ............................... 687

Chaulelasmus............................ 612

Cheiroptera................................ 494

Chelidon ................................... 549

Chelopus ................................. 637

Chelydra .................................. 640 
Chelydridæ................................. 640

Chelonia.................................. 637

Chelonidx................................... 640

Chelopus.................................. 638

Chen........................................6 619

Cherry Bird............................... 551

Chestnut sided Warbler.................. 558

Chewink .................................. 545

Chickadee ................................. 501

Chickaree................................... $\mathrm{F}_{01}$

Chicken Hawk............................ 575

Chilomycterus.......................... 769

Chilonemus ................................. 679

Chimney Swallow...................... 524

Swift .......................... 524

Chipping Sparrow ........................ 543

Chippy .............................542, 543

Chipmunk (referred to, 510).......... 502

chirurgus, Acanthurus (referred to)... 746

Chironectes............................. 764

Clinostomus............................... 681

Chloris ...................................... 556

chloris, Seriola.......................... 717

Chloroscombrus ...................... 717

Chogset ................................ 743

Chondestes.............................. 542

Chondrostei ................................ 668

Chordeiles.................................. 523

Chorophilus............................. 652

chouicha, Oncorhynchus...............6 690

Chroecocephalus ......................... 627

chromis, Pogonias....................... 739

Chrosomus ............................ 676

chrysaëtos, Aquila..................... 577

Chrysemys .............................. 638

chrysocephalus, Luxilus............... 678

chrysoleucus, Notemigonus............. 681

Chrrsomitris ........................... 538

Chrysophrys............................. 736

chrysoptera, Helminthophila......... 554

chrysops, Stenotomus, Sparus.......... 736

chrysopterum, Hæmulon............... 736

chryะos, Carangus...................... 716

chrysura, Scimna........................ 739

chrysurus Chloroscombrus........... 717

chrysus, Caranx.......................... 715

Chub ...................................6679,680

Chubby Catfish........................... 672

Chul, Mackerel.......................... 712

Sucker............................ 675

hinss, Phycis................................. 757

(s)hla................................. 727

Ciconiide .................................... +05

Cigar fish ............................... 714

ciliaris, Pomacanthus................... 745

ciliatus, Blennius....................... 755

cimbrius, Onos............................ 756

cinerea, Atalapha........................ 495

Blarina ....................... 497

cinereo argentatus, Urocyon............. 509 cinereum, Scotiapex................... 580

cinereus, Atalapha........................ 495 var. erythronotus, Pletho-

don ....................... 654 var. of Plethodon cinereus.. 654 var. of Sciurus niger........ 500

cingulatus, Zygonectes.................. 694

Cinnamon Bear........................... 512

Cinosternidx ............................. 639

Cinosternum................................ 639

Circus................................... 574

cisarctica, Balæna....................... 514

Cistothorus ................................... 567

Citharichthys ............................ 760

Claip's ......................................... 521

clamata, Rana......................... 649

Clam-cracker ............................ 666

Clangula.............................615, 616

clangula, var. americana, Glaucio-

netta..................................6 615

Clapper Rail............................... 601

Classification.............................. 492

Cliff Swallow ........................... 549

Climbing Birds................................ 518

Cliola. ................................... 677

Clivicola .................................... 550

Clupea ........................677, 684, 686

Clupea harengus (referred to)......... 578

Clupeidx............................683, 687

clymene, Delphinus...................... 515

clypeata, Spatula........................ 613

Coachman ................................. 734

Coalfish ............................................ 758

Cobia ..................................... 710

Cobitis ........................................ 693

Coccyges ................................ 522

Coccyzus .................................... 522

Cod .......................................... 758

Codfishes .............................. 756

Codling ....................................... 757

Coffin-carrier Gull..................... 626

Colaptes ................................ 521

colchicus, Phasianus (referred to).... 586

colias, Scomber......................... 712

Colinus .................................... 584

collaris, Aythya........................ 615

Collecting Specimens..................... 492

Colocephali............................... 697

Coluber ....................................... 645

Colubrida.............................. 643

colubris, Trochilus ........................ 524

Columba .................................. 584

Columbæ .................................... 583

columbarius, Falco...................... 578

columbianus, Olor...................... 620

Columbidæx..................................... 583

Colymbus.................................... 631

Colymbus torquatus..................... 633

cornatus, Cypselurus.................... 701

commersoni, Catostomus.............. 674 
Common American Eel................ 697 Atlantic Salmon............. 690

Bats......................... 494

Box Turtle................... 637

Catfish..........................6 672

Channel Cat................. 672

Chub...........................6 679

Codfish ........................ 758

Cormorant ...................6.621

Eastern Picketel.............6 696

Frog ......................... 649

Gar Pike....................6.669

Garter Snake................ 644

Gull..........................6 626

Herring .................... 684

Killifish....................... 693

Mackerel ..................... 712

Nole ......................... 498

Pheasant (referred to)...... 586

Pipefish....................... 702

Pompano..................... 718

Porpoise..................... 516

Rock Bass................... 724

Seq Horse.................... 703

Shad............................ 685

Shiner ....................... 678

Skate.. ...................... 664

Snapping Turtle............ 640

Soft-shelled Turtle............ 640

Stickleback .................. 705

Sting Ray......................666 666

Sucker........................ 674

Summer Flounder........... 761

Sunfish......................... 727

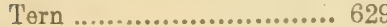

Tree-toad ...................... 650

Winter Flounder............. 762

communis, Catostomus................. 674

Phocæna ................... 516

Compsothlypis........................... 556

Condylura ............................... 498

Conger ................................... 698

Cunger Eelpout...................... 755

conger, Leptocephalus ................ 698

Connecticut Warbler...................... 561

Conner ................................... 743

conorhynchus, Albula................. 682

conspersum, Amblystoma ............. 656

constrictor, Bascanium ................. 645

Contopus............................... 527

contortrix, Ancistrodon ................. 648

cookianus, Aphredoderus............. 723

Coons................................... 512

Cooperi, Accipiter....................... 575

Sorex........................... 497

Cooper's Hawk.......................... 575

Coot....................................... 604

Coots .....................................6 618

Conelandia............................. 725

Copperhead Snake...................... 648 corax, var, principalis, Corvus....... 529

coriacea, Dermochelys................. 640

Cormorants............................... 621

Corn Crake............................... 603

Snake .......................... 647

cornubica, Lamna..................... 663

cornuta, Eremophila................. 528

cornutus, var. cornutus, Minnilus.... 678

Podiceps ...................66 631

coronata, Dendroica................... 557

Coronella................................. 647

corporalis, Semotilus.................. 679

Corvidæ................................ 529

Corvina...............................739, 740

Corvus.................................. 529

Coryphæna ............................ 722

Coryphænidæ ......................... 721

Coryphodon ............................ 645

cosmopolita, Seriola................... 717

Cottidx ................................ 748

Cottus.......................748, 749, 750

Cottopsis ............................... 749

Coturniculus passerinus................ 541

Coturnix .................................. 584

coturnix, Coturnix.................... 584

Cotyle ................................. 550

Cow Bird................................ 531

Cowfish.............................516, 765

Cow-nosed Ray.......................... 666

Crab-eaters.............................709, 710

Crampfish .............................. 664

crassus, Lepidosteus ................... 670

Crawl-a-bottom .......................... 674

crecca, Anas ............................ 612

Creekfish............................. 675

Creepers ............................... 568

Creolus................................. 733

crepitans, var. of Acris gryllus ....... 651 var. of Rallus longirostris, 601 Rallus (referred to)........ 509

Crested Diver............................ 810

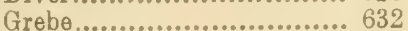

Crevalli.............................715, 716

Crex ..................................... 603

crex, Crex.............................. 603

Cricket Frog............................ 651

Crimson-spotted Triton................. 656

crinitus, Blephar1s.................... 716

Caranx......................... 715

Myiarchus.................... 526

cristata, Condylura ...................... 498

Cyanocitta (referred to, 540), 529

cristatus, Colymbus ..................... 632

Pavo (referred to).......... 586

Croaker................................... 740

Croakers ................................ 738

cromis, Pogonias...................... 739

Crossbills..........................537, 538

Cross Fox .............................. 508

Crotalidæ ............................... 648 
Crotalus.................................. 648

Crow........................................ 574

Crow Blackbird........................ 535

Crows .............................529, 530

crumenophthalmus, Caranx.......... 715

Crymophilus .............................. 588

cryptosus, Rhombus.................... 721

Ctenolabrus .............................. 743

cubifrons, Malthe ..................... 765

Cuckold.................................... 765

Cuckoos ..................................... 522

cucullatus, Lophodytes .................. 610

Cuculi..................................... 522

Cuculidæ ..................................... 522

cunicularia, Speotyto................... 582

Cunner .................................... 743

cupido, Cupidonia......................... 585

Cupidonia ................................. 585

cupreus, var. of Amiurus natalis..... 672

curema, Mugil......................... 706

Curlews.................................... 597

Curlew Sandpiper........................ 592

Cursores ............................... 583

curtus, Vomer........................... 717

Curvirostra.............................. 537

curvirostra, var. minor, Loxia......... 537

cuspicauda, Alutera.................... 767

Cusk ................................... 757

Cutlass-tish ............................ 711

Cutwater.................................... 631

cyanea, Passerina........................ 546

Cyanocitta............................... 529

Cyanocitta cristata (referred to)...... 540

cyanonoton, Alosa,.................... 685

Cyanura.................................. 529

Cyclonhis....................................... 646

Cyclopteridx ........................... 752

Cyclopteris ................................. 753

Cyclostomi................................. 657

cyclotis, Ceratichthys.................... 679

Cygnus..................................... 620

Cynocephalus........................... 660

Cynoscion ................................. 741

cypho, Esox............................. 696

Cyphosus .................................... 738

Cyprinella .............................. 677

Cyprinide...............................6 676

Cyprinodon ..........................692, 694

Cyprinodontidæo......................6 692

Cyprinus ................674, 679, 681, 682

cyprinus, Ictiobus...................... 674

Cypiseli ....................................... 523

Cypselidxe ................................ 524

Cypselurus .............................. 701

D.

Dab.chick .............................. 632

Dace .....................678,679, 680, 681

Dactylopterus ........................ 752

Dafila .................................... 613

Darters ............................728, 729

Dasyatis ............................6 666

Dasybatis .............................. $6 b^{3} t^{\circ}$

Day Owl................................ 582

Decapterus ............................... 714

decumanus, Mus....................... 504

Deer ....................................... 513

Deer Mouse............................ 505

defensor, Caranx....................... 716

deglandi, Oidemia...................... 618

dekayi, Gasterosteus..................... 704

Isuropsis ....................... 663

Isurus......................... 663

Phycis ........................ 757

Pimelodus..................... 672

Pygosteus ...................... 704

Scomber ........................ 712

Scomberomorus................ 713

Storeria ....................... 644

De Kay's Brown Snake............... 644

Shrew .......................... 496

delawarensis, Larus.................... 627

delicata, Gallinago.................... 589

Delphinus............................ 515 see Globicephalus .......... 517 see Grampus ................. 516

see Phoccena ................ 516

Delphinus intermedius.................. 517

delphinus, Phocæna.................. 516

delphis, Delphinus...................... 515

Dendroica .............................. 556

dentata, Pomatopsetta ................ 761

dentatus, Paralichthys .................. 761

Denticete ............................... 515

Diodon ................................. 768

Diplodus ................................. 738

deprandus, Esox........................ 696

Dermochelydidæ........................ 640

Dermochelys ........................... 640

Desmognathide ........................ 653

Desmognathus......................... 653

Descriptions ............................. 490

Devil Diver............................ 632

Devil-fish .............................. 667

Diabasis ............................... 735

Diacope.................................. 731

Diadophis ................................... 646

Diamond-back Turtle................... 639

diaphanes, Raia........................ 661

diaphanus, Fundulus................... 693

Diapterus.............................. 742

Didelphia ............................... 492

Didelphidx............................ 517

Didelphys ............................. 517

Diedapper............................ 632

Diemyetylus............................. 652

dilophus, Phalacrocorax.............. 622

discolor, Dendroica..................... 560

discors, Anas......................... 011 
Ditch Pike

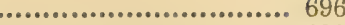

Dogfish .............................660, 696

Dogfishes ............................... 659

Dogs ....................................... 508

Dog Shark............................ 660

doliatus, Ophibolus.................... 647

Dolichonyx............................ 531

Doliodon.................................... 718

Dollar-fish ............................ 721

dolomiei, Micropterus.................. 728

Dolphins (Fishes) .................... 721

Dolphin (Mammal).................... 515

domestica, var. of Columba livia...... 584 Gallus (referred to)........ 586 Spizella...................... 543

domesticus, Passer...................... 539 Troglodytes .............. 566

dominica, Dendroica.................... 559

domınicensis. Tyrannus................ 526

dominicus, Charadrius ................ 597 Nomonyx................. 619

dorsalis, var. of Eutænia sirtalis...... 645 Semotilus...................... 679

dorsatus, Erethizon.................... 507

Dorosoma.............................. 687

Dorosomatidæ......................... 687

Dory .. $\quad$....................716, 718, 731

dougalli. Sterna........................ 630

Dough Bird... ......................... 597

Double-crested Cormorant ............ 622

Double-bearded Flying-fish........... 701

Dovekio ............................. 636

Doves ................................... 583

Dowitcher................................. 590

Downy Woodpecker................... 519

dresseri, Somateria..................... 617

Drumfish (referred to)................. 516

drummondii, Otolithus ................ 741

Dryobates............................... 518

Dubertus (referred to)................. 514

Duck Hawk.......................... 577

Ducks. ................................ 609

ductor, Naucrates........................ 718

Dules.. . ............................... 734

Dusky Bat............................. 495

Duck ............................. 611

Salamander ..................... 653

Shark,.......................... 660

duodecim, Engraulis.................... 688

\section{E.}

Eagle 577

Eagle Rays.............................. 666

Eared Grebe.............................. 632

Easter Mackerel........................ 712

Eastern Hemitremia.................... 677

Pickerel...................... 696
Eastern Red Horse..................... 675

Eaves Swallow .......................... 549

Echelus ................................ 698

Echeneidx ............................... 708

Echeneis................................. 708

Ectopistes............................... 583

Eelpouts ................................ 755

Eels ...................................6.697, 698

Eft .................................. 652

eglanteria, Raia....................664, 665

Egret.............................607, 608

egretta, Ardea.......................... 607

Eider Ducks............................... 617

Elacate.................................. 710

Elacatidæ ............................... 709

Elanoides................................. 574

Elasmobranchii ......................... 659

elegans, Rallus.......................... 601

Electric Rays............................. 664

ellipticus, Chatoëssus.................. 687

elongata, Clupea......................... 684

Elopidx .................................. 683

Elops................................... 683

emarginatus, Neomænis................. 734

Empidonax.......................... 527

Emydidø ............................... 637

Enchelyopus ......................755, 756

Enchylycephali ........................ 697

English Sparrow...................... 539 Teal ........................ 612

Engraulididæ........................... 688

Engraulis ................................... 688

Enneacanthus............................ 725

enucleator, var. canadensis, Pinicola, 537 eos, var. of Chrosomus erythrogaster.. 676

Ephippidæ.............................. 744

Ephippus................................ 744

Epinephelus......................733, 734

equisetis, Coryphæna.................. 722

erate, Lobotes.......................... 736

erebennus, Tursiops .................... 515

eremophila, Cornuta.................... 528

Erethizon ........................... 507

Ereunetes .............................. 593

Erimyzon .. ............................ 675

erinacea, Raia......................... 664

Erismatura............................... 619

Ermine................................... 510

ermineus, Putorius..................... 510

erythrocephalus, Melanerpes.......... 520

erochrous, Pœcilichthys................. 730

erythrogaster, Chelidon................. 549

var. eos, Chrosomus... 676

Epinephelus .......... 734

erythromelas, Piranga................... 547

erythrophthalmus, Coccyzus............ 522 Pipilo.............. 545

erythrorhynchus, Pelecanus........... 622 erythronotus, var. of Plethodon cinereus 
esculentus, Carangus................... 716 Erox....................682, 693, 695, 699

Esquimaux Curlew .................. 597

estor, Esox.............................. 696

Estrella..................................... 728

Etheostoma...................728, 729, 730

Etheostomatidx ......................... 728

Etrumeus.................................. 684

Eubalæna ............................. 514

Euchalarodus.......................... 762

Fucinostomus.......................... 742

Eudocimus............................. 604

Eudytes................................. 633

Eudytide ..................................... 633

Eulamia................................. 660

Euleptorhamphus....................... 700

Eumeces .................................. 642

Eupomotis................................ 72 th

European Carp......................... 682

Eel.........................6 698

Goldfinch ..................... 539

House Sparrow............. 539

Quail ......................... 584

Teal .........................6 612

Vidgeon....................6 612

Woodcock .................. 589

Eutrnia ............................... 644

eurystole, Stolephorus................. 688

Eventognathi........................... 673

Evet ...................................... 652

evolans, Halocypselus ............... 700

Prionotus ........................ 751

Evotomys ............................ 505 excubitorides, var, of Lanius ludovi

cianus................................ 552

exilis, Botaurus........................ 606

exiliens, Exocotus....................... 701

eximia, Coronella...................... 647

eximius, Cyprinodon..................... 692

Exocœtidx ................................. 699

Exoccetus .........................700, 701

exsiliens, Exocœtus.................... 701

\section{F.}

faber, Chrotodipterus.................... 744

falcatus, Caranx............................ 715

Falco Trachynotus................. 718

Falconide..................................... $57 t$

Falcons .............................. 574

Falco sparverius (referred to)......... 540

falcinellus, Plegadis.................... 605

Fallfish....................................... 680

Fall Herring............................. 684

Nackerel............................ 712

familiaris, var, americana, Certhia, 568

Fan-tailed Darter........................ 729

fasciata, Amblystoma ................... 655 fasciata, Melospiza ..................... 544

Seriola............................ 719

fasciatus, Achirus........................ 763

Bryttus...................... 725

E80x ........................... 695

Eumeces ...................... 642

Grystes ....................... 728

Pogonias..................... 739

Syngnathus ................. 702

Fat-batk.................................. 686

Fatbird ............................... 591

fedoa. Limosa................................ 593

Felidæ .................................... 508

felis, Arius................................... 673

Fence Lizard........................... 641

Feræ .................................492, 508

ferina, Aythya.......................... 614

ferruginea, Tringa..................... 592

ferrugineus, Scolecophagus.............. 534

Fiber ................................ 506

fiber, Castor.................................. 503

Field Mice............................... 492

Mouse ...................................... 506

Plover .......................... 596

Sparrow ............................ 543

Filefish ............................766, 767

filamentosus, Phycis..................... 757

fimbriatus, Zoarces...................... 755

Fin-back Whale (referred to)......... 514

Finches .................................. 537

Fine-scaled Sucker...................... 674

Fire Bird .................................. 534

Tanager ......................... 547

Fisher................................ 509

Fishes ...............................4992, 657

Fish Crow ............................... 530

Duck ...........................609, 610

Hawk .............................. 578

Fishing-frogs,........................... 763

Fistularia ................................ 703

Fistulariidæ............................... 703

flabellare, Etheostoma.................... 729

Flasher ................................... 736

Flat Fishes.............................. 759

flavescens, Bodianus.................... 731

Brosmius ..................... 757

flavifrons. Vireo.......................... 553

flavipes, Totanus........................ 594

flaviventris, Empidonax................. 528

flavolineatus, Pimelepterus.............. 738

tlavulus, Esox.............................. 693

flavus, Noturus........................ 671

Flicker (referred to, 572).............. 521

Florida.................................6 607

Florida Gallinule........................ 603

floridana, Cichla........................ 727

Neotoma ......................... 505

floridensis, Fundulus................... 693

Flounders.................759, 760, 761, 762

Fluke ................................ 762 
fluviatilis, Fudsonius...................6 677

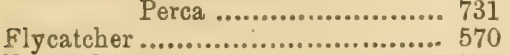

Flycatchers............................. 552

Flying Gurnard......................... 752

Flying-fish ...................700, 701, 751

Flying-fishez ............................ 699

Flying Squirrel........................... 501

Fly-up-the-Creek ........................ 608

fortens, Synodus............................ 689

fontinalis, Rana..........................6 649

Salmo ...................... 691

Foolfish ............................766, 767

Foolish Guillemot...................... 635

forficatus, Catonotus ................. 729

Elanoides.................... 574

Milvulus ................... 526

Fork-tailed Flycatcher................. 525

Gull....................... 628

formosa, Geothlypis...................... 561

Perca, Hæmulon................ 735

forsteri, Sorex.......................... 496

Sterna................................. 629

Forster's Tern.......................... 629

Four-bearded Rockling.................. 756

Fourteen-laminated Remora.......... 709

Four-toed Salamander.................. 654

Fox-colored Sparrow................... 545

Fox Shark.............................. 662

Snake............................. 646

Sparrow............................ 545

Squirrel................................. 500

Fratercula ............................... 634

freminvillei, Myliobates.................. 666

frenata, Sterna ......................... 630

Fresh-water Marsh Hen............... 601

Sculpin................ 749

Friar .................................... 707

Frigate Mackerel........................ 712

Fringed-tongue Warbler............... 556

Fringillidæ .............................. 537

frœnatus, Prodelphinus................. 515

Frogs................................... 649

Frog-fishes................................. 764

Frost-bird ................................. 597

Frost.figh............................689, 758

frugivorus, Corvus..................... 530

fucorum, Blennius...................... 754

Fulica ................................, 604

Fulica americana (referred to)......... 633

fulicarius, Crymophilus................. 588

fuliginosa, Sterna........................ 630

fuliginosus, Balistes .................... 766 var. of Chilomycterus geometricus............. 769

Fuligula ................................... 615

Fulix............................................ 615

Fulmar ......................................... 623

Fulmarus..................................... 623

fulvemaculatus, Pomadys funduloides, Squalius

681

Fundulus ...........................693, 694

funerea, Surnia ......................... 582

furcatus, Cypselurus ................. 701

furcifer, Creolus .......................... 733

fusca, Desmognathus .................. 653

Oidemia ...........................6 618

fuscescens, Turdus...................... 571

fuscicollis, Tringa..................... 591

fuscum, Siphostoma.................. 702

fuscus, Accipiter....................... 574

var. carolinensis, Vespertilio.. 495

var. fuscus, Vespertilio........ 495

Sayornis.......................... 527.

Vespertilio ..................... 495

Fusiform Darter........................... 730

fusiformis, Pœcilichthys ............. 730

\section{G.}

Gadide .................................... 756

Gadus..................................757, 759

Gadwall .................................. 612

Gaff-topsail................................ 673

Gaff-topsail Pompano................... 718

galbula, Icterus........................... 534

galeata, Gallinula ..................... 603

Galeocerdo................................... 660

Galeorhinidit ........................... 660

Galeoscoptes .............................. 565

Galeus .................................. 660

Gallinæ ................................. 584

Gallinago...................................... 589

Gallinula ............................... 603

Gallus........................................ 586

gallus, Caranx........................... 715

gallopavo, Meleagris...................... 586

gambeli, var. of Anser albifrons...... 619

Gannet ................................. 621

Ganoidei ..................................... 668

gardeniana, Hiatula .................. 743

gardeni, Nyctiardæ......................... 609

Stromateus .................... 720

Gar (referred to) ......................... 680

Garfishes ...................................... 699

Gar Pike.................................... 669

Garrot ................................... 615

garrulus, Ampelis ....................... 550

Garter Snake.............................. 643

Garzetta .............................. 608

Gaspereau....................................... 684

Gasterosteidæ ............................ 704

Gasterosteus ............... 704, 705, 720, 752

Gastrophysus............................ 768

Gelochelidon .............................. 628

geographicus, Malacoclemnys ......... 638

geometricus, Chilomycterus ............. 769

georgiana, Melospiza .................... 544

German Duck........................... 612 
Gerres................................. 742

Gerridæ .................................. 742

getulus, Ophibolus ..................... 647

gibbifrons, Exocœtus ..................... 701

gibbosus, Aphredoderus ............... 723

Lenomis...................... 727

gibbus. Antennarius.................. 764

gigas, Ephippus....................... 744

Gilt-head ................................. 736

gilvus, Vireo ............................. 553

Ginglymodi ............................. 669

Gizzard Shad........................... 687

glaber, Pleuronectes ................... 762

glacialis, Fulmarus .................... 623

Harelda .....................6.6 616

Heuronectes................... 762

Urinator ...................... 633

Gladiator Dolphin.......................... 517

gladiator, Orca......................... 517

gladius, Xiphias ............................ 710

Glaniostomi............................. 668

Glass-eye................................ 731

glauca, Isurus......................... 663

Glaucionetta............................ 615

Glaucous Gull............................. 626

glaucus, Larus........................ 626

Trachynotu8................... 718

Glires.................................... 492

Globefish............................... 769

Globicephalus ............................. 517

see Grampus........... 516

Glossy Ibis.......................... 605

gloveri, Salmo......................... 690

Glut Herring........................... 685

glutinosa, Myxine................... 657

glutinosus, Plethodon................... 654

Glyptemys .............................. 638

Gnatcatcher.............................. 570

Goatsuckers............................. 523

Gobies ................................... 747

Gobiidæ................................ 747

Gobio ..................................... 678

gobio, Cottus............................. 749

Gobiosoma .............................. 747

Gobius..................................... 747

Goby .................................. 747

Godwits (et seq.).......................... 593

Goggle.eje.............................. 724

Goggler................................. 715

Golden-crested Wren.................... 569

Golden-crowned Kinglet................ 569

Thrush................. 560

Golden-eyed Duck...................... 615

Golden Eagle.............................. 577

Robin ....................... 534

Shiner ...........................6.6.6. 681

Warbler........................ 556

Golden-winged Woodpecker........... 521

Goldfish.................................. 682

Gold-thread Roach....................... 681
Gold-thread Shiner...................... 681

Goody .................................... 740

Goosander ............................... 609

Goosefish................................ 763

gracilis, Perca............................ 731

Uranidea ..................... 749

Graculus ................................ 621

Grallæ...........................587, 601

Grallæ-Limicolæ ....................... 587

Grallæ-Paludicolæ....................... 60]

Grallatores ............................. 587

gramineus, Poocætes.................... 542

grammacus, Chondestes................. 542

Grampus .................................. 516

grandis, Fundulus....................... 693

Graptemys ............................... 638

Grass Bass ............................. 724

Finch ............................. 542

Snake ........................... 646

Snipe ............................ 591

Grasshopper Sparrow.................. 541

Gray and Black Squirrel............... 500

Gray Fox................................ 509

King-bird ....................... 526

Owl.............................. 581

Rabbit............................ 507

Salamander ....................... 654

Snapper ......................... 734

Snipe ............................. 590

Squirrel ........................... 501

Trout............................ 741

Great Auk (referred to)................ 636

Black-backed Gull.............. 626

Blue Heron......................6.606

Crested Flycatcher ............. 526

Dolphin ......................... 722

Gray Owl......................... 580

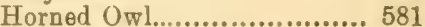

Lake Pike....................... 696

Marbled Godwit.................. 593

Northern Loon...................... 633

Northern Shrike................. 551

Sea Lamprey...................... 658

White Egret..................... 607

Greater Redpoll.......................... 538

Snow Goose..................... 619

Shearwater........................ 623

Tell-tale........................ 594

Yellow-legs ................... 694

Grebes .................................. 631

Green and Yellow Treo-toad........... 651

Green Bass............................. 727

Black-cap Flycatcher.......... 563

Black-capped Flycatching

Warbler ...................... 563

Cod ............................... 758

Greenfish ................................ 720

Green Frog ............................. 649

Greenlets ................................... 608 
Green Pike ............................... 696

Snake............................. 646

Tree-toad.......................... 650

Green-winged Teal......................... 611

grex, Scomber........................... 712

griseus, Grampus........................ 516

Macrorhampus................ 590

Mesoprion ...................... 734

grisea, Nycticorax ...................... 609

griseigena, Podiceps..................... 632

Groper....................................... 733

Ground Bird.............................. 542

Ground-hog............................... 502

Ground Snake............................ 647

Squirrel .......................... 502

Grouse.................................... 584

Grubby .................................... 750

grylle, Cepphus......................... 634

gryllus, var. crepitans, Acris............ 651

Grystes .............................727, 728

guaguancho, Sphyræna................ 707

Guara..................................... 604

Gubartas (referred to).................. 514

Guillemots .................................. 634

Guinea Fowl (referred to) .............. 586

Guiraca .................................... 546

gula, Gerres.............................. 742

Gulls......................................... 626

Gull-billed Tern......................... 628

Gunnellus................................ 754

gunnellus, Murænoides................. 754

Gurnards ................................. 751

guttata, Coryphæna..................... 722

guttatus, Enneacanthus................. 725

Nanemys ..................... 638

Percopsis ........................ 691

Pomotis ....................... 725

Upsilonphorus ...........746, 747

Gyrinophilus............................6 655

gyrinus, Noturus..................... 671

H.

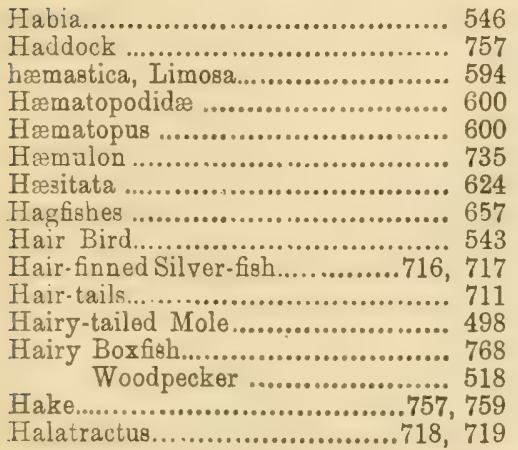

halecina, Rana........................... 649

Haliæëtus ................................ 577

haliaëtus, var, carolinensis, Pandion.. 578

Halibut..................................... 761

Half-beak .............................. 700

Halocypselus ............................. 700

Hammerheads........................... 661

Hammerhead Sucker.................... 674

Haplochilus................................ 694

Haplomi .................................. 692

Harbor Porpoise........................... 516

Seal

Hard-tail ............................... 715

harelda, Glacialis........................ 616

harengus, Clupea........................... 684

Harlequin Duck........................ 617

Harmless Snakes........................ 643

Harporhynchus .......................... 565

hastata, Estrelata...................... 624

Trygon.........................66 666

Harvest-fish.......................720, 721

Hawks .................................. 574

Headfish ................................. 770

Headfishes .................................. 769

Hedge-hog Ray......................... 664

Heath Hen..................................... 585

Hell-diver ............................. 632

Helminthophila........................... 554

Helmitherus................................ 554

helvetica, Squatarola.................... 598

Hemibranchii............................ 703

Hemidactylium ........................ 654

Hemidurgan................................. 748

Hemirhamphus.......................... 700

Hemirhombus ................................ 760

Hemioplites.............................. 725

Hemitremia ............................6.677

Hemitripterus ............................ 748

Hemlock Warbler....................... 559

henslowi, Ammodramus................. 541

Henslow's Sparrow..................... 541

heptagonus, Hippocampus.............. 702

Herbivora.............................. 513

Hermit Spadefoot.......................... 650

Thrush .......................... 571

Herodias.................................. 607

herodias, Ardea.............................. 606

Herodiones.............................. 604

Herons....................................604, 605

Herrings ................................ 683

Herring (referred to, 578).............. 684

Herring Hog ......................... 516

herschelii, Tetrapturus.................. 711

Hesperocichla ........................ 572

Hesperomys ................................. 505

heteroclitus, Fundulus................. 693

Heterodon .................................. 643

Heterosomata............................. 759

heterurus, Exoccotus........................ 701

hexacanthus, Centrarchus............... 724 
Hiatula

743

hiatula, Labrus .......................... 743

Hickory Shad 684,687

hiemalis, Troglodytes.................. 567

hioroglyphica, Pseudemys............ 639

Hieroglyphic Turtle................... 639

High-holer ............................. 521

Himantopus ........................... 588

himantopus, Micropalama............ 590

hinnulus, Mustelus...................... 660

Hippocampidø........................ 702

Hippocampus.......................... 702

hippocampus, Syngnathus............. 702

Hippoglossoides......................... 761

Hippoglossus......................... 761

hippoglossus, Pleuronectes............. 761

hippos, Carangus.......................... 715

Caranx........................ 716

Paratractus...................... 715

hippurus, Coryphæna.................. 722

hirundo, Sterna......................... 629

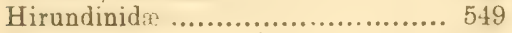

hispidus, Monacanthis.................. 766

Histrionicus .......................... 617

histrionicus, Histrionicus.............. 617

histrio, Pterophrynoides................ 764

hiulcus, Engraulis........................ 688

Hoary Bat................................ 495

Hoe Shark............................ 659

Hog Choker............................. 763

Hogfish.... ...........................729, 735

Hog-nose Snake ....................... 643

Hog Molly............................... 674

Hog Sucker............................ 674

Holacanthus ........................... 745

Holboll's Grebe.......................... 632

holbœllii, Colymbus.................... 632

holbrooki, Echeneis...................... 708

Scaphiopus................... 650

Hololepis............................729, 730

Holostei ................................. 669

Holostomi.............................. 697

homonymus, Gerres..................... 742

Hooded Flycatching Warblers....... 563 Merganser .....................6 610 Warbler ......................... 563

Hoofed Mammals ....................... 513

Hop-toad ............................... 652

horiconensis, Rana..................... 649

Horned Chub........................... 679

Dace........................... 679

Grebe..........................6.6. 631

Lark .......................... 528

Owls ......................... 579

Pout.............................. 671

Horny-head ............................ 679

horridus, Crotalus........................ 648

Horsefish .............................. 717

Horsehead ................................. 716
Horse Crevalle........................... 716

Mackerel........................ 714

House Snake...................644, 647

Wren (referred to, 567)........ 566

hoyi, Sorex........................... 497

Hoy's Shrew........................... 497

hudsonia, Cliola.......................... 677

Hudsonian Curlew...................... 597

Godwit....................... 594

hudsonica, Limosa...................... 594

Lutra........................ 510

hudsonicus, Numenius................. 597

Salmo .................... 691

Hudsonius............................. 677

hudsonius, Circus......................... 574

Hippocampus.............703 Sciurus ................500, 501

Zapus ..................... 503

humeralis, Oligocephalus............... 729

Humming Birds ....................... 524

Hump-back Pickerel.................... 696

Huro................................. 727

huronensis, Lepidosteus............... 669

Hybognathus.......................676, 677

Hybopsis .........................677, 679

Hyborhynchus .........................6 676

Hydrargyra.........................693, 694

Hydrochelidon ............................ 630

hyomalis, Clangula.................... 616

Junco ....................... 544

Hy...................................... 650

Hylidø.................................. 650

Hylomyzon ............................. 674

Hylotomus............................... 520

Hypentelium ............................. 674

hyperborea, var. nivalis, Chen......... 619

hyperboreus, Lobipes.................. 587

Hyperoartia.............................. 657

Hyperotreta ........................ 657

hypochrysea, var. of Dendroica palmarum .............................. 560 hypogæa, var. of Speotyto cunicularia ................................ 582 Hypsilepis..........................677, 678 Hystricidæ .......................... 507

\section{I.}

Ibididx ................................... 604

Ibises.................................... 604

Ibis ordii................................ 605

Ice Gull ................................. 626

Iceland Gull............................... 626

Ichthyomyzon ......................... 658

Ichthelis ................................ 726

Ictalurus ............................ 672

Icteria.................................. 562

Icteridx (referred to, 537)............ 531

Icterus.................................. 534 
Ictiobus.

674

Iguanidæ ................................ 641

iliaca, Passerella........................ 545

imber, Urinator ......................... 633

immaculata, Coryphena................ 722

immaculatus, Salmo..................... 691

immer, Urinator........................ 633

impennis, Plautus (referred to)....... 636

Indian Hen.............................. 605

Remora........................ 709

indicus, Tetrapturus..................... 711

Indigo Bunting....................... 546

ingens, Amblystoma.................. 656

insculptus, Calemys.................... 638

Insectivora ............................. 496

Insessores .................................. 525

insignis, Noturus...................... 681

intermedius, Delphinus, see Globicephalus............................... 517

interpres, Arenaria...................... 600

Ionornis............................... 603

Ipswich Sparrow....................... 541

Isabelita................................. 745

Isognatha .............................. 698

Isogomphodon. .......................66 661

isolepis, Aphredoderus ................ 723

Isospondyli.............................. 682

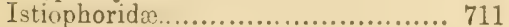

Isuropsis ................................ 663

Isurus............................... 663

\section{J.}

Jack Curlew............................ 597

Salmon .......................... 731

Snipe............................... 591

jacobæa, Remora........................ 709

Jaegers................................... 625

jamaicensis, Porzana.................... 602

jeffersonianum, Amblystoma ......... 656

Jefferson's Salamander.................. 656

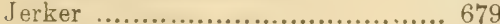

Jew fish .. .............................. 683

Johnius ............................... 741

Jordan \& Gilbert........................ 490

Jordan, Professor ....................... 490

Jumping Mouse (referred to, 505)... 503

Jungle Fowl (referred to).............. 586

Junco ................................... 544

Jurel..................................... 715

K.

Kennicott quoted 499

kentuckiensis, Ceratichthys............ 679

Kypsilepis ............. 677
Killdeer (referred to, 590)............ 598

Killer .................................. 517

Killiefish .................................. 692

Killifish ................................. 693

Kingbird................................. 526

King Eider............................ 617

Kingfish ................................. 741

Kingfishes ........................... 522

Kinglet .................................... 569

King Plover............................. 599

Rail.................................6 601

Snake............................ 647

kirtlandi, Dendroica..................... 559

Tropidoclonium .............. 644

Kirtland's Warbler...................... 559

Kittiwake Gull......................... 626

Knot ................................ 591

L.

Labidesthes ............................ 707

Labrador Duck........................... 617

labradorius, Camtolaimus.............. 617

Labrax................................. 732

Labridie ............................... 742

labrosus, Zoarces........................ 755

Labrus....724, 726, 727, 735, 739, 741, 743

Lacertilia............................. 641

Lady-fishes ................................ 682

lævicaudatus, Hippocampus.......... 702

lævigatus, Chironectes.................. 764

Lagocephalus .............. 768

lavis, Raia............................... 665

La Fayette...........................721, 740

Lagenorhynchus ........................ 516

Lagocephalus............................ 768

Lagodon ................................. 737

lagopus, var. sancti-johannis, Archi-

buteo ................................... 576

Lake Mullet.............................. 675

Lamellirostres............................. 609

Lamna...........................660, 663

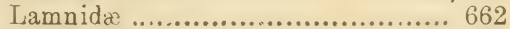

Lamnoidea ............................ 661

Lampreys ............................. 657

Lamprey.................................. 658

Lampropeltis ............................ 647

Lampugus .............................. 722

Laniide .............................. 551

Lanius ................................... 551

Lanius borealis (referred to).......... 540

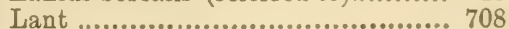

Lapland Longspur....................... 540

lapponicus, Calcarius..................... 540

Large Jillifish. ........................ 693

Large-mouthed Black Bass........... 727

Large-scaled Sucker..................... 675

Large-spotted Salamander............. $65 \hbar$

Laridæ..................................6.6.6. 
Larks

528,533

Lark Bunting.......................... 547

Finch............................. 542

Sparrow ........................... 542

Larus ...................................... 626

Lasiurus ............................... 494

latissimus, Buteo.......................... 575

latus, Caranx........................... 715

Laughing Goose........................ 619

Gull ........................ 627

lawrencei, Helminthophila........... 554

Lawrence's Warbler.................... 554

Lawyer ................................. 588

Leach's Petrel ............................. 624

Least Bittern.............................. 606

Darter............................. 730

Flycatcher ....................... 528

Sandpiper ....................... 592

Sculpin .......................... 750

Tern................................. 630

Leather Jacket.......................719, 766

Snake ......................... 643

Turtle ............................ 640

Leathery Turtle.......................... 641

Lebias ................................. 692

leberis, Regina............................ 643

Tropidonotus .................. 643

Leirug ................................ 721

lentiginosus, var. americanus, Bufo, 652 Botaurus................6 605

Leopard Frog ........................... 649

Lepidosteidro......................... 669

Lepidosteus (referred to, 680)......... 669

Lepomis .....................724, 726, 727

Leporidæ ............................. 507

Leptocephalus............................ 698

Lenturus.................................. 711

lepturus, Trichiurus.................... 711

Lepus ..................................... 507

Lesser Redpoll Linnet................... 538

Scaup Duck....................... 615

Tell-tale ...................... 594

Leuciscus ...........581, 676, 677, 678, 680

leucobronchialis, Helminthophila.... 555

leucocephalus, Haliæëtus............... 577

leucophrys, Zonotrichia................ 542

leucopsis, Branta...................... 620

leucoptera, Loxia....................... 538

leucopterus, Larus...................... 626

leucopus, Hesperomys................... 505

leucorhoa, Oceanodroma.............. 624

Leucosomus..........................679 681

Limanda .............................. 762

limandoides, var. of Hippoglossoides platessoides..

limbatus, Isogomphodon................. 661

Limicolæ................................ 587

limi, Umbra............................... 695

Limosa ................................. 593

limosa, Myxino........................ 657 linaria, Acanthis....................... 538

var. rostrata, Acanthis....... 538

lincolni, Melospiza ....................... 544

Lincoln's Finch........................ 544

Sparrow ....................... 544

lineata, Alosa.............................. 684

Echeneis ........................ 708

lineatus, Achirus....................... 763

Buteo......................... 576

Micropogon ................... 740

Mugil ........................ 706

var. of Prionotus sarritor... 751

Ling................................ 732

Linnets ..............................538, 539

Liopeltis .................................. 646

Liopsetta ............................. 762

Liostomus.................................. 740

Lirus ..................................... 721

Little Auk.............................. 636

Barracuda..................... 707

Black Rail.......................6 602

Blue Heron..................... 607

Brown Bat...................... 495

Killiefish ......................... 694

Pickerel ..........................6 696

Red Owl.......................... 581

Sapsucker ........................ 519

Skate............................ 664

Star-gazer ....................... 749

Top Minnow..................... 694

Treo-frog .......................... 652

White Egret..................... 608

littoralis, Squalus...................... 662

Odontaspis ....................6.6.6. 662

lividus, Silurus......................... 672

livia, var. domestica, Columba........ 584

Liza..................................... 706

Lizard-fish................................. 689

Lizards.................................. 641

lobatus, Phalaropus....................... 587

lobipes, hyperboreus................... 587

Lobotes..................................... 736

Lobotidre.................................. 736

loculator, Tantalus....................... 605

Loggerhead Shrike................... 552

Turtle.................... 640

lomvia, Uria............................ 635

Long-billed Curlew..................... 597

Dowitcher................ 590

Marsh Wren.............. 567

Water Thrush............ 561

Long.eared Bat ........................... 495

Sunfish ................... 720

longicauda, Bartramia.................. 596

longicaudus, Spelerpes................... 655

Stercorarius ............. 625

Longipennati ........................... 623

Longipennes............................ 625 
longipinnis, Rhombus

longirostris, var. crepitans, Rallus.... 601

Esox......................6 699

Euleptorhamphus ........ 700

Numenius................. 597

Long.jawed Catfish............................. 672

Long.nosed Dace.............................. 678

Gar..........................66 669

Long tail Shark ........................ 588

Long-tailed Duck ......................... 616

Jaeger...........................6.6.6.6. 625

Shrew ............................ 496

Loons ....................................... 633

Lophiidæ ........................................ 763

Lophius .............................763, 764,765

Lophobranchii ............................. 701

Lophodytes ................................... 610

Lophopsetta ................................... 760

lotor, Procyon............................... 512

Louisiana Heron.............................. 608

Tanager................................ 548

Woxia Water Thrush............... 561

Loxia ......................................... 537

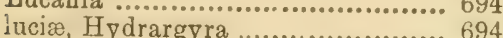

lucifugus, Vespertilio...................... 495 var. of Vespertilio subu-

latus ........................ 496

Lucioperca ............................... 731

lucius, Esox...............................695, 696

lucifugus, Vespertilio..................495, 496

ludoviciana, Habia....................... 546

Piranga...................... 548

ludovicianus, Anthus.................... 564 var. excubitorides,

Lanius ................. 552

Lanius......................... 552

Seiurus .................. 561

Thryothorus ............. 566

lumme, Urinator........................... 633

Lumpfish ................................... 753

Lump Sucker..............................752, 753

Lumpus....................................... 753

lumpus, Cyclopterus........................... 753

lunifrons, Petrochelidon.................. 549

lupus, Anarrhichas.......................... 755

Lutjanue ............................................ 734

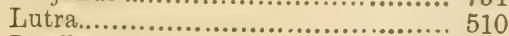

Luxilus ......................676, 677, 678

Luxilus americanus......................6 681

Lycodid $\rightsquigarrow \ldots \ldots \ldots \ldots \ldots \ldots \ldots \ldots \ldots \ldots \ldots \ldots \ldots . . . \ldots 755$

Lynx ........................................... 508

Lythrurus................................... 678

M.

macarellus, Decapterus 715

Machetes.
Mackerels.........

Mackerel Scad......................712, 713

Shark ............................. 663

macrocephalus, Anguilla............... 698

Gadus .................. 758

Gunnellus .............. 754

Physeter (referred

to) ................. 514

Macrochires................................ 523

Macrorhampus .......................... 590

macrolepidotum, Moxostoma.......... 675

macrura, Ectopistes..................... 583 Sterna ...........................6 629

macroura, Zenaidura........................ 583

macularia, Actitis....................... 596

maculata, Tringa......................... 591

maculaticeps, Boleosoma.............. 728

naculatum, Cynoscion ................... 741 var, of Labrus sque. teague................... 741

maculatus, Bothus.............................. 760

Galeocerdo .................6 660

Necturus....................6 656

maculosa, Dendroica......................... 557

maculostriatus, Diodon.................... 769

magna, Sturnella...................... 533

Magnolia Warbler ........................ 557

majalis, Fundulus....................... 693

major, Puffinus.............................. 623

Malacoclemmys......................... 638

Mallard Duck ............................ $66^{3} 10$

malleus, Zygæna........................... 661

Malthe ........................................ 765

Malthidæ .......................................... 764

Mammalia .................................... 494

Mammals.................................. 494

Mantidæ ................................... 667

mandtii, Cepphus.............................. 634

Mandt's Guillemot ........................ 634

Mangrove Snapper........................ 734

Manta ................................... 667

Manx Shearwater........................... 623

Many-8pined Stickleback................. 704

Map Turtle............................. 638

Mareca .................................... 612

margaratis, Enneacanthus............. 725

margaritus, Squalus......................... 681

marginatum, Ophidium.................. 756

marila, var. nearctica, Aythya......... 615

marinus, Elurichthys................. 673

Larus ........................ 626

Petromyzon .................. 658

Sebastes ....................... 748

Tylosurus ..................... 699

maritima, Tringa....................... 591

maritimus, Ammodramus................ 542

Corvus ..................... 530

Marlin ..................................... 593

marmoratus, Antennarius................ 764

Marmot..................................... 502 


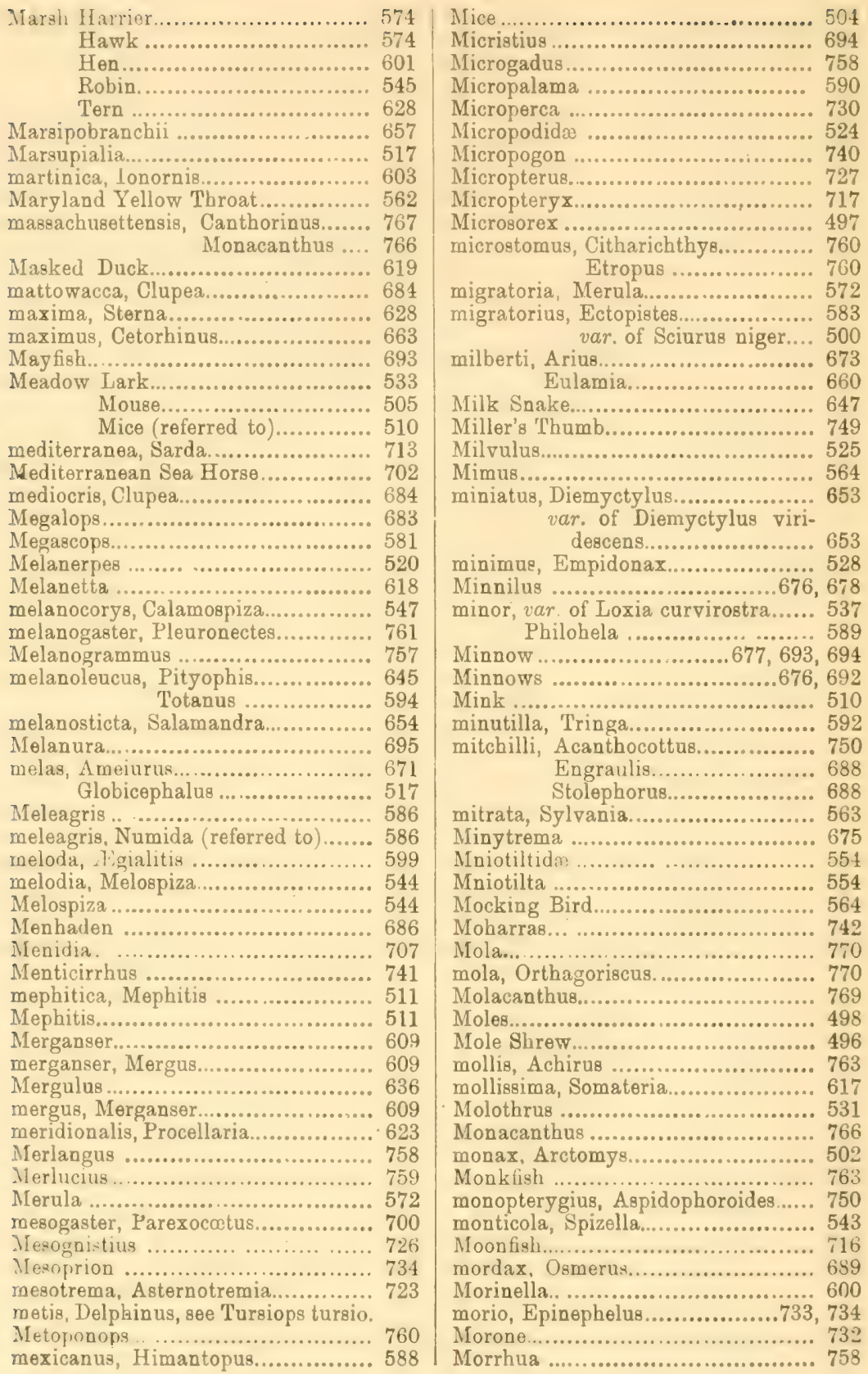


morrhua, Gadus......................... 758

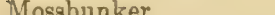

motacilla, Seiurus..................... 561

Motacillidæ ........................... 564

Motella................................... 756

Mother of Eels........................... 755

Mourning Dove........................... 583

Warbler .................. 562

Mouse.................................... 504

Mousefish................................. 764

Moxostoma............................... 675

mucronata, Perca...................... 732

mucronatum, Ophidium............... 754

Mud Dab................................... 762

Dace.............................. 695

Mudfish

Mud Hen (Fulica americana)........ 604

(Rallus longirostris)......... 601

(referred to)................ 509

Minnow............................. 695

Minnows .......................... 695

Perch .............................. 723

Sucker ..............................6. 674

Sunfish .....................724, 725

Turtle .......................638, 639

Muffle.jaw .............................. 749

Mugil.................................706, 740

Mugillide ............................... 706

muhlenbergii, Chelopus............... 637

Muhlenberg's Tortoise.................. 637

Mutica, Amyda ..................... 641

Mullet ................................... 675

Mullets................................. 706

multifasciata, Hydrargyra............. 693

Mummichog ........................6692, 693

Mupus .................................. 721

Muræna...............................697, 698

Murænoides.......................... 754

Murre..................................... 635

Miurida ................................. 504

Mus .................................... 504

Museum Specimens.................... 492

musculus, Mus.......................... 504

Muskrat................................. 506

Musk Turtle....................... 640

Mustela.............................509, 510

Mustelidæ....................... 504

mustelinus, Turdus..................... 570

Mustelus ............................... 660

Mutton fish ............................. 755

Myiarchus ............................. 526

Myiodioctes.............................. 563

Myliobatidæ.............................. 666

Myliobatis............................. 666

Myrtle Warbler.......................... 557

Mysticete.............................. 514

mysticetes, Balæna ..................... 514

Nyxine ................................. 657

Myzinidæ................................ 657

Nyzopsetta........................ 762
N.

nævia, Hesperocichla.................. 572

nævius, var. of Nycticorax nycticorax .........................6 609

Nanemys Seiurus ....................... 561

Nashville Warbler......................... 555

nasutus, Argyreus....................... 678

Leuciscus .................... 678

Natalis, var. cupreus, Amiurus........ 672

Natatores.................................. 609

Nauclerus ............................. 718

Naucrates ............................... 718

naucrates, Echeneis.................708, 709 nearctica, var. of Aythya marila..... 615

nebrascensis, Nocomis ................. 679

nebulosum, Syrnium.................... 580

nebulosus, Ameiurus.................. 671

Menticirrhus ................ 741

Necturus ............................... 656

Needle.fish ............................... 699

Nelson's Sparrow...................... 541

nelsoni, var. of Ammodramus cauda. cutus

541

Nematognathi.......................... 670

Neomænis....................... 734

Neotoma ................................ 505

Nettion .................................... 611

Newts ................................. 652

New York Stickleback................. 705

Nibbler .............................. 743

niger, Conger............................... 698

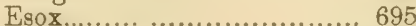

Gasterosteus................... 705

Sciurus......................... 500

var. of Sciurus niger........... 501

Night Hawk............................ 523

Jar............................. 523

nigra, Desmognathus.................. 653

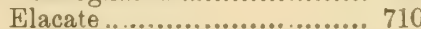

Rhynchops................... 631

var surinamensis, Hydro.

chelidon ......................6 630

nigrescens, Serranus.................. 733

nigricans, Acanthurus.................. 745

Branta ...................... 620

Catostomus.................. 674

Huro .................... 727

var. of Petromyzon mari-

nus ...................... 658

nigricollis, Colymbus.................... 632

Himantopus .............. 588

niurofasciatus, Fundulus,.............. 693

var. of Fundulus heteroclitus ............ 693

nigromaculatus, Pomoxys............... 724

nilotica, Gelochelidon.................. 628

Nine-spined Stickleback............... 704

Nisus .................................. 574 
nivalis, var. of Chen hyperborea..... 619 Plectrophenax ................ 540 nivea, Nyctea......................... 581

Nocomis ................................ 679 noctivagans, Vespertilio................ 495

Nomonyx............................. 619

Northern Black Sea Bass................ 733

Hare ..................... 507

Phalarope.....................557

Pickerel .......................6 696

Rattlesnake.................. 648

Raven ..................... 529

Scup ....................... 737

Shrike (referred to) ........ 540

Wax-wing ................... 550

notata, Menidia........................ 707

notatus, Hyborhynchus ................ 676

Notemigonus............................ 681

Notophthalmus .......................... 652

Notropis.............................677 678

Noturus................................... 671

norvegicus, Perca...................... 748

Norway Rat................................. 504

noveboracensis, Atalapha.............. 494

Exocotus ............. 701

Gasterosteus ............ 705

Naucrates ............. 718

Porzana...............6.6.602

Putorius............... 510

Seiurus................ 561

Vireo.................... 553

novemlineatus, Chasmodes............ 754

nuchalis, Hybognathus................. 676

Numbfish ............................. 664

Numenius ............................. 597

Numida meleagris (referred to) ....... 586

nummularis, Molaranthus............. 769

Nuthatch ............................. 568

nuttallii, Cypselurus...................... 701

Nyctala .................................. 580

Nyctea................................... 581

nyctea, Nyctea......................... 581

Nyctiardæ gardeni.......................6 609

Nycticorax..............................6.609

nycticorax, rar. nievius, Nycticorax.. 609

\section{o.}

obesus, Enneacanthus. .725

obscura, Anas.......................... 611

obscurus, Carcharias.................... 661

Centrarchus ................. 728

obliquus, Liostomus....................... 740

Oblong Flounder...................... 761

oblonga, Platessa, Pleuronectes........ 761

oblongurn, Mloxostoma.................. 675

oblongus, Paralichthys................... 761

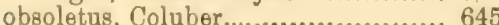

occidentalis, Conger.. occidentalis, Ereunetes................ 593

Gasterosteus ............. 704

Monacanthis.............7 766

Noturus.................. 671

Scombroides............... 719

Torpedo.................. 664

occipitomsculata, Storeria.............. 644

oceanica, Isognatha.................... 698

Oceanic Catfish........................... 673

oceanites ................................. 624

oceanodroma ........................... 624

oceanus, Oceanites....................... 624

ocellaris, Chænopsetta.................. 761

Paralichthys ................. 761

ocellata, Raia............................. 664

Sciæna ......................... 740

ocellatus, Platophrys.................... 761

ochrophcea, Desmognathus............ 653

octodecimspinosus, Cottus............... 749

Odontaspidæ............................. 662

Odontaspis .............................. 662

Odontocete ............................ 515

odoratus, Aromochelys................... 640

ogak, Gadus.............................. 758

oglinum, Opisthonema................. 686

Oidemia ..................................... 618

Old Squaw................................ 616

Oldwite..............................616, 740

Oligocephalus ........................... 729

Oligoplites............................... 719

olivaceus, Vireo........................ 552

Olive-backed Thrush..................... 571

Olive-sided Flycatcher................ 527

olmstedi, Boleosoma.................... 728

Olor...................................... 620

Oncorhynchus.......................... 690

oneida, Ptychostomus................... 675

onitis, Hiatula......................... 743

Onas .................................... 756

opaca, A mblystoma..................... 655

Opaque Salamander.................... 655

Opheodrys ............................ 646

Ophibolus ............................... 647

Ophidia.................................. 643

Ophidiid

Ophidium ........................... 754, 756

ophryas, Paralichthys.................. 761

Opisthonema .......................... 686

Oporornis .............................. 561

Opossum .............................. 517

Orange-crowned Warbler............... 555

Orange-throated Warbler................ 559

Orbidus .................................... 768

Orca....................................... 517

erca, Orca............................. 517

Orchard Oriole......................... 534

ordii, Ibis.............................. 605

ordinata, var. of Eutænia sirtalis...... 645

Oregon Robin.............................. 572

ornatus, Esox......................... 695 
Ornichthys

Orthagoriscidæ........................... 7

Orthagoriscus ............................ 770

Orthopistis................................ 735

Orthopsetta .............................. 760

orientalis, Oncorhynchus............... 690

Orioles ............................. 531

Ortolan .................................... 602

Ortyx ................................ 584

Orycnus ................................. 714

oryzivorus, Dolichonyz................ 531

osmerinus, Hybognathus ............... 676

Osmerus ............................... 689

Osprey (referred to) .................. 577

osseus, Lepidosteus....................... 669

ossifragus, Corvus...................... 530

osteochir, Rombochirus.................. 709

Ostraciidæ............................. 765

Ostracium ................................ 765

Oswego Bass.............................. 727

Otocoris ................................... 528

Otolithus................................... 741

Otter........................................ 510

ovatus, Trachynotus.................... 718

Oven Bird........................... 560

ovicephalus, Sargus.................... 738

ovinus, Lebias........................... 692

ovis, Sargus.............................. 738

Owl ................................... 579

Oxbird ................................... 592

Ox-eye................................ 598

Oxyrhina................................ 663

oxyrhynchus, var. of Acipenser

sturio

668

oxypterus, Epinephelus.................. 733

oxyuris, Lepidosteus.................... 669

Oyster-catchers............................ 600

Oyster-fish.............................743, 753

Ozotheca.................................. 640

\section{P.}

pacifica, var. of Tringa alpina......... 592

pacificus, Argyreiosus................... 716

Pagrus..................................... 736

Painted Turtle.......................... 638

Palinurichthys.......................... 721

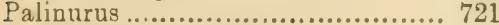

pallasi, Molacanthus.................... 769 var. of Turdus aonalaschkæ... 571

palliatus, Hæmatopus................... 600

pallida, Lepomis.......................... 727

palmarum, Dendroica................. 560

var. hypochrysea, Dendroica........ 560

palmipes, Prionotus...................... 757

Palm Warbler.......................... 560

Paludicolæ .............................. 601

palustris, Cistothorus................... 567 palustris, Hesperomys.................. 505

Malacoclemmys.............6 639

Melospiza .................... 544

Rana......................... 649

Pammelas............................... 721

pampanus, Bothrolæmus.............. 718

Pandion ............................. 578

Panther (referred to)................... 513

paradisæa, Sterna....................629, 630

Paralichtys................................ 761

Paranthias ............................... 733

Parasitic Jaeger.......................... 625

parasiticus, Simenchelys .............. 696

Stercorarius ................6. 625

Paratractus.............................. 715

pardalis, Monacanthis................ 767

Parephippus .............................. 744

Parexocotus............................. 700

Paridæ .................................... 568

Partridge.............................584, 585

Parula ................................ 556

Parula Warbler........................... 556

Parus.. ..................................... 569

paru, Stromateus........................ 720

parva, Blarina.......................... 497

Lucania ......................... 694

Passenger Pigeon...................... 583

Passerella.................................... 545

Passer................................... 539

passerculus, Ammodranus............... 541

Passeres ...................................... 525

Passerina ............................... 546

passerinus, var. of Ammodramus gavannarum ................. 541

Coturniculus............... 541

Pavio cristatus (referred to)............ 586

Pavoncella................................. 595

Peabody Bird............................... 543

Peacock (referred to) .................. 586

Pearly Dace.............................. 681

peckianus, Syngnathus.................. 702

Pectoral Sandpiper...................... 591 Snipe......................... 591

Pediculati ................................ 763

Peep ................................... 592, 593

Pee-wee................................. 527

Pee-wit ............................. 527

Pegador ................................... 708

pelagica, Chætura..................... 524

Procellaria (referred to)... 624

Pelamys ................................... 713

Pelecanidæ ................................ 622

Pelecanus ................................... 622

Pelicans ............................... 622

Pelionetta................................ 618

penelope, Anas......................... 612

pennantii, Mustela..................... 509

pennsylvanica, Dendroica.............. 558

pennsylvanicum, Cinosternum........ 639

pennsylvanicus, Anthus............... 564 
pennsylvanicus, Arvicola.............. 505

Peprilus ................................. 720 Perca...............720, 727, 729, 731, 733, $735,738,739,740,748$

I'erch ............................. 731

Perches.................................... 728

Perching Birds........................... 525

Percidæ...........................728, 731

perciformis, Lirus....................... 721

Percina .................................... 729

Percopsidx .............................. 691

Percopsis..................................6 691

peregrina, Helminthophila............ 555

Peregrine Falcon...................... 577

peregrinus, var, anatum, Falco....... 577

perfasciatus, Stolephorus............... 688

Perissoglossa ........................... $556^{\circ}$

personatus, Sorex...................... 497

perspicillata, Oidemia.................. 618

perspicillatus, Lagenorhynchus........ 516

perspicuus, Hyborhynchus............. 676

Petrels.................................623, 624

Petrochelidon............................ 549

Petromyzontidæ......................... 657

petrosus, Mugil......................... 706

Phalacrocorax........................... 621

Phalacrocoracidæe .......................6 621

Phalaropes ........................... 587

Phalaropodidæ .......................... 587

Phalaropus ................................ 587

Phasianidæ............................. 586

Phasianus colchicus (referred to)..... 586

Pheasant (referred to, 586)............ 585

phenax, Lepomis ..................... 726

philarlelphia, Geothlypis ............. 562

Larus .................. 627

Philadelphia Greenlet................. 552

Vireo ................... 552

Warbler ................. 552

philadelphicus, Vireo................... 552

Philohola .............................. 589

phlebotomus, Acanthurus.............. 745

Phoca .................................. 508

Phocæna............................. 515

phocæna, Phocæna....................... 516

Phocidæ ................................ 508

Phube ............................... 5:7

Tilube, sayornis..................... 527

phoraiceus, Agelaius................... 532

Pholis ................................. 754

Photogensis (or Photogenis)............ 677

Phoxinus .................................. 681

Phycis .................................... 756

Phyllophilophis ...................... 646

Physeter macrocephalus (referred to), 514

Physoclisti ............................... 699

Physostomi ............................ 670

Yici. .................................... 518

Picidæ ............................... 518
Pickerel... .........................695, 696

Pickerel Frog............................ thto

pickeringii, Hyla.....................6 651

Pickering's 'Tree-toad................... 651

picta, Chrysemys....................... 638

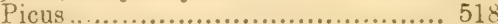

Pied Shelldrake........................ 610

Pied-billed Grebe........................ 632

Pigeon Hawk.........................574, 578

Pigeons ................................ 583

Pike (referred to, 523).......695, 696, 731

pilatus, Prionotus....................... 751

Pileated Woodpecker....................... 520

pileatus, Ceophlceus....................... 520

Pileoma............................... 729

pilosus, Diodon........................ 768

Trichodiodon...................... 768

Pilot ................................. 721

Pilot-fishes............................. 714

Pilot fish ...........................517, 718

Pilot Snake............................... 645

Pimelepterus ............................ 738

Pimephales.............................. 676

Pimelodus.............................. 671

Pimelodus ccorulescens................. 672

Pinicola .................................... 537

Pine-creeping Warbler................. 559

Pine Finch............................ 539

Linnet............................ 539

Mouse............................. 506

Siskin ........................ 539

Snake .............................. 645

Warbler ........................... 559

pinetorum, Arvicola................... 506

Pine-tree Lizard......................... 641

Pintish .................................. 737

piniger, Enneacantbus.................... 725

Pintado .................................... 713

Pin-tail .................................. 613

pinus, Dendroica......................... 559

Helminthophila................. 555

Spinus .......................... 539

pipiens, Rana........................... 650

Piping Plover ............................ 599

Pipefishes............................... 702

Pipefish .................................. 703

Pipilo ................................... 545

Piranga ............................... 547

Pirate Perches........................ 722

Perch............................. 723

J'isces .................................. 657

piscatorius, Lophius..................... 763

pisculentus, Esox, Fundulus........... 693

pigquetus, Caranx....................... 715

Pityophis................................ 645

nlagiodon, Prodelphinus.............. 515

Plagiostomi ............................ 659

Plaice ................................. 762

Plargyrus ............................ 678

Platessa ...........................761, 762 
platessoides, Hippoglossoides......... 761 Platophrys............................... 761 platycephalus, Noturus................. 671 Platypodon.............................. 660

platyrhinus, Heterodon................ 643 Sorex .................... 497

platystomus, Lepidosteus............... 670

Plautus impennis (referred to)......... 636

Plectognathi............................. 765

Plectospondyli.......................... 673

Plectrophenax............................ 540

Plegadis................................ 605

Plestiodon ............................... 642

Plestiodon striatus ..................... 642

Plethodon............................... 654

Plethodontidæ........................... 654

Plethostigma ........................... 761

Pleurodelidx .............................. 652

Plouronectes ..................760, 761, 763

Pleuronectidæ ..........................., 759

Plover ........................593, 596, 598

Plovers ............................... 597

plumbea, Hydrochelidon............. 630

plumieri, Diabasis..................... 735

Mugil ........................ 706

pneumatophorus, Scomber............ 712

Pochard ................................., 614

Podiceps.................................. 631

Podiceps cornutus...................... 631

griseigena.................... 632

podiceps, Podilymbus ................... 632

Podicipidæ ............................... 631

Podilymbus ............................... 632

Pocilichthys................................ 729

Pogonias ................................. 739

Poisonous Snakes........................ 648

Pollachius............................... 758

Pollack ................................ 758

Polioptila............................... 570

polyglottus, Mimus ................... 564

Pomacanthus ............................ 745

Pomadys ................................. 735

pomarinus, Stercorarius ............... 625

Pomarine Jaeger ....................... 625

Pomatomidx ............................ 720

Pomatomus............................ 720

Pomatopsetta ............................ 761

pomatorhinus, Stercorarius ........... 625

Pomobolus ............................. 684

Pompano ............................... 718

Pomotis .....................725, 726, 727

pomotis, Acantharchus................. 725

Pomoxis ............................... 724

Pond Broad-bill......................... 615

Saw-bill......................... 610

Turtles.......................... 637

Poocætes ............................... 542

Popetue.................................. 523

Porbeagles................................ 662

Porbeagle................................ 663
Porcupine .............................. 507

Porgee ...............................737, 744

porosus, var. of Esox americanus.... 696

Poronotus ............................. 720

porphyriticus, Gyrinophilus........... 655

Porpoises ................................ 515

portlandica, Sterna................... 630

Porzana................................... 602

Potomac Channel Catfish.............. 672

præstabilis, Alosa....................... 685

Prairie Chicken........................ 585

Hen......................... 585

Warbler........................ 560

pratincola, Strix........................ 579

Prickly Ray................................ 665

princeps, Ammodramus............... 541

principalis, var. of Corvus corax...... 529

Prionodon ........................660,661

Prionotus............................... 751

Pristipoma.............................. 735

probatocephalus, Diplodus............ 738

Procellaria meridionalis ................ 623 pelagica (referred to) ..... 624

procne, Cliola............................. 677

Procyon .................................. 512

Procyonidæ.............................. 512

Prodelphinus ......................... 515

Progne.................................... 549

Proteida ................................. 656

protopteræ............................... 670

pruinosa, Morrhua .................... 758

pruinosus, Vespertilio ................... 495

Psettichthys ........................... 761

Pseudemys............................. 639

pseudoharengus, Clupea............... 684

Pseudopleuronectes..................... 762

Pseudorhombus ......................... 761

Pseudotriton.............................. 655

Pteromys................................ 501

Pterophryne.......................... 764

Pterophrynoides .. ..................... 764

Ptychemys.............................. 639

Ptychostomus............................ 675

pubescens, Dryobates.................... 519

Puffers .................................. 768

Puffinus................................. 623

puffinus, Puffinus...................... 623

pugnax, Pavoncella..................... 595

Pug-nosed Eel ........................... 698

pulchellus, Chilonemus ................ 680

pullus, Monacanthus.................... 767

Pumpkin Seed......................... 727

punctata, Lamna........................ 663

Sciæna, Perca................ 739

punctatum, Amblystoma.............. 656

punctatus, Decapterus................ 743

Diadophis .................. 646

Ictalurus................. 672

Phycis..................... 756 


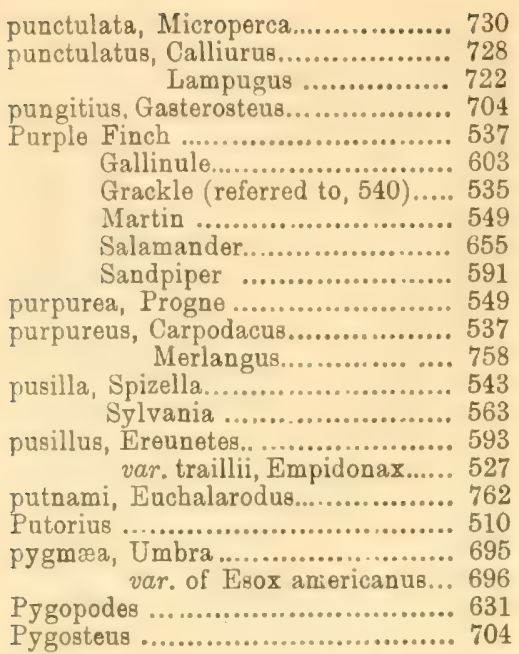

\section{Q.}

Qua Bird... 609

quadracus, Apeltes....................... 705 Gasterosteus ............... 705

quadratus, Zøus ........................ 744

quadricorne, Ostracium.................. 765

quadrilineatum, Hæmulon.............. 736

quadriloba, Rhinoptera................ 666

Quail.................................... 584

Querquedula............................. 611

quiescens, Uranidea ....................... 749

Quill-back ............................. 674

quinnat, Salmo............................ 690

Quiscalus ................................ 535

Quiscalus quiscula (referred to)....... 540

quiscula, var. æneus, Quiscalus ........ 536 Quiscalus (referred to, 540).. 535

quok .................................... 609

\section{R.}

Rabbit-fish ............................ 769

Rabbits .................................... 507

Racer..................................... 645

Raccoon, .............................. 512

radiata, Raia ........................... 665

Raft-duck ............................... 615

Raia...................................... 664

Raiæ ...................................... 663

Riaiidx....................................6 664

Rails ..............................601, 602

Rainbow Darter.......................... 729

Rainwater-fish........................... 694

Rajides....................................... 663

Rallus 601
Rallidx ................................. 601

Rallus crepitans (referred to) ......... 509 elegans (referred to)............6 601

Rana.................................... 649

Ranidæ ............................... 649

Raptores ................................... 573

Rasores .................................. 584

Rattlesnake ............................. 648

rattus, Mus............................. 504

Raven ................................. 529

Rays ........................................ 664

Razor-billed Auk........................ 635

Recurvirostra ......................... 588

Recurvirostridæ ........................ 588

Red-backed Salamander................ 654

Sandpiper ................ 592

Red Bass................................... 740

Bat.................................. 494

Red-bellied Dace........................ 676

Nuthatch ................. 569

Snake...................... 644

Terrapin ..................6 639

Woodpecker .............. 521

Redbird................................ 545

Red-breasted Merganser .............. 610

Nuthatch............... 569

Sandpiper............... 591

Snipo................... 590

Red-cockaded Woodpecker............. 519

Red Crossbill............................. 537

Deer ............................... 513

Eft ................................ 653

Evet............................ 653

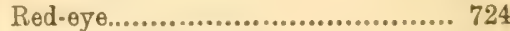

Red-eyed Flycatcher.................... 552

Vireo........................ 552

Red-fin Shiner........................... 678

Redfish ............................740, 748

Red Fox ............................ 508

Grouper 734

Red head ............................... 614

Red-headed Woodpecker ............. 520

Red Horse..........................675, 740

Red-mouth .............................. 735

Red-neck Duck.......................... 615

Red-necked Grebe ....................... 632

Red Phalarope......................... 588

Ssa Perch ........................... 748

Red-shouldered Buzzard............... 576

Hawk................ 576

Red Snake................................. 647

Squirrel ............................. 501

Red-talled Buzzard...................... 575

Hawk................... 575

Red-throated Diver..................... 633

Loon...................... 633

Red Triton ............................ 655

Red.winged Blackbird................. 532

Starling................. 532 
Red-wings ................................ 533

Reedbird ................................... 531

Reeve .................................... 595

regalis, Cynoscion........................ 741

Phycis........................ 756

regius, Hybognathus.................... 676

Phycis......................... 756

Thalasseus...................... 628

Regulus.................................. 569

remora, Echeneis........................ 709

Remoras..............................708, 709

Reniceps ................................. 661

Reptilia.................................... 637

Reptiles.................................. 492

reticulatus, Esox....................... 696

Rhinichthys........................... 678

Rhinonemus.............................. 756

Rhinoptera.............................. 666

Rhomboidal Porge日...................... 737

rhomboides, Lagodon................... 737

Trachynotus............. 718

Rhombus....................720, 721, 760

rhotheus, Semotilus....................... 680

Rhynchopidæ............................ 631

Rhynchops .............................. 631

Riband Snake.............................. 645

Ribbon-fish ............................. 711

Ricebird.................................. 531

Rice-field Mouse....................... 505

richardsoni, var, meridionalis, Ura-

nidea

Ridgway, Robert........................ 490

Right Whal

Ring-billed Gull........................ 627

Ringed Perch............................... 731

Ring-necked Duck...................... 615

Snake .................... 646

Ring-neck Plover......................... 599

Ring-tailed Eagle....................... 577

Marlin....................... 594

ringvia, Uria................................. 635

Riparia.................................... 550

riparia, Arviccla...................... 505

Clivicola......................... 550

Rissa..................................... 626

River Chub............................... 679

Roach .............................680, 681

Robin.................................. 572

Robin Snipe............................ 591

robustus, Ptychostomus................. 675

Roccus............................... 732

rochei, Auxis........................... 712

Rockfish ........................693, 729, 732

Rockfishes............................. 747

Rockling.................................. 756

Rock Mullet................................. 706

Rodentia .. ................................ 499

Romero .................................. 718

rondeletii, Exoccetus.................... 700

Rorqualis rostratus (referred to)...... 514
Rorquals (referred to)................ 514

Rorqualus borealis (referred to)...... 514

Roseate Tern............................ 630

Rose.breasted Grosbeak................. 546

Rose-colored Chub..................... 680

Rosefish................................... 748

rostrata, var. of Acanthis linaria.... 538 Anguilla ...................... 697 Platessa...................... 762

Rostrated Dory.....................716, 717

rostratus, Rorqualus (referred to).... 514

Rosy Dace................................ 681

rotunda, Mola................................ 770

Round Herring........................ 684

Round Robin........................... 714

Rough-winged Swallow................ 550

Rough Dab.............................. 761

Rough.head Shiner....................... 678

Royal Tern................................. 628

rubicauda, Ichthelis.................... 726

Pomotis....................... 726

rubida, Erismatura..................... 619

ruber, Spelerpes........................ 655

rubra, Piranga......................547, 548

Ruby-throated Humming Bird....... 524

Ruby-crowned Kinglet.................. 570

Wren.................. 570

Rudder-fish ..................719, 720, 721

Ruddy Duck............................ 619

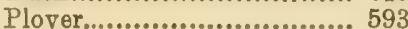

Ruff ..................................... 595

Ruffed Grouse........................... 585

rufescens, Tryngites................... 596

ruficapilla, Helminthophila........... 555

ruficollis, var. of Ardea tricolor...... 608

rufus, Harporhynchus.................. 565

Labrax ........................... 732

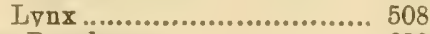

rugosa, Pseudemys...................... 639

Ruminantia............................ 513

rupestris, Amboplites.................. 724

rusticola, Scolopax...................... 589

Rusty Blackbird........................ 534

Rusty-crowned Falcon................ 578

ruticilla, Setophaga..................... 564

rutilus, Evotomys...................... 505

\section{S.}

Sabine's Gull............................. 628

sabinii, Xema........................... 628

sadina, Etrumeus....................... 684

Saddle-back Gull........................ 626

Sailfish ................................. 674

Sailor's Choice............................. 735

Salamanders .................652, 653-656

Salamandridæ........................ 652

salar, Salmo ............................... 690

Salientia ............................. 649 


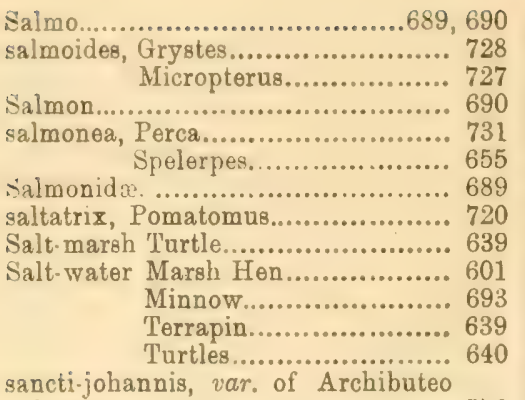
lagopus.............................. 576

Sand Dab.............................. 762

Eel................................... 708

Sanderling............................. 593

Sand Flounder............................ 760

Launces........................... 708

Martin.......................... 550

San Domingo Duck....................... 619

Sand Pike............................... 689

Sandpipers................................ 591

Sand Porgee............................... 737 Sharks.......................... 662

Sand-shoal Duck........................ 617 sandvicensis, var. acullavidus, Sterna, 629 sandwichensis, var. savanna, Ammo.

dramus

Sandwich Tern.

541

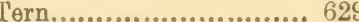

Srndy Mocking Bird................... 565

sapidissima, Alosa........................ 585

Clupea .....................6 685

Sapsucker .............................. 568

Sap-sucking Woodpeckers.............. 519

Sarda........................................ 713

sarda, Sarda ............................. 713

Sargus.............................737, 738

Sarpo....................................... 753

sarritor, Prionotus.... .................. 751

satrapa, Regulus......................... 569

Saurii ..................................... 641

saurita, Eutænia...................... 645

Saurus ................................... 689

caurus, Elops.......................... 683

Oligoplites ...................... 719

Scomberesox.................. 700

Saury .................................... 700

savanna, var. of Ammodramus sandwichensis

541

Savannah Cricket...................... 651

Savanna Sparrow....................... 541

savannarum, var, passerinus, Ammo-

dramus

$\mathrm{Saw}$-whet $\mathrm{Owl}$

541

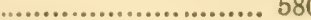

saxatilis, Menticirrhus................. 741

8ayi, Trygon........................... 666

sayanus, Aphredoderus................ 723

Sayornis.................................. 527
Sayris................................ 700

Scabbard-fish ......................... 711

Scad ....................................... 714

Scalops.................................. 498

scandiaca, Nyctea ..................... 581

Scansores ................................ 518

Scapanus ................................. 498

Scaphiopidæ ............................ 650

Scaphiopus ............................. 650

Scarlet Tanager......................... 547

Sceloporus ............................6 64l

schœpffi, Alutera........................ 767

Schuylkill Catfish....................... 671

Sciæna .............................729, 739

Sciænidæ.............................. 738

Sciænops............................. 740

Scincidæ ................................. 642

Scissor-tailed Flycatcher.............. 526

Sciuridæ ......................... 499

Sciurus .................................. 500

Sciuropterus ........................... 501

Scolecophagus .......................... 534

Scoliodon ................................ 661

scolopaceus, Macrorhampus............ 590

Scolopacidæ............................. 589

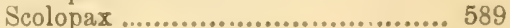

Scolopsis................................ 723

Scomber.......................712, 716, 719

Scomberesox.......................... 700

Scomberomorus ....................... 713

Scomberosocidæ ........................ 699

Scombridæ................................. 712

Scombroides .............................. 719

scombrus, Scomber..................... 712

Scopelidæ.............................. 688

Scorpæena ............................... 748

Scornenide ............................ 747

Scoters....................................... 618

Scotiapex ............................. 580

Scotophilus.............................. 495

Scotophis............................... 645

Screech Owl............................. 581

scripta, Alutera...................... 767

Sculpin ...........................749, 750

Scuppaug .............................. 737

scutatum, Hemidactylium............ 654

scutellatum, Scomberesox............... 700

Sea Bass.................................... 731

Catfish...............................6 673

Coot................................ 618

Devils............................... 667

Hog ............................... 515

Horses ........................ 702

Seals ...................................... 508

Sea Porpoise............................ 515

Raven .............................. 748

Robin .............................. 751

Sea side Finch........................... 542

Sparrow...................... 542 
sebago, Salmo............................ 690

Sebaste8 ................................ 748

sectatrix, Perca......................... 738

secundo-dorsalis, Thynnus............ 714

Seiurug ................................... 560

Selachii .................................... 659

Selachus................................... E63

Selene ............................716, 717

semifasciatum, Pileoma................. 729

semipalmata, Egialitis................. 599

Symphemia.............. 595

Sandpiper.................. 593
Tattler ................. 595

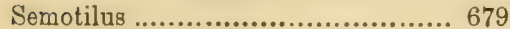

septentrionalis, Urinator ............... 633

Sergeant-fish ......................... 710

Seriola .............................717, 718

serotinus, Vesperugo................. 495

Eerpentina, Chilydra................... 640

Serpents. .............................. 613

serrata, Fistularia...................... 703

serrator, Merganser .................... 610

Serranidæ ............................. 731

Serranus ................................ 733

Serripennis, Stelgidopteryx ......... 550

setifer, Monacanthus................... 766

setipinnis, Selene...................... 717

Setophaga................................. 564

Shad ......................................... 685

Shad Frog.................................. 649

Sharks..................................... 659

Sharp-nosed Shark.................... 661

Sharp-shinned Hawk................... 574

Sharp-tailed Finch..................... 541

Shearwaters (et seq.).................... 623

Shearwater............................... 631

Sheepshead.............................. 738

Sheepshead Gull............................ 629

Shelldrake (et seq.).................... 609

Shiner....................677, 678, 681, 717

Shitepoke.............................. 608

Shoemaker............................... 716

Shore Birds............................. 587

Lark ............................. 528

Short-billed Marsh Wren............... 567

Short-eared 0 wl.......................... 580

Short-nosed Gar Pike.................... 670

Sturgeon.................... 668

Short-tailed Shrew....................... 496

Shrews ................... 497

Shovel-head Shark...................... 661

Shoveller ................................. 613

Shovel-nose ............................... 662

Shrews.......................491, 496, 497

Shrikes..................................... 551

Sialia..................................... 573

sialis, Noturus.......................... 671

Sialia........................... 573

Sibbaldius tectirostris (referred to)... 514
Sickle-bill ............................. 597

Sierra .................................... 713

Siluridæ ................................ 671

Silurus lividus........................... 672

Silver-black Bat.......................... 495

Silver Chub................................. 680 Eel................................ 711

Silver fin .........................677, 711

Silver Fox............................... 508

Gar ............................. 699

Perch.............................. 739

Silversides.........................706; 707

Silvery Carp Sucker..................... 674 Minnow .................676, 677

Simenchelys............................ 698

similis, var. of Fundulus majalis..... 693

simulans, Enneacanthus............... 725

Single-bearded Flying-fish.............. 701

sipedon, Tropidonotus.................. 643

Siphostoma........................... 702

sirtalis, Eutænia....................... 644

Sitta ................................. 568

Skates .................................. 664

Skimmers................................. 631

Skim-back ............................ 674

Skinks.................................... 642

Skipjack ............................713, 720

Skipper................................... 700

Skittle Dog.............................. 659

Skuas ...................................... 625

Skunk ................................... 511

Skunk Porpoise........................... 516

Slate-colored Junco........................ 544

Sleepmarken ............................ 657

Slender Herring......................... 684

Salamander .................. 655

Small Blue Shark....................... 660

Box Turtle ...................... 639

Dolphin .......................... 722

Green-crested Flycatcher....... 528

Smaller Spotted Salamander............ 656

Small-mouthed Black Bass............. 728

Small Mud. Turtle........................ 639

Small-8caled Sucker.................... 674

Smelt....................................... 689

smithsonianus, var. of Larus argentatus.

Smooth Hound.......................... 660

Paffer ......................... 768

Snakes................................... 643

Snapper............................... 748

Snapping Turtles........................... 640

Snipo (et seq.)......................... 589

Snooks ..................................... 710

Snow Bird............................. 544

Bunting ......................... 540

Snowflake................................ 540

Snow Goose................................ 619

Snowy Egret .............................. 608

Heron ........................... 608 


\begin{tabular}{|c|c|c|c|}
\hline & & & \\
\hline fer ...................................... & 516 & spilopterus, Photogensis........... & 677 \\
\hline alis, Spizella.......................... & 543 & Spinacidæ ........................... & \\
\hline al Whale................................ & 517 & spinarella, Gasterosteus........... & \\
\hline shelled Turtles................. 640, & 641 & spinifer, Aspidonectes.............. & \\
\hline dier-fish ................................. & & spinosus, Trachynotus............. & \\
\hline (2......................................... & & Spinus ................................ & \\
\hline & & Spiny Dory............................. & \\
\hline . . . . . & & Gurnard................... & \\
\hline Scaphiopus............... & & Spiny-rayed Fish................. & \\
\hline & & & \\
\hline & & Spizella ..... & \\
\hline litary Gree & & sponsa, Aix.................................... & \\
\hline iper .................. & & Spoon bill Duck ..................... & \\
\hline (n............. & & & \\
\hline (n)............ & & Spotted Adder....................... & \\
\hline (n.............. & & Balloon-fish ............... & \\
\hline (6) & & 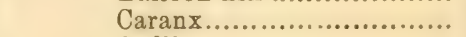 & \\
\hline ...................... & & Codling... & \\
\hline 年 & & Dolphin .................. & \\
\hline ( & & us................... & \\
\hline ...............496, & & Mackerel. & \\
\hline & & Mullet... & \\
\hline 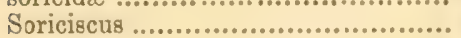 & & Sandpi & \\
\hline 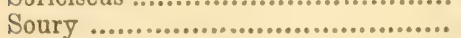 & & Spotted-fin Shark.................. & \\
\hline 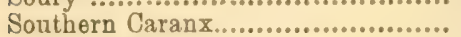 & & Spotted-finned Sunfish............ & \\
\hline Flo & & Spotted T'riton .................... & \\
\hline Por & & Sea Tr & \\
\hline Stir & & n................ & \\
\hline $\mathrm{Wa}$ & & 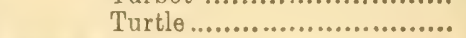 & \\
\hline h. southe & & Sprig-tail ....... & \\
\hline 更 & & Spring Frog... & \\
\hline 年 & & Mir & \\
\hline Mackerel of Europe.......... & & snake ..................... & \\
\hline 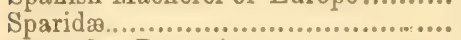 & & purius, Icterus......................... & \\
\hline & & uali......., & \\
\hline & & alipeta, Remora................... & \\
\hline Hawk (referred to)............ & & , $\ldots \ldots \ldots \ldots \ldots \ldots \ldots, \ldots$ & \\
\hline$\ldots \ldots \ldots \ldots .727,735,736,73$ & & $\ldots \ldots \ldots .659,660,6$ & \\
\hline , Falco (referred to, 540) & & ola.. & \\
\hline & & rola, Charadrius............. & \\
\hline 年 & & (..................... & \\
\hline ....................674, & & gue $\ldots . . . . . . . . . . . . . . . . . . .$. & \\
\hline Remora .................... & & de, Labrus................. & \\
\hline & & - $-6 s h, \ldots \ldots \ldots \ldots \ldots \ldots \ldots \ldots$ & \\
\hline otilus................. & & l Hake...................... & \\
\hline $00 \theta^{0} \ldots . . . . . . . . . . . . .$. & & n...................... & \\
\hline Sian & & Driver........................ & \\
\hline uth.... & & ..................... & \\
\hline & & ........................ & \\
\hline lis, Somateria................ & & , & \\
\hline . & & ed Mole..................... & \\
\hline & & Starry Ray....................... & \\
\hline Whale (referred to)........ & & stearnsii, Seriola...................... & \\
\hline Anlorma & & i............................ & \\
\hline ....... & & Steganopodes .......................... & \\
\hline 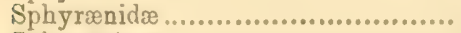 & & Steganopus wilsoni...................... & \\
\hline & & 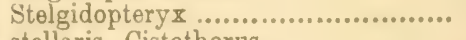 & \\
\hline & & 8 , Cistothorus ..................... & \\
\hline & & & \\
\hline
\end{tabular}


Stephanolepis

766

Stercorariidæ ,.........................6 625

Stercorarius................................ 625

Sterna .................................... 628

Sterna aranea........................... 628

Sticklebacks........................704, 705

Stiff-finned Remora..................... 709

stigmaticus, Ceratichthys.............. 679

Stilbe.................................... 687

Stilt .................................. 588

Stilt Sandpiper........................ 590

Stingaree..................................6666 666

Sting Rays............................. 665

Stink-pots ...........................639, 640

Stizostedium .......................... 731

Stolephoridø ............................ 688

Stolephorus ............................. 688

stomias, Trisotropis..................... 733

Stomodon................................. 759

Stone Catfish.............................. 671

Lugger ............................. 674

Roller .......................... 674

Snipe............................. 594

Storeria................................ 644

Storks ................................... 605

Stormy Petrel (referred to)........... 624

Strawberry Bass......................... 724

strepera, Anas.......................... 612

Strepsilas ................................ 600

striata, Dendroica ..................... 558

striatus, Plestiodon...................... 642

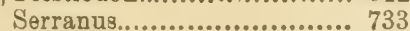

Tamias ...................500, 502

stricklandi, Puffinus................... 624

strigatus, Prionotus...................... 751

Strigidæ .................................. 579

Stripe-backed Salamander............. 654

Striped Bass............................... 732

Mullet........................... 706

Snake ......................... 644

Sucker......................... 675

Strix................................ 579

Stromateidæ ............................ 720

Stromateus ............................... 720

Sturgeons................................ 668

sturio, var. oxyrhynchus, Acipenser.. 668

Sturnella............................... 533

subarquata, Ancylocheilus............. 592

subarcuatus. Cestracion.................6.61

subis, Progne........................... 549

subruficollis, Tryngites............... 596

subulatus, Vespertilio................... 495

subviolacea, Amblystoma............. 656

sucetta, Erimyzon...................... 675

Suckers .............................673, 674

Sucking fish ........................... 709

sucklii, Squalus......................... 659

sueuri, Coryphæna...................... 722

Sula .................................... 631

Sulidre
Summer Duck........................... 614

Flounder...................... 761

Green Snake................. 646

Herring ....................... 685

Redbird ...................... 548

Tanager........................ 548

Warbler....................... 556

Sunfishes................................ 724

Bunfish...............................726, 770

superciliaris, Sterna...................... 630

superciliosa, Dendroica................. 559

Surf Birds.............................. 600

Duck ................................ 618

Scoter................................. 618

Surgeon fish .......................... 745

surinamensis, var, of Hydrochelidon

nigra ................. 630

Lobotes .............. 736

Surnia .................................. 589

Susquehanna Salmon................. 731

sutor, Caranx ........................... 716

swainsonii, var. of Turdus ustulatus.. 571

Swainson's Thrush....................... 571

Swallows............................... 549

Swallow-tailed Kite....................... 574

swampinus, Fundulus................. 693

Swamp Blackbird..................... 532

Owl.............................. 580

Sparrow ....................... 544

Tree-frog........................ 652

Swan.............................. 620,621

Swell Toad..........................768, 769

Swifts (Birds)......................... 524

(Lizards) ...........................6 641

Swift Garter Snake....................... 645

Swimming Birds....................... 609

Swingle-tail............................... 662

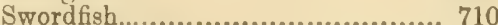

Swordfish Remora....................... 709

Sword Grampus............................ 517

Sylvania................................. 563

sylvatica, Rana........................ 650

sylvaticus, Lepus......................... 507

Sylvias.. .................................. 569

Sylviidæ .................................. 569

Sylvicolidæ (referred to) ............. 537 same as Mniotiltidæ..... 554

Symphemia ............................. 595

Synentognathi............................. 699

Syngnathide.............................. 702

Syngnathus ............................... 702

Synodus.................................... 689

Synonyms............................. 490

Synopsis of Classification............... 492

Syrnium................................ 580

$\mathrm{T}$

tabaccaria, Fistularia................... 703

Tachycineta............................ 549 
Tadpole Stone Cat.................... 671

tæniatus, Anisotremus.................. 735

Tailor Herring............................. 684

Talpidæ.................................. 498

talpoides, Blarina....................... 496

Tambor ................................... 768

Tame Duck............................... 610

Tamias .................................... 502

Tanagrider .............................. 547

Tantalidæ................................. 604

Tantalus ................................... 605

Tarpum.................................. 683

Tattlers .................................. 595

tau, Batrachus............................. 753

Tautog .................................... 743

Tautoga................................ 743

Tautogolabrus........................... 743

Tawny Thrush......................... 571

tchawytcha, Oncorhynchus........... 690

Teal Ducks (et seq.).................... 611

tectirostris, Sibbaldius (referred to)... 514

Teeter-tail .............................. 506

Teeter-tiltup (referred to, 561)........ 596

Teleocephali ............................. 670

Teleostei ................................. 670

Telestes .................................. 681

Tell-tale ................................ 594

Temnodon ................................. 720

Tennessee Warbler...................... 555

Ten-pounder............................ 683

tenuis, Phycis.......................... 757

tenuirostris, Anguilla.................. 697

teres, Catostomus ........................ 674

Cyprinus........................ 674

Etrumous..........................6 684

Terns..............................526, 628

terræ-novæ, Scoliodon.................. 661

Terrapins ...........................638, 639

Tessellated Darter........................ 728

tessellatum, Boleosoma................. 728

Testudinata ............................... 637

Tetrao ..................................... 584

Tetraodon ............................... 768

Tetraonide.............................. 584

tetraptuorum, Echeneis................ 709

Tetrasomus............................ 766

Tetrapturus ............................ 711

Tetrodon..............................768, 770

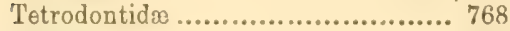

Teuthidx .................................. 745

Thallasseus caspius ...................... 628

cantiacus..................6 629

regius...................... 628

Thalassidroma wilsoni................ 624

Thalassochelys........................... 640

thazard, Auxis.......................... 712

Thick-billed Guillemot................. 635

Thimble-eye .......................... 712

Thistle Bird.............................. 538

Thread Filefish..................766, 767
Thread Herring.......................... 686

Three-spined Stickleback.............. 704

Thresher .................................. 662

Thresher Sharks........................6.661

thrissa, Opisthonema.................. 686

Thrushes (see Water Thrush, 561).... 570

Thrynosternum.......................... 639

Thryothorus.......................... 566

Thunder Snake....................... 617

Thynnus ............................. 714

thynnus, Orycnus..................... 714

tiburo, Sphyrna........................ 661

Tiger Salamander....................... 656

Shark ............................... 660

Triton............................ 656

Tigoma.................................. 681

tigrina, Dendroica..................... 556

tigrinum, Amblystoma.................. 656

tigrinus, Galeocerdo .................... 660

Tiltup [Teeter-tiltup] (referred to)... 561

Tinker Mackerel......................... 712

Tip-up..................................... 596

Titlark ................................... 564

Titmice .................................. 568

Toadfi shes................................ 753

Toadfish................................. 764

Toads ................................ 652

Tobacco-box............................ 664

tobianus, Ammodytes................... 708

Tomcod .................................... 758

tomcodus. Gadus......................... 758

Toothed Minnows......................... 692

Top Minnow ............................. 694

torda, Alca..............................6.6.6. 635

Torpedinidæ............................ 664

Torpedo ................................ 664

torquatus, Colymbus .................... 633

Histrionicus ...............6 617

Tortoikes .................................66 637

Totanus................................ 594

Toter ... ............................. 674

Towhee Bunting....................... 545

townsendii, Spiza..................... 547

Townsend's Bunting................... 547

Toxicophis............................. 648

Trachemys............................... 639

Trachurops .......................... 715

trachurus, Gasterosteus.................. 705

Trachynotus........................... 718

trachyrhynchus, Pelecanus............. 622

Trachyurus ........................... 673

tractu8, Acanthurus (referred to).... 716

traillii, var. of Empidonax pusillus.. 527

Traill's Flycatcher.................... 527

Tree Sparrow........................540, 543

Swift............................. 641

Toads .............................. 650

triacanthus, Stromateus.............. 721

triangulus, var. of Ophibolus doliatus... 
tribulus, Prionotus.

tridactyla, Rissa......................... 620

trichas, Geothlypis...................... 562

Trichiuridæ .............................. 711

Trichiurus ................................. 711

Trichodiodon .......................... 768

tricolor, Phalaropus..................... 587

Trigger-fish.............................. 766

Trigla..................................... 751

Triglidæ................................. 751

Trigonidæ ................................. 665

Trigonocepbalus ........................ 648

Tringa .................................. 591

Tringoides ............................... 596

Trionychidæ.............................. 640

triseriatus, Chorophilus................. 652

Trisotropis.............................. 733

tristis, Spinus.......................... 538

Triton ...............................652,656

'Troshilidæ............................... 524

Trochilus .............................. 524

Troglody tes ................................ 566

Troglodytidæ ........................... 564

troile, Uria ............................. 635

Tropidoclonium ......................... 644

Tropidonotus.......................643, 644

Tropidolepis ............................ 641

Trout.................................... 691

Trout Perch............................ 691

Pickerel......................... 695

trudeaui, Sterna........................... 629

'Trudeau's Tern............................ 629

True Dolphin......................... 515

True, Fred. W.......................... 516

Trumpeter Swan...................... 621

Trumpet fish .............................. 703

truncata, Belone........................ 699

Trunk-back Turtle..................... 640

Trunkfishes .............................. 765

Trygon ....................................6. 666

Tryngites............................... 596

techegrava, Sterna .................... 628

Tubinares ................................. 623

Tufted Titmouse....................... 569

Tunny.................................... 714

Turbot................................... 760

Turdidæ................................. 570

Turdus ................................. 570

turgidus, Tetrodon ...................... 768

Turnstone ............................... 600

Turkey Buzzard ........................ 573

Vulture...................... 573

Turkeys ................................... 586

Tursio................................... 515

tursio, Tursiops........................... 515

Tursiops............................... 515

Turtles .................................. 637

Turtle Dove ............................ 583

Two.colored Salamander................. 656
Two-spined Stickleback .............. 704

Two-striped Salamander.............. 654

Tylosurus ................................. 699

Tympanuchos ........................... 585

Tyrannidæ ............................. 525

Tyrannus.................................. 526

tyrannus, Alosa......................... 684

Anguilla.................... 697

Brevoortia...................6.68 686

Clupea........................6.68 686

Milvulus..................... 525

Tyrannus.................... 526

Tyrant Flycatchers................... 525

\section{U.}

ulula, Surnia,.......................... 582

umbellus, Bonasa ....................... 585

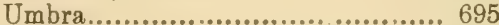

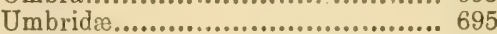

Umbrina ................................. 741

umbrosus, Esox........................ 696

undulatus, Micropogon................ 740

Sceloporus................. 641

Ungulata ............................... 513

unicolor, Bryttas...................... 726

Unicorn-fish ........................... 767

unicornis, Citharichthys............... 760

unifasciatus, Hemirhamphus........... $7 \mathrm{CO}$

Upland Plover.......................... 596

Upsilonphorus.......................... 746

Uranidia ..................................... 749

Uranoscopidæ ........................... 746

Uria ....................................... 635

Urinitoridæ ....................... 633

Urinator ................................... 633

Urophycis............................... 756

Uropsetta ................................ 751

Ursidie .................................... 512

Ursus ..................................... 512

Urocyon............................... 509

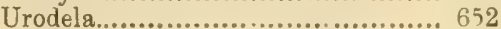

ustulatus, var. swainsonii, Turdus.... 571

\section{V.}

valisneria, Aythya................... 614

vampyrus, Cephaloptera .............. 667



variatus, Pœilichthys.................. 729

Varied Thrush......................... 572

variegatus, Antennarius................ 764

Cyprinodon ...............662 692

varius, Sphyrapicus ................... 519

Veery ................................... 571

velifer, Carpiodes ........................ 674

velox, Accipiter...................... 574 
Velvet Scoter........................... 618 velvetina, Melanetta.................... 618 venenosa, Amblystoma ................ 656 vermiculatus, Esox.................... 696 vermivorus, Helmitherus............... 554 vernalis, Clupea.......................... 684 Cyclophis....................... 646 Scomber ..................... 712

versicolor, Abramis...................... 681 Hyla...................... 650 Quiscalus .................... 535 Stenotomus ................. 737

Vertebrata .............................. 494

verticalis, Tyrannus.................... 526

Vesper Sparrow ........................ 542

Vespertilio ................................ 495

vespertilio, Malthe....................... 765

Vespertilionidæ ......................... 494

Vesperugo .................................. 495

vigorвii, Dendroica..................... 559

villosus, Dryobates......................... 518

vinciguerræ, Exocœtus................. 701

Viper......................................... 643

virens, Contopus......................... 527

Dendroica ....................... 559

Gadus ........................... 758

Icteria .......................... 562

Trireo.................................. 552

Vireonidw ................................ 552

Vireosylvia .......................... 552

virescens, Ardea ....................... 608

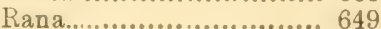

virginea, Cistudo........................ 637

virginiana, Didelphys................. 517

virginianus, Acanthocottus........... 749

Bubo ..................... 581

Cardinalis ................ 545

Cariacus.................. 513

Chordeiles................ 523

Colinus.................... 584

Rallus ...................... 601

Virginia Deer............................ 513

Rail ........................6 601

virginicus, Charadrius.................. 597

Pomadys ..................... 735

viridescens, Diemyctylus................ 625

Osmerus ................... 689

viridis, var. of Hyla versicolor....... 651

viscosa, var. of Uranidea richardsoni. .................................. 749

vison, Putorius.......................... 510

Viscid Salamander....................... 651

vitreum, Stizostedium.................. 731

vittatus, Engraulis...................... $6 \varepsilon 8$

vitulina, Phoca........................ 508

viviparus, var, of Sebastes marinus.. 748

vocifera, Egialitis....................... 598

vociferus, Antrostomus................ 523

volans, Sciuropterus..................... 501

politans, Cephalacanthus............. 732 volitans, Exocotus ..................... 701

volucella, Sciuropterus.................. 501

Tomer.................................... 717

vomer, Argyreiosus.................... 717

Selene ........................... 716

vomerinus, Anarrhichas............... 755

vulgaris, Acanthias..................... 659

Amiurus ....................6 672

Anguilla ..................... 698

Auxis ......................... 712

Brosmius .................... 757

Conger......................... 698

Hippoglossus................. 761

Mustelus ...................... 660

Pomotis....................... 727

Sphyræua .................... 707

Thynnus.................... 714

Vulpes ................................. 503

vulpes, Albula........................... 682

Alopias............................ 662

Vulpes......................... 508

vulpinus, Coluber....................... 646

Vulturidæ.................................. 573

Vultures .............................. 573

\section{W.}

Wading Birds............................. 587

Wagtalls .................................. 564

Wake-up ............................... 521

Wall-eyed Pike.......................... 731

Warbling Flycatcher................... 553

Tireo ............................ 553

Water

Lizard ........................... 653

Snake .......................... 643

Thrush ........................ 5 n'l

Turtle...........................6.637

Wagtail......................... 561

Witch .......................... 632

Wax-wings ............................. 550

Weakfish ................................ 741

Weasels .............................509, 510

Western Sandpiper...................... 593

Whalebone Whale..................... 514

Whales.................................. 514

wheatlandi, Gasterosteus.............. 704

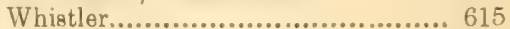

Whistling Swan......................... 6 620

Whip poor-will......................... 523

Whitebait ............................ 684

White-bellied Nuthatch................ 568

Sapsucker ............... 568

Sivallow................ 549

White-broasted Nuthatch............... 568

Sapsucker ............. 568

White Catfish............................ 672

White crowned Sparrow:.............. 542 


\section{INDEX.}

White eyed Flycatcher................ 553
Vireo ...................... 553

Whitefish ................................... 6586

White-footed Mouse.................... 505

White-fronted Goose..................... 619

White Hake............................ 757

Heron ...............................6 607

Mullet........................... 706

Perch .................................. 732

Rabbit ......................... 507

White-rumped Sandpiper............... 591

Shrike ................. 552

White Sucker......................674, 675

White-tailed Remora..................... 709

White-throated Sparrow............... 543

Warbler .............. 555

White-winged Blackbird.............. 547

Coot...................... 618

Crossbill ................. 538

Gull .................... 626

Scoter..................6 618

Surf Duck.............. 618

Whiting ...................................... 741

Widgeons ................................. 612

Wild-cat...................................... 508

Wild Goose.................................. 620

Pigeon................................ 583

Turkey.............................. 58 58

Willet................................... 595

wilsonia, Afgialitis....................... 598

wilsonianus, Asio....................... 579

wilsoni, Gallinago...................... 589

Steganopus ..................... 587

Sterna ........................6.6. 629

Thalassidroma ...................6 624

Wilson's Petrel............................. 624

Phalarope........................ 587

Plover......................... 598

Snipe.......................... 589

Tern ................................. 629

Thrush........................... 571

Warbler................................ 563

Window pane ............................... 760

Winter Falcon................................. 576

Flounder............................ 762

Wren .............................. 567

Wolf (referred to)......................... 513

Wolf-fish..................................... 755

Woodchuck ................................ 502

Woodcock............................... 589

Wood Duck.................................... 614

Ibis ....................................66 605

Woodpeckers.................................. 518

Wood Pee-wee.................................. 527

Rat ..................................... 505

Terrapin ........................ 638

Thrush .............................. 570

Tortoise.............................. 638

Warblers................................ 554

Wren ................................ 566
Worm-•ating Swamp Warbler........ 554

Wrasses.................................... 742

Wrens ........................................ 564

Wren............................................. 569

$\mathrm{X}$.

Xanthocephalus........................ 532

zanthocephalus, Xanthocephalus.... 532

zanthurus, Homoprion................. 739

Liostomus........................ 740

Xema ....................................... 628

Xenisma .................................. 693

Xiphias ................................... 710

Xiphiidæ......................................... 710

$\mathrm{Y}$.

Yarup .................................. 521

Yellow-bellied Flycatcher............... 528

Sapsucker ............. 519

Yellow-billed Woodpecker ........... 519

Yellow Bird................................. 538

Yellow-breasted Chat..................... 562

Yellow Caranx............................. 715

Catfish ............................ 672

Desmograth ........................6.6.6. 653

Yellow-finned Red-mouth.............. 735

Yellow Hammer ....................... 521

Yellow-headed Blackbird .............. 532

Yellow-legs ................................ 594

Yellow-masked Warbler ................. 563

Yellow Mocker .......................... 563

Yellow Palm Warbler...................... 560

Perch.............................. 731

Pike.................................. 731

Rail .................................. 602

Redpoll Warbler................. 560

Yellow.rumped Warbler .................. 557

Yellow shanks ............................... 594

Yellow Stone Cat ......................... 671

Yellow-tail.. ............................686, 717

Yellow-tail Perch.......................... 739

Yellow-throated Flycatcher ............. 553

Vireo................... 553

Warbler ............... 559

Yellow Triton............................. 655

Warbler .......................... 556

Yellow-winged Sparrow................ 541

Yelting .................................. 734

Yucker .......................................... 521

\section{Z.}

Zamelodia.................................. 546

Zapodidæ .................................... 503 
INDEX.

Zapus..................................... 503

zebra, Fundulus........................ 693

Zenaidura................................. 583

Zeus...................................716, 744

zibethicus, Fiber........................ 506

Zoarces.................................. 755

zonata, Seriola.......................718, 719

zonatus, Ephippus .................... 744

Zonichthys.............................. 719

Zonotrichia............................... 542

zygæna, Sphyrna........................ 661

Zygonectes .............................6 694 





SMITHSONIAN INSTITUTION LIBRARIES 